



Digitized by the Internet Archive in 2007 with funding from Microsoft Corporation 
FOSSIL BOTANY

SOLMS-LAUBACH 
Enon

IIENRY FROWDE

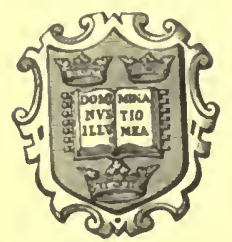

Oxford University Press Warehouse

AMen Corner, E.C. 


\section{FOSSIL BOTANY}

BEING AN

INTRODUCTION TO PALAEOPHYTOLOGY

FROM THE STANDPOINT OF THE BOTANIST

'HY

H. Graf zU S SOLMS-LAUBACH PROFESSOR IN THE UNIVERSITY OF GÖTTINGEN

THE AUTHORISED ENGLISH TRANSLATION BY

HENRY E. F. GARNSEY, M.A.

Fellow of Magdalen College, Oxford

REVISED BY

ISAAC BAYLEY BALFOUR, M.A., M.D., F.R.S.

Queen's Botanist in Scotland, Professor of Botany in the University and Keeper of the Royal Botanic Garden, Edinburgh

WITH FORTY-NINE ILLUSTRATIONS

\section{Oxford}

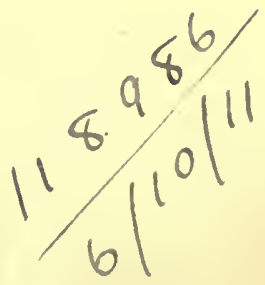

AT THE CLARENDON PRESS

I 89 I

[All rights reserved] 
Oxford

PRINTED AT THE CLARENDON PRESS

WY HORACH HAKT, PRINTER TO THE UNIVERSITY 


\section{P REF A C E}

THE object of this work is to give such an account of palaeophytology as shall meet the special requirements of the botanist, and it can scarcely be necessary to offer a detailed or lengthy plea in justification of my undertaking. Botany, which in former times generally treated palaeophytology in a very step-motherly manner, now finds it to be a subject of the highest interest to herself on account of the prominence at present assumed by the point of view of the theory of descent. But it is no easy task to obtain a general view of such results of palaeophytological researches as are botanically useful; for, owing to the inconceivably fragmentary condition of the literature and the urgent necessity for submitting it to manifold and searching criticism, the accomplishment of this task inevitably means the devotion to it of years of work, and few professed botanists have this time to give to it. And if our present text-books do not succeed in giving us such a view, this is chiefly due to the fact that they are all more or less endeavouring to serve two masters, palaeontology and botany, and in this endeavour it is botany which as a rule comes worst off. It is hardly possible rightly to preserve unity of presentation in a book in which equal justice ought to be done to several points of view. Therefore the present account of palaeophytology, which may itself appear to some readers to be rather one-sided, may be allowed to step in as supplying an existing want. It is a first attempt in the direction indicated, and as such it has many defects which are certainly thoroughly well known to the author himself, and which he begs may not be judged too severely.

The work here offered to the general public has gradually grown up out of University Lectures delivered by me in Göttingen at three different times in the course of the last six years. I had at first intended to preserve the lecture-form, but ultimately found that this was unsuitable and must be abandoned. Then came the difficulty of finding a proper title. 
The book could not be called simply 'Palacophytology,' since it does not take in the whole of the subject. The reasons why it omits the Angiosperms and confines itself to the consideration of the Thallophytes, Archegoniatae, and Gymnosperms will be found in the introductory chapter. And if $I$ have at length decided to call it an 'Introduction to Palacophytology,' this title is after all only a way of getting out of a difficulty, for it requires that the word palaeophytology should be understood in a narrower and more botanical sense, and should mean the doctrine of the old types of vegetable forms as distinguished from the Angiosperms, which made their appearance in later times and introduced the modern era. It is in this sense only that the title and the contents correspond to one another.

In choosing the woodcuts I have contented myself with those which werc most necessary. For figures of the countless extant remains of plants the reader must have recourse, where they are not already known to him, to the 'Paléontologie végétale' of W. Ph. Schimper, to Zittel's 'Handbuch der Paläontologic,' and to Renault's 'Cours de botanique fossile.' It is impossible to give a figure of every object, and I have therefore limited myself for the most part to the representation of those which are of the greatest interest to the botanist. The larger part of the woodcuts are new, and are from drawings by Herr O. Peters, which were traced on the block itself. I have especially to thank Herr Hofrath Schenk of Leipsic for very kindly granting me the usc of some figures from the volume of Zittel's Handbuch which deals with plants.

The mastering of the literature was, as I have said, one of the chief difficulties encountered in the composition of this book. I have done my best to overcome this difficulty, and I trust that I have taken into consideration the most important of the publications which have appeared up to the end of the year 1886 ; still there may be some which I have overlooked. Among later works I have been able to refer, at least for the most essential points, only to W. C. Williamson's monograph of Stigmaria ficoides; this I could not have done but for the courtesy of the author, who supplied me with proofs of the tables of figures before the work was published.

In order to avoid frequent repetitions of the citations, a list of the literature has been compiled and placed at the end of the volume, arranged in the alphabetical order of the authors' names. For the bencfit of the less experienced reader the titles of the most important works are distinguished from the rest by being printed in italics. 
It would have been quite impossible for me to have formed an independent judgment on opposing views in regard to many and those precisely the most important points, if opportunity had not been given me in the kindest manner in very various quarters of studying a number of original specimens and original sections of great value. I here express my hearty thanks to the many persons who have aided me in this manner. I am especially indebted to Dr. W. C. Williamson of Manchester, who gave me facilities for studying the treasures of his collection; to Drs. W. Carruthers and Woodward of London, to whom I owe my knowledge of the materials in the British Museum, and especially of the collection of sections preserved in that institution and of the treasures bequeathed to it by R. Brown; to M. Renault of Paris, who assisted me in my examination of the collections in the Paris Museum, and was himself kind enough to explain to me the most important of his preparations; and to F. Römer of Breslau, who was never weary of supplying me with original specimens from Göppert's collection. Without the friendly help which I received from these labourers in the science, I should never have succeeded in doing any justice to the subject of my book.

H. GRAF ZU SOLMS-LAUBACH.

GöTTINGEN, May 27, 1887 . 


\section{PREFACE TO THE ENGLISH EDITION}

THis translation of Count Solms-Laubach's Introduction to Fossil Botany brings within reach of English readers the only critical digest as yet published of our present knowledge of Fossil Plants from the point of view of Botanical Morphology, and is an important addition to the series of standard botanical works issued by the Clarendon Press.

I have to thank the author for help in several points concerning the translation, and with his consent some corrections of statement have been made in the English text. To P'rofessor W. C. Williamson I am indebted for some of these, and I have to acknowledge aid in the rendering of geological terminology and nomenclature from Dr. Archibald Geikie and Professor F. Rudler.

I. B. B.

EUINBURGH, 1891. 


\section{O N T E N T S}

I. Introduction . . . . . . . . . . . I

Petrifaction . . . . . . . . . . . . . . 3

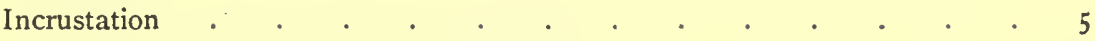

Coal-seams, a peculiar mode of incrustation . . . . . . . . 9

Peat . . . . . . . . . . . . . . . 14

Brown coal . . . . . . . . . . . . . . . 16

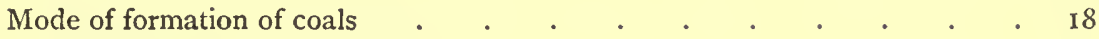

Mode of formation of petrifactions . . . . . . . . . 24

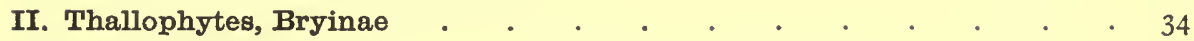

Fungi . . . . . . . . . . . . . . 34

Diatomaceae . . . . . . . . . . . . . . . 35

Chlorosporeae . . . . . . . . . . . . . . . . 36

Florideae . . . . . . . . . . . . . . 44

Doubtful Alga-forms, and forms wrongly placed with Algae . . . . 45

Mosses . . . . . . . . . . . . . . 5 I

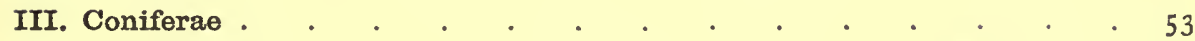

Abietineae. . . . . . . . . . . . . . . 54

Araucaria . . . . . . . . . . . . . . . 57

Sequoieae . . . . . . . . . . . . . . . . . 58

Cupressineae . . . . . . . . . . . . . . . . 60

Taxineae . . . . . . . . . . . . . 61 6

Salisburieae . . . . . . . . . . . . 62

Forms, whose place is not certainly ascertained . . . . . . 67

Leafless branches of Coniferae . . . . . . . . . . 79

Coniferous woods . . . . . . . . . . . . . . Eo

Prototaxites . . . . . . . . . . . . . . . . . 84

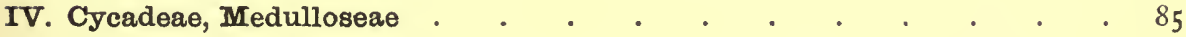

Cycas . . . . . . . . . . . . . . 86

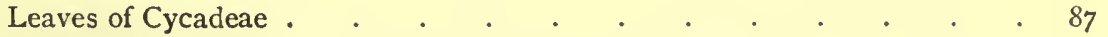

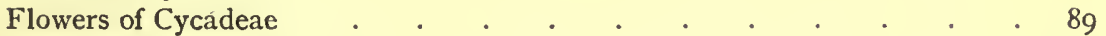

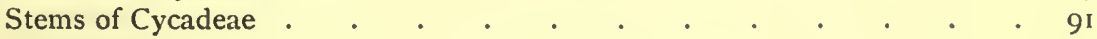

Bennettites . . . . . . . . . . . . . 94

Medullosa. . . . . . . . . . . . . . 100

v. Cordaiteae . . . . . . . . . . . . . . . 104

Leaves . . . . . . . . . . . . . 105

Branches . . . . . . . . . . . . . . 108

Artisiae . . . . . . . . . . . . . . 109

Forms from newer formations resembling Cordaitae . . . . . I Io

Flowers . . . . . . . . . . . . . . III

Seeds . . . . . . . . . . . . . . . . . II7 
VI. Dolerophyllum, Cannophyllites, Ephedrites, Gnetopsis, Schützia, Dictyothalamus, Calathiops .

PAGE

VII. Ferns

Lcaves

Fructifications (Marattiaceae) .

Botryopterideae

Leptosporangiate Fcrn-fructifications

Doubtful fructifications

Inner leaf-structure .

Rhachiopteridae (leaf-stalks) .

Mycloxylon

Fern-stems

VIII. Equisetaceae, Marsilioideae, Traquairia, Sporocarpon

\section{Lycopodites, Ptilophyton, Psilotites, Psilophyton, Isoëtites}

X. Lopidodendreae .

External character of stem of Lepidodendron .

Aspidiaria

Bergeria

Knorria

Leafy branches of Lepidodendron

Construction of the crown of Lepidodendron

Ulodendron

Lepidophloios

Anatomy of the Lepidodendreac . . . . . . 215

Lepidostrobus (fructifications of Lepidodendreae) . . . . . . . . 232

XI. Sigillarieae

External character of stems of Sigillaria . . . . . . . 242

Leives

Construction of the entire plant

Points of origin of the fructifications

Inner structure .

Fructificitions .

XII. Stigmaria

External character and states of preservation of Stigmaria ficoides . . 263

Apical growth . . . . . . . . . . . . 268

Other species of the genus . . . . . . . . . . . 269

Anatomy of the shoots . . . . . . . . . 270

Anatomy of the appendages . . . . . . . . . 275

Are the Stigmarias plants sui generis or are they members belonging to plants of Sigillaria and Lepidodendron . . . . . . . 280

Morphology of the members of Stigmaria . . . . . . . 287

Attempts to reconstruct its course of development . . . . . . 291

Cyclostigna, Arthrostigma . . . . . . . . . . 293

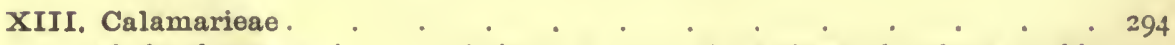

Mcde of preservation. Preliminary account of the views of authors on this point .

Anatomy of the stems of Calamaria

Casts of Calamites 
PAGE

Archaeocalamites . . . . . . . . . . . . 320

Leafy branches of Calamariae (Annularia, Asterophyllites) . . . . 322

Fructifications of Calamariae . . . . . . . . . . 324

Specimens showing fructifications and stems in conjunction . . . $\quad .338$

Justification of the division of Calamariae into archegoniate Calamitae and gymnospermous Calamodendrae . . . . . . . 340

XIV. Sphenophylleae . . . . . . . . . . . . . 343

External character of the impressions . . . . . . . . 343

Anatomy . . . . . . . . . . . . . . . 345

Fructifications . . . . . . . . . . . . . . 351

Affinities with other groups of plants . . . . . . . . 353

XV. Remains of stems of doubtful affinity, in which the character of the outer surface is unknown . . . . . . . . 355

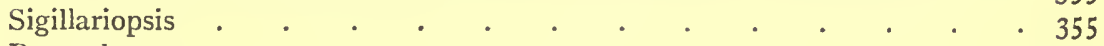

Poroxylon . . . . . . . . . . . . . . . 356

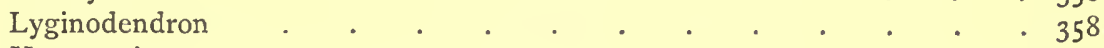

Heterangium . . . . . . . . . . . . . 362

Kaloxylon . . . . . . . . . . . . . . . 363

Amyelon . . . . . . . . . . . . . . 363

XVI. Remains of plants of doubtful affinity, in which the character of the surface only is known, while the structure is unknown . . 365

Vertebraria . . . . . . . . . . . . . 365

Aethophyllum . . . . . . . . . . . . . . 366

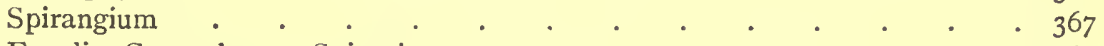

Fayolia, Gyrocalamus, Spiraxis . . . . . . . . . . 369

Williamsonia . . . . . . . . . . . . . . . . 369

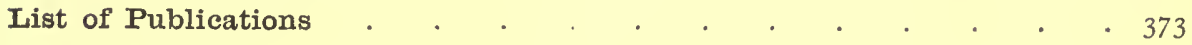




\section{ERRATA}

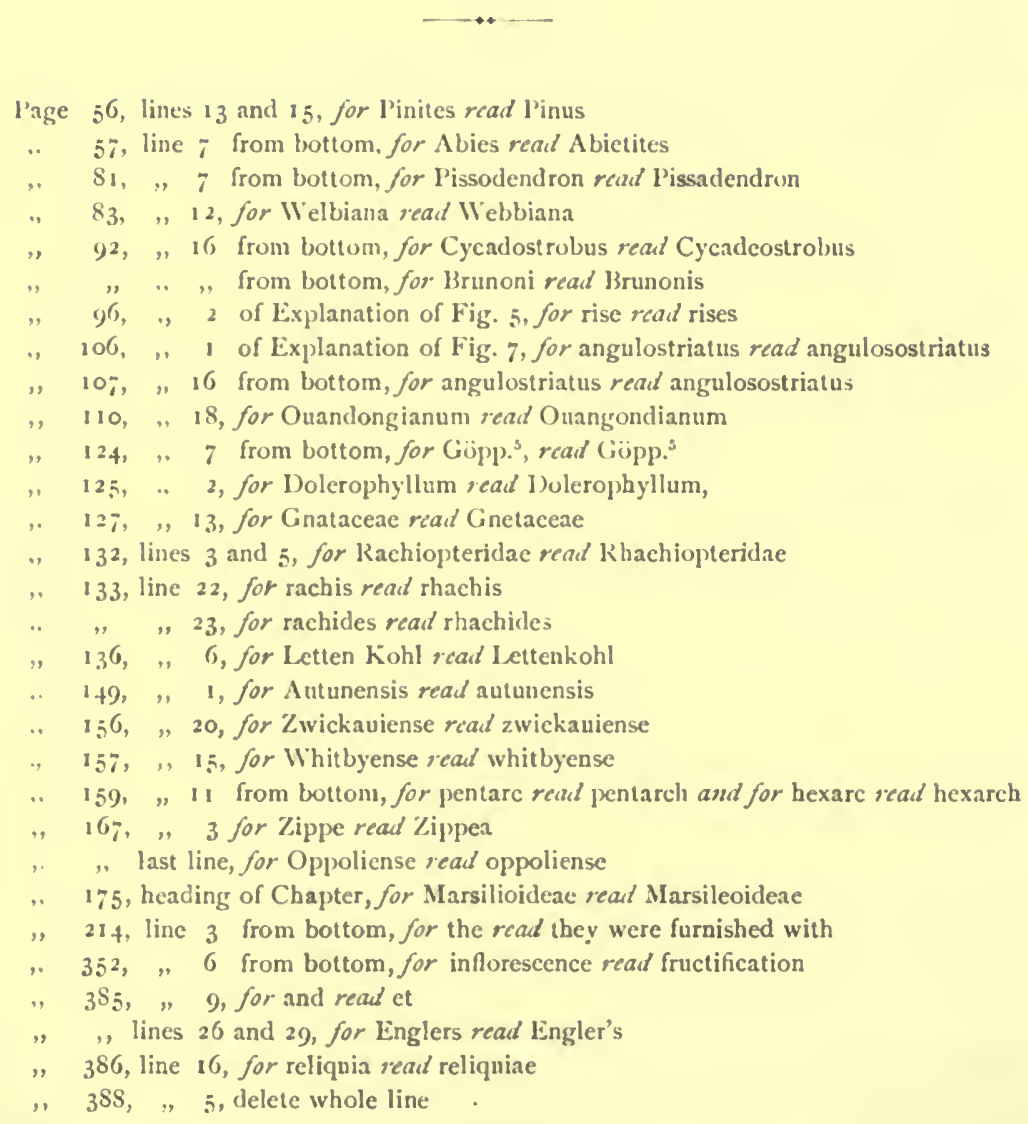




\section{PALAEOPHYTOLOGY.}

I.

\section{INTRODUCTION.}

THE subject of palaeophytology admits of very different modes of treatment; the points of view of the geologist are not those of the botanist, and the botanist looks at the remains which have come down to us in the succession of geological formations with different eyes, according as the purpose for which he examines them gives greater prominence to the interests of pure classification or of the geography of plants, of phylogeny or of physiology. On the other hand, a connected account of those results of palaeophytology which are of use to the botanist ought certainly to do justice to all these points of view. But the longer I occupied myself with the subject, the more clearly I perceived that this is at present attended with almost insuperable difficulties, at all events that I was not in a position to grapple successfully with the task. The systematist, whose business it is to submit to constant critical examination the results which the palaeophytologists have been able to establish with regard to extinct plant-types, has no need of exact descriptions of the forms, whose nearest relatives are within his reach at any moment in their living state for the determination of his bearings in every direction; fossil Angiosperms especially, at least in the form in which they can at present be set before us, have only the very smallest value for his purposes; his interest culminates in the remains which we possess from remote epochs in the development of our globe. On the other hand, it is just with these remains that the student of the geography of plants and of phylogeny can do little or nothing; he must go backwards step by step from living plants which are exactly known to him in all their parts in order to find firm ground for his investigations; objects, such as the fossil leaves of oaks and chestnuts, which are matter of indifference to the systematist, are exactly the things which interest him most.

It is evident that with the advance in knowledge which may be expected the two interests will in the future join hands, when the forms of the vegetable 
kingdom have been traced back to the old formations, and the genetic relations of extinct groups to those now existing and to their progenitors have been discovered. The filiation has actually been already traced a long way backwards in the case of single genera or cycles of affinity, and results have been obtained by $\mathrm{Hecr}^{-1}$ in the case of the Salisburicae, and in that of the Gymnosperms generally by the incomparable works of Grand' Eury ${ }^{2}$ and Renault ${ }^{3}$ on Cordaites, which are invaluable as aids to phylogenetic determinations.

But though the way has been thus clearly pointed out for palaeophytological research in various directions, yet it follows from what has been said that it is at present necessary to keep the different points of view distinctly scparate from one another. Hence it is that the present work is strictly confincd to the stand-point of the systematist, being intended to show to botanists in a perspicuous form and after application of the necessary criticism to what extent the efforts of palacophytologists have furthered the completion of the Natural System. It will be advisable that the systematic treatment of the material should be preceded by a short exposition of the methods of palacophytological research as well as by a notice of the mode of preservation of fossil remains, notwithstanding that the greater part of what can be said on these points will be found set forth in a masterly manner in Unger's work".

Since fossil plants reached the place of their deposit in almost all cases in comparatively small fragments, the first object always is to determine the manner in which these fragments, these branches, leaves, fruits, belonged to one another. It would be a similar task to reconstruct a forest from the mud of a picce of water into which the dead parts of the trees have fallen. In these circumstances we can only certainly conclude that separate parts belong to one another in two cases : first, if they occur once and exceptionally in union with one another; secondly, if they cxactly resemble one another in characteristic features of anatomical structure. Simple as this appears at first sight, yet various circumstances occur in practice to make the very greatest circumspection necessary in applying both these criteria. In the case of a specimen showing parts in connection with one another which are usually separate, since we are dealing in most cases with impressions of plants, we have to make quite sure in each several instance that there is no third formless object lying over two distinct but converging remains in such a manner as to bring about an apparent connection between them. Mistakes have as a matter of fact often arisen in this manner. With regard to the establishing the anatomical identity of two scparate fragments, it must be remembered that this presupposes an exact knowledge of the 
anatomy, for without this it is impossible to determine the value of the points of anatomical comparison which have been observed.

In all cases in which neither of these two criteria could be obtained, palaeophytologists have preferred to make use of conclusions drawn from the frequent or constant occurrence of the parts together in their places of deposit. Conclusions of this kind have been largely employed by Brongniart and Goldenberg, and also by Schimper. It cannot be denied that they may be resorted to in certain cases, but only where they are accompanied by various indications of probability. In all other cases this method of proof is not only dangerous, but is absolutely to be rejected. To see this, we have only to reflect that in this way we might distinctly conclude from the detached fossil remains of a forest composed of Podocarpus and larch, that the leaves of the one and the cones of the other genus belonged to one another, because being the more durable parts they lay there in large quantities, while the needles of the larch had rotted away and disappeared, and the seeds of Podocarpus if present at all had been crushed into shapelessness. It has been particularly unfortunate that authors in adopting this method have very commonly neglected to state the proofs on which they have founded their identifications, so that we remain in many cases of the kind in great doubt as to their value, and are often compelled to have recourse to tedious critical investigations.

The fullest accounts of the mode of preservation of fossil remains of plants will be found in Unger ${ }^{1}$, in Göppert in many places, and in Schimper ${ }^{2}$. Two essentially different cases must be distinguished; these have been known since Göppert's ${ }^{3}$ time as true petrifaction and as incrustation. To certain other cases intermediate between these two we shall recur in a future page.

The characteristic mark of true petrifaction is that the remains of the plant are thoroughly permeated by the petrifying substance. This may be amorphous or distinctly crystalline, and in the latter case the plant is simply traversed by the cleavage-surfaces. The effect is usually very beautiful, especially in petrifactions in the carbonates. If the petrifying substance is removed by suitable solvents, there remains behind an organic body usually of small size, which originates in the inclosed fossil and shows its form, and is mostly brown or black, but in a few cases displays an approach to the original colour. Göppert ${ }^{3}$ made many experiments in the dissolution of fossils, and even believes that he obtained cellulose-reaction in residua of this kind.

Very various bodies occur in nature as agents of petrifaction. Among these silicic acid has the first claim to mention here in the form both of opal

3 Unger (6).
${ }^{2}$ Schimper (1), Introd.

B 2
${ }^{3}$ Göppert (1), .Introd. 
and of chalcedony. It is the one of all others which ensures the most perfect preservation of the enclosed remains. Silicified woods are found in extraordinary quantity in all formations; it is more rare to find the more delicate parts of plants, leaves, secds, or the fructifications of ferns well preserved in the silicified state. Specimens of the latter kind occur chiefly in the hornstones of the Rothliegende at Chemnitz and in the Plauensche Grund near Dresden, in the same formation at Autun, and in the siliceous fragments of Grand' Croix near St. Etienne, which represent a fossil forest. These pebbles, which belong to the uppermost beds of the Carboniferous and supplied Renault with the principal material for his admirable rescarches, will be discussed again at greater length in a succeeding page.

The next in order of importance are the isomorphous carbonates of calcium, magnesium, and iron, $\mathrm{CACO}_{3}, \mathrm{CACO}_{3}+\mathrm{MgCO}_{3}, \mathrm{Fe} \mathrm{CO}_{3}$. Göppert is of opinion that calcium carbonate is present in some petrifactions in the form of arragonite; it occurs in most cases as calc-spar. Here too the remains of plants may in certain circumstances be in an cxcellent state of preservation. This kind of petrifaction is found in great abundance in the Coal-measures of England and of the district of the Ruhr. It occurs also in North America in the State of Missouri, but the remains, so far as I know, are still undescribcd. I have scen two fragments in F. Römer's collection, but unfortunately the place where they were found is not distinctly stated. Their surface resembles that of the Stigmarias, and transverse sections show that they contain a confused mass of fragments of Stigmarias and of leaf-stalks of Ferns in different states of preservation. Petrifactions in carbonate of iron very commonly form the nucleus of clay iron-stone nodules.

Wood petrified in fluor-spar is very rarely found, but it occurs occasionally in the Rothliegende of the Erzgebirge, and is particularly mentioned by Knop ${ }^{1}$ and Sterzcl ${ }^{2}$. Petrifaction in gypsum is still more rare; the only instance of it which $I$ have been able to find in the literature is that of the stem of a Conifer, which Göppert ${ }^{3}$ obtained from the gypsum-quarries of Katscher in Silesia, and has described under the name of Pinites gypsaceus. It is moreover doubtful whether the specimen is truly petrified, since it shows a brownish colour in places and is extremely rich in bituminous substances. Calcium triphosphate is also known as a petrifying agent; roundish lumps of this material containing well-preserved and determinable woods are found, according to Vater ${ }^{4}$, in abundance in beds of phosphorite in Brunswick. Portions of the wood of Calamites preserved in this phosphate, according to $\mathrm{Stur}^{5}$, are found also in

$$
{ }^{1} \text { Knop (1). } \quad{ }^{2} \text { Sterzel (2). } \quad \text { s Göppert (1). ' Vater (1). B Stur (8), p. } 4 \text { I8. }
$$


the uppermost beds of the Coal-measures. Grand' Eury ${ }^{1}$ reports the presence of similar fossils in the 'couche des Rochettes' and the 'couche des Littes.'

Barytes, pyrites, red and brown iron-ore, argentiferous copper-glance, and argillaceous earth are also said by various authors to be petrifying agents $^{2}$. How far the remains of plants preserved in these insoluble compounds can really be regarded as true petrifactions must be considered in a subsequent page.

Lastly, amber must be mentioned as an organic medium of petrifaction in so far as it incloses small pieces of coniferous wood perfectly resinised and sunk in the amber, but with their substance still preserved, as we learn from Berendt and Göppert ${ }^{3}$. Other organic inclosures in amber show a different behaviour.

While then true petrifactions are known by the fact that every part of their substance is permeated by the petrifying material, incrusted remains are on the contrary merely surrounded by the incrusting mass and inclosed in it; their substance is not otherwise affected, and may in process of time be changed into coal, or, if the inclosing mass is of a porous nature, may entirely decay and disappear. This has happened, for example, to all the many insects and flowers which have been inclosed in amber. These according to Conwent ${ }^{4}$ are represented by cavities, in which slight traces of coal only are found. All the sculpturings on the outer surface of the inclosed object are of course preserved on the wall of the cavity; an impression of the object is taken, whatever may become of its substance, and this impression appears on the opposite faces of the cavity when it is broken across. When the upper and under sides of the object differ in character, as is the case with bifacial leaves, these differences appear on the two faces as socn as any coal that may be present is removed. The finer the grain of the inclosing mass, the more beautiful will be the impression, most beautiful in soft clays and argillaceous schists, much less good in sandstones; yet serviceable impressions are sometimes found in tolerably coarse-grained conglomerates.

In many cases the remains which were to be inclosed had interior cavities of their own, as is commonly the case with stalks, fruits, and seeds. These cavities became also filled with the enveloping material, and a cast was produced, the surface of which shows the sculpturing on the outer bounding surface of the original cavity. The space between the cast and the mould is usually filled with coal; it may be hollow through previous decay of the part of the plant, but this must be regarded as a rare condition in the preservation of the remains. On every heap of débris from the Coal-measures are found the casts of Calamites in abundance, in many

1 Grand' Eury (1).

A. Menge), vol. ii, Introd. p. vi.
${ }^{2}$ Blum (1). $\quad$ s Berendt (l).

${ }^{4}$ Göppert (21) (Göppert und 
cases still covercd with their rind of coal, where this has not remained attached to the mould. Of this kind are the so-called Artisiae, casts of the pith-tube of stems of Cordaitac. They may be squeezed quite flat, or they may still show their natural rotundity. As a rule the cast is of the same substance as the cnveloping mass; in some instances the two may be of a different nature. This may be the case if the part of the plant was incrusted at the moment when there was a change of sediment, and then the envelope will always belong to the older, the cast to the newer layer of material.

In the casts hitherto spoken of the surface must necessarily show entircly different sculpturings from those of the mould; the reflection of the latter must be found on the surface of the layer of coal which separates the two, and there it may sometimes be observed in a very delicate form. Such cases it is true can very rarcly be scen in our collections,-though I have in my possession a Sigillaria the surface of which is wonderfully preserved in the rind of coal,- first because the coal as a rule falls to pieces very quickly when cxposed to the air, especially if it contains pyrites, and sccondly because collectors in their want of understanding often injure their specimens by carefully cleaning them. But, as has been already said, if the organic substance of the inclosed plant has entircly decayed and disappeared, and the resulting cavity, as sometimes happens, is occupied by the enveloping material or by some other substance, the cast thus produced will itself fill the mould and present an exact impression taken in this form of the surface-features of the inclosed plant, the same impression as is shown in the other case on the outside of the rind of coal. The Pliocene and Quaternary tuffs of Meximieux ncar Lyons and of Cannstadt inclose countless holes and cavities, from which the vegetable substance has cntircly disappeared; these are so many moulds, in which we can restore it bodily with all its cxternal characters by forcing melted wax with the aid of the air-pump into the pieces of tuff, and then dissolving the calcium which surrounds them by dilute hydrochloric acid. Fine specimens of the kind are cxhibited in the Paris Museum. In the collection also at the Sorbonne there is a series of such preparations obtained by Munier Chalmas from the lower Eocene tuffs of Sezanne; the most remarkable of them is a flower of Byttneriaceae with all its parts well preserved. We often find the same process carried out in pyrites, only there it is the work of nature herself; another instance is that of the fern-leaves of the Carboniferous beds of the Tarentaise, which glisten white and conspicuous on a dark ground; in these the substance which has disappeared has been replaced by a cast of magnesium silicate which fills the cleft-like cavity.

It is evident therefore that in cxamining specimens of this kind careful attention must be paid to the relations of form between the cast and the mould, and this care will be the more necessary, because circumstances now 
to be mentioned may add considerably to the complications. Both mould and cast in the same object, for example in a stem, may turn out quite differently according to the condition in which it was inclosed in the petrifying substance, a fact to which Steinhauer ${ }^{1}$, as far as I know, was the first to call attention. For example, every one is acquainted with the ordinary impressions of Sigillaria, such as are common on every heap of refuse from our coal-pits, which answer to the outer surface of the epidermis and are characterised by the projecting rib-like orthostichies with the leaf-
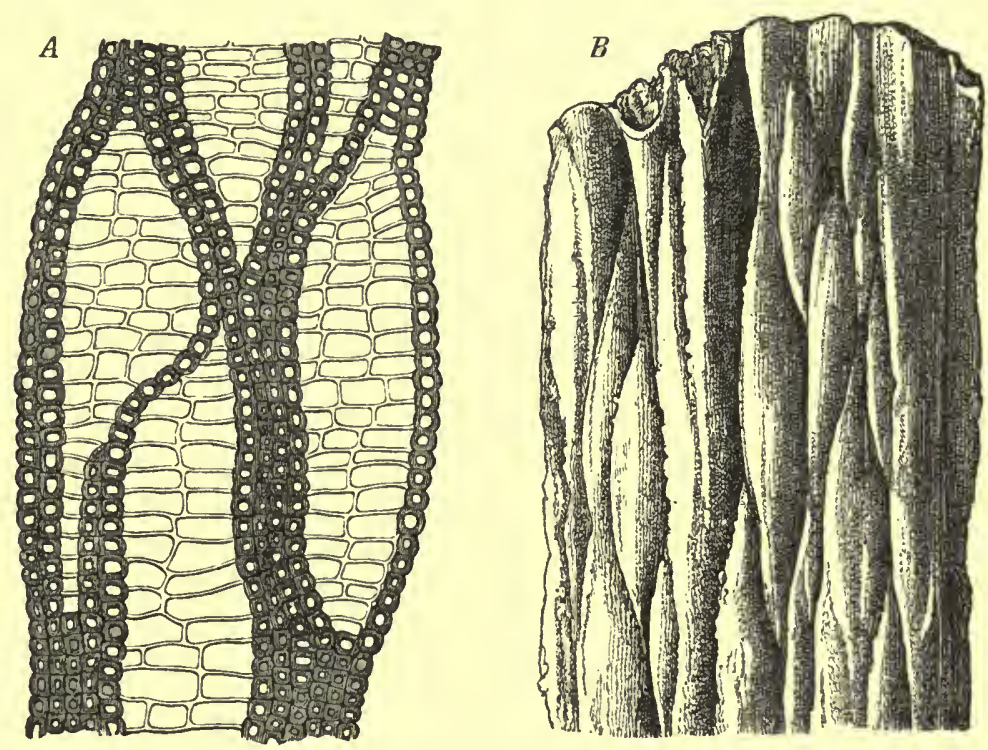

FIG. I. Dictyoxylon-structure of the rind as it occurs in some Lepidodendrae and Sigillariae, and in Lyginodendron, \&c. $A$ transverse section of the outer rind of Lepidodendron rhodumnense, B. Ren., showing the anastomosing plates of sclerenchyma which bound the meshes filled with parenchyma; the longitudinal section is quite similar, only the sclerenchymatous elements are seen in elongated form. $B$ impression of the inner side of such a Dictyoxylon-rind separated from the stem. The ribs are more prominent owing to the disappearance of the parenchyma, and answer to the furrows. The rhombic cushions fill the depressions caused by this disappearance of tissue in the meshes. $A$ after Renault ${ }^{2}, B$ after Williamson ${ }^{3}$.

scars marked on them at regular distances. The examination of silicified specimens shows that the parenchyma of the rind of these plants was traversed by a net-work of sclerenchymatous strands forming vertical elongated meshes of irregular rhombic form (Fig. I $A$ ). Now impressions exactly reflecting this structure are found, though not too frequently, in which the rhombic areolae appear as similar convex projections of unequal elevation (Fig. I B). There are many reasons for believing that in these objects, which look so unlike one another, we have merely the impressions of stems of Sigillarias stripped of their rind, and with the net-work of 
lignified ribs projecting on the surface above the shrunken parenchyma. Williamson ${ }^{1}$ has explained this peculiar state of preservation. As the rind of the Sigillarias went by the name of Dictyoxylon, Will., when its connection with the stem was not yet recognised, the word, though now superfluous, may still be used to designate this particular form of structure. There are many species from the Carboniferous which had these Dictyoxylon-rinds.

Other plants beside the Sigillariae, the Lepidodendrac for example, occur in the form of impressions which represent the different surfaces of denudation of the stems. In transverse sections through the casts of Stigmarias we often observe a narrow circular line of fissure which appears to be filled with traces of coal. Longitudinal fracture shows that this line answers to the bounding surface of a second exactly cylindrical cast lying within the other, and having its surface marked by entirely different and characteristic features of its own. There can be no doubt that this inner cast owes its origin to the circumstance, that on the destruction of the inner tissue previously to the filling in with mincral matter a hollow cylinder of tissue answering to the inner side of the secondary wood resisted decay longer than the rest, so that when it disappeared two hollow cylinders of preserved tissue remained lying one inside the other. The inner cast answers to the inner space occupied by the inner tissuc, the outer to that occupied by the outer. The dividing layer cannot indeed have been very substantial, for in that case it must have appeared in the form of an evident rind of coal.

A quite peculiar and usually rare kind of mould and formation of a cast has recently played an important part in the controversy which has arisen between Gaston de Saporta ${ }^{2}$ and Nathorst ${ }^{3}$ respecting the algal nature of certain fossils. In some regularly stratified deposits (Saporta gives as his chief instance the Kimmeridge strata of Cirin with branches of coniferous plants) on the under surface of the beds casts are found, which project in half-relief only, and fill corresponding depressions forming half-moulds in the bed as it lies. There is no rind of coal ; mould and cast show the same sculpture negative and positive. There are only two ways of explaining such cases as these. They may have arisen from the investment of parts of plants which contained little solid material and much water, and which soon collapscd, such as are of frequent occurrence among Algae. The thick algal thallus collapsed immediately after investment, the mud which covered it being still soft sank with it, and the organic substance was so scanty that it oozed away in the under-layer, or at any rate could not give rise to any appreciable quantity of coal. But this mode of explanation does not suit branches of Conifers, and in their case we can only imagine, that after being deposited in the mud they were then removed from their beds by subse- 
quent denudation of the covering mass, and that these beds served later on as moulds for succeeding deposits, exactly as in the case of the tracks of crabs described by Nathorst. A similar explanation may be given of the leaves of Nymphaeaceae from Tertiary formations adduced by Saporta ${ }^{1}$ in his elaborate account of this 'fossilisation en demi-relief;' in the case of the fragments of the rhizomes of the same plants shreds of the epidermis may have been set free by the rotting of the plant, and been floated into the place where the fragment was being preserved. A careful examination of this question will be found also in the introduction to Delgado's work ${ }^{2}$.

Coal-seams, or coal-streaks as they are termed when they are only slightly developed, are a very special kind of incrustation. The only difference between them and the impressions of plants hitherto described is, that in their case not single fragments but huge deposits of vegetable remains are incrusted together with conversion of their substance into coal, and are inclosed in a mass of material which hardens into stone. The opposite faces in the impression are in this case the roof and floor of the seam, and parts of plants which happened to lie on the surface of the seam, and which cannot now be distinguished in the coal itself, are not unfrequently shown in well-preserved moulds in the bounding surface, especially in the roof. Many instances of the kind are adduced by Göppert ${ }^{3}$, who found in the roof of coal-seams in Upper Silesia impressions of one side of large tree-stems which could sometimes be traced for a length of several metres.

It is in a very small portion only of the coal-seams that their origin from fragments of higher plants can be readily seen at the first glance. This is most frequently the case in the brown coals of the more recent formations; it occurs much more rarely in the coals of the mesozoic and palaeozoic ages. An excellent example is afforded by the coal-beds of Central Russia. We learn from Göppert ${ }^{4}$ that at Malöwka in the Government of Tula, besides more compact kinds of coal there is one which consists entirely of flakes, like sheets of paper, loosely united together and pierced with little holes, and that closer examination shows that these flakes are shreds of the cuticle of Lepidodendreae (Lepidodendron tenerrimum, Eichw., Bothrodendron punctatum, Grand' Eury). They are so slightly coherent that they can be blown apart by the wind. Nevertheless these coals belong to the oldest formation, which generally contains beds of the most compact coal; for geologists, though they differ in opinion on particular points, agree in placing them on the horizon of the Carboniferous limestone.

The older coals, the pit-coals, are usually compact, more or less schistose and tolerably homogeneous, dull or bright, and of a black colour. From their outward appearance they would be taken for simple minerals, 
as was done by the earlier writers. It was by different ways that men at length arrived at the conviction that they are all of organic origin, and that they consist of fragments of plants in a greatly altered condition, placed in layers one above another, and firmly caked together with the help of a fine silt or detritus.

One way was the cxamination of thin sections of coal under the microscope - a method first adopted by Witham ${ }^{1}$ in 1833 , and recently employed by Reinsch ${ }^{2}$, and by Fischer and Ruist ${ }^{3}$. We are still looking for the results of similar investigations commenced by Williamson some time ago. In this way we have learnt that anthracite in the mass is almost absolutely homogeneous and non-transparent. A few evident traces of the tissue of the higher plants were detected in anthracites, together with a great number of small spaces or areas occupied by a transparent orange-ycllow or garnetred substance, which might certainly be compared to cells filled with secretion, though very dissimilar in shape. The substance of these arcas is said by Fischer and Ruist to consist of resin or some hydrocarbon ; it burns readily, and is partially soluble in carbon bisulphide or in ether, the dissolved portion crystallising in needles on cvaporation of the solvents. These areas are much more abundant in cannel coal than in anthracitc. Boghead coal from Scotland appeared to be almost entirely composed of them. Large quantitics of hydrocarbon may be obtained according to $\mathrm{Muck}^{-4}$ from coals of this description by treating them with ether, and the solution is beautifully fluorescent. Reinsch, who also observed these brown-coloured arcas, saw in them the remains of organised structure; he recognised in the mass of coal, that is, in the small partial layers of the seam, stromata with cavities interspersed, and considers them to be the product of membraneless protoplasm-masses springing from lower organisms. In presence of the botanical investigations which we shall have to notice, we need not go further into these fancies, which must not be taken seriously.

The probability of our getting sight of organic fragments to any considerable cxtent on the surface of a section of coal was never very great. It is not surprising therefore that greater success was attained from the first by simply breaking up the coal into very small splinters, and endeavouring to make these transparent by means of petroleum. Link $^{5}$ especially, and Göppert ${ }^{6}$ also, pursued this method, and the latter demonstrated the presence of the skeletons of single cells and fragments of vessels in coal-ashes.

But by far the most important method of investigation was that tried by Schmid and Schleiden ${ }^{7}$, who endeavoured to reduce the compactness of the coal by maccration. Their imperfect mode of treatment with

\footnotetext{
${ }^{1}$ Witham (1). $\quad{ }^{2}$ Reinsch (1). $\quad$ ' Fischer (1) (Fischer und Ruist). 'Muck (1), p. ${ }_{4} 8$.

${ }^{3}$ Link (1). "Göppert (2). 'T Schmid und Schleiden (1).
} 
sodium carbonate was not without success; but F. Schulze ${ }^{1}$ obtained much more important results by maceration with the fluid which is named after him, and by subsequent treatment with ammonia. In this way, especially if the treatment is continued for a long time and the temperature is not raised, it is in fact possible to isolate fragments of tissue in large quantities from most kinds of coal. I have seen single scalariform tracheides and groups of the same, and spores of every kind in excellent preservation in original preparations by Schulze, and have convinced myself by repeated trials of the suitableness of this mode of proceeding. The method has been quite recently improved by Gümbel ${ }^{2}$, who has substituted absolute alcohol for ammonia in washing the specimens, since it was found that parts still preserved and showing the form of the remains were dissolved by the ammonia.

The tissue-remains which can be thus isolated in the coal are in the great majority of cases such parts of the plant as have their membranes strongly cuticularised, spores for example, and bits of cuticle which show the gaps for the stomata. These objects are in general well preserved, though great caution must be observed in judging of the details of their form, because cuticularised membranes from a certain plasticity which they possess are apt to suffer changes of form, which long experience alone can enable the observer to recognise as artificial with any degree of certainty. It will be an important work to examine the epidermal structure of the rind of coal in known fossils on a more extended scale with the aid of the methods here described, since comparatively little can be learnt on this point from thin slices. We owe much the largest part of what has been done in the way of this examination of the epidermis to the labours of Schenk, who has been careful in all cases to examine the carbonised coating of the impressions, and has generally obtained connected shreds of cuticle, even where the component parts of the rest of the tissue could no longer be distinguished. Fragments of the membrane of highly lignified elements, scalariform tracheides for example, are much less frequently obtained; at the same time they are always almost entirely unchanged, showing pits and bordered pits sharply defined. Their fragile nature, for they split up into diminutive angular pieces, explains perhaps the rarity of their occurrence. Spiral tracheides and sclerenchyma-cells out of shape are observed here and there, while ordinary parenchyma is scarcely ever seen. Much useful information on these points is to be found in Reinsch's ${ }^{3}$ work, only we must disregard his interpretations.

We may now proceed to consider how far the results obtained by many observers from the examination of the coal-seams themselves go to prove that compact coal is composed of the fragments of plants. These results are to be seen collected together in Göppert's ${ }^{4}$ larger treatise, where

1 F. Schulze (1).

${ }^{2}$ Gümbel (2).

${ }^{3}$ Reinsch (1).

+ Göppert (14). 
there is also an account of his own protracted researches, especially in the coal-districts of Silesia. First of all coal-seams are found which may be directly shown to be composed of the stems of Sigillaria and Lepidodendron, for impressions of these plants may be seen in abundance on the bounding surfaces of every layer. Such seams are found in England, but according to Lindley and Hutton ${ }^{1}$ they do not seem to have been often observed there; in Upper Silesia they are quite common. Two instances may be given from the many cited by Göppert. He found thick seams in the southern district of Glciwitz or Nicolai which show this character completely. These Sigillaria-coals are obtained especially from the Fricdrich pit near Zawada. Göppert gives a figure of a piece of coal from the neighbouring Leopold pit which shows numerous impressions of this plant lying across one another in two distinct layers. At Heinrichsfreude near Lendzin the coal consists almost entircly of Stigmarias, and these together with the many small stems of Araucarites which are said to occur close by them would be well worth renewed investigation. At Zawada, moreover, between the Sigillaria-seams were observed smaller layers consisting exclusively of leaves, which Göppert says are the leaves of Sigillaria. At Dombrowa and Myslowitz flattened stems of coniferous structure were found plentifully in the seams, and similar stems at Radnitz in Bohemia. Impressions of ferns also are sometimes though rarely found; I have seen them myself from the coal (Plattelkohle ${ }^{2}$ ) of Nürschau in Bohemia. A further series of examples is supplied by Grand' Eury ${ }^{3}$ from the coal-mines of Central France. In Avaize the coal consists of Psaroniae, Calamites and Fernleaves, in other places almost entirely of leaves of Cordaites. The coal of the Wealden formation of Duingen in Hanover contains frequent intermediate layers formed entirely of needles of Conifers (Abietites Linkii of authors), which may be isolated.

An important part of Göppert's treatise is devoted to proving that the differences, which we find at the present day in pit-coal, may often be traced back to the original composition of the substances obtained from the remains of different plants and converted into coal. Lindley and Hutton ${ }^{4}$ had already given utterance to the same idea. Göppert derives his proofs from the present condition of the coal itself. Far from consisting of pure carbon, it is possible that it contains no carbon at all in the free state (see Muck ${ }^{5}$ ), but only a mixture of hydrocarbons of varying composition and compounds of a variety of substances rich in carbon. The chemical constitution determines the practical distinction into caking coal, fritting coal,

1 Lindley and Hutton (1), vol. ii, Introd.

[ ${ }^{2}$ Mr. F. W. Rudler, of the Museum of Practical Geology, sends the following explanalion of this word:-'Plattelkohle-also Blattelkohle and Brettelkohle-a bituminous schist in Bohemia, like Boghead mineral or like Cannel, and used with ordinary coal in gas-making.']

' Grand' Eury (2), p. $4_{4}$. 'Lindley and Hutton (1). 'Muck (1). 
non-caking coal, and anthracite; the differences are made apparent by the application of heat, when caking coal swells up considerably and liquefies and forms coke, but the other kinds do not. The amount of carbon contained in them increases constantly from caking coal to anthracite, while that of the volatile hydrocarbons diminishes in the same direction, and this change is generally coincident with decrease in the number of the transparent yellow or red areas mentioned above. Coals may also be divided according to their external character, colour, texture,- - a mode of division which shows no relation to the one previously mentioned,-and in this way we distinguish brown coal or lignite, anthracite, cannel coal and fibrous coal (the fusain of the French, fossil wood-coal of older authors).

Ordinary observation teaches us that external conditions have had a great deal to do with causing these differences in the constitution of the different kinds of coal. Every one knows how rapidly coal taken from the mine changes in the air, how it falls to pieces even when it contains little or no iron pyrites, and thus loses some of its value as fuel. Analogous processes have gone on in the course of time in the seams themselves before removal from the mine. Thus Göppert ${ }^{1}$ cites many cases in which seams of caking coal in the neighbourhood of that which is being removed change gradually into fritting coal and non-caking coal; he states that the two latter kinds almost everywhere take the place of caking coal at points where great faults traverse the seam and displacements have occurred. Moreover, the coal of seams of the most different character becomes anthracitic by contact with intrusive porphyry, and this is often accompanied with the appearance of columnar structure. Seams of caking coal also are locally converted into coke by similar intrusions; the eruptive rock may even occasionally change the coal into graphite. Delesse ${ }^{2}$ mentions a case of this kind described by Boué from New Cumnock in Scotland, in which the direct passage of coal into anthracite and graphite may be observed. A similar case occurs according to Rink in Greenland, where coal is changed into coke, into anthracite with a semi-metallic lustre, and even into graphite ${ }^{3}$. Hence it would appear that caking coal, fritting coal, non-caking coal, anthracite, and graphite are successive stages of development, through which any given coal-seam may pass. If this is so, there is ground for surmising that some layers of graphite, at least of the old formations, are the final condition of a process of development, which our seams of coal may also in certain circumstances eventually reach.

If the seams exposed to these external influences throughout their entire mass in essentially like manner always contained coals of thoroughly similar character, we might in that case ascribe the differences which distinguish them from one another exclusively to the different effects of these

$$
{ }^{1} \text { Göppert (14). } \quad{ }^{2} \text { Delesse (1). } \quad{ }^{3} \text { Heer (3), vol. i, Introd. p. } 4 .
$$


influences. This is, however, almost never the case. It commonly happens that layers of very different character alternate in the seams, and as they are suitable for different economic purposes, they are kept separate when the coal is removed from the mine. The single layer too is seldom of the same composition throughout, but is very frequently made up of thin alternating secondary layers, - of dull, for example, and of highly lustrous coal. Further, in many places, such as Upper Silesia, Zwickau, and St. Etienne, fibrous coal is found in irregular nests, masses and strips breaking through and traversing the other kind of coal, so that the whole assumes a highly complicated structure, which varies from case to case and has been taken into consideration in naming the different coals. Thus anthracite, which is traversed by an unusual number of layers and strands of fibrous coal, is termed sooty coal $^{1}$, and as in such cases the parts of the seam which are of like character were exposed to the like external influences, the difference in detail must depend, as Göppert concludes, on the originally dissimilar character of the material employed in the formation of the coal. This dissimilarity we may ascribe with Göppert to the association of different species of plants in varying proportions, or with Grand' Eury ${ }^{2}$ to the bringing together of parts of plants, in which specific difference had less effect than the varying degrec of decay and maceration in each case. -

To increase the probability of all these conclusions, Göppert ${ }^{3}$ also set himself to test them by the method of experiment. Similar attempts had been alrcady made by Wiegmann, and after him by Petzholdt ${ }^{4}$. Unfortunately they were none of them thoroughly and logically carried out. Göppert experimented with portions of plants in closed vessels with water at a temperature of $60-80^{\circ} \mathrm{R}$., and for a period extending over several years, and he states that his material formed at length a brown coal-like mass. Lustre and black colour were only obtained by addition of a small quantity of sulphate of iron. Coarse cloth which covered the cylinder in a cloth-manufactory, after being many years in use, was found to be converted into black coal with conchoidal fracture. Unfortunately none of these substances was cxamined chemically; we do not know therefore how far it could be compared with true pit-coal.

From all that has been ascertained through the efforts of different observers, there can be no longer any doubt that layers of coal have been formed of fragments of plants and of vegetable detritus under water; and therefore we have long seen the necessity of studying analogous processes going on before our eyes at the present time under similar conditions, namely those which result in the formation of peat and brown coal.

The formation of peat is everywhere dependent on the presence of

${ }^{1}$ Mietzsch (1) $\quad$ 2 Grand' Eury (2). $\quad$ 'Göppert (15). ' Petzholdt (1).


water, which, held up by impermeable strata and remaining on the surface for some time, thus protects the parts of plants which find their way into it from rapid normal decay. Instead of this decay, a different chemical change takes place with formation of hydrocarbons and acids rich in carbon (humus-acids). By this means the vegetable mass, which to some extent breaks up into diminutive fragments, becomes converted in comparatively short periods of time into a tolerably homogeneous brown to brownish black pulpy substance, the constituent elements of which can no longer be perceived without minute examination. Two kinds of peat essentially different from one another may be distinguished according to the mode of formation, and especially also according to the plants which supplied the material ${ }^{1}$.

There is, first, the peat of meadow peat-mosses and lake-marshes (lowland or lake-turbary), such as so often occupy the bottoms of valleys and other depressions in the north of Germany, or are found everywhere accompanying the course of streams and covering a greater or less extent of ground. Such peat-beds are in their first stage generally lakes bordered by marshy ground, but the remains of vegetation gradually push forward from the edge of the lake and ultimately form an unstable covering over the whole surface of the water, and continually sinking to the bottom there collect and fill up the lake, which thus passes into its second stage. The plants which form the sinking mass of peat are mainly Cyperaceae, with some grasses and other angiospermous growths and a few mosses. The mosses are not Sphagna so much as Hypneae, Aulacomnion, Meesia, Philonotis, and similar forms. The matter which covers the bottorn of the lake is a brown detrital mass mixed with many membranous shreds of roots, leaves and leaf-sheaths. In peat-nosses of this kind, if the depth is not too great, Phragmites vulgaris plays an important part. With them may be classed the swamps of the coasts of North Germany, which through sinking of the land or the irruption of the sea are now below the sea-level, and are overlaid by sand and beds of clay. Here the decay of the component substances is less perfect; the leaves and stalks of reeds may be quite plainly distinguished in the exfoliating peat. These products are much less valuable than the good rich peat formed in meadow peat-mosses and deep lake-marshes.

We have, secondly, the peat of peat-bogs (mountain turbary), which is proper rather to mountain districts, but may develope in favourable circumstances upon the basis supplied by former peat-mosses. In northern countries, and especially in the neighbourhood of both poles, peat-bogs are common at lower levels; in the lowlands of Germany they occur chiefly on the expanses of higher ground which separate the river-valleys from one another. Of all the German peat-bogs those in the district of Ems have been most carefully 
examined by Grisebach ${ }^{1}$, and those of the table-land of Upper Bavaria by Sendtner ${ }^{2}$. Peat-bogs are formed only where Sphagna find facilities for their free development, where, as the first condition, they have water at command which was either free from lime from the first, or at any rate which no longer contains lime in solution. It is true that according to Grisebach, with whom most modern writers agree on this point, the Sphagna by themselves produce only a very poor peat, which is known as moss-peat, a loosely felted brown mass which never becomes true brown heavy peat. But by their vegetation they enable other plants, the Ericas especially, to thrive on the surface of the bog, and the remains of these plants give rise to a true peat of a similar character to that of the peat from the lake-marshes. A peat-bog of this kind always begins with a colony of Sphagna, which growing upwards in compact masses die down below and thus raise the surface, while they hold the water like a sponge. When the surface of the bog has thus become convex, it begins to dry up and is covered with plants which grow in clumps-Erica, Betula nana, Scirpus caespitosus, and others. The remains of these plants falling to the ground are enveloped by the Sphagna, and are thus withdrawn from the influence of the air. In this way an upper heavier layer of peculiar character is gradually formed, the weight of which depresses the general mass of the bog, and more favourable conditions of growth and a more copious supply of water are naturally secured for the Sphagna. By the continuance of this process the moss-peat is compressed, and sinks deeper and deeper in the bog beneath the weight of the overlying and constantly growing mass. Grisebach found in the bogs of Ems a thin layer of compressed moss-peat, the original Sphagnumbed, forming the base of the black peat. The deepest layers of these peatbogs are often found to contain large tree-stems only slightly macerated and altered, and erect stumps of trees. In this case the peat-bog was developed in a wet and wooded spot, and gradually destroyed the trees and closed over their prostrate stems. We may observe this process going on at the present day in our own mountain districts, in the Harz and in Thüringen; forestry in these highlands is everywhere at strife with the peat-bogs, which left to themselves are always growing, and by the advance of their margins eat their way into the adjoining forests and make irregular gaps in them. To put a stop to this process the administration is chicfly and constantly engaged in draining and planting the ground, though trees do not thrive at such an elevation and in such a soil, and they can never be expected to repay their cost.

Lignite or brown coal, of a brown, brownish black, rarely black colour, and always streaked with brown, much richer in hydrogen and oxygen than 
pit-coal, and often inclosing pieces of wood in good preservation, is widely diffused through the strata of the Tertiary and Quaternary formations. There is no doubt that it has usually proceeded from substances of the same character as our modern peats. All intermediate states are found between true lignite and normal marsh peat or lake peat with pieces of wood and stems of trees occasionally imbedded in them. The connection is established especially by the slate-coal, as it is termed, of the Quaternary formations of Utznach and Dürnten in the north of Switzerland, and in Upper Bavaria. Proof of this is supplied at great length by Heer ${ }^{1}$ and Gümbel ${ }^{2}$. Lignite occurs in many cases, as is well known, in rotten crumbling masses, which must be pressed in moulds before they can be used; in other cases it contains less water and has a slaty cleavage, but is still tolerably homogeneous. The formation of all the above coals finds an immediate parallel in that of the peat of our lake-marshes. But this is not the case with the lignite from other formations, which is composed for the most part, sometimes almost exclusively, of accumulations of wellpreserved stems of trees capable of being split like firewood, and occasionally alternates with layers consisting entirely of leaves. These deposits were doubtless formed in a different manner, but in their case also we have thoroughly suitable objects of comparison from our own times. We may cite first the colossal masses of tree-stems which are carried down by the great American rivers, the Mississippi, for example, and the Mackenzie, and deposited in lagoons in the lower part of their course, and in the stagnant waters of their deltas. Entire layers of such stems are actually found in the delta of the Mississippi buried deep in sand and mud, which though belonging to the most recent alluvial strata have already assumed the character of a true brown coal ${ }^{3}$. That this alteration of recent wood sets in very quickly may be gathered from various observations. For instance, some wrought timbers, buried in the 'Old Man' of the Rammelsberg, in the mine of St. Joachim near Zellerfeld, and in that of Dorothea near Clausthal, were disinterred according to Hirschwald ${ }^{4}$ and Hausmann ${ }^{5}$ one hundred to one hundred and fifty years perhaps after they were put up in the mines, and were found to be in a soft and moist condition, but when dry they proved to have been converted into a lignite of a black colour and lustroûs conchoidal fracture. Göppert had before observed timbers in the coal-mines of Charlottenbrunn, which after being kept in them for a long time were converted into lignite. Unger ${ }^{6}$ has described a piece of wood of this kind from the iron-mines of Turrach in Styria, which had suffered a similar alteration, as was shown by analysis. But the most striking proof of the shortness of the time required has been supplied by Mietzsch ${ }^{7}$. He.

\footnotetext{
1 Heer (16).

${ }^{2}$ Gümbel (2).

${ }^{6}$ Unger (6).

3 Lyell (1), p. 242.

4 Hirschwald (1).

${ }^{5}$ Hausmann (1).

${ }^{7}$ Mietzsch (1), p. 234.
} 
found in the coal-mine at Planitz near Zwickau, in a working which had been opened six years before but had meanwhile fallen in, a piece of wood several decimetres long which was entirely changed into a dark brown coal. All these alterations Hausmann refers directly to the effect of the sulphuric acid arising from the pyrites. Even the coals of the Coal-measures may have reached their ultimate condition in a comparatively short time. This is suggested by the remarkable rolled fragments of coal of Commentry and Champagnac les Mines, which have their edges sometimes still sharp. These fragments, the description and bibliography of which will be found in de Lapparent ${ }^{1}$, are a component part of the Carboniferous conglomerate which lies above and below the coal-seams; seams of coal must thcrefore have been in existence at the time when the conglomerates were formed from their erosion and destruction.

Again, we may compare the lignite-formations in question with the cxtensive woody swamps along the east coast of $\mathrm{N}$. America from Virginia to Florida. We are indebted to $\mathrm{Lyell}^{2}$ for a description of one of the largest of these, which lies not far from the sea in the neighbourhood of Cape Hatteras and is known by the name of the Great Dismal Sivamp. It is composcd of a black pulpy ooze overrun and concealed by a dense tangled covering of low shrubs, in which large trees, chicfly Taxodium distichum and Chamaecyparis sphaeroidea, have taken root. These trees sometimes sink of themselves in an upright position in the ooze, or they are blown down by the wind and fall into it, in which case their woody substance remains in a state of perfect preservation. Great quantities of valuable wood are thus fished out of the swamp. It is a remarkable fact that in consequence of the covering of vegetation which prevents the dispersion of the watcrs the middle of the swamp is occupied by a large lake some twelve fect higher than the surrounding land.

From all the evidence which has been collected up to the present time we may without hesitation refer the formation of the coals of every period in the carth's history, from peat backwards to graphite, not indeed to identical but to analogous processes. It would be going too far to connect them all together in onc series of dévelopments and to assume that pitcoal had at first the character of lignite, and that our deposits of lignite would in course of time become coal ; on the contrary, this mode of formation was affected in each particular case by external influences which were different at different times, as is clearly shown by the rolled coalfragments mentioned above, and by the coals from the lower beds of the Coal-measures of Central Russia which occur in conjunction with true coal and also with deposits resembling lignite. So far we may consider that there is at present a gencral consensus of opinion.

1 de Lapparent (1), vol. ii, pp. 842, 866 .

${ }^{2}$ Lyell (2), vol. i, p. $14^{2}$. 
But with this general idea of the process in question we are still far from having a thorough understanding of it. On the contrary we are confronted with a succession of new doubts. There is the question often raised by the earlier authors, where the plants grew whose remains we now see gathered together into coal-seams. The question has been answered in more than one way. Some have thought that coal was formed in the sea by the accumulation of sea-weeds, but this view was soon set aside by further investigation. Others, as Count Sternberg and Boué, appealed to the trunks of trees in the Mississippi, and conceived of masses of drift-wood accumulated by mighty rivers. Gümbel ${ }^{1}$ named this view the theory of allochthonous origin. Others again have sought a probable explanation of the matter by a comparison with our present peat-bogs and made the entire material of the coal-seams grow in loco, adopting therefore the theory of autochthonous origin. This view was defended in the eighteenth century by Beroldingen and de Luc, and it was accepted with gradually increasing decision by most of the eminent geologists and palacontologists, especially by A. Brongniart and Elie de Beaumont ${ }^{2}$; it was completed and put into consistent shape by Göppert ${ }^{3}$, and Unger $^{4}$ accepted his ideas with some reservations. The view intermediate between these two, that the mode of formation varied as in the case of the lignites and was sometimes allochthonous, sometimes autochthonous, also makes its appearance with more or less distinctness, especially among the older autochthonists. Göppert opposed this theory in the most decided manner, repeatedly pointing to the extraordinary uniformity in the layers of coal in all parts of the world. We shall see presently that it has recently reappeared with certain reasonable limitations under the auspices of Grand' Eury ${ }^{5}$.

Göppert ${ }^{6}$ and Unger $^{7}$, and before them Lindley and Hutton ${ }^{8}$, adduce many weighty arguments to show that the assemblage of phenomena presented by the seams of coal cannot be explained by the assumption of an allochthonous origin. On this assumption, says Göppert, it is inconceivable that the coal-seams should cover such enormous spaces in beds that are everywhere alike and are of equal size, and again that coal should be so homogeneous and so pure in quality that it is rare to find fragments of stone inclosed in it. For every stream that was to carry along with it so much vegetable matter must have been strong and rapid, and would have carried down at the same time mud, sand, and gravel. We should therefore expect to find in the seams a regular alternation of coal and inorganic material. But this has not been observed anywhere; a comparison with the composition of living plants shows at most a considerable increase in the ash-constituents, but this is quite intelligible if we take into considera-

\footnotetext{
1 Gümbel (2).

5 Grand' Eury (2).

${ }^{2}$ Grand' Eury (2).

3 Göppert (14).

4 Unger (6).

Göppert (14).

Unger (6).

${ }^{8}$ Lindley and Hutton (1). 
tion the loss of organic compounds necessarily connected with the process of carbonisation. Again, such powerful streams, as would be required to transport the whole of the materials which formed our seams of coal, must have been too turbulent to have been favourable to the preservation of vegetable remains. But we find all the impressions of the plants regularly spread out on the planes of stratification in the thin slates of the clay-beds, which so often occur in the roof of the seams. The most delicate fernleaves are beautifully preserved, showing their pinnae in the normal position and never twisted about by the eddies of a stream. All these circumstances are in favour of the view, that the slaty beds also which form the roof of the coal-seams were deposited with a quietness which excludes the action of a strong current.

Unger $^{1}$ also is a decided supporter of the autochthony of the beds of coal, but he is at the same time convinced that the bogs of the period of the Coal-measures could not have answered properly to our recent peatbogs, and has distinctly expressed this opinion. He shows quite convincingly ${ }^{2}$ that we must on no account imagine that they resembled the peat-bogs of our mountain districts, for a uniform tropical temperature prevailed over the whole surface of the earth during the formation of the coal-seams, and such a temperature would appear to be incompatible with the existence of upland peat-bogs. This is doubtless true; there are no beds of Sphagnum in the tropics, or they form only here and there on the highest mountains; and that a uniform temperature prevailed over the whole earth in the time of the Coal-measures is certain from the fact, that in deposits of that cra from north polar regions to Australia assemblages of plants essentially similar if not identical are found everywhere as constituents of the coal. On this point the reader may consult Carruthers ${ }^{3}$ for Brasil and also for Queensland ${ }^{4}$, O. Feistmantel ${ }^{5}$ and Mac Coy ${ }^{6}$ for Australia, Dawson ${ }^{7}$ for Canada and New Brunswick, Heer ${ }^{8}$ for Polar lands, Schenk ${ }^{9}$ for China, Zeiller ${ }^{10}$ for the Zambesi country, Grey ${ }^{11}$ for Cape-colony. Unger evidently knew of but one analogous case to which he could appeal in the tropical zone, namely that of the floating islands in the lake of Tagua in Bengal which are covered with trees and shrubs. Had he been better acquainted with the Great Dismal Swamp, he would certainly have noticed it, for it would have answered in all essential points to his idea of the swamps of the Coal-measures. Göppert ${ }^{12}$ had meanwhile become acquainted with Lyell's communications on the subject, and has quoted them in the preface to his work as an adequate representation of his idea of the bogs of the Carboniferous period.

\footnotetext{
1 Unger (6).

${ }^{2}$ Unger (6), p. 135 .

${ }^{3}$ Carruthers (7).

Carruthers (10).

${ }^{3}$ O. Feistmantel (1), iii.

19 Zeiller (13).

11 Grey (1).

7 Dawson (8).

- Heer (5).

"Schenk (2).
} 
Lastly, as has been already said, Grand' Eury ${ }^{1}$ has quite recently adopted an intermediate view on the strength both of botanical investigation and of long mining experience. He brings forward a number of facts which are opposed to Göppert's reasons for pure autochthony, and does not rest his argument solely on the stratified condition of the seams of coal, as Gümbel ${ }^{2}$ supposes, for this would not suffice for his purpose. The picture which he draws of the state of the surface of the earth when coal was formed may quite possibly come very near to the reality.

It is a known fact that fossil remains are usually found in a flattened condition; it would appear from many observations of Göppert, Grand' Eury, and others that this is the case also in coal. The cause of this phenomenon is usually alleged to be the pressure exerted by the overlying masses of stone, and this same pressure we have become accustomed to regard as the main factor along with the effects of heat and water in the formation of coal. Grand' Eury shows most convincingly that this action of pressure, if there was any, can have been of only very small importance, In the famous angular siliceous pebbles discovered by him at Grand' Croix near St. Étienne, which inclose the petrified material of a layer of coal in the act of formation, the remains of the plants are for the most part in a flattened form, although they lie loosely on and over one another in the pebbles, and there is no trace whatever of any pressure. Both in these pebbles and in normal seam-coal we have the most abundant proof of the remarkable fact that these flattened stems, roots, and branches consist wholly of a tube of rind, from which the inner tissues, and especially the woody axes, have been removed. This is the case not only with the Lepidodendreae with thick succulent rinds, but also with the Cordaitae which had larger woody bodies and must therefore have been of a much less succulent character. It is observed also that if the tubes of rind still embrace their cylinder of wood, the latter is commonly split into irregular fragments which are often displaced; sometimes single fragments are still found in their place and position while the rest are removed. It is further remarkable that the tubes of rind are very frequently slit up on one side, and then rolled over at one margin of the slit; as a rule also they occur only in pieces of moderate length, entire stems being rarely found in the seams, though, according to Göppert, these seem not to be so infrequent in Upper Silesia. Now if coals are of purely autochthonous origin, all these circumstances must appear very strange; on the other hand they are quite intelligible, if we suppose them to result from the action of a slow stream of water overflowing ground covered with dead and decaying trees and fragments of plants. We can imagine how in such a case the softened and 
disintegrated wood might be floated away from the case of rind, which would be quite inconceivable if trees and branches had simply fallen into stagnant water. As regards the softening of the wood, we know that this may be constantly observed at the present day in wet neglected forests. I have myself seen the conditions assumed by Grand' Eury in the case of the forests of the Coal-measures very well shown in the Böhmerwald, in the primeval forests at Arber and Kubany. We may also compare the description given by Göppert ${ }^{1}$. The softening of the wood reduces it to a shapeless plastic mass, which is easily penetrated in every direction by the roots of other plants (Stigmarias), and settles itself and bccomes folded together, and thus in many cases so alters the disposition of its elements, that in wide-celled coniferous woods even the lumina of the individual cells disappear by collapse of the membranes. This is the case with the wood of all kinds in lignite, and constantly strikes the attention of every one who examincs fossil woods. The timbers from the Dorothea mine near Clausthal mentioned above, which were converted into lignite, were moist and of soft leathery consistence in the place in which they werc found, and only bccame hard after a short exposure to the air. That the woods also from the petrified forest of Radowenz were in a perfectly soft state before petrification is concluded by Göppert ${ }^{2}$ from the circumstance, that they often show small superficial pits with a bit of flint at the bottom of each pit. These bits of flint must have sunk into the substance while it was still soft.

Amid similar countless fragments of wood which rottcd away on the wet soil of the forest, the flint pebbles of Grand' Croix also occasionally contain well-preserved bits of twigs and leaves, and even flowers and inflorescences in almost perfect condition. This state of things too would be very difficult to explain on the theory of a purely autochthonous deposition; we should rather cxpect to find all the remains in a nearly similar and medium condition. But it would be sure to occur in case of transport by running water, which would carry away with it at the same time fragments just fallen from a tree and such as had long lain rotting on the ground. Again, without the eddies caused by the confluence of streams we should be quite unable to account for the frequent enormous accumulations of wood, leaves, and seeds in separate heaps. Grand' Eury ${ }^{3}$ gives many examples from St. Etienne of such local accumulations of seeds of Gymnosperms, pointing to a succession of deposits in flowing water; a layer of sandstone was found in his time in a railway-cutting near Jägersfreude in Saarbrücken, which was entirely composed of hard nodules formed of casts of seeds of Gymnosperms and caked together so as to form a conglomerate. The anomalous arrangement also of the beds of conglomerates which overlie the 
coal-seams in the open air workings of Commentry, the details of which are given by de Lapparent ${ }^{1}$, quite agrees with Grand' Eury's description of the extreme case of allochthony.

Grand' Eury's conception of the matter is essentially as follows. Coalseams were formed in broad land-locked lake-basins (lagoons) surrounded by wooded swamps, in which the decaying vegetation softening and rotting as it lay on the ground produced in time a layer of matter of vast thickness. The water of frequent rain-storms running slowly off in trickling streams gradually carried away with it the softened wood in shreds from inside the encasing rind, which was itself ultimately broken up and conveyed with other deposits into the basin. Here the processes which lead to the formation of coal took the place of decay, the mass of the coal being produced from the rind, while the particles of softened wood were converted into fibrous coal. The masses of aquatic and marsh plants, which covered the surface and margins of the basins with their luxuriant growth, also supplied their contingent in the form of the parts which died and sank to the bottom.

We know that stumps of trees, the remains of former forests, are found here and there in coal-deposits, either singly or in groups, and in their natural position. One of the best known cases is that of the fossil Sigillariaforest discovered by Goldenberg ${ }^{2}$ during the construction of a tunnel on the railway from Saarbrücken to Neunkirchen. Grand' Eury gives many instances from the Coal-measures of Central France, which were brought to view by the opening of stone-quarries, and in which the chief growths were Psaroniae, Calamodendrae, and Cordaitae; and though Fayol ${ }^{3}$ is of opinion that these plants did not grow where they now stand, but were torn up and floated away and assumed the erect position in the water, it would appear that this may have happened in single cases but can scarcely be true of the whole of the phenomena which have to be considered. England also furnishes numerous examples. It is natural to assume from these cases that coal was formed in wooded swamps. But Grand' Eury points out that if this were the case, we should often find such stumps lying across the seams, with their lower extremity, their roots, immersed in them. The first case does actually occur, but it is so extremely rare that Grand' Eury ${ }^{4}$ can only cite three or four instances. Elsewhere the stumps are as a rule cut square off at the bottom of the seam, and they end in the same way where they reach decided fissures in the stratification. Moreover they never root in the coal, but only in the beds of stone which form the roof of the seam, even where they occur close above the seam itself. The coal therefore does not in fact lie in the same spots with the trees; where they grew, no coal

${ }^{3}$ de Lapparent (1), vol. ii, p. 864. $\quad{ }^{2}$ Goldenberg (1). vol. ii, p. 863 .

4 Grand' Eury (2), p. $x 78$.

${ }^{3}$ Compare de Lapparent (1), 
according to Grand' Eury was produced. The stumps are often hollow, reduced to the rind, and filled with a stony mass in which impressions of parts of other plants are often found. To explain these peculiar conditions Grand' Eury supposes that the temporary raising of the level of the water in the basins of accumulation flooded the flat swampy forest-ground far and wide, and that the trees were killed by the inundation and became rotten and at last fell to pieces, their stumps only remaining erect beneath the water. Such behaviour is quite conceivable, if we take into account the small development of wood and the succulent nature of the rind in the trees of the Carboniferous period; and that something of the kind does take place in warm climates I was able to satisfy myself in the Botanic Garden at Buitenzorg, where a colossal palm-trec, which had died after developing its terminal inflorescence, broke up and fell in pieces before my eyes with a startling crash. If the raising of the level of the water was followed by an irruption of the adjacent sea into the lagoon, - and this might very well happen when the land was so low and flat as in that cra,--then the coal-forming basins would be overlaid by inorganic deposits; and these deposits would envelope the trecstumps on the margin of the basin and fill the cavity inside them, and by local extension of the phenomenon might accumulate large masses of matter or form thin beds of stone, or bury the whole formation if they were on a still more extended scale. If the layers then lost their water, they might harden and pass into the condition of coal. We recall to mind the state of the timbers which in the mine were soft and plastic, but as they dricd were found to have been converted into coal with a conchoidal fracture.

To the above account of the origin of the incrustations of which coalseams are an example of the grandest kind, we may here append a brief description of the mode of formation of true petrifactions. These are distinguished from incrustations by being formed only when the object to be petrified is permeated by dilute solutions of the petrifying substance. The compounds which usually cause petrifaction are apt to produce incrustation only when they are in the form of a concentrated solution. On this point we may appeal to the incrusting spring of Carlsbad, to the incrusted thorns in the drying-houses in our salt-works, and to the siliceous sinter of Iceland and New Zealand. Amber only, which, as has been already said, is an agent partly of petrifaction, partly of incrustation, is an exception in this respect. As resin from Conifers of the Tertiary period it first enveloped any objects which it encountered, and if these were capable of absorbing resin they were gradually and slowly permeated by the enveloping substance, just as microscopic preparations are permeated by canadabalsam. Succulent objects on the contrary were only enveloped by the resin, and as the water evaporated it often formed vesicular spaces on and around them, which were preserved as the resin hardened into amber. For that amber in spite of the difference in its chemical character is, as is here 
assumed, a resin from stems of Conifers which lie buried in layers of lignite and hidden beneath the waters of the Baltic, is proved by its occurrence in the form of tears or as filling fissures in wood of that origin. Fossil resins are obtained from other sources, but the best kinds of the copal and dammar of commerce are dug out of the earth. Göppert ${ }^{1}$ has attempted the artificial production of amber also, and has succeeded in obtaining a substance to some extent resembling amber and almost insoluble in alcohol from Venetian turpentine digested for some years at a temperature of $80^{\circ} \mathrm{R}$. Unfortunately in this case, as in all similar experiments by Göppert, chemical analysis was omitted.

The insoluble compounds mentioned above, which are said by authors to be agents of petrifaction, cannot of course permeate the substance of plants. They can at most fill the lumina of the cells, being in this case precipitated on the spot from soluble compounds; the membranes are then preserved in the form of coal, and may eventually disappear by a slow process of oxidation. We may look upon this state of preservation as intermediate between true petrifaction and incrustation, as an incrustation of the separate membranes. Few however of the many supposed cases of the kind, which Blum ${ }^{2}$ especially has collected together in his work, can be said certainly to belong to this category. Among true examples, those should first be mentioned in which pyrites is the agent; yet here every case requires to be carefully examined, because pyrites also occurs not unfrequently as a homogeneous mass filling internal cavities, as a simple crystalline cast. In the museum at Jena may be seen fragments of pyritised wood preserved in petroleum, which may easily be separated into the threads of mineral matter which filled the tracheides, and on these, with the help of the microscope in direct light, we may still see the portions of pyrites which filled the bordered pits in the form of rows of lenticular prominences. The substance of the membrane seems quite to have disappeared. Remains of a similar character are also mentioned by Göppert ${ }^{3}$. A second and rare case is that of the remarkable wood of one of the Amygdaleae found not unfrequently in the tuffs of the Kaiserstuhl in Limburg, which has been preserved by deposition of hydrated clay silicates. Here all the membranes have entirely disappeared, and the wood which remains is simply an aggregate of exact casts of cells which may be easily isolated; the form of the cells of the medullary rays, of the tracheides, and of the matter filling the vessels is beautifully preserved, and the septa in the vessels are shown by deep annular indentations in the soft substance that filled them. Unfortunately these remains of wood can only be preserved by being saturated with gum, and even then with difficulty. 
But there are cases of the kind which we are describing, in which the membranes are preserved and converted into thin black laminae of coal, and appear on a transverse section of the clay casts as delicate black lines like strokes of a sharp lead pencil. Such cases occur, for example, in fragments of plants prescrved in the Coal-measures of Niedzielisko near Jaworzno in the district of Cracow, for a knowledge of which I am indebted to the kindness of their discoverer, F. Römer; his more cxact account of them will be found in another place. The specimens collected in the year I 865 are irregular obscurely stratified fragments of a very fine clay which may be cut with a knife, of a grayish white colour, but here and there rendered quite black by the amount of coal contained in it; cach fragment has layers and glands of crystalline pyrites occurring in its substance and a rind of impure coal. These fossils come possibly from local lenticular deposits of clay in the scams, such as are found, according to Stur ${ }^{1}$, in all the fissures of the coal-seams of Rakonitz in Bohemia, but more exact investigation on the spot is no longer possible, as the works have been abandoned. They contain seeds of Gymnosperms which are simply incrusted and have thcir testa converted into glistening coal, and with them numerous objects in the state of preservation of which we are speaking. Among these, pending more thorough investigation, may be mentioned small well-prescrved stems of Sphenophyllum, leaf-stalks of Ferns, leaves of Lcpidodendron, and a remarkable inflorescence of Calamaria. The remains showing structure from quarries of the sandstones of the Coal-measures at Chomla near Radnitz, described by Sternberg ${ }^{2}$ and Corda ${ }^{3}$, belong to the fossils which occupy an intermediate position between incrustation and true petrifaction. In specimens of Cycadites involutus, Stcrnb., which I have had the opportunity of examining, the cnveloping or petrifying agent is a hard and very fine-grained clay.

Further, Göppert ${ }^{*}$ found pure copper filling the lumina of single cells and of the large vessels in a picce of recent beech-wood from Moldowa in the Banat. The copper appeared everywhere on the transverse section in the form of scattered roundish glistening points. On the other hand it is extremely doubtful whether the branches of Ullmannia in argentiferous copper-glance from Frankenberg in Hesse is of the class of fossils which we are considering; these fossils, where they are really petrified, are converted into calc-spar; the sulphur seems to have produced rather incrustation and the filling of fissures; we do indeed here and there find casts of cells in this substance, so that a similar process to the filling of the cells with argillaceous earth mentioned above may have taken place also here. The pure sulphur may like the pyrites originate in the reduction

\footnotetext{
3 Stur (2), p. 647. 'Sternberg, Graf von (1). $\quad 3$ Corda (1). Göppert (17), p. 736.
} 
of sulphates. Moreover, there can be no doubt that cinnabar, lead-glance, barytes, and sulphur are found merely filling fissures in wood that is incrusted and turned into coal. Brown ironstone fossils ought as a rule to originate in the oxidation of the pyrites, those in red ironstone in the decomposition of the carbonate of iron which was the original petrifying agent. Lastly, Göppert ${ }^{1}$ obtained petrifactions in oxide of iron and metallic silver by artificial means. These experiments resulted, according to his own account, in the filling of the cells with the precipitates, though imperfectly and with a small amount only of their substance. The skeletons in silver of parts of plants (Erica mediterranea), which had lain a year in concentrated solution of silver, were obtained in their natural form by subjecting them to strong heat; gold chloride and platinum chloride are said to have given similar results. The less solid skeletons in oxide of iron were produced in the same way after soaking in sulphate of iron.

Even true petrifaction appears to be often preceded by a complete or partial filling of the lumina of the cells. The carbonates of the alkaline earths, for example, which, as has been before observed, are the most perfect soluble agents of petrifaction, also occur, but more rarely, as substances merely filling the cells, and after destruction of the organic matters they may be isolated in the form of spiculae representing the several elements. $\mathrm{I}^{2}$ have observed this condition in a piece of wood from the Upper Permian beds of Frankenberg, which contained so much coal that the sections proved to be entirely opaque; no view of the substance could be obtained till the coal had been removed in the flame of the blowpipe, and the cell-spiculae converted into potash had been isolated. Göppert ${ }^{3}$ observed the commencement of the process of calcification in an apparently analogous manner in recent wood. He obtained some beech-wood from a Roman conduit at Eilsen in the district of Bückeburg, in the interior of which were irregular points of calcification, and these would no doubt have united if the process had been continued. The same wood has been more closely examined and figured by Stokes ${ }^{4}$. Similar phenomena were observed in the wood of an oak-tree found in a brook at Gera by Herr Laspe; when it was polished, its cells and vessels proved to be entirely filled with carbonate of lime. Another similar case is described by Daubrée $^{5}$, in which groups of points of calcification were found inside the wooden piles of a Roman canal at Bourbonne les Bains.

The same forms of petrifaction may also be distinguished in the case of silicification. Here too the more frequent case is the dissemination of the silica throughout the organic remains, while internal cavities in them are very often wholly or partially preserved and form glands lined with

\footnotetext{
1 Göppert (17).

s Daubrée (1).

2 Solms-Laubach, Graf $z \mathfrak{u}$ (1).

3 Göppert (1) and (17).

- Stokes (1).
} 
beautiful quartz-crystals. This is very frequently seen, for example, in the larger seeds of Gymnosperms which are found in the often-mentioned black pebbles of Grand' Croix.

On the other hand, I have in my possession a piece of wood of a milkwhite colour from the Habichtswald near Cassel, and coming probably from the sands of the Drusenthal, which can be broken up into single spiculac answering to the casts of the tracheides, exactly in the manner of the silicified and calcified woods mentioned above. The substance of the membranes has entirely disappeared, the spiculae arc suspended in the interspaces which answer to the walls and are connected together only by a fragile froth-like nctwork of very thin lamellae of silica. Schimper ${ }^{1}$ mentions an cxactly similar wood, coming indecd from Tasmania, which was given to him by Robert Brown. I have seen another piece of the same kind, said to have been brought from Texas, in the botanical department of the British Muscum. From these specimens to the silicified woods of Autun, Charles, and other places in the departments of the Saône et Loire and Allier mentioned by Renault ${ }^{2}$ there is obviously but a single step. The latter are ccrtainly solid and coherent, but in the spots which correspond to the membranes they contain a system of very fine pores, which readily imbibe drops of water placed upon them. These again are merely the small interstices from which the organic substance has disappeared when exposed to the air. Since preparations from these woods in canada-balsam are too transparent, Renault puts them first of all into coloured solutions, which remain in these fine pores and show the direction of the membrancs.

From the accounts which we possess it would appcar that the silicification is accomplished in two ways, - a circumstance which Renault ${ }^{3}$ would connect with the difference in the compactness or porousness of the wood in different cases. First there is the usual process in petrifactions; after the parts of the plants were buried, either the whole of the environment stiffened into a hard encasing mass of silica, or the remains only were silicificd and thus served as centres of dispersion for the silicic acid, which either entered as free acid in solution, or was extracted from alkaline compounds by the carbonic acid, the humus-acids of the decaying organic substance. Proofs of this mode of formation may be obtained from the woods found in the district of Zobten in Silesia and described by Conwentz ${ }^{4}$, which externally have the appearance of lignite, but show centres of petrifaction in their interior in the form of hard silicified nuclei. Felix ${ }^{5}$ supposes that the wood of the lignite of Gröbers near Halle underwent the same process; but in it the periphery only is silicified, while the central portions can be cut, and burn when lighted.

\footnotetext{
${ }^{1}$ Schimper (1), Introd. ${ }^{2}$ Kenault (2), Introd. ' Renault (2). ' Conwentz (1). ${ }^{3}$ Felix (1).
} 
In the second place, it has long been thought possible, especially by Göppert ${ }^{1}$, that silicification was brought about by the ascent of the petrifying substance in the stems, which though dead were still standing erect in the open air. Such erect petrified stems are mentioned by Hausmann ${ }^{2}$ still rooted in the beds of lignite at the Hirschberg near Gross-Almerode, and according to Renault ${ }^{3}$ are of not unfrequent occurrence in the department of the Allier; similar objects were observed by Darwin ${ }^{4}$ near Uspallata on the Andes of South America as snow-white columns rising above the ground, but they may, as Darwin supposes, have been laid bare by denudation, and cannot therefore be applied in support of our conjecture. The stumps of trees rooted in the Nubian sandstone of Wadi El Tih near Cairo and mentioned by Newbold and Unger ${ }^{5}$ have never been seen again, and are doubtful. The possibility of a genetic connection between silicified fossil remains and geyser-springs, which cover everything round them with siliceous sinter, I find to have been first suggested by Schimper in the Introduction to his 'Traité de Paléontologie.'

O. Kuntze ${ }^{6}$, impressed by the facts which he observed in the geyser district of the National Park Territory in North America and which will be discussed presently, has since adopted the above idea and combined it with Göppert's view; but he has at the same time extended it in a manner which is certainly inadmissible, since he would account for all silicified wood in this way. He depicts the state of things which he found at the Boiling Lake geyser in the following words: 'I saw the wood in the immediate vicinity of the geyser destroyed, and that in a very peculiar manner; where the hot water from the geyser had run among the trees, they had lost their leaves, rind, and many of their branches, and had assumed a white colour, and in some cases their outer substance had become soft (see the remarks on this point on p. 2I); most of the trees were still standing, but many had fallen, and of these some were entirely rotted inside, whilst others, like those still standing, were in exactly the same condition as the pieces of wood which had been thrown by visitors from time to time into the basin of the geyser, that is, they were impregnated with the silicate from the siliceous water and were become white and soft. But there was one distinction to be observed, that the silicic acid in the wood which lay in the water had not become hard but had remained soft, while in the trees in the open air the hardening of the wood containing the silica was advancing gradually from without inwards; some trees were still soft and still showed the woody fibres, others were harder and the decayed woody fibre was replaced by a deposit of silica of similar structure.' Further on he draws conclusions from these cir-

\footnotetext{
${ }^{1}$ Göppert (1), Introd. Voyage, $\mathrm{ii}_{2}$ p. 99 .

${ }^{2}$ Hausmann (2), p. I 5 o.

${ }^{5}$ Unger (7). ${ }^{6}$ Kuntze (1).

3 Renault (2), i, Introd.

"Darwin,
} 
cumstances couched in too general terms: "The silicified trees are therefore never produced under water, but in situ above the surface of the ground by the constant supply of comparatively small quantities of siliceous water from geysers or hot springs; the water rises in the wood by capillary attraction and evaporates gradually in the open air.' Herr Kuntze has been kind enough to supply me with a small piece of fir-wood taken from one of the erect trec-stumps in Firehole Basin, which is of a spongy fibrous texture, and of a brown colour inside but whitish on the outside, as described above. From all the white parts I obtained, after destruction of the organic substance by means of sulphuric acid, fusiform siliceous spiculae, which looked somewhat corroded on the sides, and might stand for the casts of the cells in which they originated. It secms very natural to explain in this way with Kuntze the origin of other similar fossil woods mentioned above, and there is still a possibility that with long continuance of the process, resulting in more complete disappcarance of the organic substance of the membranes and the cementing together of the spiculae by the solution of silicic acid penetrating between them, even dense compact petrifaction may be produced. Renault ${ }^{1}$ inclines to the vicw that the majority of compact non-porous fir-woods originated in this way. I may add that sections of some of these woods, that of Nicolia aegyptiaca, for example, from the petrificd forest at Cairo, lying before me, do in fact favour this view, which is also warmly supported by Schweinfurth ${ }^{2}$. The appearance is as if sharply defined cones answering to the cells of the wood had been simply imbedded, fixed in a homogeneous matrix. All things considercd, it is very desirable that further investigation should be devoted to this subject, in which many points still require elucidation.

Lastly, there is a point of importance to be considered in connection with vegetable petrifactions. The process of petrifaction may begin at once while the stem is standing, or immediately after it has been laid in its place of deposit, but it may also be deferred to a much later time when the organic remains are already converted into coal or are in process of conversion. Unger $^{3}$ quotes as an instance of this the Miocene beds of lignite at Sagor in Carinthia, in which the seam is silicified in places to such an extent that the work of mining has to be modified accordingly. Isolated pieces of silicified wood are everywhere of frequent occurrence in beds of lignite.

Local processes of petrifaction, though much more scattered and infrequent, are also observed in seams of coal; these appear generally to have taken place at a time when the seam had not yet attained its full development. The agent of petrifaction is either silicic acid or some carbonate. The vegetable remains which form the seam are usually mixed 
up together in it in the state of confusion in which they were deposited. That they were in a soft and macerated condition is evident from their being traversed in all directions by a luxuriant growth of fibres of Stigmaria, and thus rendered useless for purposes of investigation. These phenomena are so extremely important for determining the anatomical character of the vegetable types of the Carboniferous formation, that it will be well to dwell a little longer on them and on their occurrence.

Deposits of this kind are seldom found in the silicified state. Putting aside the hornstones of the district of Chemnitz, in which the state of preservation is not usually of the best, we have really nothing to mention but the often-quoted dark brown siliceous fragments of Grand' Croix near St. Etienne, in which the parts of the plants are often so wonderfully well preserved, that Renault was able to determine from them a large number of the most important facts relating to the structure of the leaves, flowers, and seeds of the inclosed plants. These stones are sharp-angled fragments of different sizes which have never been rolled, and are associated with a variety of other objects to form a conglomerate. Many of them had been set free by weathering and lay scattered over the fields; but they have now been collected, as far as was possible, and brought to Paris, for there was reason to fear that they would soon disappear altogether by being used for industrial purposes. It is evident that they originally formed a connected stratum which was broken up, its remains only being preserved in the conglomerate. The horizon of the strata from which these fragments came lies according to Grand' Eury ${ }^{1}$ between the coal-bearing strata of St. Étienne and those of Rive de Gier; it belongs to the uppermost division of the Coal-measures.

While the vegetable remains preserved in siderite are usually single specimens and are inclosed in geodes of clay iron-stone, calc-spar and dolomite occur in many places as the petrifying agents of entire deposits, after the manner of the siliceous fragments of Grand' Croix. We have known for some years ${ }^{2}$ that certain seams in the great coal-fields of Lancashire and Yorkshire contain irregular roundish masses, large and small, which are the petrified portions of the seam. The excellent researches of Williamson and Binney rest essentially on specimens collected from these petrifactions near Halifax and Oldham. But the induration in the substance of these nodules, which consist principally of calc-spar, is very much less than that shown by the siliceous pebbles of Autun in favourable circumstances. The seams which contain them belong to the lowest beds of the Coal-measures of central England; they occur a short distance above the Millstone Grit, and alternate with certain characteristic hard beds filled with Goniatites and Aviculopecten 
and known as Gannister beds. Analyses are given in Binney's work just cited. Herr Wedekind recently found nodules quite similar to the above on refuse-heaps at Zeche Vollmond near Langendreer, but consisting of dolomite, according to Weiss ${ }^{1}$, and not of calc-spar. The Fritz seam, from which they seem to come, is unfortunately not worked at present; but in its roof occur fossils similar to those of the Gannister beds, and the vegetable remains found in the nodules are quite the same as those observed in England. Lastly, Stur ${ }^{2}$ refers to similar nodules, peat-sphaerosiderites, as he terms them, from the coal-seams of Witkowitz in Moravia and from those of the upper Carboniferous deposits of Szekul in the Banat. The analyses of the latter show that siderite and calc-spar are present together in them in varying proportion.

In Fifeshirc, north of Edinburgh, are coal-bearing strata which.lie bclow the Millstone Grit, and are known by the collective name of the Lower Burdie House Series. They correspond, according to Grand' Eury, to the upper Kulmgrauwacke. In this scries at Burntisland Grieve discovered beds, alternating with volcanic tuffs, which consist of crystalline calc-spar and are filled with vegetable remains exactly in the manner of the petrified coals; these beds have supplied much material for Williamson's researches.

Lastly, similar limestone beds occur at Laggan Bay in the Island of Arran on the west coast of Scotland, which are full of well-preserved remains, and, like the Fifeshire beds, lie between diabase-tuffs. Wünsch ${ }^{3}$ tells us that a large number of stumps of trees, standing erect where they grew, were discovered in his time in the compact black stone which takes a polish like marble. The petrified outer portions of the stumps alone remain, the inside having decayed and disappeared, and its place being taken usually by the diabase-tuff which covers the whole deposit; but the interior also of a few stumps is filled with the petrifying material.

The changes which petrifactions undergo from exposure to external influences have been already noticed in more than one place. When they are exposed to the air their organic substance is in most cases slowly dissipated, and they may then have a transparent look and be colourless or of a reddish hue, while when fresh from the place of deposit they are dark brown or almost black. Water trickling over them naturally expedites the process, and may even accomplish it before they have been exposed. This change produced by atmospheric influences is particularly well shown in the case of the silicified woods of the lignites of the districts of Meissner and Zobten in Silesia, which when exposed to the air become encased in a whitish rind. The organic substance may also be removed from petrifactions 
by strong heat, which usually causes the sections to crack and lose their colour, and often become opaque and of a whitish hue. These effects are produced also in nature in places where the deposits have been traversed by intrusive rocks. Bleached wood-opals of this kind are common in the neighbourhood of the Siebengebirge and of the eruptive trachyte of Obercassel and Tokay ${ }^{1}$. Exposure to rain sometimes completely removes the petrifying material from fossils in calc-spar, and then nothing is left in the stone but the cavity which held the fossil, and in it a few remains of organic substance. The wall of the cavity is often covered with crystals of calcspar. The well-known nodules of the refuse-heaps at the copper mines of Ilmenau, which contain fishes and small branches of Conifers, have most of them unfortunately suffered from this mode of destruction ${ }^{2}$.
1 Göppert (1) and (17).
${ }^{2}$ Solms, Graf zu (1). 
II.

THALLOPHYTES, BRYINAE.

IT lies in the nature of the case that fossil Thallophytes should as a rule be objects of very small importance to the botanist. There are indecd groups among the Thallophytes to which this statement does not apply, those chicfly in which the membranes were calcified while they were still living, and which are therefore found in an unusually perfect state of preservation. Schimper gives us a long list of Fungi and Lichens which have been described by older writers. Where these are not merely spots on leaves, but actual Pyrenomycetes, Discomycetes, and Basidiomycetes growing on leaves or on pieces of fossil wood, they still have no value except as showing what was probable without them, namely, that Fungi formed a part of the ancient floras. Where Polyporei and Lenzites occur, as in the brown coals, it is not surprising that we should also find silicified woods which have been half destroyed by their mycelia. Such mycelia from wood of the Tertiary era have been described by Unger $^{1}$ under the generic name Nyctomyces. That there were Fungi in the older formations also is proved by the fragments of thallus with local bladder-like swellings, which are occasionally found in the tissue of stems of Lepidodendron, and which have been figured by Williamson ${ }^{2}$ under the name of Peronosporites antiquarius, Worth. Smith. Similar objects have been mentioned by other writers also, for example by Renault and Bertrand ${ }^{3}$, under the name of Grilletia Sphacrospermii from seeds of the period of the Coal-measures found in the siliccous fragments of Grand' Croix. A form described by Ludwig ${ }^{4}$ from coal-scams of the Urals as Gasteromyces farinosus may be nothing more than an aggregate of spores and spore-tetrads of some archegoniate plant. That Bacteria destroyed the substance of dead plants during the period of the Coal-measures, as they do at the present day, is rendered extremely probable by the researches of van Ticghem ${ }^{5}$, who has shown that the macerated vegetable fragments in the pebbles of Grand' Croix exhibit the same progressive demolition of the cell-wall which is

\footnotetext{
1 Unger (1). (Renault and Bertrand).

${ }^{2}$ Williamson (1), xi, t. $4^{8}$, ff. 36,$37 ;$ t. 54 , ff. $28-3$ I. 3 Renault (3) - Ludwig (3). ${ }^{5}$ van Tieghem (1).
} 
observed in modern cases. Van Tieghem even believes that he has seen his Bacillus Amylobacter in a silicified state.

Somewhat better results have been obtained from investigations into fossil Algae. Of these a large number of forms have been described which are either doubtful or of no value to the botanist, and which will be briefly noticed at a later period in this work; but a certain number of groups may be selected for mention here, since their relations to recent forms can be established with more or less certainty. There are first the Diatomaceae, whose siliceous valves occur in Tertiary and Quaternary deposits in such large masses and so entirely or almost entirely free from admixture, that they form layers several metres thick of a loose white substance known as tripoli-powder, which has been largely employed of late years for technical purposes. The polishing slate of Bilin in Bohemia and of Habichtswald near Cassel, a white stratified rock of Miocene age, is almost entirely composed of these Diatom-valves. Each separate deposit of the kind usually contains a large number of species, but these are almost always so disposed that one species or a few form the chief mass of the deposit, and the rest are isolated and disseminated through it. Ehrenberg ${ }^{1}$, to whom we owe the most searching investigations into fossil Diatoms, states for example that Gallionella distans and Podosphenia nana in alternate layers form almost the entire mass of the polishing slate of Bilin, that Eunotiae and Synedra capitata predominate in the Diatom-earth of Santa Fiora, while the Cassel deposits are to a great extent composed of Naviculae. Ehrenberg ${ }^{2}$ has further shown that a large number of Diatoms are found also in the uppermost beds of the Chalk, and gives a list of them ${ }^{3}$; among them are Fragilaria, Gallionella, Coscinodiscus, Triceratium, Amphitetras, and others. Most of these forms have been found only in the Chalk marls of Oran, Caltanisetta, and Zante, but a few occur in company with Polythalamiae in the true white writing-chalk, for example, Gallionella aurichalcea, Fragilaria rhabdosoma, and Fr. striolata at Rügen and Gravesend. Pfitzer ${ }^{4}$ therefore is mistaken when he says that we search in vain for Bacillariae in the Upper Chalk. Ehrenberg ${ }^{5}$ has already shown that all these forms down to the Chalk belong to still living genera, that many of them are even identical with recent species, and that the percentage of species not now known to be living diminishes in the strata from below upwards. Even in the Chalk we meet with several species still in existence. The Diatoni-beds seem to have been formed both in fresh and salt water; most of the beds of tripoli-powder and Diatom-earth were formed in fresh water, the Chalk-marls in salt water; the latter deposits contain forms

${ }^{1}$ Ehrenberg (1).

${ }^{2}$ Ehrenberg (1) and (2).

3 Ehrenberg (2), p. II9.

${ }^{4}$ Pfitzer, die Bacillariaceen in Encyclop. d. Natw., Handb. d. Botanik von A. Schenk, ii, p. 409 (1882).

5 Ehrenberg (2). 
which, at the present time at least, live only in the sea, and are entirely wanting in the other beds. It is very remarkable that absolutely no plants of this group have been discovered in the formations below the Senonian. It is truc that Castracane ${ }^{1}$ obtained from the ash of English coal at Rome eight species of common fresh-watcr Diatoms; but the statement has never been confirmed, and though the author assures us that he adopted every measure of precaution, it must be regarded with the greatest suspicion, especially since Williamson ${ }^{2}$ has failed to find any such forms after examining coal from twenty-two different scams in order to determine the point. Pfitzer in the article just cited has expressed the opinion that the group made its appearance for the first time in the Upper Chalk. This appears to me on many grounds highly improbable. It is important to consider whether renewed investigations would not result in further interesting discoveries, for no one since Ehrenberg seems to have taken the subject seriously in hand.

The only organic remains from the older formations, which have been supposed to belong to Diatomacene, are the forms of the genus Bactryllium which have been studied chiefly by $\mathrm{Heer}^{3}$. These are small red-shaped bodies of very peculiar and doubtful character, rounded or almost rectangularly cut off at both extremities and pressed quite flat, each having a single furrow on the broader side, or two furrows separated by an intervening cushion. Their rather thick wall incloses, according to Heer, a cavity which is filled with the stony mass. In some forms a transverse striation is scen on the broader surface on both sides of the central furrow. The largest species, such as B. Schmidii, Heer, are as much as four millimetres in length. The comparison with Diatomaceae rests cntircly on the cxtcrnal appcarance; the furrow in the middle was supposed to correspond to the division between the valves, and the transverse striation to be analogous with the sculpturings upon them. The vegetable nature of these organisms is not certainly ascertained, and further examination of them is desirable. Bactryllia are found in the Keuper of the Alps and of the North of Switzerland, and are particularly plentiful in the Sankt Cassian beds, where they lic massed together in the slates. According to Schimper ${ }^{4}$ they also occur in the Muschelkalk near Heidelberg.

We are acquainted with fossil remains from several groups of the series of Chlorosporeac. The Characeae are represented in the Quaternary and Tertiary formations by a considerable number of species, which, as far as we are ablc to determine, agree entirely with recent forms. A number of species are known also from older formations, Chara Jaccardi, for example, from the Lower Chalk of the Canton of Neufchâtel and Ch. Bleicheri from

\footnotetext{
${ }^{1}$ Castracane (1). $\quad{ }^{2}$ Williamson (1), x, p. 519. $\quad{ }^{3}$ Heer (2) and (3). ' Zittel (1).
} 
the Middle Oolites (Oxford beds) of France. It is only in rare cases that the thallus of the Charas is so preserved as to show its form; it is usually broken up into small tubular fragments. The more perfect state occurs only in the most recent fresh-water cieposits, for instance in the tuffs of Cannstadt and Weimar, in which our common species Chara hispida is found incrusted, as if by a recent calcareous spring. In the case of all older forms we have nothing but the remains of the oospores with their rind, and in these the calcareous shell only has been preserved; the crown is always wanting. The fossil specimens show an orifice which answers to the point of attachment; the pedicel-cell not having been calcified has disappeared.

It has recently been shown by Munier Chalmas ${ }^{1}$ that an entire group of fossil organisms hitherto placed among Foraminiferae is connected with the family of Dasycladeae, and especially with those members of it in which the membranes are calcified, namely the genera Cymopolia and Neomeris. Unfortunately there are several serious difficulties in the way of an exact and full description of this group. The recent species belonging to it are still little known,- - I have had a monograph on the subject for some time in preparation,- and Munier Chalmas has not yet published his elaborate investigations into the fossil forms; in his preliminary communication he has given the names of many genera, but no descriptions of any of them. There is also some uncertainty about the nomenclature; Munier Chalmas' genus Polytrypa is Gümbel's ${ }^{2}$ Dactylopora, and his Dactylopora is named by Gümbel Thyrsoporella. I satisfied myself on this point when Munier Chalmas was kind enough to explain a number of his genera to me.

The unicellular thallus of the recent genus Cymopolia (Fig. 2) has an exceedingly complicated structure. It forms a tuft of branches which branch by repeated dichotomies, and each branch is composed of a row of cylindrical calcified members united together by short flexible connecting pieces which contain no lime. The surface of the members is marked out into tolerably regular areas in the manner of a honeycomb. At the extremity of every branch is a pencil of copiously branched hairs, which envelopes and conceals the youngest members as they are forming on the branch. The dichotomous branching takes place only in the connecting pieces which are not calcified. Each branch of the thallus consists of a central tube or filament, which is rounded at the extremity and beset at regular intervals with manymembered whorls of lateral branches; its lumen also is uninterrupted, and it shows only a slight stricture at the joints between the calcified members. The membrane of this central tube is of great thickness and stratified, and has no deposit of lime in any part of its substance. The lateral branches 
differ from one another according as they proceed from the members or from the joints. Their whorls are closely crowded together, more closely in the joints than in the members; the lumina of all their ramifications traverse the thick membrane of the central tube like narrow pipes and communicate with its cavity. The whorls which are upon the joints consist of short branches of simple cylindrical form directed obliquely upwards, and becoming successively shorter from below upwards. At the apex of
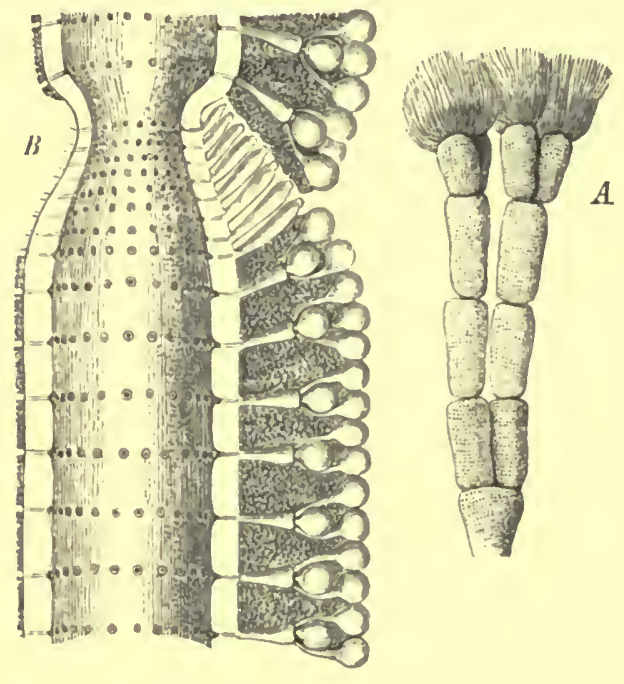

Fis. 2. Cymopolia barbata, from specimens in spirit in the collection at Gütingen, which were obtained by Askenasy in Grand Canary. $d$ showing the habit of a small piece of the plant. $B$ longitudinal section of part of the sane with one of the non-calcified places of articulation of the thallus. At this place the lateral nembers of the whorl are not branched, and terminate in a scar which once bore one of the branched hairs of the tuft; the hairs forming the normal terminal tuft are still to be seen in $d$ attaclied to the youngest parts of the thallus. Where the members are calcified, all the branches of a whorl bear a terminal sporangium and from four to six peripheral branches of the second order, which swell into the shape of a bladder at the apex. These bladder-like swellings, connected with one another by their sides and not calcitied, form a regular onter rind, which collapses in drying and is therefore wanting in fossil specimens of Polytrzpa. The limits within which the calcification is confined is indicated by dark shading. A slightly magnified. tical layer is formed, which when seen from without appears to consist merely of single separate cells. The broad gap which remains beneath this rind between the filamentous members of the first and second order is filled with a mucilage formed from the swelling up of the outer layer of their membranes, and it is this only which being thoroughly calcified becomes thereby hard and brittle. The inner membranous layers which adjoin the lumen and are not disorganised continue entirely free from lime. Bounded by these membranes, the cell-lumina of the verticillate branches and of the sporangia are seen as cavities and canals full of protoplasm traversing the 
calcareous mass, which thus forms a thick hollow cylinder about the axile tube. The exterior terminations of the members of the second order, which cohere laterally and form a rind, are never calcified; it may be presumed that they are chiefly concerned in the work of assimilation, and they cause the prettily areolate appearance of the surface. Fig. 2 on page 38 , which is drawn from nature, will serve to illustrate this description.

Among fossil forms the genus Polytrypa, Mun. Chalm. has absolutely the same structure as Cymopolia, and therefore Munier Chalmas most properly unites the two genera. Polytrypa, like most of the forms which we are about to consider, is found in the sands of the Eocene deposits in the neighbourhood of Paris. Only the calcified parts of course are preserved, and the whole plant is therefore broken up into its several members by the disappearance of the portions forming the joints. Each member shows a broad central canal (the main axis) with secondary verticillate systems of canals proceeding from it and passing through its calcareous ring; the middle branches of the whorls end of course blindly in the cavities of the sporangia, while the lateral branches, traversing the whole breadth of the calcareous matter as slender canals, are open to the outside, where they appear in the form of circular pores. They are thus open externally, because the bladder-shaped outer extremities of the cells not being calcified have one and all disappeared.

The type of Gümbel's genus Haploporella is Carpenter's ${ }^{1}$ Dactylopora Eruca, a form which is said to be still living in tropical seas, and which is based on the recent genus Neomeris, Harv., as I shall presently endeavour to show. It is left by Munier Chalmas with Polytrypa-Cymopolia, and represents the type of the section Decaisnella, which, as I have said, I am unable to distinguish from Neomeris. The thallus of Neomeris is simple and unbranched, and answers to a single calcified member of Cymopolia which has elongated by apical growth and may ultimately attain considerable dimensions. The whorls of branches are also like those of Cymopolia, but never bear more than two branches of the second order beside the sporangium, and these always occupy the median position. Moreover, the calcification is less copious and never results in the formation of a homogeneous cylinder inclosing all the lateral branch-systems; it is in fact only round the sporangium and round the swollen extremity of the branch of the first order which bears it, that it is developed to any considerable extent and that it forms a crust. Hence it is that these parts only are preserved; the slight laminae of lime which clothe the branches of the second order were not firm enough to resist disintegration. The whole plant therefore in the fossil state has separated into a countless number of small pieces, each of which usually conceals a sporangium. A single canal, 
opening to the outside and circular in the transverse section, leads naturally to the cavity of its own sporangium. Not unfrequently with increase in thickness of the calcareous rind several sporangia belonging to one whorl are caked together into a broader body of the same kind inclosing several cavities, each onc of which is provided with its conducting canal. The figures in Gümbel's ${ }^{1}$ work illustratc these points. When calcareous cases of this kind were found in the sea-sand, and their internal cavity (the sporangium) was scen to be filled with protoplasm, it was not unnatural that they should have been taken for still living Foraminifera.

But therc are many genera besides those which have now been described, chiefly in Eocene, but also in Oligocene and Miocene deposits.
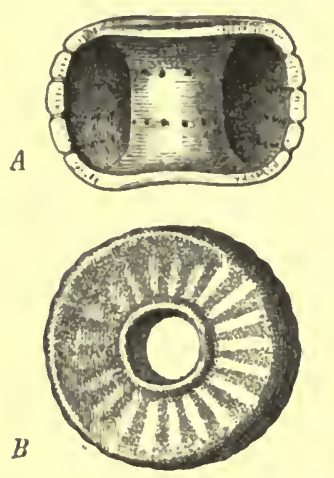

Fic. 3. Uteria Encrinella, Mich. $B$ Surface-view of a member seen from above, and showing the lumen of the main axis as a central tubular cavity. A longitudinal somewhat lateral fracture of a member, showing on the wall of the inner calcified tube of the main axis two whorls of pores, which answer to the points of attachment of the lateral branchwhorls. For each of these whorls two whorls are seen in regular order on the outer calcareous shell. Each branch therefore of the first order bears two whorls of the second order in the median position.

basal parts of the ba These differ much in character, in some cases so essentially that their mutual relations could only be thoroughly explained in a monograph. Still the structure of some of them may be made intelligible with the aid of certain unimportant assumptions, and be referred to the type of Cymopolia. I mention as an example of these Uteria Encrinclla, Mich.", a form common in sands of the Lower Eocene formation, those for example of Hérouval and Cuisc la Mothe near Paris. Their small members are flattened and barrel-shaped, and form hollow rings bounded above and below by planc surfaces rippled in radiating lines. Each of these may answer to a member of the thallus, in which the wall of the main axis is strongly calcificd, and in this respect is the opposite of Cymopolia. Nothing remains of the verticillate branches of the first order except the pores by which their lumen communicated through the calcarcous deposit with the main tube. The sporangia also which were not calcified and the appeared. The outer calcareous rind of the member, picrced by honeycomb-like openings, must be supposed to answer to a localised zone of calcification, which was developed close beneath the rind formed by the bladder-like extremities of these members of the second order. The lateral walls of the branch-systems at the terminal surfaces of each barrel are also calcified. From the position on the main axilc tube of the pores which, corresponding with the branches of the first order, mark on the peripheral calcareous rind the lines of communication of these with 
those of the second order, it may further be concluded that the latter, like those of Neomeris, were as a rule only two in number and occupied the median position, for two pores in the peripheral calcareous layer answer to a ring of pores on the axile tube. But this is not observed with perfect regularity in all cases. More searching investigation will probably show the existence of a variety of specific differences.

Among forms of more complicated structure are some which, like Zittelina, Mun. Chalm. and Terquemella, Mun. Chalm., are undoubtedly allied to the recent genus Bornetella, Mun. Chalm. But since the remarkable structure of Bornetella has nowhere been as yet fully described, and a monograph of the entire group cannot be introduced into this place, a minute description of the fossil genera is at the present moment scarcely possible. There are also genera in which the construction is still quite unexplained; one of these is a form of very frequent occurrence, Thyrsoporella cribrosa ${ }^{1}$, Gümbel (Dactylopora, Mun. Chalm.), which I have had the opportunity of examining in manyspecimens.

Some genera are of more simple structure, but it is not yet quite certain that they belong to the class of which we are speaking. They are found in the Trias, and occur especially in the Southern Alps, where they form rocky masses of very great thickness ${ }^{2}$.

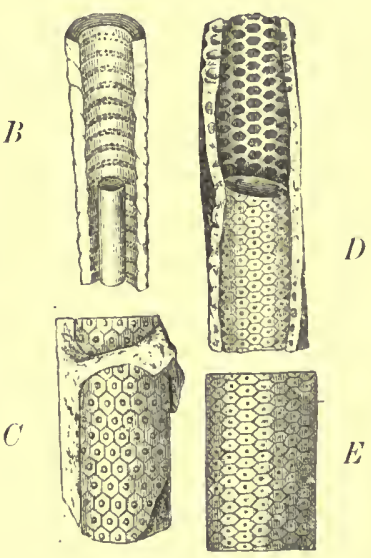

Their mode of preservation is different from the above, since all their cavities are usually filled with the material of the rock in which they lie; and if a canal still remains open in the wide tube of the main axis, its walls are usually lined with crystals closely crowded together. Diplopora annulata, Gümbel ${ }^{3}$, and its allies (Fig. $4 A, B$ ), which are peculiar to the Muschelkalk of the Alps and to the Lower Keuper (Mendola dolomite, Wettersteinkalk), have a long cylindrical obscurely segmented thallus with a dome-shaped 
apex, which however is seldom preserved. The central axile tube is of extraordinary width, and is surrounded by numerous crowded rings or whorls of lateral canals, which traverse the rind and have the passage open to the outside. A similar construction is seen in Gyroporella vesiculifera ${ }^{1}$ (Fig. $4 C-E$ ), which belongs to the main dolomite of the Upper Keuper and occurs chiefly and abundantly in the Alps of Lombardy; but here the lateral canals, forming less distinct rings, are closed on the outer side by a small and somewhat convex plate. We can scarcely be wrong in assuming that this difference arose in a construction originally alike in both cases, in consequence of the apical membrane of the branch being sometimes calcified and sometimes remaining unaltered. There is therefore an essential differcnce between the Tertiary forms first considered and these forms from the Trias; the latter, in place of complicated lateral branch-systems producing sporangia, have only whorls of short simple members, which are either cylindrical or somewhat swollen and enlarged. Whether these members developed directly into sporangia by formation of septa between them and the lumen of the main axis, or in certain circumstances produced at their extremity free sporangia which did not become calcified, we do not know. If the latter was the case, then no fruiting specimens have yet been observed, for these would show the scars of the sporangia. In the former case we should have a simplification of the type of Dasycladeae, and this would present no difficulty from the algological point of vicw. The Cretaceous genus Munieria, Hantken, which forms beds of stone near Bakony in Hungary and has been described by Deecke ${ }^{2}$, will probably be united to Diplopora and Gyroporella ; it requires further study.

Lastly, in Triploporella Fraasii, Stcinmann, from the Turonian Chalk of the Lebanon, we have a form, which seems to be intermediate between the two groups above mentioned. It has been described by Steinmann ${ }^{3}$, and externally it exactly resembles Diplopora, but each simple shortly cylindrical branch in a whorl has at its apex three small almost globular branches of the second order. As to the meaning of these branches, since there is no indication that there was once a sporangium between them, we can only say what was said of those of Gyroporella.

A few fossil genera are placed by Munier Chalmas in the group of Acetabularieae, the nearest allies of Dasycladeae. Of these I know only Acicularia, d'Archiac and Briardina, Mun. Chalm., the latter through the kindness of Munier, who himself demonstrated it to me. We find a variety of forms figured in Carpenter ${ }^{4}$ under the name Acicularia; of these, figures 27 and 31 may represent Munier's Acicularia, figures 28-30 another genus, perhaps Orioporella. I question much whether figure 32 belongs to this group

\footnotetext{
1 Giimbel (1). ' Deecke (1). ' ${ }^{3}$ Steinmann (1). 'Carpenter (1), t. 11, ff. $2 \boldsymbol{7}-32$.
} 
These forms in a fragmentary state may look very like Dactyloporidae, but they differ from them in the absence of the central canal; they are pointed or flattened conical bodies, sometimes united laterally into bundles and becoming broader and wedge-shaped in front, and are supposed to represent the separate rays of the cap of Acetabularia or Polyphysa. They contain a number of conical cavities opening to the outside, which must have inclosed the zoosporangia formed in the rays. Strange to say, they are completely filled with calcareous matter, which is never the case in recent forms.

It usually happens that as soon as ever a doubtful group has by a lucky hit found a secure place in the system, attempts are at once made to bring a series of enigmatical forms into connection with it, and this has been done in the present case. How far there is any good ground for these attempts is a question which cannot be minutely considered in this place; we must wait till we have obtained a broader basis for our knowledge of the fossil Dasycladeae, now that we have ascertained their position. Steinmann proposes to unite with them Coelotrochium Decheni, Schluit. from the Upper Devonian beds of Gerolstein, Cyclocrinus from the Silurian strata, Receptaculites also and its allies, and lastly the Jurassic Goniolina. The latter form has, on the other hand, been quite recently compared by Saporta ${ }^{1}$ with Williamsonia, and been supposed to be the fructification of a Proangiosperm, an Angiosperm in statu nascendi. Deecke ${ }^{2}$ describes the Devonian Sycidium, Sandb. as belonging to Dasycladeae, and Schlüter ${ }^{3}$ cites a number of other forms which have been taken into consideratiōn.

The genus Penicillus, Lamk. (Espera, Dcne), a form of Chlorosporeae, is known to occupy a doubtful position in the system and to require renewed examination. The unicellular thallus consists of a tuft of dichotomously branched filaments divided by constrictions into ovoid or cylindrical segments, which look like cells but communicate freely with one another. The stout solid cell-membrane becomes calcified except at the places of apparent articulation answering to the constrictions, but the incrustation affects only the outer mucilaginously softened layer of the membrane, as is the case also with Acetabularieae. The filaments of the tuft become caked together below, as the calcification increases, into a thick solid and hard but brittle stem. From the younger portions of the filaments which are not yet caked together the calcareous rind readily breaks away in tubular portions corresponding to the members of the plant, or into fragments of the same; the substance of the rind is not uniform, but is traversed by round or irregularly shaped vacant spaces irregularly disposed and crowded together, and sometimes running into one another. Why calcification was interrupted 
at these spots is not apparent; there are no emergences, such as hairs for example, which could have passed through the deposited matter. The branching is always in regular dichotomies, which commence in each case at the upper end of one of the cell-like members while still young.

Munier Chalmas ${ }^{1}$, in a recent publication, has sought to identify Penicillus with the genus Ovulites, Lamk., which is common in the sands of the Eocene formation, especially round Paris, and was formerly classed with Foraminifcrae. Though further and extended investigation may be necessary to establish the justness of this comparison, as will be shown in the remarks which follow, yet it must be regarded as a very happy and inviting suggestion.

The calcareous shells as preserved in Ovulites are ovoid or fusiform, and picreed by a large hole at both extremities; sometimes there are two holes beside one another at one extremity. The shells are everywhere very thin and fragile; their surface, which appcars smooth to the unaided eye, is scen under high magnifying power to be broken by a large number of steep-sided dot-like pores, which are surrounded by fine lines inclosing polygonal spaces. Putting aside the thinness of the shell and the irregular distribution of the pores, we have here a structure which might also be very well left bchind by a plant like Cymopolia; especially if the calcification in it was continued only to the wall of the central tube; for the wall-like sides of the pores, thin as they are, favour the view that they represent the lumina of lateral members which have themselves disappeared. Munier Chalmas indeed, and Stcinmann" also, are of opinion that there were lateral members of the kind in Penicillus also, answering to the vacant spaces in the calcareous shell. But this is a mistake. Moreover, these spaces in Penicillus have not the sharply defined boundaries of those of Ovulites, their shape is more irregular, and several of them often run together into irregular figures. There is also no appearance in Penicillus of the reticulated design characteristic of the shell of Ovulites. The occurrence of members with two axile perforations at the upper extremity certainly shows that the thallus of Penicillus was dichotomously branched; but these holes must also be found in plants of the nature of Cymopolia, if the bridge of membrane lying in the bifurcation of the branches and terminating the lower member is calcified. If it is not, the two round holes will be confluent into one ovoid hole, as in Penicillus. From all this I should conclude that we have in Ovulites menbers of a calcareous Alga, which may be compared with the group which we are considering, but whose position in the system cannot be finally determined without further investigation.

Of the incrusted Florideae the only forms at present known to exist 
in the fossil state belong to the family of Corallineae and to the section Lithothamniae, which are almost the sole components of certain deposits of former ages, as they now form extensive beds at the bottom of the sea. It is extremely difficult to distinguish the species in the living representatives of this group, and it may readily be conceived that the difficulty of dealing with the fossil forms is still greater. We shall do well to follow Unger $^{1}{ }^{\text {in }}$ this matter, and put them all together as Lithothamnium ramosissinum. The only proof that in these nodular calcareous forms with shrub-like branching we have really to do with Lithothamnium is, as Gümbel ${ }^{2}$ shows, the presence of the characteristic structure. If we find that a body of this kind consists of layers of rectangular cells lying one on another as concentric shells, there is always a possibility of confounding them with families of Bryozoa, at least when the outer surface is not in a perfect state of preservation. But in that case we have an excellent aid to discrimination in the fructifications, which in the Lithothamniae are formed in great numbers by later overarching of adjacent tissue, and are seen in the substance of the thallus as ovoid cavities into which the sporophore projects on the under side in the form of a small cone. Such undoubted Lithothamniae are abundant throughout the series of Tertiary deposits, and in some localities they form almost the entire material of systems of layers of no inconsiderable thickness, as for example in the Lower Eocene strata of Toin in the department of Ariège, and in the Pliocene deposits of the Rupe Atenea at Girgenti near Syracuse, where they are quarried in the famous Latomiae. They compose also the limestone of Leitha near Vienna, and the granitemarble of the Nummulitic rocks. They occur also in the Senonian of the Petersberg near Maestricht, in the same formation at Les Martigues near Marseilles, and in the pisolite limestones of Paris, and one species has been clearly identified from the zone of Ammonites bimammatus in the Jura. Small shrubs and bushes of the same kind and of thoroughly similar habit are also found in older formations, but as the structure has not been preserved they cannot be certainly distinguished from concretions of inorganic origin. I have found such objects repeatedly in the Muschelkalk of the Hainberg near Göttingen, but have never been able to detect any remains of structure in my sections. Lastly, the Siluro-devonian genus Nematophycus may be mentioned in this connection, which from its anatomical structure may perhaps belong to Fucaceae; but as we shall have to return to it in speaking of coniferous woods, we will reserve any further description of it for that place.

Besides the groups of Algae hitherto mentioned, there still remains a large number of forms from all the formations, from the Quaternary back*. 
to the Lower Silurian, which have been described under an abundance of generic names; but they have virtually no interest for the botanist, because there is no immediate possibility of profitable comparison with known algal types. We may perhaps be able at some future time to pick out a type here and there out of this hopeless chaos, but it is scarcely possible that we shall ever attain to a better position as regards the remainder. We must necessarily be always dependent on characters derived from external form, and these in the case of the Algae prove only too little; we can scarcely hope to penetrate to the inner structure of the fructification, which can alone determine the affinity. And, to mect an objection which may be cxpected from the palacontologists, I will add at once that I should not hesitate to say the same of the Coniferae, for instance, if we had nothing left of them but the impressions of the leaves; but there we are better off, for cones, wood, and fragments showing anatomical structure have been preserved as so many points of support for the conclusions, by which we can be continually testing the degree of probability to be assigned to new conquests. What mistakes may be made without the aid of such objects is shown by the number of impressions of Conifers, which are explained by older authors, by Brongniart for example, as Zonarites digitatus, various Caulerpitae and other Algac.

This problematical character of the remains could not well escape the attention even of the earlier observers, who soon accustomed themselves to describe everything as an Alga which could not be disposed of elsewhere. Hall's ${ }^{1}$ remark is much to the point: "It has been the habit to refer to vegetable origin all those fossil bodics of the older strata which have in their general aspect, their habit or mode of growth some similarity to plants, and in which no organic structure can be detected beyond sometimes the external markings.' That so large a proportion of 'Algae' were brought to light from the oldest formations was entircly due to the fact, that there was a more eager search for organic remains there than elsewhere to meet the requirements of geological investigation. In recent times the later formations also have been diligently examined for the same purpose; but in the Silurian and Devonian deposits cvery bit of raised surface however shapeless was named in this way, as may be seen from the figures of the genus Eophyton, Torell, to be found in Saporta ${ }^{2}$. From such an extension of the idea of a fossil Alga a specdy reaction was inevitable, and attempts were made to show that many of the objects described as Algae were casts of the tracks of animals, like the well-known impressions of Chirotherium from the Bunter Sandstein, and that others again were merely of inorganic origin. This divergence of views has recently given rise to a lively discussion 
between Saporta ${ }^{1}$ and Delgado ${ }^{2}$, as the chief maintainers of the algal nature of the objects in question, and Nathorst ${ }^{3}$ as representing the opposite opinion. So far as I may presume to judge in this matter, I should say that, as usually happens in such cases, both sides go too far. Nathorst, though he allows that there are some fossil Algae, makes the presence of a rind of coal the ultimate criterion, and roundly denies the algal nature of any form where that is not found. It appears from the remarks in the introductory chapter to the present work, that this cannot be admitted. We know that the coal may entirely disappear in the course of time from remains that are undoubtedly organic, if they are deposited in a porous rock. Moreover, Nathorst refuses to allow that any of the remains which occur in half-relief on the surface of slabs of stone belong to the vegetable kingdom. Saporta ${ }^{4}$, as has been already stated in the Introduction, attacks this doctrine on good grounds and with more than usual earnestness.

The whole question in dispute is not one in which the botanist is greatly interested, for even remains, which being provided with strips of coal are allowed by both sides to be Algae, such for example as many specimens from the Eocene beds of Mte Bolca and from the Upper Oligocene (Aquitanian) beds of Sotzka and Radoboj, are of no value to him, except in the few cases in which the external form is so well marked that he can venture to connect them with living forms, as is the case, for example, with the Cystoseiritae of Radoboj. There may possibly be remains of true Algae among specimens obtained from other formations, but no proof of this can be produced, and we cannot therefore at present attempt more exact determination of the family to which they belong.

On the other hand, it has been shown in many cases that supposed remains of Algae are of a totally different nature. Of this we have a number of striking instances, for which we are chiefly indebted to Nathorst, quite apart from mistakes such as that made by Saporta ${ }^{5}$, who confounded flattened oyster-shells with Algae, as in the case of Conchyophycus Marcignyanus, Sap. ${ }^{6}$ placed with Cutleria and Zonaria; but he has since acknowledged the real nature of this object ${ }^{7}$. It may be remarked in passing that Nathorst gives a complete list of the older literature of the subject, which may be referred to for the following statements. Resting on the observations of several of the older writers, Emmons, Hancock, Dawson and others, who had explained certain of the supposed Algae as imprints of the tracks of animals, Nathorst tried the experiment of obtaining tracks of the kind on prepared ground and then taking casts of them in plaster of Paris. A variety of imprints were thus procured in half-relief,

1 de Saporta (1), (12) and (13). $\quad{ }^{2}$ Delgado (1). $\quad{ }^{3}$ Nathorst (1). " de Saporta (1).

5 de Saporta (4). ${ }^{6}$ de Saporta (4), vol. i, p. I50; t. $11 .{ }^{7}$ de Saporta (4), vol. i, p. $4^{69}$. 
which corresponded more or less perfectly with certain supposed Algatypes. In some cases the result was striking. Eophyton, Torell was produced with the greatest ease by passing bits of Algac and parts of animals over soft mud. The casts of tracks of a crab, Corophium longicorne, gave a figure which answers so exactly to the Silurian and Carboniferous genus Crossochorda and also to Gyrochorda from the Tertiary strata of the Jura, that Saporta ${ }^{1}$ himself has consented to remove these genera from the Algae. Precisely similar tracks, according to Etheridge and Nicholson, are also made by Purpura lapillus ${ }^{2}$. Williamson ${ }^{3}$ again took casts in the same way of the furrows left behind by the retreating tide on the shore of the sandy coast of Llanfairfechan in N. Wales, and obtained figures which look exactly like the forms of leaves of recent Florideae, such as Wormskioldia sanguinea. This is quite enough to show how little value is to be set upon the Halymenitae, Delesseritae, Laminaritae, and Caulerpitae of authors, even if there can be no doubt that some of them are real impressions of Algae; this is proved, for example, in the case of Halymenites Arnaudi ${ }^{4}$ by the presence of a Membranipora, which has been preserved at one spot in the impression.

Saporta, like Schimper before him, lays special weight on the copious branching shown by many of the algal remains which he defends. He denies with Schimper that there can be any branched animal tracks. Zeiller ${ }^{5}$ however very recently made known an excellent instance of this very thing. He observed in Normandy on the moist clay bottom of some dried-up puddles some curious branched rounded elevations formed simply of small raised lumps of clay, and agreeing very nearly in outward appearance with the Jurassic genus Phymatoderma; these lumps formed the roof of a system of passages which had been made by some burrowing animal beneath the surface of the ground. The impressions of the claws on the inner wall of the passages were evidently those of the common mole-cricket, which with its rounded back had lifted up the thin roof of soil and broken it up into small pieces. In a similar manner various forms niay be explained in which the theory of foot-tracks has difficulties to encounter, and this may be the case especially with many of the branched forms of Bythotrephis and Chondrites. The variety of the tubes formed by worms and other creatures on the bed of the sea must certainly astonish every one who by frequent visits has made a close acquaintance with the strand at low water.

Hall ${ }^{6}$ has described a specimen as an Alga under the name of Dictyolithes Beckii from the Medina sandstone of the Upper. Silurian formation of the Statc of New York. This is at once recognised to be the cast of a clay floor in a half-dried state and with the cracks forming polygonal areolas as

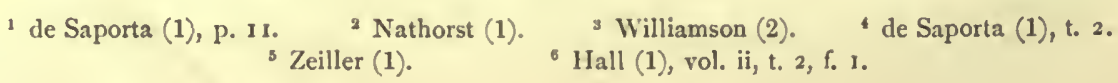


seen through an overlying layer. The fissures which bound the separate lumps appear as reticulately connected ridges in half-relief, from which run out numerous small blind processes, the casts of small capillary fissures.

Still there are a large number of specimens of this class now under consideration, to which Nathorst's explanation can only be applied with violence, or cannot be applied at all. Saporta ${ }^{1}$ acted judiciously in entirely giving up Crossochorda, while drawing attention at the same time to the poverty and indistinctness of his opponent's preparations in plaster of Paris, which in fact can in many cases very imperfectly serve the purpose for which they were intended. But if the objects in question are not the tracks of animals, it does not therefore follow, as Saporta maintains, that they are Algae. They may for instance be the excrements of many marine creatures, composed of shaped masses of mud or sand, such as may often be seen in suitable spots on the sea-shore. In this case the object will of course project in half-relief on the upper surface of the beds. The group of Gyrolithes described at length by Saporta ${ }^{2}$ may be of this kind. Tubes also of lower animals, if stoutly built and held together by a firm cement, may have something to do with this question. For example, I am unable to accept Nathorst's explanation in the case of Arthrophycus Harlani, Hall, from the Upper Silurians, though it may be a mistake, as Römer also thinks, to regard it as an Alga. That this fossil is no track of an animal is proved at once by the spirally twisted specimen figured by $\mathrm{Hall}^{3}$, in which several convolutions lie one above the other and do not intersect one another, as is usually the case. It appears also from the text-that these Arthrophycus-tubes do not project on the under surface of the slab, as Nathorst's view requires, but on the upper. I gather this from the following words of the text ${ }^{4}$ : ' - since great surfaces are crowded with its fragments; and these layers are covered only by a deposition of a few inches, when another growth, equally abundant, is found upon the succeeding layer.' Schimper ${ }^{5}$ also has understood the passage in the same way.

Such being the state of the case, I am precluded from entering in this place upon a detailed description of the fossil remains belonging to this category, and must limit myself in the following remarks to a brief recapitulation of Schimper's classification and a notice of the chief representative forms, adding only a few critical remarks on Nathorst's and Saporta's later publications.

The group of Caulerpiteae contains objects of dissimilar appearance. The Jurassic Phymatoderma which is placed here has just been mentioned. The Keckiae also are referred by Nathorst to tracks of animals. Gyrophyllites and Discophorites ${ }^{6}$, fossils from the Lower Chalk of whorled construc-

$$
1 \text { de Saporta (1). }{ }^{2} \text { de Saporta (12). } \quad{ }^{3} \text { Hall (1), t. 2, f. I c. }{ }^{6} \text { Heer (3). Hall (1), p. } 5 .
$$


tion, are considered by him to be of doubtful character, and I do not know them from personal inspection. The question whether Chordophyceae, Crossochorda, Gyrochorda and also Phyllochorda may be tracks of animals has been already fully considered. Whether the Silurian Bilobites, Dekay (Cruziana, d'Orb.) is of the same nature I am unable to determine. Two elaborate monographs on these fossils by Saporta ${ }^{1}$ and Delgado ${ }^{2}$ have recently appeared, and these contain also a complete account of the extensive and scattered literature. Both authors are at great pains to prove that the remains are those of Algae, but they will scarccly induce the botanists to take this view; they have equal claims to be regarded as Holothuriae, Ctenophorae, sponges or anything else we may please to call them. As regards the Arthrophyceae, it has been already shown that Nathorst is wrong in referring the type of this group to the tracks of animals. The Taenidiae ${ }^{3}$ I have never examined; Nathorst considers that they are the tubes of worms. The Dictyophyteac (Dictyophyton, Uphantaenia) are referred by $\mathrm{Hall}^{4}$ to sponges.

The genus Oldhamia ${ }^{5}$ from the Cambrian slates of Ireland, which has been supposed to be the oldest of all vegetative types and appears only as a delicate wrinkling of the surface of hard slate beds, is now regarded by F. Römer ${ }^{6}$ and indeed by most observers as the result of simple pressure or some similar purcly mechanical cause. Saporta ${ }^{7}$ too would seem not to consider these markings to be of vegetable origin, or he would not have failed to mention them as the oldest types of the class of Algae. With Scolithus, Haldem., Vexillum, Rouault, Eophyton, Torell, and Granularia, Sap. ${ }^{8}$, we come at last to shapeless objects of quite indefinite character. Eophyton has been already discussed; Vexillum is produced evcry day in the soft mud of our ponds, where local currents are interfered with by floating impediments, such as branches of trees and the like.

The Chondritcae, which occur in all formations and when found in the older deposits generally go by the name of Bythotrephis, are remarkable for their copious branching. Innumerable figures of them are given in the works of Heer ${ }^{9}$ and Saporta ${ }^{10}$. The latter says of them and of countless other forms ${ }^{11}$ : 'In fine, we have no hesitation in referring the whole of this assemblage of primordial types to one of the groups of inferior Algae, that of Siphoneae; this group has arisen from a very remarkable differentiation of a thallus, which though branched continues to be unicellular, \&c.' Nothing further need be added to this statement from the botanist's point of view. Nathorst of course regards them as traces or tubes of worms, and

\footnotetext{
1 de Saporta (12).

' Zittel (1), vol. ii, p. 60.

(4), vol. i, t. I 2 .

${ }^{2}$ Delgado (1).

- F. Römer (1).

${ }^{3}$ Heer (3), t. 67.

7 de Saporta (3).

1 Hall (2).

8 de Saporta

9 Heer (3).

${ }^{10}$ de Saporta (4), vol. i.

11 de Saporta (3), p. 93.
} 
is confirmed in this belief by a letter of Fuchs on the subject of the Chondritae of the Flysch printed in his work?

The group of Alectoruridae, with the genera Alectorurus, Taonurus, Cancellophycus, Glossophycus, contains a series of remarkable remains from the Silurian up to the Tertiary formations; they have been admirably figured in the works which have been already so often cited, and particularly in Saporta. Among them is the so-called Cock's-tail Alga (Spirophyton Cauda Galli), which occurs in such abundance in certain beds of the Upper Devonian formation in America, that it has given them the name of 'Cauda Galli grits.' Descriptions and figures of this fossil will be found in L. Vanuxem $^{2}$. Opinions are much divided on the question whether they are of organic or inorganic origin. Nathorst considers that he has produced analogous forms artificially; he says on this point: 'The experiment of producing a circular movement in water in a vessel, the bottom of which was covered with fine sand, has supplied me with an excellent imitation of Spirophyton Cauda Galli; from a small central cavity irregular arched markings spread on the same side towards the margin, and were not distinguishable from the corresponding structure in Spirophyton.' Unfortunately he has given no figure; and since he assumes of other similar forms that they were produced by worms, or by tufts of plants fixed at the bottom of the sea and moved about by the waves, he gives us the impression of not being quite clear in his own ideas on the subject. The figure which he gives of an analogous form produced by a worm ${ }^{3}$ has only a very general resemblance to the fossils which we are considering. There are also cases in which these Taonurae do not merely project in half-relief, but form perfectly separable casts between the layers, the margin being arched over and thickened into a cushion ${ }^{4}$. I do not quite see how we can conceive such a cast to be formed by eddies in water; but I am as little able to discover in these remains the Siphoneae which Saporta sees in them.

A few words only are required here for the fossil Mosses, which being obtained almost entirely from Tertiary and Quaternary deposits and being closely allied to recent forms are of scarcely any interest to the botanist. Most of those hitherto found are barren; a single capsule only appears to be known, and this has been described by Ludwig ${ }^{5}$ as Gymnostomum ferrugineum from the Miocene haematites of Dermbach in Nassau; Schimper considers ${ }^{6}$ it to belong to Sphagnum, and calls it Sph. Ludwigii. The reader may be fitly referred to Schimper's work for an account of the tolerably numerous barren Hypneae and other remains of Mosses which have been found in a fossil state. The type of Marchantieae is known in

\footnotetext{
1 Nathorst (1), p. 94

${ }^{2}$ Vanuxem (1), p. 128. ${ }^{3}$ Ludwig (2).

${ }^{3}$ Nathorst (1), p. 77. 'de Saporta (1), t. 8, f. 3 , and (3), p. 9 r.
}

E 2 
several species of the genus Marchantia, which agree in habit with forms now living in the tropics. Two of them have been described by Saporta ${ }^{1}$ from the Eocene tuffs of Sézanne, and are mentioned also by Schimper ${ }^{2}$. Jungermannicae have been found in small fragments in amber.

The Muscineae no doubt had their representatives in the times of the older formations also. Still it is very remarkable that so few and uncertain traces of the forms then existing have come down to us. Heer ${ }^{3}$ has found himself obliged to appeal to the caterpillar-genus Byrrhus in order to prove the existence of Mosses at the period of the Lias. As these creatures live on Mosses at the present day, he concludes that there must have been Mosses at that time also. That the conclusion is open to objection is evident. Renault and Zeiller ${ }^{4}$ have however quite recently described remains from the Coal-measures of Commentry, which look like barren Polytrichae or Rhizogoniae, and which they name provisionally Muscites polytrichaceus.

1 de Saporta (9). $\quad{ }^{2}$ Schimper (1), t. 6. $\quad{ }^{3}$ IIeer (10). ' Zeiller (21). 


\section{III.}

CONIFERAE.

IN departing from the customary arrangement in the Natural System and placing the Gymnosperms before the Vascular Cryptogams we have been influenced chiefly by practical considerations, for the adoption of this order will facilitate the discussion of the many doubtful forms which belong to one or other of these classes, but which it will be best to consider in connection with similar groups of Archegoniatae.

Remains of Coniferae, branches, leaves, cones and seeds, are found in great abundance in the Cainozoic and in the most recent of the Mesozoic formations, and have been referred to genera still living on account of their resemblance to them. Where such determination is based on wellpreserved cones, it may as a rule be considered satisfactory. Where the cones are not in such good condition, we must keep in sight the possibility of confounding them with cones and stems of Cycadeae. Where seeds only have been preserved, the task is at once more difficult. Leaves and leafy branches can be regarded by the botanist only in single exceptional cases as a safe basis for the determination of genera or groups, for the characters which they offer are few and not well marked, and the value of these few must be regarded as doubtful when we remember that there are recent genera from different families, in which the leafy branches cannot be distinguished at all by the outward appearance and with difficulty even by anatomical examination. Diselma Archeri, Hook. and Microcachrys tetragona, Hook. are examples of such forms. How difficult it was to combine the male and female specimens in these plants correctly is shown by their peculiar synonymy. Nor must the heterophylly be forgotten, which prevails so widely in the Coniferae. We have only to think of Juniperus virginiana, of Retinospora in the young states in the Cupressineae, and of Glyptostrobus chinensis. Voltzia heterophylla, which will be considered below, is an example of the same phenomenon in fossil forms, as its name imports. Perfect certainty therefore in the determination of branches of Coniferae can only be attained when we find them in conjunction with cones in a satisfactory state of preservation. But in many cases the two are not known in actual connection, being only associated 
in the ordinary manner. The younger the formations which contain the separate parts, and the more complete the resemblance to those of the recent form which serves as a tertium comparationis, the more shall we be justified in drawing the tempting but almost always hazardous conclusion that they belong to onc another.

The older formations also contain an abundance of remains of Coniferae, but it very rarely happens that their relation to still living forms can be determined with any certainty. The structural details in the cones are usually badly preserved; the number and position of the ovules, the most important points, are either unknown or very uncertain. Moreover, the descriptions of palacontologists in this respect are often a good deal coloured by the imagination. An instance of this is to be found in the doubtful Albertia, Sch., which Schimper ${ }^{1}$ confidently classes with Dammara, and Schenk ${ }^{2}$ then deals with in a similar manner. Heer ${ }^{3}$ goes so far as to say: 'The family of Abictineae appears in the Coal-measures in two genera, Walchia occurring as early as the middle of the formation, Ullmannia, as far as is yet known, only in its upper limits.' I shall endeavour to show that nothing is known of either genus which can be turned to account by the botanist, and that Hccr's assertion therefore is only calculated to lead those botanists, who have not occupied themselves closely with fossil plants, into errors and false conclusions. And I cannot say that I agree even with Schenk ${ }^{4}$, when he classes things like Brachyphyllum, Sphenolepidium, and Inolepis directly with the Taxodieae. His criticism does not appear to me to go nearly far enough, though in other respects it is thoroughly good.

From all this it follows that our present purpose will be best served by dividing the whole mass of described forms into those in which the connection with living groups is botanically assured, or is of such a kind that only onc of these groups can be compared with them, and, secondly, into those in which this connection is still doubtful; lastly, we must briefly examine the results of investigation into the fossil woods which are so common in all the formations. The reader is referred to Schenk's account ${ }^{5}$ for elaborate descriptions of the forms which represent our living genera; such descriptions would be unsuitable to this work, in which we are concerned only to show what are the oldest and most certainly established representatives of each of the main forms, and thus to gain some ground for determining their relative age.

The Abietineae are abundant in the Tertiaries and in the Chalk, but they can as a rule be certainly determined only in their cones, or in the case of the Pines in the needle-bearing branches, if these are present in

1 Schimper (1), vol. ii, pt. i, p. 256. - Zittel (1).
${ }^{2}$ Schenk (1). ${ }^{3}$ Heer (4), p. 239.

${ }^{3}$ Zittel (1). 
the necessary state of preservation. They are less abundant in the Jurassic system. The oldest remains, which are not however absolutely free from doubt, come from the Rhaetic beds of Schonen. All known Mesozoic cones of Abietineae belong, as far as I am aware, to the genera which have no squamae apophysatae. The Cenomanian beds are the earliest which supply forms of the section Pinea of Pinus. A few cones are known from the lowest Chalk of Hainault in Belgium; they recall Strobus and Cembra, but may be nearer to Strobus on account of the winged seeds. The Rhaetic form just mentioned has been described and figured by Nathorst ${ }^{1}$; it is not free from doubt, though the figure certainly resembles a small expanded cone of Cedrus. It is possible that this Pinites Lundgreni, Nath. has been rightly interpreted, since winged seeds of Coniferae are associated with it, but these after all may belong to Palissya which occurs in the same beds. Saporta ${ }^{2}$ figures a splendidly preserved cone, which shows even the inner structure perfectly, as Pinus Coemansi, Sap. Unfortunately the label which bears the words, "Oolitic formation, with no further indication of locality or position; from the collection of M. Coemans,' shows, notwithstanding Saporta's remarks on the point, that it is not certain that the fossil is Jurassic. Carruthers ${ }^{3}$ has described several recognisable but not very well preserved cones of Abietineae from the Wealden under the names of Pinites Dunkeri, Carr., P. Mantellii, Carr., and P. patens, Carr., also a splendid and indubitable Cedar-cone ${ }^{4}$, P. Leckenbyi, Carr., from the Neocomian strata of the Isle of Wight, and from the same beds ${ }^{5}$ an elongated cone like those of Pinus, which he has named Pinites sussexiensis, Carr. The carbonised specimens also from the Neocomian or Wealden formations of La Louvière in Hainault, described by Coemans ${ }^{6}$, are in very fine preservation. Of these, Pinites Corneti, Coem. is no doubt a Cedar-cone; P. Heeri, P. depressa, and P. Toillezi recall Cembra and Strobus; P. Andraei appears to stand between Strobus and Taeda. Lastly, P. Omalii and P. Briarti look very like cones of Picea or Tsuga. Various single cone-scales from the Chalk of Greenland are figured in Heer ${ }^{7}$; two fine cones, Pinites longissima, Vel. and P. Protopicea are figured by Velenovsky ${ }^{8}$. The cones from the Cenomanian beds of Moletein in Moravia may also be mentioned; one of these, Pinites Reussii, Cda., a fragment only, is described by Reuss ${ }^{9}$, the other, P. Quenstedti, Heer, having a well-preserved surface and resembling cones from the Mexican group of Taeda, will be found in Heer ${ }^{10}$. A series of cones from the English Eocene formations have been figured by Starkie Gardner ${ }^{11}$.

The needles of Coniferae are, like the cones, widely diffused through

${ }^{1}$ Nathorst (2), p. 63 ; t. 15 , ff. x, 2. ${ }^{2}$ de Saporta (4), vol. iii, p. 474; t. 19x. ${ }^{3}$ Carruthers (1).

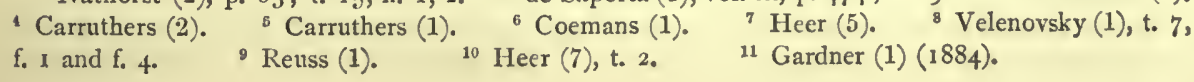


the different formations, but it is in most cases doubtful whether they belong to the Abietineae. It might indeed be maintained that there is no real certainty except in the case of Pinus, and in that genus only when the needles are connected together in their tufts. This does not appear to bc very frequently the case; still it can be shown that species of Pinus with bundles of two, three, and five needles lived in Europe during the Miocene period, and that all except Cembra and Pinus canariensis have maintained themselves to the present day in America only. side by side with the species with two needles. From this fact and from the diffusion in circumpolar regions of the Arvae, which seem to belong to older types of Abietineae, is derived, as we know, the argument for the high antiquity of these members of the American flora, and of that flora generally. Among examples of well-ascertained species with five needles may be cited Pinites Palaeostrobus, Ett., ${ }^{1}$ P. echinostrobus, P. fallax, P. Pseudotaeda, P. deflexa ${ }^{2}$; of species with three needles, Pinites Saturni, Ung. ${ }^{3}$, P. resurgens, Sap., P. trichophylla, Sap., P. divaricata, Sap. ${ }^{4}$, all of the Tertiary epoch. It is more or less probable that many other species were of similar character.

The flat needles resembling those of the Silver Fir, which are frequently recorded by authors from the Jurassic system upwards, and sometimes form of thenselves entire beds of coal (Abietites Linkii, Dk., from the Wealden of Duingen, A. Crameri, Heer, from the beds of Kome in the Urgonian formation of Greenland), may be properly passed over for the reasons mentioned above. It may be left to those who are working at the geography of plants to put things in order here, which will not be done without exact and systematic comparative examination of the epidermis of the leaf in living and fossil forms. Schenk ${ }^{5}$ has made this examination in the case of the two species of Abietites just mentioned, and the result is that neither of them can belong to Abietineae. Abietites Linkii, Dk. shows on the under side of the leaf several rows of stomata-bands separated by broad intervals and not lying on the two sides of a median nerve, somewhat as in Podocarpus. A. Crameri has the stomata in the middle zone of the leaf, Heer's median nerve, and none on the lateral parts of the leaf. In this peculiarity and in the form of the epidermal cells the plant agrees exactly with Sciadopitys, and Schenk therefore makes it the representative of Sciadopitys in the period of the Chalk.

A much greater amount of differentiation is presented by the great series of Araucaricae, in which must be included the Sequoieae and Taxodieae, if we accept the interpretation of the structure of the flower given by Sachs and Eichler. The large generic groups with their marked differences of habit must be discussed one by one.

\footnotetext{
1 von Ettingshausen (1) (Häring, t. 6, ff. 22-33), and de Saporta (7), t. 3, f. I ; t. 4 , f. 3 . ${ }^{2}$ de Saporta (8), t. 3. ${ }^{3}$ Unger (1), tt. 4, 5. "de Saporta (8), t. 4. 5 Zittel (1), p. 293.
} 
The type Araucaria is known to us in its entire cones and cone-scales from Jurassic strata, and care is requisite in dealing with it where we have unbroken cones only before us, that it may not be confounded with stems of Cycadeae. The foliage, which varies much, as we know, in recent forms, can only be certainly determined when it is found in actual connection with the cones. The general habit is seen in the cone of Araucaria sphacrocarpa, Carr. ${ }^{1}$ from the Great Oolite of Stonesfield; the original specimen preserved in the Geological Department of the British Museum shows the single seed in the median position on a detached scale. Of A. Brodiaei, Carr. ${ }^{2}$, from the Bathonian (Lower Oolite), we have also a reliable broken cone, which is attached to a. leafy stalk after the manner of Brachyphyllum described below on page 78. Of A. Philippsi, Carr. ${ }^{3}$, from the Lower Oolite of Yorkshire, only the characteristic scales are preserved, each scale having one seed. In the Upper Oolite (Kimmeridge of Bellay) are found leafy cone-bearing branches, like those of the recent $\mathrm{A}$. Bidwillii, which have been figured and described by Saporta as Araucaria microphylla, Sap. ${ }^{4}$ The same author has also described cone-scales of A. Moreauana, Sap. ${ }^{5}$ from the Coralline Oolite of St. Mihiel. Many trustworthy cone-scales also with the impression of the seeds have been obtained by O. Feistmantel from the Gondwana beds in the East Indies (which may be Jurassic). The figures of Araucarites macropterus, O. Feistm. ${ }^{6}$, and of A. cutchensis, O. Feistm. ${ }^{7}$, may be compared. Araucarias are supposed to have lived in France in Eocene times also; the English Araucarias described by Gardner ${ }^{8}$ are founded on leafy branches only. Similar branches from the Tertiaries and the Chalk have been referred to Cunninghamia ${ }^{9}$. Hardly any fossil remains of Dammara are known; the scales from the polar Chalk named by Heer ${ }^{10}$ Dammara borealis and D. macrosperma are not convincing; the latter might very well be a conescale of Araucaria. The cone-like bodies described by Presl ${ }^{11}$ under the name of $D$. albens have lately been claimed by Velenovsky ${ }^{12}$ as stems of Cycas and named Krannera.

The needles described by Heer under the name of Abies Crameri remind us of the leaf-structure of Sciadopitys, as has been already said. Another kind of needle from the Jurassic beds of Spitzbergen has been described by Heer and named by him Pinus Nordenskiöldi, but Schmalhausen ${ }^{13}$, who had similar leafy branches before him, calls it Cyclopitys and places it side by side with Sciadopitys; he has also described a second species, which he names C. Heerii. But, as Schenk has shown ${ }^{14}$, the resem-

1 Carruthers (1).

2 Carruthers (2). 5 de Saporta (4), vol. iii, t. 184 . pt. iii, p. I86; t. 8.

${ }^{7} \mathrm{Pal}$

Pas

Zittel (1).

14 Zittel (1).
3 Carruthers (2). . ${ }^{4}$ de Saporta (4), vol. iii, t. I86. - Palaeontologia Indica, ser. II, Gondwana syst. vol. i,

${ }^{8}$ Gardner (1) (1884). ${ }^{13}$ Schmalhausen (1). 
blance to recent coniferous forms is only in the habit. The branch bears whorls of many leaves at considerable intervals; there is no trace of the scale-leaves crowded as in a bud, in the axils of which the double needles are placed in the recent plant. Examination of the epidermis of the leaf in the original specimen might perhaps give some means of judging how far this is owing to the bad state of preservation.

The type of the Sequoias is represented by a great number of remains from the younger formations, and these we have been accustomed to consider chiefly on Heer's authority ${ }^{1}$ as different species of the genus Sequoia. Cones are abundant, and are sometimes attached to their branches. It is true that we are acquainted only with the outward appearance of these objects, and doubts have recently arisen whether it would not be advisable to unite some of them with other nearly allied genera, such as Arthrotaxis ${ }^{2}$. The foliation connects the fossil forms quite naturally with the recent species of the genus, with Sequoia sempervirens and S. gigantea. They extend from the Pliocene formations, where they are widely diffused, to the Lower Chalk. The most important species found in the Tertiaries, from the Eocene upwards, are the following: first, Sequoia Couttsiae, showing a foliation which answers to that of our S. gigantea ; cones are figured by Saporta ${ }^{3}$, Schenk ${ }^{4}$, and $\mathrm{Heer}^{5}$. But this very form is removed by Gardner to Arthrotaxis, and is moreover divided into several species ${ }^{6}$. The specimens from Bovey Tracy figured by Heer ${ }^{7}$ are said by Gardner to be lost, and their identity therefore with those examined by the latter cannot be ascertained, but those from Hempsted are identical. Gardner adds: 'I think it highly probable however that the specics may be found not to be a true Sequoia, and the danger is very apparent of giving the reins to the imagination and picturing the slopes round the ancient Bovey water as clothed with woods composed "mainly" of a huge coniferous tree, whose figure resembled in all probability the Sequoia gigantea of California' and the warning in existing circumstances is not out of place. Secondly, Sequoia Langsdorffii, Brongn. figured by Schimper ${ }^{8}$; Heer $^{9}$ gives the only representation known to me of the cone-bearing branch, which is morenver by no means above suspicion. This species comes near the recent Sequoia sempervirens. Forms of both kinds appear to have existed as early as the time of the Chalk, namely S. Reichenbachii, Heer ${ }^{10}$, S. fastigiata, Stbg ${ }^{11}$, S. crispa, Vel. ${ }^{12}$ belonging to the type of S. gigantea, and S. Smithiana, Heer ${ }^{13}$ to the type of S. sempervirens; and these different main forms have a number of other forms grouped round them, but it would be foreign to the objects of this

\footnotetext{
${ }^{1}$ Heer (5). "Gardner (1) (1884). ${ }^{3}$ de Saporta (8), p. 49 ; t. 2, f. $2 . \quad{ }^{4}$ Zittel (1), p. 297. ${ }^{3}$ Heer (9), t. 59 . ${ }^{-}$Gardner (1) (1883), p. 38; (1884), p. 90. ${ }^{7}$ Heer (11). ${ }^{8}$ Schimper (1). ${ }^{9}$ Heer (11), vol. iii, t. 146, f. 16. ${ }^{10}$ Heer (7), t. 1. "Velenorsky (1), tt. 8, 10. ${ }^{12}$ Velenovsky (1), t. $10 . \quad{ }^{13}$ Heer (5).
} 
work to enter more closely into their consideration. Thirdly and lastly, Sequoia Sternbergii, Heer, a species resembling S. gigantea in foliation, and one of the best known and commonest forms, especially in Miocene times; but its connection with the Sequoias has been recently questioned. Marion ${ }^{1}$ sees in it the type of a peculiar genus known as Doliostrobus (D. Sternbergii), and Renault ${ }^{2}$ assents to his view. Respecting the English plant known as Cryptomeria Sternbergii, Gardn. ${ }^{3}$, and identified with a part at least of the remains which are associated by authors with the Sequoias, I do not venture to express an opinion. It comes from the 'basaltic formation' of Ireland; its cones are plentiful but never found attached to the branches. These cones, as well as the one figured by Heer ${ }^{4}$, do not in fact look excessively like those of Sequoia.

Velenovsky's new genus Ceratostrobus, with two species, C. sequoiaephyllus and C. echinatus, is closely allied, according to that author ${ }^{5}$, with Sequoia, standing between it and Cryptomeria. The scales of the small spherical cones in this genus have a long thorn-like process in the middle of the apical areola. In both species cones and branches have been found attached to one another; the habit of the latter is to some extent that of Sequoia gigantea.

The genus Taxodium, wonderfully like Sequoia sempervirens in the structure of the lateral branches which are deciduous in autumn, is, like Sequoia, very widely diffused through the Tertiary formations from the Oligocene upwards; the detached branchlets and the very characteristic cones are both found, and are so like those of the living species that most authors are unwilling to separate the fossil form from it, and therefore speak of Taxodium distichum miocenum. According to $\mathrm{Heer}^{6}$ the leafy branches, though resembling those of Sequoia Langsdorffi, are however distinguished from it by not having the decurrent leaf-cushions of Sequoia. Good figures of the fossil cones will be found in Heer ${ }^{7}$.

Lastly, Glyptostrobus is abundant also in the Tertiaries from the Oligocene upwards. Two species are distinguished, G. europaeus, Heer, and G. Ungeri, Heer, besides two less certain forms. The highly characteristic cones are very often attached to the branches which bear them. They are figured in Schenk ${ }^{8}$ and in Unger ${ }^{9}$. Heer ${ }^{10}$ has described various small fragments of branches from the Chalk of Greenland, which are supposed to belong to Glyptostrobus; there is a figure also of a cone-scale from the Urgonian beds of Kome in Greenland, which though somewhat obscure and not in good preservation, yet may probably be classed with Glyptostrobus.

\footnotetext{
1 Marion (1). $\quad{ }^{2}$ Renault (2). $\quad{ }^{3}$ Gardner (1) (1884), p. 85, t. 10.

5 Velenovsky (1), t. 12, ff. 15, 16, and t. 1 1, ff. 1 2, 15. ${ }^{6}$ Heer (11).

Zittel (1), p. $296 . \quad 9$ Unger (3), t. I, ff. 3-1 I.

10 Heer (5).
}

4 Heer (10), p. 310.

7 Heer (12), t. 2. 
A detailed description of the fossil remains from the group of Cupressineae, which are very common in the Tertiary formations, has been given by Schenk ${ }^{1}$. The determination of the genera so far as this is based only on leafy branches, though the result of closest comparison, is nevertheless an uncertain affair, owing to the near affinity of the forms and the frequent change in the foliation of different parts of the same plant. It is otherwise where cones are to be liad, for genera founded on these may be considered to be sufficiently attested. The fossil remains of this group are of so little interest to the botanist that a short notice of them will suffice; nor have I, like Schenk, the advantage of an extensive comparative study of the foliation of recent forms, and am not in a position thercfore adequately to criticise his statements. Phyllostrobus Lorteti, Sap. ${ }^{2}$, from the Kimmeridge of Orbagnoux, should be the oldest cone-bearing form which certainly belongs to this group. A small branch with four regular rows of leaves of dissimilar form in the usual decussation bears a cone formed of two pairs of scales and resembling the cone of Callitris or Libocedrus, but only moderatcly wellpreserved. The scales of the upper pair are larger than those of the lower. Then we are acquainted with fossil cones, undoubtedly of the genus Widdringtonia and in cxcellent prescrvation, belonging to the Miocene species Widdringtonia helvetica, Heer ${ }^{3}$, W. antiqua, Sap. ${ }^{4}$, and W. brachyphylla, Sap. ${ }^{5}$, also from the Tertiaries, and cones badly preserved indeed but still probably rightly named of W. microcarpa, Sap. ${ }^{6}$ from the Kimmeridge of Armaille. Well-preserved cone-bearing remains of the genus Callitris are also known from the Tertiary strata in the South of France, and will be found figured in Saporta ${ }^{7}$. Starkic Gardncr ${ }^{8}$ very properly classes with these some small cones from the London Clay of the Isle of Sheppey, which have been described as Callitris curta and C. Ettingshauseni. The former species had been already noticed by Bowerbank ${ }^{9}$ under the name of $\mathrm{Cu}$ pressinites curtus. A single cone with three decussate pairs of scales is referred by Saporta ${ }^{10}$ to Thuiopsis. A cone-fragment with large unwinged sceds from the Miocene of Grecnland, named by Heer Biota borealis ${ }^{11}$, is perhaps rightly placed.

While it appears from the above account that the Jurassic system supplies cxtremely few satisfactory cones of Cupressineae, it contains nevertheless a great abundance of leafy branches, which from the decussate arrangement and characteristic position of the leaves may be placed in this group, as we learn from a glance at the numerous species of Palaeocyparis figured by Saporta ${ }^{12}$. Among the branches also of Coniferae from

\footnotetext{
Zittel (1).

2 de Saporta (4), vol. iii, t. 22 I.

${ }^{8}$ Heer (11).

4 de Saporta (6), t. 3 , f. 3 .

3 de Saporta (5), t. 2, f. $6 .{ }^{6}$ de Saporta (4), vol. iii, t. 2 I9.

7 de Saporta (6), t. 3, f. 2 ;

(7), t. I, f. 3 ; (8), t. I, f. $6 .{ }^{8}$ Gardner (1) (1883), t. $9 .{ }^{\circ}$ Bowerbank (1). ${ }^{10}$ de Saporta

(8), t. I, f. 5. $\quad$ "Zittel (1), p. $322 . \quad 12$ de Saporta (4), vol. iii.
} 
Solenhofen, which were all called Arthrotaxites or Echinostrobus princeps, many examples of Palaeocyparis may be distinguished by the position of the leaves. As far as we can determine from branches alone, we should be justified in classing with Cupressineae the peculiar remains which were first described as fern-leaves under the name of Moriconia Cyclotoxon by Debey and Ettingshausen ${ }^{1}$, but were afterwards seen by Saporta ${ }^{2}$ to be of coniferous origin. This form shows the pinnate habit of the fern-leaf, for the branches are occupied by two rows of lateral branchlets of limited growth with crowded decussate leaves, which are flat and sharply keeled and disposed in alternating rows, exactly after the manner of the Cupressineae. Figures of these fossils are to be found in $\mathrm{Zittel}^{3}$ and $\mathrm{Heer}^{4}$. Moriconia is known at present only from the Chalk, and is compared by Schenk to Libocedrus. To the Chalk also belong certain distinctly articulated branch-systems with lateral branches pinnately disposed in two rows, and pairs of decussated slightly projecting scales separated by long internodes and often not preserved ; these fossils, formerly known as Culmites, have been named by Schenk ${ }^{5}$ Frenelopsis Hoheneggeri. That they really belong to the Cupressineae has been made probable by the researches of Zeiller ${ }^{6}$, who examined the epidermis in specimens from the Turonian beds of Bagnols, and found that the stomata showed certain peculiarities which occur in Frenela; but Schenk ${ }^{7}$ points out that they are distinguished from Frenela by having two members only and not three in the leaf-whorls.

In speaking of the Taxineae it will be convenient to leave the Salisburias, as a special group, for after consideration. They may be properly considered a group apart on account of the peculiar development of the germ, even if we do not with van Tieghem and his school explain the female flowering shoot as a fertile scale bearing several ovules. Of the remaining forms, the majority of which have only slightly marked peculiarities in the vegetative organs, few remains have been preserved in the fossil state, and the affinities of these are in most cases more than usually doubtful, as is plainly expressed in Schenk's ${ }^{8}$ account of Torreya, Cephalotaxus, Taxus, and Podocarpus, to which we may refer the reader. If the piece of a branch bearing seeds from the beds of Patoot in Greenland, which Heer ${ }^{9}$ has figured as Cephalotaxites insignis, really belongs to the Taxineae, as the habit seems to show, we should have this type from the uppermost part of the Chalk. Remains of leaves from the Rhaetic beds ${ }^{10}$, which were formerly considered to be the ultimate ramifications of Phyllocladus, are now generally regarded as pinnae of a Fern or Cycad (Thinnfeldia). Heer ${ }^{11}$

\footnotetext{
1 Debey and von Ettingshausen (1). $\quad{ }^{2}$ de Saporta (9). $\quad$ ' Zittel (1), p. 318. * Heer (5).

5 Schenk (4); see also Zittel (1), p. 314. ${ }^{\text {I }}$ Zeiller (2). ${ }^{7}$ Zittel (1), p. 3I4. ${ }^{8}$ Zittel (1).

- Heer (5), vol. 71, t. 53. $\quad{ }^{10}$ F. Braun (1). $\quad{ }^{11}$ Heer (5), vol. 3 II, p. I 29 ; t. I7.
} 
has recently made us acquainted with a phylloclade bearing seeds from the Upper Chalk of Spitzbergen, which he names Phyllocladus rotundifolius, Heer. Without a knowledge of the original specimen it is impossible to say whether this determination can be justified or not. Lastly, Schenk ${ }^{1}$ has suggested a comparison of his Conchophyllum Richthofeni from the Coalmeasures of China with the female spikes of Dacrydium, though he is not prepared to place it with Dacrydium; for the present this fossil also must remain quite doubtful.

Bertrand ${ }^{2}$ has described some carbonised shells of seeds found in local deposits filling pockets in the Cenomanian limestones above the Wealden formation of Tournay in Belgium, which from their structure he places between Cephalotaxus and Torreya, and names Vesquia Tournaisii. He shows that these two genera are the only living forms of Taxincac in which two vascular bundles traverse the integument or shell of the seed, and that they are distinguished from one another by the distance which the two bundles, which occupy the margins of the seed, run in the woody layer of the seedcoat. Vesquia shows a similar structure; the bundles are destroyed, and in their places a canal runs throughout the whole length of the hard seed-coat ; but there is still the possibility that the seeds in question may have belonged to one of the many Salisburicae of that cpoch, Baiera, or Phoenicopsis, or Feildenia. If Ginkgo itself has no vascular bundles in its integument ${ }^{3}$, this is no proof, as the comparison of Taxus with Torreya shows, that there could have been no bundle in those older allied forms.

Ginkgo biloba, the single living type of the Salisburias, stands, as we know, alone, a perfect stranger, in the midst of recent vegetable forms. The tree, unknown in the wild state and preserved only in the groves of Chinese temples, seems to have been kept from extinction by the care of the priests. But it is almost certain that it is really the survivor of a series of allied plants which was rich in species and individuals. The merit of supplying proof of this belongs to Heer ${ }^{4}$. It is true that some of these forms were already known, having becn found in different formations from the Rhaetic beds upwards, but they had been taken for Ferns and had been generally described as Cyclopteris and Baicra. Of these forms Heer at first selected two especially, which are figured in Brongniart ${ }^{5}$ as Cyclopteris digitata, and in Lindley and Hutton ${ }^{6}$ under the same name. Heer distinguished these as Ginkgo digitata, Hecr, and G. Huttoni, Heer, on the strength of his material from the Lower Oolite of Spitzbergen in which he recognised them, and added some other species to them. That these leaves were not the pinnate leaves of ferns he concluded from their long stalk, on which the lamina

${ }^{1}$ Schenk (2), t. $4^{2} . \quad{ }^{2}$ Bertrand (1). $\quad{ }^{3}$ C. E. Bertrand, Études sur les téguments séminaux des végétaux phanérogames gymnospermes, in Ann. d. Sc. Nat., sér. 6 , vol. vii (1878), p. 70 . - Heer (1) and (5). ${ }^{3}$ Brongniart (1), vol. i, t. 6I, ff. 2, 3. ${ }^{6}$ Lindley and Hutton (1), vol. i, t. 64 . 
gradually dies out and from which the parallel nerves emerge and afterwards branch, but chiefly because the leaf-stalk is deeply channelled, and when well preserved shows a basal swelling above the smooth plane of separation. Heer was afterwards confirmed in the happy idea of comparing them with Ginkgo by finding seeds on the same slabs from Spitzbergen which reminded him of that genus, together with short bits of branches thickly beset with roundish scars which he compared to the short shoots of Ginkgo. It was important also that similar objects were found associated with Ginkgo-like leaves in other localities also in the polar zone, and with the further addition of male flowers also resembling those of Ginkgo. From all this we may with Heer consider it as proved that these leaves cannot be the leaves of ferns; the present view of them it is true rests chiefly on a conclusion from the association together of leaves, seeds and branches, which does not give absolute certainty, though it appears to be better founded in this case than it is in any other in the older formations. Heer ${ }^{1}$ says that the nervation in his forms resembles that in our Ginkgo, but this does not appear from the figures, for there the nerves which are of equal strength simply diverge and spread from the base of the leaf, and there is no sign of the two chief strands which run along the lower leaf-margins and send branches into the leaflobes. Heer also states that Baiera pluripartita, Schimp. from the Wealden is so closely allied to his Ginkgo digitata that it must be placed in the same genus, but I am not so certain of this, because, after examination of the bestpreserved specimens of the form from Osterwald in the Deister country in the Göttingen collection, I have satisfied myself that the nervation is somewhat different from that of Ginkgo. It is however very different even with the best material at one's disposal to get a clear view of the course of the nerves, especially close to the stem, which is the chief point, because the interspaces between them are here very small and the thickness of the strip of coal and the transverse corrugation of the surface, which I should take with Heer to be an original character of the leaf, come in the way and prevent an exact determination. In the same work, and in the next section, which is on the Jurassic flora of Eastern Siberia, Heer on the strength of the view once gained has gone a good deal further by adding several species to the genus Ginkgo as he conceives it, and associating with it a number of genera, more particularly Baiera, F. Braun, in an amended form. His work and that of Schenk should be consulted for further species of Ginkgo from the Chalk of Greenland and from Eocene and Miocene strata. One of the Miocene forms, G. adiantoides, Heer, found at Sinigaglia is closely allied to the living species. Heer illustrates the genus Baiera, from which he had removed several of the older species in order to put them under Ginkgo, chiefly from Baiera longifolia, Heer, which occurs abundantly in the Lower 
Oolite of Siberia, and according to Saporta ${ }^{1}$ in the Coralline Oolite of France. Better-known species of the genus are Baicra Münsteriana, Heer, from the Rhaetic beds of Bayrcuth, and B. paucipartita, Nath., from the same formation at Schonen. The Chalk also has produced remains of Baiera, which may to some extent be accepted. The leaves of Baiera, which are repeatedly and dichotomously inciso-partite, are distinguished from those of Ginkgo by the shortness of the leaf-stalk and by the narrow ribbon-like form of the grcatly elongated leaf-lobes, in which according to Heer there is no further bifurcation of the nerves. In the specimen of B. paucipartita, Nath., figured in Schenk ${ }^{2}$, the leaves which are only slightly divided are seen to be collected together, as in Ginkgo, at the summit of a branchlet. Later investigations leave little room for doubt that Salisburieae are to be found as early as in the Permian formation, and Saporta ${ }^{3}$ maintains that we have the genus Ginkgo itself in his Salisburia primigenia from the Permian deposits of Russia. The habit is not against this conclusion, but I will not venture to decide. The species Baiera digitata, Heer, peculiar to the Kupferschiefer of Europe, was formerly regarded by most writers as an Alga ${ }^{4}$ (Fucoides Zonarites); it is found usually in somewhat doubtful fragments, seldom in a perfect state, and appears always to have had leaves with only few incisions; in the Amcrican Baiera virginica, Font. et White ${ }^{5}$, the leaf-division was more copious. These authors ${ }^{6}$ also describe a type of leaf from the same formation in Pennsylvania as Saportaea salisburioides, Font. et White, in every respect like that of Ginkgo, and with a nervation which is even essentially the same as in our own recent species. The genus Rhipidopsis, Schmalh. also may according to Schmalhausen's ${ }^{7}$ description be very near to Ginkgo; the leaves with their deep flabelliform incisions show similar nervation and symmetrical configuration, the broadly wedge-shaped sections being very large in the middle of the leaf and diminishing very rapidly toward the side, so that they appear at last quite diminutive and rudimentary.

It was stated above that the leaves of Ginkgo and Baiera of the Lower Oolite of Eastern Asia are associated with fragments of branches, remains of seeds, and male flowers. The branches and seeds are considered by $\mathrm{Hecr}^{8}$ to belong to Ginkgo digitata and also to Baiera Czekanowskiana ${ }^{9}$; some male flowers and the stalk of a female inflorescence are assigned by him to Ginkgo Huttoni, other male blossoms to G. sibirica. The flowers are really like those of our own plants, but they are perhaps stouter, and have longer filaments standing out stiffly from the axis and bearing at their apex two or three spreading pollen-sacs. Heer's ${ }^{10}$ remarks on this point

\footnotetext{
1 de Saporta (4). $\quad 2$ Zittel (1), p. 262. $\quad{ }^{3}$ de Saporta (2), p. 145. $\quad$ Brongniart (1), t. I, f. 9. ${ }^{5}$ Fontaine and White (1). $\quad{ }^{6}$ Fontaine and White (1), p. 102; t. $3^{8} . \quad{ }^{7}$ Schmalhausen (1).

${ }^{8}$ Heer (5), vul. 4 I, t. 10. $\quad$ Heer (5), vol. 41 I, t. $10 . \quad 10$ Heer (1), p. 3.
} 
should be consulted. With Baiera longifolia and B. Czekanowskiana Heer once found flowers differing from those of the Ginkgo-forms in the larger number of umbellately arranged pollen-sacs. Their connection with Ginkgo is supported by Schenk's ${ }^{1}$ discovery of quite similar flowers in the Rhaetic beds of Bamberg in company with Baiera longifolia, which are described by him as Stachyopitys Preslii and are figured by Schimper ${ }^{2}$. In some of these flowers the pollen-sacs spread like the spokes of a wheel, in others they hang down, being attached above to the common conical connective: Schenk ${ }^{3}$ suspects that this indicates a generic difference, but it is conceivable that the latter is the condition of the anther before, the forme: after it is unfolded.

Further, Heer places the genera Czekanowskia and Phoenicopsis from the Jurassic formation of Siberia with the Salisburieae, but their position is much less certain than that of the forms which we have just been considering. This is owing to the circumstance that Heer ${ }^{4}$ was tempted to compare Czekanowskia with Isoëtes. Czekanowskia has fascicles of linear leaves repeatedly and dichotomously branched and with capillary terminal lobes; whether they have one or several nerves is not clear from Heer's description. They stand, as I have satisfied myself from original specimens in the British Museum, several together on a short slender shoot beset with closely crowded scale-leaves; and it is this shoot which in conjunction with the dichotomous division of the leaves has turned the scale in determining the systematic position of the plant. Besides, as Schenk reminds us, the short shoots are not thrown off in Ginkgo or in the rest of the Coniferae with the single exception of the pines; that they were regularly deciduous in Czekanowskia is evident from the constant occurrence of connected fascicles of leaves. The leaves are often beset with ovoid swellings arranged in rows or sometimes crowded together and of doubtful character', which Heer would refer to leaf-fungi. If the very peculiar fructification figured by Heer ${ }^{5}$ really belongs to Czekanowskia, as almost seems to be the case, still this genus appears to me to be essentially distinct from Ginkgo, and the habit, as Heer rightly judges, reminds us rather of Ephedra. Similar fossils are also figured by Schmalhausen ${ }^{6}$.

Phoenicopsis, Heer ${ }^{7}$ agrees with Czekanowskia in having short leafy shoots, which are surrounded by small scale-leaves, and fall off entire; but the leaves are quite simple undivided and ribbon-like, rounded at the apex, narrowing gradually to the point of attachment, and sessile. According to Heer they have simple parallel nerves. In connection with Phoenicopsis must be mentioned, lastly, Heer's genus Feildenia ${ }^{3}$, an extremely doubtful

1 Schenk (3), t. 6. (5), vol. 4 II, p. 65 . vol. $4 \mathrm{II}, \mathrm{t} .3 \mathrm{O}$.
2 Schimper (1), t. 75 , ff. 15,16 .

${ }^{5}$ Heer (5), vol. 4 II, t. 2 I, f. 8. ${ }^{8}$ Heer (5), vol. 2 III, t. 6 ; vol. 5 I, t. I.
3 Zittel (1), p. 26 r. - Schmalhausen (1).
4 Heer

7 Heer (5), 
fossil from the Miocene beds of Spitzbergen and Grinnell-land. The leaves are essentially like those of Phoenicopsis; they have scars at their base at the point of separation, and several nerves. They do not however grow on short shoots, but are found attached in spiral arrangement to a piece of a branch. Hence since the resemblance to Phoenicopsis is in the ribbon-like leaves only, and the two forms belong to so widely separated formations, it seems to me a somewhat violent proceeding to unite them; the comparison with section Nageia of Podocarpus suggested by Heer is more promising. Schenk ${ }^{1}$ has described under the name of Eolirion primigenium a branch from the lowest beds of the Chalk of Wernsdorf in the Carpathians, which is closely beset with large ribbon-like leaves. He has since referred it to Phoenicopsis ${ }^{2}$, from which it is essentially distinguished by having no short shoots. It seems to me that in Eolirion and Feildenia we have before us representatives of forms which we cannot yet determine from want of material. We must wait for future fortunate discoveries, especially in the Chalk.

Other genera, usually referred by authors to this group on what seem to me to be somewhat doubtful grounds, are Ginkgophyllum, Sap. Whittleseya, Lesq., Trichopitys, Sap., Dicranophyllum, Grand' Eury. In Ginkgophyllum, the type of which is G. Grasseti, Sap. from the Permian beds of Lodève figured by Schenk ${ }^{3}$, somewhat irregularly incised leaves like those of Ginkgo or Baiera are attached to an elongated branch, on which their insertions run a long way down. There is no indication that the stalk was channelled, nor is there any evident point of separation. Saporta ${ }^{4}$ reckons among species of this genus a lobed leaf-fragment from the Permian of the Ural, Ginkgophyllum Kamenskianum, Sap., and also a form from the English Coal-measures, G. flabellatum, Sap. (Psygmophyllum, Schpr), which is figured in Lindley and $\mathrm{Hutton}^{5}$ as a species of Nöggerathia. Some single short-stalked leaflets ending above in an obtuse toothed margin have been described by Lesquereux ${ }^{6}$ under the name of Whittleseya, and are figured also in Renault ${ }^{7}$, but they are for the present of no value to the botanist. The type of Trichopitys is also a fossil from the Permian beds of Lodève, T. heteromorpha, figured by Saporta ${ }^{8}$. This is a branch with. elongated internodes, and leaves which split up by repeated dichotomy into fascicles of fine linear divergent lobes. At the base of a lateral branch which has been preserved the leaves are abbreviated and little or not at all divided. In the axils of the leaves are seen here and there stalked bud-like forms, which Saporta ${ }^{9}$ has since sought to explain as ovules. I saw in Paris at the Ecole des Mines a specimen agreeing with Saporta's figure. The

\footnotetext{
${ }^{1}$ Schenk (4). $\quad{ }^{2}$ Zittel (1). $\quad{ }^{3}$ Zittel (1), p. $260 . \quad$ de Saporta (2), pp. ${ }_{44}$ and $9 \mathrm{r}$. ${ }^{5}$ Lindley and Hutton (1), vol. i, it. 28, 29. ${ }^{-}$Lesquereux (1). ${ }^{7}$ Renault (2), vol. iv, t. 5, ff. 9, I0. ${ }^{\circ}$ de Saporta (4), vol. iii, t. 152.
} 
other forms described as belonging to this genus, one from the Coralline Oolite of St. Mihiel, the other from the Lower Oolite of Siberia and known only in leaf-fragments, can scarcely be considered to be satisfactorily determined.

The remains from the Coal-measures, which are at present styled Dicranophyllum after Grand' Eury ${ }^{1}$ and are still little understood, can like the preceding genera be compared with Salisburieae only on the strength of their bifurcated leaves. They must be briefly noticed here on account of this connection, though they should properly have been referred to the last section of Coniferae. The Dicranophyllae, figures of which are to be found in Renault ${ }^{2}$ and Zeiller ${ }^{3}$ as well as in Grand' Eury, are represented by portions of thick branches with spirally arranged leaves and short internodes, and with their surface marked out into rhombic areolae closely crowded together and raised in the centre, like those of Lepidodendrae, and each giving rise to a leaf. The leaves are narrow needles, repeatedly and dichotomously branched, and on the older branches are usually strongly recurved. I have been able to satisfy myself with respect to these characters by personal examination of many fine specimens at the École des Mines at Paris.

Of the genera still to be considered some are probably connected with the great series of Araucarieae, though we cannot say exactly to which of the different types in that series they belong; the systematic position of the rest is quite unknown. We must hope that further discoveries will enable us to explain them.

The best-known of all extinct genera of Coniferae is Voltzia, Schpr, a form characteristic of the Trias and represented in the Permian formation also by two species. The cones of Voltzia, which are frequently found whole and even attached to the branches (see figures in Schimper ${ }^{4}$ and Geinitz ${ }^{5}$ ), have the general habit of those of Abietineae; they are cylindrical and composed of closely crowded spirally arranged scales, which appear ultimately to spread apart from one another. The stout woody scale ${ }^{6}$ narrows below into a tolerably long stalk; the flat expansion divides above into five or three obtuse terminations, on the back of which a corresponding number of striated median keels descend to the point of attachment of the stalk and there form a cushion-like elevation. On the upper inner side may be seen in very well-preserved specimens a roundish areola inclosed by a sharp keel-like ridge, to which are attached the edges corresponding to the margins of the lobes. This areola is the plane of insertion of the dependent seeds, which are probably always three in number, though sometimes only two are present standing right and left; in the latter case the median seed

\footnotetext{
${ }^{1}$ Grand' Eury (1).

${ }^{2}$ Renault (2), vol. iv, t. 4, f. 9 .

3 Zeiller (3), t. 26, f. I.

Schimper

(3), t. I 4 .

${ }^{5}$ Geinitz (2), t. 5 .

- Solms, Graf zu (1), and Geinitz (2). 
may have dropped, but it is also possible that it is really wanting, perhaps through arrest of growth. The seeds ${ }^{1}$ are flattened, ovoid or elongated, and girt by a narrow wing with an acute-angled notch at its apex. Such a structure of the cone, since there is nothing to indicate that the scale was double, affords no ground for placing the genus with Abietineae; we are naturally led to a comparison with forms of the series of Araucarieae, and in this comparison the flat scales seem to point to affinity with the typical Araucaria, the structure of the seed with Sequoia. We must remain in doubt on this point as long as we are in ignorance of the anatomical structure of the scales, for it is this which supplies the decisive characters. Male flowers which have been found with specimens of Voltzia heterophylla and $V$. recubariensis are strikingly like those of our pines. The above description of the cones of Voltzia is drawn from the best-known species, V. Liebeana, Gein., and V. heterophylla, Brongn., in both of which cones have been found attached to the branches. In V. heterophylla, a characteristic fossil of the Bunter Sandstone, very fine specimens of which have been found at Sulzbad in the Vosges, the shape of the leaves varies much. Gencrally they resemble those of Araucaria excelsa, being bent into the form of a curved thorn or hook from a decurrent base, but in places, especially at the summit of the branch, they are linear and acicular and much elongated. Schimper ${ }^{2}$ has figured fine branches with both kinds of foliation. This latter form of leaf is the only or the prevailing one in the Permian species V. Liebeana, Gein., of which splendid specimens are found about Gera ${ }^{3}$. The Permian beds of Fünfkirchen supply V. hungarica, Hecr ${ }^{4}$ also, which resembles V. Liebeana but is distinguished by the narrower lobes of the fertile scales, and the Rothliegende of Huckelheim V. hexagona, Bisch. ${ }^{5}$, in which the cone-scales have only three lobes. In both cases the scales are accompanied by branches with long leaves which have been gencrally supposed to belong to them, and which are in fact very like the well-ascertained foliage of V. Liebeana. As we have V. heterophylla in the Bunter Sandstone, so we have V. recubariensis in the Lower Muschelkalk of the Southern Alps. Recoaro near Vicenza has supplied abundant material, which has been examined by Schenk ${ }^{6}$. Here too the characteristic cone-scales have been united to male flowers and branches with short leaves solely on the strength of their all occurring together, but the propriety of this is made more than probable by the resemblance of the shoots to those of the species first considered. A peculiar species, V. coburgensis, Schaur. (Glyptolepis Keuperiana, Schpr.), occurs in the Keuper of Coburg. It is marked by long narrowly cylindrical laxly-leaved cones in which the scales have their margins divided into many

1 Solms, Graf zu (1), t. 2, ff. 29, 30, and Schenk (5), t. 11, f. I. ${ }^{2}$ Schimper (3). ${ }^{3}$ Geinitz (2). 4 Heer (13). ${ }^{3}$ Bischoff (1). ${ }^{6}$ Schenk (5). 
narrow acute lobes. The remains associated together under this name urgently require renewed and careful examination. Of three species described by Stur ${ }^{1}$ from the black slates of Raibl, one, V. raiblensis, Stur, is said to be characterised by scales having three lobes; it must therefore be nearly allied to $\mathrm{V}$. hexagona.

$\mathrm{Heer}^{2}$ has described under the name of Leptostrobus some peculiar cones from the Lower Oolite of Siberia very similar in construction to those of Voltzia coburgensis, Schaur. Schenk ${ }^{3}$ has reproduced the figure of one species. The long thin cone is clothed with quinquepartite scales in loose order, but is distinguished by being developed from a short shoot without needles which begins with scale-leaves, as in the silver firs and pines, whereas the cones of the true Voltzias are placed on the summit of leafy branches. Seeds winged as in Cupressineae and found near the cones are referred to them by Heer ${ }^{4}$, who thinks that two of them were attached in a dependent position to each scale. He describes at the same place and figures the short shoots bearing a fascicle of long flat needles, which he considers to have belonged to the shoots because they were found near them. The remains described by the same author as Schidolepium ${ }^{5}$ (the name should be Schizolepidium) are so imperfectly known that we need not stay to consider them. The genus Cheirolepis, Schpr, also is very like Voltzia in the form of the cone-scales. In this genus Schimper ${ }^{6}$ has placed the plant described by Schenk ${ }^{7}$ as Brachyphyllum Münsteri from the Rhaetic beds of Bayreuth. A second species, Cheirolepis Escheri, Heer, was afterwards found in the $\operatorname{Lias}^{8}$; the broad cone-scales scarcely narrow at all into a linear stalk, and are inciso-lobate on the upper margin. There are usually five pointed lobes, the lateral ones being the broadest; but irregularities sometimes occur. The back of the scale, according to Saporta, shows a thickened areola, which as usual he considers to be the bract in combination with the product of its axil. Two ovules are supposed to have been inserted on the opposite side. Saporta further observes that the scales are always found isolated, and concludes that the cones have fallen to pieces. In the figure of the entire cone given by Schenk, which he says consists of five-lobed scales, I can see nothing that resembles them. These remains of cones are accompanied by copiously and irregularly ramifying branches with short scale-like leaves spirally arranged; but it is not certainly proved that the two belong to one another, because the cone in question does not clearly show the characters of the genus.

The genus Schizolepis, F. Braun, has elongated thin cones resembling those of Voltzia coburgensis, but of smaller size and with scales not closely set; of this genus two well-ascertained species are known from the Rhaetic

\footnotetext{
1 Stur (1). ${ }^{2}$ Heer (5), vol. iv. ${ }^{3}$ Zittel (1), p. 291. 'Heer (5), vol. vi. ${ }^{5}$ Heer (5), vol. vi. "Schimper (1). "Schenk (3). ${ }^{8}$ de Saporta (4), vol. iii.
} 
beds, namely S. Braunii, Schenk ${ }^{1}$, from Franconia, and S. Follini, Nath. ${ }^{2}$, from Pålsjö in Schonen. An older species founded on very fragmentary remains, S. permensis, Heer, requires further verification. The scales of S. Braunii, according to Schenk, are narrowed below; the seminiferous expansion is concave, and the upper margin is split into two ovate lobes. He could sec no indication of a differentiation into coherent fertile scale and bract, and therefore thinks that the genus belongs perhaps rather to Abietineae. Saporta ${ }^{3}$ on the other hand sees in the transverse bounding line of the concave seminiferous expansion the apex of the bract-scale, which is overtopped by the adherent two-lobed fertile scale. Both authors affirm that there are two seeds, and that the point of their insertion is marked on the expansion of the scale by circular spots of a lighter colour. Of the seeds themselves Saporta says that they are not winged, and, if I understand his account aright, that they are erect. Schenk thinks that they are pendulous. I know not what is the foundation for these latter statements; as no seed is anywhere figured, I incline to belicve that they are conclusions from the position of the supposed points of insertion, which would certainly be quite inadmissible. The scales, at first pressed against the slender axis of the cone, appear afterwards to spread. The cones of the other species, similar in habit, would be distinguished according to Saporta ${ }^{4}$ by having scales not narrowing downwards, but the figures, which are taken from plaster of Paris casts of the flat moulds on the slate-beds, are diagrammatically represented. According to Nathorst's figures ${ }^{5}$ we might almost doubt whether these remains belong to the genus which we are considering, for in figures $4,5,6$, and 8 , between and by the side of the two-lobed forms, broad scales may be seen with numerous furrows and terminal lobes like those of Voltzia coburgensis. We might take the latter for the real conescales, and the two-lobed forms for the impressions of the two seeds which were attached to them, and which have been laid bare by fracture of the stone. There are in this case therefore still a number of doubts to be removed; and while we are thus imperfectly informed respecting the cones, we know nothing at all about the foliage of Schizolepis, for there is nothing to make it even probable that the numerous needles which lie one above another in the beds at Pålsjö, any more than the branches beset with needle-bearing shoots which Schenk has referred to this genus, have any connection with Schizolepis.

Heer ${ }^{6}$ has described under the name of Inolepis some cone-bearing branches from the Urgonian Cretaceous formation of Greenland, which in the decussated arrangement of their scales have entirely the habit of Cupressineae. The terminal ovoid cones, which unfortunately show

\footnotetext{
1 Schenk (3). $\quad 3$ Nathorst (2). ${ }^{5}$ Nathorst (2), t. ${ }_{5}$, ff. $4,5,6,8$.

4 de Saporta (4), vol. iii, t. 194 .

3 de Saporta (4). ${ }^{6}$ Heer (5), vol. 3 II, tt. 16, 23 .
} 
nothing of their inner structure, narrow below into the branch and are composed of spirally arranged scales, the rounded apex of the scale being marked by three deep longitudinal fold-like furrows. In this case therefore branches resembling those of Cupressineae bear cones with the outward characters of Araucarieae, and we see again how careful we must be in identifying separate bits of branches. In the genus Cyparissidium, described by Heer ${ }^{1}$ from the Urgonian beds of Greenland and afterwards found by Nathorst ${ }^{2}$ in the Rhaetic beds of Schonen, the ovoid cones are composed of scales which have pretty much the shape of those of our pines, and are arranged in spirals and appear to be striated on the back. These cones, as we learn from a small fragment of wood preserved at the back of one of them, belong to branches which have close-pressed scale-like spirally arranged leaves and irregular ramifications, and remind us of Widdringtonia. Quite similar branches also lie beside the cones of the Swedish Cyparissidium septentrionale, Nath., so that supported by the case of Heer's fossil we may fairly assume that the two belong to one another. I cannot find that the species recently described by Velenovsky ${ }^{3}$ from the Cenomanian beds of Bohemia, C. minimum, Vel., and C. pulchellum, Vel., agreed very exactly with the structure of the cone in the original type. The genus Sphenolepidium, Heer (Sphenolepis, Schenk) is also very imperfectly understood, and the structure of the cone is altogether doubtful. The species first discovered, S. Sternbergianum and S. Kurrianum, come from the Wealden of Hanover ${ }^{4}$. Saporta ${ }^{5}$ has described one very like them, $\mathrm{S}$. Terquemi, from the Rhaetic beds of the country round Metz. How far Heer's ${ }^{6}$ new species from the Wealden of the North of Portugal really belong to this genus I should be unwilling to say without examination of the original specimens. The small spherical or ovoid cones appear in fascicles on the extremities of the branches; they have the habit of those of Sequoia and consist of spirally arranged scales, which become narrow and wedge-shaped below and are obtuse above, and lic close at first but subsequently open and spread out. According to Saporta the apex of the scale developes into a scutiform expansion, as in Sequoia; the number and position of the seeds is altogether uncertain. Heer's figures of his Portuguese forms agree but little with Saporta's and Schenk's descriptions. The apex of the scales appears to be longitudinally striated, and there is no indication of the scutiform terminal formation. We are not compelled however to conclude that there is certainly any essential difference, for the text says : "The cones are strongly compressed, and it is very difficult to determine the form of the scales.' When the palaeontologist speaks thus, every doubt is

1 Heer (5), vol. 3 II, t. I9; vol. 6 II, t. 28 ; vol. 7I, t. 48 .

3 Velenovsky (1), t. 9, ff. 6, 7, and t. 5, f. 5. 4 Schenk (1).

6. Heer (14).
2 Nathorst (3), t. 4 . 5 de Saporta (4), vol. iii, t. 198. 
permitted to the botanist. The foliage of the Sphenolepidiae is spiral and close-pressed, or has the tips of the leaves spreading.

The genus Geinitzia, as far as is at present known with certainty, is peculiar to the Upper Chalk, for the specimens from the Tertiary formations of the New World cited by Schenk ${ }^{1}$ are still of too doubtful character to come into question. Of this genus we have G. cretacea, Ung. ${ }^{2}$, from Neustadt in Austria, O. formosa, $\mathrm{Heer}^{3}$, from Quedlinburg, and a fragment of a cone from the beds of Patoot in Greenland described by Hcer ${ }^{4}$ as G. hyperborea. The cylindrical concs are distinguished by their unusually thick axis, which bears scales having a scutiform polygonal terminal expansion with a deep umbo in the centre and radiating striae all round, and a central stalk of striking thickness which scarcely diminishes at all downwards. Heer's statements with respect to the seeds attached to this longitudinally striated stalk need further confirmation. That the branches found with these cones belong to them is proved, at least in the case of G. formosa, by Heer's figure ${ }^{5}$, which show's the two in connection. These branches are slender and rod-like with few ramifications, and thickly covered with spiral leaves; the bases of the leaves on the surface of the branch form rhombic areolae, which are seen with special distinctness where the projecting falcately curved apices are removed by fracture of the stone. A good figure of $G$. formosa is to be seen also in Schenk ${ }^{6}$.

Among the branches of Coniferae from the lithographic limestone of Solenhofen, besides the above-mentioned forms of Cupressineae and the Brachyphyllae which will be noticed again presently, cone-bearing branches are found which retain the name of Echinostrobus Sternbergii originally given by Schimper to these remains collectively. The chapter in Saporta ${ }^{7}$ on this point should be consulted. The branches, figured in Schenk ${ }^{8}$, are pinnately ramified and clothed with closely crowded short scale-like leaves attached by a broad rhombic base, much as in the modern genus Arthrotaxis, on which account the fossil form was named by Unger Arthrotaxites lycopodioides. The cones are spherical, and their mode of preservation is such that only the external form can be discerned. Each of the component scales ends in a stout thorn-like process. Saporta would place the genus near Arthrotaxis; he also thinks that Swedenborgia ${ }^{9}$, a peculiar Conifer from the Rhaetic beds of Schonen of which nothing has been known hitherto except cones with the habit of those of Cryptomeria, belongs to the same alliance. These cones, which are evidently over-ripe and fallen from the trees, are ovoid in shape, and their scales stand out at a right angle from the axis. The single scale is wedge-shaped and narrowed into the long stalk, and has the upper margin usually divided into five acute three-

\footnotetext{
1 Zittel (1).

2 Unger (4).

Heer (15).

4 Heer (5), vol. vii I, t. 51 , f. 13 .

3 Heer (15), t. 2, f. 5 .

- Zittel (1), p. 299.

7 de Saporta (4).

- Zittel (1), p. 302.

- Nathorst (2).
} 
cornered teeth, but these numerical relations are not constant. According to Saporta ${ }^{1}$, the middle tooth would answer to the bract, the others to the seminiferous adherent apex of the fertile scale. We are still in uncertainty respecting the seeds; Nathorst speaks of a single seed, but not without hesitation, and also gives a figure of it ${ }^{2}$; Saporta maintains that there were several.

The genus Palissya, Endl., is greatly in want of more thorough elucidation, but, as the localities have ceased to yield specimens, there is unfortunately little further to be learnt after Schenk's repeated examinations ${ }^{3}$. The name has been given to an assemblage of remains of Conifers, consisting of cones of marked character, with seeds and branches from the Rhaetic formation of Franconia; some leafy branches also from Schonen are referred by Nathorst ${ }^{4}$ to the same group, but whether rightly or not can hardly be determined, since the genus is so uncertain. Two species, P. Braunii, Endl, and P. aptera, Sch., are described, but they resemble each other so little that Saporta ${ }^{5}$ proposes to remove the latter from the genus and approximate it to Sphenolepis ; Schenk ${ }^{6}$ however protests against this arrangement, which would in fact be much more arbitrary than the placing it in Palissya. Palissya Braunii is made up of cones, branches, and seeds found near one another, and apparently united together for this reason only. The branches are in the form of thin rods with very acuminate narrow flat needles loosely and spirally arranged. It does not appear to me quite certain that the cones all belong to the same plant. Schenk ${ }^{7}$ figures one cone with spreading scales attached to the moderately thick axis, and at the same-place several others with the scales closed. In the former case he has also given figures of the separate parts ${ }^{8}$ showing the position of the seeds; his scales are flat, elongate-lanceolate, acuminate, the lower portion of the lateral margin being rendered pinnate by the presence of short lobe-like projections directed upwards. I can confirm this representation from examination of the fine specimens in the Geological Department of the British Museum. In the cylindrical closed cones, on the other hand, we can only see crowded lanceolate scales lying one over the other. In one of them which is crushed $^{9}$, and in which we might expect to see the lateral projections, these are not apparent, and this throws doubt on the connection. The figures of detached seeds also given by Schenk in the different places differ from one another in not unimportant points, and they therefore appear to me doubtful. In stating that the scale bears several seeds, Schenk refers, as appears from his work ${ }^{10}$, to the abovementioned lateral projections, which appear in the figures of the parts as

1 de Saporta (4).

4 Nathorst (2). and Zittel (1), p. 335 .
${ }^{2}$ Nathorst (2), t. 16, f. II. 5 de Saporta (4), vol. iii, p. 5 I2. s Schenk (3) and (8), and Zittel (1), p. 334.

${ }^{6}$ Zittel (1). ${ }^{7}$ Schenk (3), t. 4I, f. 9 , ${ }^{8}$ Schenk (8), and Zittel (1), p. 33\%. 'Zittel (1), f. c. ${ }^{10}$ Schenk (8). 
highly convex seeds of very irregular form; he says nothing at all on this point in his very brief original account of these fossils ${ }^{1}$. The same circumstances are explained in a different manner by Saporta, who defines the genus from the expanded cone, though Schenk protests against this proceeding. Schenk in this case, as in most others, assumes the presence of two scales which have become united to one another; in Palissya the fertile scale reaches beyond the bract-scale not with its apex but laterally, and the lobes are supposed to answer to so many projecting sections of its margin. These again are constructions for which the facts do not supply the needful material.

Palissya aptera is the name given by Schenk to some branches having spirally arranged scale-like leaves and bearing cones. The terminal ovoid cones are formed of crowded lanceolate sharply-kecled scales, and are totally different in habit from the preceding; nothing is known of their inner structure. Small elliptical bodies found on the slabs are without further reason taken to be the secds. If we are still desirous of giving a general definition of the genus Palissya, we must confine ourselves with Saporta to the form of cone which at least shows its peculiar characters, and disregard the doubtful P. aptera. It is also a question whether the branches with acicular leaves really belong to the Palissya-cones.

There are two more forms of cones which may be mentioned here, though their connection with the Coniferae is not above suspicion. Saporta ${ }^{2}$ has described under the name of Entomolepis Cynarocephala, Sap. an elliptical cone from the Miocene beds of Armissan cight centimetres in length, in which the large broad scales are firmly closed one on another, and the apex of the scale runs out into a strongly developed spreading deeply incisodentate leaf-like appendage. This cone is also noticed by Renault ${ }^{3}$ and Schenk ${ }^{4}$. And in the Geological Department of the British Museum a slab was shown me which came from Solenhofen with the Häberlein collection, and which has on it a remarkable impression named by Thiselton Dyer ${ }^{5}$ Condylites squamatus. Dyer has no doubt that we have in this impression the remains of a Conifer, and he was at first inclined to compare it with Cupressineae. Several branches lie side by side on the slab; these are sympodially developed, and terminate each with peculiar usually four-lobed bodies which may recall the cones of Callitris. Two slender innovationshoots arise on a branch beneath the extremity which bears these bodies. That the plant is a Conifer may be concluded from the presence here and there on the branches of crowded scutiform spirally arranged rhombic leafcushions, such as we see in Arthrotaxis. Dyer also conjectures that some of the sterile branches from Solenhofen which are classed with Arthrotaxites

\footnotetext{
${ }^{1}$ Schenk (3). $\quad{ }^{2}$ de Saporta (8). $\quad{ }^{3}$ Renault (2), vol. iv, p. 119; t. $14 . \quad{ }^{1}$ Zittel (1), p. 348.
} 3 Dyer, Thiselton (1). 
or Palaeocyparis may belong to this form. One feels tempted to see this same plant, but in an inferior state of preservation, in Saporta's ${ }^{1}$ algal genus Itieria, a specimen of which I have seen in the collection of the Ecole des Mines at Paris, and which belongs to the Middle and Upper Oolite, being found in the Coralline Oolite of St. Mihiel and in the Kimmeridge of Orbagnoux.

Finally, there remain yet two genera which, as the fructification is almost or entirely unknown, are founded exclusively on characters of the foliage and therefore are to a high degree provisional only. There is first Albertia, Schpr ${ }^{2}$, a fossil peculiar to the Bunter Sandstone, and up to the present time scarcely found anywhere but in the Vosges, and there chiefly in the great quarry at Sulzbad near Strassburg, which is unfortunately no longer worked. The bilaterally ramifying branches bear spirally arranged spreading flat leaves, which above the broad line of insertion have a spoon-like concavity and are rounded off at the upper extremity, and show a delicate longitudinal striation. They are commonly compared with the leaves of Dammara, but are essentially distinguished from them by the broad plane of insertion. Cones, which were assumed by Schimper to belong to these branches, are described by him as ellipsoid in shape and formed of simple ovoid scales; each scale is said to have one winged seed. Schimper certainly had no perfect cone before him when he constituted this genus, or he would have figured it and not been content with describing reconstructions only. Subsequently the Museum of Strassburg actually acquired a cone answering to the description and having very much the habit of a cone of a pine. This cone is still there, but shows no trace of the seeds, and I do not know therefore on what Schimper founded his description of them, and since it is not attached to a leafy branch, its connection with Albertia is altogether arbitrary and unsupported; the supposed male flower figured by Schimper has been determined by Schenk ${ }^{3}$ after reexamination of the original to be a young cone of Voltzia. A variety of objects appear to have been distributed under this designation, for Renault 4 describes a similar male flower, also from Sulzbad, which if it belonged to Albertia would certainly separate that genus entirely from Coniferae; we should in that case do much better to seek for objects of comparison in the group of Cordaiteae which will be considered presently. In this remarkable specimen leaf-like scales have in their axils other scales, which bear several rows of stamens. with their numerous sessile elongated anthers united in fascicles (anthères sessiles très allongées nombreuses fasciculées, etc.).

The second important genus characteristic of the Permian formation is

1 de Saporta (4), vol. i, tt. 3,4 .

${ }^{2}$ Schimper (3) and (1).

3 Zittel (1), p. 284 .

- Renault (2), vol. iv, p. 104 ; t. 7 , f. 14. 
Walchia ${ }^{1}$. In the most common species, W. piniformis, Sternb., the branchsystems, which show numerous ramifications disposed in two lines and are often found in actual connection, have thoroughly the habit of Araucaria excelsa, and are studded all round with short falcate or hooked leaves arranged in spirals. Other branches, which may however possibly belong to the same species, have no leaves with hooked extremities, while others again, which are properly regarded as belonging to a distinct species, W. filiciformis, Sternb., have their leaves less closely set and not covering the branch as with scales. The individual leaves, strongly hooked and having a stout almost conical cushion, stand out at nearly a right angle from the branch. Göppert ${ }^{2}$ says that the leaves have several nerves, but as he appeals only to the striation as seen on the surface from which we cannot conclude directly as to the course of the nerves, we must not attach any importance to the statement. All these branches are thus united under Walchia solely from their external appearance, and it is quite possible that they belonged to very different genera; and we begin to suspect that it was so, when we consider the different organs of fructification which authors have assigned to this. genus. Bergeron ", for instance, has figured a branch of Walchia from the schists of Lodève with terminal cylindrical cones on the lowest of its pinnate lateral ramifications, and as the scalcs have dropped from one of the cones, the axis only remains showing the points of attachment. The scales in these cones are imbricate and spirally arranged, and each scale is lanceolate at the apex; the structural details are not known. Weiss ${ }^{4}$ has made us acquainted with a somewhat less perfect fragment of the same kind; the unattached cones had been before described by different writers, Göppert ${ }^{5}$ for example and Schimper ${ }^{6}$. Bergeron's specimen, like a similar one from Lodève in my possession, bears its well-developed cones on long branches, and between them other cones on short shoots in a younger state. But when he concludes from this that the cone-bearing branches were developed later, after the vegetative branches, perhaps from resting buds, we must object that young cones may cease to develope at an early age, and that such imperfect growths are often found in our living species on weakly shoots which were developed at the same time with the rest.

On the other hand, Grand' Eury ${ }^{7}$ has described and figured a branch of Walchia from the bituminous schists of Autun, in which the lower of two perfectly preserved lateral branches bears ovoid carpoliths in the axils of its leaves, while the upper has in the same situation small closed buds composed of many not clearly defined leaves. The former objects he considers to be the seeds, the latter the male flowers of the plant, which according to the foliation would be referred without hesitation to Walchia. His brief

\footnotetext{
${ }^{1}$ Stemberg, Graf von (1). $\quad{ }^{2}$ Göppert (3), p. $238 . \quad{ }^{3}$ Bergeron (1).

- Göppert (3). 'Schimper (1), t. 73. ${ }^{7}$ Grand' Eury (1), p. 514.

- Weiss (1), t. 17 .
} 
remarks contained in a note are agreeably supplemented by Renault ${ }^{1}$, who has had opportunity of examining the original specimen. This author says that there can be no doubt about the axillary seeds, which are ovoid, four to five millimetres in length, and suddenly and finely acuminate; their rind of coal encloses a nucleus of pyrites. The little buds of the other branch are also converted into pyrites, and Renault has not been quite able to satisfy himself that they are male catkins. Somewhat similar remains to those described by the French authors have been noticed by Göppert ${ }^{2}$; his figure shows the extremity of a branch from which numerous small ovoid seed-like bodies are dropping; the other figure shows numerous buds in the axil of a leaf, which may be compared with the similar forms from the branch in question. Lastly, Renault ${ }^{3}$ gives the name of Pseudowalchia frondosa to a branch of some species of Walchia from Millery near Autun, in which ovoid seed-like bodies are terminal on the extremity of the branch, but he himself does not lay much weight on this solitary specimen.

If Walchia is very open to the suspicion of being an artificial and provisional collection of heterogeneous remains of similar habit, it is quite certain that this is the case with the genus Pagiophyllum, Heer (Pachyphyllum, Sap.), which we must now consider. The name is given to branches with closely crowded spiral usually short but sometimes elongate lanceolate leaves springing from decurrent leaf-cushions,--such branches as are of frequent occurrence especially in the Mesozoic formations. The leaves are often more or less strongly keeled on the back, and show numerous rows of pinhole-like stomata. A number of species from the Trias, the Jurassic system, and the Chalk will be found cited in Schenk ${ }^{4}$; the Jurassic specimens are discussed at length by Saporta ${ }^{5}$. Older authors, who may be consulted in Saporta's work, usually call them Araucaritae. Whether the Solenhofen cone figured by Saporta ${ }^{6}$ really belongs to his Pachyphyllum cirinicum is uncertain; the same may be said of the scales found by Pomel with P. rigidum, Sap., in the Infra-Liassic beds of Metz. Even if it were quite certain that they belong to P. cirinicum, they could only inform us concerning the fructification of that species; the fructification might be quite different in other species. It is only in accordance with old custom to distinguish the Ullmanniae of the Zechstein from Pagiophyllum, as I have endeavoured to show elsewhere ${ }^{7}$. The genus Ullmannia was originally established by Göppert ${ }^{8}$ by arbitrarily uniting together certain branches and cone-like objects; the branches had been for the most part described by the older writers as Caulerpites and Fucoides. As they are sometimes petrified in calcium carbonate, it has been possible to determine the

\footnotetext{
1 Renault (2), vol. iv, p. $88 . \quad{ }^{2}$ Göppert (3), t. 49, ff. I1, 13. ${ }^{3}$ Renault (4). ${ }^{4}$ Zittel (1), p. $276 . \quad 3$ de Saporta (4). $\quad{ }^{6}$ de Saporta (4), t. $180 . \quad$ ${ }^{8}$ Göppert (3) and (4).
} 
anatomical structure of the leaves. These are one-nerved in all the species, and their vascular bundle is accompanied on both sides by a broad transfusion-wing composed of reticulate tracheides. Hypodermal fibres are frequent, differently distributed in the different species. Ullmannia Bronnii, known by the name of Frankenberg copper-spikes, occurs in the cupriferous clays of Frankenberg in Hesse in small fragments of leafy branches, which are the centres of formation of the copper-glance, and were therefore formerly the object of mining operations in the district. Their crowded shortly linguiform leaves scarcely differ from those of other ordinary species of Pagiophyllum. Two or three other forms, Ullmannia selaginoides, $U$. frumentaria, and $U$. orobiformis have more elongated leaves; those of $\mathrm{U}$. frumentaria are acute and slightly keeled on the back, which is crowded with stomata; in the two other species they are almost cylindrical and rounded at the tip. They occur frequently in the form of impressions in the Kupferschiefer of many localities, especially of Gera ; as petrifactions in calcium carbonate with their structure preserved they are found only near Ilmenau in Thüringen imbedded in nodules. From the latter specimens we learn that $U$. frumentaria had distinct parallel subepidermal strands of fibres, while in the two other species a thin continuous fibre-layer is found in the same position. The facts are stated the reverse way by an oversight in Schenk ${ }^{1}$, and the synonym U. lycopodioides is placed with U. selaginoides, whereas it belongs to U. frumentaria. Elliptical or ovoid cone-like bodies are found in large numbers both at Frankenberg and Gera, made up of lanceolate scales and resembling in habit those first described under the head of Walchia. Cones of the kind have been found at Gera attached to branches of $U$. frumentaria ${ }^{2}$, but unfortunately we know nothing of their structure. They are variously figured by Geinitz ${ }^{3}$. Peculiar scales also are found in Frankenberg which are sometimes united into cone-like aggregations, and in this state they were considered by Göppert to be the fructification of Ullmannia ; as it is not certain that they belong to Coniferae, I have given them the name of Strobilites Bronnii, which does not prejudge the question. These scales are circular with an umbo on one face, and have the thickened margin embellished with radiating furrows; on the other face is a short central stalk round which, when the preservation is unusually good, a girdle of areolae may be observed, each with a minute round protuberance at its centre. These are doubtless the scars of deciduous organs, perhaps of seeds. I may refer the reader to my treatise already mentioned for further details respecting these questionable remains.

Branches and branch-systems from the Mesozoic deposits, having much the habit of Arthrotaxis, have been named by Brongniart Brachyphyllum.
1 Zittel (1), p. 274.
${ }^{2}$ Solms, Graf zu (1), t. I, f. 9.
${ }^{3}$ Geinitz (1) and (2). 
Their leaves disposed in spirals and touching one another are all alike, and are unusually abbreviated; the basal portion is developed in the form of a polygonal shield with a central boss ; the apex is very obtuse, and being usually curved inwards is thus withdrawn from observation, but in some cases it assumes a larger growth, and then it is not easy to distinguish the branches from Pagiophyllum. A dot-like often conspicuous protuberance on the back of the shield appears to answer to an oil-gland occupying the same place here as in our Cupressineae. Many Jurassic forms are to be found figured in Saporta ${ }^{1}$. The fructification of these coniferous branches can scarcely be said to be known; Saporta indeed figures some elliptical cones which in habit do to some extent resemble those mentioned under Walchia : he also, as is usual with him, indulges in a variety of conjectures respecting their structure which is but indistinctly shown; but still he does not prove that they really belong to the branches of Brachyphyllum Jauberti and B. Moreauanum, near which they were found at Verdun and Chateauroux. Heer ${ }^{2}$ has found spherical cone-like bodies attached to the extremities of the branches of his B. insigne from the Lower Oolite of Siberia, which are composed of polygonal scales like those of the branches themselves, but there is nothing by which we can judge of their internal character. A figure of this conjectural fruit of $\mathrm{B}$. insigne is to be found in Schenk ${ }^{3}$, together with an enumeration of all the described species, but this would not be of any interest in this place. It may be mentioned that Saporta has determined one species, B. nepos, from among the coniferous branches from Solenhofen which were included by Schimper in his genus Echinostrobus. These remains are present in abundance in the Middle and Upper Oolite of France and England; among them is B. mamillare, Brongn., from Scarborough.

We must mention in conclusion the genus Camptophyllum described by Nathorst ${ }^{4}$ from the Rhaetic beds of Schonen, though the author himself regards it as a fossil incertae sedis. The remains are small portions of branches with a stout axis, and flat acicular leaves bent backwards in a peculiar manner and forming an arch.

The small fragments of branches beset with scale-like leaves, and also the small acicular leaves with two longitudinal keels, which Stcrzel ${ }^{5}$ describes as Dicalamophyllum Altendorfense from the hornstones of the Rothliegende of Chemnitz, are of quite doubtful character.

The surface of primary and other branches of Coniferae without their leaves appear also to have been preserved here and there in impressions or in casts; but as it is perfectly impossible to say in the case of any of these remains that they certainly belong to Coniferae, we need not cite in this

1 de Saporta (4), vol. iii. $\quad{ }^{2}$ Heer (5). Nathorst (3), and Zittel (1), p. 35 I. $\quad{ }_{5}$ Sterzel (1). 
place the particular notices of them to be found in the literature. But I should wish briefly to mention one fossil at present in danger of being forgotten, the connection of which with the Coniferae seems to have been well established by means of sections prepared from a silicified fragment. I allude to Tylodendron speciosum, Weiss ${ }^{1}$, found originally in the sandstone of the lowest beds of the Rothliegende at Ottweiler near Saarbrücken, together with much silicified wood, and afterwards detected by Zeiller ${ }^{2}$ in the Permian beds of la Corrèze near Brive. Weiss associates with it various similar casts of branches described and figured by Eichwald ${ }^{3}$ which come partly from the Carboniferous limestone, partly from the Permian deposits of Eastern Russia. His own figures of Tylodendron speciosum show straight branches without ramifications as much as seventy centimetres in length, resembling the topmost shoots of Conifers, and everywhere covered with narrow rhombic convex spirally arranged leaf-cushions, each of which shows a groove-like impression in its upper portion. The branches swell at regular intervals and become fusiform, and the lower half of the swollen part is marked by the great abbreviation of the cushions on its surface, exactly in the manner usually to be observed in our pines at the extremity of the annual shoot where it is covered with bud-scales. Our knowledge of the anatomy of the plant is imperfect, but Weiss gives a radial section which shows exactly the picture of one of the coniferous woods which are classed with Araucaroxylon, and thus we have proof that the fossil belongs to the group under considcration.

It is well known that fragments of wood having the structure of living Conifers are found in every state of preservation throughout the entire series of geological formations from the middle Devonian upwards, and that they begin to be common everywhere as early as the higher members of the Coal-measures. Great hopes therefore have long been entertained that their examination would supply important results and points of departure. To Göppert ${ }^{4}$ must be assigned the first place in the cultivation of this field of research. Owing however to the unifornity of structure which characterises secondary growth in thickness in Coniferae, these efforts have not been crowned with that measure of success which might have been expected. First of all it has become apparent that other groups, very near the Coniferae it is true but still distinct from them, as for example the Palaeozoic Cordaiteae, possess a woody structure so like that of Coniferae, that it is impossible to distinguish them unless we have entire sections of a stem before us. Further, Göppert has perceived that it is only in the rarest cases that we can distinguish the genera within the class by the structure of the wood, and that oftentimes even the members of different families,

${ }^{1}$ Weiss (1), p. 185. 'Zeiller (4), t. 8, f. 1. ' $\quad$ Eichwald (1). Göppert (5) and (4). 
cannot be thus separated. In this way he arrived at the formation of the groups of woods known as Pinites, Araucarites, Cupressinoxylon, and Taxites, the first of which takes in most of the recent Abietineae, the second the Araucarias and Dammaras and with them the Cordaiteae, as was said above, the third the Cupressineae and Podocarpeae, the fourth the Taxineae. To these were added the generic types Physematopitys answering to the wood of Ginkgo, Protopitys which doubtless represents one of the woods of uncertain affinity now named Arthropitys, which will be noticed again presently, and the altogether doubtful Spiropitys. Unfortunately Göppert has converted the groups of woods thus obtained into genera, and founded numerous species within them on characters which are in some cases very doubtful. His main results have since been gathered up by Kraus ${ }^{1}$ and extended by splitting Pinites into Pityoxylon and Cedroxylon, the first of which takes in the firs, the second the rest of the Abietineae. Kraus has also carefully examined the characters employed in the definition of species, and has shown that the relative marks generally made use of up to that time, breadth of the annual ring, width of the cell-lumina, thickness of the cell-walls, number of rows of pits on the radial walls of the tracheides, height of the medullary rays and their frequency, can either not be employed at all or only with the extremest caution, because, as von Mohl ${ }^{2}$ has shown in his well-known treatise, they are liable to important modifications in the different organs of the same tree, in stem or branch or root, and because great individual fluctuations occur in different trees of the same species. Essner ${ }^{3}$ has supplied ample proof of the truth of these remarks as respects number and height of the medullary rays, and Kraus ${ }^{4}$ himself showed, by application of diagnoses in Göppert's manner, in the case of the connected stem and branch of a piece of wood from the lignite of the Rhön, that if the two had been found separate they would have supplied two good species. The characters of Kraus' generic groups are as follows : 1. Araucaroxylon (Dadoxylon, Endl.). Radial pits of the tracheides either in one row with contact and mutual compression, or alternating in several rows and becoming polygonal from mutual contact. Medullary rays in a single row on the tangential section. 2. Pissodendron. Distinguished from Araucaroxylon only by the presence of several rows of medullary rays. Witham ${ }^{5}$ calls such forms Pitus, Brongniart ${ }^{6}$ Palaeoxylon. 3. Cupressoxylon. Radial pits of the tracheides in a single row, circular, not touching one another, or in several rows very commonly in the root exceptionally in the stem, not alternating and polygonal but round and in irregular transverse rows. Resiniferous parenchymatous wood-cells in

${ }^{1}$ Kraus (1) and (3), and Schimper (1), p. 363. " ${ }^{2}$ H. von Mohl, Einige anatomisch-physiologische Bemerkungen uiber das Holz der Baumwurzeln (Bot. Ztg. (1862), p. 225). $\quad{ }^{3}$ Essner (1). $\quad$ " Kraus (1), p. 185. '5 Witham (1). 'Brongniart (2). 
greater or less abundancc. Medullary rays simple. 4. Pityoxylon. Tracheides as in Cupressoxylon. Resin-passages besides the parenchymatous wood-cells, but still surrounded by secretion-tissue. Medullary rays of two kinds; those in several rows with a resin-passage running horizontally through their centre. 5. Cedroxylon. Exactly as Cupressoxylon, only without resiniferous wood-parcnchyma. 6. Taxoxylon. Distinguished from Cedroxylon merely by the well-known spiral striation which projects on the inner surface of the wall of the tracheides, but which must not be confounded with the annular and spiral striation in the substance of the membrane common in the autumn-formed tracheides of coniferous woods.

We might think that it would be easy to discover and apply the above differential characters in fossil woods, but the task is not unaccompanied with difficultics. For instance, it is not always quite easy to separate the wood of the roots of Cupressoxylon and Cedroxylon with pits in several rows (Elcoxylon, Brongn. ${ }^{1}$ ) from Araucaroxylon, and the distinguishing the Araucaroxyla with pits in a single row from the other two groups may have its perplexities; and hence we scc Pinites latiporosus, Cramer ${ }^{2}$, referred by Kraus ${ }^{3}$ to Araucaroxylon, and by Schröter ${ }^{4}$ to Ccdroxylon. Again, the difference between Cupressoxylon and Cedroxylon is obscured by the circumstance that in some Cupressincac the wood contains an unusually small number of resiniferous cclls, of which Beust gives many examples ${ }^{5}$. Individual as well as specific variations have their effect, so that we can scarcely fecl quite sure that there are no such variations to be taken into account. It is also easy to mistake tracheides anomalously filled with resin for parenchymatous wood-cells, and difficult to distinguish the latter in the sections when, as often happens, they contain no resin; nor must all brown substances filling the cells in fossil woods be supposed to be resin without carcful examination; the presence or absence of the excretion in the wood of Ginkgo, for example, is still in dispute, as will appear by comparing the statements of Kraus and Beust.

Attempts have lately bcen made to establish further distinctions between fossil woods founded on the characters of the medullary rays. Kraus ${ }^{6}$ had already used these characters to break up Pityoxylon, and the process was thoroughly carried out in this group by Schröter ${ }^{7}$. From want of personal experience as regards the constancy of all these characters I am not in a position to criticise the results of these cfforts, and I must refer the reader to the original literature. At the same time I would point out that all of them, not excepting Kleeberg's ${ }^{8}$ which is the most recent, suffer from a fault in method which ought to have been avoided after the appearance of von Mohl's and Kraus' publications; the observers have pursued their investi-

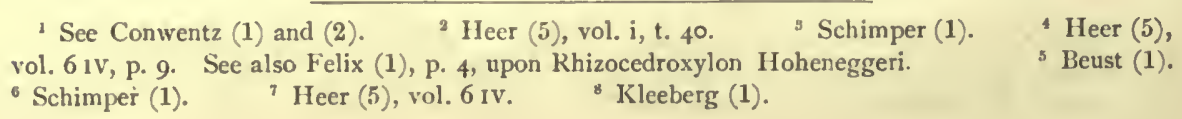


gations extensively instead of intensively. It is difficult to see the use of descriptions of all sorts of fragments of wood from the collections, though they may include hundreds of exotic species, so long as we are ignorant of the limits of variation within the species and the individuals. Far more profitable would be a comparative examination of a few species based on abundant material from all parts of the plants, for this alone can give that sure foundation without which our conclusions are precarious and oftentimes in the air. Such a mode of proceeding would be all the more obvious, because the value of the whole of these laborious investigations would be very doubtful, if the statements before us were shown to be strictly correct. According to Schröter, all species of Abies, with two exceptions, belong by the structure of their wood to Cedroxylon, Abies Welbiana only agreeing with Cupressoxylon and A. Pindrow with the first sub-form of Pityoxylon. In this sub-form he also places Pinus longifolia, Roxb., whilc all other pines belong to the second and third sub-forms. If this is so, how can we expect to conclude with any show of justification from the anatomical structure of woods that they belong to any particular divisions of our system? And it is as a rule only slightly probable that we shall find pieces of wood in actual connection with leafy branches and cones, though this may happen once now and then. The only instance known to me in which this method of determination was pursued is supplied by Schenk ${ }^{1}$. He found in the lignites of Wurzen in Saxony large cones and leafy branches of Sequoia Couttsiae, Heer, and with them larger branches and stems, and he determined the connection of the latter with that species on the strength of their agreement in structure with the leafy branches. Felix ${ }^{2}$ subsequently decided that the woody fragments belonged to Cupressoxylon Protolarix, Göpp.

According to the statements of authors, $\mathrm{Kraus}^{3}$ especially, Taxoxyla are at present known only from the Tertiaries, Cupressoxyla have been found in the Chalk, Pityoxyla and Cedroxyla as far down as the Keuper. Araucaroxyla and Pissodendra are the only woods which occur in the older formations, if we put out of sight the two doubtful kinds from the Coal-measures known as Pinites Conwentzianus, Göpp. ${ }^{4}$, and Peuce Withami, Lindl. and Hutt. ${ }^{5}$ The latter is referred by Renault to Araucaroxylon, by Kraus to Cedroxylon. The figure would allow of either conclusion; Kraus' view implies that the specimen is a piece of wood from the root. Only fresh examination of the original can decide the question. To Araucaroxylon belong, also the pieces of wood described by Dawson ${ }^{6}$ from the Middle Devonian beds of Canada and New Brunswick, Dadoxylon Ouangondianum, D. Hallii, D. Newberryi and Ormoxylon Erianum G. and S. N. The latter may be considered from the character of the pith to

\footnotetext{
1 Schenk (5). vol. i, tt. 23,24 .

${ }^{2}$ Felix (1). ${ }^{3}$ Schimper (1).

+ Göppert (6).

5 Lindley and Hutton (1), - Dawson (1).
} 
belong to Cordaitae. It has been already stated that the Cordaitae show the structure of Araucaroxylon, and that they include a large portion of the palaeozoic woods. But that there were also true Conifers with the same woody structure in the Carboniferous and Permian eras is proved from the descriptions given of Tylodendron speciosum, Weiss ${ }^{1}$. The hitherto doubtful Aporoxylon primigenium, Ung. ${ }^{2}$, from the Cypridinaschists (Upper Devonian) of Saalfeld has recently been unmasked by Göppert ${ }^{3}$ through the discovery of radial pits most of which had disappeared, and has been determined to be an Araucaroxylon.

Under the names of Prototaxites Logani and Nematoxylon crassum Dawson ${ }^{4}$ has described silicified wood from the Lower Devonian beds of Canada and New Brunswick, entire stems of which were observed in the cliffs of Little Cape Oiseau near Gaspé, as the oldest known coniferous remains. Picces in which the structure is preserved show circular transverse sections of cells not arranged in any order, and separated from one another by homogeneous partition-walls of unusual thickness. The longitudinal section shows that their substance is composed of very long uniform tubes which appear to bend irregularly hither and thither and to intertwinc, and not to run in regular and parallel lines as in normal wood of Conifers. The spiral striation, on account of which Dawson chose the name Prototaxites, has however nothing in common with Taxus; the thick wall is seen in the longitudinal section to be traversed by striac, narrow tubes, confusedly interwoven. His bordered pits look more like cross views of these striae. Carruthers ${ }^{5}$, to whom we are indebted for an exact account of the matter, finds no resemblance to the structure of coniferous woods, and thinks that Prototaxites must be considered to be an alga-stem. I have satisfied myself by examining preparations of material supplied by Dawson himself that the fossil has little in common with Coniferac; it may possibly be an Alga, but I can find no direct analogue for it among the forms known to me, and Halimeda and similar plants suggested by Carruthers can scarcely be brought into the comparison. Stems of Fucaceae with growth in thickness as represented by Reinke might at first perhaps be thought of, but these differ in not unessential points from the descriptions of Prototaxites. The samc form, or one absolutely similar, has very recently been found in Walcs in the much older Silurian beds of the Upper Landovery formation in the shape of small silicified partly brown, partly coalblack fragments cemented into the rock, and showing the described structure most beautifully. These plant-remains, which are named Nematophycus Hicksii, Eth. ${ }^{6}$, are without doubt the very oldest in which the structure still preserved can be clearly scen.

${ }^{1}$ Weiss (1). ${ }^{2}$ Unger (5). $\quad{ }^{3}$ Göppert (6). "Dawsun (1), p. 16, t. 12. $\quad$ 'Carruthers (5). - Hicks (1), ard Dawson (1), vol. ii, p. 10\%, and 3 . 


\section{CYCADEAE, MEDULLOSEAE.}

THE remains of Cycadeae attain their greatest development in the Mesozoic formations, especially in the series of beds of the Jurassic system; there can be no doubt that they were generally distributed during that period of time over the northern hemisphere. Comparatively few Palaeozoic forms are known, and most of these are remains of stems from the Permian formation and from the Coal-measures. Undoubted leaves of Cycadeae have been found but very rarely in both these systems, and have been described and figured in Saporta and Marion ${ }^{1}$ (Pterophyllum Grand' Euryanum, Sap. et Mar., and Sphenozamites Rochei, Ren.. ${ }^{2}$ ) from the Coalmeasures of St. Etienne and Autun, in Geinitz ${ }^{3}$ (Pterophyllum Cottacanum, Gein.) from the Rothliegende of $Z$ wickau, and in Sandberger ${ }^{4}$ (Pterophyllum blechnoides, Sandb.) from the Upper Coal-measures of Oppenau in Baden. A leaf also which is said to come from the Coal-measures of Eastern Russia is figured in Eichwald ${ }^{5}$ and named Pterophyllum inflexum, Eichw., and Renault and Zeiller ${ }^{6}$ mention a Zamites carbonarius from the coal of Commentry. Several others described by Göppert ${ }^{7}$ are not above suspicion.

The Cycadeae are still tolerably numerous in the lower Chalk, but after the Cenomanian beds the group diminishes greatly in importance. It must not however be forgotten that the Tertiary flora is really known to any great extent only in Europe and perhaps in the Arctic Zone, regions in which Cycads no longer live, and from which they may have gradually disappeared during the period of the Chalk. That they were still to be found in the South of Europe in Tertiary times, though few in number, is shown by some single specimens from the Lower Miocene; we have, for example, Zamites epibius, Sap. ${ }^{8}$, from Bonnieux in the Department of Vaucluse and Encephalartos Gorceixianus, Sap. ${ }^{9}$, from Kumi in Euboea, both represented by leaves which certainly have the

${ }^{1}$ Saporta et Marion (2), p. Iog. the work, that which is said of $B$ referring really to $A$, and vice versâ.

- Sandberger (1).

" de Saporta (2), p. 116.
5 Eichwald (1), vol. i, t. 15.

${ }^{2}$ de Saporta (2). p. 116, an
6 Zeiller (11).

(10), p. 298.
2 There is a mistake in the explanation of the woodcuts in

${ }^{3}$ Geinitz (1) and (4).

${ }^{7}$ Göppert ( 7 ). 
appearance of belonging to recent genera, though the connection cannot be certainly proved. To these must be added a cone-like flower supposed to belong to the Cycadeae, Zamiostrobus Saportanus, Schpr, from Armissan in the South of France. No remains of Cycads have been found by Heer in the rich Miocene flora of the Polar regions, for Nilssonia serotina, Heer ${ }^{1}$ from Sagalien may be a Fern.

The genus Cycas is a singular type without any near relatives in modern vegetation. Fossil forms teach us that this type is one of great antiquity. We find leaves with all the characters of those of Cycas, copious pinnation and lincar pointed pinnae with only one nerve, in all formations down to the Rhactic. From the Chalk may be meritioned Cycas Steenstrupii, Heer ${ }^{2}$, and C. Dicksoni, Heer ${ }^{3}$, both from the Urgonian beds of Atanc in Grecnland; from the Wealden C. Römeri, Schenk ${ }^{4}$, from the Jurassic beds C. zamioides ${ }^{5}$, and from the same formation in India C. Rajmahalensis, Oldh., C. Blandfordianus, Oldh. ${ }^{\circ}$, C. constrictus, Feistm. ${ }^{7}$, C. Lorteti, and other species $^{8}$; from the angulatus-beds of the Lias C. pectinatus, Berger " ; from the Rhaetic formation C. rectangularis, Braun ${ }^{10}$. If the small leaf-fragment named by Göppert ${ }^{11} \mathrm{C}$. taxodinus really belongs to this family, and having scen the original specimen from Rothwaltersdorf in Silesia I do not in fact know where clsc it can be placed, the type will have existed as early as the Carboniferous limestone.

But though these leaves are so characteristic and so like those of our modern Cycas-forms, yet we could not venture on the strength of them alone to ascribe so great antiquity to the recent genus. But this conclusion is supported by the carpophylls, which like the leaves are frequently met with and arc easy of recognition, and agree in all essential points with those of Cycas revoluta. A carpophyll in splendid condition lies on the same slab with the Cretaceous Cycas Stcenstrupii, Heer, and has the ovules still in situ on the extremitics of the lower pinnae. The original specimens of two similar fossils from the Coralline Oolite of Sommedicu near St. Mihiel, are unfortunately lost; the figures of them are to be seen in Saporta ${ }^{12}$ with the name of Cycadospadix Morcauanus, Sap. At the same place in Saporta and also in Schenk ${ }^{13}$, will be found an account of similar remains (Cycadospadix Hennoquei, Schpr) which occurred repeatedly in the angulatus-beds of Hettange and Coburg. It is true that in most of these cases only the extremities of the carpophylls are prcscrved, but they are associated with the before-mentioned leaves (C. pectinatus, Berger) and with very many

\footnotetext{
${ }^{1}$ Heer (5), vol. 5 III, t. $2 . \quad{ }^{2}$ Heer (5), vol. 6 II, t. 5. $\quad{ }^{3}$ Heer (5), vol. 3 II, t. 28, and vol. 6 II, t. 16. 'Schenk (1), t. 32. ${ }^{5}$ Leckenby (1), t. 8. 'Pal. Ind., ser. II, vol. i, pt. i, tt. 7, 8, 9 . ${ }^{7}$ Pal. Ind., ser. II, vol. i, pt. iv, t. 7. ${ }^{8}$ de Saporta (4), vol. ii, tt. 12, 13. ${ }^{\circ} \operatorname{Berger}(1)$. See also Göppert (8). $\quad{ }^{10}$ Schenk (3), t. 35. $\quad{ }^{11}$ Göppert (7). ${ }^{12}$ de Saporta (4), vol. ii, t. Ir6. ${ }^{13}$ Schenk (3), t. 32.
} 
casts of detached seeds, which from their size and shape may properly be considered as Cycas-seeds (Cycadeospermum hettangense, Sap.). And if we are anywhere justified in concluding that parts belong to one another because they are found lying together in the same place, we are so here, where the consideration of the whole of the circumstances leads almost of necessity to the same conclusion.

But in the case of all other remains of Cycads from the prehistoric world we have no grounds for concluding that they are affiliated to living forms. Here therefore we can only adopt confessedly artificial genera for the stems, leaves and remains of flowers, and arrange our material in these according to such external characters as we can recognise in it. In dealing with the leaves which have first to be considered, it is unfortunate that they do not of themselves enable us to distinguish between Ferns and Cycads with absolute certainty. Neither the shape of the expanded part, nor the course of the nerves, nor the form of the epidermal cells can decide the question. It is true that the epidermal cells are usually polygonal with straight side-walls in Cycads and with arcuately curved walls in Ferns, but the genus Stangeria agrees with the Ferns in this respect and was originally described by Hooker as Lomaria. Schenk therefore, who like Borne$\operatorname{mann}^{1}$ attempted to determine the nature of the leaves from this character ${ }^{2}$, has since ceased to employ it $^{3}$. The structure of the vascular bundles might possibly have supplied a certain criterion, but this is unknown, as there are no petrified specimens; the only resource left us is the habit, and this, as the case of Stangeria sufficiently shows, may mislead us. - Since the determination of all these remains rests on so insecure a foundation, we cannot be surprised that some of them have been shifted backwards and forwards by different authors from Cycads to Ferns and from Ferns to Cycads. Of such forms it will be well to select the genus Otozamites, Fr. Braun (Otopteris, Ldl. and Hutt.) for consideration in this place, and to discuss a number of others, Nöggerathia, Sternbg, Thinnfeldia, Ettingsh., Dichopteris, Zigno, Cycadopteris, Zigno, Nilssonia, Brongn., later on with the Ferns.

Oldẹr authors, like Brongniart ${ }^{4}$, were content with a few genera for the reception of their fossil forms. As the value of these genera was purely conventional, this was wisely done. The later multiplication of genera, in which great weight was attached to details of character, has become the fruitful source of endless synonymy and transference of species, and thus the general view has been obscured, while little has been gained in the way of deeper insight into the nature of the remains. A full description of all these genera, which have little interest for the botanist, is to be found in Schimper ${ }^{5}$. A few remarks founded on Brongniart's observations may be sufficient in this place.

${ }^{1}$ Bornemann (1). $\quad{ }^{2}$ Schenk (3) $\quad{ }^{3}$ Schenk (1). $\quad 4$ Brongniart (2). ${ }^{5}$ Schimper (1).


In the type of Pterophyllum, Brongn., the ribbon-like pinnae, which are all of the same breadth and are obtuse at the extremity, form a right angle with the thachis, being inserted upon it exactly perpendicularly to it on both its sides, and are often connected with one another by a narrow border; the nerves run in parallel straight lines. The well-known Pterophyllum Jägeri, Br. from the Keuper may be mentioned as an example. Certain forms of this type, as P. Schaumburgense, Dunk. from the Wealden are distinguished by very short and broad almost quadratic, and often uncqual pinnae, and are known by the name of Anomozamites. To the Pterophyllae belong also, according to Schenk ${ }^{1}$, the remains of large leaves from the Kcuper of Raibl in Carinthia which he names P. giganteum ; they were first called Nöggerathia vogesiaca by Bronn ${ }^{2}$ and ultimately appear in Schimper ${ }^{3}$ as Macropterygium.

In the Zamitae the pinnac articulate with the rhachis and separate from it in certain circumstances, but this is not possible with the Pterophyllae. Their numerous nerves, which sometimes form a single dichotomy, run parallel with onc anotherand with the margin of the pinnae, and appear to unite with one another at their extremitics to form a marginal nerve, as happens in the recent Ccratozamia. In truc Zamitae the pinnules are sharp-pointed at the apex, narrowed and abruptly rounded at the base, and are attached obliquely to the axis which they overlap and cover. In the Podozamitae they are more wedge-shaped, have the upper extremity broad and rounded off, and are said to be attached perpendicularly to the axis. When they are found isolated and detached from the axis, and this appears to be often the case, it is not easy to identify them, and they may be mistaken for portions of other similar elongated parallel-nerved leaves, for those of Phoenicopsis for example, or even for leaf-segments of Baiera and Ginkgo. This is still more truc of Rhiptozamites ${ }^{4}$, which is only known in the form of isolated pinnae. The genera Nöggerathiopsis, O. Feistm., and Euryphyllum, O. Feistm., which are also placed with Cycadeac, will be considercd again further on with the Cordaitae. Finally, the name Glossozamitae has been given by Schimper to certain forms of this type which resemble the Pterophyllae in habit, but must be carefully distinguished from them. Zamites ${ }^{-F e n e o n i s, ~} \mathrm{Br}^{5}{ }^{5}$ from the Upper Oolite, and especially frequent in the Coralline Oolite of the ncighbourhood of Lyons, may be mentioned as the best-known species of true Zamitae; as an example of Glossozamitae I should name Glossozamites Zittelii, Schpr ${ }^{6}$. and of Podozamitae Podozamites distans, Presl. ${ }^{7}$ Numerous figures of leaves of Podozamitac are moreover to be found in $\mathrm{Heer}^{8}$ and Nathorst ${ }^{9}$.

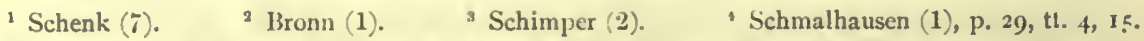
s Ettingshausen (2), t. 3. ${ }^{6}$ Schenk (4), t. 8. ${ }^{7}$ Schenk (3), tt. 35, 35, 37. ${ }^{6}$ Heer (5).

- Nathorst (3), 3. 4.
} 
The Otozamitae also have articulating pinnae which narrow at the base and overlap and cover the axis. Each pinna has on that side of the base which is towards the apex of the leaf a more or less strongly developed projecting ear-like lobe, which has suggested the name of the genus. The bases of all the pinnae when seen from the upper side and the rhachis also, if the condition is strongly marked, are covered by the auricles of the pinnae next below them; the pinnules all lie like scales one on another. The character is less prominent on the under side where the rhachis is visible, because the latter partly hides the auricles. The appearance therefore of the same leaf is quite different according to the position in which it lies on the slab, and this must be considered in determining these forms. The nervation also is essentially distinct from that of the Zamitae, and corresponds with the nervation of Neuropteris and Cyclopteris as defined by Mettenius for the Ferns. Numerous nerves run in curved lines diverging and occasionally dividing dichotomously to the margin of the leaf, so that the whole nerve-system is flabelliform in appearance. It is true that these characters are not so striking to the eye in all the forms of the type, as they are, for example, in Otozamites brevifolius, F. Braun ", in O. Bunburyanus, Zigno ${ }^{2}$, and many others. As the auricles of the basal extremities diminish in size, the fan-shaped nervation always becomes less distinctly marked. Forms of this character, which are named Ptilophyllum, Morris, are especially common in the Jurassic deposits of India, and are further distinguished, according to O. Feistmantel ${ }^{3}$, by the decurrence of the pinnules on the axis. The British Museum possesses beautiful ${ }^{-}$specimens of this kind. Countless figures of them are to be found in Feistmantel's work just quoted, and in the Palacontologia Indica ${ }^{4}$. In Schenk ${ }^{5}$, as has been before said, the forms of this type are given among the Ferns, partly on account of the structure of the epidermis, partly and chiefly because the author became acquainted with a leaf found by Benecke in Southern Tyrol and very like O. Bunburyanus, Zigno, in which the pinnae showed on their under side a thickened seam-like margin. $\mathrm{He}$ considers that this is the margin of the pinnule recurved as in Cheilanthes and covering the sori; but he has not been able to produce anything decisive in support of this view. It may possibly be correct; the difference between the leaves of Ferns and Cycads are so minute that it is not inconceivable that remains from both classes may have been placed with the Otozamitae. In connection with this point the form named by Saporta ${ }^{6}$ Otozamites marginatus may also be compared.

Of the flowers of Cycadeae only a few remains have been discovered, and the greater number of these are in an indifferent state of pre-

${ }^{1}$ Schenk (3). $\quad{ }^{2}$ de Zigno (1), f. $2 . \quad{ }^{3}$ Feistmantel, O. (1), I. $\quad$ ' Pal. Ind., ser. II, vol. i.

${ }^{3}$ Schenk (3). $\quad{ }^{6}$ de Saporta (4), vol. ii, t. 168. 
servation. The carpophylls of Cycas have been already mentioned. A male flower found in the Lower Oolite (Cornbrash) by Etrochey and described by Saporta ${ }^{1}$ as Androstrobus Balduini appears only as a surface-impression. In the cast of the cavity Saporta saw the pollen-sacs in large numbers between the scale-tips, which are rhombic on the transverse section, in a position answering to the inferior margin of each scale. The flower appears thercfore to have been buried after it was fully developed, and judging by the figure we may say without hesitation that it presents the essential characters of our genus Cycas. Another fossil described by Saporta ${ }^{2}$ and named Androstrobus Guérangeri, Brongn., from the Cenomanian deposits of Le Mans, is of much more doubtful character, and does not appear to offer much resemblance to Dioon with which it is compared. The genus Friçia also must be noticed in this connection, which Velenovsky ${ }^{3}$ has recently described from the Cretaceous strata of the White Mountain near Praguc. Of this genus we have a variety of broken cones bearing scales on their thick central axis. The scales form polygonal surfaces where they close on one another, and narrow gradually downwards into the slender point of attachment; and round their lateral surfaces they have small depressions which are considered by Velenovsky to be remains of pollen-sacs. There is lastly the obscure form which has been named by Heer ${ }^{4}$ Androstrobus sibiricus.

Of female flowers or fertile cones the first which demands our notice is Beania ${ }^{5}$, a remarkable genus but certainly belonging to the present group. Beania gracilis, Carr., from the Upper Oolite of Gristhorpe in Yorkshire, shows two-seeded carpophylls which agree perfectly in form with those of our Zamias. The notable point in this fossil is simply the enormous clongation of the internodes of the floral axis, which removes the fertile leaves to a great distance from one another. Schimper ${ }^{6}$ compares with it a fossil also from Gristhorpe, which Lindley and Hutton ${ }^{7}$ have figured as Sphaereda paradoxa. The comparison is apt; the original which I have seen in the Museum at Oxford agrees well with Beania. Some remains of fruit in a very bad state of preservation, found in two separate pieces in the Lower Lias of Arlon in Belgium (angulatus-beds) and possibly not even belonging to one another, have been described by Saporta ${ }^{8}$ as Zamiostrobus Ponceleti. The seeds which have been preserved show at all events that the specimens are fruits, and these may possibly belong to our present group. Velenovsky ${ }^{9}$ gives a full account of the fruit-remains formerly described by Corda ${ }^{10}$ as Microzamia gibba from the Cretaceous formation of Bohemia. The stalked scales, polygonal above and scutiform where they

${ }^{1}$ de Saporta (4), vol. ii, t. I15. $\quad{ }^{2}$ de Saporta (4), vol. ii, t. $78 . \quad{ }^{3}$ Velenovsky (1), p. 8, t. 3. 'Heer (5), vol. 411, t. 4. ${ }^{5}$ Carruthers (3). $\quad$ 'Schimper (1). ${ }^{7}$ Lindley and Hutton (1), vol. iii, t. ${ }^{150}{ }^{8}$ de Saporta (4), vol. ii, t. 117. Velenorsky (1), tt. 3, 4. ${ }^{10}$ Reuss (1). 
close upon one another, are supposed to have borne two seeds on the under side, but this does not appear from the figures, which seem to show the seeds irregularly disposed. The flowers are supposed to have been crowded together to form racemose inflorescences, and in this respect they depart very essentially from our recent forms. Much greater doubt appears to me to rest upon a fossil form which Nathorst has described as Zamiostrobus stenorhachis, and Saporta and Marion ${ }^{1}$ have figured. That it is the fruit of Podozamites is merely an arbitrary assumption. Androstrobus borealis, Nath. ${ }^{2}$, and Zamiostrobus orientalis, Heer ${ }^{3}$, are objects of quite uncertain nature ; the latter is a single scale and is said to be without question a conescale of Cycadeae or Abietineae. Lastly, a large number of entire conelike bodies showing the surface only have been described as forms of Zamiostrobus, and will be found enumerated in Schimper ${ }^{4}$. Some of them probably belong to the group which we are considering, for example Zamiostrobus Saportanus, Schpr from the Miocene beds of Armissan, which is figured in Saporta and Marion ${ }^{5}$. In this case a long thick stalk has been preserved which bears the ovoid cone. Where this is wanting, we remain as a rule in doubt whether we have before us the fructification of a Cycad or of a Conifer, or only a small stem of a Cycad encircled by the leaf-bases. Casts of seeds, which are often assigned by authors to the Cycadeac, are in general incapable of determination. Seeds will not be of any intercst till we succeed in finding them in such a state of preservation that we can examine into their inner structure. The remarkable fructification of Bennettites, Carr., can only be discussed in connection with the stems which bear it; and we must therefore consider them together. For Williamsonia, which is placed by English authors with the Oolitic Zamites gigas, the reader is referred to another section of this work.

Stems of Cycadeae in large numbers have long been known in the Jurassic (Purbeck beds) and Wealden especially in England and France, partly as casts, partly silicified and with the surface more or less perfectly preserved. Similar silicified stems are found not only in England and France but also in Silesia and in North Italy as rolled blocks in alluvium, and may be supposed to have belonged originally to the same formations. Several of these rolled stems are preserved in the Muscum of Bologna, having been found with vases and other utensils in the sepulchral chambers of the necropolis of the ancient Felsina ; they had evidently been buried by the Etruscans as objects of superstition with their dead. It has been already observed that the leaves of Cycadeae disappear as we ascend in the series of formations, and the stems also disappear in like manner. I have found in the literature only two stems belonging to this group, judging from

1 Saporta et Marion (2), p. I I 2.

2 Nathorst (3), 1t. I 2, 13.

3 Heer (5), vol. 411, t. I3.

\footnotetext{
- Schimper (1). $\quad 5$ Saporta et Marion (2), p. II6.
} 
the figures, one described by Brongniart ${ }^{1}$ as Endogenites echinatus, from the coarse limestone of the Eocene deposits of Soissons, and another Cycadites Escheri, Heer ${ }^{2}$, from the Molasse of Stein near Schaffhausen. On the other hand, stems and fragments of stems occur in the Upper Coalmeasures and in the Rothliegende in Saxony, Bohemia, the neighbourhood of Autun, and in the Ural Mountains, the structure of which points to their affinity with the Cycadeae, while the surface-characters cannot be recognised at all or only imperfectly. Since Cotta's ${ }^{3}$ time they have been known as Medullosae, and they must be noticed again when the Mesozoic forms just mentioncd have first been considered.

As a rule the Mesozoic stems of Cycadeae, which, as was said, are shortly cylindrical or roundish and tuber-like in form, show only the characters of thcir surface, which is covered as in living species with closely crowded spirally disposed leaf-bases and scale-leaves. The form and surface characters of the stems were used to limit the purely conventional generic groups, to which Saporta has given entircly new names, because those previously in use, Mantellia, Brongn., Bucklandia, Brongn., Clathraria, Mantell, included many remains not belonging to the group, and were in some cases founded upon them. Saporta places all tuber-likc and spherical stems with their close armour of scalcs and leaf-scars which are rhombic on the cross section in his genera Bolbopodium and Clathropodium. These genera are represented by a considerable number of species and vary much in size. If they are small we may easily be in doubt, as has been already said, whether we are dealing with stems or fruits, as for examplc in the greater part of the remains figured by Carruthers ${ }^{4}$ as Cycadostrobus. C. Brunoni, Carr., of unknown origin, is the only certain cone, but it looks more like a cone of Araucaria than of Cycadeac. In some forms figured by Saporta ${ }^{5}$ the ring of wood is clcarly to be seen when the fossil is broken across, as in Clathropodium Trigeri, Sap., found near Le Mans but not in its original place of deposit, and in C. Sarlatense, Sap., also a stray object picked up near Sarlat in the Dordogne. To judge from the figure there might be several consecutive rings of wood in this stem, as in old specimens of Cycas, and this point should be attended to in any further examination of the fossil. Its medulla is of remarkably small diameter. The stem described by Carruthers ${ }^{6}$ as Bennettites Saxbyanus is also referred by Saporta to Clathropodium, and this from his stand-point is quite justifiable. But this stem does really belong to Bennettites, Carr., for though the lateral axes so characteristic of this genus are not to be seen in the figure, yet Carruthers states that they are a general feature in all the species, and I have satisfied myself by personal examination that they are present in the three

\footnotetext{
1 Brongniart (3), D. 301 ; t. 16, f. 2.

${ }^{3}$ de Saporta (4), vol. ii, tt. I22, I 23.

${ }^{2}$ Heer (3), vol. i, t. 15.

${ }^{3}$ Cotta (1). 4 Carruthers (1).

6 Carruthers (4), t. 57 .
} 
original specimens of B. Saxbyanus, Carr. Clathropodium Trigeri, Sap., which I examined in the Paris Museum, also proved to be a stem of Bennettites.

Elongated cylindrical stems encircled by a similar armour of leafbases are called by Saporta, Cylindropodium and Platylepis. The latter name is given to forms in which the surfaces of separation are very broad and flat. The same stems are named by Carruthers Bucklandia, Yatesia and Mantellia. Cylindropodium liasinum, Sap., from the Lower Lias of Lunéville ${ }^{1}$, though badly preserved, shows the outlines of its woody cylinder.' Lastly, in Fittonia, Carr. Saporta includes all those stems in which the enveloping leaf-bases, narrowed into the shape of a cone or finger and touching one another only at the base, bear the comparatively small scar of separation at their apex. Besides the species figured by Saporta and Carruthers this genus also includès the cycadaceous stem from the Wealden of Bantorf near Hanover, which Schenk $^{2}$ has figured as Clathraria Lyellii. Figures of stems resembling Cylindropodia and Fittoniae, and said to have been found in the Permian formation of Eastern Russia, will be found in Eichwald ${ }^{3}$. Fresh examination of this author's original specimens is required in this as in many other cases.

Certain cone-like casts from the Cenomanian Chalk of Bohemia, named by Velenovsky ${ }^{4}$ Krannera mirabilis, have recently been declared by him to be stems of some form of plant allied to Cycadeae. They were formerly considered to be cones, and have been described by Presl ${ }^{5}$ under the name of Dammarites albus, by Göppert ${ }^{6}$ under that of $\mathrm{D}$. crassipes. These fossils are globular bodies beset with scales arranged in spirals, each scale showing a transverse scar of separation on the inner side of its upper margin. Fragments of parallel-nerved leaves are in a few cases still attached to the scar, showing that the scales must be regarded as woody leaf-bases. These cone-like bodies are sometimes borne on thick stalks marked with leaf-scars, and are therefore believed by Velenovsky to be the shortened thickened extremities of cylindrical leafy stalks. From the remains of the leaves found attached to the scales he suspects that to these cones belong certain parallel-nerved simple ribbon-like leaves ${ }^{i}$ with obtuse terminations common in the same locality, which were erroneously determined to be Flabellaria chamaeropifolia, Göpp. and regarded as shreds of palm-leaves. Velenovsky inclines to compare them rather with Cordaites, Phoenicopsis or Podozamites, or still better with Rhiptozamites Göpperti ${ }^{8}$ which comes near them in size. If this view

1 de Saporta (4), vol. ii, t. 118.

${ }^{2}$ Schenk (1), t. I4.

3 Eichwald (1), vol. i, tt. I7, 18.

+ Velenovsky (1), t. 4 .

5 Sternberg, Graf von (1), Heft $5-8$, t. 52 , ff. I I, I 2 .

6 Göppert (4), p. 238, t. 45 . 7 Velenorsky (1), t. I.

${ }^{8}$ Schmalhausen (1), t. 15, ff. 1-11. 
is correct, and the figured specimen certainly favours it ${ }^{1}$, then Krannera cannot be classed immediately with Cycadeae. The certain determination of its affinities must in any case depend on the discovery of fresh specimens. Lastly Vclenovsky takes some globular casts, which show the place where a stalk has becn broken off from them on one side, for the seeds of Krannera, solely because they were found with it. The only Cycad, as far as I know, in which the stem with the leaves attached can be determined with certainty, is Zamites gigas, Morr. The specimen of this plant came from the Upper Jurassic sandstone of Yorkshire, and was obtained from its owner James Yates for the Paris Museum, where I saw it. A figure of it is given by Saporta ${ }^{2}$. The stem bears a lateral bud cnveloped in handsome leaves; in this respect and in habit also it recalls Stangeria. It appears also to have been quite naked, though Saporta contends that he has discovered traces of scales and places it among his Cylindropodia. It has been already mentioned that English authors consider the peculiar flowers known as Williamsonia, Carr. to belong to Zamites gigas. Williamson ${ }^{3}$ mentions a second similar but less perfect specimen. He would also place in this species the stems covered all round with leaf-scalcs which he found near Scarborough; but from a specimen which I saw in Oxford I should say that they are the stems of Ferns. The specimens it is true lic on the same slab with several leaves of Zamites, but no conclusion can be drawn from this circumstance.

Carruthers ${ }^{4}$ has described a very remarkable stem covered with fructifications by the name of Bennettites Gibsonianus (Fig. 5). It is silicified, and in a wonderful state of prescrvation, and comes from the Lower Greensand of the Isle of Wight. Carruthers shows first of all that all the remains known as Bennettites have a distinctly elliptical and not a circular cross scction, though they have not been subjected to any particular pressure. The pith, which has no cauline bundle-system, is surrounded by a simple secondary woody ring of great thickness, which is divided by numerous tolerably broad medullary rays into portions of unequal size. The rather narrow rind is enclosed in a compact armour of leaf-bases in the same manner as in Clathropodia and Cylindropodia. At the same time there are considerable intervals between the separate members, and these are filled up with a thick mass of hair-formations resembling paleae. The fusiform transverse sections of these paleaceous scales ${ }^{5}$ show one or two cell-layers lying one above the other. The leafbases themselves are rhombic in form on the cross section and contain numerous vascular bundles in the neighbourhood of the periphery, which

' Schmalhausen (1), t. 4 , f. $4 . \quad{ }^{2}$ de Saporta (4), vol. ii, t. 8 r. 3 Williamson (3), p. $66_{5}$.

- Carrulhers (1). ${ }^{5}$ Carruthers (4), t. 6o, f. II. 
form a broad horse-shoe arrangement open above and with very short shanks inclined inwards. In some cases the parenchyma has partially disappeared (rotted out) on the surface of separation, and then the leafbases appear from the outside as rhombic cavities surrounded by a projecting network, which is formed by the silicified epidermal layers and the masses of paleaceous hairs lying between them. Similar conditions of preservation occur also in other stems of Cycadeae, as, for example, in Clathropodium foratum ${ }^{1}$, which may perhaps belong to Bennettites and which derives its name from them, and in Raumeriae also which will be noticed again further on.

But in Bennettites this armour of leaf-bases is pierced by many tightly-closed flowers or inflorescences, which surrounded by numerous leaves force their way through it and come to the surface, and there owing to the rubbing off of the tips of their leaves between the surfaces of separation of the leaf-bases appear in the form of peculiar centrically constructed whorls. It is at present uncertain whether these organs arise as axillary buds, though this is in itself probable; some other points also connected with their structure are still undetermined, notwithstanding Carruthers' excellent and searching examination of this fossil. The courtesy of Messrs. Carruthers, Hooker and Thiselton Dyer has put me in a position to make a fresh examination, and this has already cleared up some of these questions in a satisfactory manner. I must however reserve descriptive details for the connected account of the stem, which I design to give. The entire object is attached to the rind of the stem by a thick stalk, which is surrounded by lanceolate leaves ${ }^{2}$ and repeats even the details of the structure of the stem on the small scale, showing only some irregularity of shape in the transverse section in many places, due probably to pressure. The leaves also which encircle it are distinguished from the before-mentioned leaf-bases of the main axis only by the smaller and constantly decreasing size of the transverse section. The stalk terminates in a flatly convex cushion, which I conclude to have been of a fleshy succulent character ${ }^{3}$, because its tissue has been wholly destroyed, and consequently nothing can be perceived in the preparation before me but confused macerated parenchyma-cells and fragments of vascluar bundles. From the upper surface of the cushion there arises a bundle of closely crowded polygonal stalks in an envelope of several layers of linear-lanceolate leaves; the stout cortical parenchyma of these stalks has protected them from decay; and forms a sheath round the small vascular bundle which lies in the middle of a gap in the tissue. Between these stalks and filling small interstices are seen other transverse sections, each of which conceals a vascular bundle (Fig. ${ }_{5} C$ ). Whether 
these bundles belong to stalks similar to the others and lying between them but arrested in their development, as I suspect is the case, I have not yet certainly established. The members of the tuft diverge above and increase in thickness. Thus arises an elliptical cone with a ncarly even surface formed by the perfect cohesion of the apical portions of all the constituent members (Fig. $5 A$ ). The seeds, which in the specimens examined appear to be perfectly ripe, are present in large numbers and form a superficial layer in the cone. Each of them occupies a small cavity which communi-
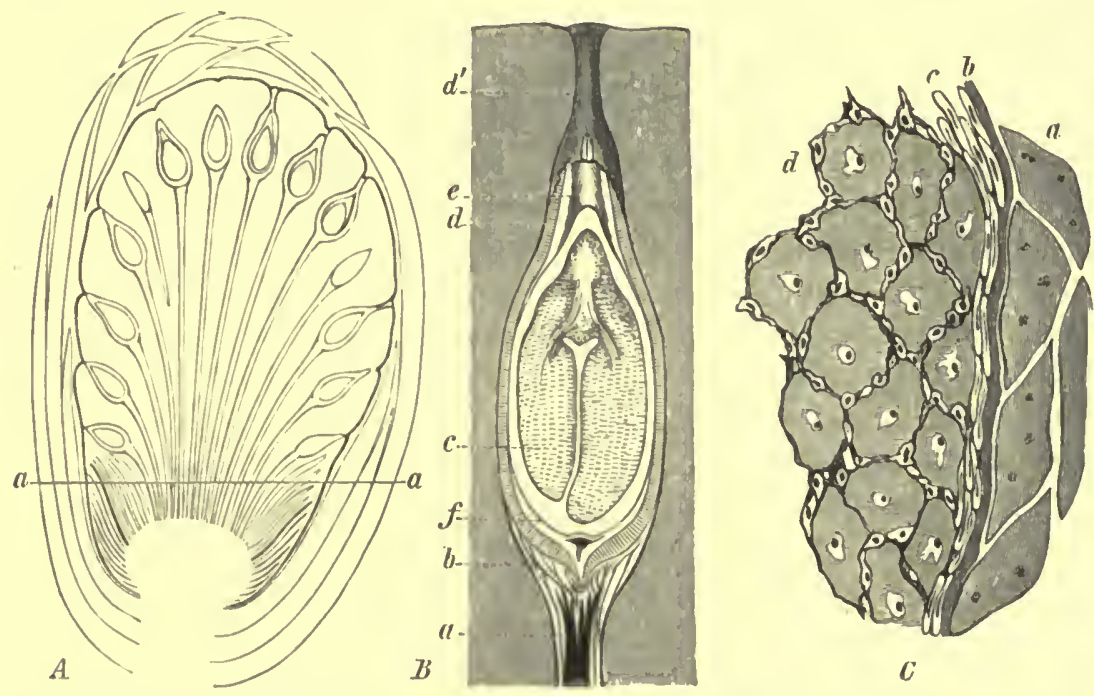

FIG. 5. Fructification of Bernettites (jibsonianus, Carr. A diagrammatic representation of the fructification-cone. Its thick leafy stem enlarges at the apex into a succulent cushion, from which rise a crowded tuft of numerous stalk. like objects, eacls traversed by a vascular bundle; the stalks unite with one another at the periphery and form a continuous surface. Each stalk bears at its apex a seed which lies in a pocket-like depression. $B$ representation of the longitudinal section of a seed, to some extent diagrammatic and constructed from several distinct figures ; $a$ the entering vascular bundle: $b$ its expansion at the base of the nucellus: $c$ the embryo with the two cotyledons; $d$ the testa formed of stout lignified palisade-like cells, which is prolonged above into a tubular process $d^{\prime \prime}$ terminating obtusely on the surface of the cone, and probably auswers to the integunent; $e$ tubular cell.layer, the continuation of a delicate membrane surrounding the embryo, and possibly answering to the outer boundary of the nucellus ; the tubular process at $\mathrm{its}$ apex represents the apex of the nucellus surrounding the pollen-chamber. $C$ portion of the transverse section through the tuft of seminiferous stalks beneath the place where the seeds begin ( $a-a$ in the diagrammatic representation of the entire conel; at $a$ the transverse sections of the enveloping lanceolate leaves which spring from the stalk. at $d$ the stalks with their central bundle surrounded by a gap in the tissue; between them small transverse sections squeezed out of shape which belong either to intermediate leaves or to arrested seed-stalks; in the periphery at $c$ there are only such small transverse sections, which are here flattened; $b$ represents the superficial homogeneous layer of the cone, which is formed by the perfect coalescence of the extremities of the entire tuft of organs. The whole from preparations lying before me and made from material preserved in the Museum at Kew.

cates with the outside by means of a narrow canal and orifice ${ }^{1}$. In its base is the termination of the vascular bundle of one of the stalks which have cohered in the surface of the cone. Each of them therefore bears an ovule at its summit. If a section of a seed is made in the direction of its axis (Fig. $5 B$ ), it is seen to have arisen from an atropous ovule; the vascular bundle spreads at the base of the nucellus into a small disk-like 
expansion. The outer boundary of the nucellus can be seen in the form of a stout line, and this is surrounded by the testa which was formed from the integument. The testa coheres below with the surrounding tissues, and contains a layer of shortly prismatic palisade-cells with a stout membrane and copious brown cell-contents. At the apex of the seed it runs out into a long exostome, which at first broad and inclosing a conical nucellar process probably surrounding the pollen-chamber, ultimately narrows into a tube, and then after becoming a little broader terminates in the surface of the cone. The behaviour of this integument is not represented by Carruthers, and is only to be observed in single seeds which have been cut through with more than usual success. The figure in the text had to be obtained from several individuals. The same may be said of the cell-contents. I have satisfied myself by searching examination of seeds in the British Museum which I have myself prepared, that inside the membrane which is all that remains of the nucellus there is a normally disposed embryo with two fleshy cotyledons lying flat on one another. The embryo so entirely fills the space as to preclude the presence of any endosperm. Carruthers' ${ }^{1}$ figure gives an indication of this embryo. The sketch in Fig. 5 shows somewhat diagrammatically the radicle, the vegetative point, the cotyledons, and their vascular leaf-traces which unite to form the vascular axis of the hypocotyledonary member. Such delineations as these it is true are seldom met with, for most seeds are not sufficiently well preserved; but we can very commonly observe in transverse or oblique sections the division between the cotyledons as a transversal fissure passing through the inner mass of the seed.

The sketch here given of Bennettites, which I hope to make more complete at some future time, is sufficient to show that its fructification departs essentially from all that we are accustomed to find in the Cycadeae; it is sharply and sufficiently characterised by its apparently axillary origin, by the peculiar immersion of the seeds in the surface of the cone, and by the absence of endosperm. It is possible that the seed-stalks may prove to be carpophylls of a peculiar kind; in that case we should be obliged to separate the Bennettiteae altogether from the Cycadeae, and to regard them as an intermediate group between Gymnosperms and Angiosperms. We should then have a typical case of that which Saporta and Marion ${ }^{2}$ call proangiospermy, though we could not perhaps assume a direct derivation of Angiosperms from this plant, and though it may have belonged to a line of development which never reached our era. However this may be, we must at all events insist on the near connection of Bennettiteae with true Cycadeae on the ground of the structure of the stem. The peculiar 
development of the female flowers from resting buds of the old stem cannot mislead us, for this circumstance, as is well known, recurs constantly as a biological adaptation at very various points in the vegetable kingdom. These conclusions enable us to dismiss Nathorst's ${ }^{1}$ view, who, if I rightly understand him in his paper, which unfortunately is only to be read in the Swedish, compares Bennettites with the Balanophoreae, and especially with Lophophytum, and considers it to be a parasite of the stem of a Cycad. Saporta $\%$, on the other hand, questions the facts of the case, and passes over the genus with the following words: "The following tribe, that of the Bennettiteae, is if possible still more strange, since according to Mr. Carruthers it had enclosed fruits situated inside the enlarged bases of the petioles. In spite of the apparent precision witl which the details of the anatomical structure are figured by the English botanist, it is difficult to admit the reality of such organic combinations.' Renault ${ }^{3}$ also secms to have been led astray by this and omits the genus altogether. A fertile shoot petrified in carbonate of iron and probably belonging to this group has been recently found in the Oxfordian beds of the Vaches noires in Normandy by Morière, and has been described by Saporta and Marion ${ }^{4}$ as the fructification of Williamsonia Morièrei, Sap. et Mar.; its resemblance to the fructifications of Bennettites seems to have escaped these writers.

Carruthers includes also in his genus a few other stems of similar elliptic form on the transverse section. First of all Bennettites Peachianus, Carr. ${ }^{5}$ from the Lower Oolite of Helmsdale in Sutherlandshire. The specimen in the Botanical Department of the British Muscum, which is not well preserved externally, shows the whorled transverse sections of the lateral axes of the inflorescence, and must therefore belong to Bennettites. A small number of rings of secondary wood are developed in the pith in a similar manner to that which will have to be noticed hercafter as characteristic of the Medullosac. Bennettites maximus, Carr., of which no figure is given, also belongs certainly to the group. I have satisfied myself of the presence of the lateral fertile shoots by examination of the original specimen in the Jermyn Strect Museum in London. Both this species and 13. Saxbyanus ${ }^{6}$ come from the Wealden formation of the Isle of Wight ; B. Saxbyanus also shows the lateral shoots, and its ring of wood is exactly like that of B. Gibsonianus. In a specimen, which is classed by Carruthers ${ }^{7}$ with the above forms and is split longitudinally, it can be seen that the leaf-traces, of which numerous horseshoe-shaped transverse sections are found in the outer rind, run direct and in straight lines in an obliquely ascending direction from the ring of wood to the leaves. They do not

1 Nathorst (5). $\quad{ }^{2}$ de Saporta (4), vol. ii, p. 53. $\quad{ }^{3}$ Renault (2). $\quad$ Saporta et Marion (2), p. $244 . \quad{ }^{3}$ Carruthers (4), t. 62. Carruthers (4), t. $57 . \quad{ }^{7}$ Carruthers (4), t. 57, f. 4. 
branch before they reach the leaf-stalks, and there is therefore no appearance of the leaf-trace-girdles which characterise our recent Cycadeae. How far this is true of all stems of Bennettites will have to be determined.

Essentially the same characters as those of Bennettites are presented by a series of forms which compose Carruthers' genus Mantellia, and which were named by Buckland Cycadoidea. The only differences adduced are the lesser height, the globular or tuber-like shape, the circular outline of the transverse section, and the circumstance that the fertile shoots project above the armour of scales and have only their basal portions preserved; : the latter character however, even if it were of universal occurrence, which I doubt, cannot be looked upon as in any way essential. To these forms belong the remarkable imperfectly silicified stems of low growth, which have their upper extremity hollowed out by decay of the tissue into the form of a bird's nest, and in this state have been found in great numbers in the stone quarries of the Isle of Portland near Weymouth. The Purbeck formation begins in this locality with marine limestones which have supplied the material for many buildings in London; these are succeeded by a fresh-water or estuarine deposit, at the base of which are two carboniferous earthy layers about a foot in thickness and separated from one another, the so-called dirt-beds, with numerous prostrate or upright silicified stems rooted in them. Among these stems and in like position are found the Cycadeae which are called birds' nests by the labourers, either singly or here and there in groups. For a further account of the matter the reader is referred to Buckland and De la Bèche ${ }^{1}$. Figures of the different species distinguishable by the size and form of the scars left by the detached scales are given by Carruthers ${ }^{2}$ (Bennettites Portlandicus; Carr., Mantellia nidiformis), by Schimper ${ }^{3}$ (Cycadoidea megalophylla, Buckl.), and by Buckland ${ }^{4}$ (Cycadoidea megalophylla, Buckl., C. microphylla, Buckl.). The commonest species in the dirt-beds is said by authors to be C. microphylla; Buckland himself may have included different forms in his C. megalophylla, for the figures show important differences. A fresh and connected examination of all these stems would be very desirable. To the same group also belongs a specimen named by Carruthers ${ }^{5}$ Mantellia inclusa, in which the fertile shoots have perished and dropped out, leaving deep and broad holes in the envelope of scales. And lastly, it seems to me probable from Göppert's ${ }^{6}$ figures that his Raumeriae are really stems of Bennettites. I can positively affirm this of Raumeria Schulziana, which was dug out of the ground in making a canal near Gleiwitz during the last century, now that I have seen the original at

${ }^{1}$ Buckland and de la Bèche (2). ${ }^{2}$ Carruthers (4), t. 6I, and t. 63 , f. I. ${ }^{3}$ Schimper (1), t. 7 I, f. Iт. See also Buckland, Geol. and Min., t. 6o. "Buckland (1), tt. $47,48,49$. 'Sarruthers (4), t. 63 , f. 3 . ${ }^{6}$ Göppert (9). 
Breslau. Between the leaf-scars are seen broad spaces filled with the transverse sections of paleaceous scales; the whorls indicated in Göppert's ${ }^{1}$ figure belong to the fertile lateral shoots. Both characters are shown still more plainly in the figure of $\mathrm{R}$. Reichenbachiana ${ }^{2}$, in the museum at Dresden, which was discovered in the year 1753 in a bog at Lednice near Wicliczka; I also believe that I can recognise them in the photographic representation of $\mathrm{R}$. Cocchiana ${ }^{3}$.

A small silicificd stem has been found in the Rothliegende of Autun, but with its surface unfortunately not preserved, which according to Renault ${ }^{+}$shows a structure directly allied to that of living Cycadeae. This form, Cycadeoxylon Fremyi, has a pith of moderate dimension surrounded by scveral rings of secondary growth (Renault's figure" gives two complete rings and one half ring interposed between them). These rings exhibit the features which are characteristic of Cycadeac. The wedges of wood are very slightly developed, being usually only two cells in breadth, and appear in the tangential section as repeatedly curved plates with enormously broad parenchymatous medullary rays running between them. The vascular bundles of the medullary sheath are no more to be seen here than in living stems of Cycadeae; they were probably destroyed at an early period by the great development of the medullary rays. But while in living forms, which show repeated formation of cambium, the successive secondary growths touch onc another, they are separated in Cycadcoxylon by broad masses of parenchyma, which have been partly destroyed; the portions of sccondary cambium must therefore have been formed in the middle of the cortical parenchyma and not on its inner margin. The tangential section of the rings of wood looks as if it had been taken from a stem of Cycas. The pits, which occur only on the radial walls of the tracheides, are in alternate rows and are polygonal from mutual contact, and have exactly the appearance of Araucaroxylon. A number of dark dots appear in the cortical parenchyma outside the outermost ring of sccondary growth, and answer according to Renault to so many gum-passages.

We have still to consider the Medullosae, a series of remains of stems from the Upper Coal-measures and the Rothliegende. The surface of these stems unfortunately is known only in a few cases, and in these only imperfectly; but in thcir anatomical structure they show many points of resemblance to the Cycadeac, though they depart from them according to the most recent investigations in some important particulars. I have been able to satisfy myself from preparations that these differences have been correctly observed. Good figures of sections of stems of Medullosa are to

\footnotetext{
1 Göppert (9), t. 7, f. 1.

${ }^{2}$ Göppert (9), tt. 8, 9 .

s Caruel (1).

- Renault (1), vol. i.
}

S Renault (1), vol. i, t. I4, f. 9. 
be found in Cotta $^{1}$ first and next in Göppert ${ }^{2}$, and lastly and especially in the new memoir on the group by Göppert and Stenzel ${ }^{3}$ (Fig. 6). In Medullosa stellata, Cotta, the oldest described species, we observe at the first glance a double peripheral secondary growth interrupted here and there by broad medullary rays, and almost always forming the outer boundary of the specimens since the cortex is usually wanting. The broad pith is traversed by so-called star-figures, annular woody bodies of small diameter and radial structure. If their transverse section is circular,

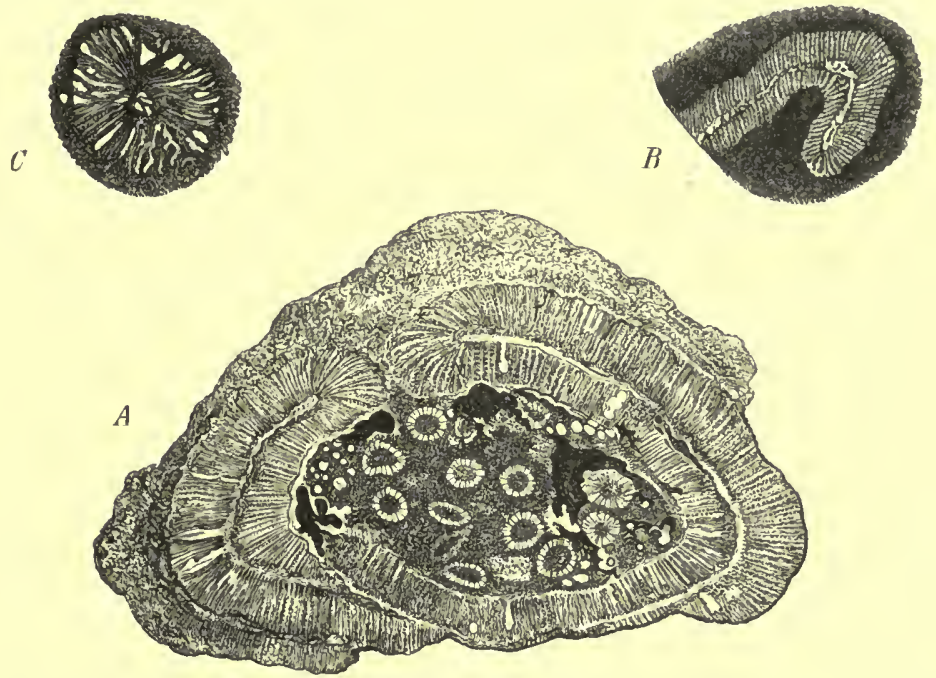

F1G. 6. Medullosa stellata. $A$ transverse section of the stem after Göppert ${ }^{4}$, somewhat altered to show the com. position of the peripheral wood from compressed plate-rings; in the pith are seen numerous star-rings. $B$ piece of a plate-ring of M. stellata, var. $\epsilon$, interrupta, after Göppert and Stenzel ${ }^{3}$. C a star-ring from the pith of M. stellata, var. $\beta$, major, G. and Stenz. ${ }^{5}$, from the same authors.

they are termed by Göppert and Stenzel star-rings (Fig. 6, C); if the section passes through the ovoid into an elongated linear form, they are known as plate-rings (Fig. $6, B$ ). If we examine these rings more closely, we find that each of them answers to a normal secondary growth, which has developed its bast-layer on the outer, its woody layer on the inner side. The plates of wood are narrow, the medullary rays which lie between them increase greatly in breadth towards the outside, and the alternation of the two causes the radial structure of the ring. The tissue in the centre of the ring is unfortunately always destroyed, but in the case of the elongated plate-rings there can be little doubt that, like the rest of the parenchyma of the pith, it represents a partial pith in each ring. This may also have been the case with the star-rings. On the other hand, the star-rings may

${ }^{1}$ Cotta (1). $\quad{ }^{2}$ Göppert (3). ${ }^{3}$ Göppert und Stenzel (11). $\quad$ 'Göppert (3). ${ }^{5}$ Göppert und Stenzel (11). 
have enclosed a medullary strand of vascular bundles, since I find in a section obtained from a specimen from Chemnitz two groups of vessels in the centre of the ring which have escaped the general destruction. This point, as well as the question of the longitudinal course of these elements, can only be cleared up by further researches, but we may have to wait some time for these in the present scantness of material. It is greatly to be regretted that the discovery of the silicified stems in the Rothliegende of Chemnitz occurred so early in the last century, for the locality is now nearly exhausted, and the most precious material has been frittered away and spoilt to make ornaments, and to furnish the mineralogical trifles in vogue at that time.

If we now examine the outer ring of wood in Medullosa stellata more closely, we become aware of the remarkable fact, first disclosed by Göppert and Stenzel, that the ring does not consist, as had long been supposed, of two consecutive annular sccondary growths, as in Cycas, but that it is composed of a variable number of plate-rings, which are narrow and more or less elongated on the transverse section and together simulate a peripheral woody circle (Fig. 6, $A$ ). The intervals mentioned above and formerly taken for broad medullary rays are simply gaps between the single plate-rings of the circle of wood. The linear partial pith of these plate-rings appears on a superficial examination as the boundary of the two consecutive secondary growths; it is of course bounded by woody tissuc on its outer and on its inner side, and this is succeeded on both sides by normal bast-masses which are traversed by many transverse sections of fibre-cells. Disturbances, curvatures, and the like are quite common in these plate-rings, as in those of the inner pith, and may naturally be referred to the pressure to which the developing masses of secondary tissue were everywhere exposed in the middle of the body of the parenchyma. It might be supposed that there was another normal woody cylinder outside the one which has just been described and which was formed of the plate-rings, and that we have therefore only the pith of the stems before us. That this is not the case however is proved by another species, M. Ludwigii, brought by Ludwig from the Uralian Steppe and described by Göppert and Stenzel. The surface, which is preserved in this stem, is covered with somewhat crowded roundish impressions, which these authors unhesitatingly compare with the leaf-scars of the stems of Cycadeae. From the figure alone I can form no opinion on the point; but the star-rings and plate-rings in this species are all confusedly and irregularly disposed, and no peripheral woody cylinder is formed from the plate-rings. All this seems to show, as Göppert and Stenzel very justly remark, that the anomalies in the growth of the stem in Medullosae remind us much less of the conditions of growth in the genera Cycas and Encephalartos than of those of Sapindaceae, and this is 
brought out into the clearest light by a fossil form which we will now consider, Medullosa Leuckarti of Göppert and Stenzel. The resemblance between Medullosa and Cycas formerly brought into prominence and much insisted upon thus loses its importance, and if we nevertheless assume a close relationship between this group and Cycadeae, this arises solely from the great similarity in the character of the tissue in both. I would add that we must enquire further whether the peripheral woody ring of some Bennettiteae, in which duplication is suspected, does not also ultimately show the conditions characteristic of Medullosae.

The form just mentioned, Medullosa Leuckarti, Göpp. and Stenz., is according to the figure a somewhat shapeless fragment of stem bearing the stump of a thick lateral branch ${ }^{1}$. Its cross section shows only a few rings of secondary wood, some of which have the character of star-rings; but the greater part appear in the form distinguished by the authors as snake-rings. These are marked by the great width of the partial pith, and also by the extremely irregular shape of the flexuous ring which forms sinuses and projections. Wood and bast are in their normal position, and appear from the figure to be well preserved ; the latter tissue contains closed plates of fibrecells. An allied form is Colpoxylon Aeduense, Ren., with respect to which Göppert and Stenzel ${ }^{2}$, who were only acquainted with Renault's figures ${ }^{3}$, still express some doubt. I have seen in the Paris Museum several of the beautiful plates prepared from the original specimens obtained at Autun and one, a present probably from Brongniart to $\mathrm{R}$. Brown, in the Botanical Department of the British Museum, and have satisfied myself that in this species, just as in Medullosa Leuckarti, there is a variable number of broad irregularly sinuous snake-rings, each of which encloses a parenchymatous partial pith. Myelopitys medullosa, Corda, from the Rothliegende of the North of Bohemia, may also be nearly allied to the Medullosae; but this question, owing to the small size of the fragment which Corda ${ }^{4}$ had before him, can scarcely be perfectly cleared up even by a fresh examination of the specimen.

1 See note on p. 16r.

${ }^{4}$ Corda (1), t. II, ff. 4-8.
Göppert und Stenzel (11).

${ }^{3}$ Renault (2), vol. i, t. 11 , f. 8. 
CORDAITEAE.

'THOSE: who have paid any special attention to palaeophytology have long since remarked with surprise, that while remains of branches and leaves of Conifers are comparatively rare and uncertain in their occurrence in the Coal-measures, silicificd woods of the type of Araucaroxylon are so frequently met with in that formation. No onc suspected at the time of the publication of Schimper's 'Paléontologie Végétale' that these woods bclonged to leaves which occur from the Devonian beds upwards, and are found in the greatest abundance in the upper deposits of the Carboniferous cra, covcring every surface of stratification with countless impressions. These leaves, on account of their ribbon-like shape and parallel nervation, were considered by most of the older authors, Göppert especially ${ }^{1}$, to be Monocotyledons, and were named Nöggerathia or Cordaites. With them werc placed certain round, heart-shaped, or ovoid casts, also very abundant, which werc called Cardiocarpus, Rhabdocarpus, \&c., according to their form, and were usually compared with fruits of palms. Brongniart ${ }^{2}$ also at first considered them to be Monocotyledons, but he soon gave up this vicw and put them and the casts of seeds just mentioned as a special family side by side with Cycadeae ${ }^{3}$, thus conjecturally recognising their real affinities. Goldenberg ${ }^{4}$ and Weiss ${ }^{5}$ supported Brongniart on the strength of important observations of their own, the latter indeed with some hesitation and after having previously allowed the group to remain in its traditional position among the Monocotyledons. But opinion, founded only on conjecture, still fluctuated with regard to the nature of these forms, till Grand' Eury ${ }^{6}$ by his excellent investigations succeeded in clearing up the important points, and in establishing their claim to be reckoned among Gymnosperms. His results were extended and confirmed by Renault's ${ }^{7}$ admirablc examination of the inflorescences preserved in the pebbles of Grand' Croix, to which Brongniart ${ }^{8}$ assigned the detached seeds occurring in the same material. It is entirely due to the efforts of these authors that the Cordaiteae, which a few years ago were among the most

\footnotetext{
1 Göppert (3) and (12).

${ }^{2}$ Brongniart (4).

3 Brongniart (5) and (2).

4 Goldenberg (2).

5 Weiss (1). 'Grand' Eury (1). $\quad{ }^{7}$ Renault (1). $\quad{ }^{8}$ Brongniart (6).
} 
doubtful of objects and were mixed up with Nöggerathiae, are now the best-known of all classes of fossil plants which are no longer included in our present vegetation.

The leaves of Cordaiteae are simple, sessile, elongate-elliptical or ribbon-like from a contracted base, and rounded or acute at the extremity. They are in all cases traversed by conspicuous parallel nerves which lie very close to one another, and according to Grand' Eury are occasionally forked. Differences appear to have been observed in the size of the nerves, but we must be careful how we make use of this character, since it depends a good deal on the mode of preservation. Usually all the nerves are of the same size, or they gradually increase in size towards the middle of the leaf; more rarely stronger and weaker nerves alternate regularly, as, for example, in Cordaites principalis, Gein., in which Grand' Eury finds four weaker nerves between every two stronger nerves. This observer has divided the entire group of Cordaiteae into three genera founded on the form of the leaves, but these must be rcgarded as entirely provisional so long as their relation to the flowers which have been discovered is not better known than it is at present. These genera are Dorycordaites, with leaves which may be fifty centimetres in length and which narrow gradually into an acute apex; Poacordaites, in which also the leaves may be half a metre in length; but are linear and grass-like and are suddenly rounded off to an obtuse termination; and Cordaites, with shorter obovate or spathulate obtuse leaves which are sometimes incised. The Poacordaitae, which are chiefly found at St. Etienne in different beds from the other two types, have been recently separated from them by Renault ${ }^{1}$ and placed with Taxineae. I am not informed respecting the reasons which have determined him in this matter.

Leaves of Cordaites are extraordinarily abundant in the black pebbles of Grand' Croix. In some fragments, such as one for which I am indebted to Renault's kindness, large numbers of the leaves lie in layers one above another like damp beech-leaves on the ground in our forests. In these specimens the structure is often well preserved, and the distribution of the tissues displays a surprising multiplicity of detail considering the uniformity of shape. Unfortunately the silicified leaves come under our observation in fragments only, and it is impossible to refer them with any certainty to the different species which have been determined from the impressions. Renault has therefore marked all the transverse sections which he has named with a note of interrogation; and Grand' Eury has given special specific names founded solely on the anatomical structure to the forms which he has examined. All the leaves which have been carefully studied, with the exception of one kind only, show a simple layer of parallel vascular bundles running in 
the middle of the substance of the leaf; in Cordaites duplicinervis, Grand' Eury, the bundles approach nearer first to the upper and then to the under side, being in the former case smaller, in the latter larger on the transverse section. Each bundle together with the adjacent parenchyma, which is often obliterated, is usually surrounded by a firm sheath formed as a rule of a single cell-layer. The bast-portion has in most cases disappeared, and the position of the gap thus produced cnables us to determine the under side of the leaf with tolerable certainty. The woody portion of the bundle,

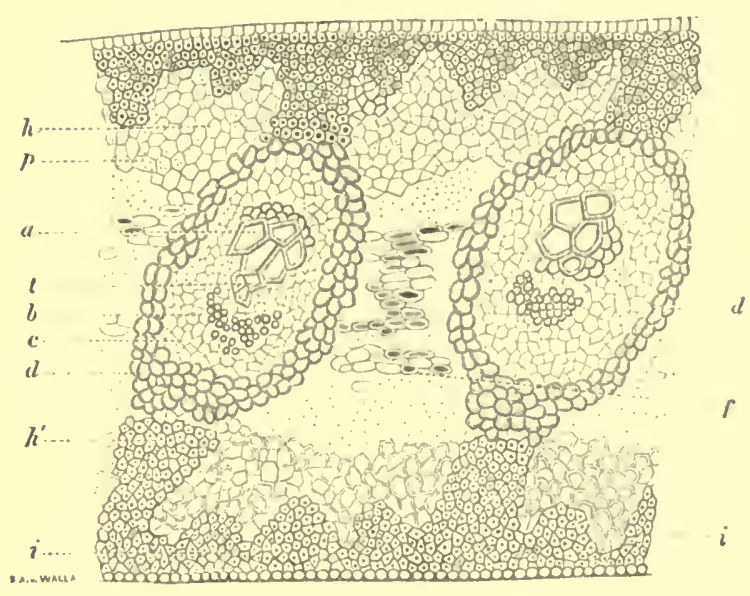

Fig. 7. "Transverse section of the leaf of Cordaites angulostriatus, Grand" Eury: $a$ inner strand of the wood-bundle (bois centripete); $b$ outer strand of the same (bois centrifuge): $t$ initial strand lying between the two portions; $c$ bast ; $d$ parenchymatous sheath; $h, h^{\prime}$ and $i$ fibrous tissue forming the mechanical system in the leaf; $f$ spongy mesophyll. After Schenk in Zittel's Handhonk. on the other hand, is marked by a peculiarity, which in our modern vegetation is found only in the leaves of Cycadcae and in those of Isoëtes and Ophioglossum. Its initial group (Fig. 7,c) lics on the bast-side of the bundle, cither close to the gap or bounded on the side of the gap in several species, according to Renault, by a group of one or more rows of tracheides which have a curved transverse scction (Fig. 7, b). In the latter case we should have exactly the structure of the leaf-stalk of Cycadeae. Inside of the initial group is a stronger and outside of it a weaker mass of wood, and the development of both appears from the accoints given of it to advance, as in Cycadcac, in both directions from the initial group. Both here, and in Cycadcae and elsewhere also, Renault terms the inner portion of the primary woody bundle the centripetal xylem (bois centripett), the outer the centrifugal xylem (bois centrifuge); he speaks of the whole bundle as the diploxylous bundle (faisceau diploxylé), to distinguish it from the normal bundle, the monoxylous bundle (faisceau monoxylé). In treating of the Sigillarieae we shall have further to consider how far this terminology is justifiable, and above all how far it answers its purpose. If, as according to Renault appears to be the case in other leaves of Cordaitae, the outer portion of the primary wood (the centrifugal xylem) is wanting, we have the structure which we find in the vascular bundle of Isoëtes. Schenk ${ }^{1}$ in his 
account of Renault's statements has not given them correctly, inasmuch as in the explanation of the figures he terms the outer strand of the primary wood the 'phloem,' and must therefore suppose that the elements in question are fibre-cells of the bast. But I have satisfied myself by examination of Renault's ${ }^{1}$ original preparations that his account of the matter is perfectly correct. With regard to the rest of the leaf-tissue, the epidermis on both sides of the leaf is formed of cells bounded by straight lines and approximately rectangular; on the under side are rows of stomata lying parallel to the surface of the leaf, but there are none on the upper. In some forms the cells of the upper side are developed into pointed papillose processes, as in Cordaites tenuistriatus ${ }^{2}$. The parenchyma of the leaf may be uniform ${ }^{3}$, but it is usually differentiated into three layers, a loose irregular tissue on the under side, a tissue more or less distinctly resembling palisade-tissue on the upper side, and an intermediate 'transfusion-tissue' occupying the space between the bundles; this middle tissue is lacunose in character with broad intercellular spaces, and is formed of cells lying across the leaf. There are also the mechanical elements in a variety of forms. Where these are slightly developed and the entire parenchyma of the leaf is also uniform (C. crassus ${ }^{4}$ ), they appear as single sub-epidermal fibres answering to the vascular bundles on both sides of the leaf, but not reaching as far as the bundlesheath. Besides these there is on the under side between every two bundles a narrow much-projecting strand of fibres, which has nothing to correspond to it on the upper side. In other forms the fibre-strands unite from above and below with the sheath of the vascular bundles, forming the well-known customary longitudinal trabeculae. Lastly, in C. angulostriatus (Fig. 7, i) these are connected together on both sides by a continuous sub-epidermal layer of fibres, which swells up into one or more rib-like projections between the bundles, and this perhaps explains the appearance in the impressions of the fine intermediate nerves peculiar to some Cordaitae. There must certainly be a connection between the greater or lesser degree of prominence of the nervation in the impressions of the leaves, and the fact that in some forms the thin leaf-surface over the nerves appears thickened into a knot in the transverse section, while in others nothing of the kind can be observed. That with all this the structure of the leaves is essentially resistant has been already remarked by Schenk ${ }^{5}$; we see by this case the great antiquity of these anatomical phenomena of adaptation to external conditions; we shall find them reappearing on different occasions as we proceed with our subject, and we may conclude on the whole that those external conditions, which we see determine this adaptation at the present day, prevailed as early as the period of the Coal-measures.
1 Renault (1), t. 16.
2 Renault (1), t. I6, f. 2.
${ }^{3}$ Renault (1), t. 16, f. 7 .
- Renault
$(1)$, t. 16, f. $7 . \quad 5$ Zittel (1). 
Branches of Cordaiteae stripped of their leaves are frequently found at St. Etienne in the beds which are filled with leaves. Specimens with these leaves still attached to them are however rare. Little attention seems to have been paid to them in other places. They occur as impressions or flattened casts covered with a rind of glistening coal, and with the leaf-scars in some cases still apparent on their surface. Numerous specimens of such portions of branches have been figured by Grand' Eury'. These scars, in correspondence with the contraction of the bases of the leaves, are elliptical on the transverse section and of no great breadth, and where the preservation is particularly good, they show a transverse row of dot-like vascular bundle-traces. They are placed, as in our pines, on the summit of scmicylindrical leaf-cushions which are decurrent on the branch, and which flatten out more or less quickly and disappear. That the branches really belong to Cordaites is proved by some drawings of Grand' Eury, in which they are still covered with the leaves and even bear inflorescences. Some care is required in judging of these figures, for the author often gives us reconstructions which he does not always distinguish quite clearly from the portions drawn from nature. For this reason I can only citc one figure as decisive, that of C. alloidius "2, Grand' Eury, which is described at length and satisfactorily in the text. In the lower part of this leafy branchlet the scars are crowded close to one another, giving to the surface the appearance of Lepidodendron; in the upper part they are widely separated through the elongation of the internodes. Apart from Grand' Eury's drawings, the tufts of leaves of Cordaites and the branches which bear them are very sparingly figured in the literature. The oldest figure is the one in Sternberg's work", which however only shows a number of leaves converging downwards with their bases broken off. It is the figure of Flabellaria borassifolia, and is taken from a specimen found at Radnitz in Bohemia. Germar ${ }^{4}$ next describes the upper extremity of a branch thickly covered with leaves as Flabellaria principalis. Then Corda" figures a splendid leafy branch under the name of Flabellaria borassifolia, Stbg; the anatomical drawings in the next plate can hardly belong to this species. Göppert ${ }^{6}$ gives an account of a very leafy branch named Nöggerathia palmacformis, Göpp. All these figures are to be referred to the type Cordaites of Grand' Eury; on the other hand, the fine specimen from the Goldberg collection, figured by $W_{\text {eiss }}{ }^{7}$ and named Cordaites microstachys, Weiss, belongs to Poacordaites, and is considered by Grand' Eury to be his P. linearis. Some at least of the many beautiful branches figured by Lesquereux ${ }^{8}$ may belong to this type. Closed leaf-buds also have been found at St. Etienne

\footnotetext{
${ }^{1}$ Grand' Eury (1), tt. 27, 28. $\quad{ }^{2}$ Grand' Eury (1), t. 21, f. $8 . \quad$ 's Sternberg, Graf von (1), Heft 1-5, t. 18. Germar (1), t. 23, f. 5. 'Corda (1), tt. 24, 25. 'Göppert (12), t. I5. 7 Weiss (1), p. 195. 'Lesquereux (1).
} 
both in impressions and in the pebbles; the leaves in these buds show the convolute acstivation, such as may be seen in the beautiful drawing of a transverse section given by Renault ${ }^{1}$. Where the inner structure can be determined in branches evidently belonging to Cordaitae, the structure of the wood is seen in all cases to be that of Araucaroxylon. We find too that the wood has exactly the same character in the portions of branches which are preserved in the pebbles of Grand' Croix, and which are remarkable for the unusual breadth of the cylinder of pith. The tissue of the pith usually disappears at an early period, persisting only in thin transverse diaphragmplates which show greater solidity, just as happens for example at the present day in branches of the walnut-tree. In consequence of this peculiar behaviour the branches of true Cordaitae are sharply differentiated from other trees with a similar woody structure. Hence also Araucaroxylon medullosum, Kr. (Pitus primaeva, With.), must certainly be placed in the present group; the broad transversely segmented pith is surrounded by primary bundle-strands, which, as in Araucaroxylon, are separated by many medullary rays. The cortex, where its structure is preserved, is marked by few special features; its uniform parenchyma encloses a rather large number of fibre-strands, and also shows here and there isolated lumina filled with a dark substance, receptacles of resin or gum, as Renault ${ }^{2}$ considers. Beautiful figures illustrating the anatomy of Cordaites will be found in this author ${ }^{3}$.

Peculiar casts of stems, to which Sternberg gave the name of Artisiae ${ }^{4}$, have long been known to occur not unfrequently on the refuse-heaps of coal-mines. These are cylindrical in shape but are usually flattened by pressure, and are divided by deep transverse annular furrows into numerous thin lamelliform segments which lie one on another like pieces of money in a roll. They separate very readily from one another at the partitions. Williamson ${ }^{5}$ was the first to perceive that these casts fill the medullary cavities of stems and branches with the structure of Araucaroxylon. There is no longer any doubt on this point, since Grand' Eury ${ }^{6}$ has shown that they occur inside undoubted branches of Cordaites, and Williamson ${ }^{7}$ and Renault ${ }^{8}$ have pointed out in the petrified axile portions the particular structure of the pith on which their form is based. The constrictions therefore in these casts answer to the persistent margins of the diaphragms of pith, which were broken through in the process of decay or were otherwise partially destroyed before infiltration. The surface of the stems is usually smooth, but angular forms and forms marked with transverse circles also occur, like those for example figured by Grand' Eury ${ }^{9}$. It is a question whether we may not be dealing in these cases with casts of the medullary

${ }^{3}$ Renault (1), t. 16, f. I. ${ }^{2}$ Renault (1). ${ }^{3}$ Renault (1), t. 15. ${ }^{4}$ Sternberg, Graf von (1), Heft I-5, t. 53. ${ }^{5}$ Williamson (4). ${ }^{6}$ Grand' Eury (1). ${ }^{7}$ Williamson (1), ix. ${ }^{8}$ Renault (1). ${ }^{9}$ Grand' Eury (1), t. 28. 
cylinder of other kinds of plants, and this seems to find support in Corda's ${ }^{1}$ belief that he has observed Artisiae occupying the centre of the stem of his Lomatofloios crassicaulis, which certainly belongs to Lepidodendreae; at the same time, when we examine the figure of the stem in question ${ }^{2}$, we cannot hclp doubting whether it rcally belongs to Lomatofloios. These same Artisiac in conjunction with Araucaroxylon have rightly determined Grand' Eury ${ }^{3}$ to claim the numcrous cylindrical main stems of trees found in the quarries in the neighbourhood of St. Etienne, in an upright position and still rooted in the ground, as belonging to Cordaitac. The fragments of roots with the normal structure of Coniferae, discovered by Renault ${ }^{4}$ in the pebbles of Grand' Croix, must also no doubt be referred to the same group.

Before proceeding to consider the structure of the flowers and seeds of Cordaitae, it will be advisable to say a few words respecting the distribution of the leaves and stems of these plants in the different formations. There can be no doubt of their existence in the Devonian beds; beautiful leaves of Cordaites Robbii are figured by Dawson ${ }^{5}$ from Canada; the same author states that he has found Artisiae inside petrified stems of his Dadoxylon (Araucaroxylon) Ouandongianum ${ }^{6}$ from the Middle Devonian. The Cordaitae are found throughout the Coal-measures, being extremely common in the uppermost beds of the formation, and are still abundant in the Rothliegende.

Whether the type of Cordaiteae was continued into the later formations, and for what length of time, we are unable to say. Leaves of similar character to those of Cordaitcac are found as high up as the Tertiaries, as may be secn by referring to Feildenia which is discussed with Taxineae. Among these doubtful forms must be reckoned a genus described by $\mathrm{O}$. Feistmantel ${ }^{\top}$ as Nöggerathiopsis and confined to India and Australia. In this genus we may place a form first introduced to notice by Dana ${ }^{8}$ under the name of Nöggerathia prisca from a deposit known as the Newcastle beds, in which the character of the fauna is said to be Palaeozoic and that of the flora Mesozoic, and which according to O. Fcistmantel is one of the lowest beds of the Trias. Another form, Nöggerathia Hislopi, Feistm., occurs in the Lower Gondwanas of India, which are said to be the equivalent of the European Trias. Nöggerathia obovata, Carr. ${ }^{9}$, from the coal fields of Southern Brazil, should perhaps be placed in the same genus. The leaves of Nöggerathiopsis greatly resemble those of Cordaitae with short broad leaves. O. Feistmantel distinguishes sharply between the two genera, apparently on account of the bifurcation of the nerves in Nöggerathiopsis, but this according to Grand' Eury is not unknown in Cordaites. Feistmantel con-

${ }^{2}$ Corda (1). ${ }^{2}$ Corda (1), t. 5, f. 2. ' ${ }^{3}$ Grand' Eury (1), tt. 29, 34. "Renault (1), t. 15. ${ }^{5}$ Dawson (1), t. 14, f. ${ }_{5} 6$. 'Dawson (1), t. 2 x. ${ }^{7}$ O. Feistmantel (1), and Pal. Ind., ser. xii.

s Dana (1), p. 7 I5. 9 Carruthers (7), t. 6, f. I. 
siders these leaves of Nöggerathiopsis to be single detached leaves of Cycadeae, but I am unable to find in his account of them any good ground for this view. He compares them with Macropterygium Bronnii, Rhiptozamites, Schmalh., and some remains described as Podozamitae; but all these forms, as has been already stated, are of very doubtful character. Details respecting Nöggerathiopsis will be found in his extensive publications, in which he has also collected the literature of the plant-bearing deposits of India, Australia, and South Africa.

We may notice also in this place the genus Yuccites ${ }^{1}$, which contains a number of fossil remains from Triassic and Jurassic deposits. Schimper himself says of it: 'It is needless to say that these fossils may come from types which are very different from one another, and which may have no real analogy with the living type with which we compare them.' Schimper says that the rush-like leaves of these Yuccitae have an appendage which embraces the stem, and this may be the only character which would certainly separate them from Cordaitae; but it appears to me to be premature to place them at once for this reason among Proangiosperms, as is done by Saporta and Marion ${ }^{2}$.

If we find ourselves on the whole in a position to pick out the Palaeozoic Cordaitae from out of this chaos of remains marked by parallel nerves and by similarity of habit, and to determine them at least in the most general features of their organisation, we owe it, as I take every opportunity of saying, solely to the exact knowledge of the flowers of a - few species which we have gained through the labours of Renault. - I will add at once that I am far from thinking that the common connection of all these forms of Cordaitae is thus certainly established. Still the following remarks will suggest some grounds for the view that this type represents a large and much differentiated group of plants, which must be coordinated with Coniferae or Cycadeae, though we can at present discern its real nature only from the characteristic marks of single selected species. We have therefore as yet no means of judging of the degree of differentiation of the characters in the group. If there were no Conifers at present in existence, and we were compelled to picture their organisation to ourselves from the flowers, suppose of Ginkgo only and Callitris, with some help from leafy branches, our condition with regard to them would in my opinion be nearly that in which we find ourselves at present in dealing with Cordaiteae.

In the siliceous fragments of Grand' Croix we find now and again small buds composed of leaves lying close one upon another, and representing male and female inflorescences (Figs. 8, 9). That thesè are flowers of Cordaitae has been directly proved by the character of the leaves in 
a female specimen, with which all the rest agree perfectly in the structure of the ovule; and that the male flowers really belong to these female flowers may be shown by means of the highly characteristic pollen-grains (Figs. $8 C, 9 C$ ), which Renault ${ }^{1}$ has discovered both in loco natali, in the loculaments of the anther, and in their place of destination, the apex of the nucellus of the ovule, and with the same characteristic appearance in both positions. Renault has figured three different male flowers, and
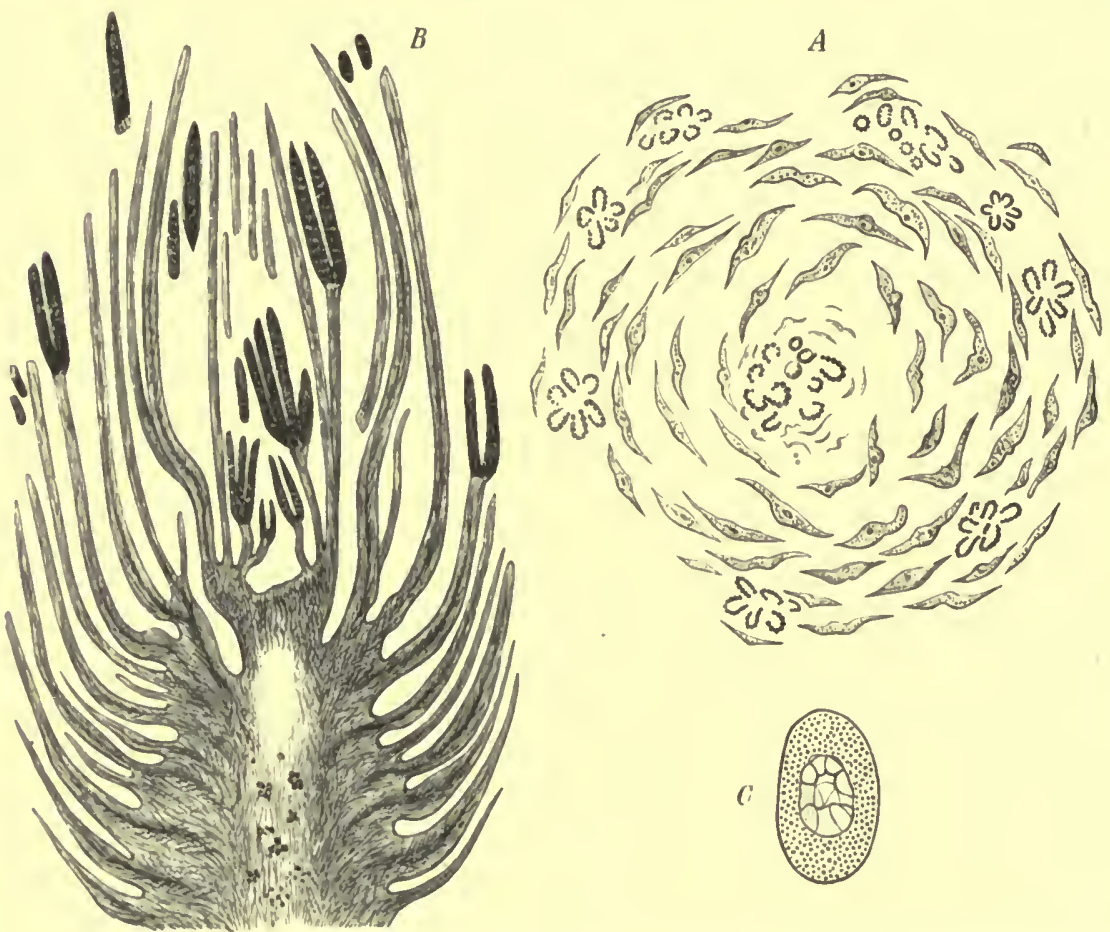

Fig. 8. Male flower of a Cordaites, after Renault 2. A transverse section. B longitudinal section of Cordaianthus penjoni, Ren., showing the elongated pollen-sacs disposed in tufts. $C$ a single pollen-grain enclosing the internal pluricellular cell-mass.

described them as Cordaianthus Penjoni, C. subglomeratus, and C. Saportanus. Thesc are the commonest species, the other and rarer kinds have yet to be published. The flower-bud of C. Penjoni consists of a tolerably thick axis closely enveloped in small narrow one-nerved spirally disposed leaves. The summit of the axis is occupied by one or two male flowers, and similar flowers, as is well shown in the transverse section ${ }^{3}$, are found scattered about among the leaves, and appear in this case to be placed in the leaf-axils. The individual flower, which is borne on a long cylindrical 
stalk, is perfectly naked, and consists of a few linear elongated cylindrical sessile erect pollen-sacs, which are attached by their base and form a tuft by their divergence. Judging by the figures of the transverse section, (Fig. 8, A) the pollen-sacs are usually five or six in number. Their walls are formed of a palisade-like cell-layer, and open by a longitudinal fissure placed on the side towards the tuft and extending down the whole length of the sac. What is here spoken of as the flower is termed by Renault the stamen; this author speaks of the flower as follows: "These flowers are extremely simple, being formed of a few stamens only, which are either scattered about in groups of two or three, or appear singly in the middle of the sterile bracts.' It is just the latter circumstance, namely that the flowers in the axils of the leaves are always reduced to a stamen of this kind, which leads me to regard each of these organs as a simple flower, and the part that bears it as a flower-stalk, not as a filament. That they are grouped together at the summit admits also of an easy explanation; the growth of the bracts may have been arrested at this spot. And all the flowers, if understood in this way, are alike in character, whereas according to Renault's view their mode of development is different in different parts of the inflorescence. Lastly, the view here taken is supported by the circumstance, that all the organs which are collected together at the apex of the shoot, while differing from one another in length and age, are arranged according to the requirements of acropetal order of development ${ }^{1}$.

The pollen-grains (Fig. 8, C) are found in the loculaments, and-occur also scattered about in great abundance in the siliceous fragments. They are ovately elliptical, their dimensions according to Renault being 0.9 and 0.5 of a millimetre. They are as a rule well preserved, evidently owing to the cuticularisation of their outer membrane, and their surface is ornamented with a fine shagreen-like reticulation. Within and adjoining the cell-wall on one side is the cell-group characteristic of Gymnosperms, which shows a remarkably high degree of development, and consists of an unusual number of thick-walled irregularly polygonal cells united together into a tissue.

Quite similar conditions are observed also in the two other species described by Renault, in which however the flowers are all crowded together at the summit of the shoot, there being none that are axillary and peripheral. Cordaianthus Saportanus moreover has a very short flowerstalk $^{2}$, and in C. subglomeratus the buds of the inflorescence are crowded together in clusters ${ }^{3}$. The figures also given by Grand' Eury may belong to this or to a similar species ${ }^{4}$. 

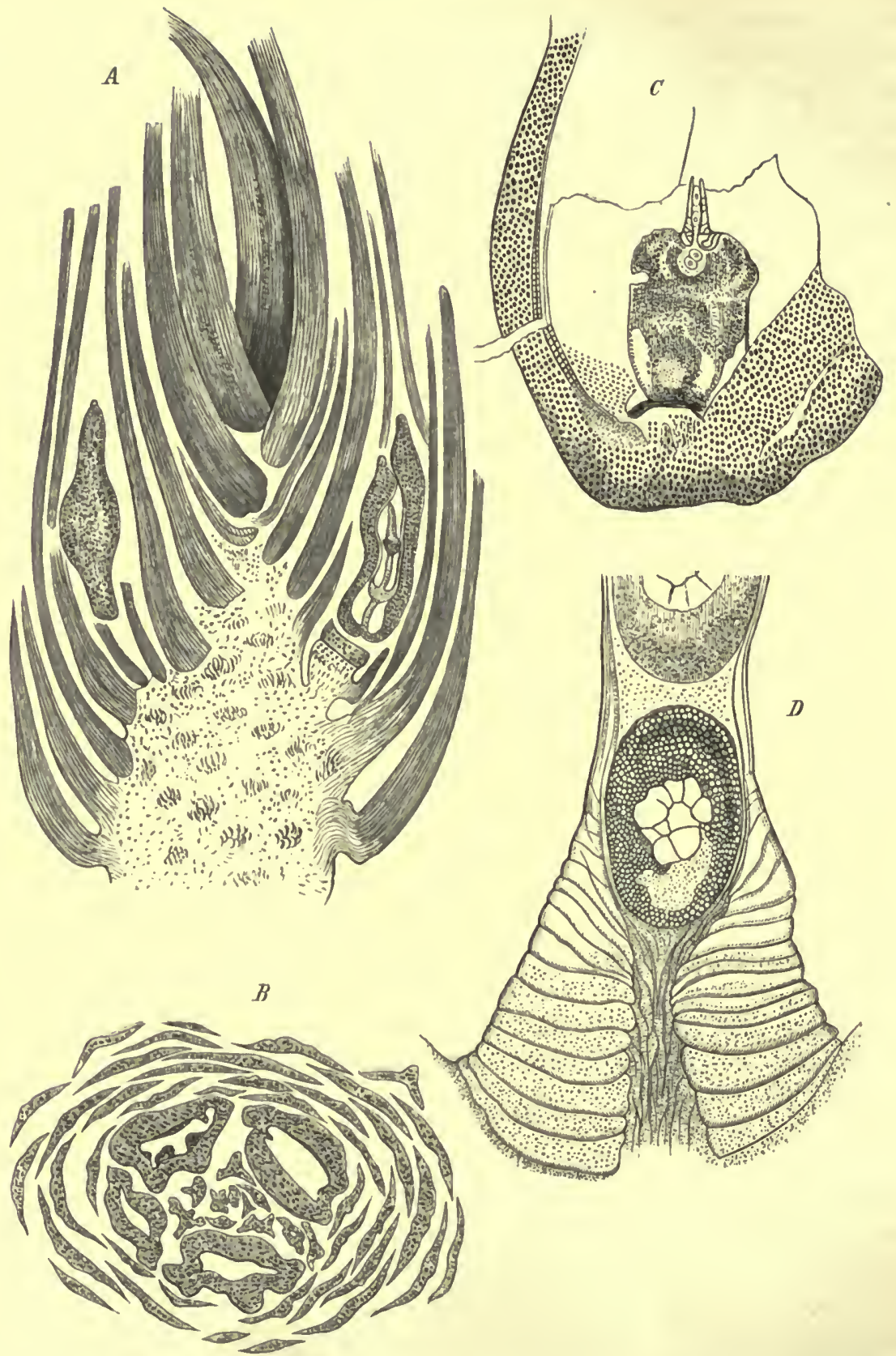

Fig, 9. Female flowers of Cordaiteae, after Renault '. A tangential section of the inflorescence of Cordaianthus William 9. Rel $B$ tanserse section of section of the ovule of Cordaianthus Grand' Euryi, Ren., with a portion of the integument and nucellus, in which there is nothing to be seen as yet of the embryo-sac; beneath the beak-like process is the pollen-chamber, and in the chamber, and in the tube which passes through the beak and gives access to the chamber, are a few pollen-grains. $D$ the beak-like process of the nucellus of the preceding figure nore highly magnified; wedged in it are the large polletı-grains with shagreened exinium and internal cell-formation. 
Four species of female Cordaianthus are described by Renault, Cordaianthus Williamsoni, C. Grand' Euryi, C. Lacattii, and C. Zeilleri. But we must combine their characters to form a general idea of the group, because we have only longitudinal sections of the first three species and only a transverse section of the last (Fig. 9, B). The figure of the fourth species ${ }^{1}$ shows us a shoot exactly resembling the male shoot, and surrounded by crowded spirally disposed leaves; four flowers in the axils of leaves are cut through in the upper portion of the shoot, and the apex is prolonged beyond the flowers and bears a tuft of stunted leaves deformed through pressure. The longitudinal sections (Fig. 9, $A)^{2}$ are all made obliquely to the axis, and therefore the longitudinal sections which they afford of the axillary flowers are sometimes more, sometimes less, exact in their direction. In Cordaianthus Williamsoni (Fig. 9, A) the apical tuft of leaves above these flowers is shown in the surface view, and the leaves have the habit of those of Cordaites. Renault states ${ }^{3}$ that the female flowers of all the Cordaitae which he has examined give off small secondary shoots, which arise in the axil of the leaf and are provided with a pair of bracteoles. The number of the leaves in the tuft is said to vary. This appears in the figures only in the case of Cordaianthus Williamsoni, where the axillary shoot lies in the exactly median plane of section, and as the short leaf exposed by it is in front (Fig. 9, $A$ ), one or two lateral leaves must have preceded it. As the axis of the inflorescence-bud is remarkablc for its unusual thickness, the axis of the flower-bearing axillary buds is also proportionally thick. The flower, which is evidently dead and on the point of falling off, is attached to the axis by a broad base, and begins with a stout envelope like an integument, which contracts into a narrow canal below and becomes wider and funnel-shaped above. The floral axis enclosed in the envelope rises in form of a thin stalk, and on the top of the stalk is the shrivelled nucellus surrounded by a broader integument, which is firmly attached to the inside of the outer envelope. The nucellus, which has a peculiarly shaped conical termination, is shrivelled and stunted; in C. Lacattii ${ }^{4}$, in which it has a similar form but is better preserved, it fills the whole of the space enclosed by the integument, and this was probably the case in the other form also. In the transverse section of the inflorescence of C. Zeilleri ${ }^{5}$, only the thick outer envelope of the flower has been preserved. The details of the structure of the nucellus have been studied by Renault from his preparation of C. Grand' Euryi (Fig. 9, C) ${ }^{6}$. The bud contaimed two axillary flowers, one of which must have been destroyed in making the section. The prolongation of the axis described above between the outer and inner envelopes is not shown. The nucellus

1 Renault (1), t. I7, f. I3.

4 Renault (1), t. 17 , f. 16.
${ }^{2}$ Renault (1), t. 17, ff. 11, 14, 16.

${ }^{3}$ Renault (1), p. 312.

${ }^{5}$ Renault (1), t. $\mathbf{1}_{7}$, f. 13. ${ }^{6}$ Renault (1), t. I7, f. I 4. 
is ovoid in form, and its rounded apex rises suddenly into a slender beaklike process, which encloses a narrow canal and has its wall formed of a single layer of large transversely broadened cells. In the apex of the nucellus exactly under the process the canal enlarges into an irregularly rounded cavity, the pollen-chamber as it has been termed, the 'chambre pollinique' of the French author. In this chamber several pollen-grains are to be seen, which exhibit the structural peculiarities known to us from the malc flower. In the conducting canal also there are two grains in excellent preservation lying one above the other and quite filling its lumen (Fig. 9, D $)^{1}$. Of the embryo-sac and its contents there is nothing to be seen. Renault has already pointed out that the flowers of Cordaitae must have been anemophilous; for unless they secreted a pollen-catching drop after the manner of Taxus, it would be impossible to imagine how the pollen-grains, which are unusually large in proportion to the breadth of the micropyle, could have found their way into the pollenchamber. I would obscrve also, that it would almost seem from the figures that the great increase in the transverse breadth of the parietal cells in the base of the beak was intended to diminish the size of the canal, and so prevent the entrance of too many pollen-grains into the pollen-chamber,an arrangement analogous with the closing of the canal of the archegonium in many Archegoniatac after the period of reception is over.

With regard to the terminology of the envelopes of the female flower, it is evident that we must set out from the principles adopted in the case of Gnetaceae, and especially in that of Ephedra; the inner envelope must in all cases be considered to be an integument, while the outer may be regarded either as the perigone, or as a second integument, according as we assent to the determinations of Eichler or of Strasburger, or even as the ovary for which Renault inclines to take it in accordance with Van Tieghem's views. The male flowers it is true are less like the male flowers of Gnetaceae, though Saporta and Marion ${ }^{2}$ have compared them with those of Gnetum. Lastly, before turning to the consideration of the ripe seeds it will be necessary to notice a view which Renault ${ }^{3}$ has formulated in the following words: 'It appears then that the pollen-grains were not yet in a condition, when they left the anther, to produce fertilisation, and that they required to remain for a longer or shorter time inside the pollen-chamber, where the cellular division commenced in the anther was completed and resulted in the maturity of the grain.' As Saporta and Marion ${ }^{4}$ have taken up this idea and applicd it to their own speculative purposes, we must briefly consider the foundations on which it rests. It is pointed out that if the pollen-grains from the anthers are compared with those

\footnotetext{
1 Renauit (1), t. 17, f. I5. et Marion (2), p. 64.

2 Saporta et Marion (2).

${ }^{3}$ Renault (1), p. 3 ro.

- Saporta
} 
in the pollen-chamber, a great and striking difference in size is at once perceived; the latter may be as much as a third larger than the others. Again, the cell-mass formed inside the grain, which was much smaller than the inner space of the grain in the anther, quite fills that space in the grains found in the chamber and its cells have increased in number. If this is indeed the general rule, the assumption of a subsequent further development of the kind described above can scarcely be avoided. The objection, that the pollen in the chamber is different from the pollen in the anther, the two organs having belonged to two different species, would explain the difference in size but leaves us still in a difficulty; for in that case we should expect to meet with the pollen of the chamber also lying freely about in the pebbles, which does not appear to be the case. But now that we know that the pollen-tube in recent Gymnosperms does not proceed from the internal cell-mass, the comparison of the process of development in the two cases must at present be regarded as altogether obscure and doubtful.

It has already been incidentally remarked that casts of very various form, named carpoliths, are objects of common occurrence in the Coalmeasures. These fossils would however be perfectly worthless from the botanical point of view, if they were not also found in a silicified state in the pebbles of Grand' Croix and in the carbonaceous nodules in seams of coal. For that in all these cases we are dealing with the same remains must be evident from their identity of form and from their mutual association, especially when it is considered that the materials which have come down to us, sometimes in the form of coal, sometimes as impressions between slates, sometimes in a silicified or calcified condition, are all alike vegetable remains from ground once covered by forests. We are indebted for searching investigation into the remains of fructifications represented by the carpoliths to Hooker and Binney ${ }^{1}$, and Williamson ${ }^{2}$, and above all to the prolonged researches of $\mathrm{A}$. Brongniart ${ }^{3}$. Now that all the various seeds which have been examined have proved without exception to be seeds of Gymnosperms, we may with great probability assume that all carpoliths from the Coal-measures are remains of Gymnosperms. But since the Cordaiteae are now acknowledged to be a highly differentiated division of the series of Gymnosperms, it is equally probable that many of the carpoliths, which are found moreover in the same deposits with Cordaiteae, are also remains of these plants. Impressions of carpoliths have in several cases been found in connection with those of leafy branches, but this point will be noticed again at greater length at the end of this chapter. Other carpoliths again may be seeds of Conifers or Cycads, or may even prove to belong to

\footnotetext{
${ }^{1}$ Hooker and Binney (1). $\quad{ }^{2}$ Williamson (1), vill. $\quad{ }^{3}$ Brongniart (6).
} 
Gnetaceae or to some other groups of Gymnosperms not yet sufficiently recognised and defined. But since it is not possible at present to distinguish these remains according to their origin, we must be content here with some general remarks upon the whole group.

All the sceds studied by Brongniart were formed from orthotropous ovulcs, and, as has been already said, are of essentially the same structure, whatever difference there may be in details. They are inclosed in a wellprescrved and often very thick testa, which is in some cases homogeneous and lignificd, but in many others has an outer fleshily succulent layer like that in the sceds of Ginkgo. The happily chosen terms sarcotesta and cndotesta have been applicd to the two layers. Where the testa appears to be formed of one layer only, it is not indeed always certain that there was not originally a sarcotesta which was destroyed before petrifaction; even in the casts known as Rhabdocarpus traces of impressions have occasionally been seen, which suggest the former cxistence of such a layer ${ }^{1}$. From ripe secds not well preserved in all their parts it is obvious that we cannot always be sure of the number of the integuments in the ovule. The nucellus lies in almost all cases immediately inside the testa; Pachytesta, Brongn., is the only species in which the apcx of the nucellus is enveloped in a distinctly discernible innermost integument ${ }^{2}$. In other forms such differcntiations, though they may possibly have been in existence at the period of flowering, can no longer be perceived. In many cases the nuccllus is quite destroyed, or its outer boundary only is preserved in the form of a fine line; in its place there is usually a cavity, the wall of which is lined with crystals of quartz. In the best state of preservation the tissue of the nuccllus has disappeared up to the outermost boundary line, but the embryosac with the endosperm inclosed in it is plainly seen. The egg-cells appear in the convexity of the upper end of the endosperm, separated by some distance from each other, as is usual in Cycadeac, and generally distinguished by their shrunken brown contents. Cardiocarpus sclerotesta, C. augustodunensis and Taxospermum Gruneri supply good examples of these phenomena (Fig. 10). The structure of the apex of the nucellus is highly characteristic in all the forms; its tissue seems to have possessed greater power of resistance, and is seen usually in a good state of preservation on the top of the bounding line which indicates the nucellus. It forms a conical projection, and is pierced by a canal which widens below into a pollen-chamber in some cases (Stephanospermum akenioides, Fig. $10, A c$ ) of considerable dimensions, and usually containing numerous pollen-grains. The structure agrees thoroughly in all these points with that of the female flowers of Cordaiteae described above. The course of the vascular bundle in the seeds follows closely that which is customary in Cycadeae. The single bundle ter- 
minates in the base of the nucellus, where its elements spread out in a radiating manner, but it previously gives off lateral branches, usually two in number, which traverse the testa till they nearly reach the micropyle. It may seem strange that the egg-cells have been observed in the substance of the endosperm, but not a developed embryo, though this has been seen in Bennettites. The probable explanation is, that in these forms the development of the embryo proceeds slowly, as is the case at the present day with Ceratozamia, Ginkgo, and Gnetum,

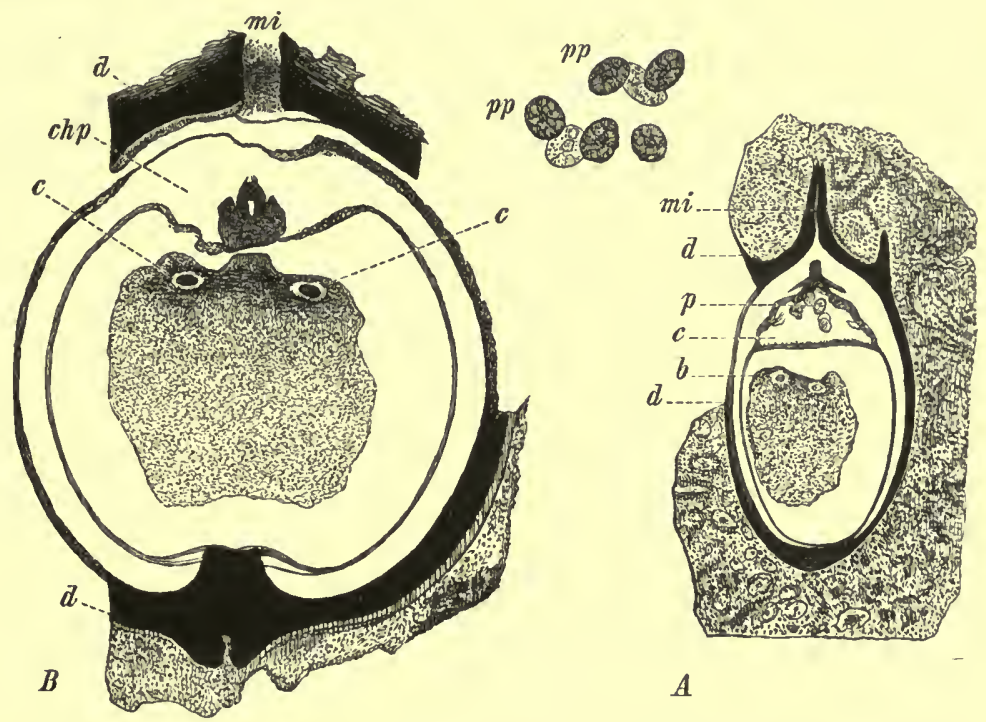

FiG. 10. Seeds of Gymnosperms from the Coal-measures. $A$ magnified longitudinal section of Stephanospermum akenioides, Brongn.; $d$ endotesta ; $b$ endosperm with two archegonia; $c$ pollen-chamber; $p$ pollen-grains in the chamber whicb are seen more highly magnified at $\not p, \not p ; m i$ micropylar end of the seed. $B$ slightly magnified longitudinal section of Cardiocarpus। sclerotesta, Brongn.; $d$ endotesta : mi micropyle; $c$ endosperm with archegonia ; chp upper terminal portion of the membrane bounding the nucellus with the pollen-chamber in it. After Saporta and Marion 1 .

Brongniart ${ }^{2}$ has distributed the seeds which he has examined among different genera according to their general form and the structure of the testa. Of these, Cardiocarpus, Rhabdocarpus, Diplotesta, Sarcotaxus, Taxospermum and Leptocaryon are flat seeds, and they are especially the forms which Renault thinks belonged to Cordaitae. The transverse section of Stephanospermum and Aetheotesta is simply circular. The former genus is distinguished by the extraordinary size of its pollen-chamber, and its testa has a winged border forming a collar round the micropylar end of the seed. In all the rest the transverse section shows three, six or eight edges of wings. In Trigonocarpus there are three flat edges, and the testa is fissured in the edges. Hexapterospermum, Polypterospermum and Polylophospermum have six simple winged edges; Ptycho- 
testa has six wing-like duplications of the testa. The seeds of Eriotesta and Codonospermum have eight of these marginal projections. Eriotesta is further distinguished by the nature of the surface of the testa, which is entirely covered with close-set hair-like fibres swelling into a knob at the apex. But the most remarkable form is seen in Codonospermum. The seed, which is depressed in the direction of the axis and has flat edges, has a wing like a circular collar on the margin of the flat basal surface, and in the same manner the entering vascular bundle is enclosed for some distance in a tube-like process of the testa.

I do not venture to decide how far the genera described by Williamson ${ }^{1}$ coincide with those of Brongniart, though from the details of their internal structure they may all be supposed to belong to the same group. They are described under the names Cardiocarpon, Trigonocarpon, Malacotesta, Lagenostoma, and Conostoma. Williamson agrees with Brongniart in speaking of the boundary-line of the nucellus in all cases as the 'nucular membranc,' and of the boundary of the embryo-sac as the 'perispermic membranc.' In some forms, Lagenostoma for example, in which the apex of the nucellus in the region of the pollen-chamber is split into two tissuelayers, the outer of these which is plicately sinuous is termed the 'canopy.' The sced described by Hooker and Binncy ${ }^{2}$ has been again found by Williamson and figured as Trigonocarpon olivacforme. In the transverse section it shows the character of Tripterospermum, Brongn., but with the difference that it has three slightly raised secondary ribs on each of the surfaces between the three wing-like projections. The beak-like apex which is pierced by the micropylar canal is formed entircly of the hard layer of the testa. It is a question whether the casts described by $\mathrm{Heer}^{3}$ as Rhynchogonium do not belong to this form. The genus Malacutesta, of which only one secd has been examined, scems to have had a single fleshy membranc and no hard endotesta.

Lastly, Dawson ${ }^{4}$ has sought to class with Brongniart's genus Aetheotesta certain fossils which have bcen found in England in the Upper Llandovery and Ludlow beds and in the Devonian formation of New Brunswick. These were first described and named Pachytheca by Hooker ${ }^{5}$, who inclined to regard them as fructifications of Lycopodinae. But they have nothing whatever to do with Aetheotesta or with any seed of Gymnosperms, as I have learnt from examination of specimens and sections, and therefore we cannot with Dawson appeal to them to show that Nematophycus Logani, which occurs with them, is a Conifer. They are small spheroidal smooth bodics of an intense chestnut-brown colour and of different sizes; they are hollow in the centre, and the thick wall of the cavity

1 Williamson (1), vin. ${ }^{2}$ Hooker and Binney (1). ${ }^{3}$ Heer (5), vol. 41, t. 5. "Dawson (1), p. 108 ; also (3) and (4), p. $306 . \quad{ }^{5}$ Hooker (2); see also Etheridge in Hicks (1). 
shows a radial structure. I have had the opportunity of seeing sections of the best-preserved specimens in the Jermyn Street Museum and from Thiselton Dyer, but I do not venture to express any opinion respecting their place in the system; the truth is that I entertain some doubts as to the vegetable nature of these remains. The fossils which J. M. Clarke ${ }^{1}$ has recently described from the Devonian formation of $\mathrm{N}$. America under the names Sporangites Huronensis, Daws., and S. (Protosalvinia) bilobata, Daws., appear to be similar objects. In the latter form several of the small bodies just described lie in a sac-like common cnvelope.

Hitherto we have considered only those flowers and seeds of Cordaiteac and any other gymnospermous forms, in which the structure can be made out with certainty in the petrified remains. But it has more than once been remarked that the same and similar remains are often found in the Coal-measures in the form of impressions, and that these have long been described in the literature under a great variety of names. We must then return to these forms in concluding the present chapter, and we may mention first a number of cases in which inflorescences have been found still attached to the branches of Cordaitae which bore them; their diversity of appearance supplies further ground for the view which has been already expressed, that the group was composed of a great variety of species, and that we can at present only form a conjecture or general idea of the differences which were developed in it, but are very far from having any real knowledge of them. A number of figures of these forms will be found in Grand' Eury ${ }^{2}$. Slender branchlets are attached laterally to portions of leafy branches, and bear in the axils of short scale-leaves clusters either of naked ovules or of small evidently male buds enclosed in scales. In one of the specimens figured ${ }^{3}$ the two kinds of lateral shoots stand side by side, which would show that this species of Cordaiteae was monoecious, provided there has been no reconstruction; but on this point I am left still in doubt. It seems a remarkable fact that all these specimens show the flowering branches in definite relation to the leaves, but at the same time so much raised above and out of their axils, that we may doubt whether they ought to be called axillary shoots. That there were differences as regards the position of the inflorescence in different forms is shown by one figure ${ }^{4}$, in which the male buds are not disposed in clusters on lateral branches, but occupy the summits of elongated branchlets which are placed in a tuft on the end of the shoot. That there were differences also in the foliation of the flowering branches is seen directly by comparing the impressions of which we are speaking with Renault's section-preparations, in which we found that the flowers, few in number, were actually immersed among strongly developed

\footnotetext{
${ }^{1}$ Clarke (1). $\quad{ }^{2}$ Grand' Eury (1), t. 21, f. 8; t. 25 , ff. 1, 3. $\quad{ }^{3}$ Grand' Eury (1), t. 25, f. 3. Grand' Eury (1), t. 21, f. 5 .
} 
leaves. The figure of Poacordaites linearis, Grand' Eury in the text of Weiss' book ${ }^{1}$ shows essentially the same condition of things as the figures in Grand' Eury; the few attached flowering branches bear male inflorescences, and are marked by the small number of their lateral flowerbuds and by the unequal length of the internodes developed between them. Lesquercux $^{2}$ also has figured a branch which resembles those of Grand' Eury. Similar objects are extremely abundant, as may be supposed, in the loose state, that is, not attached to the branches which bore them, and the literature is full of illustrations of them. Grand' Eury ${ }^{3}$ has figured a large number of these remains, among them male inflorescences which are remarkable for the length of the bract-scale which supports the flower-bud ${ }^{4}$. This same form has been already described by Ettingshausen ${ }^{5}$ from the Coal-measures of Stradonitz in Bohemia under the name of Calamites Volkmanni, Ett. Examples will be found also in Göppert ${ }^{6}$, Weiss ${ }^{7}$, Lesquercux ${ }^{8}$ and Dawson ${ }^{9}$; lastly, Schimper ${ }^{10}$ gives figures of many of these forms, and also reproductions of the more abnormal inflorescences, whi h have been described by Carruthers ${ }^{11}$ under the names of Antholithus anomalus and A. Lindleyi and are figured in Balfour ${ }^{12}$. In these the axis bears lateral clusters of compressed heart-shaped seeds on long stalks and begirt with a wing-like membrane which is emarginate at base and apex. In the places mentioned and in almost every work which describes any number of coal-plants figures will be found of countless casts of secds, but as they have no importance to the botanist the reader is referred for an account of them to Schimper's work ${ }^{13}$.

\footnotetext{
1 Weiss (1). See also above, p. $108 . \quad{ }^{2}$ Lesquercux (1), t. 76. $\quad{ }^{3}$ Grand' Eury (1), t. 26. ' Grand' Eury (1), t. 26, f. 7. ${ }^{3}$ von Ettingshausen (3), t. 5. 'Göppert (3), t. 21. ${ }^{7}$ Weiss (1), t. $28 . \quad$ "Lesquereux (1), t. 109, and (2), t. 3. 'Dawson (1) and (2). ${ }^{10}$ Schimper (1), t. $110 . \quad$ "Carruthers (6). "Balfour (1), pp. $65,66 . \quad{ }^{13}$ Schimper (1).
} 
VI.

DOLEROPHYLLUM, CANNOPHYLLITES, EPHEDRITES, GNETOPSIS, SCHÜTZIA, DICTYOTHALAMUS, CALATHIOPS.

IN the present chapter we shall consider a few gymnospermous types which are still imperfectly known and which seem to have little or no relation to one another.

The first to be noticed is the new and still very problematical genus Dolerophyllum, Sap., which might very properly have been discussed in connection with other forms, and to which I allow so much prominence only because Saporta and Marion ${ }^{1}$ treat it as quite securely established, and make use of it for the most extravagant speculations. It is founded on some peculiar bud-like objects long since known in a silicified state from the Permian formation of Eastern Russia, which were named by Eichwald ${ }^{2}$ Nöggerathia Göpperti, and were till quite recently compared by Göppert ${ }^{3}$ with inflorescence-buds of Musaceae ${ }^{4}$. Good figures of them are to be found in the authors last named and in Saporta and Marion ${ }^{5}$. The stout ovoid buds with a somewhat acute apex are formed of large probably spirally disposed leaves, which follow closely upon and are rolled round one another in the form of a sheath, and are traversed by numerous nerves which run everywhere at right angles to the margin, and here and there are forked. Göppert believed that he recognised on the cross fracture of these convolute leaves a row of longitudinal air-passages, such as are often found in Scitamineae; but the result of Renault's investigations into the anatomy of a specimen of this kind from the Ural is to show that this depends entirely 'on the state of preservation, for the transverse section figured by Saporta and Marion ${ }^{6}$ from Renault's drawings proves that the leaf is everywhere formed by uniform thin-walled parenchyma, within which the bundles lie surrounded by parenchymatous sheaths. On the under side of each bundle is a longitudinal row of large cells, which are declared by the French authors to be gum-receptacles. The bundle itself is of peculiar construction; Saporta and Marion ${ }^{7}$ say of it: 'it exhibits the duplicated

\footnotetext{
1 Saporta et Marion (2). $\quad{ }^{2}$ Eichwald (1), vol. i, t. I8, ff. 1-3. $\quad{ }^{3}$ Göppert (3), t. 62, ff. I-6.

1 Göppert (6).

${ }^{3}$ Saporta et Marion (2), p. $7 \mathrm{I}$.

${ }^{6}$ Saporta et Marion (2), p. 73 .

7 Saporta et Marion (2).
} 
construction which is constantly observed in the stems described above, and which is found in no existing Phancrogams except the Cycadcae.' Judging from the figure I should say that the resemblance to the bundles in Cycadeae is not too striking; the bundle approximates on the transverse section to the form of a five-rayed star with the initial strand lying in the centrc, and is surrounded by small-celled delicately walled tissue which may be supposed to be bast. The three under rays of the woody strand are connected together, and will of course have been regarded as the 'centrifugal $x y l \mathrm{~cm}$,' the upper rays which are separated by small intervals being the 'centripctal xylem.' The cpidermis of the under side is composed of palisade-like cells with thin conically convex outer walls. On the upper side the cells are shallow, but their outer wall is very much thickencd and is prolonged over each cell into a thorn-like process. We have already observed a similar state of things in Cordaitae. In other respects the vascular bundles are so imperfectly preserved, as I have been able through Renault's kindness to satisfy myself by inspection of the original preparations, that every definite statement about them must be taken with caution.

With these buds then Saporta ${ }^{1}$ and Marion ${ }^{2}$ associate ccrtain round cntire leaves with a cordate base and auricles often overlapping one another, which have the nervation of the leaves of the buds described above (Nervatio Cyclopteridis); these leaves have been repeatedly found at St. Eticnne by Grand' Eury, and are attached, almost at a right angle as it would appear, to small portions of branches which are in some cases preserved at their base or appear in the cross fracture. Together with other remains they form the Doleropteridae of Grand' Eury ${ }^{3}$, and are figured in a reduced but still recognisable form as Doleropteris pscudopeltata, Grand' Eury ${ }^{4}$. Saporta's name is connected with Grand' Eury's nomenclature. These leaves do in fact agree very well in habit with the convolute leaves of the buds before described; still Saporta and Marion may be going too far, unless they are in possession of proofs not yet given to the world, when they maintain: "It is certain that the leaves and consequently the branches which they covered became detached at some time or other from large conical buds,' \&c. Nöggcrathia Cyclopteroides, Göpp. ${ }^{5}$, is the only form cited from the older literature as belonging to the leaves of Dolerophyllum, but Grand' Eury had already connected these with various species of the fern-gencra Cyclopteris and Nephropteris as defined by Brongniart ${ }^{6}$. Like Brongniart and Schimper ${ }^{7}$, Grand' Eury inclines moreover to regard all these objects as anomalous pinnae of the leaf-axes of Ferns, the so-called Aphlebiae (see the chapter on Ferns), which are certainly not unlike them

\footnotetext{
1 de Saporta (11).

${ }^{2}$ Marion (2), p. 7o.

s Grand' Eury (1).

t. 16 , f. I $\mathrm{E}$.

3 Göppert (3), t. 2 I, f. 4 .

- Brongniart (2), p. 65 .

‘ Grand' Eury (1),

${ }^{7}$ Schimper (1).
} 
in form ${ }^{1}$. But some of these remains also show the most decided resemblance to the leaves figured by Saporta and classed with Dolerophyllum and especially the point of transverse fracture of the stem is often to be seen in the angle of insertion. In fact this resemblance is much greater than in the case of Nöggerathia Cyclopteroides, Göpp., of which only one leaf is known in a rather fragmentary condition. Any one may satisfy himself on this point by comparing Saporta's figures cited above with the following: Cyclopteris obliqua, Brongn. ${ }^{2}$, C. reniformis, Brongn. ${ }^{3}$, C. obliqua, Brongn.. ${ }^{4}$, C. dilatata, Lindley and Hutt. ${ }^{5}$, C. obliqua, Brongn. ${ }^{6}$, C. rarinervia, Göpp. ${ }^{7}$ All these remains from the Coal-measures, which have hitherto been regarded as extremely doubtful objects, would have their position secured to a welcome extent, if further investigation were to establish Saporta's conception of Dolerophyllae. Renault indeed has told me in conversation that he would place a part only of these Cyclopteridae with Dolerophyllum, and leave the others with the Ferns. He lays great weight with respect to this question on the presence of the gum-receptacles in Dolerophyllum (see above on p. 123), which he thinks he has recognised in certain impressions of Cyclopteris in the form of small longitudinal unevennesses like pencilstrokes between the nerves of the leaf-surface. To me it seems that Renault sees more in the sculpture of the impression than can be admitted without further proof. Again, a portion of a branch with large roundish leaf-scars is figured in the work of Saporta and Marion ${ }^{8}$, so often quoted above, and the explanation of the figure says of it : 'supposed stem of Dolerophylleae.' Why it should belong to that group is not apparent, especially since the shape of its scars is difficult to reconcile with the bases of the leaves in question. The same remark applies to the fragments of male and female flowers referred by these authors to Dolerophyllae. Impressions of single scutiform scales with excentric stalks ${ }^{9}$ have been found in the Upper Coalmeasures of Mt. Pelé near Épinac, showing on their under side numerous small elliptical depressions disposed in radiating rows and filled with a powdery substance which was seen to be pollen-grains; they were therefore compared with stamens of Cycadeae. Their structure was ascertained by the discovery of a silicified fragment, in which the pollen-sacs in the form of elongated cylindrical tubes with their contents well preserved were found sunk in the tissue of the scale. The pollen-grains according to the drawing given of them are ovoid and furnished on one side with two furrows close to one another, and their interior is entirely filled with a cellular body composed of large irregularly disposed elements. The original specimens, which

1 Lesquereux (1), t. 15, f. 3 .

${ }^{6}$ Göppert (1), tt. 4 and 5 , f. I.

9 Saporta et Marion (2), p. 75 .
2 Brongniart (1), vol. i, t. 61, f. 3. ${ }^{3}$ Brongniart (1), vol. i, 5 Lindley and Hutton (1), vol. ii, t. 916 .

${ }^{7}$ Göppert (3), t. 8, f. 9. $\quad$ S Saporta et Marion (2), p. 69. 
Renault was good enough to demonstrate to me, have convinced me that we have here to do with correctly described and highly remarkable remains. At the same time also it is the opinion of this author that no surer grounds can be obtained at present for the determination of the plant to which they belong, and the lively imagination of Saporta and Marion ${ }^{1}$ is required to enable us to conceive how they can write as follows: 'we see the close connection between the Dolerophylleae and the progymnospermic stage, but this connection appears still closer when we examine the reproductive organs of these plants, which thanks to the perspicacity of M. Renault and the researches of M. Grand' Eury may be considered to be sufficiently well known.' Then the remains of the femalc flower, which offer but little that is characteristic, are figured on page 76 . A roundish scale-like leaf, destroyed by maceration on one side up to the vascular bundles, is supposed to have borne in a depression on the middle line near the base an ovoid seed pointed at the upper end and showing striae-like fibres on the outside. Sced and leaf are figured but not in connection with one another, and the point of insertion on the leaf is not to be recognised. Saporta himself, who, as has been often shown, is not too particular about proofs of connection, is induced on this occasion to make the following remark: "We give a figure of this curious organ, though it is still of somewhat doubtful character.' All this shows how little certainty there is at present with regard to the genus Dolerophyllum. The anatomy of the leaf is as yet the only thing that can be made use of to determine its position and affinitics, and it seems to me to be very doubtful whether we are justified on this ground only in introducing it into the alliance of Cordaitac and Gymnosperms.

On occasion of discussing their Progymnosperms Saporta and Marion ${ }^{2}$ write as follows: 'Near the Dolerophylleae we should place a less-known but perhaps still more curious type, that of the Cannophylliteae of Brongniart (Megalopteris, Daws.). The Cannophylliteac appear to be to the Dolerophylleae what the modern Stangeriac are to other Cycadeae.' Then portions of a leaf of Cannophyllites Virleti, Brongn. ${ }^{3}$, are represented on page $79^{4}$. These fragments appear to me, notwithstanding the assertions just quoted, to be ordinary remains of fern-leaves with the nervation of Neuroptcris, and Megalopteris Dawsoni, Hartt., from the Devonian beds of New Brunswick, figured by Dawson ${ }^{5}$, may very well belong to the same group. Both Dawson and Lesquereux ${ }^{6}$ consider these remains to be nothing more than leaves of Ferns.

No remains of the class of Gnetaceae have yet been determined with perfect certainty. Fragments of variously striated branches of Tertiary

1 Saporta et Marion (2), p. 74 .

- Saporta et Marion (2), p. 79.
${ }^{2}$ Saporta et Marion (2), p. 77.

${ }^{3}$ Dawson (1), t. I 7 .
3 Brongniart (7), p. I29.

- Lesquereux (1), t. 24. 
origin have been described as Ephedrites, but they show little or nothing characteristic. The fructifications also from the Jurassic deposits of Siberia, which Hēer ${ }^{1}$ assigns to his Ephedrites antiquus, are more than doubtful. Schenk's ${ }^{2}$ excellent critical remarks on this subject should be consulted. Renault ${ }^{3}$ speaks of some of the seeds from the Coal-measures which were noticed in the last chapter in connection with Cordaiteae, namely Samaropsis, Cardiocarpus orbicularis, Brongn., and Stephanospermum, as doubtful remains of Gnetaceae. In his explanation of the plate in Brongniart ${ }^{4}$ he gives the following reason for his opinion as regards that form: "This seed is surrounded by two envelopes which appear to be independent of one another and not intimately connected together like the endotesta and sarcotesta in other seeds of the group of Cardiocarpeae; it reminds us in this respect of certain seeds of Gnataceae, of Gnetum Thoa, for example, and Gnetum urens. Since then there is a piece of the inner integument evidently remaining, we should in fact have three envelopes before us, as in Gnetum; but it is confessedly very hazardous to conclude the number and character of the integuments from the structure of the envelopes of the seed, especially where, as in this case, the division between sarcotesta and endotesta may very easily have been a consequence of maceration of the seed.

Lastly, the same author ${ }^{5}$ describes as Gnetopsis elliptica certain fructifications which he has discovered in the pebbles from the Upper Coalmeasures of Grand' Croix. In Saporta and Marion ${ }^{6}$, where these fossils are figured for the first time from Renault's drawings, the genus is placed next to Ephedra. Then two more species were added to the genus, Gnetopsis trigona and G. hexagona, Ren. and Zeill., forms found only as impressions in the carboniferous mountain-district of Commentry. The remains of the flower of Gnetopsis elliptica are of complicated structure. The transverse section (Fig. I I, D) shows two distinct opposite bract-like leaf-forms with curved surfaces, which are traversed by numerous parallel vascular bundles of normal structure and normal arrangement, and are covered on the inner side with long close-set hairs which fill the hollow of the leaf. These leaves divide above, as we learn from successive transverse sections, into an uneven number of apices, each of which is supposed by Renault to have a vascular bundle corresponding to it. Between the hairs which fill the inner space are seen the transverse sections of several ovules, the normal number being four, so that there are two to the space enclosed by each of the two enveloping leaves. Since the two pairs of ovules are not inserted at the same level on the summmit of the axis, they are seen at different heights on the transverse section. Further irregularities often occur, the number of de-

\footnotetext{
1 Heer (5), vol. 4II, t. I4. ${ }^{2}$ Zittel (1), p. 354.

(6), t. 7. $\quad 3$ Renault (2), vol. iv, tt. 20, 2 I, 22.

s Renault (2), vol. iv. - Brongniart - Saporta et Marion (2), p. 181.
} 
veloped ovules being sometimes reduced to two or even to one only. The longitudinal section (Fig. $1 \mathrm{I}, A, B)^{1}$ shows the summit of the obliquely ascending axis expanded into a flat surface between the two leaves, and the sessile ovules of the one leaf-axil inserted considerably higher up than those of the other; it also makes us acquainted with their structural details. The nucellus is surrounded by a single integument only, which is formed of a few cell-layers but becomes thicker at the apex, and shows
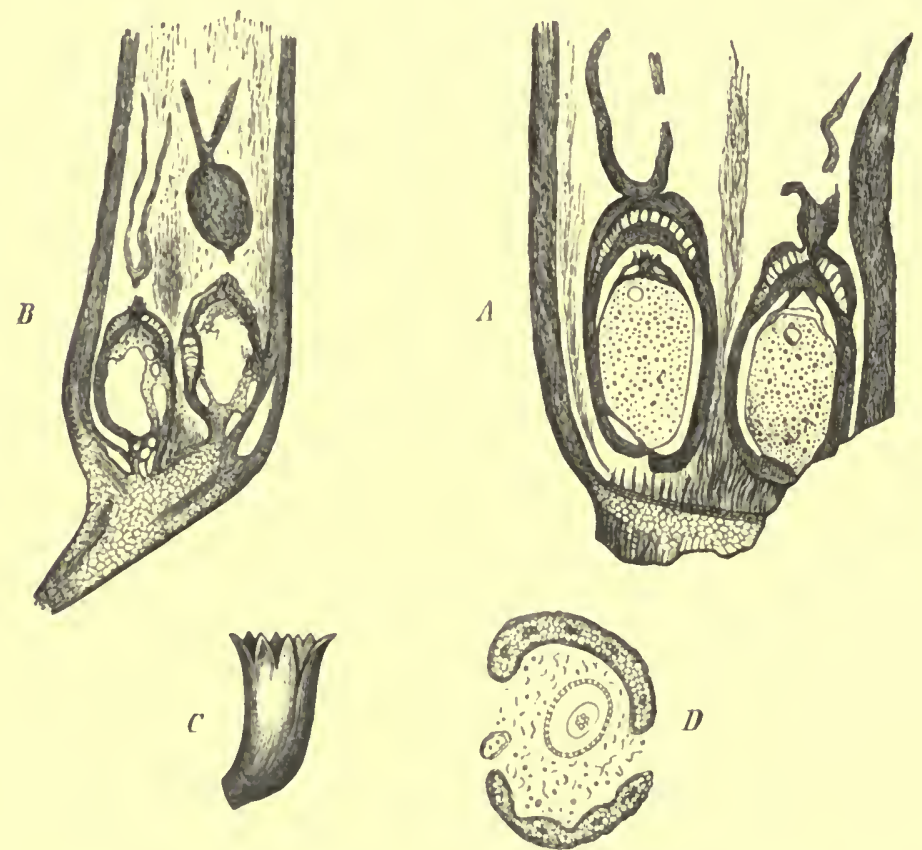

Fic. 11. Female fowers of Gnetopsis elliptica, Ren. $A$ and $B$ longitudinal sections showing the envelope which incloses several ovules. $C$ diagrammatic representation of the closed envelope, $D$ transverse section of the same showing an ovule and the sections of the numerous hairs in the form of dots. $A$ and $B$ after Saporta and Marion", $C$ and $D$ after Renault $"$.

important complications which must be noticed again presently. The apex of the nucellus encloses a broad pollen-chamber, in which are found globular pollen-grains quite filled with the interior cellular body. The embryo-sac is large and broad, and at its upper end are at least two archegonia; the endosperm in the sac is extremely well preserved. A vascular bundle enters at the base of each ovule and splits into four branches, which were seen in a transverse section by Renault ${ }^{4}$ running far up in the ovule and lying free between the remains of the integument and those of the nucellus. 
The tissue surrounding it was destroyed; it could not therefore be determined with perfect certainty in which of the two parts its course lay. That portion of the integument which encloses the apex of the nucellus behaves in a very peculiar manner, and may be compared perhaps with Lagenostoma, Will. (see above on p. I20). It attains a considerable thickness and separates into a compact outer lamina (canopy ?) and a similar inner lamina, while the cell-layer between the two is formed of extended filaments, which represent so many cells and traverse a broad intercellular space at some distance from each other. This looser tissue ceases of course at the micropylar canal, where the outer and inner layer are in connection with one another. The margin also of the orifice of the micropyle is formed of a cup-shaped expansion, which is seen to be drawn out at two points into long filiform appendages (Fig. I I $A, B$ ). It is certainly possible, as Renault thinks, that the loose open tissue surrounding the micropyle may have served as a swimming-apparatus and the long filaments attached to it as organs of flight, and that these seeds therefore were adapted at once for transport through the air and through the water; but we cannot grant more than this. There seems to be much better foundation for his view, that the drop of moisture excreted for the reception of the pollen-dust was caught between the two long cilia, which served therefore as conducting organs in the process of pollination. Organs of this kind must in fact have been a necessity in the case of flowers buried among close-set woolly hairs and overtopped by them.

From the account here given it would certainly be impossible to guess the reasons which have led Renault to place this genus among Gnetaceae. But these reasons appear at once when we employ his terminology, and say for example with Saporta and Marion ${ }^{1}$ : 'the chief difference (between Gnetopsis and Ephedra) is that the involucre or exterior pseudo-ovarian integument encloses four ovules seated on a receptacular cushion, instead of only one.' That is to say, that the leaves which were just now termed bracts must be explained to be imperfectly closing carpels, and are to be compared in accordance with van Tieghem's ideas with the outer covering of the ovule of Ephedra and Gnetum. We may certainly incline to this view from van Tieghem's stand-point, but even this does not compel us to adopt it, as will appear on referring to the artificial interpretation of the female flower of Taxus given by that author. It follows that if the assigning our genus to Gnetaceae really rests on a petitio principii, we can only properly say that it is a form of Gymnosperm, but that its affinities and relations require further investigation.

In conclusion, we must mention here a number of remains of fructifi-

- Saporta et Marion (2), p. I8I. 
cations from the Coal-measures known only in impressions and of an entirely doubtful character. The name Schützia anomala, Gein., is given by Geinitz ${ }^{1}$ and Göppert ${ }^{2}$ to certain racemose inflorescences, in which a short lateral stalk has the appearance of being enclosed in basket-like involucres which conceal the seeds. There is perhaps a certain similarity of habit between these forms and Gnetopsis. It is scarcely possible to gather more than this from the ill-preserved impressions. The remains of another fossil flower, named by Göppert Dictyothalamus Schrollianus, is found at Braunau in Bohemia and at Neurode in Silesia on the same laminae of clay-slate with Schützia. This plant has the habit of Schützia, but the lateral axes bear roundish clusters of small cylindrical bodies without an envelope. It seems natural to consider these objects as male inforcscences, and Göppert and Schimper also and Schenk are of opinion that they may belong to Schützia. Lastly, panicled inflorescences from the Culm of Rothwaltersdorf have been described by Göppert ${ }^{3}$ under the generic name Calathiops, but I can make out no further details from the figure representing them. I have been unwilling to leave these forms unmentioned, though we shall certainly not arrive at a clear understanding of them till they have been discovered in the petrified state; for the present it is useless to speculate on their affinitics. There is no need therefore to examine Nathorst's ${ }^{4}$ view that they are Balanophoreae.

\footnotetext{
1 Geinitz (3). ${ }^{2}$ Göppert (3), tt. 23, 24. 'Göppert (3), t. 64. ' Nathorst (5).
} 


\section{VII.}

\section{FILICES.}

THE Ferns are known to belong to some of the oldest living vegetable types. So far as it is possible to judge of the character of the general vegetation at any given time from the remains preserved to us in the fossil state, we see them continually increasing in the number of individuals and species from the most recent formations backwards to the Carboniferous period. The Devonian beds also are rich in beautiful and well-characterised Ferns. On the other hand, there seems to be no satisfactory example of this group of plants from Silurian deposits, for Eopteris Morieri described by Saporta ${ }^{1}$ from the Middle Silurian roofing-slates of Angers, of which I have seen fine specimens in the collection of the Royal Bergakademie at Berlin, is certainly of inorganic origin, being formed of dendritic deposits of iron pyrites. The midrib of the apparent Fern-leaf is the infiltration-canal ; the pinnulae, which are very dissimilar in size and form, show crystalline structure, and this was mistaken for the nervation of the leaf.

The stems, leaf-stalks and leaves of Ferns are almost always found separate from one another and in a more or less fragmentary condition, and this is especially the case with the many known large and copiously branched leaf-forms, of which we only now and then see fine entire specimens. Isolated pinnules are all that occur of some forms; it may be concluded from this that they separated regularly from their axes, resembling in this respect many of our living Ferns, Marattia, for example, Didymochlaena, Nephrolepis and others. It is wonderful to find in the clay-slates of the Coal-formation such numbers of impressions of quite young leaves in the bud-state. These are recorded in palaeontological works under the generic name of Spiropteris. Leaf-stalks and fragments of leaf-stalks also are constantly occurring, more particularly and in unusual abundance in the Coal-measures, and they are readily recognised on refuseheaps in coal-mines by their glistening black surface which is rough with small irregularly disposed hairs. In this condition they are, botanically 
speaking, of no value; the contrary is the case when they are petrified and it is possible to determine their inner structure. All such leaf-stalks are usually comprehended under the name Rachiopteridae. The same may be said of the stems, which form a large portion of the fern-remains preserved to us; they, like the Rachiopteridae, can only in the very rarest instances be referred with certainty to particular given leaves. It is true that we not unfrequently find the two kinds of organs spoken of in the literature as belonging to one another, but statements of this kind rest, except in a few cases $^{1}$, on conclusions from the fact that the parts occur together in the strata, and of such conclusions we have already said what is needful in the introductory chapter.

Fern-leaves furnish perhaps the one instance in which systematic botany has received a direct impulse from palaeophytology. Our entire fern-system is founded on the nature of the fructifications, and these are not often to be seen on the fossil leaves, and when present are usually indifferently preserved. When then Brongniart ${ }^{2}$ addressed himself to the task of classifying all known fossil fern-leaves, the number of which was very considerable even then, and perceived that the few fructifications with which he was acquainted could be of no use to him, he seized with his wonted energy and precision on the only expedient which presented itself, namely, the course of the nerves; and upon this character, to which little attention had been paid up to that time, he founded a classification of fossil Ferns which is confessedly artificial and not in accordance with that of recent forms. Brongniart's method was afterwards applied, as we know, by Presl ${ }^{3}$ especially and by A. Braun ${ }^{4}$ to living species, and in the hands of Mettenius ${ }^{5}$ above all others it proved to be cxtremely fruitful as a subordinate principle of division. Göppert ${ }^{6}$, who had in the meantime become acquainted with a number of fossil fructifications, thereupon attempted to combine Brongniart's classification with that of the botanists, but the attempt was an entire failure and he himself subsequently abandoned it; his genera defined and named, some simply after Brongniart, others according to the fructifications, others again from their resemblance to recent genera, run in confusion one into another, and no connected view of the whole system is possible since the main principles of division are incommensurable. Systematists have since then been repeatedly guilty of this fault in logic; Schimper's ${ }^{7}$ account of these forms especially suffers from the same cause.

It was soon felt to be necessary to break up the great form-groups which Brongniart had founded on the course of the nerves, into further divisions. Systematists have often employed for this purpose the form and

'Schimper (3), t. 40, and Sternberg, Graf von (1), Heft 5-8, t. 59 .

- Presl (1).
4. Braun (1).
2 Brongniart (1). 'Schimper (1). 
mode of branching of the whole leaf, and this course might be defended on the ground that these differences are also employed as good subordinate marks in dealing with living forms. But genera such as have been recently founded by Stur ${ }^{1}$ and Zeiller ${ }^{2}$ (Diplotmema, Stur, Mariopteris, Zeill.), which rest solely on the form of a leaf with one or two bifurcations, as in Gleichenia, and contain species with different kinds of nervation, cannot possibly find a place in any logical development of Brongniart's system. And as their value is entirely relative so long as we have no proper knowledge of their fructifications, the gain resulting from their establishment, if not altogether doubtful, must still be very small.

It is obvious that we must remain in uncertainty with respect to the configuration of the whole leaf in the many species which we know only in single detached pinnules. Imperfect remains of this kind must simply be entered under the names of the types of nervation to which they belong, and which are used as generic names, until further fortunate discoveries teach us better. This proceeding is attended with an evil which is in some cases unavoidable, namely that isolated pinnae of the same leaf are repeatedly and unconsciously registered under different names in different parts of the system. A considerable number of leaves found in the Coal-measures have in addition to the normal pinnules of the lamina of the leaf a second kind of pinnae of another shape and often with an entirely different nervation (Fig. 12), which grow in numbers either from the surface of the main rachis or at the base of the rachides of the second order, or are confined to the base of the leaf-stalk. These anomalous pinnae are now usually termed Aphlebiae, but they are noticed in the literature under various names. The same phenomenon occurs also, though rarely, in living Ferns; I have myself seen only two cases of the kind. The first is the well-known Hemitelia capensis, R. Br., common in botanic gardens, in which two much-branched A phlebiae appear on each side of the base of the leaf-stalk; a figure of this species will be found in Schimper ${ }^{3}$. A second undetermined species, which unfortunately has since died, I remember to have seen in the botanic garden at Strassburg. A very excellent and complete account of these structures has been given by Stur ${ }^{4}$, who compares them with the stipular formations of the Marattiaceae, and inclines to the belief that every fossil fern-leaf which bears these Aphlebiae must therefore belong to that family. I cannot assent to this view, on account of the recent plants just mentioned which bear Aphlebiae and belong to the family of Cyatheaceae. I now give a list of all the figures which have come to my knowledge, which show Aphlebiae in connection with the leaf which bears them. They are these : (I) Sphenopteris crenata, Lindl. and Hutt., with the Aphlebia Rhacophyl-

Stur (3), p. 283 , and (4), p. 183 .

Zeiller (5) and (6).

${ }^{3}$ Schimper (2), p. 143 .

"Stur (5), p. 195. 
lum adnascens, Lindl. and Hutt. (Fig. 12, 1)1. (2) Pecopteris dentata, Gein. not Brongn., with Rhacophyllum filiciforme, Gutb. ${ }^{2}$ (3) Odontopteris Reichiana, Gutb., with Cyclopteris trichomanoides, Brongn. ${ }^{3}$ (4) Oligocarpia quercifolia, Göpp. ${ }^{4}$ (5) Neuropteris Loshii, with Cyclopteris trichomanoides ${ }^{5}$. (6) Pecopteris Radnicensis, Strbg, with Aphlebia tenuiloba ${ }^{6}$.

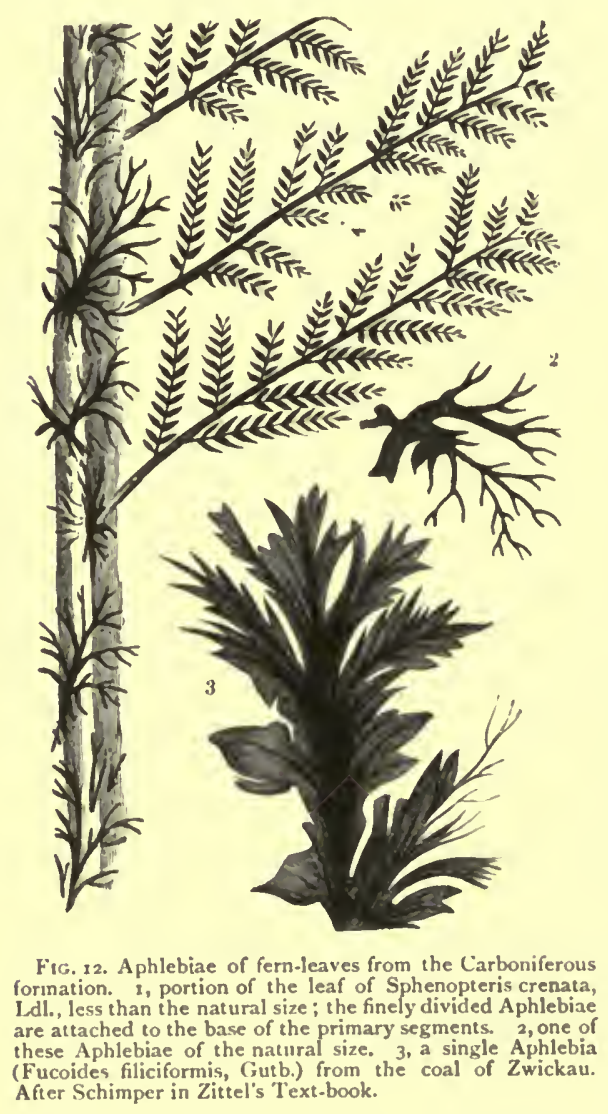

Fig. 12. A phlebiae of fern-leaves from the Carboniferous forination. I, portion of the leaf of Sphenopteris crenata, Idl. less than the natural size; the finely divided Aphlebiae are attached to the base of the primary segments. 2, one of these Aphlebiae of the natural size. 3, a single Aphlebia (Fucoides filiciformis, Gutb.) from the coal of Zwickau. After Schimper in Zittel's 'Text-book.

with Phyllocladus. We shall have to return once more to these doubtful forms in a future page.

It is impossible for me to treat at length of the countless fern-leaves which have bcen preserved in the fossil state, for I have occupied myself

${ }^{1}$ Lindley and Hutton (1), vol. ii, tt. 100, I01 ; Schimper (1), t. 48, ff, 1, 2; Zittel (1), p. 143; O. Feistmantel (3), t. $66 .{ }^{2}$ Geinitz (5), t. 25 , ff. I I-I 4 ; Schimper (1), t. 48, ff. 3-5. ${ }^{3}$ Geinitz (5), t. 26, f. 7 ; Grand' Eury (1), t. 12, p. 113; Zittel (1), p. $122 . \quad$ 'Stur (5), t. 15, f. 12. 3 Roehl (1), t. I7 ; Geinitz (4), Heft 2, t. 4, ff, 2,3

7 Lesquereux (3), t. 8, f. 5 .

- Stemberg, Graf von (1), t. 58 , ff. I, 2 . (7), t. 12, ff. I and $8 . \quad$ "Lesquereux (1), vols. i. and ii, t. 15, f. 3 . (1), t. 35 , f. 2 . 13 von Ettingshausen (2). (8) Sphenopteris (Oligocarpia) formosa, Gutb. ${ }^{8}$ (9) Sphenopteris (Diplotmema) acutiloba, Strbg. ${ }^{9} \quad$ (10) Sphenopteris coralloides, Gutb. ${ }^{10}$ (11) Lesleya grandis, Lesq. ${ }^{11}$ (I 2 ) Pecopteris dentata, with Rhacophyllum laciniatum ${ }^{12}$.

There are a few fossil fernleaves which can find no place in Brongniart's system because, owing either to the bad state of preservation or to the stout leathery consistence of the lamina of the leaf, the nervation is not distinctly shown in any of the remains hitherto observed. Such forms can of course only be given in an appendix; and this is the case also with another series of forms, which do not certainly belong to the Ferns but may most of them be quite as well classed with Cycadeae, as has been already remarked (see p. 87). In fact one of these genera, Thinnfeldia, Ett. ${ }^{13}$ is particularly compared by its author return once more to these doubtful Zeiller (7), t. II, f. 5. ${ }_{10}$ Zeiller

(7) Neuropteris rarinervis, Bunb. ${ }^{7}$ 
but little with them. Such an account of them moreover would be foreign to the plan of this work, since it would offer very little that is of interest from the botanical point of view; moreover, our living material supplies us with a much greater variety of forms of nerve-distribution. But that my work may not seem too unconnected and fragmentary, I introduce here a very brief account of the main types of nervation accompanied with a few examples.

Nervatio Pecopteridis is characterised, as is well known, by pinnately arranged tertiary nerves, which arise at a rather broad angle from the secondary nerves, and, remaining simple or bifurcating, run straight and free to the margin. Nervatio Sphenopteridis is closely allied to it, being essentially distinguished only by the very acute angle which the tertiary nerves form with the secondary. These two types of nervation are not sharply separated from one another; the form which is as nearly as possible intermediate between them is named by Mettenius Nervatio Eupteridis, and the genus Alethopteris may be quoted as an example of this type among fossil Ferns, though it is actually distinguished from Pecopteris more by habit than by very marked characters. In many cases the incisions in the leaf follow the course of the nervation with great exactness, so that the extreme point of the leaf is only traversed by a median nerve, and this produces Mettenius' Nervatio Caenopteridis. But all fern-leaves which have this character are as a matter of fact reckoned with Sphenopteris, though some of them may on closer examination be found to resemble Pecopteris rather than Sphenopteris as regards the angle of emergence of the nerves. This may be the case, for example, with Sphenopteris Hoeninghausii, Brongn., to judge by Schimper's figure ${ }^{1}$. Pecopteridae and Sphenopteridae are found in abundance throughout the whole series of Palaeozoic and Mesozoic formations. In the Cainozoic deposits the Ferns are on the whole in a minority as compared with other plants. They predominate in the Coal-measures especially, and by far the greater number of large and highly compound leaves belong to that formation. The oldest known Ferns from the Upper Devonian beds and the Culm are for the most part, though not entirely, Sphenopteridae with unusually complete division of the lamina of the leaf, which appears to be reduced everywhere to a narrow margin accompanying the nerves. Such forms are usually described in the literature as Hymenophyllites, Todea or Rhodea; as examples may be mentioned Rhodea patentissima, Ett. ${ }^{2}$ from the Culm, Todea Lipoldi ${ }^{3}$ from the roofing-slates of Moravia, Sphenopteris Condrusorum ${ }^{4}$ (Psilophyton, Crép. ${ }^{5}$ ) from the Devonian formation.

Nervatio Taeniopteridis is more sharply defined. Here the tertiary nerves emerge almost at a right angle and run in a straight line to the

$$
\begin{aligned}
& 1 \text { Schimper (1), t. }{ }^{29 .}{ }^{2} \text { Gilkinet (1). } \\
& { }^{3} \text { Crépin }(1) .
\end{aligned}
$$


margin of the leaf. If they fork, which is very commonly the case, their branches diverge at a very acute angle and soon become parallel to one another. Oleandra, Scolopendrium, Marattia supply examples among recent Ferns. The Taeniopteridae are on the whole characteristic of the Mesozoic formations; the best known forms are Taeniopteris marantacea, Presl ${ }^{1}$ (Danaeopsis marantacea, Schpr) from the Letten Kohl and T. Münsteri from the Rhaetic beds. Both species have simply pinnate leaves of considerable size. Forms with a simple lamina not pinnately divided are termed Oleandridium. A large number of simple leaves of more than usual size have been described by O. Feistmantel ${ }^{2}$ from the Lower Gondwanas (Trias) of India under the name Macrotaeniopteris. Forms of this type are very rare in the Palaeozoic formations, but some examples are figured in Lesquereux ${ }^{3}$ (Taeniopteris Smithsii, Megalopteris). I am not indeed sure that Megalopteris belongs to this division; on this point the literature cited above in connection with Cannophyllites should be consulted.

In Nervatio Neuropteridis the tertiary nerves come off at an acute angle, but they describe a curve convex to the midrib as they run to the margin of the leaf, with which both they and any parallel ramifications which may arise form nearly a right angle. If the curvature of the tertiary nerves diminishes, Neuropteris may come near to Sphenopteris or Pecopteris; on the other hand it approaches Nervatio Cyclopteridis, the next type to be mentioned, and may indeed be very like it, if the median nerve is only a little more strongly developed than the lateral. In practice it is often difficult to distinguish it from Cyclopteris, as may be seen by comparing, for example, Odontopteris obtusiloba, Naum. and Neuropteris Loshii, Brongn., which are exactly alike in the form of the leaf. In Schimper ${ }^{4}$ we find Cyclopteris and Neuropteris united for this reason into one family. The true Neuropteridae are entirely confined to the Palaeozoic formations; figures of characteristic forms are to be found in Schimper ${ }^{5}$.

Nervatio Cyclopteridis is distinguished from Nervatio Neuropteridis by the absence of a median nerve. Numerous nerves of equal strength enter the lamina of the leaf and bifurcate sepeatedly as they run in a curve which is convex towards the apex of the leaf, and at length form a right angle with the margin. Various leaves of this type are found in the oldest deposits along with the previously mentioned Sphenopteridae; on the whole the Cyclopteridae are less abundant in the Mesozoic formations. But there are some forms belonging to the present vegetation which follow this type of nervation. Various genera have been distinguished in the

\footnotetext{
Schimper (1), tt. $37,3^{8}$.

2 Pal. Ind., ser. xii.

3 Lesquereux (1), t. 25, f. 7 , and t. 24 .

- Schimper (1).

schimper (1), t. 30, ff. I1, I 2, and (2), p. 116, t. $3^{2}$.
} 
group of Cyclopteridae according to the shape of the lamina of the leaf, one or two of which may be noticed because their great antiquity makes them particularly interesting. One is the Devonian Palaeopteris, Schpr; the large handsome bipinnate leaves of $\mathrm{P}$. hibernica, Forbes, are characteristic of the Old Red Sandstone of Ireland, and will be found figured in Schimper ${ }^{1}$. Several other species are known, chiefly from Canada ${ }^{2}$. Triphyllopteris Collombi ${ }^{3}$ and Cardiopteris Köchlini ${ }^{4}$ are found in the Culm together with finely divided Sphenopteridae. The latter plant is marked by its fine roundish pinnae which are attached to the rachis by a broad base. Most of the forms of this type from the Coal-measures belong to the genus Odontopteris ${ }^{5}$.

After elimination of the genera founded on the form of the entire leaf, we have still a remainder of single pinnae of a highly problematical character. Some of the forms which were once classed with them are now seen to be leaves of Salisburieae, and have been already noticed in their proper place (see p. 62); others are certainly Aphlebiae belonging to various species of Ferns, the nervation of Cyclopteris being the prevailing, though not perhaps the only, kind in these anomalous pinnae. If Saporta's views respecting the Dolerophyllae discussed above on p. I2 5 should ever be confirmed, a number of Cyclopteridae would once more be included in that group.

If now we proceed to the forms in which the nerves anastomose, we have first Nervatio Goniopteridis, which arises out of Pecopteris when the corresponding tertiary nerves which proceed from every two adjoining secondary nerves anastomose with one another. This may happen, as we know, in the case of all or sometimes only of the lowermost of the tertiary nerves. A number of such Goniopteridae are known from the Tertiary formations ${ }^{6}$, but it would take too long to ascertain to what extent they and the allied nervation-forms, Goniophlebii, Pleocnemiae, Cyrtophlebii, etc. are distributed through the Mesozoic deposits, for the figures and descriptions of authors are not clear and distinct enough for the purpose. The forms in question are however usually collected together under the generic name of Phlebopteris; all that have simple anastomosing nervation have extremely few representatives in the Palaeozoic formations, the two chief types, both belonging to Goniopteris, appearing in the Carboniferous species Goniopteris (Diplazites) emarginata ${ }^{7}$ and G. arguta ${ }^{8}$.

Of fossil genera belonging to types with complex anastomoses we find that the greater number are also first seen in the Mesozoic formations. Only two of these are older and peculiar to the Coal-measures, Dictyo-

1 Schimper (1), t. $3^{6}$, and (2), p. I13. ${ }^{2}$ Dawson (1). ' 3 Schimper (2), p. Ir4. 'Schimper (1), t. 35 , and (2), p. Ir8. ${ }_{5}^{5}$ Schimper (2), t. 30, f. I 4 , and (2), p. I 21. 'Schimper (1), and A. Braun (1). ${ }^{7}$ Göppert (2), t. I6, ff. 1, 2. ${ }_{8}$ Brongniart (1), t. I08, ff. 3. 4. 
pteris, Gutb. ${ }^{1}$ and Lonchopteris ${ }^{2}$. The former developes the nervation of Ophioglossum, an uniform network of polygonal meshes; in the latter there is also a distinct midrib, so that the habit is that of some recent species of Pteris, Pt. aurita, for example.

Of Mesozoic forms belonging to this group two series may be distinguished; one of those in which the meshes of the network are all alike and separated by nerves of equal strength, as in the species from the Coalmeasures just mentioned, the other of those in which nerves of unequal development form by their anastomoses meshes of a higher and a lower order, answering therefore to some extent to Mettenius' types, Anaxetum, Drynaria, and Drynaria appendiculata.

Of the first series the genus Sagenopteris, Presl, has the first claim to notice. Sagenopteris rhoifolia, Presl, the best-known species, is peculiar to the Rhaetic beds, and is found both near Bamberg and in Schonen ${ }^{3}$. A few other species belong to the Lias and the Lower Oolite beds. At the extremity of the long leaf-stalk is the lamina composed of four pinnae which spring from the same point. The ovate pinnae have a nervation like that of Ophioglossum and show no trace of a median nerve. A number of genera with similar nervation have been described by O. Feistmantel from the Lower Gondwanas (Trias) of India, from deposits in Australia overlying the Coal-measures, and from South Africa ${ }^{4}$. Such are Palaeovittaria with leaves of probably the same structure as those of Sagenopteris, and forms with simple ligulate leaves like Gangamopteris and the genus Glossopteris ${ }^{5}$, which is said by Feistmantel to be provided with a median nerve; lastly, the strange Belemnopteris with a simple sagittate leaf-blade. The different attempts of authors to prove that Sagenopteris has its place with Marsileaceae will be noticed in discussing that group.

From the second series of genera the Rhaetic form Thaumatopteris Münsteri, Göpp., may be selected for notice as the one with which we are best acquainted; many good figures of it are to be found in different authors ${ }^{6}$. The deeply sinuate pinnatifid leaf-segments combine to form a handsome palmate sympodial leaf-blade. Clathropteris, Brongn. ${ }^{7}$ and Dictyophyllum, Lindl. and Hutt. ${ }^{8}$ are also from the Rhaetic beds, but Dictyophyllum rugosum also occurs in the Oolite of Scarborough. Camptopteris, Presl ${ }^{9}$, with a handsome leaf like that of Thaumatopteris, is peculiar to the Keuper.

It remains only to notice in a few words those leaf-forms which cannot be regarded as certainly belonging to the Ferns. One of them, the

\footnotetext{
1 Göppert (1), 5 and 6, t. 3. $\quad{ }^{3}$ Brongniart (1), t. 131. $\quad$ ' Zittel (1), p. 155 ; Schenk (3), t. 12 ; Nathorst (2), t. 4, ff. 3-5. "Pal. Ind., ser. xii, with numerous figures; O. Feistmantel (1), III. ${ }^{5}$ Schimper (2), p. ${ }^{3} 34 . \quad{ }^{6}$ Zittel (1), p. 137 ; Schenk (3); Nathorst (2); Göppert (1), 1 and 2 , tt. 1-3. ${ }^{7}$ Zittel (1), p. ${ }^{3}$ 8. 'Schimper (1), t. 4 r, f. 22 . 'Schimper (1), t. 42, f. 4.
} 
genus Otozamites (Otopteris, Schenk), has been already sufficiently considered in the chapter on Cycadeae. The first therefore to be mentioned in connection with Dictyopteridae is the genus Dictyozamites, Oldh. from the Upper Gondwanas (Jura ?) of the Rajmahal hills on the Madras coast, which $\mathrm{O}$. Feistmantel ${ }^{1}$ has described at length and has illustrated with numerous figures. The long imparipinnate leaves had been already discussed by Oldham and Norris in a previous chapter ${ }^{2}$ of the same work under the name Dictyopteris. They show the greatest resemblance in habit to those of Otozamites; the pinnules inserted on the upper side of the rhachis are attached to it by the middle portion of their broad base, and have somewhat large overlapping auricles on the upper and under side. But their nervation has altogether the character of Sagenopteris, and there is no conspicuous median nerve. Much as their habit would incline us to rank them with Cycadeae, we cannot do so at present, for we know as yet of no form of that group which has reticulate nervation. The doubt can be solved only by finding fresh specimens of this apparently rare fossil showing the fructification or at least the inner structure. Dichoneuron Hookeri is a leaf also with reticulate nervation, which Saporta $^{3}$ has described from the Permian formation of Eastern Russia, and which had been placed by Brongniart ${ }^{4}$ among Nöggerathiae. Its lamina is bifurcated, and the segments are irregularly toothed and incised. I cannot imagine why Saporta considers this to be the leaf of one of his Proangiosperms ; I have noticed this fossil only because he has so explained it.

The genus Nilssonia again is very like Cycadeae, and reminds us of certain Pterophyllae with short blunt pinnae-like lobes. From its habit it would at first be included among Pterophyllae, as is done by Schimper ${ }^{5}$, who like Göppert ${ }^{6}$ and Nathorst ${ }^{7}$ even gives to Nilssonia species which are generally considered to belong to Pterophyllae, for example Pterophyllum comptum ${ }^{8}$, Lindl. and Hutt., from the Oolite of Scarborough. He had previously ${ }^{9}$ in compliance with Schenk's ${ }^{10}$ views dealt with it among the Ferns. In Nathorst ${ }^{11}$ also, who ranks it with Cycadeae, will be found good figures and a careful examination of the genus. The principal species, Nilssonia polymorpha, Schenk, is peculiar to the Rhaetic formation, and is very abundant both in Franconia and in Schonen; two allied species are found with it in the same localities. How far other forms from the Lias and the Lower Oolite belong to Nilssonia is difficult to determine owing to the resemblance to Pterophyllum. The ribbon-like obtuse leaves of Nilssonia polymorpha vary greatly in form, sometimes having the whole or large portions of the margin entire, but being more often divided by lateral

I O. Feistmantel (1), I ; Pal. Ind., ser. ii, vol. i, pt. iv.

Yal. Ind., ser. ii, vol. i, pt. i.

${ }^{3}$ de Saporta (11). " Brongniart (5). " Schimper (2), p. 225. ${ }^{6}$ Göppert (8). " Nathorst (2).

${ }^{8}$ Schimper (2), t. 45. $\quad$ Schimper (1), vol. i, p. 488. ${ }^{10}$ Schenk (3), tt. 29-31. 11 Nathorst (2). 
incisions into pinnae which touch one another and may be of unequal breadth. Similar conditions have been noticed above in the case of species of Pterophyllum; but in these, as Nathorst rightly observes, the lamina is inserted exactly laterally, whereas its lines of insertion in true Nilssoniae are moved quite to the upper side of the rhachis and brought close together. The form also of the individual segments shows not unimportant differences. Delicate unbranched nerves run from the strong midrib perpendicularly to the margin of the leaf, and are separated from one another by raised strips. If in spite of all this agreement with Pterophyllum I still prefer to treat of this genus among Ferns, it is because in Schenk's ${ }^{1}$ figures of the plant we see portions of leaves in which there are small roundish protuberances on the under side of the leaf in regular rows and parallel to the nervation; these he considers to be remains of sori, and though this has not been certainly proved, yet from the regular disposition of these objects I consider Schenk's view more probable than that of Saporta ${ }^{2}$, who takes them for leaf-fungi.

A genus with the nervation of Neuropteris and calling for notice in this place is Thinnfeldia, Ett., which in its typical species belongs to the Rhaetic deposits and to the angulatus-beds of the Lower Lias. It was first accurately described by Ettingshausen ${ }^{3}$ from Steierdorf in the Banat, and next by Schenk ${ }^{4}$ from the neighbourhood of Bayreuth. A detailed description of it, accompanied with good figures, is to be found also in Saporta ${ }^{5}$. Another species, Thinnfeldia crassinervis, has been described by Geinitz ${ }^{6}$ from the Rhaetic beds of the Argentine Republic. A species from deposits in Australia above the Coal-measures has been referred by O. Feistmantel ${ }^{7}$ to this genus, but as it shows the nervation of Cyclopteris it is a doubtful Thinnfeldia. The thick solid leaves of Thinnfeldiae are simply pinnate; the entire or lobed pinnae are connected together at the base by a margin of tissue which accompanies the midrib. In Ettingshausen and Geinitz they are represented with a forked division in the middle of the lamina. The resemblance to Phyllocladus on which Ettingshausen insists, and which Nathorst ${ }^{8}$ also admits with some reserve, is, as Schenk ${ }^{9}$ has shown, not very important. The nervation, that is to say, is essentially different, it is the consistence only of the leaves which supplies a point of comparison. After Schenk's excellent discussion of the question there would be no reason for doubting that these leaves are the remains of Ferns, if stomata were not found on both sides of them, and if the stomata were not slightly sunk beneath the epidermis and walled round by the adjacent cells which rise above them. The latter structure is very common in Cycadeae and Coniferae; it has never been observed by Schenk in Ferns.

1 Schenk (3), t. 2 I, ff. I, 2.

2 de Saporta (4), vol. ii, p. 4 I.

von Ettingshausen (2).

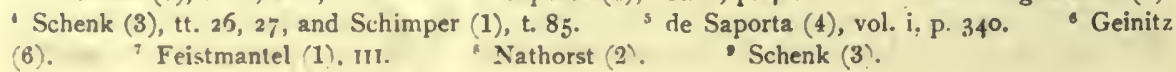


He therefore does not decide for one or the other view, so long as the fructifications are unknown, and inclines to see in Thinnfeldia and its allies a group intermediate between Ferns and Gymnosperms. Though this is in fact a possible supposition, for we shall be compelled by other observations, as in the case of Lyginodendron, to assume the existence of such intermediate groups, yet I would point out that Lomatopteris ${ }^{1}$ and $\mathrm{Cy}$ cadopteris $^{2}$, genera especially comparable with Thinnfeldia and for which Saporta's ${ }^{3}$ description should be consulted, are seen to be far more like Ferns. These genera are represented in the Jurassic system by a large number of species. In Cycadopteris Brauniana, common in the district of Vicenza, Zigno believes that he has discovered the sori; these according to his figure, which is not indeed very convincing, are like strokes following the nerves, and each is bounded by the two stout lips of an indusium.

The genus Nöggerathia was founded by Sternberg in 1823 on a pinnate leaf common in the Radnitz beds of the Bohemian Coal-measures. The specimen was figured as Nöggerathia foliosa, Strbg. ${ }^{4}$ This species is at present restored to its position as the representative of the type of Nöggerathia, now that we are clear of the confusion caused by Brongniart ${ }^{5}$, when he united a mixed multitude of heterogeneous forms under this name. Of these forms, Ginkgophyllum (Nöggerathia flabellata) ${ }^{6}$, Dolerophyllum Göpperti, Sap. ${ }^{7}$, Dichoneuron Hookeri, Sap. ${ }^{8}$, and Macropterygium Bronnii, Schpr (Nöggerathia vogesiaca, Bronn) ${ }^{9}$, have al ready been considered. Good figures of the large handsome pinnate leaves of $\mathrm{N}$. foliosa are found in $\mathrm{O}$. Feistmantel ${ }^{10}$ and in the illustrations accompanying the text of Stur's work ${ }^{11}$. The pinnae are wedge-shaped with a rounded anterior margin, and the nervation which belongs to the type of Cyclopteris is unusually close and fine. The habit of these leaves recalls certain forms of Cycadeae (Sphenozamites), because the pinnae which are inserted obliquely on the rhachis and a little to one side overlap and cover one another. For this reason the genus is by most authors placed among Cycadeae, by Schimper ${ }^{12}$, for example, by Saporta ${ }^{13}$, and by Geinitz ${ }^{14}$.

The view that Nöggerathia belongs to the Ferns has quite recently made its appearance, and is due to Stur's ${ }^{15}$ careful examination of specimens in fructification; it was at once adopted by $\mathrm{K} \cdot{ }^{16}$ and O. Feistmantel ${ }^{17}$. The fructification of this plant will be considered at greater length below. We will only obscrve in this place that, putting the fructification aside, the belief that this genus belongs to Ferns is supported by the circumstance

I Schimper (1), p. 472.

2 de Zigno (1), vol. i, p. 151 ; tt. $16-18$.

3 de Saporta (4).

4 Sternberg, Graf von (1), Heft 1-4, t. 20. ${ }_{5}$ Brongniart (5). 'See above, p. $66 .{ }^{7}$ See above, p. I24. See above, p. I39.

- See above, p. 88.

10 O. Feistmantel (3), t. 62 .

"Stur (3), p. ro; (4), p. 13. ${ }^{12}$ Schimper (1), vol. ii, p. J29; (2), p. 227. ${ }^{13}$ de Saporta (11).

${ }^{14}$ Geinitz (7). $\quad{ }_{15}$ Stur (3) and (4). ${ }^{16}$ K. Feistmantel (1). $\quad{ }^{17}$ O. Feistmantel (2). 
that it has an extraordinary resemblance in habit to the genus Rhacopteris, Schpr, which is undoubtedly a Fern and of which we also know the fructification. In fact several species of Rhacopteris have been placed by authors in the genus Nöggerathia, though they differ from it in the purely lateral insertion and in the direction of the pinnae. The literature has been collected by Stur ${ }^{1}$. It is remarkable that the two genera are found almost exclusively in Bohemia, Saxony, and Silesia, Nöggerathia being represented by several species in the Culm also of those countries. Rhacopteris Sarana ${ }^{2}$ is, I believe, the only known species from the Rhenish Coal-measures.

FERN-FRUCTIFICATIONS. It has already been remarked that at the time that Brongniart founded his classification of fossil Ferns on their nervation, scarcely anything was known of their fructifications. But much has been added since that time to our knowledge of these organs through the labours of different observers, among whom Göppert ${ }^{3}$, Schenk ${ }^{4}$, Weiss ${ }^{5}$, and Grand' Eury ${ }^{6}$ stand preeminent. It was especially from the examination of the silicified specimens from Grand' Croix that the points of view were obtained, which made it possible to judge with certainty of the remains of fructifications present only in their impressions. It was shown once more in the case of these objects, as in that of the remains of Coniferae, that the direct comparison of them with the fructifications of our recent genera is altogether precarious and dangerous, that it is allowable only when dealing with remains from the newest deposits, and then only with all proper restrictions. In this respect also must Göppert's attempt at a classification of fossil Ferns, which has been already mentioned, be regarded as a failure. At the present moment our knowledge of Palaeozoic and Mesozoic forms is very incomplete; there are a multitude of species in which the fructifications are either unknown, or exist in a thoroughly unsatisfactory state of preservation. But this much has been gained, that Stur $^{7}$ by his researclies, which are unparalleled for their care and extent, has found himself in a position to lay down the necessary principles of a rational classification of fossil Ferns ; and though some of his conclusions may be open to objection and untenable, yet the greater number of them will certainly hold their ground. A valuable publication of Zeiller's ${ }^{8}$ on this subject has also appeared almost at the same time as Stur's works. Unfortunately these two authors, working independently of onc another, have described the same objects under different names, and different objects under the same names, and thus the nomenclature has fallen into confusion. I shall adopt Stur's nomenclature in the following remarks, because his work covers the whole field of study more

\footnotetext{
$\begin{aligned} & \text { 'Stur (4). } \quad{ }^{2} \text { Beyschlag (1). } \\ & \text { Eury (1). }\end{aligned} \quad{ }^{7}$ Stur (3) and (4).
} 
completely than that of Zeiller; and if in these remarks I omit all mention of the Ferns of the Tertiary and Upper Cretaceous formations, which, as it appears, are allied at all points to living species, this proceeding will not require an elaborate justification. The gap between the Mesozoic and succeeding forms, which is repeatedly bridged over in the case of the Coniferae, is found to be impassable in that of the Ferns in consequence of our almost entire ignorance of everything relating to the Jurassic types. Hence it is that in the former case we are often compelled to unite the Tertiary with the later forms, in the latter we are entirely exempt from this necessity.

First of all, Stur ${ }^{1}$ has proved most convincingly that the Marattiaceae were much richer in species and forms, were a much more highly differentiated family, in earlier periods of the earth's history than they are at the present day. 'Grand' Eury ${ }^{2}$ had already established the fact, that a large number of the big multipinnate Pecopteridae and Sphenopteridae of the Coal-measures belong to this family. The whole group is separated by Stur according to certain characteristic marks into the subdivisions, Aphlebiocarpeae, Sphyropterideae, Senftenbergieae, Angiopterideae, Hawleeae, Asterotheceae, Kaulfussieae, Danaeeae, and Marattieae, of which the Kaulfussieae and Marattieae are living forms only, the Angiopterideae and Danaeeae are both living and fossil, and all the rest are known only in the fossil state. This arrangement, if we put aside the first two groups which appear scarcely satisfactory, may be considered to be a very happy one. It will be convenient to commence our survey with the Asterotheceae, because this division includes the genus Scolecopteris, Zenk., the fructification of which was long ago carefully examined in silicified specimens from the neighbourhood of Dresden, and was distinctly recognised as belonging to Marattiaceae ${ }^{3}$. Stur assigns to the genus Scolecopteris a number of species of Pecopteris from the Coal-measures and the Permian formation, as for example Pecopteris polymorpha, Brongn. (Fig. 13, D), P. Cyathea, Brongn., P. arborescens, Schl., the fructifications of which are also figured in Grand' Eury ${ }^{4}$ and Renault ${ }^{5}$. We are not fully acquainted with the form of the leaf in the long-known species Scolecopteris elegans, Zenk., because we have it only in silicified fragments. The fructifications also of other species have been found at Grand' Croix in the silicified state. The sori, which are roundish star-shaped on the transverse section, stand in a single row on the back of the tertiary nerves on each side of a secondary nerve and are formed of a small number of sporangia, and each sporangium has its lower half adnate to a common receptacle, which in Scolecopteris elegans and its allies is prolonged into a distinct little stalk bearing the

1 Stur (3) and (4).

${ }^{3}$ Renault (2), vol. iii.
${ }^{2}$ Grand'. Eury (1).

"Strasburger (1).

' Grand' Eury (1). 
whole sorus. The sporangia are elongate-ovoid in shape with a long free upper extremity, and dehisce by a slit on the inner side; in S. Cyathea they bulge out strongly on the dorsal side and acquire a somewhat different shape. The wall of the sporangium is stout and of the same character all round, and there is no indication of an annulus. If we compare this structure of the parts of the fructification with that of our recent forms, the cohesion of the sporangia into a roundish synangium directs us to Kaulfussia, while section Eupodium of Marattia supplies an exact resemblance to the elongated stalk-like base of the receptacle; the frce extremities only of the sporangia with their long acuminations are quite peculiar to the genus. The nearest ally of Scolecopteris, and of the group of Scolecopteris Cyathea in particular, is Asterotheca, Presl (Fig. I $3, E$ ), which is founded on Pecopteris truncata ${ }^{1}$, from the Coal-measures, and is still represented in later formations, as is shown by $\mathrm{P}$. Meriani which belongs to the genus and is of frequent occurrence in the Kcuper of Lunzer. The sori, which are perfectly spheroidal and are usually composed of six sporangia in close contact with one another, are sessile and placed in a single row on each side of the median nerve of each pinna. The sporangia have no annulus and resemble those of Scolecopteris Cyathea in the bulging of the dorsal side, but they are flattened at the top and end in a small and very short point. Owing to the firm cohesion of the sporangia in the sorus, the dehiscence-slit cannot be certainly perceived in the leaf-impressions, which are the only form of specimen that we possess, but it is probably to be found in the steep inner margin. Closely related to Asterotheca, as Stur has convincingly shown, is Ptychocarpus hexastichus ${ }^{2}$, which is Diplazites, Göpp. in Stur; but this name, since it is based on the nervation of the fern-leaf, should not be employed. The sori are placed in several rows on both sides of the median nerve in each pinna, and are formed of a number of cohering sporangia disposed in a circle, but they are in most cases laterally squeezed and crushed, so that in the side-view we generally get sight of two adjacent sporangia separated from one another by an intervening line. Asterocarpus Sternbergii ${ }^{3}, \mathrm{~A} . \mathrm{Meriani}{ }^{4}$, and Cyathocarpus eucarpus ${ }^{5}$ may be mentioned here as older figures of fructifications of Asterotheca.

The genus Renaultia, Stur (Pecopteris intermedia) ${ }^{6}$, in which the shape of the lamina of the leaf is not known as our only specimens are in sections of the pebbles of Grand' Croix, deviates more widely in some respects from Scolecopteris and Asterotheca. Renault's drawing of the sorus shows five sporangia disposed in a circle and opening on the inner side, free above and adnate below to the fleshy receptacle, and distinguished by their irregular ovoid form and occasional apical appendages, but above all

\footnotetext{
${ }^{3}$ Germar (1), t. 1\%. ${ }^{2}$ Weiss (1), t. 11. ' Göppert (2), t. 6, ff. I-3. +Heer (3), Trias, 1. 24. B Weiss (1), tt. 9, $10 . \quad$ Renault (2), vol. iii, t. 22.
} 
by the presence in their wall of an apical group of abnormally thick-walled cells which extend some way down on the outer side of the sporangium ; these cells have quite the appearance of an annulus, and are moreover developed at the spot where the rudiment of the annulus is seen to arise in Angiopteris.

Another group is that of the Hawleeae, which differ from Asterotheceae in having free non-coherent sporangia, but agree with them in the circular form of their sori. The genus Hawlea ${ }^{1}$, originally founded on a small fragment of a leaf from the Coal-measures of Sviná in Bohemia, has been enriched by Stur with many species which appear in the older literature as Pecopteris, for example Pecopteris Miltoni, Germ., P. crenata, Stbg, P. Bucklandi, Ldl. and Hutt.(not Brongn.). To this genus also he refers the remains described by Zeiller ${ }^{2}$ as Calymmatotheca, which he contends do not belong to the genus of that name. The sporangia in Hawlea are sessile and elongate-ovoid in form, and spread out from one another in all directions, so that the dehiscenceslit on the inner side is directed straight upwards and the sporangium when open has the form of a boat. The sori on the back of the tertiary nerves form a single row on each side of the secondary nerve. Oligocarpia, Göpp. (Fig. I $3, C$ ) is distinguished from Hawlea chiefly by the character and disposition of the sporangia; the two forms agree in the circular shape and arrangement of the sori. Oligocarpia Gutbieri ${ }^{3}$ was the species

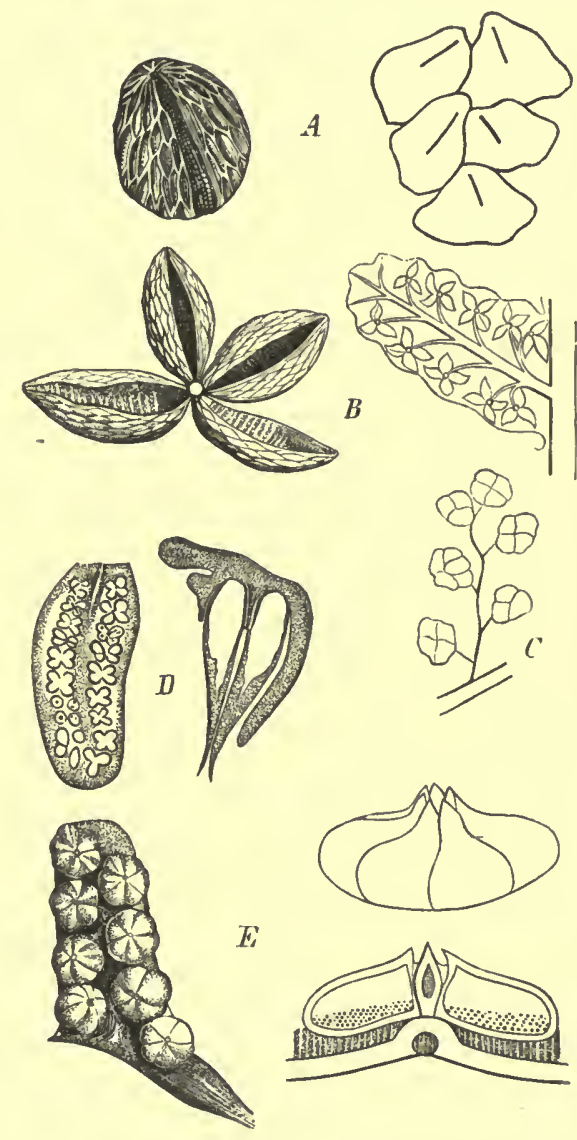

Frg. 13. Fructifications of fossit Marattiaceae from the Carboniferous fornation. $A$ Senftenbergia ophidermatica; to the left the position of the sporangia on both sides of the median nerve of the pinnule, to the right a single sporangium seen from above. $B$ Hawlea Miltoni ; to the left pinnae with the sori on the extremities of the lateral nerves, to the right a single sorus more highly magnified. C Oligocarpia lindsaeoides, showing position of the few-membered circular sori on the nerves of the pinnule. $D$ Scolecopteris polymorpha, Brongn.; to the ritht a pinnule showing the position of the sori in transverse section, to the left a Iongitudinal section of a sorus in which the sporangia are grown together below into a columnar receptacle. $E$ Asterotheca Sternbergii; to the right the pinnule with sori, to the left a side-view of a sorus and a sorus in radial section. $D$ and $E$ diagram. matically represented. All the figures after Stur.

first described, and Stur has included in it several other forms from the Coal-measures. If the sporangia in the sorus of the Oligocarpiae are few

1 Corda (1), t. 57 , ff. $7-8$. 
in number, they form a simple circle and are laterally in contact with one another; when there are more of them, as in Oligocarpia Brongniartii, we find a central group of two or three sporangia surrounded by a simple outer circle. They are attached to the expanded receptacle by a broad flat basal surface; they are obliquely pyramidal in shape and incline towards one another and towards the middle of the sorus. Stur is of opinion that the place of dehiscence may be seen in the form of a pore at the obtuse apex; at all events a gaping lateral slit has never been observed in any of the numerous specimens which have been examined. The stout wall, at least in the upper pyramid-shaped portion, is formed of large polygonal very thick-walled cells, which are developed however in a similar manner all round, so that no proper annulus can be distinguished. Göppert had already credited his Oligocarpia Gutbieri with a well-developed annulus, which he compared with that of Polypodiae; Zeiller subsequently reaffirmed its existence and described it as an 'annulus transversalis,' and thus the genus came to be placed among Gleicheniaceae. By the kindness of the latter author I have had the opportunity of secing his specimens, and I am still obliged to assent to Stur's denial of the independent existence of this annulus. If we look at the obliquely conical sporangium from above, we get a profile view of one or more transverse rows of the strongly thickened cell-ivalls, and may mistake them for an annulus; but we find that whenever we alter the position of a detached sporangium, the supposed annulus appears in another place. Stur is right in his remark that Zeiller's figures do in fact show this, and that the ring appears in them in a different position according as the sporangia are seen from above, or in the side-view.

Stur's account of his genera Discopteris and Saccopteris, which he would refer to this place, is not so convincing as that of Hawlea and Oligocarpia. Discopteris, which includes various Sphenopteridae, \&c., from the Coal-measures, as Sphenopteris Goldenbergii, Andrae, S. Coemansi, Andrae, has round sori formed of a large number of sporangia (70-100). The sporangia are very small and have a 'superficies reticulato-areolata.' Zciller ${ }^{1}$ compares his Myriotheca with Discopteris; but in Myriotheca, according to the description, the free ovoid sporangia which resemble those of Marattiaceae cover the whole under surface of the leaf without forming distinct sori, somewhat after the manner of Acrostichum. Saccopteris, Stur, is composed of forms from the Coal-measures, which by their nervation belong to Pecopteris, Alethopteris, and Sphenopteris. Its sori, placed in two rows on the pinnae, are circular in shape and are formed of numerous irregularly disposed elliptical sporangia, which are attached by a narrow base and open on the inner side towards the apex by a pore with a steep border. Stur endeavours to show that Zeiller has described under the name 
Grand' Eurya, Zeill. (not Stur) species of this very Saccopteris and others belonging to Desmopteris, Stur, a genus which he has figured only in the sterile state. But the figure given by Zeiller shows important points of difference, and as I have satisfied myself of its correctness by comparing it with the original specimens, I cannot at present acquiesce in this identification. For in the plants of the French author we have sori formed of erect sporangia in close contact with one another, each of which is furnished with a broad sharply defined annulus-band running arch-wise across the apex, which Stur indeed explains as due to the state of preservation. These characters, as the author ${ }^{1}$ himself points out, remind us to some extent of the group of Botryopterideae, which will be considered presently. But when the two remains of fructification, to all appearance so unlike one another, are united by their authors with the same fern-leaves, with Sphenopteris Essinghii, Andr. and S. coralloides, Gutb. Gein., or S., erosa, Gutb. Gein., it may be remarked that sterile leaf-forms very like one another belong to different genera, and lastly that the fertile leaves of the Ferns in question differ considerably from the sterile, and that this must render their determination difficult. For the details of this controversy, on which fresh light is needed, the reader should consult the original publications, and especially Zeiller's ${ }^{2}$ reply to Stur.

Corda's ${ }^{3}$ genus Senftenbergia (Fig. I 3, $A$ ), which has been submitted by $\mathrm{Stur}^{4}$ to a fresh and searching examination, is the type of the Senftenbergieae. The plants of this group also are by their nervation Pecopteridae and Sphenopteridae; among them for example are Pecopteris aspera, Brongn., P. plumosa, Art., Sphenopteris crenata, Ldl. and Hutt., and others from the Coal-measures. Of the Triassic fern-fructifications enumerated by Stur ${ }^{5}$ there are none belonging to this group. The free sporangia are not collected into sori but are found one by one on the back of the tertiary nerves, forming a longitudinal row on each side of the secondary nerve. Each sporangium in the typical Senftenbergia elegans is obliquely conical and acuminate from a rounded base, and turns the gentler curve, on which is the dehiscence-slit, towards the outside. On its stout wall at the conical apex may be seen a hood-shaped annulus, which is formed of several circular rows of cells lying one on another, and according to Stur is not distinctly defined below. Corda ${ }^{6}$ and after him Renault ${ }^{7}$ and Zeiller ${ }^{8}$ represent this annulus in their drawings with a much sharper boundary-line below, and make it the ground for putting the genus amoing Schizaeaceae. Stur rightly objects to this that in Schizaeaceae the strongly individualised annulus is in all cases formed of a single circular row of cells, and attaches great weight to the fact that the rudimentary annulus of Senftenbergia is easy to connect

\footnotetext{
${ }^{1}$ Zeiller (6), p. 205. $\quad{ }^{2}$ Zeiller (6). $\quad{ }^{3}$ Corda (1), t. 57. $\quad{ }^{4} \operatorname{Stur}(5,4,3) . \quad{ }^{5}$ Stur $(7)$.

- Corda (1). $\quad 7$ Renault (2), vol. iii, t. I 2, ff. 7,8 . ${ }^{8}$ Zeiller ( 7 ), t. I0, ff. I-5.
}

L 2 
with others of the kind, such as are found in the series of Marattiaceae. Again, Stur unites the genus Dactylotheca ${ }^{1}$ and also Pecopteris exigua ${ }^{2}$, known only from the siliceous fragments of Grand' Croix, to Corda's genus, while Zeiller ${ }^{3}$ protests warmly against this proceeding. In both certainly the sporangia are isolated, as in Senftenbergia, but fresh researches may be required to clcar up their differences. Lastly, to come back once more to the disputed question of placing our genus with Marattiaceae, it is clear that we must extend the characters of this family considerably before we can introduce into it forms with so highly developed an annulus as Renaultia and Senftenbergia; still this would be a wiser course, considering other points of connection which exist between these Ferns and forms which undoubtedly belong to Marattiaceac, than to found new families upon them, or to thrust them not without violence into others that are already established. There may possibly be intermediate forms ready to our hand, which would actually fill the gap between the exannulate Marattiaceae and various annulate groups, and in that case we might think of Senftenbergia in connection with Schizaeaceae and of Renaultia with Osmundaceae. For we cannot with Stur so entirely put aside the resemblance between the sporangium of Senftenbergia and that of Schizaeae, when Bunbury ${ }^{4}$ also, describing the fructification of Pecopteris exilis, Phill. from the Oolite of Scarborough, says in reference to its likeness to Corda's Senftenbergia that it is distinguished from it only by the circumstance that its apical annulus consists of a single row of cells. We should thus have a genuine member of the family of Schizaeaccae from deposits which are at any rate fairly old. A re-examination of the original specimen would be very desirable. As regards Stur's ${ }^{5}$ genera Sphyropteris and Hapalopteris, of whose connection with Senftenbergia I am not fully convinced from the author's statements, it will be sufficient to refer the reader to the original publications. In conclusion. Sarcopteris Bertrandi ${ }^{6}$ should be noticed here, a species known to us only in a few transverse sections of fragments of fertile leaves from the pebbles of Grand' Croix. The spherical thick-walled sporangia stand singly, and not grouped in sori, on the lower surface of the very thick lamina, and show on one side a large-celled irregularly defined tissue marking the position of an annulus and reminding us of Stur's Renaultia.

The Angiopterideae, which are characterised, as is well known, by free sporangia uniting to form sori with a distinct configuration, are considered by Stur to include only two forms, the remains of which were obtained by Renault ${ }^{7}$ from the pebbles of Grand' Croix and placed in the genus Pecopteris. These species are named by Stur Grand' Eurya Renaulti and

'Zeiller (7), t. o. p. 188 ; t. 13 , f. .: (2), t. 3 , f. 19 .
${ }^{3}$ Renault (2), vol. iii, t. I9, ff. 13-18. ${ }^{3}$ Zeiller (6). 4 Bunbury (1), ${ }^{3}$ Stur (3) and (4). "Renault (2), vol. iii, t. 21, ff. 12-1 5. " Renault 
G. Autunensis, and with our present knowledge of them they would certainly appear to belong to the type of Angiopterideae; the sori, which are formed of a large number of sporangia, are elliptical, and are developed on the back of the tertiary nerves. Renault's drawings of the sporangia show no rudiment of an annulus. According to Schenk ${ }^{1}$ the genus Angiopteridium ${ }^{2}$, founded on Taeniopteris Münster ${ }^{3}$ from the Rhaetic beds, also belongs to this group. The fructification which he has figured does in fact show the very greatest likeness to that of our recent Angiopteris. Schenk states distinctly that the sporangia of Angiopteridium, like those of Angiopteris, do not cohere; the figures it is true are not decisive on this point. Since we have to depend entirely on impressions of the plant, we cannot obtain absolute certainty on this question; and if it is proved that the sporangia are coherent, the genus must be moved nearer to Marattia, which Schimper ${ }^{4}$ thinks is its proper place.

With Danaeaceae Stur places the genus Danaeites ${ }^{5}$, which was originally founded on a Pecopteris from the Coal-measures with a more than doubtful fructification, and was afterwards somewhat more certainly determined by him with the help of fresh specimens. The tertiary nerves of Danaeites saraepontanus, Stur, like those of Danaea, bear linear sori parallel to and touching one another and composed of numerous sporangia in two rows; but the boundary-lines of the cohering sporangia can be distinguished in the surface-view, which is not the case in the living genus. Stur even maintains that he has observed indications of the characteristic membranous indusial cup on pinnae from which the sori have fallen off; he has not been able to determine the mode of dehiscence. Another apparently allied form is Danaeites Heeri ${ }^{6}$ from the Lias of Upper Italy. The leaves of this species show the nervation of Taeniopteris, and bear sori which have quite the habit of those of Danaea. Unfortunately we know only the external form; the figure also is perhaps rather too roughly sketched, as it does not show the isolated round dehiscence-spots on the sporangia mentioned in the diagnosis. Whether this is the case, or whether the diagnosis says too much, ean only be decided by inspection of the original specimens. Further investigation is also required in order to determine how far- Danaeopsis (Taeniopteris) marantacea, Heer, the fructification of which is figured in Schimper ${ }^{7}$, belongs to the above forms. The sori of this handsome fern, which is peculiar to the Keuper coal-beds, agree very fairly in habit with those of Danaea. They too appear, according to Schimper's drawings, to dehisce by dot-like pores; but it is still a question whether they cohere, as in Danaea, or not.

In connection with the long series of fossil Marattiaceae it will be as

I Schenk (3), t. 20.

- Schimper (2), p. 86.
2 Schimper (1), vol. i, p. 603.

3 Göppert (1), Lief. 3 and 4, t. 4 . ${ }^{5}$ Göppert (2), f. 19.
${ }^{6}$ de Zigno (1), vol. i, t. 25.
${ }^{7}$ Schimper (1), t. $3 \%$. 
well to notice the small group of Botryopterideae, with which Renault's ${ }^{1}$ excellent investigations have made us tolerably well acquainted. Collections of fragments of fruiting leaves of these plants are occasionally found in the pebbles of Grand' Croix and Autun, from thin sections of which we learn that the leaf had no normal lamina, but that crowded and irregularly branched bunches of stalked sporangia formed the final terminations of a branched and regularly pinnated leaf. The sporangia themselves are ovoid (Botryopteris), or elongate-ovoid and slightly curved (Zygopteris), and had stout walls, but the mode of dehiscence is not stated. The wall is formed of one layer of cells according to Renault, but Grand' Eury ${ }^{2}$, who has also figured this or a similar form, depicts several cell-layers. It may be conjectured that the inner layers were destroyed in Renault's specimens, and his figures show a sac-like envelope inclosing the spores, which I can only suppose to be a crushed cell-layer. Both genera show an annulus, which if not sharply defined is still evident. In Zygopteris the annulus forms two longitudinal bands running from top to bottom, which unite perhaps above the apcx, and which can be distinctly perceived to the right and left on the transverse section as large-celled parietal tissue. Its shape reminds us to some cxtent of Grand' Eurya, Zeill. (not Stur), which was described above. In Botryopteris the annulus is on one side and less distinct, and is morc like that of Renaultia, Stur, except that it does not extend to the apex of the sporangium. Renault ${ }^{3}$ thinks it is 'rather a disk analogous to that of Todea or Osmunda, only more developed and differently disposed.'

It was stated above that Grand' Eury ${ }^{4}$ had already compared these bunches of sporangia known to him from Autun with certain impressions from St. Etienne which he names Androstachys, but which had been previously found near Wettin and described by Germar ${ }^{5}$ as Araucarites spiciformis, and indeed had explained them both as male organs of plants resembling Nöggerathia. We do in fact find in this Androstachys of Grand' Eury the same little clusters of organs as those just described, and they are ranged on both sides of the thick rib-like bladeless primary rays of a regularly pinnated leaf. It can scarcely be doubted therefore that they belong to one another. And lastly, Grand' Eury succeeded in finding sterile leaves also with the same habit, in which the bunches of sporangia are simply replaced by delicate and apparently irregularly divided portions of the lamina, in which the nervation could not be determined, though it was supposed to be that of Caenopteris. These sterile leaves, to which Grand' Eury gave the name Schizopteris pinnata, have been claimed by Renault as belonging to Zygopteris, and it appears to me extremely probable that the

\footnotetext{
1 Renault (4) and (5).

${ }^{3}$ Germar (1), t. 33, ff. 1, 2.

2 Grand' Eury (1), t. 17.

3 Renault (4).

4 Grand' Eury (1), t. 17 .
} 
two do belong to one another. From the knowledge which we possess of the leaf-stalks and stems of Botryopterideae, and which also we owe to Renault, it seems tolerably certain that the group consisted of delicate herbaceous Ferns. We shall have to return to them further on in order to consider the anatomical details of their structure.

The genera Rhacopteris and Nöggerathia, the barren leaves of which have already been discussed at some length, are both known also in the fertile form. Stur is perhaps right in placing them in the family of Ophioglossaceae on account of their fructifications, but this relationship will not be satisfactorily established for the botanist, until the remains have been found as petrifactions and with their structure preserved. The only leaf of Rhacopteris paniculifera ${ }^{1}$ hitherto discovered has normal sterile pinnae below; the main axis forks repeatedly at its upper end and forms a loose tuft of small branches, the extremities of which are surrounded by crushed and for the most part detached sporangia. These sporangia are small and globular, and on one of them Stur believes that he has seen a fissure. $\mathrm{He}$ is led to refer this fossil to Ophioglossaceae and to compare it with Botrychium chiefly from the development of a fertile and a sterile portion of the lamina in the same leaf, and because he could perceive no annulus on the crushed sporangia. This reference therefore is obviously very precarious, for an analogous behaviour is observed in the fertile leaves of very various Ferns, and as regards the terminal position of the fertile leaf-segment there is no really serviceable object of comparison to be found in Ophioglossaceae. A similar state of things to that which occurs in Rhacopteris is also observed according to Schimper ${ }^{2}$ in Triphyllopteris Collumbi, Schpr., from the Culm of Thann; but here we have no certain ground to go upon owing to the indifferent preservation of the specimen, and moreover it does not appear from the text whether there is any proof of the connection between the sterile and fertile portions figured, or whether this connection is concluded merely from their occurring together in the strata.

Essentially similar objections may also be raised respecting the genus Nöggerathia ${ }^{3}$. Its fructification, clearly ascertained from the circumstance that the lowermost pinnate leaves are sometimes sterile and also show the characteristic features of Nöggerathia foliosa, was first described by Geinitz ${ }^{4}$, and was declared to be of gymnospermous origin. Further light was afterwards thrown on the question, and by no one more than by $\mathrm{K}$. Feistmantel ${ }^{5}$. The literature of the subject has been collected by Stur ${ }^{6}$. By the close approximation of the pinnules to one another the fertile leaves or leaf-segments assume the appearance of dense spikes ; the pinnae themselves change their form and become broad scales with the anterior margin

\footnotetext{
${ }^{1}$ Stur (4), p. 8, and (5), t. 8 .

${ }^{2}$ Zittel (1), p. 114 .

3 Stur (4) and ' 5 ,

Geinitz (7,. 
dentate, and overlap and quite conceal the rhachis. These pinnae bear the sporangia, which are present in large numbers and are attached to the upper surface. That these small ovoid bodies cannot be seeds of a gymnosperm is proved by K. Feistmantel's discovery of numerous spores inside them. No annulus has been observed in their wall, which is formed of several layers of cells. Taking all this into consideration, we may agree with Stur, who will not hear of a comparison with Cycadeae or Coniferae. On the other hand, the botanist, when he looks at the figures, will not see too many or too obvious points of resemblance to Botrychium or Helminthostachys.

Under the name of Aphlebiocarpus Schützei Stur ${ }^{1}$ has described a remarkable but unfortunately very imperfect fructification, which must without doubt have belonged to a fern. A piece of a repcatedly branched leaf-axis bears at the extremity of the branches stellately-lobed foliar formations, which are attached by their central point and have here and there on their surface small protuberant insertion-points. The lobes inclining towards one another from the first like the leaves of an involucre, enclosed a number of sporangia, as is seen in other specimens; thesc sporangia according to Stur were ovoid and without an annulus, and resembled those of Senftenbergia. But when Stur attempts to found a formal history of development on these facts, and makes these formations be at first open and then close up to form a capsule and develope sporangia, he is pursuing a path on which I cannot follow him. As little can I accept his reasons for considering that the genus in question belongs to Marattiaceae, and for establishing a special sub-group, Aphlebiocarpeae, to receive it. The farthest that wc can go in this matter, is to admit the proof that the sporangium is like that of Senftenbergia; for Stur's favourite comparison of the stellatcly-lobed envelope with Aphlebiae, even if proved or only made very probable, which is not the case, would still be far from supporting the view that the fructification in question belongs to Marattiaceae, since such a conclusion, as was shown above, is based on the decidedly erroneous supposition, that the Aphlebiae are peculiar to this family and homologous with their stipular formations. We will hope that further discoveries may throw more light on the structure of this remarkable fossil.

If, as the foregoing remarks have endeavoured to show, we are able to recognise with more or less certainty a fair number of genera of Eusporangiate Filicineae, our success in determining the Leptosporangiate forms has been much more limited. As far as I know, scarcely a single specimen of the latter kind above suspicion has been obtained from the Coal-measures; this is the more remarkable because we might think that the characters of 
the annulus, which is distinctly formed in each case, would afford an excellent means of distinguishing them. It is true that Williamson ", for example, and Carruthers ${ }^{2}$ have figured a good many sporangia in sections from English calcareous nodules, which they consider to belong to Gleicheniaceae or Hymenophylleae. I possess a variety of sections through these sporangia in which at first sight we fancy that we see an evident circular annulus. But if we happen to light upon a surface-view of these objects, we see that the wall is everywhere of the same structure, and that every section therefore in whatever direction it is made would show an illusory annulus transversalis; there is nothing therefore which compels us to regard them as anything else but sporangia of Marattiaceae, especially when we know how generally the latter are distributed through the groups of the Palaeozoic formations. The best-known example from the Coal-measures is certainly the fern-leaf figured by Zeiller ${ }^{3}$ as Hymenophyllites delicatulus, Stbg. Here there does really seem to be a transversal annulus, as appears especially from the side-views given in Zeiller's figures ${ }^{4}$. It is true that I have never myself seen sporangia in this position in the original specimens, which the author demonstrated to me in the kindest manner, probably because the shortness of the time at my command did not admit of a thorough study of the slab; but I carried away with me the general impression that the facts had been correctly interpreted and that no other explanation of the pictures was possible. We need not indeed go into the question whether we are justified in calling the leaf Hymenophyllites; it is in favour of this determination that the sporangia which are no longer in situ lie in groups in front of the extremities of the nerves of the tip of the leaf; there is no trace of the characteristic thorn-shaped placenta or of the cup-shaped indusium. Another form described as of the same group, Hymenophyllum Weissii ${ }^{5}$ from Saarbrïcken, is to my mind more than doubtful; its sporangia are unknown, and I have been unable to satisfy myself from the specimens in the Museum at Strassburg that the character of the sori is as described by the author. Heyer ${ }^{6}$ also, who had the specimens in the. Goldenberg collection before him, was not more successful than myself. The same remark applies also to Hymenophyllites Humboldti, Göpp., and Trichomanites Beinerti ${ }^{7}$, as well as to the genus Palaeopteris, of which Schimper figures the fruiting heteromorphous leafsegments ${ }^{8}$. In these also the structural details of the fructifications, which are declared by the author to be two-lobed indusia, cannot be certainly determined.

While it is thus scarcely within our power to prove the cxistence of

${ }^{1}$ Williamson (1), vil, t. 7. $\quad{ }^{2}$ Carruthers $(6)$, p. 3. $\quad{ }^{3}$ Zeiller ( 7$)$, t. 10, ff. 23-32. $\quad$ Ibid., ff. 30, 31. ${ }^{3}$ Schimper (1), t. 28, ff. 4, 5. $\quad$ Heyer (1), p. 394. ${ }^{7}$ Göppert (1). ${ }^{8}$ Schimper (1), t. 36, and Zittel (1), p. 113 . 
Leptosporangiate Ferns during the periods of the Coal-measures, we know on the other hand from Schenk's ${ }^{1}$ researches that there were a considerable number of them already in being while the Rhaetic beds were in process of deposition, and that they are to be assigned to the genera Laccopteris, Presl, Selenocarpus, Schenk, Andriania, F. Braun, Clathropteris, Brongn., Dictyophyllum, Lindl. and Hutt., and Thaumatopteris, Göpp. The sori of all these ferns are composed of a few large sporangia, and in this respect they agree with Gleicheniaceae; but each sporangium has a closed oblique and unusually well-marked annulus, quite in the manner of Cyatheaceae. This was fully proved at first by Schenk ${ }^{2}$, and it has recently been positively confirmed by Zeiller ${ }^{3}$ in the case of Laccopteris. Schenk has already called attention to the agreement between these characters and those of the Malayan genus Matonia, which standing as it does quite alone in our present vegetation and in an intermediate position between Cyatheaceae and Gleicheniaceae evidently represents an ancient type now in course of extinction; and Zeiller has shown the perfect identity of the sori of Matonia and Laccopteris by placing figures of them side by side. The great variety in the character of the lamina of the leaf in all these ferns shows plainly how very dangerous it is to make use of this part of the plant for the purposes of rational classification. Osmundaceae also seem to occur as early as the Jurassic period. To this group belongs Alethopteris australis, Morris, from Queensland, according to Renault ${ }^{4}$. Its ovoid sporangia are in longitudinal rows along the course of the secondary nerves of the pinnules, and are furnished on one side with a 'plaque de déhiscence.' Pecopteris Williamsonis, Brongn., from the Oolite of Scarborough is also placed by Schenk ${ }^{5}$ with Osmundaceae, and named in accordance with this position Todea Williamsonis. A figure of the plant is to be seen in Lindley and Hutton ${ }^{6}$. Schenk gives a good description of its sporangia and of the spores which they contain.

It remains only to mention the fern-fructifications in which we know the external characters only and little or nothing of the sporangia; the position of such forms in the system cannot be determined with any degrec of certainty, except when they come from Tertiary formations and have some claim to be connected with living species.

The genus Calymmotheca, Stur appears to occur in many parts of the Coal-measures, and to be represented there by numerous species. It was first observed by Schimper in the Culm of the Vosges, and thoroughly examined and established by $\mathrm{Stur}^{7}$; and the attempt recently made by Kidston ${ }^{8}$ to separate a new genus Zeilleria from this group must in

\footnotetext{
${ }^{1}$ Schenk (3). $\quad{ }^{2}$ Schenk (3).

${ }^{3}$ Schenk (11), p. I68; t. 15, ff. $3 a, 3 b$.

${ }^{3}$ Zciller (8). 'Renault (2), vol. iii, p. 81 ; t. II.

$(3,4,5,6)$. Kidston (1).

${ }^{6}$ Lindley and Hutton (1), vol. ii, t. 126.
} 
the present state of our knowledge be regarded as premature. Stur has included a large number of Sphenopteridae in his genus Calymmotheca; these all agree in the circumstance that their fertile leaf-segments terminate in peculiar capsule-like indusia formed of several lobes, which close upon one another like valves and ultimately expand and assume the form of a star or almost of a corolla. These indusia show a remarkable variety of dimensions, and in some species from the Culm especially they reach a very considerable size. The details of their form also vary much; the valves on the median line of the dorsal surface in Calymmotheca Stangeri, Stur, are covered with thorn-like projections. Stur has done well to bring genera like Sphaeropteris, Wall. and Diacalpe, Bl. from among recent Ferns into comparison with Calymmotheca, and Cyathea Brunonis, Wall. might be added to them ; if the laminae of the leaves disappear from Sphaeropteris barbata, Wall., and the nerves only are left with the thick-walled stalked sori, a form like Calymmotheca would in fact be produced. But this comparison, serviceable as it is in some respects, tells us nothing about the affinity of our forms, nor shall we be able to determine that point until we succeed in discovering the altogether unknown sporangia. Stur himself, who inclines to place them with Cyatheaceae, fully recognises the precarious nature of this disposition. From Calymmotheca Stur next proceeds to the consideration of his genus Sorotheca, in which the fruiting terminal pinnae are flattened out and thickened, and are encircled with numerous narrowly lanceolate indusial valves. The points of insertion of the sporangia can be seen as small scars on the surface of the pinnae. At first the valves of the indusium are connivent, but they subsequently expand in a stellate manner. Zeiller ${ }^{1}$ indeed, who has described the same plant from the Belgian coal-fields as Crossotheca Crépini, explains the parts of the fructification in a totally different manner, since he takes the lanceolate projections, Stur's indusial valves, for the sporangia themselves. In that case the scars observed by Stur, which Zeiller $^{2}$ in his rejoinder to Stur rather passes over, would not be easy to understand. Lesquereux ${ }^{3}$ has figured some fructifications which look like these of Sorotheca', but whether they should be placed with that genus or with Calymmotheca is a point which cannot be determined from the somewhat imperfect account given of them. The American author has named these objects Staphylopteris, Lesq. (S. Wortheni, S. asteroides, S. stellata), but he also includes in his genus various other forms, such as S. sagittatus, Lesq., which evidently have nothing whatever to do with it, as has been already pointed out by Schimper ${ }^{4}$.

The doubts, which are shared by Stur himself, as was before said, respecting the relationship of the genera Calymmotheca and Sorotheca to

\footnotetext{
${ }_{1}$ Zeiller (7).

2 Zeiller (6).

${ }^{3}$ Lesquereux (3), vol. iv, p. 405 ; t. 14 , and (4), p. 310 ;

t. 2, f. 2 . ${ }^{4}$ Schimper (1), vol. iii, p. $5^{1} \mathbf{3}$.
} 
Cyatheaceae, are with him founded chiefly on the analogies which seem to exist between his genera and a fossil form hitherto of very doubtful nature, which Corda $^{1}$ described as Chorionopteris gleichenioides, and without any apparent reason referred to Gleicheniaceae. This object is a diminutive fragment of a fruiting fern-leaf from the Coal-measures of Radnitz in Bohemia; it is found in the silicified beds of Millstone grit in that locality, and shows the structure when the sections are examined in direct light. A thin axis bears several closed capsules about a millimetre in diameter, which are formed of several layers of cells and are of a solid character. Each capsule opens by four valves and contains four sporangia filled with spores. There is no indication of an annulus on the thin wall of the sporangia, and their points of attachment are not clearly shown. If we adopt Stur's very natural comparison of this many-lobed indusial capsule with that of Calymmotheca, yet the structure of the sporangia would scarcely suggest any close affinity with Cyatheaceae.

Stur founded his genus Diplotmema, as has been already shown, mercly on the form and mode of branching of the lamina of the leaf, and compared it with the recent genus Rhipidopteris. Points of attachment of the fructifications are of rare occurrence on the leaves, and in Diplotmema Zwickauicnse, Gutb., the one species in which they appear, they are found on the terminations of the tertiary nerves, which emerging from the surface of the leaf within the margin form in a peculiar way a small disk-like and toothed expansion. On this structure the unknown sporangia are supposed by Stur to have been seated, which is possible but is certainly not proved ${ }^{2}$. The same author ${ }^{3}$ had previously given a different description of the fructification of D. geniculatum, and placed it in the bifurcation of the leafstalk, where he still keeps it. With other authors, Zeiller for example, I am disposed to see in these objects simply buds, such as those which shoot forth so abundantly in the forks of the leaves of Gleicheniaceae.

A number of fossil remains have been directly united with the recent monotypic genus Thyrsopteris, Kze, which lives in the Island of Juan Fernandez and was placed by Mettenius with Cyatheaceae, solely on account of their appearance and of the character of the receptacles which contain the fructifications, the sporangia being unknown. Heer ${ }^{4}$, relying on several fossil forms from the Oolitic strata of Siberia, is especially earnest in his support of this classification. His descriptions apply most exactly to Thyrsopteris Murrayana, whose fertile pinnate leaves have no lamina, and are covered with stalked cup-shaped involucres concealing the sori. Th. Makiana is a similar form; a fossil known as Th. gracilis, Heer, seems to me very doubtful. Th. Murrayana is also found in the Oolitic beds of 
Scarborough; when it was first found it was taken for an alga and named Tympanophora ${ }^{1}$; it was subsequently recognised by Williamson ${ }^{2}$ as the fructification of a fern, Pecopteris Murrayana. This view has since been worked out by Bunbury ${ }^{3}$ and Leckenby ${ }^{4}$ and illustrated by figures. Saporta ${ }^{5}$ has retained the name Coniopteris given by Brongniart for this fructification in spite of its great resemblance to our living Thyrsopteris; and this course is in my opinion worthy of imitation, because it shows caution. If Thyrsopteris schistorum ${ }^{6}$ from the roofing-slates of the Culm of Moravia and Silesia really belongs to this genus, which from the habit does certainly appear to be the case, this would be a very ancient type; but on this point Stur himself speaks with all reserve.

Several fern-leaves from the Jurassic system are placed by $\mathrm{Heer}^{7}$ in the genera Dicksonia and Asplenium solely on account of the habit of the sori as preserved in impressions; thus we have Dicksonia Saportana, Heer (Scleropteris, Sap.), and Asplenium spectabile, Heer, and A. Whitbyense (Cladophlebis, Auct.). It is no longer necessary to insist at length on the precariousness of this determination. Lastly must be mentioned the genus Stachypteris, Pomel, from the Coralline Oolite of Verdun, in which bipinnate leaves resembling those of Cheilanthes show segments of the third order of abnormal and peculiar form, the supposed fertile pinnules. Its discoverer Pomel compared it with Lygodium; Saporta ${ }^{8}$ does not assent to this, and would refer it rather to Onychium.

INNER LEAF-STRUCTURE, RHACHIOPTERIDAE AND FERN-STEMS. In connection with the above account of the leaves of fossil Ferns and of the fructifications which they bear we may now proceed to consider certain anatomical peculiarities such as are described in the works of Williamson $^{9}$ and Renault ${ }^{10}$, and which are disclosed by sections of the laminae of petrified leaves. In general it appears that the structure of fernleaves in the period of the Coal-measures was essentially the same as that of recent species, being as a rule distinctly bifacial with several layers of palisade-cells on the upper and spongy parenchyma on the under side. The nerves also, which often project strongly on the back of the leaf, are formed in the normal manner either of one strand of vascular bundles, or of several variously fashioned and concentric strands. Tissues also with mechanical function are often present in the form of strips of sclerenchyma beneath the epidermis of the upper side of the leaf, often with local strengthening ribs like bands, as in Pecopteris Geriensis ${ }^{11}$. In other cases, as in the Alethopteris figured by Renault ${ }^{12}$, the subepidermal strips of

\footnotetext{
1 Lindley and Hutton (1), vol. iii, t. 17o. ${ }^{2}$ Brongniart (2). ${ }^{3}$ Bunbury (1). $\quad$ Leckenby (1). ${ }^{5}$ de Saporta (4). $\quad$ Stur (6) and (4). ${ }^{7}$ Heer (5), vol. 4 II, t. 2, ff. I6-I8 and $21 . \quad$ de Saporta (4), vol. i, p. 379; t. 49. Williamson (1), vi, viIl. ${ }^{10}$ Renault (2). 11 Renault (2), vol. iii, t. $22 . \quad{ }_{12}$ Renault (2), vol. iii, t. 27.
} 
tissue are wanting, and in place of them we have the well-known T-shaped trabeculae very perfectly developed traversing the lamina of the leaf and enclosing the bundle-sheath. We have already observed the like arrangement of the mechanical system in Cordaiteae, and shall meet with it again further on in very many cases. In further exemplification of this subject may be mentioned the figures given by Williamson ${ }^{1}$ of the leaf-structure of his Rhachiopteris aspera. I have satisfied myself with regard to the facts in the case of both these ferns from various preparations in my possession. In Pecopteris densifolia, Ren. and $\mathrm{P}$. exigua ${ }^{2}$, there appear to be no mechanical elements in the surface of the leaf, and none in Sarcopteris Bertrandi ${ }^{3}$. Well-preserved hairs, either detached or still in situ, have been observed not unfrequently in specimens from the pebbles of Grand' Croix. In one leaffragment of a Pecopteris the substance of the under side of the leaf swells up between the tertiary nerves, and forms receptacles like deep channels running parallel to the course of the nerves and having the fissure which forms their aperture closed by a dense growth of hairs; on account of this peculiarity Renault has made a separate genus of this form, which he names Scaphidopteris Gilliotti, but this is hardly admissible. Lastly, Renault has drawn attention to the water-stomata and epithemata over the extremities of the nerves of the pinnae in a number of species; but the genus Lageniopteris which he has founded on this character is quite untenable, for these organs of excretion are observed in many Pecopteridae and are probably widely diffused. They are most beautifully and clearly shown in the figure which Renault has given of Lageniopteris obtusiloba ${ }^{4}$. The section has passed exactly through one of them in the longitudinal direction, and we see the swollen club-shaped extremity of the tracheidportion of the vascular bundle of the leaf surrounded by a small-celled epithema, in which a wide canal of exit is closed by an unusually large stoma. In the other form figured the organ is traversed by the section in an oblique and less favourable direction.

Rhachiopteridae, leaf-stalks of various orders of leaf-branching, are reckoned among the most numcrous of petrified vegetable remains in which the structure is preserved, as might be expected indeed when we consider the stoutness and solidity of character which they usually possess, and the wide distribution of Ferns in early periods of the earth's history. Owing to their uniformity of structure they are for the most part of small importance to the botanist; still there are some forms among them which are in the highest degree interesting, though unfortunately they have not yet been fully explained. Their cross-section shows a homogeneous parenchyma inclosing a varying number of vascular bundles of very different and often

1 Williamson (1), vi. (2), vol. iii, t. 23 , ff. 3,4 .
${ }^{2}$ Renault (2), vol. iii, t. 19.

s Renault (2), vol. iii, t. I9.
- Renault 
very peculiar form, and in these points they agree exactly with the axes of recent fern-leaves. There are also in very many cases longitudinal subepidermal regularly disposed bands of sclerenchyma, which extend more or less far into the parenchyma. Corda ${ }^{1}$, to whom we are indebted for the first examination into the anatomical details of these remains, has divided them into numerous genera founded essentially on the form and position of the concentric bundles of the wood. Later authors, with a more superficial treatment of the subject, have on the whole adopted Corda's terminology, though Brongniart ${ }^{2}$ carefully insisted that this distribution was quite provisional, since an axis of a lower order of branching often differs in structure from the main axis in the same species, and that the two would therefore in Corda's system be placed in different genera. This restriction has ultimately been applied in practice by Williamson ${ }^{3}$, who has included by far the larger number of these bits of leaf-stalk in the genus Rhachiopteris, rightly keeping a few only separate from the rest, because they are distinguished by special peculiarities of structure in thick and thin pieces alike. The leaf-stalks occur in very many cases as isolated detached fragments, especially in the often-mentioned calcareous nodules of the Coal-measures and in the siliceous pebbles of Grand' Croix; but they have sometimes been found in thick bundles interwoven with numerous roots, a state of preservation to which Corda has given the generic name of Tempskya, but which is sometimes also termed Endogenites, Spreng., though this appellation belongs particularly to the wood of palms. It is obvious then that this genus cannot be maintained as it is, but it may be conveniently employed as a general term for this particular state of preservation, so that Zygopteris for example would be known both in the free state and in the Tempskya-condition. We may observe here briefly that the adventitious roots of Temskyae which are interwoven with the leaf-stalks show thoroughly the normal fernstructure with a central radial usually pentarc or hexarc vascular bundle.

We now proceed to notice the most important of Corda's ${ }^{4}$ genera, all of which come from the Coal-measures of Bohemia. The transverse sections of Selenopteris ${ }^{5}$, Anachoropteris ${ }^{6}$, and Gyropteris ${ }^{7}$ show a single bundle, which in the last genus is coiled, in the first is crescent-shaped, and in Anachoropteris is in the shape of a horse-shoe with involute extremities. Next comes Selenochlaena resembling Selenopteris and founded on Cotta's ${ }^{8}$ Tubicaulis dubius and Solenites, and Zygopteris founded on his Tubicaulis primarius. In the latter form, of which through Renault's ${ }^{9}$ researches we know the stems and fructification, the bundle has somewhat the shape of a Latin $H$. Finally, in Kalopteris ${ }^{10}$ besides the crescent-shaped bundle of

\footnotetext{
1 Corda (1).

2 Brongniart (2), p. 85 .

${ }^{3}$ Williamson (1), vI. 4 Corda (1). ${ }_{5}^{5}$ Corda

(1), tt. 53,54 .

${ }^{6}$ Corda (1), tt. 56,57 .

7 Corda (1), t. 54 .

${ }^{8}$ Cotta (1).

- Renault (5).

${ }_{10}$ Corda (1), t. I9.
} 
Selenopteris there are two smaller bundles lying in its concavity. The Tempskyae are different; in one of them, Tempskya pulchra, Corda ${ }^{1}$, we have several crescent-shaped bundles, one of which, the largest, often closes into a ring. Göppert ${ }^{2}$ again has figured fragments of Gyropteris and Zygopteris from the Carboniferous Limestone of Glätzisch-Falkenberg in Silesia, and with them, it is true, a form named Sphenopteris refracta, to which we must return presently. Numerous figures of Zygopteris, Anachoropteris, and other Rhachiopteridae from the English Coal-measures, in which the transverse section of the bundles differs from those already described, are to be found in Williamson ${ }^{3}$. A number of petrifactions from the Upper Devonian beds (Cypridina-shales) of Saalfeld, but almost all in an extremely bad state of preservation, have been described by Unger ${ }^{4}$ under many generic names. A large portion of these he has himself recognised as Rhachiopteridae; among them for example Clepsydropsis, which in the form of the transverse section of the vascular bundles agrees pretty closely with Williamson's Rhachiopteris duplex ${ }^{5}$. For some of the remainder he forms the groups Haplocalameae and Stereocalameae, which he would prefer to unite with Calamitae. After inspection of an original preparation of Calamosyrinx devonica, preserved in the Museum of Practical Geology in London, which belongs to the former of the two groups, I should say that it is only the rhachis of a fern-leaf. What Unger distinguishes in them as bundles of the pith may in fact be the vascular bundles; the outer peripheral woody body will correspond, as I imagine, to the mechanical subepidermal ribs of sclerenchyma. The figures of Kalymma ${ }^{6}$, Calamopteris ${ }^{7}$, and Calamosyrinx ${ }^{8}$ should be compared.

A very remarkable fossil is the old Medullosa elegans, Cotta, which was afterwards named by Göppert ${ }^{9}$ Stenzelia from specimens from the Rothliegende of Chemnitz, and then Myeloxylon by Brongniart ${ }^{10}$ from material obtained at Autun. Both authors see more than one stock in this form, and Göppert recognised it as one of his prototypes, which uniting in themselves the anatomical peculiarities of different main groups of the vegetable kingdom, in this case the Monocotyledons and the Ferns, cannot be clirectly classed with any one of them. Williamson ${ }^{11}$ has examined specimens from the English calcareous nodules; the plant has also been found in Bohemia with its structure preserved, for Corda's ${ }^{12}$ Palmacites leptoxylon and P. carbonigerus belong to it. Then on the strength of searching examination of many specimens from Autun and Grand' Croix Renault ${ }^{19}$ declared that Myeloxylon is simply the stalk of a fern-leaf, and

\footnotetext{
' Corda (1), t. 58 , ff. I-5

${ }^{2}$ Göppert (12).

3 Williamson (1), Vir, VII, X. 4 Unger (5).

5 Williamson (1), vi. t. 55 .

- Unger (5), t. 1 .

7 Unger (5), t. 2. Unger (5), t. 3 .

- Göppert (3).

10 Brongniart (2), p. 109.

"Williamson (1), vir.

12 Corda (1), tt. I9, 20.

13 Renault (6).
} 
accordingly altered Brongniart's name into Myelopteris; he also endeavoured to prove ${ }^{1}$ that these leaf-stalks belong to Alethopteris aquilina which is so common a species at Grand' Croix. Since that time no further doubt has been openly expressed with respect to the nature of these remains, though Schenk ${ }^{2}$ has lately contended that they are the leaf-stalks of Cycads and not of Ferns. If I discuss them here with Ferns, it is entirely from motives of convenience and after frequent examination of specimens in my possession; decisive proof of one or the other view appears to me to be still wanting.

The cylindrical leaf-stalks of Myeloxylon ${ }^{3}$ (Fig. 14)-I use this name rather than Stenzelia because it is better known-are of unusually varying
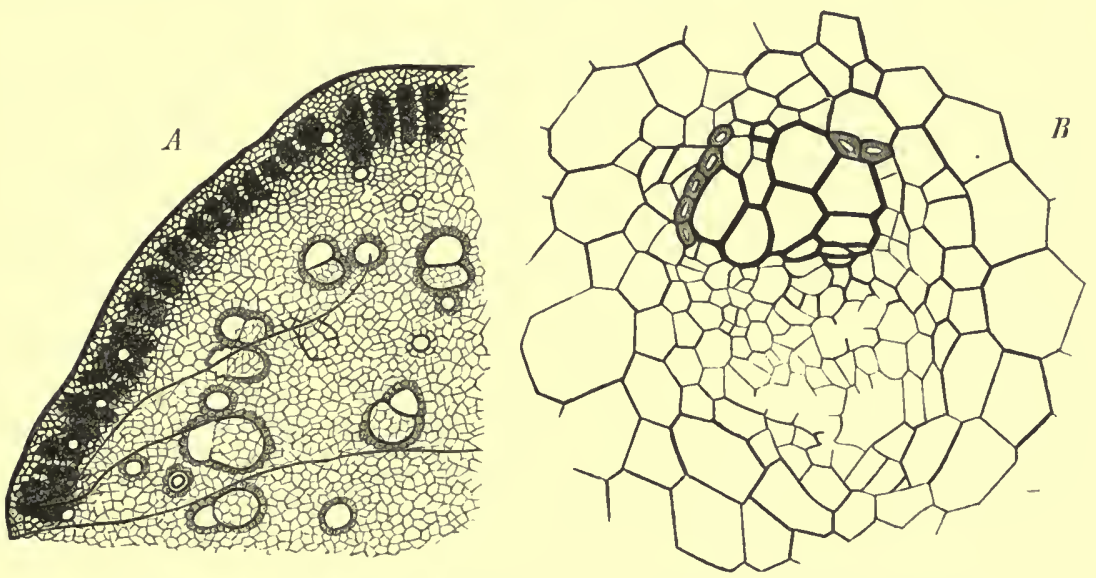

Fig. 14. Transverse section of leaf-stalk of Myeloxylon. A synoptical view showing the subepidermal fibre-strands, the vascular bundles, and the gum-passages. $B$ transverse section of a single bundle with phloem preserved. $A$ after Renault, $B$ after a preparation in my collection.

thickness; I have some before me with a diameter of seven, eleven, and sixty millimetres, and Renault has figured some that are much thicker. Their uniform parenchymatous fundamental tissue encloses a large number of vascular bundles, which though not quite regularly disposed yet form numerous concentric circles. There are also many gum-passages, which are filled as a rule with some dark substance, and may be known by the usually well-preserved epithelium. A rather broad subepidermal zone is quite filled with one or more rows of crowded radiately disposed scleren-

1 Renault (2), vol. iii.

${ }^{2}$ Schenk (9).

3 The latest observations have made it probable that the Myeloxyla are the leaf-stalks of the Medullosae described on p. 103. The owner of the precious bit of Medullosa Leuckarti mentioned there has recently had the lateral branch cut through transversely, and the section seems really to show the structure of Myeloxylon, as far as can be defermined without examination of thin slices. If this unexpected find is confirmed by further investigation, a new and important weight will be added to the scale on the side of Cycadeae. I am indebted to Herr Leuckart's kindness for my knowledge of the specimen in its present state. 
chymatous cell-groups, which sometimes enclose gum-passages, and the differences in the form of the transverse sections of these groups have been employed for distinguishing species. These sclerenchymatous strands which are sometimes much crowded together never, as far as I know, touch immediately on the epidermis, being everywhere separated from it by parenchyma; but it is true that the tissue-layers outside the sclerenchyma-zone are very rarely preserved. The individual vascular bundle shows a very characteristic structure, being undoubtedly collateral with the xylem towards the centre. This part of the bundle, consisting of a variable number of broad scalariform tracheides, shows in all cases, where there is any means of deciding this rather difficult question, the narrow elements of the protoxylem on the side towards the phloem of the bundle, as it is in Cycadeae; but the xylem next the phloem which is present in Cycadcae (the bois centrifuge of French authors) is cntirely wanting. The phlocm-portion is almost always destroyed, and in its place is a broad vacant space. But in bundles in which it is preserved, as is the case in a specimen before me from Grand' Croix which belongs to the collection at Strassburg (Fig. I4, B), it is entirely composed of delicate thin-walled clements of which I can say nothing further, as I know them only in the transverse section. The whole bundle is surrounded by a sheath of small-celled parenchyma, the elements of which, where they border on the xylem, have their membranes thickened to a variable extent and are changed into elongated sclerenchyma-cells. Now when Renault endeavours to prove that the remains which we are considering are of the nature of ferns, he relies chiefly on the following circumstances. First of all it is certain that they were branched. This might have been concluded at once from the very great variations in the diameter, which if referred to one rhachis would have led necessarily to the assumption that the leaf was one of prodigious length. Renault ${ }^{3}$ however has figured a superabundance of branched specimens. The leaf must thercfore have been of considerable size and repeatedly pinnate, and this is the case, as we know, in no recent Cycad except Bowenia. Then it is in the highest degree remarkable that in the pebbles of Grand' Croix Myeloxylon is almost always associated with detached and well-preserved pinnae of Alethopteris, that some fragments contain nothing else,- - a fact which is confirmed by the testimony of Renault and Grand' Eury ${ }^{2}$, and which I can vouch for unreservedly from examination of specimens at my disposal. Lastly, Renault has observed the structure characteristic of Myeloxylon in the very prominent median nerve on the under side of pinnae which belong by common consent and undoubtedly to Alethopteris, and has figured it ${ }^{3}$ also, but unfortunately on so small a scale that his drawings alone would not remove every doubt.

'Renault (2), t. 28 , f. 10. $\quad 2$ Grand' Eury (1). $\quad 3$ Renault (2), vol. iii, t. 27, f. 12. 
Schenk on the other hand takes his stand chiefly on the structure of the vascular bundles, which cannot, he thinks, be reconciled with that of Ferns; he does not go sufficiently into the argument drawn by Renault from the branching. He is no doubt right in saying that the bundles have the habit of those of Cycadeae, as appears more particularly in the position of the protoxylem on the phloem-side of the xylem. But I am not convinced that there is any special resemblance between them and the bundles of Macrozamia, as Schenk contends, for in the latter the xylem on the phloem-side is well developed, while it is entirely wanting in Mycloxylon. Collateral bundles also occur, as is well known, in Ophioglosseae and Osmundaceae, nor are they uncommon in the Ferns generally, though it is true that they are usually found only in the weak ramifications of the nerves of the laminae of the leaves. It is therefore quite possible that in the forms from the Coalmeasures this structure may have extended downwards as far as the axes of the pinnae and the leaf-stalks ; and in our recent Marattiaceae, according to Holle, the phloem is as a rule more strongly developed on one side in all foliar bundles. The view here indicated, and which requires further investigation, is at variance with one fact only, namely that, as Haberlandt has shown, in ferns with collateral bundles in which the protoxylem and protophloëm are in the normal position, the displacement of the former and its approximation to the phloem, which are characteristic of the leaves of Cycadeae and occur also in Myeloxylon, have never been observed. Williamson again, to prove that Myeloxylon is a fern, insists very particularly on the resemblance between it and Angiopteris; but it appears from the foregoing remarks that this resemblance is confined rather to the general habit, though it must be acknowledged that the English fossils which go under that name do appear from preparations, for which I am indebted to Williamson's kindness, to show deviations in structure and to approach nearer to that of Marattiaceae. The figures too in Williamson give an essentially different position to the fibre-strands. And now while I prefer not to give a decided opinion on the systematic position of the leaf-stalk which we have been considering, because I see that further research is required fully to clear up the facts of the case, I cannot help saying that the connection between the laminae of the leaves of Alethopteris and the leaf-stalks of Myeloxylon cannot well be disputed without crediting Renault with mistakes of observation, such as must not in any case be imputed a priori to so experienced an observer. It is another question whether the leaves thus reconstructed, which resemble fern-leaves and by their structure remind us of the leaves of Cycadeae, should be placed in the one or the other class. We cannot decide this question so long as the fructification of Alethopteridae is unknown. Perhaps neither of the alternatives is right; we may be dealing perhaps with an intermediate group, and that there have been such groups is becoming more and more probable. The reader should consult the remarks on this point on p. I4I. 
Before leaving the Rhachiopteridae and going on to fern-stems, it is necessary to mention one fossil, which, if it is really the leaf-stalk of a Fern, would show what great anatomical differences, unheard of in our modern vegetation, must have been exemplified in the ferns of the old deposits. I speak of Göppert's ${ }^{1}$ Sphenopteris refracta from the Carboniferous Limestone of Glätzisch-Falkenberg in Silesia. I am indebted to the kindness of $\mathrm{F}$. Römer for a knowledge of several specimens from the Museum at Breslau, which I hope to be able to examine more thoroughly at some future time. Among them was the original specimen studied by Göppert; the sections

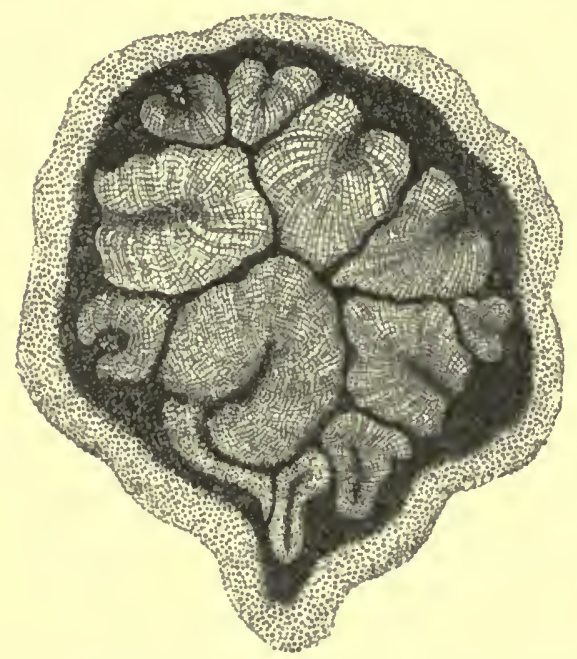

Fic. 15. Transverse section of the leaf-stalk of Sphenopteris refracta, (;opp.; each vascular bundle surrounded by a horseshoe-shaped secondary growth with its convexity turned towards the centre: the bundle is seen in the sinus. After (iuppert with some alteration. which he had before him could not be found. The specimens are irregularly-shaped fragments of very hard calcareous grauwacke, which are traversed in every direction by thin black lines, and show here and there, but not often, minute bits of the pinnae of Sphenopteris. The one figured by Göppert ${ }^{2}$, however, is not to be found in the original stone, and was probably taken from another specinen. The fragments also contain longer portions of stalks which are often broken in the longitudinal direction, and have their structure well preserved. The connection of all these pieces, though it may be assumed to be probable from the peculiar penetration of the stone. has not however been certainly established; for it does not appear even from Göppert's remarks, which are unhappily too brief, whether the rhachis through which his section passed was in direct connection with an evident fragment of a leaf-blade. For this reason I cannot at once dismiss Unger' ${ }^{3}$ opinion as untenable, though $I$ do not myself share it. He declares that the structure of this picce of leaf-stalk shows that it cannot have belonged to a fern-leaf. Certainly its anatomy as illustrated by Göppert's beautiful figures is so peculiar, that I know nothing with which it can be directly compared (see Fig. 15). First there is a moderately thick outer rind formed of tolerably uniform thick-walled parenchymacells arranged in radial rows. Beneath this is a rnuch compressed and inconspicuous tissue, a collection of larger and smaller woody masses of irregular horseshoe-shape, which all turn their concavity outwards, and 
towards the inside impinge so closely upon one another through the pressure of the intermediate tissue that their contour lines seem to be modelled one upon the other. Göppert's fine figure shows that the scalariform tracheides of these woody bodies are arranged in regular rows, which radiate from the interior sinus to the convex outer boundary. At the same time the diameter is very different in the different masses of wood; some larger ones meet together in the centre, while other smaller ones wedge themselves in between their shanks. The preparation which I was permitted to make from the original specimen also showed what does not appear in Göppert's figures, namely that in the sinus of each of these horseshoe-shaped cross sections and surrounded by crushed tissue there lies a small vascular bundle of roundish outline, the peripheral portion of which is everywhere of like structure and appears to enclose within it the narrower elements, though these are not very clearly seen (Fig. 15). Now where the structure is so anomalous, and especially in the absence of more searching investigation into a form which is known only in one or two fragments, it is very venturous to go at all beyond a mere description of the facts. Still in studying the section the thought forces itself on my mind, that in the horseshoe-shaped woody bodies we may recognise secondary growths, the product of cambium, and that these stand in some relation to the bundles in their sinus, either because the bundle was collateral, or the zone of secondary tissue has been developed on the periphery of the phloem. However this may be, we can do no more at present than record the existence of this remarkable fossil ; let us hope that we shall see our way in time to a fruitful comparison.

Fern-stems in great numbers have been described from very various formations. By far the larger part of them, being preserved in the form of casts only, possess extremely small interest for the botanist. When remains of this kind took the form of erect leafy stems with the leaves disposed in spirals, they were included by Lindley and Hutton ${ }^{1}$ and the earlier observers under the collective name Caulopteris. This was certainly better than the process of division commenced by Corda and pursued by various authors, which being founded on unimportant characters could not possibly produce rational genera, and which was less necessary because the number of the stems in question was by no means unmanageable. The scars left by the detached lcaves are in many cases more or less plainly marked on the periphery of the casts. The stems are not unfrequently clad in an armour composed of spirally arranged leaf-stalks of different lengths, which crowded together and interwoven with roots form a covering over the whole surface. Casts of this kind, which do not even show the bundle-traces on the transverse section of the leaf-stalk with any distinctness, are recorded in the 
literature under various generic names, Chelepteris, Cda, Bathypteris, Eichw., Sphallopteris, Sch., Anomorhoea, Eichw. Figures and explanations of these objects are to be found in abundance in Schimper's Paléontologie Végétale. Another genus is Rhizomopteris, Schpr, embracing creeping fernrhizomes, of which however there are not too many known. Nathorst ${ }^{1}$ has figured some fine specimens from the Rhaetic beds of Schonen. One more genus may be mentioned, Schizodendron ${ }^{2}$, with a few stems of similar appearance which have been described by Zeiller ${ }^{3}$. In other forms some characters at least may be obtained from the mode of arrangement of the bundle-traces on the leaf-scars, and genera may thus be distinguished, though these too have but little real importance, as is shown by the fact that the distribution of the bundles cven in recent Ferns becomes so much changed in the base of the leaf and within small distances, that stems with simple scars and stems clothed with leaf-bases cannot be compared together. Moreover Zeiller ${ }^{4}$ has recently shown that two of the genera to be mentioned here, Stemmatopteris, Cda, and Caulopteris, Cda (not Lindl. and Hutt.) may be omitted as being different surface-impressions of the same stem. These two form-genera have on their surface large circular or elliptical scars, which in the former are sharply defined and smooth, in the latter forked, and which almost touch one another in the orthostichies. Each scar contains a closed circular or elliptical tracc, and inside this another small trace in the form of a $\mathrm{V}$ or $\mathrm{U}$ opening upwards. Zeiller ${ }^{5}$ would see in the peripheral contour-line of the scar the boundary line of the leaf-cushion, in the outer trace the boundary-line of the detached leaf-stalk, and only in the inner $\mathrm{V}$ the bundle-trace. But it is also possible that, as was supposed by the older authors ${ }^{6}$, the inner circular line may represent the trace of a circular vascular bundle, in which case the $\mathrm{V}$ would answer to the emerging strand of a medullary bundle-system. We cannot hope to determine this point till we find a stem of the kind with its structure prescrved, and this has not yet been done. The name Protopteris is given by Corda to all stems which have a single trace in their leaf-scars of the shape here represented $§$. He has described several of these stems from the Coalmeasures ${ }^{7}$, and one of the same kind from the Permian formation under the name of Thamnopteris Schlechtendalii ${ }^{8}$. Protopteris Witteana ${ }^{9}$ belongs to the Wealden, the stem named Dicksonia Buvignieri ${ }^{10}$ to the Chalk. Other individuals from the Chalk of Bohenia with a more complex and many-stranded trace in the leaf-scars will be found figured in O. Feistmantel ${ }^{11}$ as Alsophilina Kaunitziana, Dorm., and Oncopteris Nettwallii, Dorm.

1 Nathorst (2), t. 1, and (4), 1. 1 . $(9)$ t. $18 . \quad$ Zeiller $(9)$ and $(10)$. Eichwald (1), vol. i, t. 3, ff. 2, 3. vol. iii, p. 73 , t. 9 .
2 Fichwald (1), vol. i, 19, f. 9, and t. 20, f. I1. ' Zeiller ${ }^{3}$ Zeiller (9). ${ }^{6}$ Sehimper (1). ${ }^{7}$ Corda (1). - Schenk (1), p. 226. t. 30, f. $6 .{ }^{10}$ Renault (2), 
All the stems hitherto described are marked by the spiral arrangement of the leaves and the numerous orthostichies; from these the genera Megaphytum, Artis and Zippe, Corda, which are only known in the form of casts, are most sharply distinguished by the exactly distichous position of their leaf-scars. These genera have no direct analogies in recent vegetation, for all recent fern-stems with distichous arrangement of the leaves are prostrate and creeping, which was certainly not the case with the genera in question, for their structure is radial and exactly the same all round, and there is no indication that one side was turned to the soil and bore roots. The Megaphyta, of which many good figures are to be found in the literature ${ }^{1}$, appear to have been confined entirely to the Coal-measures; their huge shield-like leaf-scars are circular in form and in appearance like those of Stemmatopteris. The large bundle-trace has usually the shape of a crescent opening upwards and with its horns bent inwards. There may also be other smaller traces, the character of which has still to be investigated. From the scale of the flattened cylindrical casts, a metre in length, which are met with occasionally, it would appear that these plants must have had tall erect and somewhat slender stems. A magnificent specimen is preserved in the collection of the Bergschule at Saarbrücken. The genus Zippea ${ }^{2}$, founded on a few remains from the Bohemian Coal-measures, is closely allied to Megaphytum, and the trace has the same character as in that genus, but the leaf-scars are much smaller and less prominent.

It has been already observed more than once that we are as a rule acquainted only with casts of the fern-stems of which we have hitherto been speaking. The inner structure can only be distinguished in a few cases, but in these it is found not to differ essentially from the ordinary structure of recent stems. This will be seen by examining Renault's ${ }^{3}$ figure of his Dicksonia Buvignieri, as also the transverse section of Caulopteris Cottaeana ${ }^{4}$, of which however there is no figure showing the habit; the drawings also of Pecopteris Cottai ${ }^{5}$ may be mentioned in this connection. It is uncertain whether this form comes from the Coal-measures or from the Rothliegende, since it has been found in the district of Schwemmland in the neighbourhood of Grossenhain in Saxony. The broad pith of this stem, of which I have scen a transverse section in the Geological Department of the British Museum, is traversed by a rank growth of thin extraneous rootlets which look at first sight like medullary bundles. A well-preserved stem of this kind from the Turonian Chalk of Oppeln has been described by Stenzel ${ }^{6}$ as Protopteris fibrosa. From the same formation we have the specimen covered with a felt of roots and named by Göppert Rhizopterodendron Oppoliense, which is

1 Schimper (1), t. 52 .

2 , vol. iii, t. 8 , f. 10 .
${ }^{2}$ Corda (1), t. 26.

5 Corda (1), 1. 49 .
3 Renault (2), vol. iii, p. 73 , t. 9 .

- Stenzel (3), t. 3, ff. 30-36.

4 Renault 
also described as belonging to our present group and as coming from the same locality. In Zippea disticha ${ }^{1}$ also it has been shown that the vascular bundles formed a simple hollow cylinder. It is true that we have only the cast of the stem, but the bundles are preserved inside it as quite thin strips of coal inclosed in the mass of stone; this is a mode of preservation which as far as I know is observed only in Saxony and Bohemia and near St. Etienne, but which is of frequent occurrence in these districts, especially in the fine clays of Radnitz and the fine-grained sandstones of the Coal-measures of Chomle.

But there is another series of fern-stems from the Upper beds of the Coal-measures and from the Rothliegende, of which, in exact contrast to those just discussed and by reason of their mode of preservation, we know a good deal of the inner structure but very little of the character of the surface. These stems, which bear the collective name of Psaroniae, are distinguished by a system of circular vascular bundles one inside another like box within box, and show the structure characteristic of recent Marattiaccac, and of a few genera, such as Saccoloma, among Cyatheaceae and Polypodiaccac. And now that we know how large a number of Ferns in the period of the Coal-measures had the fructification of Marattiaceac, we have some justification for thinking that we see in the Psaroniae the stems bclonging to these fructifications, though their mutual relations cannot be determined in all their details. The silicified Psaroniac of the Rothliegende of Saxony and Bohemia have long been known, having been cut up wholesale during the last century to make ornaments for all kinds of objects on account of the graceful designs which appear in the sections, so that very few of them are now to be found. The surface is never preserved either in them or in the similar specimens from Val d'Ajol in the Vosges, from Kammerberg near Ilmenau, from Autun or from St. Eticnne. I have also seen spccimens in the same state of preservation in the British Museum from the state of Ohio and from Brazil. They are usually shapeless fragments of small dimensions and weathered on the outside, but longer cylindrical stems of the kind are to be found in a few museums. Fragments of Psaroniae, in the same state as Zippea disticha, Corda just described, are also met with near Zwickau, Chomle and Radnitz, and are easy to recognise by the peculiar arrangement of the vascular bundles which have been converted into strips of coal. Lastly, Grand' Eury ${ }^{2}$ has found in the mines round St. Etienne whole stems in this state of preservation, still rooted in the soil in which they grew, and has figured them under the name of Psaroniocaulon. From these, as also from some of the silicified specimens, we learn that the stems of these plants were long and cylindrical, and that the very gradual conical enlargement which appears in them towards the base is chiefly due

$$
\text { 'Corda (1), t. } 26 . \quad 2 \text { Grand' Eury } 1,1,11 .
$$


to the development of a covering of adventitious roots, which is of almost universal occurrence. It is this thick felt of roots more than anything else which conceals from our view the surface of the stem and the form of the trace in the leaf-scars. There are no silicified specimens without this covering, if we except Caulopteris Giffordi, Lesq. ${ }^{1}$ from the Coal-measures of Illinois which belongs here, and only a few instances can be adduced among the stems that are preserved as casts, and these perhaps represent the uppermost portions of the stem. Here too the leaf-scars are indifferently preserved as regards matters of detail, though it appears that the relative positions of the leaves were not always the same; in Psaronius Freislebeni ${ }^{2}$, for example, the leaves are in spira!s with six orthostichies, while P. arenaceus $^{3}$ shows only four orthostichies and P. carbonifer (P. musaeformis, Corda $\left.{ }^{4}\right)$ has its leaves in two lines after the manner of Zippea and Megaphytum. That there are the like differences also in the stems which are surrounded with a covering of roots may be concluded from the distribution of the vascular bundles, which goes hand in hand with the position of the leaves.

The anatomy of the stems of Psaroniae is very well known, thanks to Stenzel's ${ }^{5}$ careful and comprehensive researches founded chiefly on materials from Saxony and Bohemia. The French specimens and those which are not European have not yet been sufficiently studied. In the parenchyma, which has in very many cases been destroyed, we find the characteristic concentric net-work of vascular bundles, the several circles of which appear to be united together here and there by radial connecting strands. The transverse sections of the vascular bundles form broad curved plates which in many cases have their margins bent inwards till they become hooked, and are developed in larger or smaller numbers and are quite loosely or extremely closely packed, according to the species. An instance of loose arrangement of the bundles is seen in Psaronius Bibractensis ${ }^{6}$, in which moreover, in contrast to all other known species, solid sclerenchyma-bands of the same shape as the vaseular plates are seen lying between them. The opposite condition appears in P. infarctus, Ung. ${ }^{7}$, in which the plates almost touch one another. A firm lignified sheath enclosing the whole bundlesystem of the stem is often present, but may be wanting both in this and in other species. The relative position of the vascular bundles on the transverse section of the stem is different in different species, and this is in direct connection with the phyllotaxy, as we learn from the specimens described above, which are preserved in the form of casts and show the outer surface. In the specimens which have the leaves arranged in two lines (Fig. 16) they

1 Lesquereux (1), p. 343, t. 60, ff. I, $2 . \quad{ }^{2}$ Corda $(1)$, t. $29 . \quad{ }^{3}$ Corda $(1)$, t. 28, ff. 5-9. Corda (1), t. 45, f. 3. ${ }^{5}$ Stenzel (1); Göppert (3). ${ }^{6}$ Renault (2), t. 26 , f. $2 .{ }^{7}$ Göppert (3), t. 5, f. I. 
form a transverse row in such a manner that all the margins of the bundles are towards the sides on which the leaves arise. Here we see the emerging leaf-traces in the form of crescents surrounded by lateral sinuses in the sclerenchyma-sheath, when this is present. In some cases the extremities of the bundle-plates are united together by irregular bridges, the section having passed exactly through a connecting strand. The arrangement is much less regular in stems in which the phyllotaxy presents numerous orthostichies; here the transverse section shows one or more bundles passing into the leaves, and from this Stenzel would conclude that the

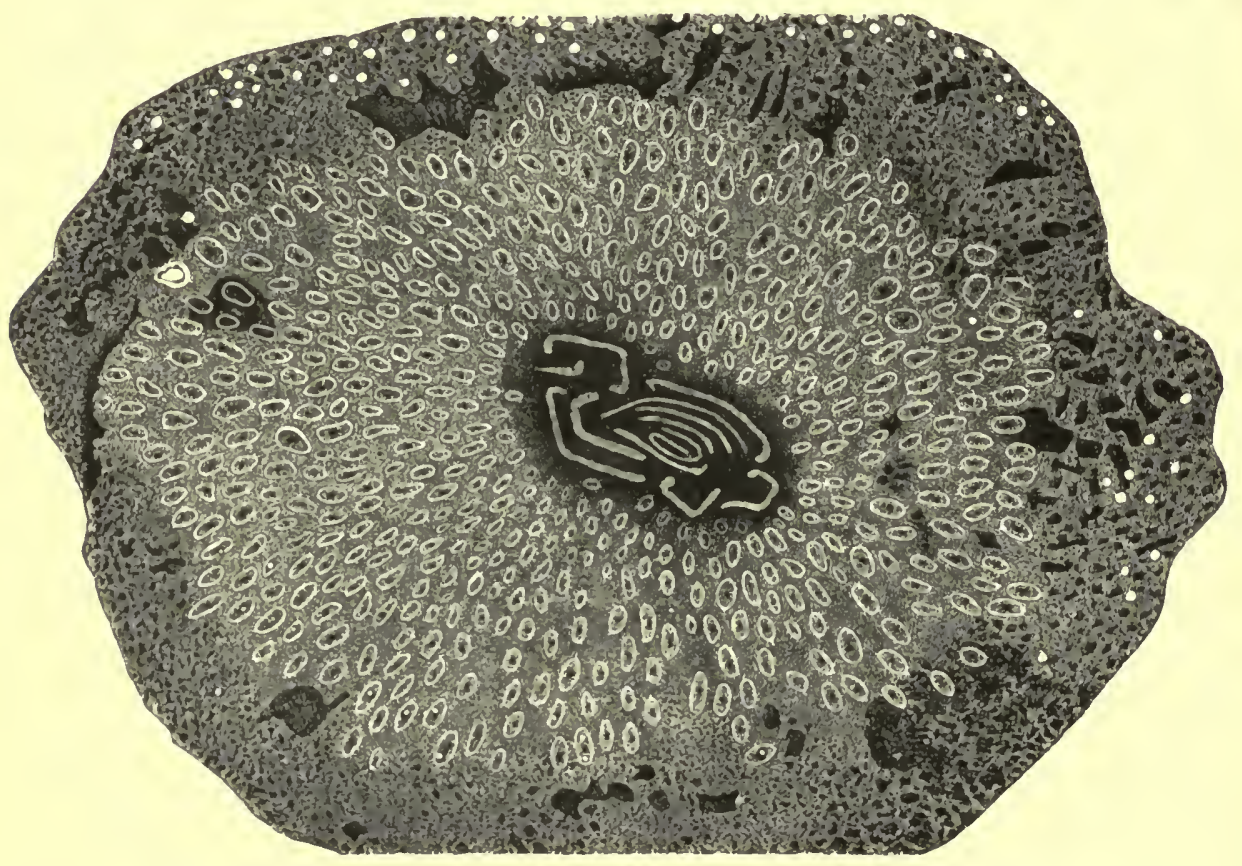

FIl, 16. Transverse section of Psaronius Guthieri, $\mathrm{Cda}$ The thick cortex is pierced by ummerous adventitious roots. In the centre of the stem are vascular bundle-plates in two lines a little displaced; on one side of them and answering to the gaps between them are the strongly curved bundles of the emerging leaf-traces. From Zittel's Text-book.

leaves were arranged in spirals and whorls.- But we may more readily refer these differences to the different elongation of the internodes in different species. In the case of very short internodes the traces of several leaves would naturally be together on the same transverse section. There is a fine apparently tetrastichous Psaronius to be seen in well-preserved silicified specimens in the British Museum, which would be suitable for the determination of this question and which should be carefully examined. It appears to have come from Brazil, and is said to have been brought by Claussen from the Museum at Rio Janeiro. It is, as far as I know, the only known specimen of a tetrastichous species in a condition to show the 
structure. I may take this opportunity of saying that I am indebted to the kindness of Herr Schwacke of Rio Janeiro for some notices of stems of Psaroniae preserved in the museum in that city. The chief specimen, forty centimetres in length, appears from the drawing before me not to belong to the same species as the disks in the British Museum. Its history unfortunately is not certainly known, but various fragments of Psaroniae have been discovered in the provinces of São Paolo and Paronà, in company as usual with Araucaroxylon.

The centre of the stem thus constituted is surrounded by a rind of parenchymatous tissue of varying thickness, which is always so pierced and traversed by countless crowded unbranched adventitious roots running almost perpendicularly downwards, that its tissue appears as if it were only complemental tissue between the transverse sections of the roots. Each of these roots has a central stellate usually hexarc strand of xylem inclosed in a primary cortex of compact or loose parenchyma, which is surrounded on the outside by a strong dark-coloured cylinder of sclerenchyma; the phloem-strands in the sinuses of the xylem are scarcely ever preserved. The sclerenchymatous tissue has no very sharply defined boundary-line, but appears to be in immediate communication with the tissue of the stem traversed by the roots; this, according to the analogy of Ophioglossum and of the roots which grow downwards in the base of the stem of tropical Lycopodiae, can only be due to very intimate secondary coherence of the two parts. Stenzel ${ }^{1}$ it is true takes a different view of the matter; he speaks of the roots, so far as they are inclosed in the cortical tissue of the stem, as root-primordia; but this view is not easy to reconcile with what we know from more recent researches of the mode of formation of adventitious fern-roots. The sclerenchymatous envelopes of the roots are seen on the transverse section as delicate brown circles; the pitted appearance which they produce on the surface of the section has given occasion to comparison with the breast of the starling, and in Germany to the trivial name of Staarstein. We should expect to find everywhere between the transverse sections of the roots the transverse sections of the leaf-traces cut through at different points in their course; but they are not to be seen, or only to a very limited extent and only in the vicinity of the axis of the stem. It is conceivable that the trace on issuing from the leaf separates at once into numerous bundles of minute size on the transverse section, and that these are lost to sight amid the mass of roots. On the other hand, we may assume with Stenzel a considerable growth in thickness of the peripheral parenchyma, the entire cortex, and that this takes place also at the surface where the leaves are detached from the stem and causes the extremities of the bundles gradually to disappear within it. 
The mass of roots which surrounds the axis may attain an enormous size and much exceed the diameter of the centre of the stem. In the specimens from St. Etienne preserved as casts it appears as a layer of carbonaceous substance, which increases constantly in size as it approaches the base of the stem; it can be recognised in this form in the sections of Psaronius carbonifer, Cda, figured by Corda ${ }^{1}$. Its size in the silicified specimens is in favour of the view that they are entirely the bases of stems. Careful examination shows that this peripheral investment consists of two distinct layers: first, the rind of the stem above described which is traversed by the roots; next, a mass of closely interwoven roots which project free above the surface, where they also show ramifications. These roots are of course distinguished from the basal portions in the rind by the circumstance, that while sharply defined on the outside they still show a narrow parenchymatous rind lying outside the cylinder of sclerenchyma. Specimens showing the entire transverse section with the centre of the stem and the whole of the enveloping mass of roots are rare. By far the larger part of the Psaroniae preserved in collections are fraginents of the envelopes, sometimes of extraordinary dimensions. Similar silicified masses of entangled roots, belonging to other ferns and found in a fragmentary state at Chemnitz, have been described as roots of Protopteris by Stenzel ${ }^{2}$, who compares them with Corda's ${ }^{3}$ figure of his Protopteris microrhiza. They are distinguished from those of P'saroniac by diarc root-strands. Such strands are found also in the compact root-investment of the stem known as Rhizopterodendron Oppoliense, Göpp. with the structure of Protopteris, which comes from the Turonian beds of Oppeln, and for which Stenzel's * claborate description should be consulted.

Two small fern-stems, in which the thin herbaccous axis is surrounded by a closed woody panoply of leaf-stalk-bases lying close one on another, are described in the literature under the name Osmundites. These are Osmundites Schemnicensis ${ }^{5}$ from the Tertiary quartz rocks of Ilia in Hungary, and O. Dowkeri ${ }^{6}$, also a Tertiary fossil from the Lower Eocene beds of Herne Bay in England. A third quite similar silicified specimen, not yet described, was picked up as a loose stone in the alluvium of the lower course of the Lena in Sibcria, and has found its way as part of Blumenbach's bequest into the palaeontological collection of the University of Göttingen. The centre of all these stems is occupied by the ring of vascular bundles composed of very irregularly shaped transverse sections of bundles and surrounding the parenchymatous medullary tissue. On the outer side of this ring is a thick envelope of sclerenchyma, which is traversed by the crescent-shaped leafbundles, and to which the free leaf-stalks ultimately become attached. The

1 Corda (1), t. 2 s. 2 Stenzel $(2$.

${ }^{3}$ Corda (1), t. 50, If. 7-10.

Stenzel (3,

\footnotetext{
s Unger $(\varepsilon)$. $\quad$ Carruthers $(\varepsilon$.
} 
sclerenchyma is less conspicuous in the small Göttingen stem ; every section through one of its leaf-stalks shows in the concavity of a crescent-shaped transverse section of a leaf-trace two other smaller roundish leaf-trace-sections. The determination of these objects as stems of Osmundaceae rested at first on the habit only, which does certainly agree absolutely with that of Osmunda. But now that leaves have also been found in the same freshwater quartz rocks in Hungary which have been declared to belong to Osmunda ${ }^{1}$, we must certainly allow that there are good grounds for this determination, though it has not been proved that the stems have the characteristic course or the collateral structure of the bundles of Osmundaceae. The habit alone would scarcely be sufficient, as is shown by a small and remarkable stem from the Rothliegende of Chemnitz, which was first described by Cotta ${ }^{2}$, and has received from Corda ${ }^{3}$ the name Asterochlaena Cottai, Corda. A full description of this fossil is to be found in Göppert ${ }^{4}$. I have myself had opportunity of seeing a transverse section of it in the British Museum which came from Cotta, and other specimens in the municipal collection at Chemnitz. On superficial examination it recalls Osmunditae, but it is distinguished from that group by one very important particular; instead of a vascular bundle-ring in its axis, it has a single central bundle of considerable dimensions and with an irregularly stellate transverse section, the rays of which are variously curved and sometimes also split into diverging branches. This is a structure without a parallel in living Ferns, but something like it occurs apparently in another small stem from the Upper Devonian beds (Portage group) of New York, which Dawson ${ }^{5}$ has described and named Asteropteris noveboracensis, Daws. Here too there is a star-shaped xylem-bundle in the axis with long rays, which may be simple or regularly branched. A peripheral sclerenchymatous tissue incloses leaf-traces with a peculiar biscuit-shaped transverse section. Dawson has unhesitatingly placed this genus of his with Ferns, but from his own statements it is not impossible that it may belong to Lycopodiaceae; and Unger's ${ }^{6}$ Cladoxylon, with which he compares it, is usually ranked with that group. Cladoxylon itself will be considered in a later chapter with Lycopodia.

Lastly, some very small herbaceous stems with simple structure are seen in the genera Zygopteris and Botryopteris, the fructifications and leafstalks of which have already been considered. That the stems in question do belong to these genera is well ascertained, for Renault ${ }^{7}$ has found them in actual connection with the characteristic leaf-stalks. In Zygopteris the vascular body lies in the uniform parenchyma, which is traversed by numerous leaf-traces, in the form of a closed ring surrounding a pith which

\footnotetext{
${ }^{1}$ Schimper (1), vol. i, p. $678 . \quad{ }^{2} \operatorname{Cotta}(1) . \quad{ }^{3} \operatorname{Corda}(1)$, p. 8 I. $\quad$ Göppert (3), p. 41 ; t. 9, f. I. "Dawson (4), t. 12 . $\quad{ }_{7}^{6}$ Unger (5). Renault $(2,4,5,7)$.
} 
puts out rays in a stellate manner; in Botryopteris there is only a simple central strand with a roundish transverse section. The examination of Tubicaulis primarius ${ }^{1}$ seems indeed to show that there were other and much thicker stems with the structure of the leaf-stalk of Zygopteris, for tolerably large fragments of that species have been found which have all the characters of Tempskya (sce above on p. 159).

1 Cotta (1). 


\section{VIII.}

\section{EQUISETACEAE, MARSILIOIDEAE, TRAQUAIRIA, SPOROCARPON.}

THERE is nothing more indicative of the revolution, which has been accomplished in the domain of palaeophytology during the last twenty or thirty years, than the fact that the Equisetaceae, which were formerly considered to be the best-known of all fossil vegetable remains, are now one of the groups with which we are not so well acquainted. The reason is that, except in the case of Calamariae whose connection with Equisetaceae is doubtful, we have no remains of this family before us in the form of petrifactions showing structure, but are limited entirely to casts and impressions. The smaller leafy branches and fructifications, the latter very few in number, are known only in the form of impressions; the main stems, which are sometimes of great size, are usually found as casts; and these may be either casts of the broad cylinder of pith surrounded by a rind of coal, or may represent the outer surface of the stem itself. Consequently it is from the habit chiefly that the remains are determined; we conclude that they are Equisetaceae from the sheaths with their toothed margins, from the big interior casts which point, as was said, to a broad cylinder of pith, from the striated surface, and from the remains of fructifications which may happen to be found with them. But most of these determinations in the absence of any knowledge of the anatomy are to a certain extent insecure; and this insecurity is the greater, because we are acquainted with a series of forms having exactly the same habit, the Calamariae, in which the structure is in many respects essentially different from that of our living Equisetae, and because we do not know whether the forms supposed to be Equisetaceae agreed in this respect more with the one or with the other group. The latter difficulty meets us of course chiefly when dealing with the remains of the Palaeozoic and Mesozoic deposits; doubts and considerations of the kind are less important in the case of the many described Equisetitae from the Tertiary formations which will be found collected together in Schimper ${ }^{1}$. The period of the greatest development of Equisetaceae appears to have been

${ }^{1}$ Schimper (1), vol. i, p. 259. 
that of the Trias, the most gigantic forms of the group being peculiar to the upper members of that formation. Their importance in the general vegetation diminishes as we reach Jurassic times, while in the Coal-measures in the other direction only a few impressions have been found and these not wholly above suspicion.

The best-known remains of Equiseteae belong to the genus Equisetites, which Schimper frankly terms Equisetum. One of the most typical species and at the same time the most gigantic in size is Equisetites arenaceus, Bronn, which is characteristic of the Keuper and especially of the Letten Kohle, and is found in splendid specimens in the Stuttgart Schilfsandstein in the neighbourhood of Wuirzburg and Heidelberg. Many good figures of it are given in Schimper ${ }^{1}$. This species has been found in the above localities in very various states of prescrvation Large cylindrical pieces of erect shoots which may be of the thickness of an arm are of very frequent occurrence, and show the leaf-sheaths and the surface of the internodes both in the mould and on the cast. The surface is characterised, as in living species, by alternating ridges and furrows, which are not very prominent on the whole but become more distinctly marked towards the sheath. The alternation of these is often plainly to be seen on the successive internodes, but is sometimes obscure. The sheatlis are tubular and are closely applied to the stem; they have their upper margin divided into short but very numerous teeth (Schimper states that he has counted more than one hundred in stout specimens), and each tooth ends in a long thorn-like process. The basal portions of the erect shoots, by which they are attached to the rhizome, are sometimes disclosed to view. Pieces of stem of this kind narrow gradually and become conical, the internodes being shortened at the same time; they are thus easily distinguished from the upper extremities of shoots, which are also sometimes preserved and are seen to narrow but slightly and to be rounded off into a dome-like termination. We sometimes get a view of such shoot-tops, especially in buds formed on the rhizome, either vertically compressed or from above ${ }^{2}$, and then the shortened internodes with their sheatlis are seen as so many concentric circles.

Nodal diaphragms of solid construction are found in Equisetites arenaceus, as in our living species; they are often preserved, and are then usually attached to the sheaths which belong to them. They are not unfrequently disclosed in splitting the stone, especially where the stems lie across the stratification; the sheath is in that case always vertically compresscd and spread out flat. The diaphragm, when well preserved, shows a flat unsculptured central field and a raised and rounded ring, in which the impressions of the vascular bundle-system can be distinguished as radiating furrows or folds. It is possible that Emmons' ${ }^{3}$ genus Lepacyclotes from the

$$
\text { Schimper (1), tt. 9-11. } \quad 2 \text { Schimper (1), t. 9, f. 3. } \quad \text { SEmms (1), t. 3, ff. 4, } 6 .
$$


Keuper of N. Carolina may be such a sheath-bearing diaphragm of an Equisetaceous plant.

Casts of the broad medullary cavity of the stem are also extraordinarily abundant, finely striated cylinders, which separate by sharp incisions into portions answering to the internodes; the striation, following the course of the vascular bundles, is quite regular in its alternations. Each furrow in such a cast may have come from a vascular bundle, which projected as a slight rib on the wall bounding the medullary cavity. The incisions at the nodes are the places where the homogeneity of the cast is interrupted by the presence of the diaphragms. Objects in this state of preservation are described in the older authors as Calamites arenaceus on account of their resemblance to stems of Calamitae which we shall consider presently; their connection with Equisetites was first demonstrated by Petzholdt ${ }^{1}$ and Ettingshausen". The latter states that he has seen Equisetitae in Bronn's collection, which had a Calamites arenaceus inside it as an interior cast. Portions also of the rhizomes of the plants occur frequently in a similar state of preservation to that of the erect stems, and sometimes with the lateral buds of the shoots attached ${ }^{3}$. They are distinguished, where the surface can be seen, by the absence of the leaf-sheaths which were destroyed at an earlier period, and by the numerous scars of larger branches and stems present on the nodes. Together with all these remains there have been found in the sandstones of the Keuper in many localities casts of the shape of roundish usually somewhat flattened tubers often with folds on the surface, which show an insertion-scar on one side and are of considerable dimensions, though their size varies greatly ${ }^{4}$. Though these bodies have never been found, as far as I know, actually attached to the rhizomes', yet a consideration of the facts in the case of Equisetites Burchardti, Dunk. is sufficient to show that they are the well-known thickened portions of rhizomes of our Equiseta. The Museum at Göttingen contains plates with long pieces of the rhizome of this much smaller species, which is found in the Wealden of Hanover, and to these are attached a number of the roundish tubers which are similar in character to them. Schenk ${ }^{5}$ gives a figure of one of these rhizomes. Lastly, the soft gray clays of the Lettenkohle of Basle have supplied, in company with numerous flattened stems of Equisetites arenaceus preserved in their rind of coal, groups of the moulds of polygonal scutiform bodies ${ }^{6}$, which are said to be the remains of the fructifications of the stems. It is quite possible that this view is correct. Each shield has a flat space in the centre (the apical surface), which is bordered all round with narrow right-angled sloping planes answering to the number of its sides.

1 Petzholdt (1).

(1), t. I1, f. 4 .
2 von Ettingshansen ( 8 ). ${ }^{3}$ Schenk (1), t. 22, f. 1 .
3 Schimper (1), t. 10, f. 3 .

- Schimper (2), p. 162, f. 4 .
- Schimper 
In the formations which succeed the Keuper much smaller species take the place of Equisetites arenaceus; E. Münsteri, for example, which has been fully discussed by Schenk ${ }^{1}$, is characteristic of the Rhaetic deposits. This species is distinguished by its broad flat furrows and its sharp ribs, of which there are a few only in the circumference of the stem. A globular fructification has been found attached to the organs of vegetation. In E. columnaris ${ }^{2}$ from the Lower Oolite of Scarborough and Whitby we have another colossal form resembling E. arenaceus. Several smaller species from the same formation in the Southern Alps have been examined by Zigno ${ }^{3}$; of E. Burchardti from the Wälderkohle we have already spoken. It is unnecessary to go further into the consideration of the many forms described from the more recent formation.

Having thus proceeded upwards in our survey from the Equisetites arenaceus of the Keuper, we must add a few words respecting the pre-Triassic Equisetaccae. There are first the remains from the Coal-measures which Schimper thas brought together under the name Equisetides. As these are only short bits of stem with single sheaths and nothing is known of the fructifications, they must be classed among the most doubtful of fossils. Equisetides lingulatus ${ }^{5}$ from the Coal-measures of Wettin and $\mathrm{E}$. brevidens ${ }^{~}$ may be mentioned as the best-known examples. The more thorough examination of these species must be preceded by the procuring of material from the coal-districts, for there are but few specimens in the collections. They do not appear to be at all abundant, but they are inconspicuous and may have been overlooked. The reader should refer to the remarks which will be found on a later page in connection with Cingularia and Calamostachys. Dawson ${ }^{\top}$ has figured as Equisetides Wrightiana a very unlikely looking fossil from the Upper Devonian beds of Chemung; this according to $\mathrm{Hall}^{8}$ is the remains of a Crustacean, and represents two abdominal scgments of a creature not unlike the genus Stylonurus.

Here must be mentioned the fossil known as Equisetum mirabile ${ }^{\text {, a }}$ peculiar form, in which there is much that still remains to be determined; a full discussion of it accompanied by fine and careful figures will be found in Weiss ${ }^{10}$ and Stur ${ }^{11}$. The latter author has founded a new genus for this plant, and named it Eleutherophyllum. Equisetum mirabile is one of the very rarest of the fossils of the Coal-measures, and has hitherto been known only in a few fragments of impressions from the Waldenburg district. Stur has given the names of the Museums in which these specimens are preserved.

1 Schenk (3). vol. i, p. 286 .

7 Dawson (4).

t. I, f. I $a$ and $b$.

p. Iร I ; t. I, ff. I-;.
${ }^{2}$ Brongniart (1), vol. i, t. I3. ${ }^{3}$ de Zigno (1), vol. i. $\quad$ Schimper (1), ${ }^{5}$ Germar (1), t. 10, f. 3; Weiss (5), t. I6, f. 10. ${ }^{6}$ Schimper (1), t. I 7, f. 4 . - Wright (1), Explanation to t. 15, f. I. ' Sternberg, Graf von (1), Heft 5-8, 10 Weiss (6), p. 133 ; t. 18, f. 2, and (5), p. 149; t. 16a, f. 9.11 Stur (5), 
The thick cylindrical flattened stems are divided by many nodes into very short members with longitudinal waved ribs, which alternate regularly from node to node. The nodes bear impressions of organs which are supposed to be leaf-teeth with flatly rounded extremities. These leaf-teeth according to Stur are free, according to Weiss they are united below into a sheath. A peculiar sculpture observed on the surface indicates according to Stur the presence in each tooth of a sporangium, which glimmers faintly through the surface of the leaf; the whole would therefore belong to the fructifications. But Weiss has been unable to convince himself of this; he believes that the appearance is due to small folds caused by the firn pressure of the sheath upon the zigzag line connecting the ribs, which unite together in the nodes. Further examination of fresh material must decide these questions. I have no opinion of my own, having had opportunity for a hasty look only at the plant.

The genus Schizoneura has found its place next to Equisetites since Schimper's ${ }^{1}$ description laid the foundation of our knowledge of the group. The oldest known species is from the Buntsandstein of the Vosges. A second very closely allied form, S. Gondwanensis ${ }^{2}$, from the Lower Gondwanas (Trias) of India has since been described and illustrated by numerous figures; I have seen one specimen of it in the Botanical Department of the British Museum. Two other species are less exactly known, S. Meriani ${ }^{3}$ from the Lettenkohle and S. Heerensis, Schpr. ${ }^{4}$ The stems of Schizoneura are divided into members and striated; O. Feistmantel distinctly states that the ridges do not alternate. The long lax cylindrical sheaths which loosely embrace the stem have very short teeth to the upper margin, and being torn in process of time between the fine nerves down to the base they become separated into two or more spreading lobes of unequal breadth, which look like whorls of leaves of some monocotyledonous plant, and have given rise to the name Convallarites as employed by the older authors. Numerous leafless stems and casts with the character of Equisetaceae, and found with the leafy branches in the Lower Gondwanas, have been united by O. Feistmantel with Schizoneura.

Of the genus Phyllotheca, Brongn. we have in Europe only a few remains in the Oolitic strata of the Southern Alps, and these have been described by Zigno ${ }^{5}$ as $\mathrm{Ph}$. Brongniartiana and Ph. equisetiformis. Several other species, among them $\mathrm{Ph}$. australis originally described by Brongniart ${ }^{6}$, are peculiar to the Trias of Australia ${ }^{7}$ and the Lower Gondwanas of India. Some other forms have been discovered in the Oolitic strata of Siberia by

${ }^{2}$ Schimper (3), tt. 24-26, and (1), vol. i, p. $282 ;$ tt. 13,$14 ;$ Zittel (1), p. 161. ${ }^{2}$ Pal. Ind. ser. XII, pt. II. ${ }^{3}$ de Zigno (1), tt. 7,8 .

S Schimper (1). 6 Brongniart (4), p. 15 I.

4 Nathorst (3), t. I; Heer (14), tt. I, 2. mantel $(1$, III. 
Heer ${ }^{1}$ and Schmalhausen ${ }^{2}$; in the latter author will be found an incidentally inserted monograph of the genus. Lastly, Equisetum laterale, Phill. from the Lower Oolite of Scarborough ${ }^{3}$ has been removed by Heer to the genus Phyllotheca, to which it must belong rather than to Schizoneura where it is placed by Schimper ${ }^{4}$.

It is chiefly by their habit that the leafy shoots of Phyllotheca are distinguished from those of Equisetitae. The striation according to Schmalhausen does not alternate in the successive internodes. The leaf-sheaths are closely appressed, becoming wider and funnel-shaped above in some species; their margin bears an unusually large number of linear much elongated obtuse one-nerved teeth, which diverge and curve outwards, and are sometimes again incurved at the points and become hooked. These long-spreading sheath-tecth give a very peculiar habit to the genus (Fig. $17, A$ ). In Phyllotheca indica and in the Siberian form $\mathrm{Ph}$. deliquescens, Schmalh. the branches are said to be arranged in whorls at the nodes, in other species to stand singly and with their points of insertion in some cases bencath the node-line, in others above it. This is all that I can say with respect to the characters of the branching, as I have no knowledge of the original specimens. Casts accompany some of the species, according to $\mathrm{M}^{\mathrm{c}} \mathrm{Coy}$ and Schmalhausen, and show the well-known striation, but have the nodal lines less deeply incised. If there are any branch-scars, they are placed exactly on the node.

Circular disks of peculiar appearance are often found with the branches of Phyllotheca, and are usually explained to be the nodal diaphragms of that genus. They lie most frequently on the internodes of the leafy stems on one side of them. They occur with Equisetum laterale, Phill. from Scarborough in the same manner as with the Asiatic forms, and have given it its name, and it is for this reason that Heer has removed the plant to Phyllotheca. The disks show very pretty sculpturing. They are plane and smooth in the middle, but their curved margin is marked with a strong radial striation. I have seen many specimens in the Museum at Oxford with a thick covering of coal, which was split at the periphery into numerous lobes corresponding to the striation, and on the lobes appeared small and peculiar scars. In presence of these facts the usual explanation of these structures appears to me, as to Heer, very doubtful. If it is correct, it is not easy to see why they are so often found in a lateral position at the middle of the internodes; we are driven to the very arbitrary assumption, that they represent the lowest nodes of the lateral branches which were inserted above the line of the nodes of the stem.

Various objects have been taken for fructifications of Phyllotheca.

${ }^{1}$ Heer (5), vol. 4 II, t. 4, and vol. 6 I, t. I. Hutton (1), vol. iii, t. 186. 
We may pass over certain remains in an extremely bad state of preservation, which have been thus explained by Schmalhausen ${ }^{1}$ without apparent reason and have been figured by him ; but this author has also described and figured ${ }^{2}$ some highly remarkable objects as fructifications of his Phyllotheca deliquescens. I had opportunity of seeing the second of his two specimens in Strassburg, where it had been sent by him from St. Petersburg to be prepared. It is admirably rendered in the drawing in Fig. 17 , $B$. A striated axis with sheaths thoroughly like those of Phyllotheca bears on the internodes between the sheaths in a lateral position certain small organs, which are exactly like the sporangiferous peltate disks of our Equiseta. They lie indeed in numbers all round the axis in the interval between cvery two sheaths. The other specimen has just the same appearance, but only one sterile sheath is preserved in it together with portions of the two adjoining internodes.

Since these specimens have both of them the characteristic foliar sheaths of Phyllotheca, it seems unreasonable to doubt whether they belong to that genus, which would thus differ from true Equisetaceae in having its fertile spikes repeatedly interrupted by ordinary vegetative leaf-whorls. But in any case Hecr ${ }^{3}$ is not justified in uniting with his Phyllotheca sibirica two spikes of another species, which he thinks himself are very like those of Ginkgo, merely because they lie beside it in the specimen, and then going on to speak of
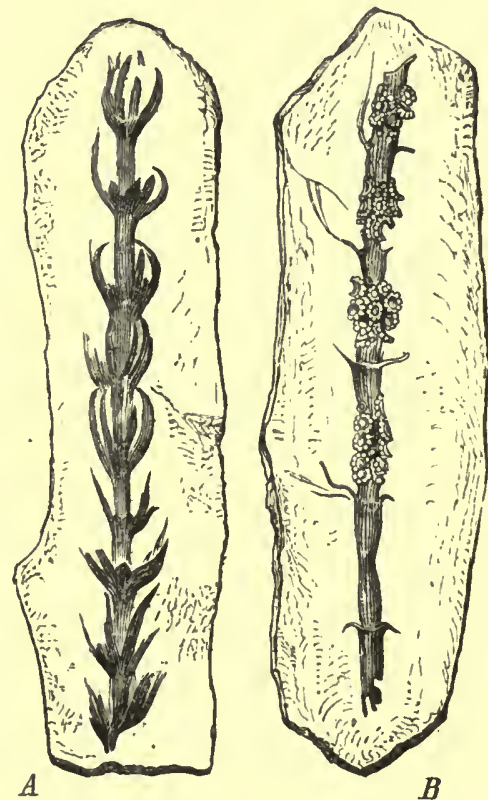

Frg. 17. Phyllotheca, Zigno. A Ph. equisetiformis from Rovere di Velo near Verona. $B$ in. florescence from Siberia, placed by Schmalhausen with Phyllotheca. $A$ from a specimen collected by myself, $B$ after Schmalhausen . different types ' which in time will have to be made into separate genera.'

All that we know of fossil Hydropteridae is so small, so fragmentary, and for the most part so doubtful, that we may proceed at once to give some account of them. From the group of Marsileaceae Heer ${ }^{5}$ describes the fruit-capsules of a Pilularia from Oeningen; Marion 6 has found in the Upper Eocene beds of Ronzon (Haute Loire) an opened capsule, which has since been recognised by A. Braun ${ }^{7}$ as the fruit of a Marsilea (M. Marioni,

1 Schmalhausen (1), t. 9, f. 17. ${ }^{2}$ Schmalhausen (1), t. 1, f. 3, and t. 9, f. 16. vol. 6 I, p. 9 ; t. I, f. 5 .

- Schmalhausen (1),

5 IIeer (3), vol. iii, t. 145 .

3 Heer (5), 7 A. Braun (2). 
A. Br.). The leaves of the plant are still unknown in the fossil state. Some remains also from the older formations have been placed by authors with Hydropteridae, the genus Sagenopteris, Presl, for exanıle, the leaves of which were noticed above on page $13^{8}$. Zigno ${ }^{1}$ has observed some small round bodies in company with these leaves, and Nathorst ${ }^{2}$, who found similar objects in Schonen, thinks that they are sporocarps, but has given no reason for his opinion. He then proceeds to argue in a manner which is little convincing that these sporocarps belonged to Sagenopteris, and that Sagenopteris therefore was one of the Marsileaceac. Schimper ${ }^{3}$ too has since given his assent to this view.

It is extremely doubtful whether the fossil leaf described by Schenk ${ }^{4}$ as Marsilidium speciosum from the Wealden formation of Osterwald in Hanover, which was placed in the group which we are considering solely on account of the habit of the single original specimen, really belongs to it. The lamina is formed of six broadly wedge-shaped pinnae inserted on the end of a long petiole; the nervation is that of Cyclopteris and the anterior margin is finely toothed.

Remains of leaves have been described from the Keuper of N. Carolina as Sphenoglossum quadrifolium ${ }^{5}$; they consist of four broadly wedgeshaped entire leaves or pinnae, which lie in one plane and are inserted at the same point.

The family of Salviniaceae, represented by several well-preserved and indubitable species of Salvinia, has been found in the form of impressions of leaves in the Miocene strata of Schrotzburg in Switzerland ${ }^{6}$, and in the same formation at Schossnitz in Silesia ', and at Priesen near Bilin in Bohemia ${ }^{8}$. No similar forms have been found in older deposits, nor have any remains of Azolla, as far as I know, been described hitherto. This of course does not prove that these very peculiar plants had not made their appearance in the earlier periods of the world's history. Their tender vegetative organs perished perhaps by an early decay, and have not come down to us. We may incline to this supposition in presence of certain diminutive remains of fructification which are occasionally found in the calcarcous nodules of the English Coal-measures, and which have been described in great numbers by Williamson ${ }^{9}$ and by Carruthers ${ }^{10}$ under the names Sporocarpon, Will., Traquairia, Carr., and Zygosporites, Will. I have made acquaintance with a large number of specimens of these objects in Williamson's collection, and I have some myself for which I am indebted to his kindness and to that of Mr. W. Cash of Halifax. Their origin has been the subject of various conjectures; they have been thought

\footnotetext{
1 de Zigno (1), vol. i, t. 20, ff. 2, 3 .

1. 26, f. 3 .

S Emmons (1), t. I, f. 2.

2 Nathorst (6).

3 Zittel (1), p. I54.

- Schenk (1),

ff. $21-23$.

- von Eutingshausen (4).

- Heer (3), vol. iii, t. 145 .

- IVilliamson (1), Ix, X.

7 Göppert (18), t. I,

30 Williamson (1), x.
} 
to be macrospores of Lepidodendreae, Radiolariae, and zygotes of Desmidieae. It appears to me, and to Strasburger ${ }^{1}$ also, that if they can be compared with anything, it is first of all with the massulae of Azolla, or with the sporocarps which contain them; and though this comparison must be distinctly proposed as a possibility only, we may nevertheless consider these remains in this place, since none more appropriate has been found.

Sporocarpon compactum ${ }^{2}$ is a small spheroidal body scarcely visible to the unaided eye, and consists of a stout solid case of very peculiar structure inclosing an inner cavity, which contains a variable number of round smooth-walled cells. Outside and between these cells is a brown and formless mass, but they are also not unfrequently clothed with a thin folded membrane. The case is itself composed of a homogeneous structureless firm inner leaf with a double contour-line, and on this leaf and occupying the position of a compact palisade-tissue are hollow cylindrical bodies, which grow narrower and cone-shaped towards the apex, or in some cases are prolonged into conical hairs, and form a closed rind; no contents are discoverable in these bodies, and their wall is formed of the same substance as the leaf on which they rest, but is of slighter consistence. Williamson has employed the sculpturing of the outer case to distinguish several other species of the genus; in his Sporocarpon elegans (Fig. I8, B) the hollow cylinders which form the rind have the shape of an hour-glass and leave empty spaces or cell-like gaps between them, but are in immediate contact at base and apex all the way round. Some of them also are prolonged into long conical hairs. Williamson ${ }^{4}$ supposes that this was originally the case with all of them, but that in the greater number the hairs have been broken off. Another form resembling Sporocarpon compactum without hairs is named by Williamson ${ }^{5} \mathrm{~S}$. tubulatum. In a few other forms also placed in the group, S. pachyderma ${ }^{6}, \mathrm{~S}$. asteroides ${ }^{7}$, and $\mathrm{S}$. ornatum ${ }^{8}$, the layer of cylindrical bodies is replaced by a thick frothy mass

1 Williamson (1), x, p. 515 .

3 Williamson (1), $\mathrm{x}$.

"Williamson (1), x, t. 17 , ff. 35,36 .

8 Williamson (1), $x$, t. 18, f. 39 .

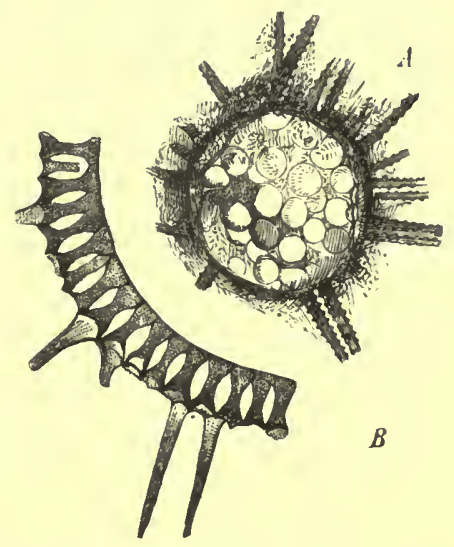

Fig, 18. A large receptacle of Traquairia, Carr., inclosing numerous spores, and covered on the outside with hollow tubular processes fragment of the outer wall of Sporocarpon fragment of the outer wall of Sporocarpon elegans, Will., with the hollow conith
pendages. Both after Williamson ${ }^{3}$. 
consisting of many isodiametric cells lying one above another, and in S. ornatum the cells which are near the surface are also prolonged into irregular hairs. Closely allied to Sporocarpon is Traquairia, Carr. (Fig. 18, $A$ ), which is distinguished from it by the structure of the outer layer of the envelope, but agrees with it in all other points. Williamson's tenth paper in the Philosophical Transactions gives a full account of this genus and some beautiful figures. The inner or supporting leaf of the envelope has on it long spines forming hollow cylinders with obtuse extremities. These give rise at regular distances to lateral branches of like character to themselves, and these may in certain circumstances branch very copiously and anastomose, and thus present an extraordinarily complicated net-work or sponge-like aggregate of hollow tubes, which is traversed in the direction of the radii by the much broader main canals formed by the spines. These relations are shown with especial beauty in radial and tangential sections of the case, such as are figured by Williamson ${ }^{1}$. Zygosporites, Will., a genus which owes its name to its likeness in habit to the zygotes of Cosmarium, may perhaps, judging from some figures of Williamson ${ }^{2}$, be found to belong to our present group. But this form, like Oidospora ${ }^{3}$ and Calcisphaera, Sollas ${ }^{4}$ found in the Carboniferous limestone in the neighbourhood of Chester, distinctly requires further investigation.

If now from this detailed statement of facts we turn to the different explanations which these objects have received, we must observe first that Carruthers' idea that they are Radiolariae, in support of which he appeals to Traquairia, can scarcely be maintained. According to this view the outer system of tubes must be homologous with the skeleton and the supporting lamella with the rind of the central capsule; the sarcode-body perished of course before petrifaction, but some remains of it were preserved in the inner cells. Haeckel, to whom Williamson ${ }^{5}$ had sent his most important original preparations, assures us that there is no Radiolarian with such structural conditions as we find in the remains in question. Williamson on the other hand sees in all these forms macrospores of Lepidodendreae, and of allied forms which cannot be more precisely determined. He says in the supplement to his paper ${ }^{6}$, that he has received through $\mathrm{Mr}$. Binns a series of sections of a 'crushed Lepidostrobus, in all of which Traquairiae occur under such conditions as leave no doubt that they are the macrospores of a Lycopodiaceous plant.' I have seen these preparations in his collection, and I must acknowledge that small groups of Traquairiae or single Traquairiae do lie inside many of the sporangia. But the whole specimen is so macerated that these might well have found their way in from the out-

\footnotetext{
1 Williamson (1), x, t. 18, ff. 86, 87 .

${ }^{2}$ Williamson (1), x, t. 19, f. 55. Ix, t. 25, f. 102. 'Williamson (1), x, t. 20. ' 3 Williamson (1), x, p. 5 I1.

${ }^{3}$ Williamson (1), - Williamson (10), t. 21, f. 82 .
} 
side while it was rotting in the water, especially as other sporangia of the same cone contain small remains of tissue, which could not have got there in any other way. And if the Traquairiae and Sporocarpae are macrospores, how shall we explain the cells inside them? Evidently there is nothing left but to consider them to be remains of the prothallium ${ }^{1}$, the preservation of which, considering its delicate nature, would not be too probable. Now these interior cells will give us less trouble, if with Strassburg and myself we compare the entire bodies with the massulae of Azolla. In this case they may be either spores, or else remains of single vacuole-spaces of the spongy net-work of massulae which surrounds the spores. The one and the other may perhaps be there together. I have for instance seen in some preparations in the collection of Mr. W. Cash two different kinds of interior cells, both sharply defined, but in the one case with a single circumscribing line, in the other with an evident doubly-contoured membrane. Williamson objects to our view, that there are indubitable macrospores with interior cells, which are recognisable by their shape and by their strongly thickened membrane beset with appendages on the outside. It is certain that there are receptacles of the kind which come very near in form to undoubted macrospores, as will be seen by comparing the figures which Williamson ${ }^{2}$ has given of both these objects. But that the outer surface of the massulae could vary much in character is shown by the differences which we find in this respect in the few living representatives of the genus Azolla; and the perinium of the macrospores which has a similar origin may easily have developed a similar configuration to that of the other sexual form. In conclusion, I may say that nothing has confirmed me in this view of mine so much as a preparation quite recently made by Mr. Binns and not yet described, which I had the opportunity of seeing when I was with Mr. Cash. A dark very thick-walled capsule resembling a macrospore encloses a number of cell-like spherical bodies closely crowded together, each of which is filled quite full with small well-preserved microspores. In the same preparation is another similar capsule containing only a single mass with a frothy vacuolated appearance. The obvious view is that the capsule is a sporocarp, in which the solid tissue is no longer visible, and that the globular bodies are massulae which conceal spores. The other specimen would in that case answer to an imperfectly developed conceptaculum, the contents of which had stiffened into a sporeless ball of froth. However, I have no doubt that by continued research we shall in time arrive at a more perfect understanding of these objects. 


\section{LYCOPODITES, PTILOPHYTON, PSILOTITES, PSILOPHYTON; ISOËTITES.}

WE find mention in the literature of a considerable number of remains which exist in the form of impressions and are known by the name of Lycopodites and Selaginites. These are either heterophyllous forms and resemble Selaginclla, or they are homophyllous branches beset all round with crowded scale-like leaves, and putting us in mind rather of true Lycopods. It is of course impossible, without accurate knowledge of the fructifications which are either wanting or are indistinctly shown, to keep these two groups separate from one another. As regards the homophyllous forms, their external characters are not very pronounced, and this nccessarily introduces uncertainty of various kinds into the determination. Many remains once termed Lycopoditae have since proved to be branches of Conifers, for example Lycopodites Stiehlerianus, Göpp. which is now Walchia, or branches of certain Lepidodendrae which will be discussed presently. On the other hand, Lycopoditae may easily be mistaken for some of the larger Mosses, the impressions of which cannot be distinguished with perfect certainty from those of delicate Lycopodiae. As instances of this kind may be mentioned Lycopodites Maakii ${ }^{1}$ from the Coal-measures of North America, and L. uncinatus ${ }^{2}$, also from the Carboniferous; the latter form by its branching and the hooked curvature of its extremities reminds us in the most striking manner of certain Hypneae. Even fern-stems covered with paleae may be confounded with Lycopoditae, as is done by Schimper in the case of Selaginites cavifolius ${ }^{3}$, which its author compares with Selaginites Erdmanni ${ }^{4}$ usually reckoned among Ferns. Still there can scarcely be any doubt but that certain homophyllous branches described by Goldenberg from the Coal-measures of Saarbrücken (Lycopodites elongatus ${ }^{5}, \mathrm{~L}$. denticulatus $^{6}$ ) are really of the nature of Lycopods. A remarkably fine form with the habit of Lycopodium Phlegmaria and with thick clavate terminal

\footnotetext{
1 Lesquereux (1), t. 62, f. 1 .

${ }^{2}$ Lesquereux (3), vol. ii, t. $4^{\text {I, }}$ f. 3. vol. ii, t. 39 , f. 8.

* Germar (1), t. 26.

s Goldenberg (1), t. 1, f. 2.

${ }^{3}$ Lesquereux (3), t. I, f. I.

- Coldenberg (1),
} 
fertile spikes has bcen described by Kidston ${ }^{1}$ as Lycopodites Stockii. It comes from the Millstone Grit of Scotland. The figure does not enable us to feel sufficiently sure about the Devonian Lycopodites Matthewi ${ }^{2}$ from New Brunswick. I know of no homophyllous Lycopoditae from other younger formations.

It is only in the case of a few of the heterophyllous Selaginella-like forms that the presence of the small ventral leaves can be ascertained; if the impression is seen from above, they are of course concealed, but in the opposite position also they are usually withdrawn from observation through their clinging close to the stem. For this reason all Lycopoditae with distichous leaves may be reckoned without hesitation among heterophyllous forms. A good description of two forms from the Coal-measures, Lycopodites primaevus, Goldenberg ${ }^{3}$, and L. macrophyllus, Goldenberg ${ }^{4}$, will be found in Goldenberg. The former species is provided with terminal fructifications like closed buds, and a very similar form, L. Gutbieri, Göpp., also bears fertile catkins; a figure of it is given in Schimper ${ }^{5}$. L. Richardsoni, Daws. from the Upper Devonian beds of America has been placed by Dawson ${ }^{6}$ in this group, but is extremely doubtful. The figure shows a small branch like a Graptolite beset with distichous tooth-like leaves (?), and attached to it a short lateral branch also with distichous leaves but of different shape and limited growth, of which it is briefly said in the description, 'fertile branches, lateral, one-sided, in the form of sessile strobiles.' Its author, as usual, gives no particular reason for this assertion. From more recent formations the only plant which I know belonging to this group is Lycopodites falcatus ${ }^{7}$ from the Oolitic deposits on the coast of Scarborough, which is distinguished by the loose disposition of its leaves and by the hook-like forward curvature of the extremities of its elliptical entire leaves.

Renault ${ }^{8}$ on the other hand has found in the siliceous fragments of the Upper Coal-measures of Autun small broken pieces of diminutive stems of two different kinds, which from their structure do most probably belong to this group, though their surface-view unfortunately is not known. He has named these forms Lycopodium punctatum and L. Renaultii. The transverse section in both forms shows an axile bundle-strand containing scattered groups of vessels and reminding us to some extent of that of Lycopodium Phlegmaria. Numerous weak horizontal strands are given off from it at the same height, and pass through the cortex into the leaves. From the regularity with which these are seen all round the transverse section Renault concludes that the leaves which are not preserved were arranged in

1 Kidston (5), t. 5 .

t Goldenberg (1), t. I, f. 5 .

' Lindley and Hutton (1), vol. i, t. $6 \mathrm{I}$.
${ }^{2}$ Dawson (1), vol. i, t. 8 , ff. $85-8_{7}$.

5 Schimper (1), t. 57 .

8 Renault, 7 .
${ }^{3}$ Goldenberg (1), t. I, f. 3 .

${ }_{6}$ Dawson (1), vol. i, t. 7 , f. $8 \mathrm{r}$. 
whorls. The longitudinal section teaches us that the leaf-circles must have been separated from one another by only short internodes. It is peculiar, that reticulately thickened tracheides are found in Lycopodium Renaultii, and tracheides with several rows of bordered pits polygonally flattened by mutual pressure in L. punctatum, while in recent species scalariform tracheides are the prevailing form ; but Renault states that he has observed pitting of a similar kind in several living species. As I have been unable to procure the only species, L. pachystachyum, cited in proof of this statement, I have been unable to verify it. We feel here very disagreeably our want of knowledge of the inner structure of Lycopodiaceae. Fibre-strands are developed in the cortex of $\mathrm{L}$. Renaultii, and are wanting in the other species; in these the transverse sections of roots with normal pentarch bundles are seen in the middle of the cortical parenchyma. This feature reminds us strongly of living Lycopodiae, in which it was discovered by Brongniart ${ }^{1}$ at the base of the stem and illustrated by excellent figures.

It may be probable that Unger's ${ }^{2}$ Arctopodium from the Cypridinacslates of Saalfeld belongs to our present group, as its author supposes. Unfortunately the ill-preserved remains are known only in transverse sections, which show in the centre of the stem a group of vascular bands vividly recalling our Lycopodiae. These bands are radially disposed in Arctopodium radiatum ${ }^{3}$, variously twisted, curved and branched in A. insigne ${ }^{4}$. The cortex is destroyed in both cases and nothing can be seen of the leaf-bundles. On the other hand, the specimen described by Unger at the same place under the name of Cladoxylon mirabile ${ }^{5}$ is quite doubtful. Here the vascular plates, if such they are, unite in the middle into an irregular mesh-work; but I have satisficd myself by examination of an original preparation in the Jermyn Street Museum in London of the hopelessly bad state of preservation of this fossil. Only the discovery of fresh specimens will give us the needful certainty respecting it. Such specimens are said by Dawson ${ }^{6}$ to be already in our possession from the Upper Devonian beds of N. America (Styliola limestone), but we have at present only superficial descriptions of them. Unger would unite another form of this genus of his, Cladoxylon dubium ${ }^{7}$, with Sphenopteris refracta which was noticed above on p. 164, and it cannot be denicd that there is a certain resemblance between them. The genus Asteropteris, Daws. has been already discussed on p. 173 in connection with Asterochlaena. Its central star-shaped vascular bundle, but especially the regular simple ring of emerging leaf-bundles, may in this case also lead us to suspect that the genus would more rightly find its place herc among plants resembling

\footnotetext{
1 Brongniart (1), vol. ii, t. 8. $\quad{ }^{2}$ Unger (5). $\quad{ }^{3}$ Unger (5), t. 12, f. 4. 'Unger (5), t. 1 2, ff. 1, 2. ${ }^{3}$ Unger (5), t. 12, f. 6, 7. ${ }^{6}$ Dawson $(1)$, vol. ii, p. 1 26. "Unger (5), t. 10, f. 11 .
} 
Lycopods; but this cannot be determined without study of the original preparations.

A series of very dubious remains from the Devonian and Carboniferous deposits of North-Eastern America has recently been grouped together by Dawson ${ }^{1}$ under the name Ptilophyton, Daws. Hall has described the same objects as hydroid polypes and given them the name Plumalina; in Lesquereux ${ }^{2}$ they are called Trochophyllum and are appended to Calamariae. The species first discovered, Ptilophyton Vanuxemi, Daws., which had been already figured by Vanuxem ${ }^{3}$, appears in Dawson's earlier publications ${ }^{4}$ as Lycopodites Vanuxemi, and with it a form from the Lower Coalmeasures of Canada as L. Plumula ${ }^{5}$. This author also introduces into his genus L. pennaeformis ${ }^{6}$ from the Millstone Grit of Altwasser in Silesia, which is known in one piece only and is of a very questionable character. The specimen unfortunately was not to be found for the moment, when I was in Breslau. Little can be gathered from Dawson's and Lesquereux's somewhat rough figures; specimens of the American forms do not appear to have reached Europe. These are thin branches with a striated surface and crowded verticillate scars : and on these branches and on both sides of them are linear leaves (?) which are still in situ and very nearly form a right angle with the branch, and which in the drawing of Ptilophyton lineare, Lesq. look almost like the needles of Coniferae. Dawson it is true does not state that the leaves are verticillate: he says 'slender leaves in two or more ranks.' The character of the surface in the stem figured by Lesquereux is strikingly suggestive of the remarkable and little-known Equisetum mirabile noticed above on p. 178 , and it was this resemblance which led him to place this form with Calamariae. In conclusion, I must express my doubt's as to whether all these objects thus grouped together by Dawson do really belong to one another; and I am confirmed in these doubts by the circumstance that Lesquereux in the work in which he describes Trochophyllae reckons Lycopodites Vanuxemi ${ }^{7}$ among Lycopodiaceae, with the remark it is true 'It may be an Encrinite,' without thinking of comparing them.

The statements respecting fossil remains of the family Psilotaceae are few and uncertain, nor is this surprising in such simple and slightly differentiated forms. If Psilotites lithanthracis ${ }^{8}$ and Ps. unilateralis ${ }^{9}$ do really belong to this group, a point which I am unable to determine from the' figures, we should be able to follow the type as far down as the period of the Coal-measures.

It has become more and more a settled practice with palaeontologists and botanists to unite the genus Psilophyton with Psilotaceae ${ }^{10}$. Dawson

'Dawson (1), vol. ii, p. $119 . \quad{ }^{2}$ Lesquereux (1), p. 63.

(1), vol. i, p. 35 .

7 Lesquereux (1), p. 362.
${ }^{5}$ Dawson ( 7 ), p. 24; t. I, ff. 7-9.

${ }^{8}$ Goldenberg (1), t. 2, f. 7 .
3 Vanuxem (1). "Dawson

${ }^{6}$ Göppert (19), p. 508; t. $4^{2}$. 
himself inclines to this comparison, though elsewhere ${ }^{3}$ he conceives of these plants as 'synthetic or generalised plants,' such as Göppert meant by his prototypes, which unite the characters of Lycopodiaceae and Ferns. Now this would be all very right and good, if we could have more clear and exact information about these characters. Dawson's description of the genus rests chiefly on the impression made upon him in his repeated researches at the localities where the fossils are found, especially Gaspé. Of the correctness of this impression in kind and degree we, who are dependent on the few and as a rule ill-preserved specimens in European collections, are the less able to judge, because Dawson unfortunately gives no exact description of individual specimens, though it is this which is so needful, but puts us off with an account of the general idea which he has drawn from his study of them. The botanist cannot possibly feel inspired with any great confidence, when side by side with better specimens of Psilophyton in the collections at London. Strassburg or Göttingen he sces others named by Dawson himself, which appear to him to be quite undeterminable remains of some kind of leaf-stalk. Dawson ${ }^{2}$ has determined as Psilophyton princeps and Ps. robustius numerous renains in the collection at Edinburgh, which according to I'each are common in the Middle Devonian beds of Scotland but have been hitherto generally taken for 'fucoids or roots.' Considering the inclination at the time to determine fossil objects from these older formations, these remains must certainly have been regarded as very formless things. Nor is the comparison with Eoplyyton, Torell " (sec on p. 46) very reassuring. There is only one of Dawson's species of Psilophyton which supplies real tangible characters, namely Ps. princeps, which is found in many localities in Canada and New Brunswick in the entire series of formations from the Upper Silurian to the Upper Devonian. I have seen several tolerably good specimens of this species, and they agree with Dawson's figures ${ }^{4}$. The erect stems or branches have attached to them at a right angle somewhat numerous thorn-like processes, rudimentary leaves according to Dawson, and where these are wanting their point of attachment is shown by a small ovoid scar. The upper end when preserved is bent inwards in the shape of a hook or crosier, as in young fern-leaves. The branching is rather copious, sometimes plainly dichotomous with small divergence on the part of the daughter-members, elsewhere on the same specimens apparently monopodial; we shall not be wrong in assuming that the development of the stem was sympodial. The delicate curved extremities, detached and looking like snail-shells, fill entire beds of slate at Gaspé ${ }^{5}$. The stems when fully grown show woody structure according to Dawson, and their appendages are thorn-like and rigid. We have descriptions also

1 Dawson (1), p. $3^{3}$. ${ }^{2}$ Dawson (1), vol, i, p. 77 . (1), vol. i, t. y. '5 Tawson (5), p. $4^{80 .}$ 
of the horizontal creeping rhizomes, and figures of them from Dawson? These when preserved in their natural position fill at Gaspé certain hard beds of clay, as Stigmariae fill the underclays of coal-seams. They are horizontal creeping stems with occasional bifurcations; their smooth surface bears here and there small circular scars, from which roots proceed vertically downwards and traverse the beds beneath. Unfortunately there is no figure of a portion of rhizome attached to an evident stem of Psilophyton, though the author states that he has seen entire plants two or three feet long in connection. In his first publication ${ }^{2}$ Dawson figured an object of indefinite form having several lobes and attached laterally to a branch, which he explained as the fructification of the plant. In the description he says of it, 'Fructification probably in lateral masses, protected by leafy bracts.' Subsequently ${ }^{3}$ the fructifications assume a totally different appearance. Small branches with repeated bifurcations, smooth and showing none of the distinctive features of the species, bear at their extremities groups of small stalked ovate-lanceolate bodies, sporangia according to Dawson, which open, as he maintains, on one side by a longitudinal fissure. Not only the character of this fructification, but its connection also with our plant, is thus thoroughly obscure and doubtful. In one piece Dawson found anatomical structure preserved. The specimen in question is unfortunately not very fully described, and the figure ${ }^{4}$ does not altogether agree with the description of the rhizome to which the fructification was attached. The only transverse section of this specimen figured is oblique in its direction and very imperfect ${ }^{5}$. It seems to contain a central vascular bundle-strand, in which the presence of scalariform tracheides was ascertained, and which is said to be surrounded by a zone of 'woody fibres.'

The other described species of the genus are in much worse case than Psilophyton princeps. The specimen figured by Dawson ${ }^{6}$ as Ps. robustius looks like something very different, and indeed the author himself says that fragments of this species are scarcely to be distinguished from leaf-stalks of Ferns. Bodies of indefinite form set in bunches on the extremities of such stalks or of their lateral branches are supposed to be fructifications. This form is said to be confined to the Upper Silurian formation. The figure of Ps. glabrum in Dawson ${ }^{7}$ looks like a fragment of a branched leaf-stalk of some Fern; that of Ps. elegans ${ }^{8}$ shows only some irregular sinuous lines. The same species appears in another and not much better figure ${ }^{9}$ made up of bundles of these hooked lines. And if the author himself admits so many quite undecipherable remains into his genus, it is not

1 Dawson (5), p. 479, and (1), vol. i, t. ro.

4 Dawson (1), vol. i, t. 20, ff. 241, 242.

2 Dawson (5).

3 Dawson (1), vol. i, tt. 9, 10.

t. 18, f. 22 .

6 Dawson (1), vol, i, t. I 2.

5 Dawson (1), vol. i, t. II, f. I34, and (10), p. 465 ;

${ }^{7}$ Dawson (1), vol. i, t. 7, f. $79 . \quad{ }^{8}$ Dawson (1),

vol. i, t. IO, ff. 122,123 .

9 Dawson (6), t. I4, ff. 29, 30.j 
surprising that he has found imitators. Thus two species, Ps. gracillimum, Lesq. and Ps. cornutum, Lesq., from the Silurian deposits of N. America, have been described by Lesquereux ${ }^{1}$ and are fit associates of Dawson's Ps. elegans. A fossil form from the Lower Devonian beds of Rhenish Prussia was described by Göppert ${ }^{2}$ in his time under the name of Haliserites Dechenianus and placed among the Algae. Its delicate tufts of branches by their incurved hooked extremities recall Psilophyton princeps, though they are quite smooth and have no lateral thorns. Dawson ${ }^{3}$ first removed this form conjecturally to his Psilophyton, and Carruthers ${ }^{4}$ has since followed his example. The latter author has moreover added to the same group certain fossils from the Devonian Sandstone of the north of Scotland, which were originally described as Lycopodites Milleri ${ }^{5}$, and which if judged by the figures do in fact show some resemblance to Psilophytae. Carruthers names them Psilophyton Dechenianum, Carr., and unites Haliserites with them. In like manner Sphenopteris Condrusorum, Gilk., which has been already noticed, was first described by Crépin ${ }^{6}$ as a species of Psilophyton. Lastly, as we are on the subject of these ancient and obscure remains, we may mention here the very recently published Berwynia Carruthersii ${ }^{7}$ from the Middle Silurian deposits of Corwen in Wales, which has been supposed to be the stem of a Lycopod of great dimensions. In spite of the good accompanying figure I would rather not express any opinion respecting either this fossil, or Drepanophycus spiniformis ${ }^{8}$ from the Upper Devonian Spiriferae-Sandstone of Hachenburg in Nassau, which to some cxtent resembles Berwynia.

Of the group of Isoeteae we know only two Miocene forms found at Ocningen and strongly recalling our Isoëtes lacustris, for which it will be sufficient to refer the reader to Schimper ${ }^{9}$. Solenites Murrayana, Lindl. and Hutt., from the Oolite of Scarborough, will be found noticed in the same work as a doubtful form. This fossil has been excellently described in Lindley and Hutton ${ }^{10}$. It consists of long linear pointed leaves lying together in tufts and found in large numbers on certain slabs of stone. According to the figure, the epidermis, which was brought out by treatment with nitric acid, is formed of irregularly angular cells, between which no stomata were observed. This would certainly agree with the structure of the submerged Isoëtae; but fresh examination of the facts with the better means now at our disposal is much to be desired, since the tufts of leaves in Solenites may quite as well be supposed to be short shoots of Conifers like those of Phoenicopsis and Czekanowskia, and then stomata must certainly be found on the leaves. Something also might be gained from an examination

\footnotetext{
1 Lesquereux (5).

${ }^{2}$ Göppert (12), 1. 2.

${ }^{3}$ Dawson (1).

4 Carruthers (9).

s Salter (1). 'Crépin (1). "Hicks (2).

- Göppert (12), t. 41, f. 1.

- Schimper (1).

10 Lindley and Hutton (1), vol. ii, t. I 2 I.
} 
of the point of insertion of the leaves; it would be important to know whether this was surrounded or not by scale-leaves, as is the case in the Conifers just mentioned. Though I have gone through the rich stores in the Museums of London, Oxford and Scarborough, I have unfortunately never succeeded in finding a single tuft of leaves with a distinct and wellpreserved base. A second form also found near Scarborough and placed with Isoëteae is Solenites furcatus ${ }^{1}$, unfortunately known only from some scanty remains in not too good a state of preservation. In this spec:es the linear leaves, which are only found singly, are repeatedly and dichotomously branched, and thus have a still greater resemblance to Czekanowskia. The suspicion of a nearer affinity between the two forms is strengthened by the circumstance that both alike belong to the Lower Oolite formation.

1 Lindley and Hutton (1), vol. iii, p. 209. 


\section{LFPIDODENDREAE.}

THE family of Lepidodendreac is one of the most conspicuous among those vegetable types which have become extinct in the course of geological times. Like most of these types, it culminates in the Carboniferous period, attaining its greatest development in the lower and middle divisions of the Coal-measures ${ }^{1}$. Soon after that period it disappears, some scanty remains only being known from the Rothliegende. The furthest point to which the group can be followed in the other direction is the lower portion of the Devonian system, to which the schists of Wieda in the Harz are considered to belong. These beds have produced two indubitable remains of Lepidodendron, which were originally described by A. Römer ${ }^{2}$ and have been submitted by Weiss" to rencwed and thorough examination. It is very doubtful whether the two older Silurian remains, Protostigma sigillarioides ${ }^{4}$ from the Cincinnati group of the Middle Silurian deposits and Glyptodendron eatonense ${ }^{5}$ from the Clinton Limestone which forms the base of the Upper Silurians, belong to Lepidodendrcac. I must refer the reader to the original publications for an account of these forms.

We are acquainted with a large number of stems, branches, leaves, and fructifications of Lepidodendreae, which are proved beyond doubt to have belonged to one another by having been found attached to one another. And if the group is here brought into immediate connection with Lycopodiaceae, the reason for this arrangement is to be found not merely in the habit of the organs of vegetation, but chiefly and emphatically in the structure of the cones of the fructification, which have been very carcfully studicd and which positively exclude a closer alliance with any other family. We shall return to this subject, as well as to the anatomy of the organs of vegetation, in a subsequent page.

The surface of the stem when well preserved, as it very often is, presents a highly characteristic appearance, and hence Lepidodendrae came to be noticed by authors as early as the eighteenth century, by Volkmann ${ }^{6}$

\footnotetext{
1 Grand' Eury (1). S Claypole (1).

${ }^{2}$ A. Römer (1), v. - Volkmann (1). 
for example and Walch ${ }^{2}$, and can be recognised from their figures.' It is entirely covered with elongate-rhomboidal flatly conical cushions which touch one another, and each cushion bears a detachment-scar at its most elevated point. This scar answers to the place of separation of a leaf, the whole cushion to the decurrent leaf-base which has remained on the stem. In the crowded position of the cushions which are everywhere in contact with one another the parastichies are very clearly shown, as in fircones, and careful study of them discloses very complicated conditions in the arrangement of the leaves. In the large stem of Lepidodendron Sternbergii preserved in the Museum at Prague, Max Braun found that the phyllotaxy was $\frac{89}{\frac{89}{3} 3}$. Elaborate researches into the phyllotaxies which occur in Lepidodendreae have been made by Naumann ${ }^{3}$ and Stur ${ }^{4}$. From these it appears that the complicated succession of many-membered cycles with definite divergences, which are exceptional in fir-cones but are frequent in Lycopodiaceae, are the rule in Lepidodendreae, and that simple spiral arrangement is seldom observed. The latter was found by Stur ${ }^{5}$ in Lepidodendron Haidingeri with the divergence $\frac{34}{89}:$ two-leaved whorls occur in L. Veltheimianum with the divergence $\frac{1}{3} \frac{1}{7} \frac{4}{6}$, and three-leaved whorls in the same species with the divergence $\frac{99}{23}$ : five-leaved whorls with the divergence $\frac{89}{23}$ and seven-leaved whorls with the same divergence were ascertained in Ulodendron commutatum. From Stur's original account we may learn how he overcame the difficulty arising from the circumstance, that the entire circumference of the stem is not usually open to examination.

Stur ${ }^{6}$ has also given an elaborate description of the single cushion in all its details. The lateral angles of its rhombic outline are obtuse and the upper and lower angles are acute, and hence it is seen to be bounded by two lateral sinuous lines. It is separated from the eight adjoining cushions either by broad flat strips, or only by sharp linear furrows. In the latter case the bases of the leaves are in immediate contact with one another, in the former they are divided from one another by narrow portions of the smooth surface of the stem. How far this circumstance depends, as Stur thinks, on differences in age, or to what extent it is due to specific distinctions, I would prefer to leave undecided. The specimens with broad intermediate strips are in his opinion younger plants; by further arching over of the cushions the interstices between them were depressed and became continually more like furrows, the narrow intermediate strips being more and more covered over and withdrawn from observation. The scar, from which the leaf-blade separated, occupies the highest point in the flatly pyramidal cushion. It varies in size and is transversely rhombic in

\footnotetext{
1 Walch (1).

2 Schimper (1), vol. ii, pt. I, p. I5.

${ }^{3}$ Stur (5), p. $259 . \quad$ Stur (5), p. 227.

3 Naumann (1). + Stur (5), p. $23^{6}$
} 
form, and in very many cases through the opening out of the lower angle of the rhomb it approximates to an equilateral triangle with one angle at the upper end. In normal circumstances its lower corner nearly coincides with the point of intersection of the diagonals of the rhombic cushion or lies a little above them. On its flat surface near the lower margin three marks are seen, which in casts are depressed, in moulds, where they are usually very conspicuous, are strongly protuberant. They may be all of the same shape and dot-like, but in some cases the lateral ones are elongate and linear, and the middle one only is either punctiform, or triangular with one angle at the lower end and the sides prolonged and in the shape of a V. Nothing is more natural than to see in these three marks the points of severance of the leaf-trace bundles, and this is the view of most authors. But since we know from Renault's ${ }^{1}$ observations on analogous conditions in Sigillariae that in these plants only the middle mark really answers to the transverse fracture of a vascular bundle, whilc the lateral marks represent a different point of structure, it will be well to assume provisionally that this is the case also in the group before us; but the matter will have to be considered again more fully in dealing with Sigillaria. At present we have in fact nothing to go upon but such a conclusion from analogy, because cxamination into the anatomy of Lepidodendrae has as yet thrown no iight on the question.

Both the area of the scar and the outline of the leaf-cushion represent transverse sections of a four-sided pyramid, and the angles of both are therefore connected by projecting edges which divide the surface of the cushion into four laterally disposed segments, the faces of the pyramid. The median ridges running in a straight line are more strongly marked than the lateral ones; the lower one is generally longer than the upper, because the scar has been moved a little out of its position in the upward direction. They bisect the upper and the lower acute angle of the rhomb. Each of the latcral edges on the other hand, running a little obliquely downwards from the lateral angles of the scar, divides the lateral angles of the rhombic cushion into an upper more acute and a lower less acute angle. In wellpreserved specimens the facets may show a delicate velvety punctation of their entire surface, caused probably by the impression of the individual epidermis-cells; in some species they are marked with transverse folds and wrinkles, which are sometimes very prominent. . Again, in the upper angle of each of the two lower and larger facets, and near the median ridges which separate them, there is usually a conspicuous roundish or ovate depression, which may however sometimes appear as a projection. Stur proposes to call both of these marks the vascular glands of the leaf-cushion, 
because he sees in them the secreting extremities of small branches of the vascular bundle which runs through the leaf-cushion. I should rather compare them with the orifices, which are found variously disposed on the base of the leaf-stalks of tree-ferns. But I believe that it will be best to refrain from all hypotheses with respect to this point, and to wait till we have gained the needful light from the anatomical examination of a wellpreserved stem-surface. There are still two other distinct marks to be mentioned, which are inserted in the course of the median upper ridge separating the two upper facets of the cushion, and which Stur was the first to notice with the proper attention. One of these marks is close to the upper angle of the scar, and forms in all cases according to Stur a slight depression in the coal of the leaf-cushion; it is triangular in shape, with the point directed upwards. It must therefore be always seen on the mould as a small protuberance. Nevertheless I have before me a particularly well-preserved mould of a forked stem belonging probably to Lepidodendron Göppertianum which I found in the Dutweiler mine near Saarbrücken, in which this mark appears as a deep pit-like depression. I must presume therefore that a cliange has taken place in this object similar to that which affects the trace-points in the lower faces. And when Stur appeals to Selaginella and considers this pit to be the ligular pit of Lepidodendron, the comparison is perhaps a just one, for the position does in fact agree with that of the ligule in Selaginella. But no proof can be adduced for or against this view, and both the absence of a ligula in Lycopodium and the resemblance between the small trace and other small scars in the cushion suggest caution, and makc so wide an interpretation of minute facts appear too imaginative. The second spot which is situated on the median upper corner occupies the very uppermost angle of the leaf-cushion; it is raised and prominent, and like the other is triangular in form. Stur sees in it a rudimentary indication of the point at the base of the leaf, on which the sporangium is seated in the fertile leaves of Isoëtes and Selaginella. As this view is simply the logical consequence of the hypotheses just described, it stands or falls with them. The object of the present work does not require us to discuss the distribution into numerous species, which is chiefly founded on the form of the cushion and the position of the scar. Figure 19, $A$ and $D$, will illustrate the above remarks.

Hithertome have been engaged exclusively with the character of the surface of the stem in a perfect state of preservation. But specimens of impressions are very frequently met with which have a different appearance, and these were consequently grouped together by the older authors under distinct genera; but further research has had the result of showing with greater or less certainty that these forms are nothing more than states of preservation of stems of Lepidodendron. In the case of most of them this view is generally accepted at the present day, and the old generic names 
are given in Schimper ${ }^{1}$ as mere synonyms of Lepidodendron. But as some states of preservation have a different appearance from the rest, doubts are still expressed as to whether they are derived from one and the same genus of plants. In answer to this I would call attention once more to the fact which was considered in the introductory chapter, that we must necessarily see the remains of the same species under a quite different form, if it is composed of portions of tissue of different power of resistance, since these must have been affected by external influences in a different manner in each case. A stem of this kind will have an entirely different appearance in the fossil state if it rotted first of all on the damp ground in a forest, or was covered by water while still fresh, or if it was exposed to the two kinds of influence several times in succession. And that the first-mentioned condition, the presence of tissues of different power of resistance, was not wanting in Lepidodendrae is shown by the anatomy of these plants, which will be considered presently. We may notice first the form described by Sternberg ${ }^{2}$ as Aspidiaria, Presl, which he had himself previously united with Lepidodendron (Fig. 19, A). Göppert ${ }^{3}$ has already given a complete explanation of the mode of formation of these Aspidiariac, and his descriptions have been fully confirmed by $\mathrm{O}$. Feistmantel ${ }^{*}$, and again reviewed at length by Stur ${ }^{5}$. When the cortical covering of the stem is removed, the cushions seen from the inside form rhomboidal depressions; whether this was in consequence of the perishing of their delicate central tissue, or because, as Stur thinks, there was a central lysigenctic intercellular space traversed by a vascular bundle formed already during the life of the plant, as in living heterophyllous Lycopodicac, is a matter of indifference and cannot be determined. These hollows are filled up with the stony material, and in this way flat or slightly convex lozenge-shaped areolae are formed, which without further structure show the trace of the emerging foliar bundle as a dot-like protuberance or an irregular central longitudinal elevation, while nothing can be seen of the lateral traces. If the trace in Aspidiaria is seen in the middle of the cushion, somewhat deeper therefore than in the surface-picture of Lepidodendron, this is connected with the ascending course of the bundle, for owing to this, the trace will appear in a lower position in proportion as the surface of the cylinder bearing the impression is further removed from the outer surface of the stem. By suitable treatment of his specimen Stur has succeeded in extracting single rhombs which filled the cavities, and by this means the surface of the leaf-cushion was disclosed to view in its normal condition (Fig. 19, A). Schimper ${ }^{6}$ gives the figure of an Aspidiaria which is said to belong to Lepidodendron acule-

${ }^{1}$ Schimper (1). $\quad{ }^{2}$ Sternberg, Graf von (1), Heft 1-4, t. 28, and Heft 5-8, t. 68. ${ }^{3}$ Göppert $12)$, p. 48 . Schimper $(1$, t. 60, f. 6 . 
atum, Stbg, in which the entire leaf-trace of the scar is depicted, but this is no doubt a mistake. Similar pictures are produced, when the rind of coal remains in the mould of the surface ${ }^{1}$. The cast, stripped of this rind and coinciding with the boundary between two layers of parenchyma of different character, is in this case usually furnished only with small slightly raised elongate-linear protuberances as indications of the leaf-bundles. Casts of this kind are found in very extraordinary abundance. Casts are described in Sternberg ${ }^{2}$ as Bergeria, Presl (Fig. 19, B, C), the surface of which agrees exactly with that of a Lepidodendron when deprived of its epidermis ; some at least of these casts have belonged to a Lepidodendron, as is seen from L. diplotegicides as reproduced by Schimper ${ }^{3}$ after Lesquereux ${ }^{4}$. They show raised rhombic cushions separated from one
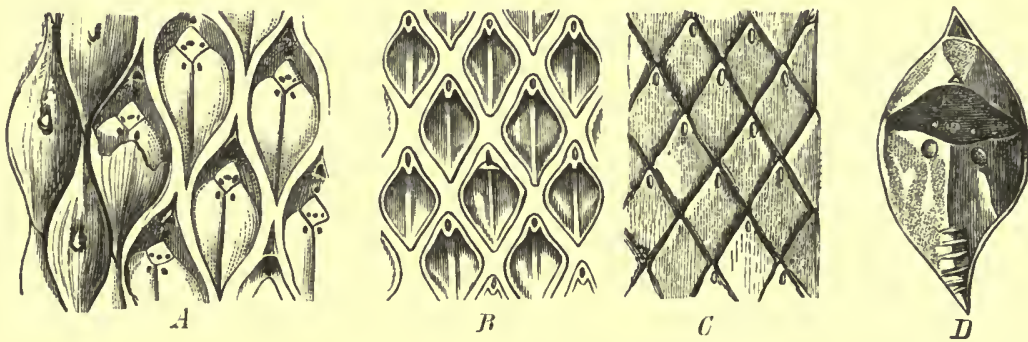

FIG. 19. Various states of preservation of the surface of the stem of Lepidodendron. A Lepidodendron obovatum, to some extent improved and diagrammatically represented; on the right side the surface in the mould, on the left the Aspidiaria-state, the latter introduced from other specimens; above the rhombic scar of separation of the leaf are seen the two trace-scars one above the other. $B$ and $C$ Bergeria-states. $B$ Bergeria angulata, $C$ Lepidodenciron nothum, Ung., from Australia. $D$ single leaf-cushion of the cast of a Lepidodendron, a diagrammatic representation showing the different traces and marks. $A$ and $C$ after $O$. Feistmantel $5, B$ after Sternberg ${ }^{6}, D$ after Stur 7 .

another by narrow intervals; the bundle-trace is seen as a depression at the point of highest elevation. In the examples of this state of preservation figured in Sternberg the emergence of the vascular bundle is extremely close to the upper angle of the area of the cushion; the difference in size between the upper and lower faces in these forms must have been very pronounced (Fig. 19, B). At the same time the two diagonals of the cushion are of nearly the same length, its outline approaching the form of a square. To this group undoubtedly belong several remains figured by Schmalhausen ${ }^{8}$ from the Ursa zone of Bear Island in Siberia, and also Lepidodendron tetragonum from the Coal-measures of Saxony 9. O. Feistmantel's ${ }^{10}$ remarks on this point should be referred to ; this author considers Bergeriae to be states of preservation both of Lepidodendron and of the genus Lepidophloios which will be noticed presently, and he may be quite

1 Göppert (19), t. 39, f. 2.

${ }^{2}$ Sternberg, Graf von (1), t. 6S, ff. 16-19.

${ }^{3}$ Schimper (1),

t. 60, f. 7 .

- Lesquerenx (1).

5 Feistmantel (1), III.

${ }^{6}$ Stermberg, Graf von (1).

"Stur (5).

${ }^{6}$ Schmalhausen (3), t. 2, f. 5 .

Geinitz (8), t. 3, ff. 1, 2, and Schimper (1),

t. 60, ff. $9,10$. 10 O. Feistmantel (3), p. 200. 
right in this view, though the proof of it cannot at present be produced. Carruthers ${ }^{1}$ also has expressed the same opinion. Lepidodendron nothum ${ }^{2}$ again from the Cypridina-schists of Saalfeld appears to be similar in character, as are also certain bits of stem from the Upper Devonian and Lower Carboniferous strata of South Australia and Queensland, which have been described as L. australe, $\mathrm{M}^{\mathrm{C}} \mathrm{Coy}^{3}$ and as L. nothum, Ung. by Carruthers ${ }^{4}$ and O. Feistmantel ${ }^{5}$ (Fig. 19,C). The figures themselves show that the original surface is wanting in all thesc specimens, and I have besides assured myself of the fact from numerous specimens from Queensland which are preserved in the British Museum. If indeed the remains figured by Carruthers ${ }^{6}$ in the work cited below and described by him as leafy branches, which unfortunately I did not see, really belong to this group, then we may

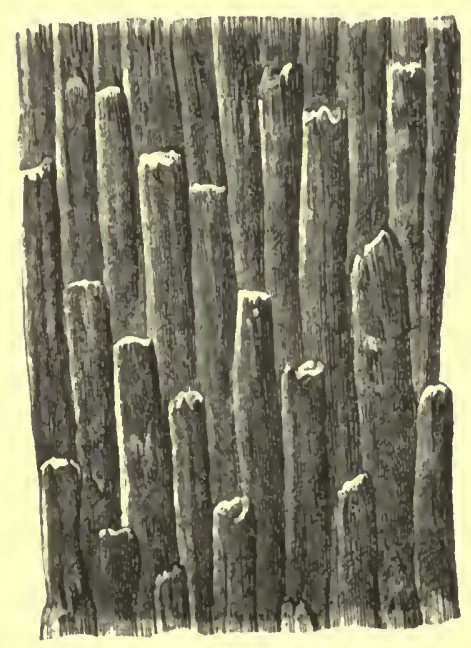

Fig. 20. Surface of cast of Knorria imbricata, Stlog from the Culm of Burbach near Thann in the Vosges. After Schimper in Zittel's Text-book. be dealing here with a genus distinct from Lepidodendron and agrceing with it only in certain states of preservation. Carruthers unites with his Lepidodendron nothum, Ung. a Devonian fossil from Canada and Maine which Dawson ${ }^{7}$ had described as Leptophloeum rhombicum, and to all appearance he is right in doing so; it may differ, if at all, only in the somewhat decper position of the vascular bundle-trace, for the Artisiapith which is appealed to by Dawson, who protests loudly against Carruthers's opinion, is more than uncertain and looks in his figure merely as an indefinite cross striation. Artisia-cylinders are it is true claimed by Corda also as belonging to Lomatophloios a genus of Lepidodendreac, but these cases also are quite doubtful on other grounds; they have hitherto been regarded with certainty as stems and branches of Cordaiteae.

With regard to the genus Knorria, Stbg (Fig. 20), which must now be considered, authors are much divided in opinion; we know however that it represents an inner subepidermal state of preservation of lepidodendroid plants. The frequent dichotomies, which will be further noticed below, prove that it cannot belong to Coniferae, as Sternberg ${ }^{8}$, its first describer, believed. It was then regarded as a proper and well-characterised genus of

\footnotetext{
' Carruthers (12). ${ }^{2}$ Unger (5). ${ }^{3}$ O. Feistmantel (1), 1II, t. 13. 1 Carruthers (10), t. 26. ${ }^{3}$ O. Feistmantel (1), III, tt. 1, 14. 'Carruthers (10), t. 26, ff. 1, $2 .{ }^{7}$ Dawson (1), vol. i, p. 36, ff. 88, 89, and vol. ii, p. 105 . B Sternberg, Graf von (1), Heft 1-5, t. 27.
} 
the group which we are considering, till Göppert, who had at first taken up the same position ${ }^{1}$, came forward in support of the view that it belongs as a cast-form to species of Lepidodendron ${ }^{2}$. He cites Lepidodendron Veltheimianum and Knorria imbricata as forms which belong to one another, and tries to prove this by figuring numerous specimens. His ideas have met with much assent, but they have not been able to triumph over all doubts. Schimper ${ }^{3}$ both before and since has taken the opposite view, and so has Heer ${ }^{4}$; and Weiss ${ }^{5}$ has recently spoken doubtfully and cautiously on this point, resting chiefly on the fact that the Knorriae which are scattered through the Devonian system and are abundant in the Culm are scarcely, if ever, found in the higher members of the Carboniferous formation which are full of Lepidodendrae, but are replaced by Aspidiariae and Bergeriae. He concludes from this ${ }^{6}$, ' that at all events it is not every Lepidodendron that has a Knorria for a cast.' Many figures of Knorriae are to be found in the works quoted, in Schmalhausen ${ }^{7}$ and in Schimper ${ }^{8}$. In the typical state the entire surface of the stem is occupied by spirally disposed protuberances running a greater or less distance down the stem, and ending above in a conical point pressed close to the stem but separated from it by a sharp furrow; at the extremity of this point when the preservation is very good is a depression, deeper or shallower as the case may be, which is considered by all authors, and not without reason, to contain the scar-trace of the foliar bundle. The length and shape of these leaf-cushions, their acute or more obtuse terminations, their looser or more crowded arrangement, their greater or less convexity were then used to distinguish a large number of species in the genus, but these have been all finally united again by Göppert ${ }^{9}$ in one category as states of preservation of a few Lepidodendrae,-Lepidodendron Veltheimianum, and. L. aculeatum. In this proceeding he relies especially on two fragments from the quarries of Landshut in Silesia, the different faces of which he has figured from photographs ${ }^{10}$. One of these specimens ${ }^{11}$ certainly shows quite different leaf-scars on various parts of its circumference, some of which represent a typical Knorria, the others a Bergeria, though in a rather rough state of preservation. As the narrow fissure between the conical terminations of the leaf-cushions in Knorria and the surface of the stem is filled with a rind of coal, certain portions of tissue have been preserved in this case on the upper side of the cushion when the cast was made, which had disappeared by that time in the places where we see scars of Bergeria. Another specimen, that of Knorria princeps figured by Göppert ${ }^{12}$, which I have had opportunity of

1 Göppert (1) and (12), p. 195.

(5), vol. 2 I, p. 42 I.

8 Schimper (1), t. 65 .

t. 39 , ff. $3 \mathrm{~A}, 4 \mathrm{D} ; \mathrm{t} .4 \mathrm{O}$, f. I B.
3 Weiss (3).

๑ Göppert (19).

2 Göppert (19), p. 5 r 2.

- Weiss (3), p. I6I.

12 Göppert (12), t. 31 , f. I.
${ }^{3}$ Schimper (4). ${ }^{4}$ Heer

${ }^{7}$ Schmalhansen (3), tt. 3,4 . ${ }^{11}$ Göppert (19), 
examining in the Museum at Breslau, has appeared to me to be of very special importance in connection with this question. Herescars of a Lepidodendron are plainly to be seen on the rind of coal preserved at one spot in the stem, so that this fragment virtually decides the matter as far as I am concerned. Goldenberg ${ }^{1}$ also states that he has found Knorria Sellonii, Stbg (the word should be written Selloi, as the species is named from Bergdirector Scllo of Saarbrücken) in the roof of the Auerswald seam at Saarbrïcken attached to indubitable rind of Lepidodendron. Unfortunately the figure which he has given of his specimen is not an exact and working one. Grand' Eury ${ }^{2}$ is of the same opinion, though he has not given his reasons in full. Ife says only ${ }^{3}$ : 'From the observations of MM. Goldenberg and Göppert and from my own, the Knorriac are nothing more than the subcortical mould of Lepidodendreae, though this is not M.Schimper's opinion;' and further on, 'A Knorria from St. Eticnne with the tubercles prolonged into horizontal threads reflects the form of a deeper layer situated at a considerable distance from the rind.' It appears also from this passage that the form of preservation which we are considering is found also in the higher beds of the Carbonifcrous system, and is not confined to its lower portion. But according to $\mathrm{Hecr}^{4}$ the infra-Carboniferous Knorriae of Bear Island (the Ursa zone), which have no doubt becn correctly detcrmincd, are essentially different. He founds his view on a specimen figured in the work just cited ${ }^{5}$. This is a portion of a cast covered with Knorria-scars with pointed extremities, and has its covering of coal still preserved here and there; and on the outer finely-striated surface of the coal are comparatively diminutive circular scars at considerable distances from one another and with punctiform remains of a central leaf-trace. It appears from the text that these small scars are placed in regular oblique rows, each appcaring to answer to the pointed extremity of the underlying tubercle. If this is so, then the figure is incorrect, for there the regular rows can scarcely be perceived and the scars in some places do not coincide with the extremitics of the Knorriacushions. The matter cannot be cleared up without fresh examination of the original specimen. If Heer's statements are shown to be correct, we shall then be forced to conclude that the surface of the stems which gave rise to certain forms of Knorria was similar in character to that which we find in the genus Bothrodendron, which will have to be considered presently.

Two other genera which take their place with Knorria have been described by Göppert ${ }^{*}$ as Ancistrophyllum stigmariaeforme and Didymophyllum Schottini. A few specimens of them have been found in the Culm of Landshut in Silesia, and subsequently in the same formation at Thann in Alsace. In the latter species the Knorria-like cushions of the cast are

\footnotetext{
${ }^{3}$ Coldenberg (1). $\quad{ }^{2}$ Grand' Eury (1). vol. 2 I. Hlecr (5), vol. 2 1, t. 10, f. 4 . ${ }^{3}$ Grand' Eury (1), p. I44. 'Heer (5), ${ }^{6}$ Göppert (1), Lief. I and 2, It. I7, IS.
} 
shortly decurrent and loosely arranged, and have their extremities slightly emarginate; the former appears in rather shapeless casts studded with irregularly shaped pad-like protuberances which are broader in the transverse direction. Knorria Richteri ${ }^{1}$, also, from the hard coal of Oberhohndorf in Saxony, belongs to our present group, as its author expressly states. Schimper, who has also given a figure of Ancistrophyllum ${ }^{2}$, showed subsequently ${ }^{3}$ that the two genera are portions of the base of the stem of Knorria longifolia; he states that he found the characters of the three genera united in a stem discovered at Burbach near Thann. He refers the difference in shape of the remains of the leaf-cushions to changes connected with the growth of the stem, which may have affected the outer form as well as the inner structure. One more genus remains to be mentioned, Dechenia, Göpp., about which I refrain from expressing any decided opinion. Dechenia Römeriana, Göpp. ${ }^{4}$, from the Lower Devonian deposits, reminds us of Knorria; D. Euphorbioides ${ }^{5}$ from the Culm of Landshut in Silesia is a rather shapeless approximately cylindrical piece of stone covered with spirally disposed cushion-like projections.

Leafy branches of Lepidodendron are excessively abundant in the Coal-measures, and have essentially the habit of Lycopodiae. By the disappearance of the leaves which drop off regularly, as they do not in Lycopodium, the characteristic leaf-cushions are disclosed to view, and are at first small, but subsequently follow the further growth of the stems and branches, and increase in size. Little attention therefore is to be paid to these cushions in determining the limits of the species; and other changes of form may possibly be connected with them of which we know little, owing to the fragmentary character of the material, and which may therefore be the source of fresh causes of error in defining species. For this reason the statements of authors, that certain leafy branches must belong to certain species which are known by the structure of the stem, must be accepted with the greatest caution, since they scarcely ever rest on observation of the actual attachment of the branches to the pieces of stem to be determined. The leaves themselves are of very different size and shape; they are flat, linear, and pointed, and of very considerable length in the branch figured by Schimper ${ }^{6}$ after Röhl and identified as Brongniart's Lepidodendron longifolium. Similar leaves, but much shorter and more strongly squarrose and not collected into a parallel tuft, are drawn by Brongniart ${ }^{7}$ in his Lepidodendron elegans and L. gracile, which are both referred by Schimper to the collective species L. Sternbergii, Brongn. It is true that they have

1 Geinitz (5), p. 39 ; t. 4, f. $2 . \quad{ }^{2}$ Schimper (4), tt. I 1, 1 2. $\quad{ }^{3}$ Schimper (1), vol. ii, pp. 58 and 118. $\quad 4$ A. Römer (1), II, t. I4, f. I. $\quad{ }^{5}$ Göppert (1), Lief. 3-4, t. 3. ${ }^{6}$ Schimper (1), t. 59, f. 1. $\quad{ }^{7}$ Brongniart (1), vol. ii, t. 14 and t. 15 , and Lindley and IIttlon (1), vol. ii, t. 113 , and vol. i, t. 4 . 
an essentially different appearance in the remains which Ettingshausen ${ }^{1}$ connects with this species, and are almost equal in length to those of $\mathrm{L}$. longifolium, Brongn., with which Schimper places them. Finc branches with broadly lanceolate leaves are described in the same publication of Ettingshausen as L. Haidingeri ${ }^{2}$, and others with short linear leaves as L. brevifolium, Ett. ${ }^{3}$ Lastly, the name L. selaginoides, Stbg is given by authors to certain portions of branches with many ramifications, which are furnished with short leaves incurved and hooked after the manner of Araucariae or Walchiac. I have found such leaves in grcat abundance near Saarbrücken, and particularly fine specimens of them occur in the clayironstone nodules of Coalbrook Dale in England; figures of them will be found in Brongniart ${ }^{4}$, O. Feistmantel ${ }^{5}$, Lindley and Hutton ${ }^{6}$, and Schmalhausen ${ }^{7}$. The forms known as Lepidophyllum and regarded by Stur as foliage-leaves of Lepidodendron will be noticed again in a subsequent page.

But it is not only in the form of the leaves that the foliage-branches which lave been described cliffer from one another; the leaf-bearing axes themselves vary much in character. Some are stiff, little or not at all branched, and of remarkable thickness, as for cxample in Ettinghausen's Lepidodendron brevifolium, L. Sternbergii, and L. Haidingeri; others are thin and slender like so many rods, and are then usually copiously branched with repeated bifurcations, as is the case in general with the forms named Lepidodendron selaginoides. It cannot be doubted that these differences indicate important variations in the construction of the entire head of the trees, which in the latter case may have been copiously and densely branched with the terminal ramifications occasionally pendulous, while in the other case its branches may have been stiff, open, and few in number. And this leads to the consideration of the morphological building up of the entire plants, of which we have hitherto been discussing the separate parts. In numberless cases, as has been observed more than once beforc, both in evident Lepidodendrac and in Knorriac also, we can point to clearly ascertained dichotomies, which repeat themselves sometimes in larger fragments in the successive branch-generations. For this we may appeal to the figures already cited. As frequently, and usually on the same pieces with the dichotomics, we find lateral branching also variously distributed. Cases of this kind may in wonted measure and following the opinion of authors be explained by assuming sympodial development of the dichotomous systems, though it scems scarcely necessary to have recourse to this method, now that we know that the two forms of branching are present side by side in Psilotum, that in fact there is no fundamental difference between them.

\footnotetext{
${ }^{1}$ von Ettingshausen (5), tt. $26-28 .{ }^{2}$ von Ettingshausen (5), t. $22 .{ }^{3}$ von Ettingshausen (5), t. 25. Brongniart (1), vol. ii, t. 17. ${ }^{3} \mathrm{O}$. Feistmantel (3), tt. 30, 31 ' Lindley and Ifutton (1), vol. i, t. $12 . \quad{ }^{7}$ Schmalhausen (2), t. 2 , ff. $5,6$.
} 
In the Knorriae, in which this lateral branching is particularly common, the thinner lateral branch will often impede the further growth in thickness of the main stem, and then the base of the side-branch is seen to be imbedded in a lateral groove which forms on the sten1. The branch is then usually found to be broken short off, and the appearance is sometimes as though this fracture took place before the specimen was imbedded in the stone; this is the case when the lateral furrow terminates suddenly with a curved outline just above the place of fracture, and the stem at once recovers the original form of the transverse section.

Though such large portions of the head of Lepidodendrae have come under observation, yet, as might be expected, it is only in a few cases that the main ramifications have been seen attached to the stem which bore them. From these few discoveries it cannot be distinctly gathered, whether the considerable differences have specific or only individual significance; still they are so strong that we necessarily incline towards the former view. Among the first stems which have a claim to precedence of notice is the one described by Lindley and Hutton ${ }^{1}$ as Lepidodendron Sternbergii. It was discovered in the roof of a seam in Jarrow mine in England, and was laid bare from the base to the branches of the crown, a length of thirty-nine feet. The stem, which is three feet thick in its lower portion, is flattened, and, if I understand the accounts properly, shows the Bergeriacharacter on the surface. It branches dichotomously in the most regular manner, and its crown is preserved through three generations of bifurcating shoots, but is then broken off by a small fault. In Sternberg's ${ }^{2}$ famous stcm, on the other hand, which was discovered in the roof of the lower Radnitz seam at Svinná in Bohemia and with its branches is four metres in length, the crown begins with two branches placed exactly laterally right and left and at a distance of forty-six centimetres from one another; we know nothing of their subsequent ramifications, as they are broken off near the base. The first regular bifurcation is forty-six centimetres further down. the stem, and this is repeated twice in the branches and then passes into lateral branching. We are indebted to Stur ${ }^{3}$ for the description of a third case. The colossal stem, five hundred and twenty-two centimetres in length and sixty-three centimetres in diameter at the bottom, had had its head broken off down to the lowest and exactly lateral branch; it was found in the Alberti mine at Hruschau in Bohemia, and was carefully drawn as it lay. The one branch, which is thirty-one centimetres in diameter at the point of attachment and narrows rapidly, forms a right angle with the stem and shows sympodial branching.

Certain forms of Lepidodendron have been collected into a group and

1 Lindley and Hntton (1), vol. iii, t. 203.

${ }^{2}$ Sternberg, Graf von (1), Heft I-4, t. I.

${ }^{3}$ Stur (5), p. 224. 
named Ulodendron since Sternberg's time. Their distinguishing feature is the presence on their outer surface, which is covered with Lepidodendroncushions, of two opposite vertical rows of enormous usually depressed platter-shaped or cup-shaped scars, which may be either crowded together till they touch onc another, or be separated by wider intervals within each row. The Ulodendron-character is usually seen in strong thick stems, in which branching is an extremely rare occurrence; but Williamson " has described one case of the kind, in which one of the large cup-shaped scars lies exactly in the angle between the members of the dichotomy. It is not often that these stems are found with the surface-characters clearly shown; they arc usually observed in the form of interior casts, on which the position of the leaves is shown by the small linear protuberances due to the tracc-bundles. The Ulodendrac have recently been submitted to careful examination by Stur ${ }^{2}$, Kidston ${ }^{3}$, and Zeiller ${ }^{4}$. In Kidston will be also found a very complete collection of the older literature. The authors just cited, though differing in their vicws on other points, all agrce in thinking that the stems in question show variations in the character of their surface, and may accordingly be divided into three groups. We will confine our attention for the present to the first of these groups, which shows an almost absolute agrecment with the normal and well-known I.cpidodendron Velthcimianum, while the remains contained in it are usually named Ulodendron commutatum, Schpr., and arc directly united with that species by the authors just mentioned ${ }^{5}$. The leaf-cushions in specimens of Ulodendron are however as a rule considerably smaller than those of ordinary Lepidodendron-stems of equal thickness, though they agree with them in other respects. If we examine the peculiar plattershaped or cup-shaped scars, we find that they are roundish, elliptic or ovate, and more or less decply depressed, and that they appear therefore on the mould as a convex projection; a somewhat sharp cdge forms their boundary linc. At the decpest point is a nearly circular scar of separation, in the middle of which a dot-like trace may still be seen when the state of preservation is sufficiently good. This point of separation is not however central; it can always be seen, morc or less distinctly, to be pushed towards the lower side of the cup, so that the slope on that sidc is steeper and the radii shorter than on the upper side. The whole surface of the slope surrounding the scar bears small keel-like protuberances arranged pretty nearly in radiating rows, which look like the leaf-trace-marks of poor interior casts of Lepidodendrae, and are apt to run together into irregular and indistinct radial ribs, especially on the upper flatter slope of the platter. These stripes may be the only markings visible on the entire

1 Williamson (1), x, p. 499.

2 Stur (5).

3 Kidston (2).

- Zeiller (3) and (11).

${ }^{5}$ Schimper (1), t. 63 ; Kidston (2), t. 3 ; Brongniart (1), vol, ii, t. 18; Stur (5), tt. 2 1, 22, f. 3 . 
surface of the scar when the preservation is imperfect. - Ulodendron-stems have occasionally been mistaken for stems of Megaphytum which have also two lines of scars (see above on p. I67), as the literature testifies, but such confusion is only possible where both the surface of the stem and the cups are very badly preserved, and may be avoided in most cases by careful examination of the specimens.

Now comes the question, what were the organs which were inserted on these scars. On this point a great variety of opinions finds expression in the literature. Carruthers ${ }^{1}$, differing from all other authors, who look upon the central circle only as the scar of separation of the lateral member and explain the formation of the cup as the effect of the pressure of that member, has tried to prove that the entire cup answers to the place of separation. $\mathrm{He}$ considers the dot-like protuberances on its slope and the central scar also to be vascular bundle-traces, and assumes the existence of strong adventitious roots springing from these places. Apart from the fact that no trace of such adventitious roots has ever been found, the anatomy of the organs is most decidedly opposed to this view, as will be shown below. "The idea of a root with a mass of cortical bundles as well as the central strand must seem to the botanist to be a priori open to objection; and Kidston ${ }^{2}$ has supplied an excess of proof by describing and figuring a specimen in which the slope of the cups is covered with quite normal cushions of the leaves of Lepidodendron, and which is thus shown to be most certainly a segment of the surface of the stem. There remains therefore only the possibility that the scars in question bore vegetative branches or organs of fructification. It is improbable that they bore vegetative branches, as Stur ${ }^{3}$ has shown against Geinitz ${ }^{4}$; the great objection to this view is the regularity of the planes of separation, for which 'no analogue can be found except in the cladoptosis of our forest trees, the oak for example. That such separations are at least not invariable is shown by the branching of Knorriae which was described above, in which the pressure of the stumps that are left causes the formation of lateral furrows on the main stem. Thus we come back to the most natural and oldest idea, that these scars are the places of separation of the fructifications. And here Stur has been led by a speculation, which in my judgment 's quite unfounded, to a very remarkable result. He sets out from the view that the surface of the stem is of exactly the same character in Lepidodendron Veltheimianum and in Ulodendron commutatum, and that the two must therefore be considered to be identical forms. As he knows that there were cones of fructification attached to the extremities of thin leafy terminal branches in Lepidodendron Veltheimianum, the scars on the thick stems could not possibly have also borne cones. Vegetative branches are excluded for the reasons

1 Carruthers (11).

${ }^{2}$ Kidston (2), t. 4 , f. 2.

${ }^{3}$ Stur (5).

4 Geinitz (8). 
already given. But since something must have had its place there, he proceeds to study living Lycopodiaceae in order to find an analogue for this something that is required. And so the bulbils of Lycopodium Selago and L. lucidulum must be pressed into the service. The marks in Ulodendron are thereupon declared to be the scars of bulbils, of the nature of which the author ${ }^{1}$ distinctly says that he knows nothing. And when he nevertheless endeavours to show that these hypothetical bulbils were developed in the axils of leaves by explaining a small irregularity in the arrangement of the leaves, which was observed on a bit of stem ${ }^{2}$, as a young state of the same, the arbitrary character of the assumption is so obvious that it need not be submitted to closer examination. A specimen described by Goldenberg, in which Stur thinks that he has seen the basal portions at least of his bulbils, will be noticed again below, when the genus Lepidophloios is under consideration. If we try in this way to pick out the course of thought from among the many details of the account, the fallacy which is at the bottom of the whole theory comes out to the light of day. I myself draw only this conclusion from the facts, that there werc several forms of Lepidodendron with similar or the same sculpture on branches and stems, which differed however essentially in the position and mode of development of their cones. We have only to compare in reference to this point the living specics Lycopodium annotinum and L. lateralc from Australia. And since concs of fructification of the most various forms are known in abundance and there are no examples of brood-buds, I take my stand in this matter cntirely on the ground of facts. It may be observed here that cases have recently become known, in which cones are still attached to the scars in Ulodendron. Such a case has been described by Thompson ${ }^{3}$, though it would appcar from the figure not to be entircly beyond the reach of controversy. There is another specimen about which there can be no doubt, also found by Thompson near Edinburgh but not as it seems yet published, which I saw some years ago when I was with Williamson in Manchester, and which he has noticed incidentally ${ }^{4}$. Herc the cones are sessile and form cylinders of considerable thickness. It night therefore be expected that a pressure-surface would be formed between the cones and the stem which probably increased in thickness during their development, and it must have been cup-shaped to fit the base of the cone. The place of separation will then be decper and more excentric in proportion to the acuteness of the angle which the cone forms with the stem which bears it; nor can the displacement of the leaf-traces from their normal position in the cup-shaped scars cause any surprise in view of this mutual pressure.

\footnotetext{
${ }^{1}$ Stur (5), p. 263.

${ }^{3}$ Stur (5), p. $370 ;$ t. 23 , f. 3 .

3 Thompson (1).

+ Williamson 
The second group of branches with Ulodendron character comes nearest in surface-features to the Bergeria-forms with a deep-lying bundle-trace, which were discussed above on p. 199, and which we have compared with Dawson's Leptophloeum. To this group belong for example Ulodendron majus and U. minus ${ }^{1}$, Stur's figures ${ }^{2}$ which were classed by him with Lepidodendron Veltheimianum but can scarcely belong to it, and a few drawings of Carruthers ${ }^{3}$ and Kidston ${ }^{4}$. The latter author refers all these forms without hesitation to the genus Sigillaria, uniting them with the two species Sigillaria Taylori, Carr. and S. discophora, Koenig. But the only reason for this, as Zeiller ${ }^{5}$ has well shown, is a certain resemblance in habit, a resemblance which has misled Goldenberg ${ }^{6}$ also into figuring a fragment of Lepidophloios as Sigillaria Menardi. I do not know what it was that decided Stur to place the two specimens mentioned above as resembling Leptophloeum with Lepidodendron Veltheimianum. He found the shortly lanceolate leaves still attached to one of them, and concluded from this ${ }^{7}$ that it was a young stem and that the leaf-scars were not yet developed. Even this conclusion appears to me to be thoroughly rash, considering the little knowledge which we possess respecting the development of the leaf and leaf-cushion. If Zeiller's view is right, and it still requires confirmation, the Leptophloeum-forms which we are considering would have retained their leaves a long time, and would have lost them at last by irregular fracture, not by dismemberment. He mentions a piece of stem with excessively long leaves from the mines of Liévin, in which the areolae of the broad bases of the leaves were quite like those of Ulodendron majus. I have some pieces in my possession which make me think it probable that Leptophloeum may represent a distinct genus, though one nearly allied to Lepidodendron. But much further research is needed for the clearing up of these questions.

The last type of ulodendroid stems is represented by Lindley and Hutton's ${ }^{8}$ genus Bothrodendron, which though impugned by Kidston ${ }^{9}$ has been successfully defended by Zeiller ${ }^{10}$. The most clearly ascertained species of the genus is Bothrodendron punctatum (Ulodendron Lindleyanum ${ }^{11}$ ), with large cups widely separated from one another, in which the scar is very deep and very excentric. The surface of the stem is preserved in places on the layer of coal which covers the casts, and is extremely characteristic. It is marked by the very feeble development of the base of the leaf, and as consequently there was no formation of cushions it is quite flat and even, being furnished only with small sinuous longitudinal wrinkles. The scars from which the leaves parted appear on it as small dots, separated

${ }^{1}$ Lindley and Hutton (1), vol. i, tt. 5,6 .

4 Kidston (2), t. 4 , f. 5 ; t. 5 , ff. 8,9 ; t. 7 , f. I 2.

${ }^{7}$ Stur (5), p. 288.

(11), t. 8.
8 Lindley and Hutton (1), tt. 80, 81.

2 Stur (5), t. 22 , ff. 1, 2.

3 Zeiller (11).

11 Stemberg, Graf von (1), t. 45, f. 4.
3 Carruthers (11).

- Goldenberg (1), t. 7 , f. I. 9 Kidston (2).

${ }^{10}$ Zeiller 
from one another by wide intervals; according to Zeiller's account they are polygonal with the latcral corners truncated, and show the characteristic three trace-points. Close above them in all cases is the so-called ligular pit, which is depicted by Zeiller as a diminutive circular scar. The genus appears unfortunately to be a scarce one; the only perfectly satisfactory well-preserved specimens that I have seen are in the collection of the Ecole des Mines at Paris. If indeed the flakes of cuticle pierced with small holes which form the paper-coal of Tovarkova near Tula belong to Bothrodendron, as Zeiller ${ }^{1}$ endeavours to show and as is indeed probable, the genus must have been enormously developed in that locality very low down in the Carboniferous formation on the horizon of the Carboniferous Limestone. In fact all our specimens hitherto have come from the Lower Carboniferous deposits, or at least from the bottom of the Middle series. And when we consider Heer's statements noticed above on p. 202 respecting the rind of certain infra-Carboniferous Knorriae, we can scarcely avoid the conclusion that these are states of preservation of Bothrodendron. At Carvin, in the Department of the Pas de Calais, Zeiller has also found leafy branches with repeated bifurcations, which are proved by the leaf-scars on the older parts to belong certainly to Bothrodendron. These branches bear very short almost scale-like acutely lanceolate leaves, which are in loose array and show the smooth surface of the stem between them. Exactly similar stems, which also have similar leafy branches but without the large Ulodendroid cup-shaped scars, have been described by Boulay ${ }^{2}$ as Rhytidodendron minutifolium; a figure of the surface of the plant will be found in Zeiller ${ }^{3}$. According to Kidston these stems occur not only in the North of France, but also in several parts of Scotland. It is natural to assume with Zeiller that there is a similar relation between Bothrodendron and Rhytidodendron to that which has been shown to be probable between Ulodendron and Lepidodendron. In both cases we should have the cones in different species of the same type at one time on the stem and on the thicker branches, at another terminal on the extremities of snaller branches.

Closely connected with the Ulodendron-forms, in the opinion of all authors, is the genus Lepidophloios ${ }^{4}$, to which Lomatophloios, Corda may also be joined. Though this genus has been known for a long time, yet it is greatly in need of fresh examination, for there are various points connected with it which are still obscure. The most thorough treatment of it up to the present time will be found in Corda ${ }^{5}$, Goldenberg ${ }^{6}$, Weiss ${ }^{7}$, and O. Feistmantel ${ }^{8}$; Stur ${ }^{9}$ also has occupied himself with it. The platter-shaped scars are quite similar in character to those of the remains which we have been considering, but they are arranged on the stem in four lines instead of

\footnotetext{
' Zeiller (2). $\quad$ 'Boulay (1)。 $\quad$ 'Zeiller (2), t. 9, f. 2. ' 'Sternberg, Graf von (1), Heft I-4, p. I3 ; t. II, ff. 2-4. ${ }^{5} \operatorname{Corda}(1) .{ }^{6}$ Goldenberg (1). ${ }^{7}$ Weiss (1). ${ }^{8}$ O. Feistmantel (3). ${ }^{9}$ Stur (5).
} 
two, and the genus is further distinguished by the quite peculiar configuration of the leaf-cushions. These are not flat as in Lepidodendron, but are developed in the form of tall steep-sided cones which are crowded close together and gird the stem with an armour of leaf-bases, just as in our modern Cycadeae. In addition to this the base of the cushion is transversely rhombic in form, the angles at the lateral edges being acute and those at the median very obtuse, and thus the cushions differ altogether in habit from the elongated cushions of Lepidodendron, and have the appearance of scale-like leaves. From their crowded position they necessarily cover one another like the tiles in a roof; in looking at them from the outside we get sight of the anterior portion only of one pair of facets of each cushion, and the areola of separation of the leaf-blade lies on the most anterior point of its margin. This areola has a similar outline to that of the whole cushion, its lateral edges are very sharp, and as compared with that of Lepidodendron it is strongly compressed in the median direction. Upon it are found the usual three trace-points, the middle one of which corresponds, as we saw, to the transverse fracture of the vascular bundle. We said just now, that in the outside view we can see only one of the two pairs of facets, and now comes the somewhat difficult question whether this is the upper or the lower one. On this depends the determination of the upper and lower side of the fragments of stem. If it is the lower pair, then the scales of the armour were directed obliquely upwards and bore the scar above on the apex, in the opposite case they were reversed and the scar is placed on the lowest point of their margin. In the former case the development of the lower pair is the greater, in the second that of the upper, a point which Stur has discussed at length. Now the views of authors are much divided on this question, the scar being placed below in Sternberg and Schimper ${ }^{1}$, above in Corda ${ }^{2}$, O. Feistmantel ${ }^{3}$ and Geinitz ${ }^{4}$ and recently in Renault ${ }^{5}$, while Goldenberg disposes his pieces in more than one way and divides them accordingly into the genera Lepidophloios and Lomatophloios, giving to the latter the species which he thinks had crect scales and to the former those with the scales reversed. Weiss ${ }^{6}$ however has reunited the two groups; he insists very justly on the subjective character of Goldenberg's division, in which everything depends on the disposition of the specimens. He seeks also to lessen the value of the other marks which Goldenberg adduces in support of his genera. Among these may be mentioned the form of the three trace-dots on the scar, which obviously depend too mucl on the preservation to be capable of being used in this manner; and next the medullary cylinders of the Artisia kind on which Goldenberg relies, which are said to be smooth in Lepidophloios, transversely furrowed

'. Schimper (1).

- Weiss (1).
2 Corda (1).

3 O. Feistmantel (3).

${ }^{4}$ Geinitz (8).

${ }^{5}$ Renault (2). 
in Lomatophloios. Corda had previously drawn an Artisia-pith for his form; but this stem does not show the characteristic outer surface, and might very well have belonged to a Cordaites which had been referred here by mistake. And the remark applies also to Goldenberg, who seems to rest in this case on Corda's authority, and is so convinced of the correctness of his views, that on the strength merely of the discovery of Artisiae near Schwalbach (the Ottweiler beds) he thinks himself justificd in asserting that Lomatophloios occurs there ${ }^{1}$. After what has now been said, and notwithstanding all Dawson's ${ }^{2}$ assertions, I belicve that the connection of these medullary cylinders with the genera which we are considering is highly questionable. In any case it is clear that we cannot turn them to account for diagnostic purposes. Goldenberg says that the leaves in Lepidophloios are three-nerved, in Lomatophloios one-nerved. These leaves, which were on several occasions found attached to their bases ${ }^{3}$, are linearlanceolate; their transverse sections, which have been figured by Corda,

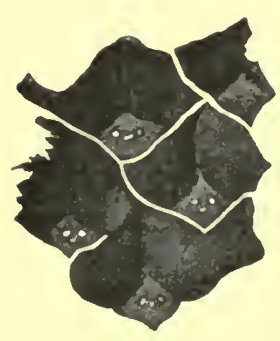

Fir. 2r. Some scales from the armour of leaf-bases of 1,epidophloios(1.omatophloios crassicaulis), Corda. After Corda' but in reverse posi.
tion. settling the question. He has himself had the opportunity of examining a forked stem, but he appeals chiefly to the specimen figured by Goldenberg ${ }^{5}$, which indeed lcaves little room for further doubt. Here three of the four rows of scars can be seen, and the two lateral rows which lie in the plane of the stratification still have the members attached to them in the form of lateral branches; the scars of the middle row have lost their members. The branches stand out squarrosely from the stem, but some at least are so strongly inclincd that there can be no question respecting the direction of the piece, and it appears that all the cushions point backwards towards the main stem. This figure reappears in Renault ${ }^{6}$ in a distorted form, all the leaf-cushions being drawn in reversed, the stem in the upright position. The author is scarcely justified in saying in the explanation of

\footnotetext{
${ }^{1}$ Weiss (1), p. 156. $\quad{ }^{3}$ Dawson (9). $\quad{ }^{3}$ Goldenberg (1), t. 14 , f. 12 , and Corda (1), t. 4. t Corda (1). ' ${ }^{3}$ Goldenberg (1), t. 16, f. 6. Renault (2), vol. ii, t. 9, f. 1.
} 
the figure: 'after a figure of M. Goldenberg but put upright.' Stur too has discussed this specimen and has sought support in it for his bulbiltheory; he sees in the branches, which are all broken short off at the margin of the plate, the bases of his brood-buds. I can myself see nothing more in them than ordinary branches, which may perhaps have borne cones on their extremities. The scars left by them on the stem appear from the drawing to have been simple circles; there is no sign of the cup-formation which is produced by the base of the sessile cone in Ulodendron. If nevertheless I incline to regard them as stalks of fructifications and not as ordinary lateral branches, it is solely because the scparation from the stem seems always to have been basal. Supposing them however to have been vegetative branches, we should then have in this specimen a case of exceptionally copious lateral branching. It is also in favour of the view which we have been advocating with respect to the direction of the pieces of stem of Lepidophloios, that the so-called ligular pit can in almost all cases be seen in well-preserved specimens on the two facets which are visible on the median line; this is a point on which Stur ${ }^{1}$ has specially insisted. This pit is distinctly shown in the figures in $\mathrm{O}$. Feistmantel ${ }^{2}$, though he is not quite clear in his own mind as to its meaning. Weiss ${ }^{3}$ too has observed it and has figured it with his usual accuracy. The specimens of Lepidophloiae which have been preserved without the rind have been so little studied up to the present time, that there is nothing definite to be said about them. Some of them perhaps belong to the Bergeria-forms noticed above, and which are still imperfectly understood. A specimen given by Lesquereux ${ }^{4}$ as Lepidophloios obcordatus, Lesq. reminds us of Knorria; it is partly covered with the rind of coal, but in other places shows two-lobed protuberances, while a small cone rises in the anterior sinus of the lobes. It may be observed in conclusion that if the question of the distinction of species is a difficult one in Lepidodendrae, it is much more difficult in Lepidophloiae. The size of the leaf-cushions and the convexity of the anterior margin which bears the scars vary greatly. In large stems the cushions may attain considerable dimensions; in a piece before me which answers to one of Corda's ${ }^{5}$ figures I find the breadth to be sixteen millimetres. How far such differences may be due to later growth may-be left undetermined; they are referred to this cause by Weiss, who virtually distinguishes the species by the form of the scar. That growth of this kind helps to produce the variations in question cannot be doubted, if we consider the colossal size of the stems which have these broad leaf-bases.

The genus Halonia, Ldl. and Hutt. is closely allied to Lepidophloios, and Cyclocladia, Goldenberg not Ldl. and Hutt. is not distinct from

1 Stur (5), t. 19. $\quad{ }^{2}$ O. Feistmantel (3), t. 33, f. I, and t. 34, f. $3 . \quad{ }^{3}$ Weiss (1), t. 15, f. 8 a.

${ }^{4}$ Lesquereux (3), vol. ii, t. 4 I, f. I. $\quad{ }^{5}$ Corda (1), t. I. 
Halonia. As Halonia is on the whole of rare occurrence, only a few authors have described it with any fulness. Carruthers's ${ }^{1}$ account of it is good and perspicuous, and is accompanied with abundant examination of the literature. Halonia is very closely allied to Lepidophloios, so closely that $\mathrm{O}$. Feistmantel ${ }^{2}$ desired to unite it at once with L. laricinus. Where the covering of scale-like leaf-bases on the stem is preserved, which is not often the case, it is said by authors to be of exactly the same character as in Lepidophloios. Figures of stems in this condition will be found in $\mathrm{O}$. Feistmantel ${ }^{3}$, but the execution of them leaves much to be desired; there are similar figures also in Schimper ${ }^{4}$ and Lesquereux ${ }^{5}$. Instead of four rows of sunken scars we have here six to eight vertical lines of prominent bluntly rounded protuberances, which are surrounded by leaf-bases and show a rounded often depressed scar of separation on the apex only. Mould-specimens, in which these scars are especially distinct, are the foundation of Goldenberg's ${ }^{6}$ account of Cyclocladia. Cyclocladia is sometimes found in the neighbourhood of Saarbrücken, and I have satisfied myself of its identity with genuine Haloniac through the medium of a stem found by myself in that locality and agreeing in every respect with the figure. Casts without the outer rind are much more abundant. In this form Cyclocladia occurs not unfrequently in the Millstone Grit of the English Coal-measures. A fine specimen has been figured by Binney ?, and similar ones will be found in Brongniart ${ }^{8}$ and in Lindley and Hutton ${ }^{9}$. On these casts the traces of the foliar vascular bundles are seen only in the form of the well-known small linear protuberances; the scars of separation on the apex of the protuberances may have a distinctly circular outline and be depressed, but with a central raised bundle-trace-point; and when, as often happens, there is nothing more to be seen of the points of emergence of the foliar bundles, the Haloniac have sometimes a wonderful rescmblance to the Stigmariac which will have to be considered later on. Binney ${ }^{10}$ has described pieces of stem of this kind, the connection of which with Haloniae might appear doubtful where their anatomical structure is not known. Such specimens gave rise to the view that Haloniae must be the roots of Lepidodendreae, a view which we find in older authors, Dawes ${ }^{11}$ for example, and which was subsequently maintained by Binney in spite of the discovery of more than one specimen showing the leaves, and by Renault ${ }^{12}$ also with certain limitations. The remaining authors, Schimper ${ }^{13}$ among them, consider that we are dealing in this case with branches of lepidendroid growths, and that the protuberances repre-

\footnotetext{
1 Carruthers (12).

${ }^{2}$ O. Feistmantel (3).

3 O. Feistmantel (3), tt. 36, 37.

- Schimper

(1), t. 66 . 'sesquereux (1), vols. i, ii, t. 87 , f. I.

- Goldenberg (1), t. 3, f. I1. ${ }^{7}$ Binney

(1), III, t. 18 .

${ }^{8}$ Brongniart (1), vol. ii, t. 28.

- Lindley and Hutton (1), vol. iii, t. 228.

${ }^{10}$ Binney (1), III, t. 16, f. 1 , and t. 17, f. 1. ${ }^{11}$ Dawes (1). ${ }^{12}$ Renault, vol. ii. ${ }^{13}$ Schimper (1).
} 
sent small abbreviated lateral branches, the extremities of which were probably occupied by cones of fructification and have dropped off. When Renault takes some of these forms for rhizomes and others for fertile branches, the construction is artificial, and in my judgment rests on very weak foundations and must be rejected. The anatomical reasons which he advances in support of it will have to be discussed further on when we are giving an account of the anatomy of these plants. He imagines too that he has seen the root still attached to a protuberance in one of Binney's specimens ${ }^{1}$; but this is shown to be a mistake by Williamson ${ }^{2}$, who examined the original in Owens College in Manchester and ascertained that the supposed root was a casual corner of the enveloping sandstone. The latter author moreover long before produced weighty reasons for thinking that Haloniae must have been the fruit-bearing branches of the crown of lepidendroid plants; in a lengthy note on these forms ${ }^{3}$ he describes an ordinary and evident branch of Lepidodendron, which after bifurcation retains its character on one branch and assumes that of Halonia on the other. In this case therefore we can no longer speak of our fossil being of the nature of a root, and the idea of a rhizome is excluded, or else the normally constituted sister-branch must also be supposed to belong to the subterranean parts; we also obtain a point of vantage for determining other more imperfect specimens. This unhappily is all that can be said about Haloniae; we know neither their leaves nor their fructifications; neither leaf nor fructification has yet been found in immediate connection with them.

The structure of the stems and branches of Lepidodendreae is well known to us from the abundant material supplied by the calcareous nodules of the English Coal-measures. Renault has also made us acquainted with some small and important stems from Autun, but they are extremely rare in that locality; nor is this surprising, since the entire group sinks into comparative insignificance as early as the upper portion of the Carboniferous formation, to which the beds at Autun belong. On the other hand, we should scarcely know anything of the structure of the leaves, if we did not find them preserved in the cones of the fructification, of which we shall speak again presently. We thus are able with some degree of confidence to infer the structure of the foliage-leaves from the character of the fruit-bearing leaves. The structure of the stem, with all the variety of its details, follows everywhere essentially the same fundamental plan. We find a central bundle-strand, from the periphery of which the leaf-traces are given off and ascend in a curved line, and a parenchymatous cortical tissue separating into layers of dissimilar charaçter, the outer surface of which, even in thick stems, is bounded by

${ }^{1}$ Renault (2), vol. ii, t. 8, f. x. $\quad{ }^{2}$ Williamson (5). $\quad{ }^{3}$ Williamson (1), II, p. 225. 
the epidermis-covered tissue-layer which forms the leaf-cushions. Sometimes the growth in thickness of the stem falls either wholly or principally to certain portions of the cortex only, and in that case the developinent of the axile bundle is relatively small. But various forms of the group are so far differently constituted, that they have in addition a secondary woody body, the product of cambium, which forms a ring round the central bundle and may in certain circumstances be of very considerable size.

These various stems thus differing in structure cannot of course be referred with perfect certainty to the species founded on the character of the surface. The preservation of the leaf-cushions in our material never suffices for this, and in the majority of cases even the genera cannot be distinguished. When identifications of the kind are nevertheless attempted, they are apt to appear somewhat arbitrary in character. This is the case for example with a type of Lepidodendron extremely abundant in the calcareous nodules of the Lancashire coal-field, which has been referred by Carruthers ${ }^{1}$ to Lepidodendron selaginoides, Stbg, itself a decidedly obscure form. Williamson" has followed Carruthers in this, though there was already another name for the species, L. vasculare, Binney, whereas he has elsewhere cautiously applied to the types which differ in their anatomical structure a peculiar nomenclature which runs parallel with the other. The latter is in my opinion the more convenient plan, because the same structuretype may contain distinct species which we cannot distinguish from one another.

The simplest case is presented to us in Lepidodendron rhodumnense, Ren., which was found by Grand' Eury near Combres in the Department of the Loirc and has been described by Renault ${ }^{3}$. Young branches have the leaves still attached to them; thesc leaves spread almost at a right angle with the branch and are then curved upwards and become hooked; the transverse section of their basal portion is transversely rhombic, that of the upper part is flatly crescent-shaped, and they contain a single median vascular bundle. The central bundle-strand of the stem is homogeneous in character and consists entirely of scalariform tracheides; its circumference shows a number of small tooth-like projections, which answer to the transverse sections of the points of attachment of the leaf-traces. The section passes through the weak trace-bundles in the cortex at different points in their course. The entire woody bundle is surrounded by a very thin layer of delicate elongated parenchymatous cells, which should belong to the bast, not, as Renault thinks, to the bundle-sheath. In the xylem the tracheides of smallest size on the transverse section lie in groups on the periphery, and these groups correspond to the attachment of the leaf-traces and are explained by Renault to be protoxylem-elements. The rind 
separates into three layers. The innermost, which consisted probably of spongy parenchyma, has entirely disappeared. The outer layer is a stout parenchyma, and contains the leaf-cushions which are cut through at different elevations. The third layer, which is the boundary on the outer side of the cavity formed by the disappearance of the innermost layer, consists of a few layers of right-angled cells forming regular radial rows. Renault was also able to investigate an older bit of stem some five centimetres in thickness. Here in the middle of the solid central xylem-strand
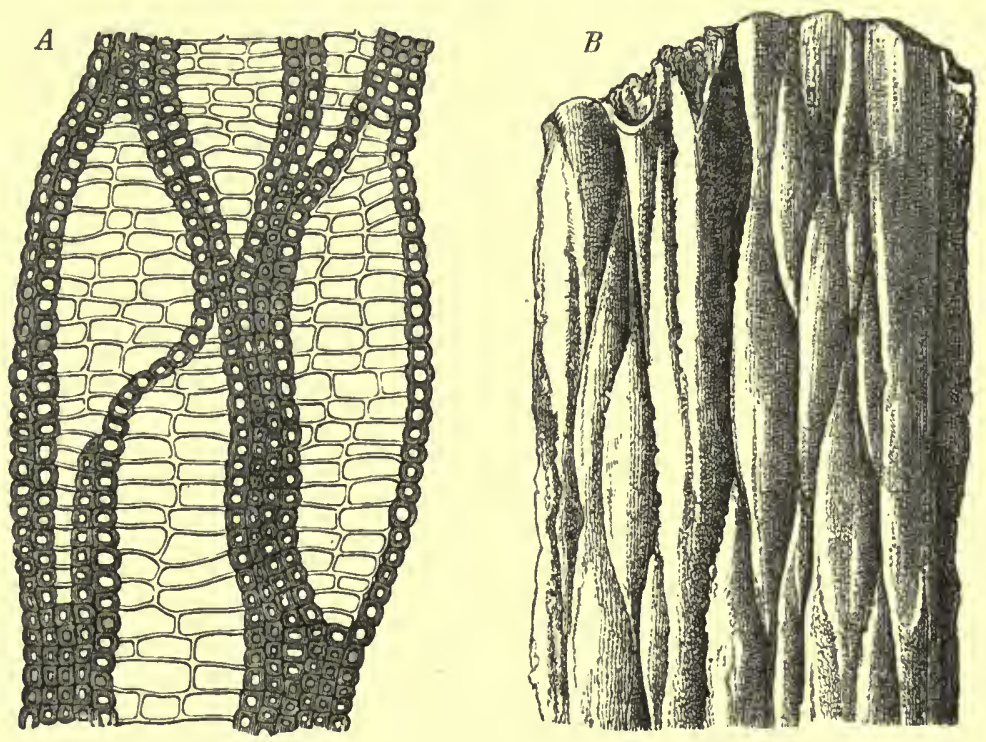

F1G. 22. Dictyoxylon-structure of the rind, as it occurs in some Lepidodendrae and Sigillariae, and in Lyginodendron, etc. $A$ transverse section of the outer rind of Lepidodendron rhodumnense, $B$. Ren., showing the anastomosing plates of sclerenchyma which bound the meshes filled with parenchyma; the longitudinal section is quite similar, only the sclerenchymatous elements are seen in elongated form. $B$ impression of the inner side of such a Dictyoxylon-rind separated from the stem. The ribs are more prominent owing to the disappearance of the parenchyma and answer to the furrows. The rhombic cushions fill the depressions caused by this disappearance of tissue in the ineshes. $A$ after Renault ${ }^{1}, B$ after Williamson?

is an irregular fissure-like gap. The character of the rind, which had lost its original outer surface, is peculiar. The parenchymatous fundamental tissue is traversed by plates of sclerenchyma, which run on the whole in a radial direction, but are so curved and undulated that they cut one another at regular distances at an acute angle, and thus the parenchyma is seen on the transverse and tangential sections to be divided into fusiform segments (Fig. 22, A). Since these segments are of nearly the same length, zones are formed at the places where the plates cross one another, and as the sclerenchymatous tissue predominates in the zones, the unaided eye sees on the transverse section a system of circular bands. This peculiar arrange- 
ment of the tissue, evidently a special provision for giving firmness to the plant, will be met with again more or less strongly developed in different species, and especially in many Sigillariae. Cortical tissues of this kind, separated from the woody bodies to which they belonged, are met with not unfrequently at Autun, and received from Brongniart the provisional name of Dictyoxylon, which being no longer required as a generic name may now very well be used as a short expression for this peculiar structure. It has been already stated in the Introductory chapter on p. 7 that we also have the traces of Dictyoxylon-rinds in the form of impressions. It is obvious that after the parencliyma had rotted away, impressions of the network might in certain circumstances be formed, and in that case the mineral matter making its way into the meshes of the net would form irregular fusiform humps separated from one another by sharp deep furrows corresponding to the ridges of sclerenchyma. It is to a state of preservation of this kind that Williamson ${ }^{1}$ has referred the form belonging to Sagenaria fusiformis which has been figured by Corda ${ }^{2}$, and also an impression which was described by Gourlie as Lyginodendron Landsburghii, and this name he has applied to a distinct collective form with a very remarkable structure which he had previously named Dictyoxylon, and which must be discussed further on. I have not myself seen Gourlie's work; a specimen of the state of preservation in question, which I possess from the Bacmeister seam in the Hannibal mine near Essen, makes me think Williamson's interpretation very plausible.

A second very different type is presented to us in Renault's ${ }^{3}$ Lepidodendron Jutieri. We are not in a position unfortunately to arrive at any certain decision with respect to this form, since it has not up to the present time been either figured or fully described. It is known only in a branch one hundred and five millimetres in length and fifty-eight millimetres in thickness and split longitudinally, which was found near Autun. It appears from Renault's brief remarks that its thick rind consists of homogeneous parenchyma; of its axile portion this author says: 'This specimen appears to me to be without the continuous wood-cylinder which is met with in our former Lepidodendrons, and which would be represented only by a circle of vascular bundles giving rise to the strands which pass to the leaves.' It is not even certain therefore whether we have bẹfore us a circle of bundles surrounding a central pith, or a single strand with its central portion formed of parenchymatous tissue and giving off a number of vascular groups from its periphery. We will hope that this fossil will soon be more thoroughly investigated; its importance will appear still further when we are considering the group of Sigillarieae.

The structure of Lepidodendron vasculare, Binney (L. selaginoides,

1 Williamson (1), Iv, p. 393 .

${ }^{2}$ Corda (1), t. 4 , f. 6.

${ }^{3}$ Renault (1), p. 258 . 
Carr. Williamson) is very exactly known; the fullest account of it will be found in Williamson ${ }^{1}$. Binney's ${ }^{2}$ fine figures of this form should also be consulted; the text which they accompany is not it is true of equal value, and should be read with great circumspection. If we look first at the primary structure, we find in the centre of the stem a woody cylinder slightly developed in proportion to the thickness of the rind, circular on the transverse section, and composed of scalariform and reticulately-thickened tracheides, between which parenchymatous cells in tolerably large quantity and increasing in number towards the centre are interspersed singly or in groups. The longitudinal section shows that the tracheides are of two kinds, that sometimes they are elongated and tubular, and again short and isodiametric, and with their cross walls usually showing particularly beautiful reticulate markings. The latter kind is found chiefly in the middle of the bundle, the former is present everywhere and is the sole constituent of the periphery. The narrowest elements of the bundle are found on its outermost margin. The rather broad ring of bast which surrounds the wood-cylinder has generally disappeared up to its innermost layer; it is but rarely that its delicate tissue is perfectly preserved. It is traversed by the xylem-strands of the leaf-traces, the transverse sections of which are found in great numbers in the immediate neighbourhood of the edges of the xylem of the central strand, and are surrounded by the remains of bast-tissue. In the well-preserved preparations before me I see only one homogeneous bundle of tracheal elements on the transverse section of the leaf-trace. The protoxylem-groups I am unable to distinguish with the needful certainty; there ought to be two of them present as in Ferns, according to Renault ${ }^{3}$, who however relies for this point on Corda's ${ }^{4}$ extremely doubtful figures. How much uncertainty still remains with respect to these points is further shown by van Tieghem's ${ }^{5}$ account, who ascribes a collateral structure to the leaf-traces of Lepidodendron and finds their initial strand on the outer borders of the xylem. He then makes the homogeneous central cylinder of the stem be formed by the union of several such bundles with their xylem-portions. The state of preservation of the associated bastportion being so unfavourable, I do not venture to decide whether we have a concentric bundle before us or a collateral, although for various reasons, to which I shall presently have to return, I incline to the view that the plan of structure is of the latter kind. Moreover this collateral structure occurs at the present day, according to Russow and Janczewski, in Isoëtes. And here we may draw attention to a point which will have to be noticed often again, namely how little we can rely on distinguishing the protoxylem-

${ }^{1}$ Williamson (1), II, III, XI. $\quad{ }^{2}$ Binney (1), III, 2 and 3. $\quad{ }^{3}$ Renault (2), vol. iii, Introd. p. II ; t. 10. 'Corda (1), (Lomatophloios crassicaulis, t. 3 , f. 8). ${ }^{5}$ van Tieghem (2), p. 1305 . 
strands when we only know the mature state of the bundles, and how dangerous it therefore appears to draw conclusions in this direction from the relative size of the elements, as has often been done by Renault, though at other times he lays great stress and rightly on this point. On the outer limit of the bast-portion is a sheath of stout parenchyma, which, consisting only of a few cell-layers, is often preserved in cases where both the bast and the inner layer of the cortical tissue lying outside the bast are entirely destroyed.

The rind is in general very thick, and separates into three cylinders one within the other, which may conveniently be distinguished in the following remarks as the outer, middle, and inner cylinders. The inner cylinder, which is evidently composed of loose spongy tissue, is almost always entirely destroyed; a broad circular space filled with crystalline carbonates and detritus which has floated into it takes its place (Fig. 23). Remains of this tissue have been preserved in a few specimens, for example in a transverse section figured by Williamson ${ }^{1}$. The outer cylinder readily comes away from the middle one with a sharp circular line of separation and is therefore often wanting, and may occur detached and variously curved and rolled up. Its outer margin formed by the epidermis is rendered uneven by crowded protuberances, the transverse sections of the leafcushions, and these sections necessarily vary much in size and form since they cut the cushions at different elevations. This outer cylinder is composed of stout-celled parcnchyma, the cells of which beneath the epidermis add continually to the thickness of their walls, and assume the character of sclerenchyma. The epidermis itself is often remeved, and then the surface bears some resemblance to a Bergeria-cast. Lastly, if the whole of the outer cylinder is wanting, we then have the stems in the well-known state in which they so frequently occur, covered with small flat protuberances, in the usual phrase, stripped of their rind. The middle cylinder, at least as thick as the outer and inner cylinder put together and usually much thicker, is traversed on the transverse section by radiate stripe-like lacunae (Fig. 23). In each of the lacunae runs, longitudinally or a little obliquely, the upper horizontal portion of the emerging foliar bundlc, of which the xylem-portion only is usually preserved. The entire tissue-mass of this cylinder is parenchymatous, but two essentially different layers may always be distinguished in it, the relative thickness of which changes with time; in young stems with a small transverse section the inner layer is the thicker and the outer is often only a very narrow zone, while in older pieces of stem it is the outer zone which attains to very considerable thickness. In this zone the somewhat thin-walled parenchyma-cells are rectangular on the transverse section a::d arranged in radial rows, on the other they have a much broader

1 Williamson (1), XI, t. 52, and Binney (3), . 35, f. 5 . 
lumen, are thick-walled, roundish in shape, and irregular in their disposition. From the arrangement of the cells in the outer layer, and still more from the circumstance that having been at first feebly developed they increase so much in size in old specimens and surpass the inner unaltered cells, we may conclude that the outer layer is formed by the constant activity of a meristem. We may in fact satisfy ourselves from specimens

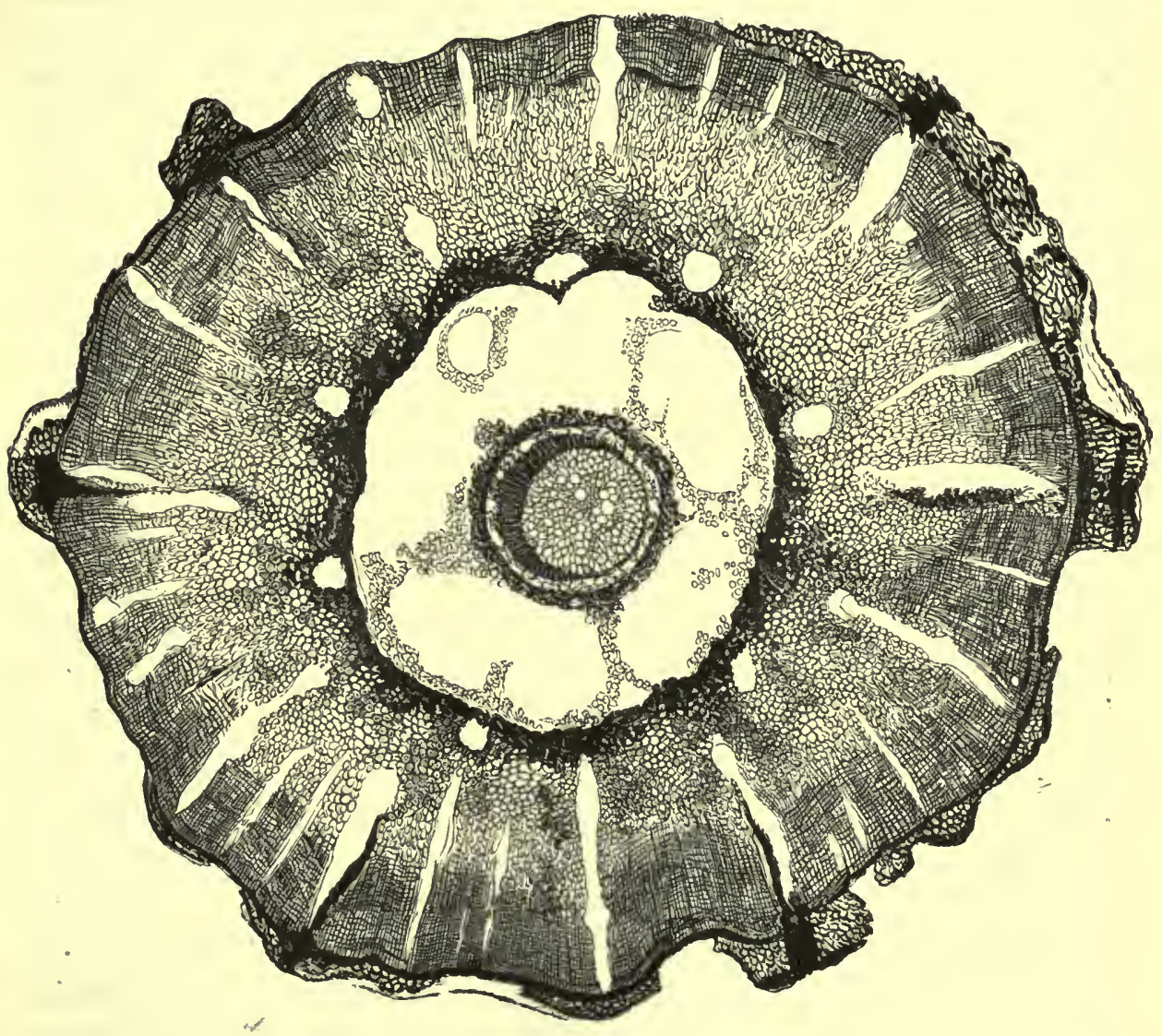

F1G. 23. Transverse section of the stem of sepidodendron selaginoides, Will. In the centre is the concentric central.vascular bundle-strand, and next it on one side is a thin crescent-shaped layer of secondary wood. The inner rind is destroyed, the thick cylinder of the middle rind is traversed by radial fissures containing the foliar bundles. On the outside are still to be seen some remains of the subepidermal zone to which the leaf-cushions belong. Afier a preparation in my collection from the calcareous nodules of the English Coal-measures.

in a particularly good state of preservation, that near the outer edge of the layer there is such a hollow cylinder of meristematic comprcssed cells, which may be compared to some extent with the phellogen of the rind in recent plants; this zone gives rise to a considerable amount of phelloderm on its inside, while the phellem is produced in small quantities only, and usually comes away with the outer cylinder in the form of a thin layer 
of radially disposed cells. As this phelloderm consists of prismatically elongated cells, it is termed by Williamson the 'outer or prosenchymatous layer of the bark,' the primary tissue being with him 'the middle parenchymatous part of the bark.' When Renault regularly calls this phellodermportion of the middle cylinder the 'assise subéreuse,' he means to call attention to its connection with the peridermal system. For we cannot imagine any formation of real cork either in the phelloderm or in the phellem ; the main growth in thickness of the tree devolves on the phellogen, and if this were to produce anything but normal parenchyma-cells on the phellem-side, the tissue-cushions of the leaf-bases would at once die away and disappear, but this is by no means the casc. On the contrary, we find them still preserved on stems in which the periderm has already reached a considerable development ${ }^{\text {? }}$.

It was said above that the type of Lepidodendron vasculare, Binn. is further distinguished by the appearance of a secondary woody body. Lepidodendron-stems of this kind have often been described under other names; such are Anabathra pulcherrima ${ }^{2}$ and Diploxylon cycadoideum ${ }^{3}$, which are one and the same form, as Brongniart ${ }^{4}$ was the first to perceive. $\mathrm{He}$ and Renault do not admit that they belong to Lepidodendron, and usually speak of them by Corda's names. Stems of this kind are termed in Binney Sigillaria vascularis, and are figured in great numbers in the publications just cited. The secondary growth of wood begins to develope on the boundary between wood-strand and bast-portion; its inner side is in contact with the former and the cmerging leaf-trace-bundles are inclosed in it; the bast and the formative cambium are more and more thrust towards the outside. In many cases the new growth does not appear simultaneously on the whole of the circumference (Fig. 23), but is developed in a one-sided manner, and may be of great size on one side, while it has not even begun to be formed in the opposite quarter. It consists of clongated scalariform tracheides, which normally are disposed in radial rows and increase in brcadth towards the outside. It is traversed by numerous parenchymatous medullary rays, which are seen on the tangential section to be of two kinds; one narrow and formed of one cell-layer, shallow and one to a few cells in depth, and this kind is vcry abundant; the other formed of several laycrs, but like the first of small depth, fusiform and inclosing the emerging foliar bundles at the broadest part. As against Carruthers's ${ }^{5}$ views it may be observed that all these medullary rays agree perfectly with those of the roots of recent trees. The size attained by the secondary wood here described varies much. This variation may be partly due to specific differences, and is usually confined within moderate limits,

\footnotetext{
1 Binney (3), t. 35, ff. $5,6$.

Witham (1), p. $74 ;$ t. 8, f. 7 .

3 Corda (1), t. 10.

- Brongniart (7). 3 Carruthers (13).
} 
though Binney ${ }^{1}$ has figured a transverse section of a stem of the vascularetype, in which the central strand, seven millimetres in thickness, is quite insignificant as compared with the secondary wood, which is sixty-two millimetres thick. The disposition also of the tissue of the primary wood in this specimen is somewhat abnormal.

These stems with secondary wood have hitherto been unhesitatingly regarded as more advanced states of development of Lepidodendron. It is necessary however to show some reasons for this view, since we know that no such secondary formations occur in recent Archegoniatae, or only in a quite rudimentary form in Isoëtes. Secondary wood is said by recent authors to be found in older stems of Botrychium, but the point requires to be cleared up by further investigation. The view which Renault has developed in conjunction with Brongniart, that the presence of secondary xylem must exclude any form from the class of Archegoniatae, is at once refuted by the case of Isoëtes. For if it can be shown that the character is present in the class in one instance only and in ever so rudimentary a form, it is difficult to see why it should not have occurred fully developed in other extinct representatives of the class. And when we see this additional character present in so many specimens, which perfectly agree with Lepidodendron in all points of structure and surface-features, it seems to me that we shall be doing violence to nature if we are determined to keep them separate from that genus, and place them in another group of the vegetable kingdom for the sake of some view once adopted which has become a favourite with us. Now this is Renault's position, when he refers the remains in question to Sigillarieae and with them to Gymnosperms, and Williamson ${ }^{2}$ is quite right in maintaining that his classification rests entirely on a petitio principii; nor can I help acknowledging that I am of his opinion after repeated careful study of the numerous specimens in his own possession and in that of Carruthers, Cash, and myself. Renault has naturally endeavoured to support the view which he received from Brongniart by as many further arguments as he could command, and their unsatisfactory character has been also exposed at length by Williamson and Hartog ${ }^{3}$. Renault's prime contention is, that the surface of the specimens examined. by the English authors is not well enough preserved to allow of their being' certainly determined to be Lepidodendron, and separated from Sigillaria on grounds which carry conviction. The characters of the latter type will be described in the chapter devoted to it, but it has already been remarked that great caution is necessary in distinguishing between the impressions of certain Lepidodendrae and Sigillariae, because they afford no absolute marks of distinction, with the exception perhaps of the dimensions of the scar of separation of the leaf. This cannot be better seen than 
from the comparison of the two types by Renault ${ }^{1}$ himself. It might indeed be supposed from this comparison that there were important differences in connection with the vascular bundle-trace; but it has been already pointed out, that in Lepidodendron also, exactly as in Sigillaria, the lateral points are most probably not to be taken as belonging to the bundle-trace. From Renault's objections on this point we should expect that the surface of the specimens, the structure of which corresponds to that of the vasculare-typc, would bear on it the characteristic marks of Lepidophloiae, since these are the forms in the series of Lepidodendreae which are more like Sigillaria. But exactly the contrary is the case. We find elongated rhombic cushions with the bundle-trace in the normal position, though they do not show the scar of separation, because the epidermis has disappeared in every case which has bcen observed. I myself possess several specimens of the kind; others have been figured by Binney ${ }^{2}$, and these are all the more instructive bccause, having exactly the same surface, they are distinguished anatomically only by the presence or absence of the secondary growth, and were accordingly named Lepidodendron vasculare and Sigillaria vascularis. In this case the surface shows not the least trace of any resemblance to Sigillaria. There is yet another distinction which Renault establishes between the two families, and which rests on the structure of the leaf-trace-bundle; but this too will have to be noticed again in discussing Sigillariae, and we shall therefore only say what is absolutely necessary about it in this place. Renault states that in Sigillariac the bundle is diploxylous, that is, is constructed after the manner of the leaf-traces of Cycadcae, while in the type before us it is monoxylous. Upon this it is to be observed that in this respect there is not the slightest difference between the stems of Lepidodendron vasculare with and without growth in thickness, and of this I have fully satisficd myself from numerous preparations, both transverse and tangential sections. Whether they are diploxylous or not cannot be certainly ascertained until we know whether they belong to the collatcral or the concentric type. Nothing at all can be gathered on this point from Renault's ${ }^{3}$ figure of his Diploxylon (Anabathra pulcherrima, Witham). It appears then that Williamson ${ }^{4}$ is again right in maintaining that Binney's and Renault's Sigillaria vascularis in the young state, before the formation of secondary xylem, would not be distinguishable from a Lepidodendron vasculare. And since we found that the surface of the two forms was the same, and there is therefore an absence of all differential characters, they form together one and the same species. It may be remarked in conclusion that Renault's objections in this matter are the less cogent, because he can have examined little more of the 
English material than two preparations of Witham's Anabathra in a very bad state of preparation, since he writes as follows ${ }^{1}$ : 'The fact observed by Williamson of young branches of Sigillaria vascularis, without exterior centrifugal wood, forming a continuous zone round the centripetal cylinder is certainly correct, but we do not doubt that the foliar bundles given off from it are formed, like those of Diploxylon and of the Sigillariae, of two distinct portions with their growth inverse in relation to one another.'

The above arguments have only gained in strength from Zeiller's ${ }^{2}$ discovery, which has proved that an archegoniate fructification resembling Lepidostrobus is beyond doubt a Sigillaria, on which subject some further remarks will appear below. For now that we know that the Sigillariae also belong to this class, the argumentation of Renault and his predecessors has entirely lost its point of departure. I cannot be wrong in this persuasion, when he himself has recently attempted to save his case by the following assumption. He says ${ }^{3}$ : 'The Sigillariae, an essentially transitional group, would thus be divided into Leiodermarieae or phanerogamous Sigillariae with smooth rind allied to Cycadeae and Rhytidolepis or cryptogamous Sigillariae with fluted rind near to Isoëtes.'

The behaviour of the central strand in the bifurcation of the stem as represented by Williamson ${ }^{4}$ and Binney ${ }^{5}$ is peculiar (Fig. 24). It apparently divides at that point into two halves. The peripheral exclusively

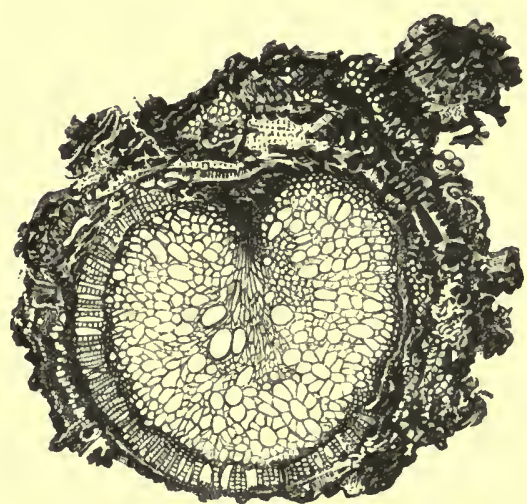

Fig. 24. Transverse section of one of the central bundles of Lepidodendron selaginoides, Will immediately above the bifurcation. Un one side, the inner side, the bundle is not closed up again, its central tissue abuts immediately on that of the rind. After Binney. tracheal portion separates into two semicircular segments, and each segment incloses a half of the middle mixed tissue which is in immediate connection with the surrounding parenchyma on the side towards the centre of the stem. Then each of the semicircular tracheal outer portions, gradually closing in each branch round the central tissue, unites into a circle and the normal structure is restored. Corda's ${ }^{6}$ Leptoxylon geminum must quite certainly be considered to be such a Lepidodendron-stem in the act of bifurcation, though owing to its unfavourable state of preservation it is not clear whether it belongs to this type or to that of Lepidodendron Harcourtii, With. which we are about to consider.

Unlike the vasculare-type, within which we are not in a position to

\footnotetext{
1 Renault (2), vol. i, p. I 50. ${ }^{2}$ Zeiller (12).

3 Renault (9).

t. 49 , f. 8 .

${ }^{5}$ Binney (1), III, t. I4, ff. 4,5 .

${ }^{6}$ Corda (1), t. 15.

I Williamson (1), $\mathrm{xi}_{\text {, }}$
} 
distinguish species with any certainty, that of Lepidodendron Harcourtii, With. is represented by two well-defined species. One of these appears to be very rare, and to it belongs the stem first discovered by Witham. It is only quite recently that we have succeeded in obtaining further specimens of it, and I am indebted to Mr. Cash's kindness for a transverse section of one of these. The other species, which is tolerably plentiful in Lancashire, was in the meantime examined repcatedly by Williamson and Binney, but it was not distinguished from the first species and went by the same name. We will call it here Lepidodendron Williamsoni (L. Harcourtii, Will. ex pte, not With.). The preponderating development of the parenchymatous cortex is much more striking in the Harcourtii-type than in that of L. vasculare; as compared with it the central strand is still more insignificant. There is usually no secondary growth in thickness, or else it appears in a feebly developed and rudimentary form, and on one side only of the periphery of the central xylem-strand. The latter separates into a central pith-like purely parenchymatous cylinder entirely without tracheides, and this is surrounded by a closed ring of tracheal elements which is sharply defined on its inner side, while its outer boundary is rendered sinuous in a peculiar manner by the presence of numerous small sharp teeth, which correspond to the sections of the points of attachment of the strongly decurrent leaftraces. The transverse sections of these bundles, which have already set out from the central cylinder, and which agree in all important points of structure with the trace-bundles of the vasculare-type, lie in the sinuses and are inclosed in delicate tissue. There is this difference between the two species, that the small teeth in the boundary-line of the central strand project much more sharply and are also longer in Lepidodendron Harcourtii than in L. Williamsoni. A further difference is that the trace-bundles of the former species contain a group of bast-fibres which is wanting in those of the latter. Hence in the one case the bundles in their course through the rind appear under the lens to be made up of two brown points, in the other to be single. The inner one of these two points consists of wellpreserved tracheides, the outer is less distinct, and it is only in rare cases that its cells can be certainly distinguished ${ }^{1}$. Between the two there is always a gap, which was formerly filled with soft bast. Whether this bast surrounded the wood-portion, in other words whether the bundle was concentric or collateral, must again be left undecided; from the figure given by Binney ${ }^{2}$ we might almost suspect that it was collateral. But I have not met with so well-preserved a bundle in the preparations which I have examined.

Of the rind, it is to be observed that its outer cylinder with the leafcushions has never been found with the structure preserved; for even 
Witham's original specimen figured in Lindley and Hutton ", and in Brongniart $^{2}$ is merely the ordinary cast without the rind. The specimen with a Bergeria-surface figured in Binney ${ }^{3}$ as Lepidodendron Harcourtii is structureless up to the central strand, which is in the act of dividing, and is filled with clay-ironstone; it cannot therefore be taken into consideration here, though from the structure of the xylem-strands it is probable, if not quite certain, that it has been correctly determined. We know therefore only the middle and inner cylinders, which are both of great thickness and consist entirely of parenchyma. The growth in thickness appears in this case to be much less localised; notwithstanding the great thickness of the rind, the periderm is much less developed and not nearly so conspicuous as in the previous type. But while in Lepidodendron Williamsoni these two cylinders, which differ little in the character of their tissue, are both as a rule in a like state of preservation and are not distinctly separate from one another, in the other species on the contrary the inner cylinder is more or less destroyed-in my specimen entirely destroyed up to the leaf-tracebundles by which it is traversed, while the outer, consisting of thick-walled parenchyma, is remarkably well preserved. The consequence is that the two species can be distinguished at first sight in a preparation. The behaviour also of the central bundle in the formation of lateral branches is known in the case of the type of Lepidodendron Harcourtii, and has been figured by Williamson ${ }^{4}$. The strand divides exactly as in the formation of a dichotomy, only the two parts are not of equal size, as they are in the latter case, which has been observed in Lepidodendron vasculare. A small segment in the form of a portion of a flat arch separates from the circular tracheid-zone of the bundle, so that the remaining portion is seen to have an aperture on one side and to be in the form of a horse-shoe. The small opening thus formed soon closes again above, and thus forms a longish lateral slit in the tracheal tube, through which the central parenchyma of the strand enters into communication with the rind. The process was observed to be exactly the same in the normal bifurcation of the vascularetype, only there the opening was at the top of the basal piece in the angle of the dichotomy. The two cases are accordingly distinguished only by the lateral displacement connected with the formation of a sympodium.

Various previously described remains with imperfectly preserved inner structure appear from the statements of authors to belong to the type of Lepidodendron Harcourtii. Lepidodendron nothum and L. Richteri ${ }^{5}$ from the Cypridinae-schists (Upper Devonian beds) of Saalfeld may be first mentioned, and after them L. squamosum ${ }^{6}$ from the Carboniferous Limestone of Glätzisch-Falkenberg, in which the form of the central

${ }^{1}$ Lindley and Hutton (1), vol. ii, t. $98 . \quad{ }^{2}$ Brongniart (7), t. $30 . \quad{ }^{3}$ Binney (1), III, t. I 4 , f. I. 4 Williamson (1), XI, t. $5^{2}$. ${ }^{3}$ Unger (5), tt. IO, II. ${ }^{6}$ Göppert (12), tt. 2 I, 22. 
strand is well preserved; and the tracheides with their structure can be distinguished. The plant too described by Corda ${ }^{1}$ as Lomatophloios crassicaulis certainly belongs to this place; all the characters which mark the xylem-strand in this type are given in one of his figures ${ }^{2}$ with unmistakable distinctness. I have made assurance doubly sure by examination of an original preparation of Corda in the botanical department of the British Museum which was sent by him to $R$. Brown. It shows only the very small central cylinder preserved in transparent stone, the cell-walls of which have one and all been changed into opaque black coal. The well-preserved teeth of the periphery projecting sharp and long show distinctly that it belongs to the true Lepidodendron Harcourtii, and not to L. Williamsoni. Since Corda found the outer surface in these remains well preserved, there can be no doubt that Lepidopliloios had the structure of Lepidodendron Harcourtii. Whether this was the case with all the species, and whether it was not also the case with true Lepidodendrae, remains an open question and is not prejudiced by Corda's discovery.

Young terminal ramifications of Lepidodendrae have been found here and there, though not frequently, in the Lancashire and Yorkshire coal-field. On the other hand they are found in great quantities in the plant-petrifactions of Burntisland ${ }^{3}$ and Laggan Bay in Arran ${ }^{4}$, Scotland, which were noticed in the introductory chapter; they are accompanied in both localities by larger stems and branches, in which a strong secondary growth of wood has been devcloped. Many fructifications also occur with these remains in Burntisland showing the same characteristic features, and it is natural to assume with Williamson that the remains of the different parts of the same species lie side by side in these deposits, though absolute proof of this cannot at present be produced. To the fragments from Burntisland thus united to one another Williamson has given the name Lepidophloios brevifolius, but he has abstained from naming the Arran plants. If the stronger stems are compared with the two preceding types, it appears that the Arran Lepidodendron is nearer the type of Lepidodendron Harcourtii, and that the Burntisland forms may occupy an intermediate position between that type and the type of $\mathrm{L}$. vasculare. Its central strand is differentiated as in $\mathrm{L}$. Harcourtii, but it has not the peculiar angular outline, and the trace-bundles seem, as in L. vasculare, to be only slightly carinately decurrent. It agrees also with L. vasculare in the strong development of the secondary wood, and this distinguishes it at the same time from a stem of true L. Harcourtii. Unfortunately we know next to nothing of the characteristic features of the surface in either form. In both cases the young branches show essentially the same structure, only they are most strongly compressed in the remains from Burntisland. The outer cylinder of the rind is preserved, and is
${ }^{1}$ Corda (1), tt. $1-4$.
${ }^{2}$ Corda (1), t. 3 .
Williamson (1), IIr.
4. Williamson (1), $\mathrm{x}$. 
furnished with prominent angular projections of varied shape, the transverse sections of the leaf-cushions, and each projection receives a vascular bundle. Dichotomies, such as have been described above, are frequent. In the preparations before me I find the epidermis preserved, but in many cases already partly separated by a fissure caused possibly by maceration. The central bundle must be discussed at somewhat greater length. In all the transverse sections of branches from Burntisland which Williamson was able to examine, the centre was formed of parenchymatous tissue, the periphery of a closed ring of tracheides which showed on the inside a slightly irregular boundary-line. In the smallest branches the mass of central parenchyma was small, and was surrounded only by two or by a few layers of tracheides. In larger branches it was broader, the ring of tracheides thicker, and consisting in the radial direction of from five to eight elements. Lastly, still thicker branches showed the presence of secondary wood, and the larger the transverse section of a stem or branch, the more voluminous was the mass of parenchyma of the central strand and the broader the layer of tracheides surrounding it. The same results were obtained from the examination of the Arran material. Here in the very smallest branches there was no parenchymatous centre at all, the entire central strand was composed of one form of tracheides; the medullary tube made its appearance as the branches grew larger. I have before me a young branch of this kind from Halifax for which I am indebted to Mr. Cash; its structure agrees perfectly with that of a specimen figured by Williamson ${ }^{1}$, and shows a closed tracheal strand. If then all the remains from Burntisland or Arran are brought together to form one vegetable species, as is done by Williamson, and if further the whole of the known branches and stems are combined in sequence of time to make up a course of development which each of them would have passed through if undisturbed in its vegetation, we are driven in presence of the actual conditions to the conclusion that the central strand possessed unlimited growth, which is manifested in the enlargement of the inner parenchyma, and in the growth of the outer layer of tracheides, both in the surface direction by intercalation and in thickness by increasing the number of the elements in the radial direction. And therefore Williamson also has concluded, and quite logically from his position, that in the Arran Lepidodendron, for example, the central strand at first solid begins by forming parenchyma in its centre and then goes on increasing by growth, and that this growth and the constant increase in volume which results from it is in no way retarded or stopped even by the development of secondary tissue. It is this latter point, as Renault ${ }^{2}$ justly urges, which is not very intelligible, since it is difficult to see how the secondary wood can allow space for the further growth of the primary strand; and we know that this growth in 
living plants, as "in the stems of Tecoma radicans, inevitably results in the bursting of the outer ring of wood, no signs of which have ever been observed in Lepidodendron. We must indeed have recourse to assumptions before the formation of secondary wood, in order to understand the increase in size of the central strand, as Williamson conceives it. First of all, if his view is correct, there must always have been parenchyma-cells present between the tracheides, to be the starting-point of the formation of the inner parenchyma in the originally solid strand. Next, these parenchyma-cells must have been able subsequently to give rise to more tracheides, for the increase in the thickness of the peripheral ring could not otherwise be explained; and lastly, cells of the kind must have been introduced into the ring itself, to render its surface-growth possible. All this is however quite possible ; the single parenchyma-cells from which the development proceeds, may easily have been overlooked in the preparations, and it is indeed in favour of this supposition, that Williamson ${ }^{1}$ has in a few cases met with the central parenchyma apparently in the state of meristem. The preparation here cited, which his kindness enabled me to examine, certainly gives quite this impression. If therefore we allow the possibility of the increase in volume up to the time when the central strand is inclosed in the secondary wood, it is entirely excluded after that time, as has been already said. And this shows that the way in which Williamson has arranged his preparations to represent a course of development cannot be right. It is to be remembered, that we must not simply compare the terminal ramifications of the head of a tree with the still young and growing ends of the main shoot or of its subordinate branches. The central strand in the main shoot and in the branches may and will have had a very different diameter at the beginning of the growth in thickness from that of the later generations of branches, the last of which may have had no growth of the kind. If this is so, and I have no doubt whatever about it, every arrangement of the single stages into a successive series is naturally precluded, for we must know to what part of the branch-system each piece belonged, and this in the fragmentary condition of our remains we are unable to determine.

The chief sources of our knowledge of the anatomy of Halonia are the works of Dawes ${ }^{2}$, Binney ${ }^{3}$ and Williamson ${ }^{4}$. From these we learn that there is on the whole essential agreement in structure between this form and the type of Lepidodendron Harcourtii, or with that of the Burntisland plant; there is indeed no growth in thickness, but it is quite intelligible that there should be no such growth in a branch serving only as a fructificationstalk. Only we know nothing of the character of the outer cylinder of the rind, since this has never been observed in the specimens with the structure

1 Williamson (1), XII, t. 33, f. 20 .

2 Dawes (1).

3 Binney (1), III.

Williamson (1), II, P. 222 and notes, and XII, p. 466 ; t. 32, f. 2 I. 
preserved. Binney ${ }^{1}$ has figured fine transverse sections of his Haloniae, but unfortunately they are not sufficiently magnified to show the behaviour of the different traces which traverse the rind, and which run partly to the leaves, partly to the scars where the lateral branches have separated from the stem; for the two are according to Williamson essentially different. The foliar bundles arise normally on the outside of the wood-cylinder, but without affecting its structure. The other and much stronger bundles behave exactly like those which supply lateral branches in Lepidodendron Harcourtii in the manner described above; they originate in a division of the central strand, in which a fissure-like gap appears above the point of departure. I have seen the preparations in Williamson's collection, but they have unfortunately never been figured. If the section does not happen to hit on one of the very small fissures, as is often the case, then the central strand is not distinguishable from the normal type of Harcourtii; this perhaps is the explanation of the absence of this peculiar character from Binney's drawings. It was mentioned above that Renault ${ }^{2}$, combining Dawes' and Binney's views in modified form with those of other authors, pleads for the division of Haloniae, some of which he looks upon as rhizomes, the others as aerial branches of Lepidodendreae. To make the origin of this opinion intelligible it should be first observed, that the majority of palaeophytologists regard the Stigmariae, which will have to be considered further on, as the rooting organs both of Sigillariae and Lepidodendreae. But since these Stigmariae contain undeniable secondary wood, and Renault, following Brongniart's views, cannot allow of any such formation in Archegoniatae, he is obliged to keep all Stigmariae for the Sigillarieae, and is then met by the difficulty, that there are no subterranean organs left for the Lepidodendreae. He inclines therefore to see their rhizomes in Haloniae. And since this does not do for all their forms for reasons which have been already noticed, he endeavours by help of the difference which exists between Williamson's and Binney's descriptions to separate them into two groups, and considers the specimens of the latter author, who finds no difference in the bundles of the trace, to be rhizomes, and those of Williamson with two kinds of traces, one of which originates in the division of the axile strand, to be branches of the heads of the trees to which they belong. That this is the true account of the process of thought in Renault's mind, as it may be gathered from his various publications, is sufficiently attested by the following passage ${ }^{3}$ : 'The separation of the species of Halonia into two distinct groups, which we have noticed here as a hypothesis serving to reconcile the anatomical results of different English authors, is justified also by the examination of the figure given by Brongniart,' \&c. The figures cited appear to me to be merely casts of various states of 
decortication. But apart from this, I cannot think it allowable to bring contradictory statements of this kind into agreement with one another by means of conciliatory hypotheses without fresh investigation. It is my opinion that we ought not at present to hold either to Binney only or only to Williamson; the older publication by Dawes, which was excellent in its time, cannot now be taken into consideration. I have myself no doubt as to which of the two first authors deserves the greater confidence. Binney is dead, and his original specimens have been for a long time inaccessible: whenever the opportunity comes for submitting them to fresh examination, it will be possible finally to settle this question; and then his Haloniae also will ultimately show the two kinds of trace-bundles, which, as he says himself in the Introduction, may not have been brought out with the necessary distinctness by the entirely unprejudiced draughtsmen. A few words must be added in conclusion about Ulodendron. Carruthers ${ }^{1}$ and Williamson ${ }^{2}$ have stated a few facts only respecting its inner structure, which is said to be essentially that of Lepidodendron Harcourtii. But I confess that I am not perfectly satisficd with regard to the determination of Williamson's specimens, for he encountered on the tangential section ${ }^{3}$ transversely rhombic leaf-cushions, such as occur in Lepidophloios but not in Ulodendron; and leaf-bases are figured in the radial section ${ }^{4}$, which also remind us rather of Lepidophloios. It is true that the great cone-scars are said to be in the usual two-rowed position in the specimen; unfortunately no figure of the surface is given.

The fructifications only remain to be considered. These have long been known as conc-like extremitics of shoots close set with spirally arranged sporangiferous leaves, the connection of which with indubitable branches of Lepidodendron has been so clearly established in particular cases, that the true nature even of such specimens as have not been met with in the same close connection cannot usually be disputed. Still figures proving this are not common in the literature; those of Stur ${ }^{5}$, Lesquereux ${ }^{6}$ and Brongniart ${ }^{7}$ may be named as the most important. Further confirmation is obtained from the results of the anatomical investigation of the axes of petrified specimens, which show the essential points of the structure of the shoots of Lepidodendron. These cones, usually known by the collective name of Lepidostrobus, are everywhere abundant on heaps of refuse coal in the form of impressions; they occur here and there as petrifactions in the English calcareous nodules, and in certain sphaerosiderites from the neighhourhood of Wolverhampton. Few silicified specimens are known, but in these the inner structure is wonderfully well preserved.

1 Carruthers (13). 2 Williamson (1), 11, p. 209; tt. 26, 27. f. 28 Williamson (1), II, t. 28, f. $27 . \quad{ }^{5}$ Stur (5); t. 19, f. 9. t. $10_{7}$, f. $2 . \quad{ }^{7}$ Bronguiart (1), vol. ii, t. 24, f. 5 and t. 25, f. 2.
3 Williamson (1), 11, t. 28 , - Lesquereux (1), vol. iii, 
The study of the impressions has revealed the main features in the organisation of these cones. The straight usually tolerably thick axis, which is bifurcated in one instance only ${ }^{1}$, bears all round it sporophylls closely crowded and exactly like one another, on each of which can be distinguished the peculiarly developed leaf-base (the cushion of the vegetative homologue), the single sporangium attached to it, and the lamina. The leaf-base, the characteristic features of which are correctly described by Stur ${ }^{2}$, is developed in the form of a long pyramid scarcely narrowing upwards and sometimes winged on the sides, which stands out at a right angle from the axis ; its cross section is transversely rhombic and flattened in the median direction; it bears on its upper side the cylindrical usually very capacious sporangium, which is bluntly rounded at the extremity, and
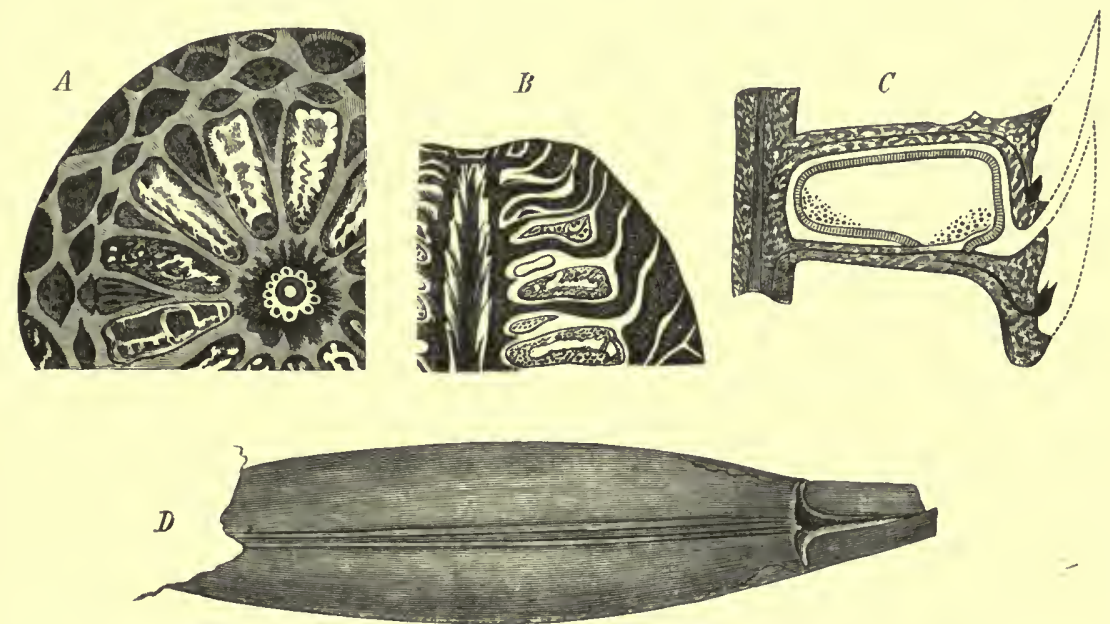

Fig. 25. Fructifications of Lepidodendron. $A$ transverse section of the cone of Lepidostrobus Brownii, Schpr, showing in the centre the axis and the bundles on their way to the leaves; next to these are the sporangia in longitudinal section, and beyond them several layers of trausverse sections of the erect apices of sporophylls of lower insertion. $B$ longitudinal section of the apex of the same cone. $C$ diagrammatic longitudinal section of a Lepidostrobus ornatus, Hook. $D$ a detached fertile leaf (Lepidophyllum) seen from above, the basal portion separated by a transverse fold from the originally erect apex; the sporangium was attached to its median line. $A$ and $B$ after Schimper. $C$ after Hooker. $D$ after a specimen in my possession collected by myself in the Gerhard mine at Saarbrücken.

sometimes even allows the spores to be seen in it. Binney's ${ }^{3}$ figures should be consulted. The usually lanceolate lamina is attached by its entire breadth to the top of the leaf-base, and bends upwards so as to be parallel to the axis, and to overlap and cover the laminae next above it like a tile on a roof, while the outer extremity of the sporangium is close against its inner surface (Fig. $25 \mathrm{~B}$ ). Sometimes its sharp lower margin projects beyond the top of the leaf-base, so that a somewhat peltate attachment results, as in

\footnotetext{
${ }^{1}$ Lindley and Hutton (1), vol. iii, t. 163. $\quad{ }^{2}$ Stur (5), p. $233 . \quad{ }^{3}$ Binney (1), 11, tt. 9, 10.
} 
Binney's ${ }^{1}$ figures, in one of which ${ }^{2}$, owing to an erroneous conception of the crowded organs, the sporangium appears attached to the under side of the leaf-cushion. The sporangium in question evidently belongs to an adjacent leaf-base from below. Stur states that the lamina of these sporophylls drops off, as in the vegetative branches, leaving behind it a transversely rhombic scar-surface with a distinctly defined bounding line, and cites Lepidostrobus Goldenbergii ${ }^{3}$ as an example, and such in fact appears to be the case in that species. Certain figures of Lesquereux, his Lepidostrobus macrocystis for example ${ }^{4}$, are perhaps to be understood in a similar way, but his treatment of them is so summary that it is impossible to speak with any certainty without a knowledge of the original specimens. But on the other hand, in a very large number and indeed in the vast majority of Lepidostrobi, the lamina does not regularly separate from the base of the leaf, but remains firmly attached to the sporangiferous cushion, or is torn from it only occasionally and more by chance and irregularly.

It is of course seldom possible to observe all the above details on the impression of a single cone, and only when it is broken up in different plancs. I have before me a specimen of the kind from Dutweiler, which shows quitc unanswerably that all the forms of preservation which we are about to examine simply represent different sections through the same organs. Seen from without Lepidostrobi look very like fir-cones; we see nothing but the lanceolate laminae of their scales, which lie one over the other like tiles on a roof. The median fracture is more instructive; in this the axis is seen beset with crowded linear protuberances, the bundle-traces of the cast, when the rind formed from the leaf-cushions is removed. The lateral leaves are then seen in longitudinal section; they are distinctly shown in most cases as fine shining strips of coal in the stone, and the splintering of the stone will sometimes wholly or partially expose the surface of a lamina. The sporangia are particularly well and clearly seen as a rule in this view; they lie above the leaf-line like thick cushions usually filled with the stony material and surrounded by a thin rind of coal, as will be seen in Binney's ${ }^{5}$ and in Brongniart's ${ }^{6}$ figures. Another common mode of fracture is also shown in Binney's figure just mentioned, where we look down from above on the outer extremities of the sporangia. The opposite face would have shown from the inside either the base of all the laminac of the leaves, or the apices of the cushions, according to the direction of the fracture. On a counter impression of this kind, which I found in the Gegenort mine at Dutweiler, I observe on several of the leaves, close to where the line of fracture passes through their bases, a small ob-

\footnotetext{
1 Binney (1), III, tt. 7,8 .

${ }^{2}$ Binney (1), 11I, t. 7 , f. 8 .

$s$ Binney (1), 111, t. 10, f. 26.

3 Schimper (1), t. 61, f. 4 .

- Lesquereux (1), vol. i, t. 69, ff. $1,2$.

t. 25, f. 3 .

- Brongniart (1),
} 
tusely triangular scar with a trace-point in its centre, which from its median position is probably the object discovered by Stur on the barren cushion, and called by him the ligular pit. Its occurrence in Lepidostrobi was till now unknown; the very obscure impressions, the only ones on which it can be shown, are not often found in the collections. It remains only to mention transverse fractures of the cones, which present the surface-view of the sporophylls, and show the whole form of the sporangia on their bases; these too are not altogether rare ${ }^{1}$.

The cones are of very various dimensions, from the size of catkins of the hazel to the length of one and a-half feet, with corresponding thickness. Cylindrical cones of considerable length are figured for example by Lesquereux $^{2}$ as Lepidostrobus princeps, by O. Feistmantel as L. variabilis, Ldl. and Hutt., and by Geinitz ${ }^{3}$ under the same name. Remains of cones of great size, remarkable for the unusual thickness of the axis, are classed by Lesquereux ${ }^{4}$ with Lepidophloios. Weiss ${ }^{5}$ also has described a similarly colossal cone as Lomatophloios macrolepidotus, but unfortunately there is no detailed account of it. The enormous size of the axis in these specimens gives rise to a suspicion that the fructification was not confined to special fertile shoots, but might occasionally appear on the leaves even of the main stem which then increased in thickness, much as we see in the present day in the female flower of Cycas, and mutatis mutandis in Lycopodium Selago. We naturally ask, on what sort of scars could such cones be seated as lateral organs?

The leaves too on the cones differ very essentially from one another in form and size. We get a particularly clear view of them when they have been torn with the supporting cushion from the cone, and lie as flattened impressions on the faces of the stratification. The angle formed by the lamina and base of the leaf is in this case pressed flat, but there is an evident parting between them in the shape of a transverse fold or thickening. Sporophylls in this state are common enough in some deposits, and are named after Brongniart ${ }^{6}$ Lepidophyllum; but they are rarely found quite perfect, and it is generally the upper part, the lamina, which is preserved. The lamina varies much in shape; it may be lanceolate, or linear and sharply pointed, or it may be broad and contract into an obtuse apex; it is always traversed by a conspicuous median nerve, which often becomes broad and ribbon-shaped. The base of the leaf also is seen when preserved to be divided by an evident median nerve into two halves, which are parted from the lamina by the transverse folds mentioned above. The place of insertion of the sporangium is shown by a strong linear projection on the 
median keel (Fig. $25 \mathrm{D}$ ). It is only in a few authors that we find more than a superficial notice of these Lepidophylla, which were usually taken, even by O. Feistmantel ${ }^{1}$, for example, and by Stur ${ }^{2}$, for vegetative leaves, but were recognised as sporophylls by Goldenberg and Schimper. Even good figures are scarce, those especially which show the base of the leaf attached to the lamina; some examples will be found in Goldenberg ${ }^{3}$, O. Feistmantel ${ }^{4}$, Lesquereux ${ }^{5}$ and Schimper ${ }^{6}$, and also in Geinitz ${ }^{7}$. The large forms with obtuse terminations to the laminae evidently belong to cones of gigantic size, and agree in habit with those figured by Lesquereux in the fructification mentioned above which he classes with Lepidophloios; they occur abundantly with remains of stems of that genus in the neighbourhood of Saarbrücken, and may be peculiar to it.

All the facts which we have been discussing hitherto, and which are to be observed in the impressions of our plants, are entirely confirmed by the examination of silicified specimens; but it is from the latter only that we have obtained a complete knowledge of the spores which are contained in the sporangia, and which could only be studied exceptionally and imperfectly in impressions. The most important point is, that heterospory, such as that of Selaginella, has been distinctly ascertained in several individuals of Lepidostrobus. But we must be careful not to draw any general conclusion from this fact, since there may have been isosporous and heterosporous families with the same habit among Lepidodendreae, as there are in Lycopodiac and Selaginellae in our recent vegetation. We are in possession of a number of cones which apparently contain only one kind of spores, but these are only fragments of a larger or smaller size. It might be just in the part that is wanting that the other spore-form may have been contained, and the suspicion is the more reasonable because in our Selaginellae, as we know, the macrospores are often confined to a small space at the base of the cone, in Selaginella spinulosa to the lowest sporophyll. And even if a perfect cone were ever found with spores of only one kind, it might still be objected that the other kind may have been confined to different cones on the same plant; it is true that this arrangement does not occur at the present day, but this seems to be no reason why it may not have occurred in former ages. But though we cannot expect that this question will ever be certainly determined, yet it will be convenient to speak generally of macrospores and microspores, as in well-ascertained examples of heterospory, and to include under the word microspores those cases also in which, as we know of no other kind of spores, there may have been isosporous as well as heterosporous forms. We will now

${ }^{1}$ O. Feistniantel (3).

4 O. Feistmantel (3), t. 42.

7 Geinitz (5), t. 2.
${ }^{2}$ Stur (5).

s Lesquereux (1), vols. i, ii, t. 69 .
${ }^{3}$ Goldenberg (1), t. 15, f. 5 and t. 16, ff. 11-13. Schimper (1), t. 61 . 
proceed to notice all the instances of heterospory which are at present known.

Heterosporous cones have bcen described by Binney ${ }^{1}$ under the names Lepidostrobus Wünschianus and I. levidensis, the former of which comes from Laggan Bay in Arran, the latter from the Carboniferous ironstone (Blackband) of Airdrie, in Scotland. It is not stated whether the former specimen showed structure, though this is probable from the locality in which it was found. The second was structureless; its substance was turned into coal and the spores partly replaced by pyrites. Both specimens are narrowly cylindrical; in both the sporangia on the upper part of the sporophylls contain a fine-grained mass composed of microspores; those on the lower part are filled with tolerably large macrospores flattened into the forms of disks or plates, and in Lepidostrobus Wünschianus there appear to have been very few of these macrospores in each sporangium. The carbonised macrosporangia in Lepidostrobus levidensis are of precisely the same character as those of a fructification also found at Airdrie, which had been previously described by Carruthers ${ }^{2}$ as Flemingites, and the identity of this form with Lepidostrobus is also vouched for by Kidston ${ }^{3}$, who examined the original specimen in the British Museum. The creation of this new genus was due to the fact that Carruthers, owing to the entire disappearance of the walls of the sporangia, mistook the macrospores for so many sporangia, which must have been present therefore in great numbers on each sporophyll. It may be observed in passing that similar flattened macrospores, showing the three edges of their pyramidal apex with great distinctness, are widely disseminated through the coal. They are of very various dimensions, being sometimes visible to the unaided eye, and may be easily isolated by maceration. Many figures of them have been given by Reinsch ${ }^{4}$, who named them Triletae. Some of these at least certainly belong to Lepidostrobi. One much crushed cone from Halifax described and figured by Williamson ${ }^{5}$ must be mentioned in this place. Four macrospores disposed in the form of a tetrahedron occupy the. sporangia in the lower part of the cone. They are of large size, and are provided with an irregular tubular process at the apex. The exosporium is covered with fibrous appendages. The structure of the axis of the cone is essentially that of the type of Lepidodendron Harcourtii. Two other cones are known in the silicified state. One of them, Lepidostrobus Dabadianus, Schpr, was found as a loose stone in the department of the Haute-Garonne at the mouth of the Volpethal, and was sawn through lengthwise and described by Brongniart ${ }^{6}$. One half is at Paris, the other, formerly in Schimper's possession, will now be in the British Museum. The surface of the thick ovoid

\footnotetext{
Binney (1), II, t. II, f. 2 and t. Io, ff, I, 2.

4 Reinsch (1).

5 Williamson (1), $x, t$. 15, ff. 8-12.

2 Carruthers (14).

3 Kidston (2).

- Brongniart (8).
} 
cone, which is eleven centimetres in length and five centimetres in breadth; is injured by abrasion, the points of the leaves are gone, and a roundish protuberance corresponds to the extremity of each sporophyll. The sporangia filled with globular macrospores are replaced in the upper part of the cone for about two-fifths of its length by microsporangia, the spores of which are connected together in fours. Nothing can be learnt about the character of the axis from Schimper's ${ }^{1}$ or Renault's ${ }^{2}$ figures ; it may have been destroyed in a great measure by the longitudinal section. There is great resemblance between Lepidostrobus Dabadianus and two fragments of unknown origin, which have only microspores connected together in tetrads in their sporangia, and which were united bySchimper ${ }^{3}$ under the name of Lepidostrobus Brownii. One of them passed some time since from the collection of Baron Roger at Paris into the British Museum, and a transverse section of it is in the Paris Museum. It was described and figured by $\mathrm{R}$. Brown ${ }^{4}$ under the name Triplosporites. The other specimen, one half of which is in the British Museum, the other in the collection of the Jardin des plantes at Paris, was originally purchased at a curiosity-shop in Paris, and was long in Schimper's possession. The structure of both these specimens agrees perfectly with that of Lepidostrobus Dabadianus, and the abrasion of its surface is still greater (Fig. $25 A, B$ ). The axial strand which is surrounded by numerous transverse sections of leaf-traces has the structure of Lepidodendron Harcourtii. Another similar small fragment of a cone containing only microspore-tetrads was found near Cabrières in the department of Hérault and was described as Lepidostrobus Rouvillei ${ }^{5}$. Two fragments of the kind showing in their axes the type of Harcourtii, and both coming from the calcareous nodules of Oldham, have been figured by Binney ${ }^{6}$, and a number of broken pieces of cones have been described by Hooker ${ }^{7}$. The latter came from the Carboniferous ironstone of Wolverhampton mear Birmingham, and some of them were found inside stems of Lepidodendron which have the bark still well preserved, having been conveyed into them by the action of water. From specimens now in the Jermyn Street Muscum in London I have been able to satisfy myself, that in some cases the axile strand of the hollow stem is still present, and shows the structure of Lepidodendron vasculare. The same structure is also apparent in the axis of one of the cones, in the rest the central portions are too imperfectly preserved. The structure and character of the stems and of the fructifications inclosed in them have been illustrated by extraordinary drawings. In some specimens the shortly lanceolate leaf-tips are prescrved.

${ }^{1}$ Schimper (1), t. 62, ff. I-I2 and (2), vol. ii, p. I91.

${ }^{3}$ Schimper (1), vol. ii, pt. 1, p. 67 ; t. 62, ff. r3-33.

Marion (3), p. 193 ; Renault (2), vol, ii, p. 35, t. 7 , ff. I-3.

7 Hooker (3).
${ }^{2}$ Renault (2), vol. ii, t. 6, ff. 9-12. 4. Brown (1). 'Saporta et Binney (1), III, tt. 7,8 . 
The walls of the sporangia are unusually thin, being formed of a single layer of palisade-like cells; the isolated microspores (?) which they contain are globular; the edges of their pyramidal apices are winged, and are produced at the basal extremity into spreading triangular teeth (Fig. $25 \mathrm{C}$ ). It was remarked above that Williamson ${ }^{1}$ has found fragments of cones in the plant-petrifaction of Burntisland, along with branches and stems of his Lepidophloios brevifolius, and that he assigns them to the vegetative remains as their fructifications. The microsporangia were only met with in one instance along with the other parts, and then they occupied as usual the basal portions of the cones. Their spores are large and clothed all round with a close array of curved filiform membranous processes. In one figure ${ }^{2}$ Williamson gives a tangential section, which passes through the upper part of the strobilus where the microspores are concealed, and shows the rhombic transverse sections of the sporophylls with wings on both sides exceedingly well. These are provided on the under side with a wing-like process answering to the median bundle, and on the upper side bear the sporangium, the narrow insertion being plainly seen in the middle of the lamina. The sporangium has its wall formed of one layer of cells, and is filled inside with a great number of small microspores united together in fours.

The only form which remains to be mentioned is an imperfectly known strobilus, which Williamson ${ }^{3}$ has described from materials found near Oldham and Halifax; here the macrospores are the only spores that are known, and they are marked by sundry peculiarities. That this fossil belongs to Lepidodendreae is rendered very probable by the spiral not verticillate position of its sporophylls, and by the presence of only one sporangium over the transverse section of each scale, as the tangential section shows ${ }^{4}$. The structure of the axis is not to be seen in the specimens which have been figured; but I find from a preparation, for which I am indebted to Mr. Cash, that it resembles that of Lepidodendron Harcourtii. The macrospores have the usual tetrahedral form, the edges of the sides of the pyramids project strongly, and the base is convex; but they are furnished with a hollow bladder-like appendage, which runs across the middle of the basal surface like a curved tube, and evidently represents an organ analogous with the air-sacs of the pollen of the pine. If the spore is cut through in a direction parallel to its length, it appears of course as a broad one-sided wing. Transverse sections pass through it twice at its two extremities, and then there appear to be two hollow bladder-like appendages opposite to one another. Williamson also states that he has found a large number of minute cells inside the spores, but he says nothing precise about their nature. I have certainly seen these cells in the preparation

1 Williamson (1), III, t. 44 .

2 Williamson (1), III, t. 44, f. 24. t. 22. 4 Williamson (1), IX, t. 22, f. 55 .

3 Williamson (1), $1 x$, 
which I possess, and in those which I had the opportunity of examining in $\mathrm{Mr}$. Cash's collection, but they appeared to me to be connected together and to form an internal and tolerably voluminous cell-structure, which we should be inclined to compare with the inner cell-complex in the pollen of Gymnosperms and Cordaiteae, and with the early tissue-formation in the microspores of Selaginella. We cannot at present say anything further or more definite respecting this apparently rare fossil; we must await the discovery of other and better specimens. 


\section{XI.}

\section{SIGILLARIEAE.}

IT has been observed above in describing Lepidodendron, that the Sigillariae rank next to that genus from the similarity of the surface-character of their stems, and indeed come so near it, that certain species have repeatedly given occasion to confusion between the two groups. Unfortunately we are not so well acquainted with the development and structure of all the separate parts of the plants in Sigillarieae as in Lepidodendreae; fragments of stems are extremely abundant in the form of impressions and casts, but as regards the anatomical structure, the fructifications, and even the foliage leaves, we have to be content with the information to be derived from a few scanty remains. The duration of Sigillarieae in the series of formations resembles that of Lepidodendreae, but is still more limited. Sigillarieae disappear with Lepidodendreae in the Rothliegende, having been found in the lower members of that formation near Autun, near Oltendorf in Bohemia ${ }^{1}$, and near Schmalkald; but they do not make their appearance before the beginning of the Coal-measures, and are still extremely rare in its lowermost deposits, in the Millstone Grit for example. They appear in great abundance, and as the dominant form of vegetation only in the middle deposits of this period, as in the Schatzlar and Saarbrücken beds. Stur ${ }^{2}$ has put together a number of species from the base of the whole formation. Some older remains supposed to belong to the group are mentioned by Göppert ${ }^{3}$, but they are more than doubtful. The same may be said not only of the form known as Sigillaria Vanuxemii, Göpp ${ }^{4}$, from the Chemung (Devenian) beds of Oswego in New York, but also and more particularly of his S. Hausmanniana ${ }^{5}$, which was found by Hausmann in the beginning of the century between Idre and Särna in Norway in supposed Lower Devonian strata. Later authors have rightly determined that this specimen is merely a ripple-mark. In the other direction from beds that are more recent than the Rothliegende I only know of one fragment described and figured from the Upper Bunter Sandstone of

\footnotetext{
1 Göppert (3) p. 184, f. 5 r.

${ }^{2}$ Stur (5), p. 292. 5 Göppert (19), t. 35, f. r.

${ }^{3}$ Göppert (19), p. 543.

1 Vanuxem (1),
} 
Heimbach near Commern in the Eifel, and this is not altogether above suspicion, though Weiss ${ }^{1}$ too has recently pronounced in favour of its belonging to Sigillaria. The form in question, Sigillaria oculina ${ }^{2}$, is in fact vcry like those of the group Leiodermaria, and this is exactly the dominant group in the most recent of the deposits which contain any Sigillariae.

Turning to the consideration of the impressions and casts of stems, we find it scarcely possible to give a general account of them, because the groups of species, the genera if we choose so to call them, differ so greatly from one another. The old genus Sigillaria separates after removal of the Megaphytae which were placed in it by earlier authors, Brongniart ${ }^{3}$ for example, into the divisions or genera, Rhytidolepis, Clathraria, Favularia and Lciodermaria. The most peculiar form and the one which departs most widely from the habit of Lepidodendreae is Rhytidolepis, and it may therefore be placed first in the list. Here the entire surface of the stem is formed of peculiar broad vertical ribs, which bear the leaf-scars on their flatly convex dorsal surface, and are separated from one another by shallow but acutc-angled furrows. The arrangement of the leaves has been specially studied by Goldenberg ${ }^{4}$ and Stur ${ }^{5}$. The latter seeks to prove that the longitudinal ribs do not correspond to the orthostichies, but represent a system of parastichics which by a peculiar displacement has passed into a vertical position. In that case we should not have, as appcars at first sight, a succession of somewhat irregular many-leaved alternating whorls, but the relative positions of the lcaves would be as in Lepidodendron, only altered by displacement, and with a divergence which was determined in one case to be $\frac{90}{23}$. Stur's publication will give further information on this point; here we will add only that he ${ }^{6}$ also occasionally found a distinct appearance of orthostichics in Lepidodendron, and that he refers this also to one of the steep oblique line-systems and explains it by displacement. Lepidodendron costatum is a similar impression ${ }^{7}$. Various other irregularities occur in the position of the leaves, and are not unconnected with the fact that new ribs, ending blindly below, suddenly and not unfrequently make their appearance between the old ones in stems of Sigillariae ${ }^{8}$.

The longitudinal ribs of the stem of Rhytidolepis originate in the coalescence of the leaf-cushions which stand vertically one above another. When the coalescence is very perfect, the scars of the laminae of the leaves lie at regular distances on the smooth uniformly convex surface of the ribs, and the separating furrows are simply straight lines (Fig. $26 \mathrm{~A}$ ). In proof of this we may point to Sigillaria Voltzii in the long list of Brongniart's ${ }^{9}$ figures. But an indication of the separate leaf-cushions which have united

\footnotetext{
1 Weiss (9). ${ }^{2}$ Blanckenhorn (1), p. 132; t. 20, f. 9. $\quad$ s Brongniart (1). ' Goldenberg (1).

${ }^{3} \operatorname{Stnr}(5)$, p. 293. 'Stur (5), t. 23, f. 2. ' ${ }^{3}$ Lesqnerenx (3), vol. ii, t. 44, f. 7. (1), t. 15, ff. 1, 2. 9 Brongniart (1), vol. i, t. 144, f. x.
} 
to form ribs is very often shown in the serpentine course of the furrows, which is due to the circumstance that the cushions are broadest at the insertion of the leaves and narrow downwards, so that every leaf-scar lies on a knot-like swelling of the rib. This is also accompanied in most cases with a regular alternation of greater or slighter elevation above the surface. An excellent example will be found in Sigillaria contracta ${ }^{1}$. All possible intermediate cases between these extremes are of course to be seen. The group has received its name from the polygonal leaf-scars, which look like the impressions of seals. These scars are considerably larger than those of Lepidodendrae, and by flattening of the two median angles to a greater or less extent they become more or less decidedly hexagonal, sometimes almost round or ovate. The hexagon will be broader or longer according as the median or lateral boundarylines are the longer. Differences of this kind are generally employed to distinguish species. The details of the surface of the scar can usually be seen best in mould-specimens after the remains of the coal have been removed, only rarely in the cast; they appear in more than usual perfectness when the entire thickness of the rind of coal has separated with them from the mould. The trace does not lie as in Lepidodendron on the lower margin of the scar, but in the
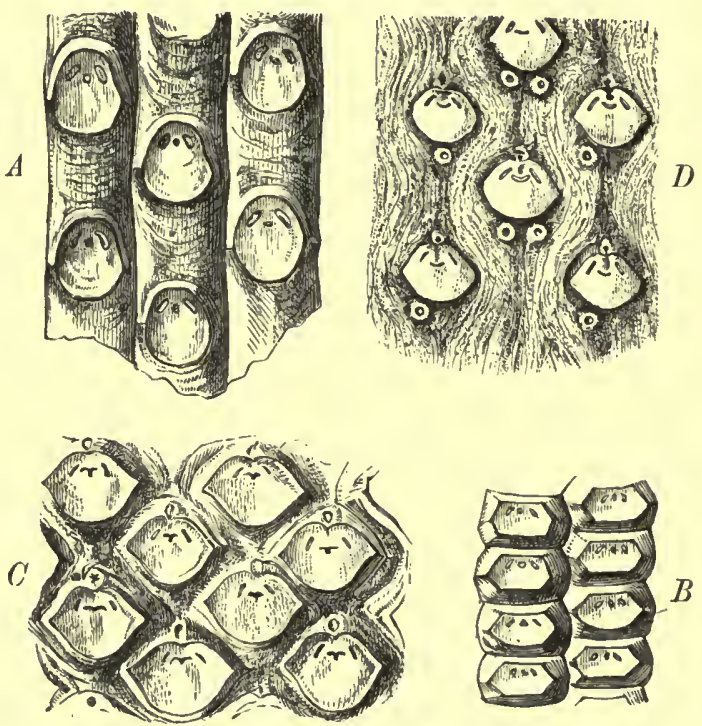

Fıg. 26. Sigillaria. $A$ surface of Sigillaria Saullii, Brongn. belonging to the group of Rhytidolepis. $B$ surface of Sigillaria hexagona, Brongn. of the section Favularia. $C$ surface of Sigillaria Brardii, Brongn. belonging to Clathraria. $D$ surface of Sigillaria spinulosa, Brongn. belonging to Leiodermaria. $A$ and $B$ after Brongniart (1), $C$ and $D$ after Germar (1).

middle of the scar or somewhat above the middle. It consists of three small protuberances or impressions, the middle one of which is punctiform or a little elongated transversely and represents the scar of fracture of the vascular bundle. The lateral marks are as a rule elongated into the shape of a stroke or comma, and diverging below deviate from the vertical direction. In some instances, as for example in a stem of Sigillaria elegans from Anzin which lies before me, the deviation may be so great that the marks may become almost horizontal; usually they enclose the middle trace- 
point, so that it appears to be in brackets. The organisation of the cortical tissue, which lies at the foundation of these two marks, will have to be considered further on; but of one thing there can be no doubt, that they are not esscntially distinct from the similar structures in Lepidodendrae, and that considering the variations in form to which they are subject in both groups we shall scarcely be able to found a differential character upon them, as Renault ${ }^{1}$ has attempted to do. In addition to these three marks wrinkles more or less strongly marked are to be observed on the surface of the scars, radiating generally from them to the periphery and running either a straight or an undulating course. The strongest of these are apt to attach themselves to the mark and to run in the direction of the median plane. The whole surface of the scar between the wrinkles appears when the preservation is particularly good to be finely shagreened, evidently the impression of the individual cells. In many cases the leaf-scars are as broad as the ribs and extend from one lateral furrow to another, in othcr cases they are much narrower than the ribs and occupy only a portion of their convex surface. Dawson ${ }^{2}$ has attempted to separate the latter forms as belonging to Sigillaria sensu strictiori from the others, which he leaves with Rhytidolepis; to the latter division belongs also Renault's ${ }^{3}$ section Polleriana, founded on Brongniart's ${ }^{4}$ Sigillaria Polleriana, S. Deutschiana and similar forms. Longitudinal striation and furrowing of the dorsal surface of the ribs is a common phenomenon in these broad-ribbed forms. Further the leaf-cushions which coalesce to form a rib differ considerably in length, as has been already said, and the scars thereforc are separated by very unequal distances. If the leaf-scars are far apart, the portions of the dorsal surface of the rib which lie between them arc very commonly marked with transversal and more or less developed folds and wrinkles, and then if the preservation is sufficiently good a minute pit is often to be seen close above each leaf-scar, and a feathery tuft of delicatc markings proceeds from the pit and spreads in every direction. Stur ${ }^{5}$, who was the first to draw proper attention to this peculiarity, secs in it the homologue of his ligular pit in Lepidodendrae, and cites some of the figures from various authors ${ }^{6}$ which show this small depression. It should be observed however that the figures in Germar's twenty-fifth table represent forms from the groups Clathraria and Leiodermaria; a figure from Lesquereux ${ }^{7}$ may be added to the list. If the leaf-scars are nearer together, the surface of the cushions necessarily grows smaller. Even in distinct Rhytidolepis-forms we not unfrequently observe indications of transverse boundary-lines of the cushion in the form

1 Renault (2), vol. iii, Introd. p. 4. "Dawson (8).

3 Renault (2), vol. i, p. 134 .

4 Brongniart (1), t. $16_{5}$.

Stur (5), p. 293.

6 Brongniart (1), vol. i, t. I44, f. 4 ;

Goldenberg (1), t. 9, f. 4 ; Germar (1), t. I I, f. 2, and t. 25 , ff. I, 2. $\quad$ Lesquereux (1), vols. i, ii, t. 72 , f. II. 
of flat transversal furrows running above the scars. If these furrows become deeper and more distinctly marked, and the scars are at the same time more crowded together on the rib, then each cushion projects more decidedly beyond the dorsal surface of the rib, and we have the character of Favularia (Fig. $26 \mathrm{~B}$ ), the type of which is seen in Sigillaria elegans ${ }^{1}$ and S. tessellata ${ }^{2}$. In these forms the sharply polygonal leaf-scars, raised on conspicuous cushions above the common projecting rib which bears them, are crowded together till they touch one another; they alternate in the adjacent rows, and as they occupy the entire breadth of the rib their lateral angles are thrust a little in between one another, and the bounding furrows are slightly bent into a zigzag line. Species, in which the transversely separated cushions are somewhat farther removed from one another, are intermediate between Rhytidolepis and Favularia; such are Sigillaria Dournaisii ${ }^{3}$ and S. Knorrii ${ }^{4}$. Lastly the transversal separation of the cushions may go so far, that the rib on which they are placed disappears or becomes quite inconspicuous, and then we have the Clathrariae (Fig. 26 C) or, as Weiss names them, the cancellate Sigillariae. If even in Favularia two systems of parastichies are distinctly apparent by the side of the orthostichy, this is still more decidedly the case in Cancellatae. In addition to this a considerable increase in breadth takes place in the transverse direction in the cushions of Cancellatae; they become rhombic in form and thrust themselves laterally with their acute angles in between their neighbours, so that the parastichies are sometimes more distinctly apparent than the orthostichies. There may then be great resemblance in habit to Lepidophloios, with which genus, as has been already mentioned, these forms have often been confounded; but the size of the leaf-scar and the equal growth of the cushion in every part make it casy as a rule to distinguish them if carefully examined from Lepidophloios, in which the upper facets of the cushion are excessively developed. The following figures of typical Clathrariae may be cited: Sigillaria Defrancei ${ }^{5}, \mathrm{~S}$. Brardii ${ }^{6}$, and S. Menardi ${ }^{7}$.

While Rhytidolepis, Clathraria and Favularia are linked together by intermediate forms, this cannot be said of Leiodermariae (Fig. $26 \mathrm{D}$ ), in which the leaf-cushions as such are entirely wanting, and the leaf-scars are set on the perfectly level surface of the rind and at wide distances from one another. From among the figures of this group may be mentioned Brongniart's Sigillaria leioderma, S. obliqua and S. venosa ${ }^{8}$, also S. lepidodendrifolia ${ }^{9}$ and $\mathrm{S}$. spinulosa ${ }^{10}$. The finest representation of a form of

1 Brongniart (1), vol. i, t. I 46, f. 1.

(1), t. 153 , f. 5 ; Goldenberg (1), t. 7 .

(1), vol. i, t. 159 , f. I.

(1), t. 7 ; Weiss $(1)$, t. 16.

9 Brongniart (1), t. $16 \mathrm{I}$. 3rongniart (1), vol. i, t. 156 , f. I.

4 Brongniart (1), t. 156 , ff. I, 2 . 5 Brongniart

${ }^{6}$ Brongniart (1), t. I58, f. 4 ; Germar (1), t. I I, ff. I, 2 ; Goldenberg

7 Brongniart (1), t. 158 , ff. 5,6 .

10 Renault (8), t. I, ff. 2,3 .

${ }^{8}$ Brongniart (1), t. 157 . 
this kind (S. spinulosa) we owe to Germar ${ }^{1}$. The Leiodermariae bear much the same relation to the preceding forms as Bothrodendrae bear to Lepidodendrac; they are separated from them on the whole in time also, being chiefly found in the most recent formations that contain any Sigillarieae, though Goldenberg has obtained a few of them, but rarely, from the beds at Saarbrücken. In the specimen of Sigillaria spinulosa figured by Germar the entire surface is rough with small anastomosing folds; its leaf-scars show the characteristic trace in the normal manner. Close under the upper margin of the trace lies the ligular pit as a minute point, and beneath each pit are other marks, in which the depressed centre is surrounded by a circular wall. Ordinarily there are two of these marks standing right and left of the median plane; sometimes only one mark is present in a lateral position, and occasionally there are none. They occupy exactly the positions of the two marks in Lepidodendron, and are therefore compared with them by Stur, though nothing of the kind is known in other Sigillaricae. Germar had regarded them as the points of attachment of prickles. Zeillcr ${ }^{2}$ and Renault ${ }^{3}$ consider them to be the scars of adventitious roots. Renault gives a figurc of Sigillaria spinulosa ${ }^{4}$ in which they are distributed in groups, and do not occupy the regular position, as in Germar's spccimen. Further investigation is desirable, but I have not the necessary material. Whether Semapteris carinthiaca ${ }^{5}$ from the anthracites of Carinthia belongs to Leiodermariae I cannot positively say from the figure only. The cushions on the smooth surface of the stem are far apart from one another and are somewhat decurrent; their scars ccrtainly are like those of Sigillaria. Semapteris tessellata, also described in. Unger's work, may be a badly-preserved form of Clathrariae. Unger indeed would place not only these two forms but all the Clathrariae as well with Ferns; of Leiodermariae he does not speak with perfect distinctness.

Hitherto wc have becn speaking only of the surface-impressions. In a cast these can be examined only, as was said above, when the whole of the rind of coal is preserved. If this is removed, there remains behind an inner impressed surface answering to some extent to the casts of Lepidodendrae, which are beset with linear bundle-traces. The surface of this impression is quite smooth in Leiodermariae, but the vertical ridges are plainly seen upon it in Rhytidolepis. But the leaf-trace is marked in both cases by three protuberances, not by one as in Lepidodendrae; the small middle one it is true is often very indistinct, while the two lateral ones appear plainly as parallel strokes. In those Rhytidolepis-forms which have very broad ribs and narrow leaf-scars, such as Sigillaria reniformis ${ }^{6}$

${ }^{1}$ Germar (1), t. 25, ff. 1, $2 . \quad 2$ eiller (3), p. $138 . \quad 3$ Renault (2), vol. i. $\quad$ Renault (2), vol. i, t. 17, f. 2. ${ }^{5}$ Unger (10), t. 3, f. I. 'Brongniart (1), vol. i, t. 1 42. $^{2}$ 
and S. laevigata ${ }^{1}$, these parallel trace-lines may attain a considerable breadth and become almost ovoid, and moving apart from one another may leave a distinct space between them. Such casts were regarded by the older authors as a separate genus and named Syringodendron, Stbg. In these specimens the ribs are usually marked with fine longitudinal striae, which are shown with especial clearness on the mould of the surface, in those places in which the rind of coal remains attached to it and shows us its inner side. How far it is the case that other casts than these occur in Sigillariae, answering to some extent to Bergeria-forms in Lepidodendrae, is a question which deserves further enquiry. We might conclude from Renault's ${ }^{2}$ figure that Sigillaria microstigma, Br. is such a form of preservation belonging to $\mathrm{S}$. tessellata, but since our information about them is scanty, and I have never myself seen any specimens, I must refrain from giving a decision. Since, as will have to be shown later on, Dictyoxylon-structure of the rind has been observed in some Sigillariae, there can be no doubt but that some of the impressions which answer to this structure (Fig. I $B$ on p. 7 , Fig. $22 B$ on p. 217) will belong to the group which we are considering, though we may not be able to distinguish them from the rest.

The stems of Sigillariae are accompanied by large numbers of long linear leaves with a keel formed by the strongly projecting median nerve. It is usually assumed that these leaves belong to Sigillariae, and appeal is made to a few discoveries, which though not absolutely proving the connection yet are calculated to render it very probable. In these instances leaves of the above description were found lying apparently in their natural position and nearly parallel with one another upon and close to portions of Sigillaria-stems. But absolute proof is still wanting, for, as far as I know, the attachment of the leaf to the scar of the cushion has never yet been certainly observed. It is remarkable how rare such specimens seem to be, and I can only cite a very few figures from the literature, though Renault $^{3}$ states that portions of Sigillaria elegans, S. rhomboidea and $\mathrm{S}$. Brardii with leaves are preserved in the Paris Museum. The bestknown figure is that of Sigillaria lepidodendrifolia in Brongniart ${ }^{4}$; a similar figure of S. Cortei, which belongs to Rhytidolepis, is given in Geinitz ${ }^{5}$. The figures of S. rimosa, Goldbg and S. aequabilis, Goldbg supplied by Goldenberg ${ }^{6}$ are less convincing. From the circumstance that pieces of stem only of Sigillariae have hitherto been found, never any leafy branches such as are so abundant in Lepidodendrae, it may be concluded that Sigillariae must have had their branch-system very slightly developed, and the conclusion is supported by the great scarcity of pieces in which branching can be perceived. Wherever it has been observed it is found to be truly

\footnotetext{
1 Brongniart (1), vol. i, t. 143 .

${ }^{2}$ Renault (2), vol. i, t. 17, f. 3 .

${ }^{3}$ Renault (2), vol. iii, p. 8.

- Brongniart (1), vol. i, t. 161, f. x.

${ }^{5}$ Geinitz (5), t. 6, f. I.

${ }^{6}$ Goldenberg (1), t. 6.
} 
dichotomous. Weiss in the year 1869 could only cite three figures of these branched stem-fragments, two of which belong to Sigillaria hexagona ${ }^{1}$ and one to $\mathrm{S}$. elegans ${ }^{2}$, and not one of these figures is quite above suspicion. Dawson's drawing is too small and too imperfect, and the others do not clearly show the line of separation on the inner side between the two branches, which terminate here with the zigzag bounding line of a longitudinal rib. These figures may therefore be quite as well explained by supposing that a simple piece of stem had been separated by crushing into two parts. Little more has been added since that time as far as I know. But we have at last an absolutcly certain and convincing case in Sigillaria Eugenii, Stur, from the Culm (Ostrau beds), which has been studied by Stur ${ }^{3}$. Here the mould and the cast of the bifurcating stem are both preserved, and it is stated that we have similar remains also of Sigillaria Brardii ${ }^{4}$.

While there can therefore be no doubt of the occurrence of dichotomous branching in Sigillariac, it can also be shown on the other hand that certain stems were simple and unbranched throughout. Much the most important specimen of this kind was found in constructing the Friedrichsthal tunnel in the mountain-district of Saarbriicken, and was examined by Goldenberg. There is the more reason to regret that a connected account of the fossil has never been published, and that we are still dependent on the scattered occasional notices of this author. He says ${ }^{5}$ : "Thus among other things in the construction of the railway near Neunkirchen a regular forcst of Sigillariae was exposed to view in the state in which it lived and had its being. The roots of these plants lay on the same gcological level, and the stems were still in their original erect position on this their old ground and soil. Most of these stems belonging to the Sigillariae with broadly-fluted rind, Sigillaria reniformis, \&c., were from two to three feet in diameter at the basc, and ended above in a rounded apex without showing any sign of branching.' Two only of these complete stems have been figured ${ }^{6}$. The first of them, belonging to Sigillaria reniformis, was rooted in the ground, was from five to six metres in height, and was unusually thick. Quite unbranched it contracts rather suddenly into a dome-shaped termination. The other, Goldenberg's ${ }^{7}$ Sigillaria cactiformis, which is afterwards merged in the allied form S. reniformis and is not mentioned again, is broken off above the root-system, but has its apex well preserved and fashioned as in the preceding species. In its upper portion occurs the interpolation, mentioned above on p. 242, of four longitudinal ribs. Its dimensions are however much smaller; it is eighteen

1 Brongniart (1), vol. i, t. 158 ; von Röhl (1), t. 28, f. 17. ${ }^{3} \cdot \operatorname{Stur}(5)$, p. 296, t. 25 , ff. 2,3 .

- Goldenberg (1), t. B, f. 13, and t. 4, f. 1.
2 Dawson (8), t. 7, f. 26 d. ${ }^{3}$ Goldenberg (1), p. 27 .

\footnotetext{
${ }^{7}$ Goldenberg (1), vol. i, p. 28.
} 
inches high and nine inches thick at the base. Two other stems, also figured in Goldenberg ${ }^{1}$, seem to have been longer and more cylindrical. As they are broken across at the upper end, they have nothing to do with the present question. We may also reserve for the succeeding chapter any further notice of the many stumps of trees broken short off, and of the bases of stems which are rooted in the ground and whose subterranean organs have proved to be Stigmariae. They have become known to us from very various parts of the Carboniferous formation.

Every one who has collected much even on the refuse coal-heaps is sure to have met with fragments of Sigillariae, in which the regularity of the ribs and their leaf-cushions is seen to be completely disturbed over portions of the surface. Closer examination shows that this is due to the presence among the regular rows of intrusive scars of a different character, between which lie the ribs in their normal condition, except that they are slightly curved and sinuous. Brongniart ${ }^{2}$ had himself figured such a piece of Sigillaria Knorrii, though not a very marked specimen of the kind, but he saw in it only a casual irregularity. Schimper ${ }^{3}$ was the first to give a full account of the matter in describing his Sigillaria Lalayana (Fig. 27), and suggested that the organs of fructification may have been seated on these scars. There is very much to be said for this idea, since the plants have so

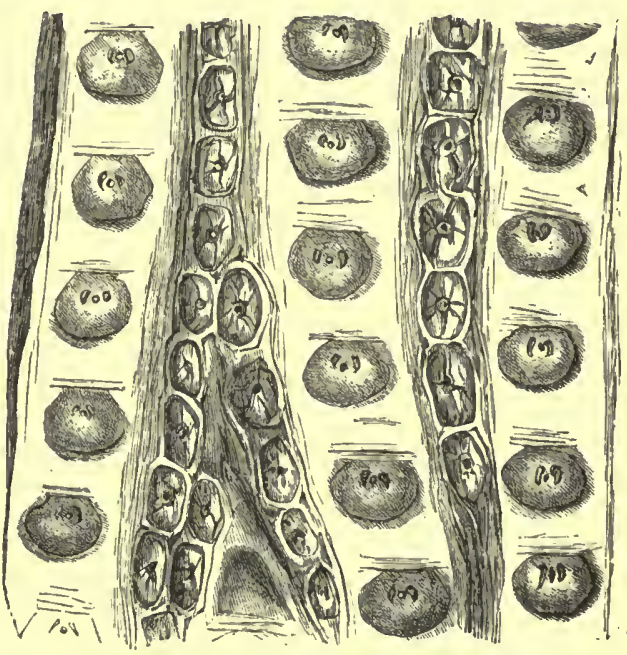

Fig. 27. Piece of the fruit-bearing zone of a stem of Sigillaria Lalayana, Schpr. from Lach in the Weilerthal (Vosges), showing the rows of intercalated scars to which the cones must have been attached. After Schimper in Zittel's Text-book.

few branches and these organs must have been attached somewhere, and all later authors seem to have adopted it. Other good figures of specimens of the kind will be found in Zeiller ${ }^{4}$, Renault ${ }^{5}$ and Williamson ${ }^{6}$. The shape of the scars in question varies; it may be circular or elongate and angular, and the point may be supposed to be unimportant since it depends directly on the contact with adjoining scars and with the ribs which bear them. They are in fact of circular form in Sigillaria spinulosa, the

1 Goldenberg (1), t. 10, ff. 6, 7 .

(1), t. 67, f. 2 , and (2), vol. ii, p. 204 .

(1), II, t. 3 I, f. $5^{8}$ (position reversed).
${ }^{2}$ Brongniart (1), vol. i, p. 446 , t. 162, f. 6. ${ }^{4}$ Zeiller (1). 5. Renault (1), vol. $\mathbf{i}_{\text {. }}$
3 Schimper - Williamson 
only Leiodermaria in which they are known ${ }^{1}$, and this is the effect of lateral contact at every point owing to the peculiar character of the surface. They are polygonal on the other hand and elongate, as far as is known, in Rhytidolepis and Favularia. Sigillaria Brardii is the only species in the group of Cancellatae in which scars of this kind have as yet been found; here according to Zciller's ${ }^{2}$ fine figure the scars are isodiametrically polygonal, and if they are represented as circular in Renault ${ }^{3}$ this may very well be explained by the imperfectness of the figure. Williamson's description cited above, which belongs according to Renault to this species, agrees essentially with that of Zeiller. The character of the surface of the scar, which projects convexly in the mould, is quite different to that of the leaf-scar. In its centre is a circular protuberant trace of considerable dimensions, and the entire periphery is occupied by stout sinuous radiating wrinkles, between which there are usually fragments of coal still adhering. We should no doubt be able to see other details on the surface of the rind of coal on the cast; but though I have myself found several good specimens of moulds, a well-preserved cast of the kind has not yet fallen in my way.

Authors have described a number of species of Sigillariac, all of which are distinguished by the form and character of the leaf-cushions. The method is very precarious, for we cannot say to what extent alterations supervene with the growth of the plant. The scars of the fructification are known as yet in very few forms, and yet distinctions have been already observed in their distribution on the surface of the stem, and these secm to supply characteristic marks. From this source we may expect to obtain much help in arranging the group, as Zeiller ${ }^{5}$ has very conclusively shown, if we can once arrive at more extended knowledge through further rescarch. So far as we can venture to generalise from our present scanty knowledge, the scars of the fructification are confined in Rhytidolepis and Favularia to more or less broad intercalary zones, which form rings round the stem. Within these zones the scars, touching one another above and below, form vertical rows inserted between the ribs in Sigillaria tessellata ${ }^{6}$, in $\mathrm{S}$. Lalayana, Schimp. (Fig. 27), and in Sigillaria Lorwayana ${ }^{7}$. In these species they are nearly rectangular through mutual pressure. On the determination of species by authors I do not venture to express an opinion; but I may call attention to the great resemblance between the two figures first cited. The scars are developed in a broad transverse zone between the ribs, and being everywhere isolated they are elliptical in form or two-

\footnotetext{
1 Renault (2), vol. i, t. I7, f. 2. 4 Renault (2), vol, iii, p. 9 .

'Zeiller (1), t. 174, f. I.

Renault (2), vol. i, t. 17, f. I. (12), p. 43 with figures.
} 
angled in Sigillaria scutellata ${ }^{1}$, S. mamillaris $^{2}$, and S. alveolaris ${ }^{3}$. S. Knorrii, Brongn. also (see above on p. 245) and S. oculata ${ }^{4}$ appear to belong to this group. I also find them so arranged in several pieces of Rhytidolepis in my collection. Lastly the scars appear from the figures to be placed not in broad zones of the circumference of the stem, but in single widely-separated circles, in Sigillaria Brardii and S. spinulosa (see the figure cited above on p. 246), the only species of Clathraria and Leiodermaria in which they are known. Renault ${ }^{5}$ says that they must have been arranged in these two species 'in a spiral with more or lesss distant turns'; I have never had the opportunity of seeing them myself.

Authentic remains of Sigillariae with the structure preserved are extremely rare. A single diminutive fragment of a small stem of Sigillaria Menardi is all that is at present known from the group of Cancellatae. This specimen was made use of by Brongniart ${ }^{6}$ for his famous monograph, and it was there described under the name of Sigillaria elegans, but Zeiller ${ }^{7}$ has proved that this is a wrong determination and that it belongs to S. Menardi. S. elegans does not generally occur in deposits so recent as those which contain the siliceous fragments of Autun, from which this specimen was obtained. The transverse section of it shows a broad medullary tube, but the tissue has disappeared and been replaced by a homogeneous mass of silica. The tube is immediately surrounded by a ring of many crescent-shaped strands of tracheides, which have their convexity turned inwards and are in lateral contact with one another, and in which the narrowest elements are in the concavity of the outer side. The strands appear to be entirely composed of scalariform tracheides of considerable length. The leaf-trace-bundles join them on their outer side. This ring is surrounded by a mass of secondary wood which is divided into separate wedges by primary medullary rays, and each wedge corresponds to one of the inner bundles. This woody mass is of perfectly normal character, and like the secondary wood of Cycadeae is divided by fascicular rays into many narrow plates, in which the transverse sections of the scalariform tracheides are arranged in regular radial rows. The leaftrace-strands run almost horizontally through the secondary wood, and it is not till they reach the rind that they begin to ascend in steep curves. The consequence is that they pass through the wedges of the wood very nearly in the transverse direction, so that if the transverse section encounters one of them, the wedge of wood is seen to be divided by it into two parts, as is shown in Fig. 28 and in Brongniart's ${ }^{8}$ and Renault's ${ }^{9}$ figures. Little of the cortical tissue is preserved in our specimen; the inner and

1 Zeiller (1), t. I73, f. I.

${ }^{2}$ Lesquereux (1), vols. i, ii, t. 72, f. 5 .

t. 7, f. 16. Geinitz (1), t. 5, f. $10 . \quad{ }^{3}$ Renault (2), vol. iii, p. 9.

${ }^{3}$ Goldenberg (1),

7 Zeiller (12), p. 259.

${ }^{8}$ Brongniart (7), t. 25.

${ }^{9}$ Renault (1), t. II, f. I3.

- Brongniart (7). 
middle portions are entirely destroyed; in the inner portion there remain only the transverse sections of the ascending leaf-traces, and these are obtusely triangular in form and have one angle turned towards the outside. We shall have to return to the character of the leaf-trace-bundles of Sigillariae in concluding our account of the anatomy of the group. The outer rind which bears the leaf-cushions is preserved; it consists of compact parenchyma and separates into two not very distinct layers, of which the inner is composed of elongated elements disposed in rows on the transverse section, the outer of ordinary isodiametric parenchyma. The former is always termed in Renault's publications the 'couche subéreuse,' an expression which must be understood here as in Lepidodendreae in a morphological, not in a physiological sense, being intended

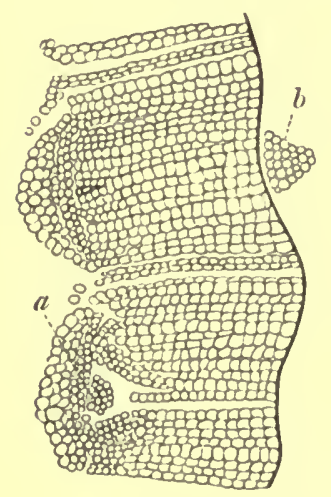

FIG. 28. Sigillaria Menardi, Brongn. Fragment of the transverse section of the ring of wood. The primary bundles show their initual strands on the outer side; the section has encountered an emerging foliar strand at $a$; at $b$ is the transverse section of a similar strand which has already passed through the secondary wood. After Renault (2), vol. i. to show the connection with a periderm. We are in fact vividly reminded of the formation of periderm, which we observed in Lepidodendreae.

Of the group of Leiodermariae we are acquainted through Renault' ${ }^{1}$ labours with the structure of Sigillaria spinulosa, of which a good many specimens have been obtained at Autun. Rind and wood are there usually found separate from one another, and the surface of the former is in most cases not preserved. The rind had been known for some time, and had been named by Brongniart Dictyoxylon bcfore the relation of the two remains to each other was cleared up by the help of some fortunate discoveries, which showed them in actual connection with one another and revealed at the same time the characteristic features of the surface. Here too there is a central cavity evidently once occupied by the pith; this cavity is surrounded as in Sigillaria Menardi by a number of vascular strands, which are more or less circular in form and are succeeded on the outside by a much thicker mass of secondary xylem. The bundles also which surround the pith are similar in structure to those of Sigillaria Menardi, but they have not their regularity of form; they vary greatly in breadth and several of them are often attached laterally to one another. To put the matter briefly, we cannot dismiss the impression that we have to do in this case with a circular tracheal zone, which through unequal development has been broken up into many separate fragments having naturally therefore the form of strands. This is not so distinctly shown in Renault's ${ }^{2}$ 
drawings, especially not in those that are less highly magnified. His sections may have too regularly avoided this zone. For this reason I give here a sketch of the central portion of a stem which was determined by Renault himself and given by him to Williamson, who most kindly lent it to me for the purpose of this drawing. I remark at the same time that the specimens preserved in the Paris Museum are perhaps less irregular, but have essentially the same character, and of this I have satisfied myself by repeated examination. This is so far important as tending to make us less inclined to the assumption of a pith surrounded by distinct bundles than to the view that the whole together is a central bundlestrand, the centre of which is parenchymatous, while portions of the periphery are tracheal in character to an extent not exactly defined. And since, as we know, the smallest narrowest elements lie on the outside, the result would be a picture similar to that which would be produced for example in Lepidodendron Harcourtii, if its tracheal ring were broken up into separate portions, as is actually the case in L. Jutieri. And if this is the natural conception as regards one species of the genus, we are further driven to adopt the same explanation of the other species, Sigillaria Menardi, which differs only by its greater regularity and more perfect consolidation. We cannot enter further here into

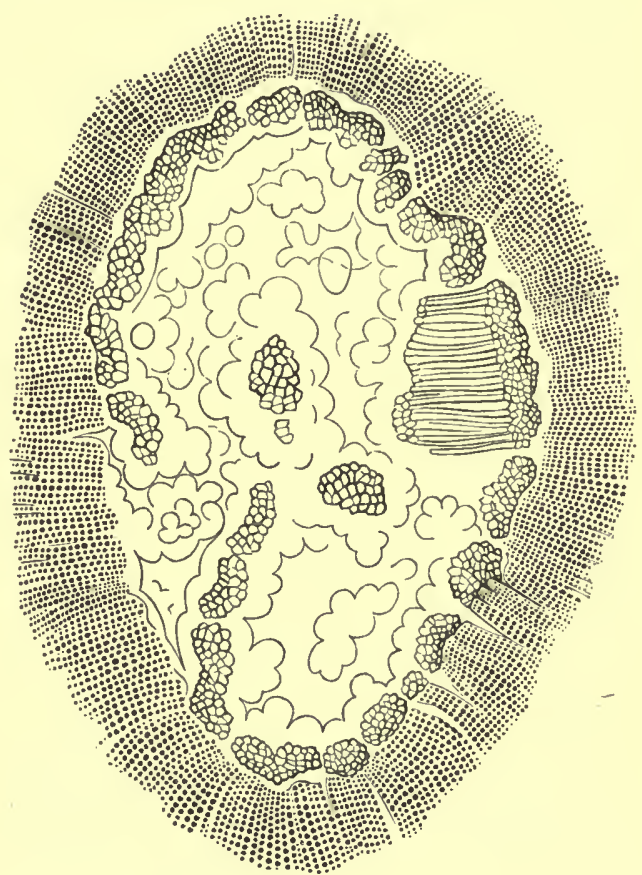

Frg. 29. Sigillaria spinulosa, Germ. Centre of the stem in transverse section, showing the ring of primary wood divided into irregular bundles, and the inner portion of the secondary growth. Drawn from a specimen in Williamson's collection presented by Renault himself. Slightly magnified.

the consequences which result from this view; we should quickly arrive by this path at the general conception already adopted by some authors, namely that pith and peripheral ring of vascular bundles have been formed by differentiation from the originally simple central strand. Van Tieghem's ${ }^{1}$ view is determined by the opposite idea, for he would everywhere explain the axile cauline bundles as due to the coalescence of several trace-bundles with their wood-portions turned one towards 
the other. He accordingly considers the central wood also of Lepidodendron to be composed of these leaf-traces. The secondary wood of Sigillaria spinulosa forms a firmly-closed ring of considerable thickness traversed by numerous rays of more than one kind, and has no special features; there is one point only to be noticed, that its primary rays do not always coincide on the inner boundary with the places where the tracheal ring of the central cylinder is interrupted, and that in this point also there is less dependence of the two systems on one another in this species, than appears to exist in Sigillaria Menardi. The inner cortical layer, consisting of delicate tissue and inclosing the transverse sections of the ascending leaf-trace-bundles, is only rarely and imperfectly preserved; the contiguous layer on the outer side shows exquisite Dictyoxylon-structure throughout up to close beneath the surface; this is caused by the undulated plates of sclerenchyma approaching each other and uniting together here and there, and then again separating from one another. This layer is also termed by Rcnault in his accustomed way the 'couche subéreuse.' How far it really belongs to the periderm I am unable to determine; the question must be left to further investigation.

While the scarcity of the Sigillariae in the upper beds of the Carboniferous formation makes it easy to understand why well-preserved remains of them should be so rare in the French deposits, it is very surprising to find that they are equally rare in the English coal-fields, though impressions of Rhytidolepis-forms are abundant enough, and even their outer rinds with the structure preserved cannot be said to be scarce. Only one specimen has been found up to the present time, as far as I know, which shows the rind and the woody body in connection. This comes from Oldham and is in Carruthers's possession. Since the well-preserved surface shows that it belongs to a species of the section Rhytidolepis, probably Sigillaria Saullii, it is most desirable that it should speedily be submitted to the examination which has hitherto been deferred. Its owner, however, has been kind enough to show me the rough specimen, and I can only confirm the statements of Williamson and Hartog ${ }^{1}$. The latter authors say: 'The fragment has the continuous cylinder and all the internal organisation of Corda's Diploxylon'; it has therefore a structure, which, if we disregard the secondary wood, answers perfectly to that of the central cylinder of Lepidodendron Harcourtii. This only confirms us in the view which has been already explained respecting the pith and the tracheal zone surrounding it in Sigillaria spinulosa and Sigillaria Menardi, and we shall be able perhaps to set this view in a still clearer light, when once the details of the structure of this Sigillaria Saullii have been laid before us. The little that Williamson ${ }^{2}$ has said about Rhytidolepis concerns only the outer- 
most cortical layer composed of stout parenchyma, the elements of which are directed inwards in rows; it is therefore of small importance. What Dawson ${ }^{1}$ has termed Sigillaria-structure is so imperfectly described by him that we can arrive at no conclusion respecting it; as the stems in question showed the pith of Artisiae and vessels with bordered pits, it is natural to suspect that they belonged to Cordaiteae.

To conclude-it will be necessary to submit the structure of the leaftrace-bundles of Sigillaria Menardi and S. spinulosa to further and closer consideration, because Renault in his different publications has made it the ground of some far-reaching conclusions. According to his figures ${ }^{2}$ each trace-strand behaves very differently in different parts of its course. Tangential sections through the secondary wood present it in rather oblique tranverse section. It is formed of two evidently separate tracheal groups, between which lie according to the text the spirally thickened initial elements. This would evidently be the so-called diploxylous structure of Cordaiteae. Then in the inner rind the strand assumes much greater unity of character; the transverse section ${ }^{3}$ shows a quite compact apparently homogeneous xylem-strand obtusely triangular in form, in which the spiral tracheides are said in the text to be centrally situated, a little nearer to the outer side. We do not learn from these sections, any more than from those previously mentioned, whether the bundle is collateral or concentric. This appears for the first time in a figure in Renault ${ }^{4}$, a tangential section through the Dictyoxylon-layer of the rind which has hit the emerging foliar bundle exactly transversely. The bundle is now broader than before and its transverse section is crescent-shaped and no longer triangular. Its upper inner segment (bois centripète) consists of tracheides lying together in no particular order. The lower outer (bois centrifuge), which was very feebly developed in the previous section and answered to the outwardly inclined apex of the triangular transverse section, is now considerably enlarged, and its tracheides arranged in rows have rays of parenchymatous tissue between them. Next to it the bastlayer is still to be seen in the form of an arch, and as it does not appear elsewhere round the wood, it is evidence of the collateral character of the bundle-strand. We are thus undoubtedly justified in comparing it with the foliar bundle of Cycadeae mentioned above on p. I06 in the chapter on Cordaitac. Reference may also be made to former remarks on Myelopteris, but Lepidodendreae must for the present be left out of consideration, since observation has led to no direct conclusions in their case, and we are first led to suspect collateral structure in the strand by considerations connected with the behaviour of the Stigmariae which we have yet to consider.

1 Dawson (8). $\quad 3$ Renault (1), t. I I, ff. 18, I9.

${ }^{3}$ Renault (1), t. I I, f. 20 and (8), 
The peculiar structure of the trace-bundle of Cycadeae has been well explained by Mettenius ${ }^{1}$, who was the first to notice the distinction between the centripetal and centrifugal portions of the xylem, between which lies the initial strand, and the terminology of the French authors may therefore be traced directly to him. But at the same time the terms which they employ are unfortunately chosen, since they may mislead the reader into regarding the two parts of the bundle as anatomical members essentially distinct from and entirely independent of one another. Mettenius was perfectly aware that this is not the case; he is careful to show how the initial strand, so placed in the inner angle of the leaf-trace in the segment of the stem that there is only 'bois centrifuge' present, gradually moves towards the outside while the bundle is still young, till it has reached the central position characteristic of the lcaf-segment. It is true that two woody portions now appear on the single transverse section, but they are in no respect essentially different from one another; they are connected laterally below, and together they form the one xylem-strand of the bundle, in which the displacement of the initial group has simply given rise to an unimportant alteration. It appears to me therefore that the French anatomists, van Tieghem and his school, bave not rightly understood Mettenius, when they oppose the two parts to one another as 'bois centripète' and 'bois centrifuge,' and regard them as distinctly different things. Thus we find van Ticghem ${ }^{2}$ saying unreservedly: 'This second portion of the wood (centrifugal) corresponds to the normal wood of the cauline bundle; it is the fan formed by the centripetal wood which is the superadded portion.' This is not correct; it is the two parts together which correspond to the 'bois normal,' and nothing beside is added to it, only the initial point of the ultimate development has suffered displacement. And this fundamental error appears in other authors in a more advanced and more pronounced form. Thus Bertrand and Renault ${ }^{3}$ have written quite recently: 'The cauline bundle preserves its structure when it enters the leaf, only its primary wood is reduced and a new tissue, the centripetal wood, is intercalated between its pole and its anterior face. The centripetal wood of a unipolar diploxylous bundle is therefore not the homologue of the displaced primary wood of the normal unipolar bundles. The tissue is a relic of a former organisation.' There is scarcely a word in this sentence to which I am not obliged to take exception. Mettenius' figures themselves teach the exact contrary, but I have also satisfied myself perfectly by personal examination of various young individuals of the group of Cycadeae that the actual state of things is as I have here portrayed it. Had Mettenius adopted a different ter-

1 Mettenius, G., Beiträge zur Anatomie der Cycadeen in Abh. d. kgl. sächs. Ges. d. Wiss. Bd. vil (Math. Natw. Cl. vol. v), Leipzig, 186r.

sertrand and Renault (1). 
minology, had he called for instance the leaf-strand of Cycadeae mesarch; and that of Isoëtes exarch in opposition to the normal form, we might perhaps have been spared this misconception. It is evident from what has been said above that to employ the current phraseology and speak of a diploxylous bundle has no meaning, except when we are dealing with a certainly collateral trace-strand. For this reason I have been able to employ the word without hesitation when speaking of Cordaiteae, and it may also be used here for the leaf-trace which passes through the cortex of Sigillariae. But we must think twice before we go beyond this, and say with van Tieghem': "this double wood is also found in the leaves of Sigillariae, but here we are going back to the rule, for the stem too has a double wood, the interior primary and centripetal, the exterior secondary and centrifugal.' It is true that this is also going back to Mettenius ${ }^{2}$, but he only knew Sigillaria from Brongniart's description. The objection is that in this mode of conceiving the matter a sufficiently sharp distinction is not drawn between primary wood and secondary additional growth. If the latter supervenes, it certainly unites immediately with the outer portion of the xylem. But whether in a given stem of the species in question having secondary growth the original structure of the primary bundle followed the type of Isoëtes or that of Cycadeae cannot be determined, unless we are in a position to study the history of the development of the specimen. Van Tieghem appears to underrate the importance of this distinction, or else he could not possibly say ${ }^{3}$ : 'The leaf of Sigillariae derives its ligneous elements at once from the angles of the primary wood and from the inner margin of the superposed secondary wood'; for this leaves it uncertain whether the latter elements connect with the outer strand of the primary wood or with that of the secondary, or partly with the one and partly with the other. Moreover the above sentence determines a priori the extremely doubtful question of the anatomy of Sigillariae, for it assumes the presence of a medullary cylinder surrounded by isolated leaf-trace-strands. And yet we have seen how strongly the stages in the differentiation of the primary structure point to the conception, that the central parenchyma with the surrounding ring of bundles is a single central strand partly developed in the form of parenchyma, after the analogy of Lepidodendron Harcourtii. The strand would in that case be concentric in structure and could not come into consideration here; the diploxylous leaf-traces would be attached to its periphery. Van Tieghem it is true would not consider this an important distinction, for he considers every central strand of the kind to be formed by the coalescence of collateral leaf-traces, as was observed above on p. 253 . To discuss in detail the mutual relations of the two distinct types which

' van Tieghem, Traité de bot. 1884, p. 812. s van Tieghem, Traité de bot. 1884, p. $130 \%$.
${ }^{2}$ van Tieghem, Traité de bot. 1884, p. 582 . 
have here to be brought into comparison, that of Gymnosperms on the one hand and that of Lycopodiae and Lepidodendrae on the other, would require a lengthy inquiry into the elementary anatomical ideas of French and German authors. This would carry us too far from our immediate subject, and the intimations already given will be sufficient for the botanist. An inquiry into the comparative anatomy with special reference to this point might possibly bear good fruit ; it might perhaps bring us nearer to the understanding of the mode in which the existing types of structure in stem and root have been developed from a common initial form.

We cannot leave the consideration of the leaf-trace without a brief notice of the two small lateral scars, which like a pair of brackets inclose the place of fracture of the vascular bundle in Sigillariae, and which were observed in similar form on the scar of Lepidodendrae. Renault ${ }^{1}$ has shown in the case of Sigillaria spinulosa that they are not remains of vascular bundles, but are simply parenchymatous, and Stur's ${ }^{2}$ statement, who refers them to the division of the foliar bundle in the cortex, must be corrected accordingly. On other points Renault's account does not supply us with much certain information with respect to these objects. He usually terms them 'lacunes,' and says that they are gaps on the two sides of the vascular bundle; in the preface ${ }^{3}$, which is directed against Williamson, he says: 'the two lateral lacunac answer to gum-canals.' But the statement in the samc place ${ }^{4}$, that these canals pass through the entire thickness of the rind, does not properly agree with his own drawings, in which they by no means appear everywhere close to the vascular bundle; they may possibly have been at an unusual distance from it and could not be included in the drawing. This will be scen by comparing his figures ${ }^{5}$; and other figures ${ }^{6}$, in which they certainly appear, show them in such varicty of form that it is hopeless to think of forming a clear idea of their character. In any case we cannot regard it as proved, that they represent or inclose gum-passages.

Renault " gives some transverse sections of leaves of Sigillariae, which show a single very broad diploxylous vascular bundle. It is quite possible that these remains really belong to Sigillariae, but it is certainly not yet proved, as Renault ${ }^{8}$ himself admits when he says, "which I think may be referred to Sigillariae on account of their outward form,' \&c.

As regards the affinities of Sigillariac, now that the ideas of older authors, who like Corda, for example, compared them with Cacteae and Euphorbiae, have been definitively set aside, there remain only two opposing views, one of which was founded by Brongniart and places them with Cycadeac, while the other is maintained by Goldenberg, Schimper, and the

1 Renault (8).

2 Stur (5), p. 293.

${ }^{3}$ Renault (2), vol. iii, p. 4 .

4 Renault (2), vol. iii, p. 5 . "Renault (1), t. 12, f. 1 and 8, t. 3, f. 17, t. 5, f. 32 .

- Renault (8), t. 3, f. 18 , 1. 5, f. 31, t. 6, f. 33 .

7 Renault (1), 1. 12, ff. 6-9.

${ }^{8}$ Reuault (1), p. 265. 
English authors, Williamson especially, and brings them into close relations with Lepidodendrae, and through them with Archegoniatae. This divergence of opinion has very recently given occasion to a controversy between Renault and Williamson, which has been already noticed more than once, and which has been conducted by the two opponents in several of the publications cited above. One of the chief arguments advanced by Renault, and drawn from the growth in thickness of the stem, which is supposed not to occur in Archegoniatae, has already been sufficiently examined in the chapter on Lepidodendrae. He finds a second and fundamental difference, which ought to prevent any approximation of Sigillariae and Lepidodendrae, in the structure of the leaf-trace-bundles. These are diploxylous in Sigillariae, and such bundles do not occur in Archegoniatae; Sigillariae therefore cannot belong to Archegoniatae, while Lepidodendrae being Archegoniatae have monoxylous bundles. This argument, which is quite analogous in character with the argument from growth in thickness, I must also consider to be inconclusive, for we have in Isoëtes an Archegoniate plant with anomalous position of the initial strand, and there is no apparent reason why there should not have been more of them. Renault himself places Myelopteris among Ferns, notwithstanding that it exhibits the like anomaly. Moreover, as has been already said, we are not yet certain whether the structure of the leaf-trace in Lepidodendrae was collateral or concentric. I incline myself, as I have said, to the view that it was collateral, not only because in Lepidodendron Harcourtii we find a group of bast-fibres in front of one side only, the outer side, of the transverse section of the bundle, but chiefly on account of the character of the traces in Stigmariae, of which we shall have to speak at greater length in the next chapter. But if the bundle in Lepidodendron is collateral, then it is also immediately diploxylous, if Renault is right in his view with regard to the position of its initial group, and every essential difference in this respect between the two groups falls to the ground. If on the other hand it is concentric, then there is really a difference between them, and the only question is as to the importance of this difference; but on this point there can be no dispute. Lastly, as regards the separate bundle-strands which surround the pith in Sigillaria, their relations to the annular border of tracheides in the central strand of Lepidodendron Harcourtii have already been sufficiently considered; and the like character appears to be found also in one type of Lepidodendron, L. Jutieri, Ren., as is justly and strongly urged by Williamson ${ }^{1}$. It is true that a careful examination of this specimen, which may possibly correspond with Sigillaria Menardi or S. spinulosa before the formation of secondary. wood, is much to be desired. When I thus weigh in my own mind all the arguments and counter arguments, and take also into consideration the 
question of Stigmariae, which cannot be treated here, but must form the subject of the next chapter, I arrive at the result that it is impossible to obtain incontestable proof of either of the two views from purely anatomical sources, but that Williamson's remains the more probable, because the main argument in support of the contrary view is entirely overthrown by the proof of the presence of secondary wood in Lepidodendron, which is undoubtedly one of the Archegoniatae.

It has long since been perceived that the most decisive proof in one or the other direction would be obtained by the discovery of fructifications of Sigillaria, but such a discovery exhibiting the fruit of Sigillaria in direct connection with undubitable scars of the plant long remained a pium desiderium. Both sides appealed to cases in which the two parts were supposed to occur together, but of these cases there was no sufficient proof. Renault ${ }^{1}$ acknowledging them to be conjectural has never used the fructifications in support of his view, while those who maintain that the group belongs to Gymnosperms, Dawson ${ }^{2}$ especially, look for them as a rule among the numcrous seeds of the Carboniferous formation, which we have considered in connection with Cordaiteae. Certain spike-like fructifications, resembling those of Lepidodendrac, have been described by the representatives of the other view under the name of Sigillariostrobus. Goldenberg ${ }^{3}$ especially has figured a number of remains of cones in a very crushed condition, which he ascribes without apparent reason to Sigillariae, and in which groups of macrospores lic between flat lcaves with a broad basc. Single detached leaves showed a small heap of similar spores at their base on the inner side; the wall of the sporangium which contained them could not be seen. The three edges of the pyramid were distinctly shown in the single spores. O. Feistmantel ${ }^{4}$ also has figurcd various Sigillariostrobi which had been previously described in different publications, and has drawn up a complete list of the literature. These remains of cones, in other respects apparently in no very good state of preservation, are said to have short obtuse sporangial leaves, on the inner side of which were laid numerous macrospores. As there is no proof that they belonged to Sigillaria, they have but small importance for us, and it will be sufficient to refer the reader for further details concerning them to the original literature.

The question being in the position which has been now described, it can be understood that Zeiller's ${ }^{5}$ latest discovery of cones with long stalks showing the character of the axes of Sigillaria is of the greatest importance. These cones, several in number, come from the mine L'Escapelle, in the coal-field of the department of the Nord, and are preserved in the

\footnotetext{
1 Renault (2), vol. i, p. 15 5 , and vol. iii, p. 8.

${ }^{2}$ Dawson (8).

s Goldenberg (1), t. Io.

- O. Feistmantel (3), p. 25 T, t. 60.
} 
form of impressions with an outer crust of coal. Through the kindness of their discoverer I have had the opportunity of inspecting them carefully, and I have thereby fully satisfied myself of the correctness of his statements. But I would observe at the same time that the specimens require to be examined with extreme care and in various lights, and that the details of the organisation are by no means so apparent on the dull black rind of coal as on the tables appended to the memoir. The cones are described as different species of Sigillariostrobus, and the one which shows strict proof of Sigillaria-nature is named Sigillariostrobus Tieghemi ${ }^{1}$. The specimen consists of the lower portion of the cone placed on a tolerably long stalk surrounded by linear leaves. The rows of scars on the stalk allow of an approximate determination of the plant as Sigillaria scutellata, Brongn., or S. periploca, Boulay, a species which is particularly abundant in the seam from which the cones come. The leaves which bear sporangia all stand out from the stem, the macrospores lie on their cushions which are narrowed into the shape of a wedge, and the lamina is broadly lanceolate, pointed and one-nerved. There is really therefore a perfect resemblance to Goldenberg's Sigillariostrobus, which was only a little smaller. In the other and similar species also, which occurred in the form of large fragments from different parts of the cone, Zeiller could find only the same kind of macrospores. He considers the possibility ${ }^{2}$, which in fact there really is, that these Sigillaria-cones may have been isosporous, though the considerable size of the spores is not in favour of this, and he also raises the question whether the two forms of spores might not have been produced on different cones, in which case the cones that contained the microspores could not be recognised as such when preserved in coal. In fact on one of his cones (Sigillariostrobus nobilis ${ }^{3}$ ) there was no trace of a spore to be seen. Renault ${ }^{4}$ has just published a preliminary communication on a spike-like fructification which he classes with Clathraria or Leiodermaria, but without stating his reasons. He says: 'The general appearance of this spike, its dimensions, the form and length of the bracts, their disposition in close spirals and the diameter of the axis bring it very near to, if they do not identify it with, the spikes which are often met with among the leaves at the extremity of the stem of Sigillaria Brardii.' That is all. It is stated that pollen-sacs in large numbers were attached on the under side of the horizontal basal portion of the spike on both sides of the median nerve, and that orange-yellow pollen-grains of elliptic outline were to be obtained from them. I was unfortunately unable to see the specimen, which was just then being engraved, and a drawing of it did not give me all the information which I required.

When then Renault goes on to say, "The Sigillariae with smooth

\footnotetext{
1 Zeiller (12), t. II, f. I.

- Renault (9).
}

${ }^{2}$ Zeiller (12), p. 273.

${ }^{3}$ Zeiller (12), t. I 2, ff. 1, 2. 
rinds, distinctly marked cicatrices and the structure above described, are phanerogamous gymnospermous plants near modern Cycads,' we can scarcely think his statcment justified, when we consider that we do not even know whether the specimen on which he founds this conclusion really belongs to Sigillariae. But since he acknowledges, though not without rescrve, the correctness of Zeiller's observations, he arrives ultimately at the following conclusion: 'The Sigillariac, an essentially transitional group of plants, would therefore scparate into Leiodermarieae or phanerogamous Sigillariae with smooth rind near Cycadeae, and into Rhytidolepis or cryptogamous Sigillariac with fluted rind allied to Isoëtes.' But this sentence is simply a pctitio principii, for it is not easy to see why we should separate the ribbed Sigillariae from the others, so long as there are no reasons which compel us to do so. And now that we are acquainted with an archegoniate fructification in the one group, we must with WVilliamson and Zeiller assume the existence of a similar fructification in the other group till proof to the contrary is produced. No doubt the question of transition groups may have to be considered here, but it must first be shown that there were such groups. And so till Renault can prove his view, I shall from the facts which lic before us hold fast on the whole to the opinion that the Sigillariae were of the nature of Archegoniatac. 


\section{XII.}

\section{STIGMARIA.}

THE Stigmariae are some of the best-known and commonest of fossil forms, and are constantly to be found on every refuse-heap in a coal-mine. They occur sometimes as cylindrical casts of greater or less thickness beset with peculiar regularly disposed scars, sometimes as impressions in which long finger-like appendages with blunt terminations are attached to the scars. The distribution of these remains through the series of formations agrees very nearly with that of Lepidodendreae. Most abundant in the Coal-measures they are still frequent in the Carboniferous Limestone, and may be traced backwards into the Devonian formation. Dawson ${ }^{1}$ has figured remains from St. John in New Brunswick and from Gaspé, of which Stigmaria perlata ${ }^{2}$ at least may be regarded as certainly belonging to this group. They are found in the other direction as high as the Rothliegende, in which, as we see, the last undoubted Sigillariae occur, at Autun for example, and also according to Weiss ${ }^{3}$ near Schmalkald in Thuringia and near Zorge in the Harz. Above this point they disappear entirely. The most complete collection of the older literature on Stigmaria is to be found in Göppert ${ }^{4}$ and Weiss ${ }^{5}$; for the newer the reader may be referred to Renault ${ }^{6}$ and to Williamson's ${ }^{7}$ last publication.

The common species, which is generally distributed through the strata from the Limestone below to the upper beds of the Carboniferous formation, is Stigmaria ficoides, Brongn.; and closely connected with it are a number of other forms which will be briefly noticed presently, and which are treated by most authors, by Göppert also and Schimper ${ }^{8}$, as mere varieties, though some at least of them differ greatly from it in habit. The casts of Stigmaria ficoides, usually merely cylindrical fragments, are not unfrequently of considerable length. Hooker ${ }^{2}$ mentions some that were twenty metres, Göppert ${ }^{10}$ one that was thirty metres in length. Their branching is always dichotomous, and the two arms of the bifurcation pursue a parallel course

${ }^{1}$ Dawson (1), vol. i, t. 3 .

${ }^{2}$ Dawson (1), vol. i, t. 3 , f. 32 .

${ }^{3}$ Weiss (1).

Göpper

(3), (20).

${ }^{5}$ Weiss (1), p. 171 .

${ }^{6}$ Renault (2), vol. ii, p. 152, vol. iii, Introd. and (10).

7 Williamson (6).

${ }^{8}$ Schimper (1).

- Hooker (4), p. 432.

10 Göppert (3), p. 188. 
from the beginning. Their surface is smooth or slightly uneven, and is furnished with shallow pits containing the fracture-scars of the appendages; these are in loose order and show regular quincuncial arrangement. The positional relations which are at the foundation of this arrangement have not yet, as far as I know, been accurately determined. The outline of the Stigmariae is circular, and the boundary-line of their circumference is sharply defined; in the centre is a second circle, the central point of which is a dotlike protuberance. Good figures are supplied by Schimper ${ }^{1}, \mathrm{Heer}^{2}$, and Goldenberg ${ }^{3}$.

The appendages are found in unusual abundance in immediate connection with the axes; where these occur as impressions in coal, the appendages are scarcely ever wanting, and they spread out on the two sides forming a right-angle with the axis. And when the rock is examined in

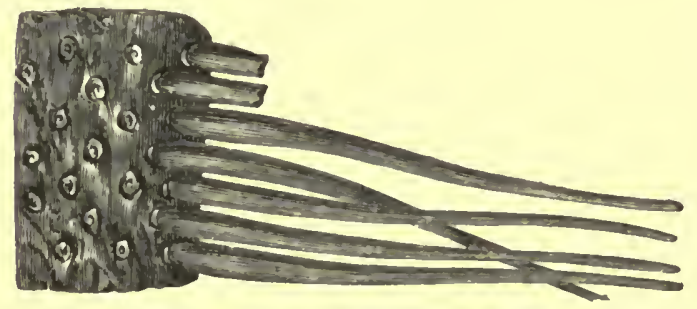

F1G. 30. Stigmaria ficoides. Piece of a cast showing the appendages attached. After Schimper in Zittel's Text-book, diagrammatically represented. which the casts of the axes lie, every surface of division in it is seen to be traversed by the appendages, which spread like rays on all sides from its transverse fractures. Where they lie free their whole length through, they appear as cylindrical or dactyliform bodies flatly rounded at the upper extremity and suddenly contracted at the base, and having a smooth surface. If they are pressed flat, as is always the case in impressions, the original cylindrical form can usually be concluded from the longitudinal folds. The finest specimens are those which are obtained by skilful use of the hammer from the English calcareous nodules. These facts have all been given by Steinhaucr ${ }^{4}$ in his excellent account of Stigmaria. Really good figures (Fig. 30) are only rarely to be met with in the literaturc. Lindley and Hutton ${ }^{5}$, Corda ${ }^{6}$, Sternberg ${ }^{7}$, and Zeiller ${ }^{8}$ may be consulted. The fossil is in fact so common that most authors have not thought it necessary to give an illustrative figure. - Sometimes, but not very often, the appendages are dichotomously divided, and in that case each branch has its extremity flatly rounded off in the usual manner. Goldenberg ${ }^{9}$ and Corda ${ }^{10}$ have given figures of such cases. Goldenberg found an ovoid body in the bifurcation; a similar body marked with a longitudinal furrow is represented on

\footnotetext{
'Schimper (1), t. 119, f. 8.

${ }^{2}$ Heer (5), vol. 2 I, t. 12.

3 Goldenberg (1), t. ז 3 .

- Steinhauer (1). ${ }_{5}^{5}$ Lindley and Hutton (1), vol. i, tt. $3^{2}, 33,3^{6}$.

${ }^{7}$ Sternberg, Graf von (1), Heft I-4, t. I 2 . Zeiller (3), t. I 73 .

${ }^{10}$ Corda (1), t. 12.

- Corda (1), t. I 2, f. I.

- Goldenberg (1), t. 13 .
} 
Corda's fine specimen on the upper extremity of a simple appendage. In other specimens, according to Goldenberg ${ }^{1}$ and Göppert ${ }^{2}$, there is at least a small circular scar in the angle of bifurcation, which Goldenberg supposes to be the point of attachment of the ovoid body. But the lastnamed forms, not being attached to the axes, are not above suspicion. Though Goldenberg and Corda consider these ovoid bodies to be fructifications of Stigmariae, it seems to me that there is as yet no sufficient ground for this view, and I must consider any determination of them at present to be premature.

From this notice of the appendages we must return once more to the axes, and take note of some states of preservation which demand careful consideration. The first to be noticed are the internal casts mentioned above on p. 8. It very often happens that we find inclosed in the Stigmaria a cylindrical cast of small diameter, which being sharply separated from the surrounding mass is plainly distinguishable on every transverse fracture, and may by splitting the stone be laid bare sometimes for a considerable distance. That we are here concerned with an integral part of the plant, and not with some other remains introduced with the fossilising material, is shown by the great prevalence of the phenomenon and the regularity with which it is observed, if attention is directed to it. It is only in Stigmariae that these internal cylinders are found, or if something analogous is met with here and there in Lepidodendron, it is of rare and exceptional occurrence. The possible reason for this better state of preservation in Stigmariae will be considered further on. In pieces favourably split through, such as are found occasionally in coal-refuse and in particularly good condition in the hard sandstone of the Culm of Burbach near Thann, the surface of the interior cast is seen to be marked with somewhat crowded fusiform areolas, which thrust their extremities in between one another and are separated by a lattice-work of narrow bars. In the specimens from Burbach this network is generally very clearly shown by its dark brown colour. If the remains are preserved in fine grayish black clay-slate, there is then no difference of colour, and the lattice-structure is generally less distinct, though in this case it becomes more apparent if the areolae are somewhat convex and raised above the surface, and the bars look like furrows lying between them. I have myself repeatedly found instructive specimens of this kind at Saarbrücken. There can then be no doubt, as was said above on p. 8 , that this interior cylinder is the cast of the central cylinder surrounded by the ring of wood. The inner surface of the ring of wood necessarily left its impression on the cast, and the markings on the cast correspond with that impression. When the cast was fully formed, the ring of wood entirely or almost entirely disappeared. The outer 
cast which encloses the other has taken the place of the peripheral portions of the axis of the Stigmaria. This mode of explanation, which was suggested long ago by Steinhauer ${ }^{1}$, and has been accepted by all authors, is in agreement with the fact that the interior cylinder is never found in a central position, but lies excentrically almost touching the surface of the surrounding cast on one side, and that when the entire axis is sunk in and pressed flat, the cylinder is always in the middle of the one broad side of it, having reached that position by its own weight. The Stigmaria-casts are very often firmly connected by a narrow strip of substance on onc side to the rock in which they are imbedded, and then they do not fall out of their cylindrical mould. In such cases the cylinder of cortical tissue must have been split longitudinally when the mould was filled, and through this fissure the cast was brought into direct communication with the surrounding matrix ; displacements also were usually produced and longitudinal foldings of the surface, and these serve as characteristic marks. From specimens of this kind, either through the operation of running water or if they were split by pressure, the interior cylinder might obviously slip out on one side, and it is sometimes found free in the rock. This happens occasionally in the Culm of Burbach. I have a specimen of the kind myself twelve centimetres in length, in which the characteristic features of the surface are most distinctly to be seen. Good figures of such casts are given in Williamson ${ }^{2}$ and in Schimper ${ }^{3}$. Further indications of original structure are occasionally observed in the substance of the casts, but we must defer any notice of these till we come to speak of the anatomical structure.

Hooker ${ }^{4}$ described in 1848 two small fragments of Stigmaria from the English Coal-measures, which are distinguished by the particularly sharp preservation of the surface and depart in essential points from the ordinary character. These specimens are not round casts, but irregular fragments with scars on one side only. The scars, which ordinarily lie in slight depressions, here occupy the apex of flat protuberances. In each of these protuberances is sunk a smooth-walled crater-like cavity rather broader below, which penetrates to a depth of six millimetres and resembles the canal of a boring animal. The exterior margin of the orifice is slightly raised and thickened. From the bottom of each pit rises a conical body nearly filling the pit, which narrows a little towards the upper part, and being broken off transversely exactly at the orifice, shows on the surface of fracture a slightly depressed central trace-point. According to Hooker these cones are the basal portions of the appendages, the projecting portion having been broken off above the depression. The different appearance of the ordinary specimens before described is referred by him to the deforma-

\footnotetext{
' Steinhauer (1).

- Hooker (4).

Williamson (6), tt. I3, I4.

s Schimper (1), t. IIg, f. II.
} 
tion caused by pressure, to which the bases of the pits containing the appendages were exposed. All authors, as far as I know, have either silently or expressly accepted this explanation, though the circumstance that such deep holes should have so entirely disappeared, always presented some difficulty, especially in cases where from the perfectly regular cylindrical form of the whole body the pressure, to which the surface must have been exposed, is not quite obvious. That this view is erroneous has been quite recently shown for the first time by Williamson ${ }^{1}$, who has proved his point unanswerably. He has brought together a long series of instructive specimens, some of which have been figured ${ }^{2}$. From these we learn that we are dealing here not with the surface of the cast, but with fragments of a peculiar mould. It will be shown more fully later on that there was a broad tubular cavity present in every appendage. Supposing then that these appendages were destroyed and torn away down to the preserved basal portion in a specimen which was going to be covered up, the latter will have been beset with these basal portions, as with so many open cups; and at the bottom of each of these there must have been a short thread-like process, the remains of the single vascular bundle which has been torn away. Then when the object has been buricd and the substance of these cups has been changed into coal or has entirely disappeared, if cast and mould are separated from one another, every depression will appear on the latter as a flat protuberance, and the wall of every cup as an annular fissure

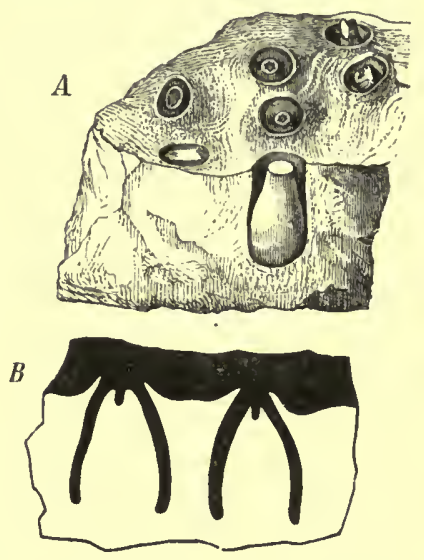

FIG. 31. Stigmaria ficoides in the state of preservation described by Hooker (1). $A$, fragment of Hooker's original figure. $B$, longitudinal section diagrammatically represented; the cast-side is black, the opposite impression is white; the latter answers exactly to Hooker's description. $\rightarrow$ entering deeply into the mould. But the cone in the pit answers to the cast which must be formed in the cavity of the cup, and necessarily comes to an end at the point of insertion of the appendage, which here corresponds to the margin of the orifice of the annular fissure. The remains of the vascular bundle which appears at this spot must leave behind it the central dot-like impression. As has been said, no doubt can ever arise with regard to this explanation. The mould figured by Williamson ${ }^{3}$ should be compared with the diagrammatic representation given here in Fig. 31. Williamson has also obtained analogous results artificially from casts of suitable Stigmariae. On the occasion of my last visit to Manchester I had opportunity through his kindness of examining 
for myself his entire series of specimens, and in the Museum at York I saw another highly instructive specimen, which may be bricfly noticed in this place. On one side of the block of stone is the mould of the axis of a Stigmaria which has been split nearly through the middle, and in it appear the bases of the appendages in the form of round holes. The cavities corresponding to the appendages run like long tubes through the entire piece of stone, showing the original rounded form. In each of these tubes is a cast of compact, crystalline, milkwhite limestone, which does not however touch the wall, and may therefore be shaken to and fro in its bed. Of course only the basal surface of the cast can be seen filling the orifice of the tubcs. On the sides of the block where portions of the stone have been removed, a number of the tubes have been broken off, and the limestone cylinders have fallen out. In this case also the space between the imbedding mass and the cylinder is duc to the disappearance of the cortical substance which originally lay between them.

Therc can be no doubt that the axes of Stigmariae became elongated by apical growth. Unfortunately it is only in comparatively few cascs that it has becn possible to examine their terminations with precision. They occur according to the statements of authors in two different forms. In the one case the casts become slightly and suddenly smaller towards the top and end in a blunt dome-like termination. An example of this is seen in Goldenberg's ${ }^{1}$ Stigmaria rimosa, in which the scars gradually diminish in size as they approach the apex, and in Stigmaria ficoides ${ }^{2}$, figured in the same place as Stigmaria Anabathra, where the size of the scars remains the same throughout; von Röhl's ${ }^{3}$ specimen, though deformed and less valuable, must also be mentioned here, and a similar dome-like termination has been previously described by Steinhauer ${ }^{4}$. The appendages of course are not preserved in all these specimens. In other cases the extremities of the axes are of very much smaller size; Williamson has shown me transverse sections of not more than eight millimetres in diameter, which undoubtedly belong to a Stigmaria, and he has figured a preparation of this kind ${ }^{5}$. I have myself found on the refuse-heap of the Gegenort mine at Dudweiler near Saarbrücken a large and still undescribed block, on which I see the extremities of three Stigmaria-axes lying close together in the mould. They diminish rapidly in size and are at last scarcely five millimetres in breadth. Two of them on the outermost margin of the block, the product of a dichotomy, appear to be united to one another, but I cannot affirm this with perfect certainty on account of the unfavourable direction of the edge of the fracture. But one of them bifurcates a little below the apex, and the two slightly diverging branches reach a length of about three centimetres, one

$$
\begin{aligned}
& { }^{1} \text { Goldenberg (1), t. 12, f. 3. } \\
& \text { Steinhauer (1). }
\end{aligned}
$$


being about twenty millimetres in diameter at the base, the other about fourteen. This specimen is particularly important and interesting, because the appendages appear in tolerably good preservation on both sides of the terminations of its axes. They grow successively smaller and shorter as they approach the terminations, and the distances between them diminish. They also become curved in the forward direction and close together bud-like round the apex. Hence it is only as they develope that they acquire their definitive position at right angles to the axis, resembling in this respect foliage-leaves. At the same time their regular progressive increase in size on both sides of every bifurcation proves that the division is not apparent merely, a mere separation of the parts by crushing, and also that the line of fracture was not essentially oblique. Otherwise there could not possibly be this uniform decrease in size; appendages of equal length to those adjoining them would be found at the very apex. One figure only of a mould of this kind is known to me from the literature, and this is to be found in Göppert ${ }^{1}$, and has been reproduced by him several times. The specimen is diagrammatically represented; the appendages are all developed alike and spring also from the apex, and there is therefore reason to suspect that the line of fracture passed obliquely near the apex, and is therefore of no value. The original specimen must be examined anew, and I do not at present venture to speak decidedly about it. It would in any case be very desirable to obtain fresh specimens, and these will certainly be found without difficulty, if they are searched for, on the refuse-heaps.

Before we proceed to consider the anatomy of Stigmaria, we may say a few words respecting the various forms which have been described in connection with Stigmaria ficoides, Brongn. One of the best characterised of these forms is no doubt Stigmaria stellata ${ }^{2}$, which is known as a cast and also as a mould with appendages of the usual character attached. Each of its superficial scars is surrounded by short flat radiating furrows. This form seems to be particularly abundant in the coal-district of Waldenburg. In other places it is entirely wanting or is of very rare occurrence, as for example in Lancashire, in Scotland, and in Canada. It is mentioned by Dawson ${ }^{3}$ from both the latter countries. Another form to be noticed is Stigmaria conferta ${ }^{4}$, in which the scars are rather close to one another, being separated only by narrow portions of the surface, for which reason the systems of parastichies are very distinctly shown. This form, which may possibly not really belong to the group, is rare like the last, having been found apparently up to the present time.only in the neighbourhood of Radnitz and Svinà in Bohemia. Stigmaria rimosa ${ }^{5}$, named Stigmaria

1 Göppert (1), Lief. I and 2, t. 9, f. 6. and $2, t .10$, f. I2 ; Williamson (6), t. 13 . ${ }^{3}$ Goldenberg (1), t. I 2.
${ }^{2}$ Eichwald (1), vol. i, t. I5, f. 2 ; Göppert (1), Lief. I 3 Dawson (11), p. 69.

* Corda (1), t. 13, f. 9 . 
abbreviata on Goldenberg's plate, comes from Hirschbach near Saarbrücken, and has numerous strong longitudinal furrows on its surface running from one scar to another; the scars themselves lie in small pits, are broader in the transverse direction, and have sharp lateral edges. This species bears some resemblance to Sigillaria, and will have to be mentioned again later on. Besides these marked forms there are some others which depart less widely from the type of Stigmaria ficoides. We will mention here only Stigmaria ficoides var. undulata ${ }^{1}$ and Stigmaria ficoides var. sigillarioides ${ }^{2}$. In the latter the scars are placed in longitudinal rows on vertical flatly-convex ribs, and this gives it the habit of Sigillaria; in the other form they are inclosed within sinuous furrows forming fusiform figures, which are connected together in the longitudinal direction by narrow bridges, and have each of them a central scar.

Numerous axes of Stigmariac with the structure preserved have been obtained from the calcarcous nodules of the English and Rhenish Coalmeasures, from the sphaerosiderites of Coalbrook dale, from the lenticular calcareous stones of the Culm of Falkenberg in Silesia, and from the pebbles of Autun. Similar fossils have also been found at Radnitz in Bohemia. Their anatomy has been discussed by a great variety of authors, and has been illustrated by means of figures. The most cminent works on the subject are those of Lindley and Hutton ", Corda ${ }^{4}$, IBrongniart ${ }^{5}$, Göppert ${ }^{6}$, Hooker ${ }^{7}$, Williamson ${ }^{8}$ : Binney ${ }^{9}$, and Renault ${ }^{10}$. These specimens have usually lost the rind and the appendages, and show only an annular woody body of some thickness. The central portion of this body is almost always a hollow cylinder filled with a mass of stone showing no structure. This is always the case, for example, in the specinnens from Coalbrook dale, which are imbedded in a reddish-brown stone and show only the wood, but in a very good state of preservation; usually also in those from the calcareous nodules, in which the crushed condition and displacement of the parts testify to the soft state proper to the material when the object was being imbedded.

The transverse section shows this ring of wood broken up into a number of wedge-shaped segments, which are broader towards the outside, and are separated from one another by primary rays or gaps passing through the wood. All the wedges come to an end abruptly, as if cut off, on the side towards the central tube, and show a flat bluntly-rounded termination, on which no prominent primary bundle can be perceived. In other respects they have no special peculiarity; they are traversed by numerous parenchymatous secondary rays, and consist of scalariform tracheides, with broad lumira and

1 Göppert (1), Lief. 1 and 2, t. 9, ff. 5-9.

s Lindley and Hutton (1), vol, iii, t. 166.

- Göppert (1), tt. 13, 14. "Hooker (4).

${ }^{10}$ Renault (2), vol. $i$, vol. iii, Introd. and (10).
2 Göppert (1), Parts I and 2, t. 10, f. 13.

- Corda (1), 1t. 13, 14. Brongniart (7).

- Williamson (1), $11, \mathrm{xI}$. Binney (1), 11. 
approximately quadratic transverse section, arranged in regular rows. But just on the innermost margin of the wcdge this regularity is lost, and the elements, which have a much smaller transverse section, are no longer arranged in rows. Here too the secondary rays come to an end, being separated from the inner margin of the wedge by a narrow tissue-layer, as is shown in Williamson's figure ${ }^{1}$. In nany, but by no means in all cases, a peculiar disturbance of a different kind makes its appearance here and there in the wood ${ }^{2}$, much narrower elements in much more numerous radial rows being quite suddenly formed over larger or smaller segments of the circumference. If this occurs on an extended scale and at one time, the appearance may be that of the formation of an annual ring. If on the contrary it is confined within narrower limits, then it looks as if patches of a different character had been introduced into the otherwise uniform ring of wood.

The traces of the appendages, which have their origin on the inner margin of the wedges, traverse the broad rays which separate the wedges, and pass out into the rind ${ }^{3}$. As their course is at first ascending inside the ray, then almost horizontal and curving outwards, the transverse section meets them sometimes in the transverse, sometimes in the longitudinal or even in the. oblique direction.

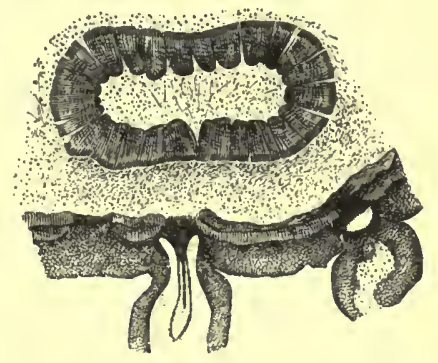

FIG. 32. Stigmaria ficoides, Transverse section of the axis; beneath is the rind bearing the two appendages cut through longitudinally. Above is the ring of wood composed of numerous wedges, After Williamson, reduced.

Where they are cut through transversely, they always appcar as long narrow wedges which are composed of a few rows of tracheides lying near one another and separated by rays. In certain circumstances they might be taken for narrower intercalated segments of the woody ring. Their appearance therefore favours the supposition that they participate in the further growth in thickness of the ring. Very instructive pictures quite confirming this view are afforded by tangential sections, such as those described and figured in Brongniart ${ }^{4}$ and Williamson ${ }^{5}$ (Fig. $33 A, B$ ). Here the rays which separate the wedges appear as broad fissures mucli elongated in the direction of the apex, of moderate depth, and often showing at the margins traces of preserved parenchyma. But from the basal end of every fissure of the kind there springs a broad cone-like process, the elements of which are shown in longitudinal section below, in transverse section at the apex. It is the section through the lowest extremity of the leaf-trace, so far as its course is vertical. And as the same picture is obtained in every tangential section, whether made outside or inside in the wood, it

1 Williamson (6), t. 4.

2 Williamson (6), t. 4; Göppert (1), t. I3, f. 3 1.

t. 29, f. 3 .

- Brongniart (7), t. 29, ff. 6,7 .

5 Williamson $(6), \mathrm{t} .5$.

s Brongniart (7), 
follows that the growth in thickness advances at the same rate in the ring of wood and in the trace, that the secondary elements of the trace at every depth are in direct connection with the corresponding elements of the ring. It is in perfect accord with this that the radial section (Fig. $33 C$ ) shows these large rays as simple intervals ${ }^{1}$, the lower boundary of which is formed

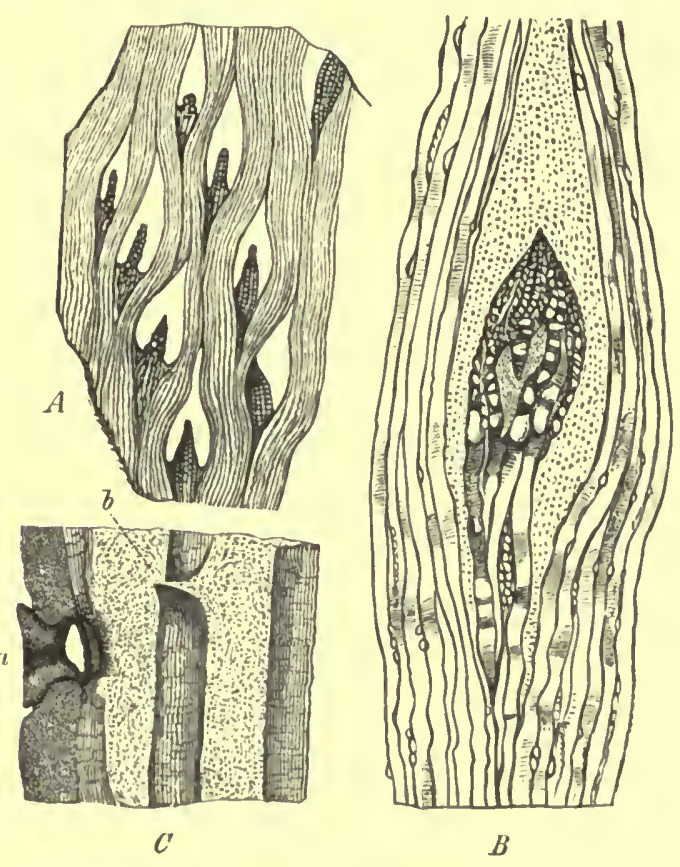

F16. 33. Radial and tangential sections of the ring of wood in the axis of Stigmaria. A tangential section showing the cleft-like primary rays with a strand arising at the lower extremity of each ray, and passing out into an appendage, The apex points upwards. $B$ small piece of the former figure showing the connection of the emerging bundle with the secondary. wood of the axis; beneath are seen the outer tracheides of the bundle in longitudinal section, higher up obliquely cut through, and quite at the top the inner elements of the same in transverse section. $C$ radial longitudinal section of the axis, showing at $a$ the attachment of an appendage to the rind, at $b$ the point of interruption of the secondary wood lying above the emerging bundle and answering to the primary ray. It is evident that the emerging bundle, the continuation of which through the inner rind cannot indeed be seen, shares constantly in the secondary growth in thickness. All after Wil. liamson (6). $A$ and $C$ slightly magnified, $B$ more highly magnified. by the arched convexity of the inner margin of the trace. We see how this extends into the inner margin of the ring of wood; we see further that it is in direct connection by means of its secondary growth towards the outside with all successive layers of this wood. Exactly the same structure is found in quite young apices of Stigmariae, only in a smaller form, as is shown by a transverse section of scarcely I millimetre in diameter, which I saw in Williamson's collection. This author has also published a figure of a similar specimen ${ }^{2}$.

The secondary rays show quite normal customary conditions both on the tangential and on the radial section. In the former they may be short and formed of a single row of cells, sometimes even be reduced to one cell; they mayalso be higher and consist of from two to three rows of cells lying side by side. Their form is that of an ordinary brick placed on its longer edge. Authors differ much in their views of the nature of the tissue which filled the central cavity within the ring of wood during the life of the plant. According to Williamson it was simply delicate thin-walled parenchyma, remains of which are in fact sometimes found in the English Stigmariae

' Williamson (6), t. 6 ; Binney (1), IV, t. 2 I, f. 2 ; Hooker (4), t. 2, f. 13.

${ }^{2}$ Williamson (6), t. 9 . 
lining the wall of the hollow cylinder. Similar remains of parenchyma are also figured by Göppert ${ }^{1}$, but these are according to his account traversed by isolated tracheal strands, which emerge further on through the primary rays and give rise to the traces of the appendages. Though it is not easy. to reconcile this statement with Brongniart's ${ }^{2}$ fine figure, yet it has been adopted by Hooker ${ }^{3}$ and by Binney ${ }^{4}$. That Binney has been deceived in this matter is evident from a glance at his figure. His tracheal strands are only transverse sections of appendages of Stigmaria, which, as so very frequently happens, have found their way through exuberance of growth into the interior of the specimen. Williamson, who has pointed emphatically to this source of error ${ }^{5}$, has already suggested that this same mistake may be at the bottom of Göppert's statements; and by fresh examination of the original specimen, which the kindness of $\mathrm{F}$. Römer placed at my disposal, I have in fact satisfied myself that his view is correct. These statements therefore, on which Renault has relied so much for his conclusions, are not to be trusted.

It appears however that this central tissue was not composed of parenchyma in all Stigmariae, for Renault has found that in his Stigmaria augustodunensis the whole of the space inclosed by the wood was filled with a closed strand consisting of narrow tracheides. He has kindly shown me his preparations, which are all made from the same specimen, the only one which has the central strand preserved. Unfortunately we have received no account of the character of the surface, so that there is still room for doubt whether the specimen belongs to Stigmaria.

The structure here described enables us to understand certain forms of preservation in the cast, which are noticed in the literature. Williamson ${ }^{6}$ gives the transverse sections of an inclosed cast, in which the inner cast is separated from the outer by a broad annular interval, and is connected with it only by thin rods of stone which cross the gap like spokes in a wheel. It is evident that in this case the two casts were formed at the same time. And the ring of wood was also in existence at that time; the mineral matter could only make its way into the primary rays, in which the tissue had disappeared, and take casts of them. The subsequent disappearance of the wood resulted in the formation of the empty space which is crossed by the isolated rods, the casts of the primary rays. Von Röhl ${ }^{7}$ had previously published a similar specimen, and interpreted it quite rightly; but his interior cast is broken away, and only the outer portions of the rods which represent the rays are preserved in situ.

The rind (Fig. 32) which remains to be described, is, as was said above,

' Göppert (1), t. 13, f. 31.

'Williamson (1), II, p. 2 I4.
2 Brongniart (7), t. 29.

${ }^{6}$ Williamson (6), t. 13 .
${ }^{3}$ Hooker (4). ' Binney (4), f. 2. 7 von Röhl (1), t. 24. 
very seldom preserved. Figures giving the details of such cases will be found in Williamson ${ }^{1}$. The inner layer, composed probably of loose parenchyma, is always entirely destroyed and its place occupied by structureless stone. This is usually the case also with the ring of bast, though I have seen tolerably distinct remains of this portion of the rind in a specimen belonging to the collection at Strassburg. The outer rind on the other hand which bears the appendages is, when present, generally well-preserved. It consists of an outer layer of isodiametric thick-walled parenchyma, and an inner tissue composed of radially disposed parenchyma-cells. The former may answer to the primary rind, the latter will be the product of a sccondary zone of meristem on its inner margin. The boundary-line between them is very distinctly marked in longitudinal sections ${ }^{2}$ because of the difference of form in their elements, which in the primary parenchyma are isodiametric, in the inner layer on the contrary are elongated. The entire rind is of course traversed by the traces which pass out into the appendages, and which here too, so far as we know from our present rescarches, show sccondary growth, and consequently maintain unchanged the characteristic form of the isosccles triangle with the acute angle pointing inwards. Of the course of the traces in the inner rind which has disappeared we learn somcthing from single specimens in a peculiar form of prescrvation. There is a magnificent specimen of this kind to be secn in the Museum at Breslau. This is an intcrior cast found in 1884 at the mine named Wildsteiner Segen in Upper Silesia; it is formed of fine-grained slate-clay, and is split exactly in the radiate direction. The outer cast contains a number of very delicate lincar traces preserved in coal, which pass through it in shallow curves with an outward direction, and are partly it is true displaced and irregularly confused together. These are the traces running to the appendages, which resisted decay longer than the surrounding tissuc, and were inclosed in the matter forming the cast: Similar specimens are given in Göppert ${ }^{3}$, and Williamson ${ }^{4}$ figures one of the kind, but it is not so well preserved. On the same table Williamson has given two more figures exemplifying another closely allied state of preservation. One of these is a petrified piece of wood, the other a piece of the outer rind seen from the inside. Both are covered with irregularly curved flattened vermiform cylindrical bodies, the petrified remains of the traces traversing the inner rind, which has otherwise disappeared; the traces are also incrusted by surface-addition of the petrifying material. Exactly the same state preserved in clay-ironstone is described in Lindley and Hutton ${ }^{5}$. as Caulopteris gracilis.

1 Williamson (6), tt. 6,8 , and (1), II. t. 3 I, f. 52 . t. Io, f. I7, and t. II, f. I8. t. 141 .
2 Williamson (6), t. $6 . \quad$ s Göppert (1),

- Williamson (6), t. 12 . 'Sindley and Hutton (1), vol. ii, 
Sections of the appendages in any desired direction are obtained in the greatest abundance by slicing. the calcareous nodules from the coalmeasures. The appendages traverse these nodules on all sides, forming with fragments of fern-leaves much the larger portion of their contents. Here too it is extremely rare to find all the tissues preserved alike. In the following remarks we will first consider the usual state of the specimens. A thin peripheral cylinder of parenchyma surrounds a broad cavity filled with a structureless mass of matter, in which lies a second similar hollow cylinder inclosing the wood-strand. The broad tube of the outer cylinder, which is generally circular on the transverse section, is often squeezed together, or even bent and folded in a great variety of ways, especially when the appendages lie several of them close together or have had to force themselves through narrow orifices. The inner cylinder often lies free in the centre of the cavity of the outer, or it may be connected with its wall by means of a bridge-like plate of parenchyma which has been preserved ${ }^{1}$. In other cases again it is quite excentric and rests against the wall of the outer cylinder, having evidently subsided into this position after the destruction of the surrounding tissue. The inner cylinder too is by no means entirely filled by the wood-strand, which touches it only at one point. The two are separated everywhere else by a nearly circular intervening space, which, moderate in its dimensions, is broadest exactly opposite the point of contact and decreases from this point in both directions. It has been already stated on p. 264 that the appendages sometimes branch dichotomously. I have seen in Williamson's collection several sections passing exactly through the place of bifurcation. Then the xylem-strand separates by median division into two lateral halves, which at first lie side by side in the expanded ovoid inner cylinder but afterwards move further apart, while a bridge of parenchyma makes its appearance between them and divides the space into two distinct compartments. Sections ${ }^{2}$ a little higher up show the two compartments moved away from one another, and developed into separate inner cylinders, which in many cases are still connected by traces of parenchyma, such as might easily have been preserved in the narrow intervening space.

Williamson ${ }^{3}$ has given a figure of an appendage of the normal kind, but with all its tissues preserved. Here the space between the outer and inner cylinder is filled with a layer of thin-walled tissue with its boundaries on both sides sharply defined. The transverse section ${ }^{4}$ also is of quite similar characters; only its outer cylinder is unusually large and shows two distinct cell-layers, the inner one of which is remarkable for the thickness

1 Williamson (6), t. 13 and (1), xI, t. 53, f. 16 .

${ }^{2}$ Williamson $(6)$, t. II. 3.Williamson $(1), x i, t .53$, f. 15 .

*Williamson (6), t. 9 . 
of all the cell-ivalls. In Hooker's ${ }^{1}$ figure no such differentiation of the layers is apparent; the wood-strand here lies excentrically inside a perfectly uniform mass of tissue. Whether all these variations point to specific distinctions between the specimens which have been examined cannot unfortunately be at present determined.

The character and outline of the central wood-strand are not found to be exactly the same in all transverse sections. A careful consideration of the differences which here present themselves is the more necessary, because

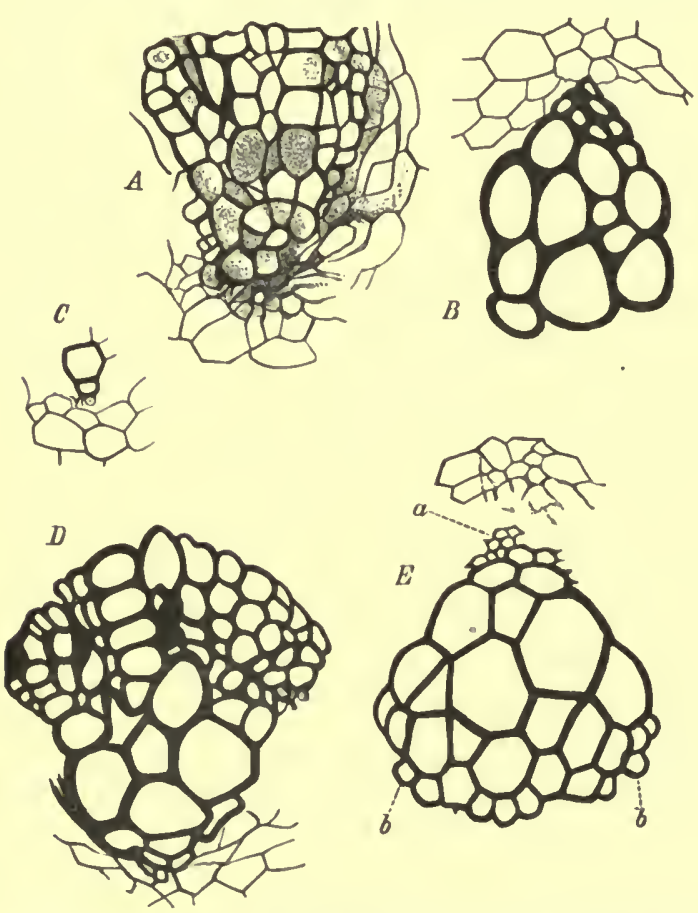

Fig. 34. Stigmaria. Transverse sections of the wood-bundles of the appendages. $I$ collateral bundle with secondary increase of the kind first described. $B, C, D$ bundles of the forms of the second category. $B$ of the ordinary normal kind, $C$ much reduced, $D$ with secondary increase. $E$ lundle of the third kind considered by Renault to be a triarch root-strand. At $a$ the evident initial strand, about which there can be no question, at $b$ the places which Renault inclines to regard also as initial strands. All after Williamson (6) and (1), xt.
Renault in reliance upon them has arrived at some important conclusions, to which we shall have to recur more than once in the succeeding pages. The cases to be distinguished are chiefly three. First of all, there are the appendages in which the transverse section of the bundle showing secondary increase has the corresponding form of an isosceles triangle (Fig. $34 A$ ), such as we have beforc observed in the tracebundles in the wood and rind; only the mass of the normal wood traversed by fascicular rays is smaller, the angle at the point of the triangle is less acute. That the bast-zone, when preserved, is to be found at its base, I have satisfied myself from a preparation in the Botanical Department of the British Museum. Renault ${ }^{2}$ has figured a transverse scction of this kind with remains of bast; figures showing the ordinary condition will be found in Williamson ${ }^{3}$ and Renault ${ }^{4}$.

Secondly, there are appendages of a different habit (Fig. $34 B, C, D$ ), figured by Williamson ${ }^{5}$ on the same tables as the preceding, in which the wood-strand is composed of an ovate group of tracheides wide on trans-

\footnotetext{
'Hooker (4), t. 2, f. 2. $\quad 2$ Renault (10), t. I, f. 4.

4 Renault (2), vol. i, t. 20 , ff. I, 8 , and vol. iii, t. A, ff. 1, 3, 5,7 .

Williamson (6), tt. 9, ir. s Williamson (6).
} 
verse section, and this group is succeeded on the side where it adjoins the inner cortical cylinder by a number of smaller ones with narrow lumina, which form a projecting point. It is highly probable, as Williamson suggests, that this point is the initial group of the bundle. Sometimes a few other isolated broader elements are also found on its other side $^{1}$, which may be explained with Renault to be an indication of an inner woodportion, a 'bois centripète.' The size of the transverse section of bundles of this type varies extremely, the bundle being often reduced to a few or even to a single one of the broad elements (Fig. $34 \mathrm{C}$ ), and the the initial group suffers corresponding diminution in size, though it never entirely disappears. That the bundles in this, as in the preceding case, are collateral and capable of secondary growth is evident at once from the inspection of a transverse section figured by Williamson ${ }^{2}$, which shows an unmistakable bundle of Stigmaria (Fig. $34 D$ ); but joining on to it on the side opposite to the initial group is a well-developed layer of secondary wood with comparatively narrow elements disposed in regular rows. The bundles of the category which we are here considering are often found in very thin and small appendages; but it is hardly possible to lay down a rule on this point, for they occur on the other hand in the very broadest, so that apart from the internal structure we cannot very well unite them as states of development with those of the first-mentioned type.

A third class again is composed of bundles, which resembling those of the second class in general habit are distinguished from them by the less regular form of the transverse section, which is triangular with the angles rounded off (Fig. $34 E$ ). But the angle $(a)$ which abuts on the inner cylinder is always more prominent than the other two $(b, b)$, and in these also we find elements with a smaller transverse section, but varying in number and arrangement, and sometimes combining to foum a narrow band which bounds one side of the bundle. Bundles of this kind have been figured by Williamson ${ }^{3}$ especially, and next to him by Renault ${ }^{4}$, who considers the three angles to be alike and to be initial strands, and therefore conceives of the entire bundles as triarch root-strands, a view against which Williamson everywhere protests most vigorously. In fact the essential difference between the three angles, one of which only shows indubitable signs of its initial character, and also the excentric position of the strand which never touches the inner cylinder with more than this one angle, must necessarily give rise to very grave doubts. It has already been frequently pointed out, that it is very dangerous to determine the position of the initial strands so directly from the diminution in size of the tracheides. And in this case it is quite possible to take an entirely different view of the matter

1 Williamson (6), t. II, f. 59 .

2 Williamson (6), t. II, f.. $6 \mathrm{I}$.

3 Williamson (6).

4 Renault (2), vol. i, t. 30, ff. 2, 3, 4, and vol. iii, t. A, ff. I, 2, 4, and (10), tt. I, 2, 
by assuming with Williamson that the collateral bundle has developed a few smaller elements on its outer margin, and that these were not disposed in any regular order, but were often crowded together at the angles. We may even be able to see in them the first beginning of the secondary growth, which, as has been before remarked, is certainly present in some cases in bundles of the second type. And this view even appears to me to be much simpler and more probable than that which Renault has developed. But this author has produced other arguments in support of his opinion. $\mathrm{He}$ has figured the tangential section through the rind of an axis found near

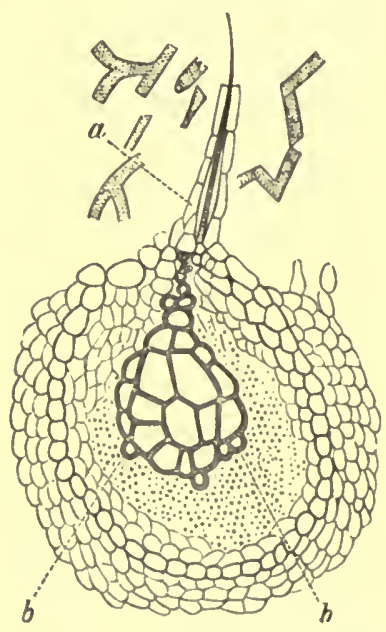

Fic. 35. Reproduction of Renault's principal preparation proving that the appendages of Stigmaria of the third category are of the nature of roots. At $a$ the place where the lateral root is given off which is supposed to be furnished with a central tracheide, At $b$ the places where Renault thinks that he sees the two other initial strands of his triarch root-bundles.

Autun ', and this contains two transverse sections of traces, one of which is a collateral, the other a triarch stellate bundle. The two are in fact very different from one another. The stellate bundle, which is much macerated, is cut through rather obliquely but shows tracheides with round pits, such as never occur in genuine Stigmariae. The collateral bundle also shows important differences, so that it is more than doubtful whether the specimen belongs to Stigmariae. Yet Renault ${ }^{2}$ says himself: 'It is possible that this Stigmaria may be the rhizome of Sigillariopsis Decaisnei, which slows in the structure of the wood of the stem a combination of radiate, reticulate and dotted tracheides.' It is obvious that the specimen cannot in these circumstances prove anything in connection with the characters of Stigmariae. Renault next maintains that in examining material from England, which doubtless belongs to Stigmariae, he has found appendages with a triarch wood-strand, from the angles of which proceed delicate vascular bundles destined for lateral roots, and he has more than once reproduced the preparation which is intended to prove this view ${ }^{3}$ (Fig. 35). The specimen shows a wood-strand which in form comes very near to the second type; but it is only the angle touching the inner cylinder which has the appearance of an initial strand, while this would be a forced interpretation of the other two. The supposed lateral root-bundle connects with the angle which is evidently an initial angle, and the longitudinal view of it shows a single tracheide; but the nature of this bundle is very doubtful. I was unable to recognise the

1 Renault (10), t. 3, ff. $2, \cdot 3,7$.

2 Renault (10), p. 35 .

Renault (2), vol. i, t. 20 ,

f. I, and vol. iii, t. A, f. 4 bis, and (10), t. 2, f. 8 . 
tracheide as such with any certainty in the preparation which Renault most kindly demonstrated to me; and he told me indeed that it could once be more plainly seen. But apart from this I am chicfly impressed by the fact that neither I nor any one else have been able to find anything of the kind before or since in material from England, which has been examined over and over again. And yet according to Renault these lateral roots occur frequently all round the appendages; he says distinctly" ${ }^{1}$ ' It seldom happens that a transverse section through any part of a radicular appendage does not disclose indications of the first beginning of a rootlet at one of the three angles of the primary wood.' Unfortunately he gives us no more precise information about these 'indications.' From these doubtful statements he proceeds to the conclusion that the surface of these appendages must show three vertical longitudinal rows of 'cicatricules.' That the presence of these scars has never been ascertained by direct observation, he attributes to their minuteness (they are supposed to be only from one to two-tenths of a millimetre in thickness), and to the insufficient state of preservation of the specimens.

Lastly, the point of insertion of the appendages on the axis in Stigmariae shows some further anatomical peculiarities (Fig. $3^{6}$ ), and it is Williamson again who has directed his attention especially to this subject ${ }^{2}$. The vacant space which separates the outer and the inner cylinder from one another comes to an end quite suddenly exactly at the point of attachment. It is cut off by a transverse

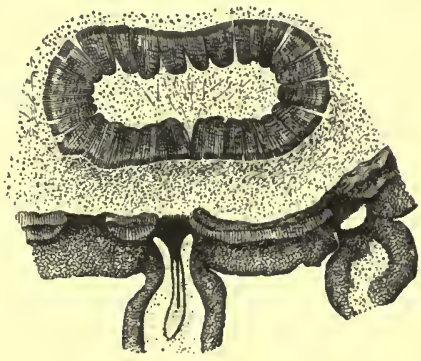

F1G. 36. Stigmaria ficoides. Transverse section of the axis; beneath is the rind bearing the two appendages cut through longitudinally, above is the ring of wood composed of numerous wedges. After Williamson (6), less than the natural size. diaphragm formed of stout tissue, and represents the portion of the outer rind of the axis beneath the appendage. The diaphragm is traversed by the trace-bundle, which, as it emerges to enter the appendage, is still surrounded for a short distance by a sheath of the stout parenchyma which ultimately comes to an end in the inner cylinder. Horizontal sections of the diaphragm-plate are seldom obtained; the only one which I find in my preparations agrees perfectly with the one which Williamson has figured ${ }^{3}$. Within the stout plate of parenchyma is a weak bundle-trace, which certainly belongs to the type of the second class described above. In these specimens therefore the secondary growth in the traces must have ceased while they were passing through the rind, if there was any growth of the kind,-a point which in the absence of transverse sections of these specimens cannot be certainly proved. Analogy with the 
many other transverse sections which have been studied is the only probable argument which can be advanced. But since we find great numbers of detached appendages which inclose a bundle endowed with secondary growth, there remains only one of two alternatives; either growth in thickness reappeared in these appendages, or the trace in them passed through the basal diaphragm in another form than that of the specimen hitherto studied, namely, with retention of the secondary wood. Should the latter be the right conclusion, we should then be obliged to assume that there were distinct species of Stigmaria differing from one another in this respect. Renault indeed states that he has seen very different forms of trace at the same time on one and the same axis, but his arguments in proof of this, which we must notice again presently, are not to my mind conclusive. Nor can the facts as here given be reconciled without forced interpretations with Williamson's ${ }^{1}$ view, who sees in the different trace-types only the pictures of different portions of one and the same organ of the same plant. These are just the questions in which the anatomy of the parts is not a decisive guide in any direction. There are no successive sections, as far as I know, of appendages still attached to manifest axes of Stigmaria; but these alone can clear up the questions which we have been considering.

Many very different accounts have been given in the course of time both of the position of Stigmariae in the system and of their morphological differentiation. Opinion has been more divided on these points than in the case of any other fossil vegetable remains, and no full and certain determination of them has been obtained up to this day in spite of the almost overwhelming litcrature. In proceeding to review the efforts which have been made to effect this purpose, we may very well avoid any lengthy consideration of the comparisons proposed by earlier authors with Opuntiae, Cacaliac, Ficoideac, Stapeliae, Aroideae, and even with Palms. A summary notice of them will be found in Göppert ${ }^{2}$.

The first person who suggested, though on weak grounds, a close connection of our remains with Lycopodinae, and especially with Isoëtes, was Brongniart ${ }^{3}$. His idea, which did not at first meet with much approval, won its way in time to recognition when better arguments could be adduced in its support, and may now be said to be very generally accepted. The first distinct, and for some time the standard, account of the structure of these plants was communicated by Lindley and Hutton ${ }^{4}$, and was founded on the branched specimen discovered in the roof of the Bensham seam in Jarrow mine, and figured by them. This specimen, which being fixed in the roof can be seen only from below, shows twelve well-preserved in some cases dichotomously divided Stigmaria-branches, which even have the

1 Williamson (5), p. $35^{\circ}$.

* Lindley and Hutton (1), vol. i, t. 3 I.

${ }^{2}$ Göppert (20), also (1) and (3).

${ }^{3}$ Brongniart (4), p. 82. 
appendages still attached and spreading obliquely like rays from a central mass. The ideal longitudinal section appended by the authors gives therefore the outline of a cupola or dome to the entire branch-system. Their conclusions from these facts, with the aid of the knowledge which had been previously gained, are as follows : I. That Stigmaria was a land-plant of low growth, whose branches spread regularly from the common centre, and at length branched dichotomously. They are not certain whether the 'domed centre' is a generic character or not; they think it possible that the plant grew on a small hillock, from which its branches spread downwards in every direction. 2. That it was a succulent Dicotyledon. This is concluded from Steinhauer's previously mentioned observations on the central cylinder. 3. That the roundish scars on the surface are the places where the leaves have separated from the stem. It is cautiously concluded from their regular quincuncial disposition all round the stem that they could not properly have been roots. 4. That these leaves were cylindrical and fleshy. The authors rightly attach little value to comparisons with certain groups of Dicotyledons, for 'it must be confessed that this is but a rude kind of analogy ${ }^{1}$ ' Fourteen other similar specimens were soon after discovered in the same mine, some of which were removed from it. These too were discussed by Lindley and Hutton in the Introduction to the second volume of their work ${ }^{2}$. One of the specimens removed from the mine, showing the upper side, is figured in the same work ${ }^{3}$. From the fact that the appendages spread at right angles in every direction and lie across the bedding, it is concluded that the plants grew 'in the soft mud most likely of still and shallow water.' These views, which accorded well with the state of knowledge at the time, were generally accepted not in England only but also on the Continent, where they found warm supporters especially in Corda ${ }^{4}$ and Sternberg ${ }^{5}$, and in Göppert ${ }^{6}$ also, though the latter, doubtful about their affinity with Dicotyledons, preferred to regard them as 'cryptogamous Monocotyledons,' or as intermediate forms connecting Lycopodiae with Cycadeae.

An entirely new impulse was given to the question in the years 1845 and 1846 by Binney's ${ }^{7}$ discovery of erect stumps of Sigillaria-stems, each of which terminated below in four root-branches with the character of Stigmariae. The three first specimens were discovered as early as 1843 at St. Helen's near Manchester. When they came to be examined, they had already suffered great damage through exposure, and if there can be no doubt of their being Sigillariae, yet their Stigmaria-roots were not too convincing, especially in the figure. But the stump with roots discovered

1 Lindley and Hutton (1), vol. i, p. 109. ${ }^{3}$ Lindley and Hutton (1), vol, ii, p. I 3 : 5-8, and Supplement.
- Göppert (1).
${ }^{2}$ Lindley and Hutton (1), vol. ii, p. I2.

4 Corda (1). $\quad{ }^{3}$ Sternberg, Graf von (1), Heft 7 Binney (5) and (6). 
in the Victoria mine at Dukinfield near Manchester ${ }^{1}$ at once removed the doubts which still existed. It was found in the floor of the cannel-seam, whence it was got out and carried to the Manchester Museum, of which it is at present one of the chief ornaments. The branches of the roots, some of which may be followed to their extremities, ran, bifurcating here and there, in the underclay of the seam, and proved to be indubitable Stigmariae. The stump of the stem, measuring fifteen inches in height and four feet in circumference, shows plainly the characters of a Syringodendron. I have been able to satisfy mysclf on all these points by personal examination. When Binney on the strength of those observations gave it as his decided opinion that Stigmariae are the root-stocks of Sigillariae, he was met by the expression of grcat doubts on the part of many Continental observers, though Brongniart ${ }^{2}$ at once and Göppert ${ }^{3}$ at a later time took the part of the English botanist. The objections which were raised against this connection of Stigmaria with Sigillariae are for the most part not difficult to meet. They cannot taken all together hold their own against the long series of stems, which have since that time been found in actual union with Stigmaria-roots. For if Goldenberg ${ }^{4}$ is of opinion that the dome-shaped central stock in Lindley and Hutton's specimens shows no surface of fracture, and cannot therefore be a mutilated form, the answer is that this surface may very well have disappeared or become obscured by latcral pressure and the formation of slickensides. The same author says further on: 'As regards the observation of Binney and Hooker cited above, on which so great weight has bcen laid, I am willing to believe that these gentlemen observed scars very like the scars of Stigmariae on roots which were still attached to stems of Sigillariae. Such scars are to be found on all fossil plants, in which the branches of the root had root-fibres of the thickness of a quill,' \&c. If Goldenberg had seen the specimens at Manchester he would not have written thus, for they are so characteristic that every doubt disappears. We cannot of course enter upon the question of the supposed fructifications mentioned on p. 265, which Goldenberg discovered and has appealed to as an argument against Binney's view, so long as their real nature is not better ascertained. Another determined and formidable opponent appeared in 1870 in the person of Unger. He says ${ }^{5}$ : 'To suppose Stigmaria to be the root of Sigillariae, to which it is said to have been found attached, is in a word a morphological impossibility, apart from the fact that the former presents all the characters of an independent plant.' $\mathrm{He}$ is careful indeed not to say what characters he means. He rests his judgment on the appendages, which he says have not the morphological characters of lateral roots. This must be adnitted.

1 Binney (6). Heft III, p. 9 .
2 Brongniart (2).

${ }^{5}$ Unger (10).
3 Göppert (3).

- Goldenberg (1), 
But it must be remembered that subterranean organs may also be rhizomes, and in that case the objection falls to the ground. Brongniart ${ }^{1}$, who had similar difficulties, was much more cautious. But when Unger goes on to maintain that it is impossible to reconcile the anatomy of Stigmaria with that of Sigillaria he raises an objection which deserves all attention and requires to be properly examined. In comparing the two together, we encounter really two important points of difference. First there is the growth in thickness of the trace-bundles of Stigmaria, and we find nothing that resembles growth of this kind in Sigillaria; but the more important point is that in Sigillaria, as we have seen, there is no layer of primary wood (bois centripète) differentiated into irregular bundles in the periphery of the pith, such as we observed in Stigmaria on the inner side of the secondary growth. We are therefore obliged to assume that the central cylinder in Stigmaria was purely parenchymatous, with a network only in its periphery of weak, probably normally disposed, tracheal strands, with which the growth in thickness connects at once and immediately, as in the stem of Botrychium. This would explain the fact, that we find it impossible or difficult to distinguish the wedges of wood from the primary strands, that the structure of the youngest extremities is essentially the same as that of the older parts. In Stigmaria augustodunensis, though its connection with the group is not perfectly assured (see p. 273), the entire central strand, which is parenchymatous in Stigmaria ficoides, is composed of tracheides. How the one form of structure passed into the other at the base of the upright stem we cannot tell, nor is it likely that we shall ever find this portion of the plant with the structure preserved. But the difficulties in this case are certainly much less important than those which would arise in reconciling the structure of stem and root in our living plants, if we had only unconnected fragments of them before us.

A number of stems with Stigmaria-roots attached were described in the years 1846,1848 , and 1849 by Richard Brown ${ }^{2}$, from the Carboniferous formation of the island of Cape Breton in Nova Scotia. In none of them could there be any doubt with regard to the nature of the diverging rootsystem. The stems, it is true, which were described in Brown's first publication, could not be certainly determined; but those of the third work were shown to be genuine Sigillariae (Fig. 37 C). Those of the year I 848 were described by Brown as Lepidodendrae; but judging by the figures I can only see the impression of Dictyoxylon-structure, and as this occurs also in the rind of Sigillaria, Lyginodendron, Heterangium, and other forms, its presence cannot well be employed to prove that Lepidodendrae also had Stigmaria-roots. If the view expressed by Rich. Brown 
nevertheless met with a favourable reception, it was only because there appeared to be other reasons compelling its adoption; Geinitz ${ }^{1}$, for example, and Schimper ${ }^{2}$ after him had insisted on the extraordinary abundance of Stigmaria ficoides in the sandstones of the Culm, in which there are no Sigillariae but great numbers of Lepidodendrae and Knorriae. This is the case at Burbach near Thann, and also near Hainichen and Ebersdorf in Saxony, and in the anthracites of the Roannais ${ }^{3}$; and Gcinitz ${ }^{4}$ expressly states that the roots of Lepidodendron rimosum, which he examined in the mines at Niedercainsdorf in Saxony, showed quite the characters of Stigmariae. The views of all these authors have been confirmed by the discovery of a stem from the quarries at Burbach, which is now in the Museum at Colmar. Schimper ${ }^{5}$ says that this stem has the characters of Knorria longifolia above, lower down those of Didymophyllum Schottini and Ancistrophyllum, and that an indubitable Stigmaria with one bifurcation is attached laterally to its base. When I saw the specimen, some years ago it is true, it scemed to me also quite convincing.

Hitherto we have been exclusively occupied with the question of the kind of stems which ended below in Stigmariac; it remains to describe the form of the bases of these stems, and of this we have very accurate knowledge from the number of specimens which have been met with in recent times. The most important fact to notice is that a tap-root has never in any case been found as the direct prolongation of the stem, but that the latter ends abruptly, and only gives rise to lateral branches which run in a horizontal direction and soon assume the character of Stigmariae. These diverging main branches are always four in number, and being connected together like the arms of a cross, they inclose the somewhat depressed lower surface of the base of the stem. So much had been already observed by Lindley and Hutton in their stems. The central depression may be seen, when the preservation is good, to be traversed by four furrows which meet in the central point, and are the boundaries of the areas of origin of the four Stigmariae. As good examples of this regular division into four, which it seems natural to refer to rapidly repeated dichotomy, may be mentioned Richard Brown's ${ }^{6}$ specimens which were noticed on the previous page, the stumps from Bradford described by Binney ${ }^{7}$ and preserved in the Museum at Leeds, Göppert's ${ }^{8}$ specimens from Schatzlar, and Williamson's ${ }^{9}$ extremely beautiful new figures (Fig. $37 \mathrm{~B}$ ). If Temme's ${ }^{10}$ stem from Piesberg is represented with six roots, this is no doubt because two of its four original branches have each formed a new bifurcation at once and without

\footnotetext{
1 Geinitz (5) and (8).

${ }^{2}$ Schimper (4).

${ }^{3}$ Grand' Eury (1), p. 4 II. 4 Geinitz (5), p. 36. 'Schimper (1), vol. ii, Part I, p. $117 . \quad{ }^{6}$ Brown, Rich. (1) and (2). ${ }^{7}$ Binney (7), ff. 5, 6. $\quad$ Göppert (14), p. 79, t. 15 and (3), t. 36, ff. 1, 2 ; Römer, F. (1), p. 232. Williamson (6), tt. 2, 3 . 10 Temme (1).
} 
any considerable previous elongation. And the like may certainly be assumed in the case of all specimens in which numerous lateral branches spring immediately from the base of the stem, and among them of Binney's and Harkness' ${ }^{1}$ stems from St. Helen's, of Rich. Brown's ${ }^{2}$ of the year I 849 from Cape Breton, of the stem in the Museum at Bonn from the Holzhauerthal near Saarbrücken described by Göppert ${ }^{3}$, and of the stem quite recently found near Bradford ${ }^{4}$ (Fig. $37 A$ ), for a photograph of which taken on the spot I am indebted to the kindness of Mr. Cash. The repeated dichotomy is most clearly seen in the two last specimens and in one of

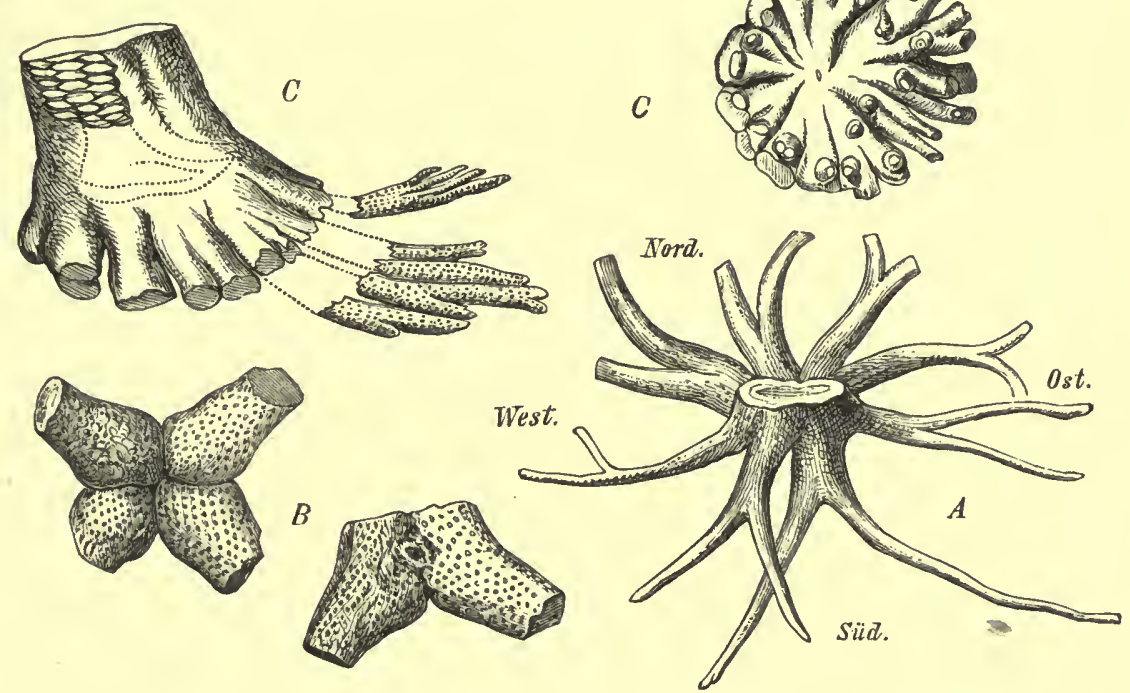

Ftg. 37. Stumps of stems of Sigillaria with Stigmariae attached. $A$ the stump lately found near Bradford; its breadth from north to south is $29 \frac{1}{2}$ English feet, from east to west 29 English feet. $B$ stump of a stem with four diverging roots forming a cross, and showing the character of Stigmariae, seen from the side and from below. $C$ stump of stem of Sigillaria with many Stigmariae repeatedly and dichotomously branched and preserved up to their extremities, seen from the side and from below, and showing in the latter view the conical processes (tap-roots) mentioned in the text, which are placed at the base of each bifurcation and go vertically downwards. At one spot in this stem there is an appearance of something like Dictyoxylon-structure. $A$ after a pencil sketch by Williamson. $B$ after Williamson (6). C after R. Brown (3).

Brown's, and was duly noticed in the description of the Bonn stem given by Weber and printed by Göppert ${ }^{5}$.

A special peculiarity is observed in one of Brown's ${ }^{6}$ stumps (Fig. 37 C). On the under side of its Stigmariae are blunt conical processes directed vertically downwards, and with their surface covered with transverse wrinkles of apparently accidental origin. The discoverer notices particularly that they are arranged in two circles, the inner containing sixteen processes, the outer thirty-two. The figure it is true does not point to these numerical relations, but it shows that each process, a 'tap-root' according to Brown,

1 Binney and Harkness (5).

4 Williamson (6), t. I5. $_{5}$.
2 Brown, Rich. (3).

5 Göppert (20).
3 Göppert (20), t. 12 and (3), t. 37, f. 2.

6 Brown, Rich. (3). 
is developed at the base of a dichotomy, as the roots are developed beneath the place where the stem branches in Selaginella. From this we may at least conclude that these conical bodies are not objects of casual occurrence, but that they stand in some distinct though not yet determinable relation to the structure of the stem.

If now from all the circumstances which have been discussed there can no longer be any doubt that Stigmariae are simply members of stems of Sigillarieac and Lepidodendreae which performed the functions of roots, and that they must be removed from the system as a distinct group of plants, yet a few further facts connected with the positions in which they are found may be brought forward in confirmation of this view. It has long been known that in Westphalia, in England, in Canada and elsewhere, the floor of the coal-seams is usually formed of beds of clay of varying thickness, which are traversed by countless Stigmariae. These beds are called in England Stigmarian underclays. These Stigmarias appear in gencral to have no connection with the seam of coal, but Grand' Eury ${ }^{1}$ tells us that he has observed a direct transition of the kind at Dombrowa in the coal-field of Poland and Upper Silesia. That the plants must have grown in the substance of these beds of clay is shown by the arrangement of their appendages already noticed by Lindley and Hutton ${ }^{2}$; when the appendages spread on all sides at right angles to the axis they lie parallel with the bedding, but when they are directed upwards or downwards they are at right angles to it. Consequently, if they grew so luxuriantly in the mud of the Carboniferous swamps on the surface of which the formation of coal began, they cannot well have been organs of assimilation, but must have been adapted rather to take up material from the substratum. They are distributed in like manner through the roof of the seams, but are not so abundant there, and they seldom reach the level of the coal itself but are separated from it by a layer, though often only a thin layer, of the clay. This is intelligible, if we consider that a certain time must have elapsed before a fresh vegetation of Stigmariac could commence on the mud which covered the Carboniferous swamp, and which was deposited through the irruption of streams of water from other quarters. As they were safe in their mud from being floated away by running water, it was easier for the cylindrical axes when once formed to remain in their natural position, and therefore it is that they are found so abundantly in the case of Stigmariae, while those of the stems both of Sigillarieae and Lepidodendreae are of rare occurrence (see on p. 265).

Further, the study of the seams themselves and of the calcareous nodules sometimes present in them gives occasion to similar considerations. 
An abundance of the appendages is to be found in "every section of the nodules, even where they contain no axes of Stigmariae. These appendages in the exuberance of their growth have penetrated in every direction through the heap of vegetable fragments which forms the chief mass of the nodules, and they make their way into every crevice and into every bit of softened wood. The hollow medullary cylinders of stems of all kinds are found traversed by them lengthwise; and often by whole bundles of them. Some appendages may inclose a number of others with a narrower lumen (Fig. $3^{8}$ ). We saw on p. 273 how in this case they may give rise to mistakes. But all these things prove that they grew luxuriantly in this organic soil, and that they did not merely sink down in it at some later period. As the roots of trees develope abundantly at the present day in the rotten wood of the primeval forests in every zone, and spread abroad in it copiously in every direction, so did the Stigmariae also in the Carboniferous period. They are also frequently preserved in the coal of the seams, but then they are always flattened in the planes of stratification; many instances of this kind will be found in Grand' Eury'. The flattening took place therefore after the formation of the calcareous nodules in the masses that were laid in their final resting-place, and while these were in the act of subsiding. Stigmariae must accordingly have been continually present during the formation of the seams, and on the spots where they were being formed. And, to sum up briefly what has been said, if the Stigmariae were adapted to grow at one time in

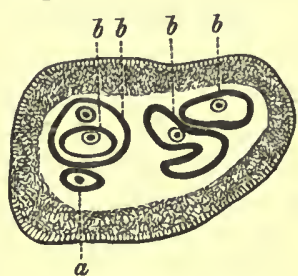

Fig. 38. Transverse section of the appendage of a Stig. maria, in the cavity of which are other appendages which have made their way in from the outside; $a$ internal cylinder and bundle of the inclos. ing appendage; $b$ the other appendages inside it, one of which shows yet another which has forced way into it. After Renault (10). the inorganic slime of the later underclays, presumably at the bottom of the water, and at another time in the organic mass of the seam itself, in the latter case perhaps forming part of the matted growth covering the surface of the water in the coal-swamps, it is plain that they must have possessed a developed faculty of adaptation to external circumstances of very different kinds.

With this result the physiologist may rest content; morphology must institute some further enquiries into the character of the separate members of the stock in Stigmariae. Here again opinions are widely divided. Brongniart ${ }^{2}$ himself had remarked that some of their characters do not quite agree with those of recent roots, and though he does not think that this is a matter of much importance, still he says: 'The only fact which is opposed to this view is that the rootlets. are not disposed in limited longitudinal rows, but in quincunces.' Then . Schimper ${ }^{3}$ insisted 
more strongly on this point, and made use of it, in conjunction with fresh arguments, as the foundation of another view, namely, that the axes were rhizomes and their appendages leaves. In this case the Sigillaricae and Lepidodendreae must, as he argues, be compared with the rootless stock of Psilotum, though the leaves, which are present in Stigmaria, are quite wanting on the rhizome-shoots of the other plant. This view is very vigorously opposed by Williamson ${ }^{1}$. Putting aside the occasional bifurcations and the puzzling scars in the angles, he appeals more particularly to the anatomical structure, which he finds to be almost identical with that of the rhizophores of Selaginella Martensii. The two organisms are certainly like one another in appearance, and this might be expected, since we have to do in the one case with the rare monarch radial strand, in the other with a collateral bundle. It is only from the position of the bast or cambium that the difference between them can be determined. However, the resemblance does not go so far as might be imagined from Williamson's ${ }^{2}$ figure of the transverse section of Selaginella, which is correctly drawn indecd, but wrongly explained. The large cells opposite the initial group, which Williamson supposes to be the bast, are really parts of the wood-strand, tracheides in the young state; the real bast is to be sought in the small-celled peripheral zone marked $C$. The bundle in this case is late in reaching its ultimate development, and hence the mistake, which is easy to understand. But it cannot be denied that Schimper's idea cntirely gets rid of most of the difficulties. There is first the fact that the dichotomously branched axes develope their appendages in progressive succession. On the supposition of a branch-system consisting of similar members (roots and lateral roots), this would imply a different structure and origin for the members of the same generation. And this would certainly be remarkable and without direct analogy in living vegetation, even supposing the distinction between progressive and dichotomous branching to have lost its importance to the same extent as at the present day. But if we consider the Stigmariae to be leafy rhizomes, everything is as it should be. It has been repeatedly observed before that the position of the appendages does not agree with that of lateral roots, but that it does agree very well with that of the leaves; that they leave scars behind them of a definite shape when they drop off, which never or at least only very rarely happens with roots, is a point which Schimper regards as most important. The specimen in my possession and described above on p. 268 , which has the vegetative points, may also really favour Schimper's view; for there the young appendages approach nearer to the apex than is ever the case with roots on account of the root-cap, for which there is too little room left. There is, 
moreover, the distinct formation of buds, the hyponasty and epinasty of which would also be something quite unheard of in the case of roots; and it may be remarked by the way that this formation of buds proves to my mind that the Stigmariae were exclusively adapted to a soft pulpy environment, for this would be unsuitable and almost impossible in solid ground.

The latest elaborate examination of the question which we are considering has come from the pen of Renault? He, too, takes Schimper's view, and regards the greater number of Stigmariae at least-the exceptions will be noticed presently-as rhizomes. He differs from him to the extent of distinguishing the appendages into two classes, one of leaves, the other of adventitious roots. This distinction he rests entirely on the differences in anatomical structure described above on p. 276. I have, however, already shown that these differences may very well be interpreted in a different manner. There are absolutely no external characters present, which could serve for this distinction into leaves and fibrous roots; and when Renault ${ }^{2}$ says: 'In the cortical region the number of bundles belonging to roots becomes greater because the roots are to a great extent of later formation than the cylinder of wood ; their late appearance gives rise to supernumerary spirals, or to scars irregularly distributed on the surface of certain specimens,' it appears to me that this short sentence, which has no particular prominence in the text and really contains two unproved assertions, is the Achilles' heel of the whole argument. First of all, specimens with 'supernumerary spirals' are supposed to have been unusually abundant. For Renault assumes as a necessary consequence of his view, that the portions of a shoot which have appendages with the character of leaves come from the immediate vicinity of the apex, that those which bear roots only belong to the older lower part of the shoot which has lost its leaves, while the portions which are furnished with both kinds of organs represent a middle region. And then it must be assumed that the older portions of rhizomes must be more abundant in the fossil remains than the youngest. Now all Stigmariae, as far as I know, exhibit essentially the same regularly quincuncial arrangement of the scars. I have never been able to see anything of the 'supernumerary spirals' and other irregularities, though I have examined a great many specimens and figures for this purpose, nor have I seen any specimens in Renault's collection which prove the point. In the sections tangential to the surface of a Stigmaria which he has figured ${ }^{3}$, and which pass through both kinds of organs, there is no certainty that all the sections are really sections of the same axis. In the transverse section ${ }^{4}$ the 'root' marked $c$ certainly does not belong to the specimen, but is merely a later introduction.

1 Renault (2), vol. i, and Introd. to vol. iii, and (10).

(10), t. 1, ff. 3 and $7 . \quad 4$ Renault (10), t. I, f. I.

${ }^{2}$ Renault (10), p. 23 .

${ }^{3}$ Renault 
On the other hand, we know that the trace-bundles, wherever they are examined, are found to originate on the inner margin of the wedges of wood in the axis of Stigmariae, that their basal portion runs through the primary rays and grows in thickness pari passu with the neighbouring wood. If then so many late-formed adventitious members as Renault supposes really appeared on these axes, we should expect to find their trace-strands somewhere or other, though they could not of course have made their way so far as the inner margin of the ring of wood. But no one has yet succeeded in finding them; and if the plant was capable of forming normal roots as organs of absorption, it must seem a surprising piece of luxury that it should at the same time have leaves adapted to the same function. Functional adaptation of certain organs to supply the place of others that are wanting is a frequent phenomenon, but I know of no analogous instance of such a biological arrangement as is here described.

It will be apparent from the above remarks that, until proof to the contrary is forthcoming, I must hold to the opinion that all appendages are members of the like morphological character. It matters little whether they are supposed to be roots or leaves, and it would perhaps be well to avoid any such precise definition of ideas in the casc of organs, which have no direct analogues in the whole of our recent vegetation.

Besides his 'stigmarhizomes,' of which we have hitherto been speaking, Renault considers that he has found Stigmarize which were real roots, being supposed never to have borne foliar appendages at any time, but always only root-appendages. These are his 'stigmarhizes,' of which however he has so little to say that he dismisses them in less than the space of a page of his monograph ${ }^{1}$, while he devotes fourteen pages to the description of the rhizomes. The only figure of the transverse section of a 'stigmarhize' which the work contains is taken from a fragment from Autun ${ }^{2}$; and the anomalies in structure which it exhibits, and for which the original should be compared, make me think that it can hardly be a Stigmaria at all. As even Renault's reply ${ }^{3}$ to Williamson's and Hartog's objections affords no better explanation of the whole matter, we are compelled to ask what it was that suggested to him the idea of these 'stigmarhizes.' The further we search into the literature, the more we shall be convinced that the scanty array of facts which it supplies can scarcely by itself have given occasion to it. The truth is that the theory of 'stigmarhizes' rests entirely on certain views of Grand' Eury which appeared in his first work ${ }^{4}$, and which he subsequently carried out still further ${ }^{5}$. Grand' Eury attempted to distinguish the entire group of fossils which we are considering into two genera,

1 Renault (10), p. 35 .

- Grand' Eury (1), p. 166.
2 Renault (10), t. I, f. I4.

3 Grand' Eury (2), p. I 5 O.
Senault (2), vol. iii. Introd. 
according to external marks observed in loco, and to these he gave the names Stigmaria and Stigmariopsis. To the latter genus belong the rootstocks which are found in connection with Syringodendron-casts of Sigillariae. But the difficulty of carrying out this distinction will be apparent to everyone who considers the indefiniteness of the characters employed. Grand' Eury ${ }^{1}$ himself says; 'There are other stigmarioid growths which have been confounded with true Stigmariae when fragments of them only have been examined, but a complete knowledge of them enables me to distinguish them,' \&c., and further on ${ }^{2}$ : 'These differences are complete in the extreme cases. But though important they diminish in some intermediate cases; and this is why, after having at first removed Stigmariopsis from Stigmaria, I now bring them near together within the limits of the same family.' But his characters are of as little use botanically speaking as those of Renault. The latter author endeavours to save Stigmariopsis by means of this theory of 'stigmarhizes,' which are supposed to be developed only when a branch of a Stigmaria-rhizome raises itself into the air as a Sigillaria-stem. Renault ${ }^{3}$ says distinctly: "When the rhizome continued to grow as a Sigillaria, the latter put forth on its part voluminous dichotomous roots of stigmarioid form (Stigmariopsis), on which only radicular appendages were developed.' And this brings us to the history of development.

The same circumstance, which formerly made continental botanists so cautious and reserved in the matter of the connection between Sigillaria and Stigmaria, gave rise, as soon as this connection was acknowledged, to attempts to reconstruct the history of development of Sigillariae. Then it became necessary to explain the fact, that in some deposits Stigmariae are found almost or entirely without the stems belonging to them, that the underclays are sometimes thirty feet thick and yet contain nothing but Stigmariae, as we learn from Lesquereux ${ }^{4}$. The same author also states that in some localities in North America layers of underclay above the ground are covered over considerable spaces by axes which cross one another and creep in all directions, without any trace of stems to which they were attached. Göppert ${ }^{5}$ was the first who attempted to give an explanation of all this from the history of development. On occasion of a tour of investigation in the chief mountain district of Westphalia by direction of the Board of Trade in the year I850, he found in the President mine near Bochum in the middle of the coal of the Sonnenschein seam some peculiar nodules, round or elongated and sometimes divided at the extremities, and consisting of stone or pyrites. Outside

1 Grand' Eury (1), p. I77.

' Lesquereux (1), vol. i, and vol. ii, p. 500; Grand' Eury (2), p. I8r. (3), p. 188.
${ }^{2}$ Grand' Eury (1), p. I 78 .

$\mathrm{U} 2$ s Renault (2), vol. i, p. I63.

Göppert (20) and 
they showed Stigmaria-scars, and on many of them no surfaces of fracture could be seen. For this reason Göppert pronounced these nodules to be young individuals, perfectly preserved all round, which would branch by further bifurcation of their extremitics and develope into the well-known rhizomes. He supposed the tuber-like stock to have been formed by irregular swelling at some spot in its middle portion, and that it might under favourable circumstances grow into a Sigillaria-stem, or in other cases continue for a very long time or even always in its original condition. For the mode of development of this tuber-like stock he appcals to an observation of Steinhauer ${ }^{1}$, who saw scveral branches of Stigmaria proceed from a central tuber from one to four decimetres thick, and reach a length of twenty decimetres. And he himself on the same journey in Westphalia observed a similar specimen on a perpendicular wall of Carboniferous sandstone at Kirchhörde near Dortmund, varying from fifty to a hundred fect in height, and has given a figure of it ${ }^{2}$. It was a tuber-like body of irregular form some two fect thick, having branches of Stigmaria going off from it in every direction,- the figure gives four of them,- - but with their extremitics not preserved or hidden in the stone. The account has no doubt an air of truth about it, and explains satisfactorily that which it had to explain; and recent vegetation supplies analogous cases for comparison, as in Psilotum and less exactly in Corallorhiza, Epipogium and other plants. This is why it has so greatly influenced the accounts given by all subsequent authors, but the foundation on which it rests is not really of much value, for the tuber-like bodics from Bochum from Göppert's collection, for some of which I am indebted to F. Römer, are in fact shapeless objects in part slicken-sided, and can prove nothing.

While Göppert supposes all Stigmariac to spread like spokes of a wheel from a central stock or from the bese of Sigillariae, and to clongate in every direction with repeated bifurcations, the French authors Renault ${ }^{3}$ and Saporta and Marion ${ }^{4}$ are of a somewhat different opinion on this point. The first says, for example ${ }^{5}$ : "The life of a Stigmaria was undoubtedly confined for a long time to the almost unlimited production of dichotomous ramifications.' But then single periphcral extremities of branches of these rhizomes are supposed to become erect and as 'aerial buds' to give rise to the stems, which in their turn put forth two proper roots ('stigmarhizes') at their base. Hence the four diverging and repeatedly bifurcating branches of the base of the stem must be 'stigmarhizes,' and somewhere between them must be the place where the rhizome-shoot was broken off, the apex of which grew upwards in the form of a stem. Putting aside the purely hypothetical nature of these 'stigmarhizes,' the facts do not give the smallest

\footnotetext{
1 Steinhauer (1). Marion (2), p. 55.

${ }^{3}$ Göppert (3), t. 35. $\quad{ }^{3}$ Renault (2), vol. i, p. 162. ${ }^{3}$ Renault (2), vol. i, p. 163.

- Saporta et
} 
support to this assumption, as has been justly urged by Williamson and Hartog ${ }^{1}$. It is true that they themselves go too far again in the following sentence ${ }^{2}$ : 'two or four shoots of Stigmaria of equal size, opposite or verticillate, are found at the base of the stem of Sigillaria, which makes it impossible to admit that Sigillaria was at first an ascending bud,' \&c. In any case we shall do well to withhold assent to these views of the French authors, so long as they are unable to produce stronger proof in support of them.

Other remains resembling Stigmaria from the Devonian formation have been described under the names Cyclostigma ${ }^{3}$ and Arthrostigma ${ }^{4}$, but they are only known in impressions, and are therefore of small importance to the botanist. Cyclostigma kiltorkense, Haught. with some other forms is abundant in the yellow Upper Devonian sandstone of Kiltorkan Hill in Ireland, and occurs also according to $\mathrm{Heer}^{5}$ in the deposits of his Ursa stage (the confines of the Devonian and Carboniferous formations) in Bear Island. According to Haughton the smooth or wrinkled surface of the fossil is marked with small circular distant scars in regular many-membered whorls. Heer, who had specimens from Bear Island before him, declares that Haughton's drawings are bad, and figures a quincuncial position of the scars exactly like that of Stigmariae; and this is found in an Irish specimen which I saw in the Museum at Breslau, and which is figured by F. Römer ${ }^{6}$. Other similar remains have been repeatedly described; for example, by Schmalhausen ${ }^{7}$ from the Ursa stage of Siberia, by Weiss ${ }^{8}$ (Cyclostigma hercynicum), by O. Feistmantel ${ }^{9}$ (C. australe, O. Feistm.) from the confines of the Devonian and Carboniferous formations in New South Wales and Queensland.

Dawson has devoted an entire plate to his genus Arthrostigma discovered in the Lower Devonian beds of Gaspé in Canada; its branched axes are striated and furrowed and beset with very irregular whorls of round scars, to which sharp-pointed thorn-like appendages with a broad base are attached at right angles to the axis.

1 Williamson and Hartog (5), p. 349.

3 Haughton (1); Schimper (1), vol. iii, p. 53 .

(1), vol. iii, p. 549 .

7 Schmalhausen (3), t. I.

pp. 70,75 ; t. I, f. 6 , and t. 5 , f. I.

${ }^{2}$ Williamson and Hartog (5), p. 349. 4 Dawson (1), vol. i, p. 4 I ; t. I 3 ; Schimper ${ }^{6}$ F. Römer (1), vol. i, p. 225. - O. Feistmantel (1), III, Part II, 


\section{XIII.}

\section{CALAMARIEAE.}

IT was long believed that there was no group of extinct palaeozoic plants in which the affinitics were more distinctly recognised and determined, than in that of the Calamaricae which we have now to consider. But this belief has been so far shaken at the present day, that it is not even possible to give such a connected account of the actual material and of the results which have been obtained from its investigation, as those which have appeared in the former chapters of this work. The best plan therefore will be, first to give a short summary of the facts and of the views entertained respecting them, next to consider separately the different categories of fossil remains which have been referred to the group, and lastly to append a critical cxamination of the conclusions which have been founded upon them. We begin with the stems and branches usually united together under the name Calamitae, and shall go on to the smaller leafy branches and to the fructifications which have been assigned to them.

Calamitae are found in enormous quantities throughout the entire series of Carboniferous deposits. They are the well-known fluted stems divided into members at regular intervals and often attaining colossal dimensions, which appear in the form of impressions and casts. Their resemblance in habit to Equisetae is so great, that it soon came to be the one generally insisted upon, and the comparisons with the bamboo-cane and similar stems, such as occur in the oldest authors, Steinhauer ${ }^{1}$ for example, were soon forgotten. As early as 1828 Brongniart ${ }^{2}$ placed Equisetum and Calamites side by side as equivalent genera of Equiseteae, and in the latter genus among other forms he placed Calamites Mougeotii and C. arenaceus, which have since that time been determined to be casts of the central cavities of Triassic Equisetitae, as was stated above on p. I77. In contrast to Equisetitae, whose leaf-sheaths are often prescrved in the form of impressions, the leaves of Calamitae are unusually rare. They 
are linear and not united laterally into a sheath, and will have to be described in greater detail in the sequel. In addition to the leaves large patelliform scars, the points of attachment of lateral branches, are found at the nodes with a different arrangement and distribution in each case. In many instances entire branch-systems have been found in connection, and in this way it has been ascertained that the branches often narrow and become conical at the base, as in Equisetitae. Impressions also of adventitious roots have not unfrequently bcen seen connected with the stems which produce them.

There are virtually three different states of preservation in which these Calamitae are presented to our notice. They appear most commonly as cylindrical or flattened casts, presenting the form of a broad inner medullary cylinder, and analogous with the calamitoid casts of Equisetitae. They appear also in the form of surface-impressions with the leaf-scars, to which in extremely rare cases the leaves are still attached. Such surface-pictures occur more especially on the rind of coal on the casts, where that is well preserved; but it is true that this is not often the case in our collections. Lastly, they are found in a state of petrifaction, and then usually without the rind, and containing only the vascular bundlesystem or xylem-system which incloses the medullary cavity. Silicified specimens of this kind occur especially at Autun, Grand' Croix and Chemnitz, and are a generally distributed portion of the material contained in the calcareous nodules of England and Westphalia. It is remarkable that almost all the many petrified specimens which have been examined show the presence of a considerable mass of secondary wood traversed by primary and secondary rays.

Further, undoubted impressions of Calamitae have been repeatedly found in immediate connection with well-characterised spike-like fructifications, which are also of frequent occurrence under other circumstances; these fructifications present the characters of those of archegoniate plants, sometimes even allowing spores of two kinds to be seen, and in most cases recall mutatis mutandis even at first sight the conditions observed in Equisetum.

On the facts thus briefly enumerated, and which must be examined more carefully later on, are founded the views which prevail among the different authors respecting the systematic position of Calamarieae. We must here give a preliminary account of these views, in order to make our further remarks intelligible.

The question seemed to the older authors to be extremely simple, so long as the petrified specimens were either not known or little regarded. The stems and the fructifications just mentioned were considered to belong to one another, and thus was formed the family of Calamarieae, which appeared to stand in the very closest relationship to Equisetae. Afterwards 
when, in consequence of the impulse given by Brongniart ${ }^{1}$, the fact of the secondary growth of wood in the stems of Calamitae began to be taken into account, opinions became at once divided. Brongniart himself on elementary grounds, which we have already considered in the chapter on Sigillariae, was entirely opposed to the assumption of a secondary growth in thickness in archegoniate plants, and suggested the separation of Calamaricae into two groups, which belonging to quite different divisions of the vegetable kingdom were supposed to show great resemblance to one another only in the vegetative region. He was followed on this path not only by his pupils, Renault especially and Grand' Eury ${ }^{2}$, but by Göppert ${ }^{3}$ also and more recently by Schenk ${ }^{4}$. One of these groups, the Calamiteae, was to include the fructifications of archegoniatc character, together with the impressions of stems belonging to them and also a portion of the casts ; it was supposed to belong to the cycle of affinity of Equisetinae, and to have no sccondary growth. To the other group, that of Calamodendreae, was assigned all the petrified spccimens with secondary growth and a corresponding number of impressions and casts, and these were referred to Gymnosperms on account of the structure of their wood. Renault ${ }^{5}$ has recently inclined to connect them with Gnetaceac, and to look upon some of the fossil carpoliths as their seeds.

There is another group of authors, with Schimper ${ }^{6}$, Williamson ${ }^{7}$ and more recently Stur ${ }^{8}$ at their head, who hold firmly to the belief that the remains of Calamitae all belong to one division of plants, and see in them a group allied to Equisetcae, and distinguished from them by the introduction of secondary growth, just as Lepidodendron and Sigillaria are distinguished from recent Lycopodiaceae.

As the occasion for this difference of opinion came from the petrified spccimens, it will be well to take them first into consideration. In general thcy are nothing more than the hollow cylinder of wood deprived of the rind, and inclosing a broad medullary tube filled with the mineralising matter. If the section has not passed directly through a node, it discloses a perfectly regular circle of wedges of wood. Each of these wedges terminates on the side of the pith in a sharply projecting primary bundle, the transverse section of which may vary much in its form, and in the inner angle of the bundle there is usually a roundish irregularly defined lacuna, which has often been taken for the analogue of the carinal canal of Equisetae. The lacuna is usually bounded on the inside by a group of elements with rather broad lumen, and these are succeeded by any parenchyma-cells which still persist in the periphery of the medullary tube. In some rare

1 Brongniart (2), p. 97 .

2 Grand' Eury (1).

${ }^{3}$ Göppert (3).

and Zitlel (1). $\quad{ }_{5}$ Renault (2), vol. iv, p. 215.

* Stur (8).

- Schimper (1).

4 Schenk (2), 7 Williamson (1). 
cases the tissue which originally filled this lacuna is present, and then on the transverse section it is either exactly like the tissue which surrounds it, or it consists of more thin-walled elements with broader lumina, but between these there are often single thick-walled cells with narrower transverse section and without regular arrangement. Schenk ${ }^{1}$, who has figured a badly-preserved specimen of this kind, explains the mass which fills the lacuna as bast, and the large elements which adjoin it on the inside as the tracheides of the primary wood, so that the whole of the secondary growth must have originated in extrafascicular cambium. But the original preparations, which he sent me at my request, being all exact
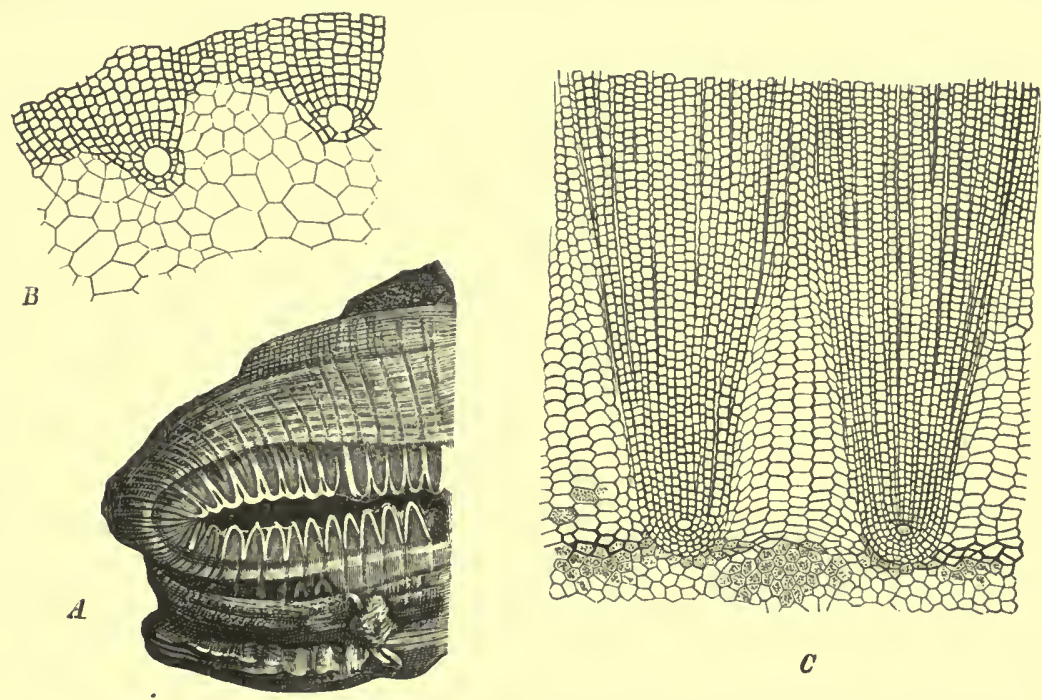

$c$

Fig. 39. Structure of Arthropitys. A portion of the transverse section. $B$ fragment of a transverse section of the ring of wood with the adjacent parenchyma of the pith, showing two wedges of wood, each of which has a lacuna in its primary strand; between them the primary strand is converted into closed wood. $C$ portion of a transverse section form the ring of wood of an Arthropitys; the wedges of wood are separated from one another by narrow primary rays which increase rapidly in breadth towards the pith; there is a lacuna of diminutive size in the primary bundle of each wedge. $A$ after Binney (1), slightly magnified. $B$ after Weiss (5). $C$ after Binney (1).

transverse sections, do not at all justify this explanation; and I am still less able to declare my assent to it, since Renault ${ }^{2}$ has found none but tracheal elements in the portion of the wedge of wood in question in the similar form Astromyelon, and also because the large elements regarded by Schenk as the primary xylem-bundle have proved to be parenchymatous cells in every case, in which obliquely directed sections have made it possible to determine them exactly. I have had opportunity of examining specimens supplying extremely clear and indubitable proofs of the point, especially in the collection of scctions in the Botanical Department of the British Muscum. Unfortunately there are not unimportant difficulties 
in the way of getting together any great number of cases of the kind. Longitudinal sections directed with a view to such minute details are precarious, and to this must be added that they are of value only where the sculptures of the cell-walls are perfectly preserved, which is seldom the case. But with all this I still have no doubt but that in the lacunae or in the tissue which fills them we are dealing with the tracheal initial strand of the primary bundle. Apart from this portion the xylem-wedges, according to the accordant testimony of Unger ${ }^{1}$, Göppert ${ }^{2}$ and Renault ${ }^{3}$, consist essentially of rows of scalariform tracheides, and with thesc, according to Renault, are several rows of pitted elcments. The medullary rays will be noticed again by-and-by. In the preparations before me I find only scalariform vessels, but I have in fact seen sections in the British Museum, in which both forms were present connected by intermediate forms. Annual rings, which might have been expected where the ring of wood is sometimes of unusual thickness, as much as a foot thick, are never seen; the wood seems everywhere uniform, only tangential fissures or local displacements through pressure, such as often occur, might to a hasty glance have the appearance of rings. It is this absence of annual growth, as well as the peculiar broad bordered pits in single rows which make me suspect, as I have alrcady said, that the wood described by Göppert ${ }^{4}$ as Protopitys Buchiana from the Culm of Glätzisch-Falkenberg in Silesia belongs to the present group.

The wood of all Calamitae has not only the interfascicular but also numcrous secondary rays. These differ considerably from one another, but they are all strikingly distinguished from those of Coniferae, as Renault ${ }^{5}$ has pointed out, by having their elements prolonged in the direction of the axis of the stem, not in that of the radius, as in the latter group. We have no exact information as to the nature of the pitting, and indeed the structure gencrally of these woods urgently requires further searching investigation. The interfascicular rays also show unusual multiplicity of structure. Cotta ${ }^{6}$ himself was struck by these variations in character, and employed them to distinguish the species striata and bistriata in his genus Calamitea, and these were afterwards raised by Göppert ${ }^{7}$ to the rank of genera, and named Calamodendron striatum and Arthropitys bistriata. Brongniart's name, which originally included all calamitoid stems with secondary growth, is thus confined to a particular type of them, and Göppert's nomenclature was then adopted by the French school, which treats the two genera as members of the family of Calamodendreae. The two types can usually be readily distinguished even on the simply polished surface of a section, for in Arthropitys the primary rays disappear towards

\footnotetext{
1 Unger (9).

2 Göppert (3), p. 179.

Renault (13).

t. $3^{6}$ and (4), p. 229, tt. $37,3^{8}$.

Renault (13).

6 Cotta (1).

4 Göppert (12), p. 252,

7 Göppert (3).
} 
the outside in the secondary wood, that is they become indistinguishable there, while in Calamodendron they retain their breadth and distinctness throughout. The wood of Arthropitys is nearly uniform, that of the other genus is composed of alternating ribbon-like bands of nearly equal breadth, some of which represent the wedges of the bundle, the others the rays. There is a difference also in the vertical distribution of the two types. Arthropitys is found in various horizons of the true Coal-measures from the base upwards, being extremely abundant in the Coal-measures of Lancashire, in which no trace of Calamodendron has hitherto been found. In fact the latter genus seems to be confined to the uppermost beds of the Carboniferous formation and to the Rothliegende, in which it has been shown to occur associated with Arthropitys at Chemnitz and Autun, in the Val d'Ajol and at Grand' Croix. The specimens from Grand' Croix are black throughout; in those of Chemnitz, figured first by Cotta ${ }^{1}$, the bands in the transverse section are alternately lighter and darker in colour, and the whole has thus a pretty and highly characteristic appearance.

Detailed accounts of the peculiar composition of the medullary rays in Calamodendron are not frequent either in Unger ${ }^{2}$, Petzholdt ${ }^{3}$, or Renault ${ }^{4}$. According to the latter author they consist chiefly of elongated thick-walled fibres. Either each ray consists of two fibrous laminae which are separated by an intervening band of parenchyma and adjoin the bundles, or of five successive laminae, the lateral and central laminae being composed of fibres, the two between them of parenchyma. The account given by Unger, who examined the specimens from Chemnitz only, while Renault relies on those from Autun and Grand' Croix, is somewhat different. He says that the wood consists of alternating bands of different structure. Both these bands contain ordinary parenchymatous medullary rays which may be formed of several rows of cells, but in some of them the mass of the wood consists of scalariform vessels, in the others entirely of parenchyma-cells of narrow diameter and with strongly thickened walls. But the figure of a tangential section given in Petzholdt ${ }^{5}$ does not answer to this description, but agrees rather with Renault's account. In specimens from Grand' Croix I find the structure to correspond exactly with Renault's description. A specimen from Chemnitz on the other hand shows an entirely different structure, and agrees to some extent with Unger's description. In the former the primary ray consists of two lateral laminae of fibres with a narrow band of parenchyma interposed between them; in the latter of a compact fibrous, not, as Unger supposes, a parenchymatous mass, which encloses numerous rays of moderate depth and varying breadth. We should in the latter case in fact be more correct if we spoke of an interfascicular wood rather than of a

1 Cotta (1).

${ }^{2}$ Unger (9).

${ }^{3}$ Pelzholdt (1), with figure.

4 Renault (15).

3 Petzholdt (1), t. 8, f. 4 . 
primary ray. The lacunae in the tissue, expressly mentioned by Renault; are also described by Unger ${ }^{1}$. In Petzholdt's figure these lacunae alternate with other broader passages, which are in all cases placed where the primary ray passes into the pith. They appear to answer rather to incidental gaps, fissures in the tissue, such as are found in this situation in the wood of many Calamitae. It is plain from the above incoherent and imperfect statements how necessary it would be to procure a connected examination of all the material stored up in the Museums.

The forms grouped together under the name Arthropitys also show many variations in respect to the behaviour of their primary rays (Fig. 39), and these variations may hereafter give rise to the formation of new genera. But at present little has been done in this direction; a more extended anatomical investigation of these woods has still to be made. I must therefore content myself with a reference to the few figures of transverse sections of Arthropitys which the literature supplies. In all of these we find that the primary rays project distinctly where they unite with the pith, and give it a stellate toothed outline, and that towards the outside they cither gradually or quite suddenly become indistinct, their tissue approximating in character to that of the wedges of wood. In the former case this appears to be brought about either by the formation of numerous narrow interfascicular strands, an example of which will be found in Williamson ${ }^{2}$, or by gradual increase in breadth of the wedges of wood at the expense of the rays (Fig. $39 \mathrm{C}$ ), as is shown in Williamson's ${ }^{3}$ and Weiss' ${ }^{4}$ figures. On the other hand there are cases in which the entire tissue of the medullary rays in the secondary growth assumes the character of wood after the manner of some herbaceous plants, Labiatae for example and Scrophulariaceae (Fig. 39 B), as appears from figures in Weiss ${ }^{5}$ and Williamson ${ }^{6}$; but the character of the wood, almost unknown, will have to be further inquired into. How far all the differences here indicated are sharply distinguishable from one another, or are connected together by intermediate forms, the meagre material afforded by the literature in the absence of personal investigations of any extent does not enable me to determine.

Archacocalamites (Bornia) radiatus also, which will have to be considered more in detail presently, shows similar structure of the wood, as appears especially from Renault's ${ }^{7}$ recent descriptions. $\mathrm{He}$ has found portions of silicified stems with the characteristic striation in the porphyrytuffs of Enost north of Autun. A broad pith is surrounded by a closed ring of wood, and the well-known lacunae are found in the primary bundles. The tracheides bear three rows of bordered pits, and the cells of the

1 Pelzholdt (1), t. 8, f. 6.

2 Williamson (1), 1, t. 25 , ff. 16, 17.

3 Williamson (1), I, t. 27, f. 26.

4 Weiss (5), p. 10, ff. 1, 2.

Weiss (5), p. 10, f. 3 .

6 Williamson (1), 1, t. 24, f. 15 , and t. 25, f. 20 .

7 Renault (19). 
medullary rays, which though formed most of them of only one row of cells are still of some depth, are elongated in the direction of the axis of the stem, as in the woods which we have been considering. These remains are named Bornia enosti, Ren. Richter ${ }^{1}$ had previously noticed these fossils, but his account of them is not intelligible; Göppert also had discovered remains undoubtedly belonging to this plant in the Carboniferous limestone of Glätzisch-Falkenberg, and his remarks upon them are of a better kind; his specimens ${ }^{2}$ are it is true very fragmentary, but they show single shallow medullary rays of one row of cells, and treatment of the sections with acids also discloses tracheides with bordered pits broader than long, and irregularly disposed in several rows.

The rind is only rarely preserved in its connection with the wood, and its structure appears from the statements of authors to be very variable. The structure of the rind in the genus Astromyelon will be noticed again presently. Renault ${ }^{3}$ found that the rind of Arthropitys medullata was composed of compact uniform parenchyma, and contained groups of resin-canals (?) in front of the wedges of wood; and that in A. bistriata and A. lineata there was Dictyoxylon-structure also in the outer portion of the rind,- the well-known reticulated system of radial laterally anastomosing strands of sclerenchyma. The only preparation before me in which the rind is preserved, and which is from the Oldham nodules, presents to some extent the conditions of the species first mentioned. A good specimen of the kind is figured in Hick and Cash ${ }^{4}$; it shows the soft bast which is bounded on the outside by a layer of thick-walled cells. The primary rind consists of an inner portion with delicate cells and with many fissures caused by the tearing of the tissue, and of an outer layer, the elements of which have thicker walls and frequently contain coal. Unfortunately no longitudinal sections of this specimen have been published.

In examining the wood in these plants it is not an uncommon thing to come upon preparations which have struck the region of a node. I possess such a preparation with the beginnings of four branches proceeding from the node. The presence of the nodes can sometimes be recognised even from without, if weathering or planes of fracture running in a favourable direction have laid bare the outer surface of the wood stripped of the rind, or the boundary line between it and the pith. Stur ${ }^{5}$, with a right perception of the fact that it is only by attention to these points that we can have any proof that certain casts of Calamitae belong to our woody bodies-a proof, on which rests the course of exposition here adopted-has been careful to collect all the cases of this kind known to him, and to discuss them fully. His finest specimen ${ }^{6}$ is represented in Fig. 40. It is a well-preserved

\footnotetext{
1 Richter (1), p. 167. and Cash (1), t. 19 .

${ }^{2}$ Göppert (2), p. 100, tt. ${ }_{6}^{38,39 .}{ }^{3}$ Stur (8), p. 439.

' Hick
} 
example of Arthropitys bistriata from Chemnitz, in the museum of the Provincial Geological Institution at Leipsic, in which the medullary tube is not filled up, but allows the inner boundary of the woody body to be seen in all its details. Four nodes are visible as transverse projecting lines; the short internodes show regular longitudinal striation, in which the ridges correspond to the bundles of the medullary sheath, and the furrows to the primary rays. By means of squeezes with gutta-percha Stur has obtained the picture of the cast of the specimen, which answers absolutely to an
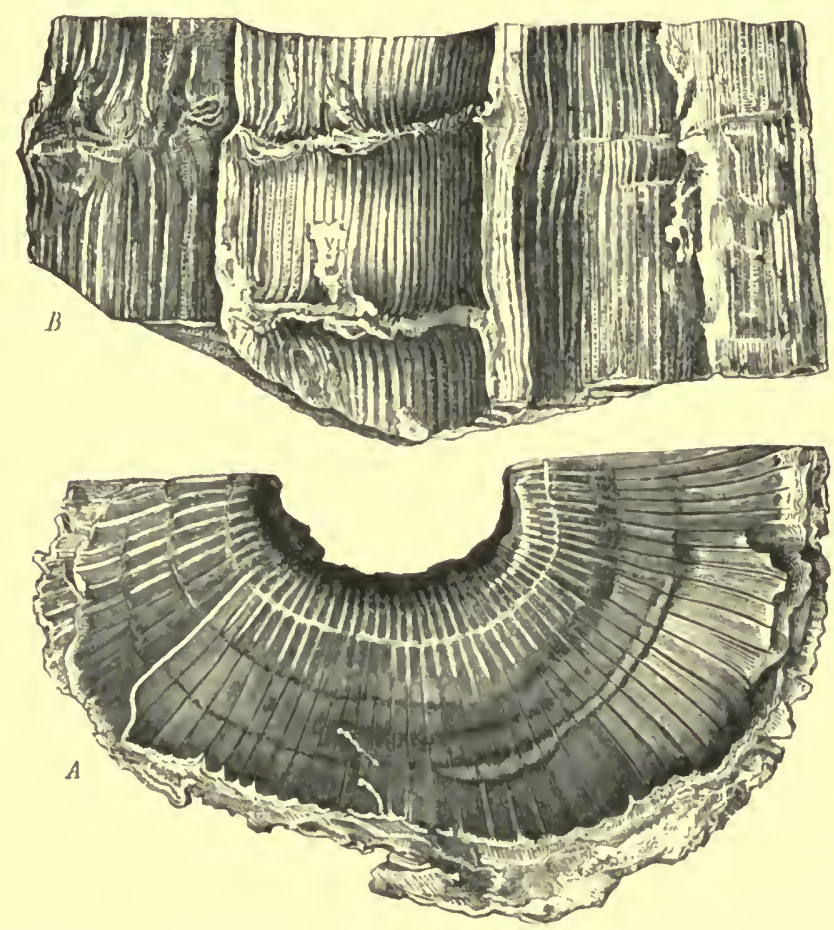

FIG. 40. Arthropitys from Chemnitz. Petrified woody body, showing where it borders on the pith the normal striation and articulation of the casts of Calamitae. A view of the transverse section with the wedges of wood. $B$ longitudinal section. After Stur (\$).

ordinary cast of Calamitae, and shows the lines of the nodes as transverse furrows. The bands of the medullary rays now appear of course as ribs, the bundles of the medullary sheath as furrows on the surface. Almost as beautiful is the specimen represented on another table ${ }^{1}$, an Arthropitys from the Rothliegende of Neu-Paka in the Museum of the Imperial National Institution. A portion of the quartz which filled the medullary tube came away from the two halves, and the surface of the cast thus preserved presented the picture of one of the Calamitae with all the characteristic details

I Stur (8), p. 453, f. 10. 
of its surface. Exactly similar pictures result when the outer surface of the woody body deprived of the rind is disclosed to view, as is the case with a piece of petrified wood of Arthropitys from St. Berain (Saône et Loire) in my possession. Unfortunately this piece of wood, which is as thick as an arm, though it shows the wedges on the face of the section, is too badly preserved for microscopical examination ${ }^{1}$. I have verified this specimen by comparison with two others from the calcareous nodules of Langendreer and Oldham, the rbest of which is kept in the Museum at Strassburg. But in these, in contrast with the cast, the ridges on the surface, which is marked by slightly sinuous furrows, answer to the somewhat convex outer faces of the wedges of wood, the furrows to the rays. The Strassburg specimen shows a nodal line tolerably distinctly as a transverse swelling. A still finer piece from Oldham also showing a node may be seen in Binney ${ }^{2}$.

Williamson ${ }^{3}$, Binney ${ }^{4}$, and Stur ${ }^{5}$ have published longitudinal sections through these nodes. Williamson's first figure is taken from a specimen with a weakly developed woody body, elongated internodes, and the rind preserved; that of Stur, determined as Calamites approximatus, has quite short internodes and numerous equidistant nodes; its woody body is of considerable thickness. A diaphragm stretches across the medullary cavity at each node. This diaphragm is a parenchymatous structure of no slight thickness, and in Stur's specimen it maintains this thickness in all parts, but in Williamson's it fines down towards the centre into a thin lamina. In a similar preparation in the collection of sections in the Botanical department of the British Museum, a foliar bundle may be seen in exact longitudinal section on the line of the diaphragm running towards the outside. But the tangential sections are much more important and instructive when they pass through a node, as happens in some of Williamson's figures ${ }^{6}$. From the two figures especially in the first of the monographs, one of which is here reproduced in Fig. 41 $A$, and in which the sections have encountered the woody body in the neighbourhood of the pith where the primary rays are broad and evident, we see that the position of the secondary wedges of wood directly follows the original primary course of the strands. This course agrees essentially with that of recent Equisetae. Each bundle passes downwards through an internode, and then forks and unites by its limbs with the adjoining bundles in the node next below, which thus shows the well-known broken zigzagged commissural-strand. In this process the descending bifurcating strands are often split up in such a manner as to enclose a wedge-shaped space with two pointed ends, which resembles a medullary ray and is filled with parenchyma. And other sections in the ninth monograph, unfortunately of too

\footnotetext{
1 Grand' Eury (1), p. 286.

${ }^{2}$ Binney (1), I, t. 3 , f. I.

- Binney (1), I, t. 3, f. 3 .

s Williamson (1), I, t. 24 ,

${ }^{5}$ Stur (8), p. 459 , f. 14

- Williamson (1), I, t. 23, f. 2 ; t. 26 , ff. 22,25 ; IX, t. 20 , ff. $23,24,29$; t. 21, ff. 26,28 .
} 
small extent, show that still greater deviations occur in the nodes (Fig. $41 B$ ), and that by repeated formation of intermediate cauline strands from the upper and possibly from the lower extremities of the primary rays, other elliptical portions of the kind bounded by loops of wood may be cut off. Such complications, unknown as yet in the nodal zone of Equisetae, are extremely common in Angiosperms, in which according to present observations they cannot at all be referred to distinct types, but secm to be absolutely irregular. In many cases, not indecd necessarily in all, these small meshes are traversed by bundle-strands passing outwards (leaf-traces or traces of adventitious roots), the transverse sections of which lie in the middle of their parenchyma; this has been already recognised and described by Williamson. The lateral shoots also, where they traverse the wood, are seen to be surrounded by similar strand loops ${ }^{1}$. IVhere the primary rays of Williamson's lower internode end above towards the zigzag strand of the node, the tangential scction very commonly shows in each of them a roundish or ovoid empty
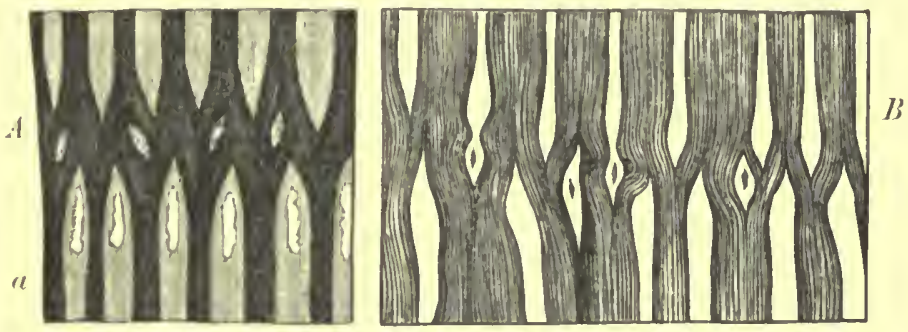

Fic. 4l. Tangential section throngh the woud of Arthropity's, showing the irregularities of its course in the node as mentioned in the text; at $a$ the so-called infranodal canals. In some of the small rhombic nodal medullary rays are transverse sections of vascular bundle-strands running towards the outside and indicated by points. After Williamson (1).

space with tolerably distinct boundary lines (Fig. 41), which, as appears from some preparations in Williamson's collection, passes from within outwards through the whole length of the medullary ray ${ }^{2}$. These peculiar canals, called by Williamson infranodal canals, are proved by other sections in the same collection to be caused by the disappearance of a strip of parenchyma, which differs a little in character from the surrounding parenchyma of the ray. Then in many cases the terminal segment which conceals the canal is separated by formation of anastomoses from the internodal portion of the ray, and is clianged into one of the previously mentioned nodal lacunae. We should accordingly have to distinguish two kinds of these nodal rays, one containing the infranodal canals arranged in a regular circle but no bundle-strands, the other, with much less regularity of development in number and position, inclosing the bases of the branches, and in some cases allowing other casual trace-bundles to pass through them. Williamson places the latter exactly on the line of the node, the former beneath it. 
Further, the course of the strands in Calamarieae appears to deviate in not unimportant points from that hitherto assigned to Equisetae, as may be gathered from certain anomalies in the sculpture of the casts which must be considered by-and-by. On this point there is scarcely anything to be said in the absence of investigations into the details of the subject. I may mention however that I have seen a section in the British Museum, in the node of which several adjacent xylem-strands of the successive internodes instead of alternating lay exactly one on another. The upper trace-strand divides into two limbs, which diverging first of all and anastomosing laterally with neighbouring strands, afterwards converge again and unite to form the lower trace-strand. In the mesh thus formed, which breaks the direct continuity of the strands, there was always to be seen the transverse section of an emerging bundle, or at least the trace of the particular node.

Lastly, before going on to speak of casts of Calamitae it will be necessary to notice the genus Astromyelon, about which very different views have been expressed in recent times. This genus was founded by Williamson ${ }^{1}$ on remains which showed in their transverse sections the characters of Arthropitys, with the exception of the intercellular cavity in the primary bundle; and in it he now places several of the transverse sections ${ }^{2}$ which he had himself before named Calamites, and makes its most important character to be the absence of stem-nodes bearing whorls. It is also said that the parenchyma of the medullary cylinder is usually though not invariably preserved. Meantime remains of peculiar stems with spongy lacunose rind and with the medullary cylinder filled with parenchyma were discovered by Hick and $\mathrm{Cash}^{3}$ in Halifax, and were described as Myriophylloides Williamsonis; but they were subsequently re-examined by Williamson ${ }^{4}$ and united with Astromyelon, the peculiar feature of the rind being added to the characters of the genus. However, Hick and Cash ${ }^{5}$ have at once raised objections to this identification. That the transverse section of the wood-body of Myriophylloides does really show a picture different in not unimportant points from that of Arthropitys, I have been able to satisfy myself by inspection of sections obtained from Mr. Cash himself $^{6}$; but it is useless to discuss the question till we have more information respecting the nature of the longitudinal sections.

The characteristic structure of the rind depends on the presence of a simple girdle of wide intercellular spaces in the middle of the rind, which become broader and wedge-shaped towards the outside, and which, evidently schizogenetic in origin, are separated from one another by narrow radial plates of tissue from two to a few cells in breadth. But a structure of

1 Williamson (1), IX, p. 319.

2 Williamson (1), 1, t. 25 , f. 16, and t. 27, f. 39 .

3 Hick and Cash (2). (1), XII, f. 5 . 
this kind, as we know, and as Hick and Cash ${ }^{1}$ have well shown, may make its appearance in a similar manner in plants very far removed from one another, if only they have certain adaptations in common, such as growing in water or in wet places; it can hardly therefore be employed to determine a genus or a group, or, if so, only in peculiar circumstances.

Further, Renault ${ }^{2}$ lias described several species which he assigns to Astromyclon, and has figured three of them, Astromyelon augustodunense, Ren., A. dadoxylinum, Ren. and A. nodosum, Ren., on the three plates of his work. He too, like Williamson, insists especially on the absence of nodes, and remarks that the structure of the wood shows the greatest resemblance to that of Arthropitys, being essentially distinguished from it only by the presence of the 'bois centripete,' which is closely connected with the 'bois centrifuge' and is surrounded by it. From this remark, and also from the circumstance that Renault cites in this connection Schenk's ${ }^{3}$ figure noticed above, and will not allow it to be an Arthropitys, I perceive that the 'bois centripète' does not mean here the entire primary bundle, as it usually does elscwhere, but only its initial strand, and further that on the transverse section at least there is no difference to be observed between Renault's Astromyclon and his Arthropitys. We saw above that in the same section the initial strand may be preserved in some bundles, and may be replaced by a lacuna in others. The absence of nodes would then be the only remaining difference. It is not for me to determine what is the true account of the matter, for I have had no opportunity of properly studying the remains in question. It is to be hoped that Renault himself will soon give us some further explanation. The structure of the rind is only known in one of the three species described by him, Astromyclon augustodunense ${ }^{4}$. There it is entirely parenchymatous, and the inner portion which surrounds the ring of wood is traversed by groups of dark-coloured cells, which lie in front of the wedges of wood, and are explained as 'canaux' or 'cellules à gommc.' The intercellular spaces of the middle portion of the rind are only of moderate breadth, and are separated from one another by thick plates of tissue consisting of several layers of cells.

It is evident from what has now been said that nothing at all certain can be stated at present respecting Astromyelon, and that it is possible that different plant-forms have been united under this name. The structure of the wood affords not the slightest ground for comparing this genus with Marsilea, as is done by Williamson ${ }^{5}$; if there are points of resemblance, and I am myself unable to find them, they must be of purely external character. Renault ${ }^{6}$ even has not ventured to draw any conclusion from the circumstance that these remains are often associated at Grand' Croix with

1 Hick and Cash (1), p. 91. ${ }^{2}$ Renault (13). (13), t. 7 , ff. I, 2.

S Williamson (1), xu.

3 Zittel (1), p. 237.

- Renault (13).

* Renault 
Stephanospermum, Polylophospermum and Gnetopsis elliptica; but he has now ${ }^{1}$ come to the conclusion that all the forms of Astromyelon are roots of Calamodendron and Arthropitys, and that Astromyelon dadoxylinum belongs to Calamodendron and $\mathrm{A}$. augustodunense to Arthropitys. In face of the evident stem-structure shown by his own figures, and which it is scarcely possible to call in question, the botanist finds it difficult to understand how such a view is possible. Its author himself says that the general root-character can only be seen on young branches, and the reason which he proceeds to give for his opinion appears, if I rightly understand it, to rest on an assumption of the boldest kind. It would require some time to examine into this assumption, and I am the less inclined to do so, because it is before us at present only in the form of a sketch suited to the preliminary communication in which it is contained, and it is therefore hardly possible to avoid misunderstandings.

The larger portion of the casts, which have long since been known by the general name of Calamitae, belongs, as may be gathered from the previous remarks, in part at least to the woody bodies known as Calamodendreae. Another portion according to the French authors comes from hypothetical plants resembling Equisetum, and having no growth in thickness. The question at once arises whether it is possible to separate the casts of the two kinds and how this is to be done, a question which engaged the attention of Brongniart ${ }^{2}$ himself, but which has been studied more particularly and in the widest extent by Grand' Eury ${ }^{3}$ and Renault ${ }^{4}$. Grand' Eury, after consideration.of all the circumstances, and relying especially on his mining experience and on the mode of occurrence of the fossils, answers the question in the affirmative, showing that there are firstly, casts of Calamitae with a very thick rind of coal without striae on the surface, and secondly, those in which the rind is no thicker than paper, so that the striation on the cast appears even on the outside, though not so plainly. The two types, still in the erect position, occur equally abundantly in the quarries in the district of St. Etienne, of which he gives a sketch ${ }^{5}$. The specimens of the first kind, Calamodendreae, are constantly found singly, with their narrowed and fusiform extremities passing vertically through the beds, and giving off from the nodes close whorls of long simple descending roots ${ }^{6}$. Those of the other kind on the contrary ${ }^{7}$ occur in groups and converge below, and spring from erect or horizontal rhizomes; their conical base, either attached directly to the rhizome which bears them or narrowed into a long thin thread-like basal portion, is always ${ }^{8}$ bent round a little to one side in the manner described above in the case of the bases of

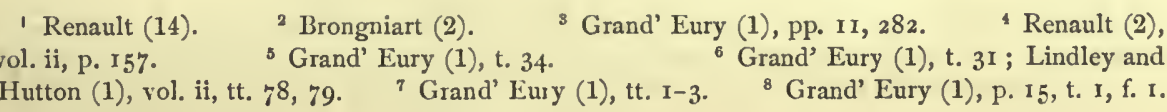


the casts of Equisetitae, and illustrated also by a figure in the text of one of Dawson's publications ${ }^{1}$. The roots which spring from the nodes spread at right angles into the adjoining rock. A similar but vertical narrowing is said to occur also in the much rarer branch-bearing upper extremitics, as for example in Calamites Cistii ${ }^{2}$. From his observations Grand Eury classes the following from among the better-known species with his genus Calamites :- Calamites Suckowii, Brongn., C. Cistii, Brongn., C. ramosus, Artis, and C. cannaeformis, Schloth.' On the other hand he claims Calamites cruciatus, Stbg as a cast of Calamodendron, to which according to Weiss' ${ }^{3}$ determination certain forms with a very thin rind of coal (Calamites multiramis ${ }^{4}$ ) also belong. I regret that $I$ have never as yet had an opportunity of making myself acquainted with these differences on the spot, which, as may be imagined, cannot be demonstrated at all or only very imperfectly in a Museum. I once indeed saw in the Museum in Paris a large basal portion of Calamodendron, which was intended to be a standard specimen, but it gave me no clear picture. On a second visit I sought for it in vain in its former position.

The casts of Calamitac, in the widest acceptation of the term, have been very recently made the objects of scarching investigation by Stur ${ }^{5}$ and Weiss ${ }^{6}$. Some details of their external sculpture, which were not noticed in our previous summary account of them, must now be taken into consideration in connection with the exhaustive treatment which they have received at the hands of these authors.

By far the larger number of the specimens in the collections are cylindrical pieces of casts or moulds broken off at both ends. This condition causes a difficulty in determining the upper and lower extremities. The pieces with short internodes and narrowed into a conical form at one end, which are also far from rare, are generally believed to answer to the bases of erect shoots; the grounds for this belicf are the facts observed in Equisetites, and the circumstance already mentioned that they are sometimes found in actual connection with the stem, which bears them ${ }^{7}$. If, indeed, upper extremities of a similar kind were to occur, as Grand' Eury affirms that they do, some caution would be necessary in this respect. Such an extremity might be present for example in the lateral branch of Calamites ramifer figured in Stur ${ }^{8}$. Longer portions of the branch-system with the parts in attachment are much less common; Weiss has figured a certain number of them ; in these specimens the upper and lower ends can generally be determined from the direction of the lateral branches. But these branches are of two kinds. The one kind has been already described; the others on the contrary are cylindrical and do not narrow at the base, but are attached by

\footnotetext{
1 Dawson (13), p. 195.

Eury (1), t. IO, f. 2 and t. 12.

${ }^{2}$ Grand' Eury (1), t. 2, f. I. 3 Weiss (5). ' Grand' f. 2 ; t. 4 , f. I, and Williamson (1), IX, t. 21 , f. 30 .

- Weiss (5).

" Stur (5), p. 156, f. 17.
} 
a broad base to the node which bears them; many examples of these branches will be found in Weiss ${ }^{1}$. Sometimes both kinds are observed on the same piece. Where conically narrowed branches are seen in impressions of stems, there are also present almost invariably long usually simple ribbonlike stripes springing from the nodes which bear the branches and from other nodes also, and often crowded together in tufts, which Weiss rightly takes for impressions of roots ${ }^{2}$. Such specimens must therefore be supposed to belong to the subterranean stem. The branches with narrowed conical base which spring from it may then be regarded with great probability as the ascending foliage-shoots, the others as branches of the rhizome with horizontal growth. And it may be further assumed, and not without reason, that fragments which are without roots, but have cylindrical lateral branches not narrowed at the base, arise from the aerial leafy portions of the plant. Their being rarer than the other kind is readily understood, if we reflect that their position in the ground is much less favourable to their breaking up into separate pieces. Weiss ${ }^{3}$ has given fine examples of these branches, and Stur ${ }^{4}$ likewise.

It has already been stated that the casts of Calamites are striated longitudinally, the broad convex ribs answering to the medullary rays, the usually narrow acute-angled furrows to the bundles of the medullary sheath. While the striation alternates in the successive internodes, the broken zigzag nodal line is formed in the node and always appears as a deeply incised furrow. This is due to the preservation of the nodal diaphragms. It may however be assumed that these were very generally broken through in the inner central portion in the process of making the casts, for the regular and perfect formation of so many connected internodes could not otherwise be explained, and the close union of the separate internodal members, which never have gaps between them, would be impossible. Deviations also from the regular alternation in the nodes are very commonly to be seen at certain spots in the casts or extending over longer distances, so that the ribs of successive internodes coincide. This is occasionally observed in almost all Calamitae; Stur ${ }^{5}$ has discussed it particularly in the case of his Calamites ostraviensis; in one form, Archaeocalamites radiatus, it is of regular occurrence, the non-alternation of the ribs in the node being characteristic of the species.

Where the preservation is good the nodal line is accompanied on both sides by small roundish or ovoid prominences rising above the surface of the cast. They stand in all cases on the back of the broad ribs which answer to the medullary rays, sometimes exactly in the middle, sometimes also on one side, and nearer to the one adjoining furrow than to the other. A small knob of this kind is usually found at the extremity of

\footnotetext{
1 Weiss (5).

2 Weiss (6), t. 19, f. Ia and (5).

${ }^{3}$ Weiss (5), tt. $5,6,7$.

Stur (5),

t. 23 , and p. 192, f. I8. $\quad{ }^{3}$ Stur (5), pp. 118, 119.
} 
every rib; but Stur says that where the preservation was more than usually good, he has found two of them one above the other on the extremity of the rib on the one side of the node. They sometimes appear in the form of small attached cylinders of regular form ${ }^{1}$, from which the usual state of preservation as produced by pressure can be readily deduccd.

In by far the greater number of cases the two rows of small knobs are not preserved with equal distinctness; very often one only can be clearly seen, the other being imperceptible or only just indicated. If now we would know whether the position of the more distinct line of knobs is a fixed one, or whether sometimes one sometimes the other line may be more prominent, we must for the reasons given above confine ourselves entirely to the examination of branched specimens in which the direction of growth is absolutcly known. The theorctical considcrations which have determined the views of authors must be rescrved for future notice. I have cxamined all the figures of the kind with which I am acquainted, and have found that in almost all cases the more apparent line of knobs corresponds to the upper end of the lower internode, and this agrees with the direction usually assigned to the fragments of stems of Calamitae and adopted also by Wciss. In Stur's figure ${ }^{2}$ only I find the opposite arrangement; both lines are present, but the line at the lower end of the upper internode is much the more prominent. As there is no reason whatever for doubting the cxactness of this very excellent figure, I conclude that no absolute rule can be laid down for the position of the stronger line of knobs, but that in case of doubt Weiss' view is to be preferred as the more probable to the opposite view represented by Brongniart and Stur.

Brongniart ${ }^{3}$ originally attempted a morphological explanation of these small knots, and Stur ${ }^{4}$ has recently turned his attention to the same subject. Stur takcs his stand, and riglitly, on the comparison with the similar course of the strand in Equisetum; but at the same time he falls into a serious error which affects all his further conclusions, and unfortunately makes them in my judgment entirely worthless from the botanical point of view. It is an axiom with him, that the small protuberances correspond to the points of attachment of leaves, buds and roots, and are therefore direct indications on the cast of the respective positions of these organs. But there are various objections to this view. It is obvious that projections on the cast of a medullary cylinder can only arise where therc are corresponding depressions in the organic substance immediately surrounding it. Hence if there has been no disappearance of tissue in the environment to cause a depression of the kind, the emergence of the vascular bundle in the direction of the lateral members cannot of itself leave any trace behind it on the cast.

1 Weiss (5), t. 17, f. 5 .

4 Stur (5).

${ }^{2}$ Stur (5), p. I92, f. 18 and t. 23, f. 2.

3 Brongniart (1) 
There is no sufficient ground therefore for Stur's ${ }^{1}$ assertion, that the presence of this character on an otherwise questionable specimen is quite sufficient to place it with perfect certainty in the class of Equisetaceae. Even if we accept Stur's conception of the protuberances, since according to Janczewski's researches branch and root spring from a common primordium, there would not be three, but only two alternating rows of small knobs on the cast of the pith in our genus. We should have not Stur's scheme for Equisetae ${ }^{b}{ }_{w}$, but $^{\mathrm{b}}{ }_{(\mathrm{a} \mathrm{w})}^{\mathrm{b}}$. But there is another point to be considered. Since the leaf-scars must be the most conspicuous objects on the nodes of leafy stems, Stur endeavours to show that the most prominent row of knobs belongs to the leaves; and this row must be the uppermost if the comparison with Equisetum is to be maintained. This is the reason why Stur, in opposition to the current view, which rests, as has been shown above, on weighty arguments, inclines to determine the direction of the stems in Calamitae in such a manner that the most conspicuous, often the only recognisable, line of knobs comes uppermost. But, as Weiss ${ }^{2}$ rightly urges, this would mean the insertion of the leaves on the base of the internode lying next above the node. There is no need to give further proof that such an insertion is not probable. But the other mode of conceiving the direction of the stems results in the same improbability; for in that case, since the commissure of the bundles must be situated in the node itself, the foliar bundles must originate beneath it and in a very strange position, and the comparison with Equisetum, in which each trace is the continuation of an ascending strand of the lower internode, could scarcely be maintained. But I have satisfied myself from the radial section in the British Museum mentioned on p. $3 \circ 3$, that the leaf-trace does in fact pass outwards exactly at the level of the node.

Further, the examination of Equisetum supplies no reason for assuming so considerable differences in height between the points of departure of the traces. For these appear first on the surface of the stem in consequence of the diverging course of the members; their points of origin, alternating with one another, are nearly at the same height, so that they can be encountered in one and the same transverse section. Hence the points corresponding to the points of departure of the traces would probably be found on a cast of the pith of Equisetum in a single circle only. Lastly, Weiss ${ }^{3}$ has brought forward yet another weighty consideration. This is founded on the examination of the mould of a Calamites from the Museum at Halle, which will have to be noticed again presently, in which the ribbing of the wood and the surface with the leaves can be seen together. In this specimen from six to seven leaves have dropped off at regular distances from one another on the nodal line over a breadth of twenty millimetres, but there are also fourteen

1 Stur (5), p. I 12.

${ }^{2}$ Weiss (5).

${ }^{3}$ Weiss (5), pp. 28 and 65, t. 1, f. 1 . 
ribs with their knobs. Since the regularity of the arrangement appears to exclude the supposition that half the leaves have dropped off, Weiss concludes that there was only one leaf to every two ribs. But in that case the leaf-traces would be twice as many as the leaves. This would necessarily imply that the course of the strands was more complicated than we are in the habit of supposing; and this may prove to have been the case in certain groups of Calamitae, for the specimen in question belongs to the Calamitinae which we shall shortly have to consider.

In contrast to all these difficulties the prominences under discussion become readily intelligible, if with Williamson we see in them the traces of the small medullary rays of the node, and also the substance filling the socalled infranodal canals mentioned above, which, as that author has shown, remain parenchymatous all through the life of the plant, and are never traversed by interfascicular strands of later formation, as is the case with the primary rays of the internodes. The differences also in the mode of development of the prominences can on this view be sufficiently explained. For if only a small portion of tissue has disappeared on their inner border, then they present only flat swellings; if more is gone and the matter filling the canals is fine enough to follow such narrow passages, then the small sharply defined cylinders are produced, to which Weiss has called attention. Lastly, the case of most complete filling is exemplified in specimens such as those figured by Williamson ", in connection with which Weiss' ${ }^{2}$ remarks should be consulted. A cylindrical cavity contains the narrowed conical extremity of a cast of Calamites, from which thin rods of stone arranged in a whorl, aud spreading like the spokes of a wheel, stretch to the outer wall which bounds the cavity. These rods answer to the substance which filled the canals and exactly occupy their place; there is no reason for regarding them with Stur as roots. The surrounding mass of wood was converted into coal, which has for the most part disappeared, though traces of it are still attached to the wall of the cavity. Since the entire cavity is inside a cast which is striated like a Calamites, we can only suppose that the base of the particular branch was deposited in the medullary tube of a broader portion of a Calamites, and in this position was inclosed in the mass of mineral matter with which the latter became filled. If this supposition is correct, it confirms also Williamson's view as to the direction of the pieces of wood of Calamitae, which coincides with that which Weiss maintains in respect to the casts. For the disappearance of much tissue in the infranodal canals will neccssarily cause the formation of the more prominent row of knobs; weaker prominences on the cast will answer to the upper medullary rays of the nodes filled with a less delicate parenchyma. I should even conjecture that the rays which lie exactly on the level of the 
node and give passage to the traces, will usually leave no knobs behind them on the cast, but that the weak protuberances of the upper internode indicate the lower extremities of its primary rays. In that case the points of emergence of the vascular bundles would be in the middle between the two rows of knobs, and this would agree well with the description given on page $3 \circ 3$.

The essential points in all these relations have been correctly recognised and explained by Williamson. But while the whole formation appears to me to rest upon the more or less complete filling up of cavities or depressions caused simply by unequal maceration, he inclines to see in them characteristic relations of organisation, the importance of which to the plant has yet to be more fully explained. And though he has since ${ }^{1}$ fully recognised the fact that the lateral branches, the roots and the transverse sections of the trace-bundles appear in the small medullary rays of its upper circle, he still thinks that the canals in the rays of the lower series must have had an important function to perform; otherwise they would not have remained unchanged throughout the entire thickness of the secondary growth, for this is never the case to the same extent with the primary rays of the internodes.

All that has hitherto been advanced may serve at least to show how difficult it is even in the case of normal ordinary structure to explain the mutual relations of the wood and casts of our Calamitae, as we have them separated from one another; and that attempts at similar explanations where the cases are anomalous must be hopeless from the first, so long as we have no greater number of investigations into their anatomy to assist us. But at present I only know of one tangential preparation of the kind, which is preserved in the British Museum and was noticed above on page 305 ; my examination of it, though only cursory, led me to the results there indicated. Nothing would be gained by a minute consideration of the constructions which Stur has obtained from the position of the nodal prominences; it will be sufficient to notice briefly his main results. Further information will be found in his publications ${ }^{2}$. The trace-scheme which he gives for the positions in ordinary Calamitae, in which there is no alternation, is ${ }^{B}{ }^{B}$, and in Archaeocalamites radiatus ${ }^{B} \mathrm{~W}$, but the latter is contested $\mathrm{W} \mathrm{W}$ A $\mathrm{W}$ W by Rothpletz ${ }^{3}$ on the strength of fresh observations and is replaced by ${ }_{B}{ }_{B}$.

I have never had opportunity to examine specimens in the high state of preservation necessary for these observations. While then Stur contrasts the course of the strands in Archaeocalamites with that in Equisetum, as he has construed it, he endeavours in a detailed discussion of the subject 4 to show the possibility of a gradual transition of the one into the other

${ }^{1}$ Williamson (1), Ix. $\quad{ }^{2}$ Stur (5), (8), (9). $\quad{ }^{3}$ Rothpletz (1), pp. 5, 6. $\quad$ 4 Stur (5), p. $55^{8}$. 
during the formation of the Ostrau deposits, and thus arrives at last at a phylogenetic arrangement of all the Calamariae. Calamites ramifer, Stur, C. cistiformis, Stur, C. approximatiformis, Stur, and C. ostraviensis, Stur, all figure in this list as transition forms. It need scarcely be observed on what fect of clay the whole structure stands. But Stur gocs much further still in his conclusions. He places Sphenophyllum also with Calamariae on account of the trace-points on the nodes, and gives it the scheme $\frac{\mathrm{A}}{\mathrm{W}}$. For this he relies chicfly on his cxamination of Sphenophyllum tenerrimum, Ett. from the Culm; but it may still be doubted whether this species belongs to the genus, and the question will have to be considered later on. He makes Sphenophyllum as well as Annularia and Asterophyllites to be nothing more than heteromorphous branches of Calamitac, bearing two different kinds of fructifications, one of which therefore will contain macrospores, the other microspores. He claims indeed to have found Sphenophyllae growing out of Astcrophyllitae ${ }^{1}$, but he has not figured his specimens. It may well be asked, whether they were not merely branches of broad-leaved and narrow-leaved Sphenophyllum in connection with one another. The reader should refer to the remarks on this point in the chapter of this work on Sphenophylleac, and to Weiss' critical cxamination of Stur's vicws ${ }^{2}$. Lastly, Stur ${ }^{3}$, setting out from the results (?) thus obtained from fossil forms, even attempts to arrive in the reverse way at conclusions respecting the morphology of living Equisetac, which contain much that is surprising to the botanist. Weiss' * summary account of these speculations should be consulted.

On the nodal line between the two rows of prominences, which have now been described, the cast also shows the scars of the attachment of the branches in varying number and arrangement. These are disk-shaped surfaces, which are often somewhat depressed and patelliform, and at their periphery they usually show radial striation ${ }^{5}$, due partly at least to the mutual convergence in that quarter of the contiguous and laterally adjacent ridges and furrows. In a figure given by Weiss ${ }^{6}$ a small portion of the stony substance has remained behind in the patelliform scar, and conceals the peripheral striation; and this is not an uncommon occurrence. In those Calamitae which have only a few branch-traces in the nodes, we may often observe on the nodal line outside and between these traces numcrous dot-like marks, to which a few adjacent ribs converge from above and from below. It is natural to suppose that these marks are the traces of undeveloped lateral branches. These traces are seen in a particularly

'Stur (10). $\quad{ }^{2}$ Weiss (8). $\quad 3$ Stur (8). ' Weiss (5), p. 13, note. $\quad{ }^{5}$ Weiss (5), t. 2 , f. 3 ; t. 7 , f. 2 ; t. I3, ff. I-3; t. 21, f. 5 ; t. 25 , f. I, and Stur (5), t. 20, f. 4 . $\quad$ Weiss (5), t. 9 , f. I. 
beautiful and well-pronounced form as rosettes of striated protuberances on the mould-plates of certain large stems of Calamitae with short members, for example in Calamites multiramis ${ }^{1}$; these plates undoubtedly represent the outer surface of the ring of wood, which is partly preserved in the form of a thin coating of coal. The varied and peculiar arrangement of the scars of the branches on the nodes, for example in the group known as Calamitinae, will be noticed again below. Certain anomalies in the sculpture, such as occur here and there on the internodes, but from which no conclusions can be drawn, will be found figured and described in Weiss ${ }^{2}$.

Now that the casts of Calamitae which are produced by the filling up of the medullary cavity have been thus fully considered, it remains only to add a few words concerning the specimens which represent the outer surface of the stem. This surface, which in ordinary Calamitae is only preserved in a rind of coal, is either quite smooth or is folded in slight wrinkles; the nodes are indistinct, and are perhaps marked only by the presence of any flat patelliform branch-traces that are present. No leaves are seen; either there were none, or they dropped off early, or were simply not preserved. Probably the latter supposition comes nearest to the truth, for since specimens of some aberrant forms of Calamitae, the Calamitinae and Archaeocalamites radiatus, have actually, though rarely, been found bearing leaves, we must ultimately assume that the rest of the group were furnished with leaves. We shall have something more to say about these remains of leafy stems further on, when describing the groups to which they belong.

A classification of the Calamitae is a difficult task. It is exactly in the casts that the characteristic marks are so sparingly preserved to us; and if we must be content consciously to have recourse to an artificial arrangement, as best fitted to give a clear view of the whole, the one framed by Weiss ${ }^{3}$ is recommended by its simplicity and convenience, and by the circumstance that it nowhere oversteps the frame supplied by the remains of stems. Weiss has himself described with clearness the objects which he had in view in his divisions, and the importance which he attaches to them. He says ${ }^{4}$ distinctly: "A grouping of Calamitae without regard to their appendicular organs, especially the organs of fructification, is only a more or less elegant mode of getting them arranged in some order, a mechanical procedure for practical convenience,' and in another place: 'If we nevertheless propose to group the Calamitae according to sterile bits of stems, and not even to employ their elementary structure as a principle of division, the only value of such a classification would be to make it more easy to get a general view of the whole from certain interesting points.' Such points are especially the distribution and position of the branches; and if Stur ${ }^{5}$ refuses

1 Weiss (5), t. Io, f. 2 , and t. 12.

3 Weiss (5).

Weiss (5), p. I39̄.
2 Weiss (5), t. 17, f. 4 , and p. 1 35 , with figure. 5 Stur (5), p. I64. 
to allow that these have any systematic value, Weiss ${ }^{1}$ shows that this is virtually because he has united a number of badly identified specimens into one species. At all events Stur has not found a better character for the distinction of species to take their place.

Weiss then distinguishes four form-groups, genera if we like to call them so, of a provisional character. The first of these, named Stylocalamites, Weiss, and embracing the typical forms Calamites Suckowii and C. arborescens, Stbg, is characterised by the unusually small number of branches on the stems, which for long distances may sometimes be entirely without a branch. The pillar-like stems are composed of shorter and longer members without regularity in their succession; the ribs alternate regularly at the nodes. The chief example of the second group, Eucalamites, Weiss, is Calamites cruciatus ${ }^{2}$, and Weiss also places in it C. ramosus, Artis. The former specics, as has been already said, is placed by Grand' Eury with Calamodendron. The pillar-like stems show alternating ribs at the nodes and are copiously branched, one branch springing from each node or several together, which then alternate in the successive whorls. The forms with a few, one to two, branches to each node are classed by Weiss with Calamites ramosus, those with three, four, six or more with C. multiramis, Weiss, which shows the highest number of branch-traces, about nine. A figure of it is given in Weiss ${ }^{3}$.

Somewhat more of detail is required in noticing the third group Calamitina, Weiss (Asterophyllites, Ren., Calamophyllitcs, Grand' Eury), since it includes all the specimens in which the surface of the stem is seen with the leaves attached. The casts of Calamitinae are chiefly found in collections under the name Calamites varians, Stbg, some of them under that of C. approximatus, Brongn. Their distinguishing mark is that branchtraces are not found on every node; the nodes which have them are separated from each other by a number of nodes on which no branches were formed. The nodes with branches display a great number of scars which are usually in lateral contact with one another. Where the ribs are distinctly shown they alternate in the usual manner. The number of the nodes which intervene between the periodically recurrent whorls of branches is generally constant in each specimen; there are, as far as is known, two at least and nine at most; the intermediate numbers three, four, six and eight are frequently observed. The details connected with this point will be found in Weiss ${ }^{4}$. Between the periodic nodes a definite relation is usually apparent in the length of the internodes, which either increases or diminishes from below upwards.

In this third group, as in all other Calamitae, there is no appearance of the characteristic ribs on the surface of the stem.. The surface is either
1 Weiss (5), p. 1 \&1.
${ }^{2}$ Brongniart (1), t. 19.
Weiss (5), t. 12.
4 Weiss (5). 
perfectly smooth, or is traversed by single longitudinal folds and by many irregular transversal wrinkles, which $\mathrm{can}^{1}$ evidently be only produced by displacement, as Stur rightly insists and do not represent an original feature. Specimens from this group, such as are kept in the collections, show not unimportant variations, which are due in part at least to specific differences, in part perhaps to dissimilar mode of preservation. Ordinarily we find on every node a row of small leaf-scars laterally in contact with one another, which are broader in the transverse direction and have a trace-point in the centre. A similar row is also observed on the nodes of the branches, but they are pushed in various ways out of their regular annular position by the large disk-like scars of branches which are developed close to them (whether above them or beneath them cannot be determined), as is excellently described by Weiss ${ }^{2}$ (Fig. 42). Good figures of specimens of this kind are to be found in Weiss ${ }^{3}$, Ettingshau$\operatorname{sen}^{4}$ and O. Feistmantel ${ }^{5}$. In one of the lastmentioned specimens which have been described by Weiss, the leaves are still attached on both sides in the form of thin curved lines of . coal. Specimens of the
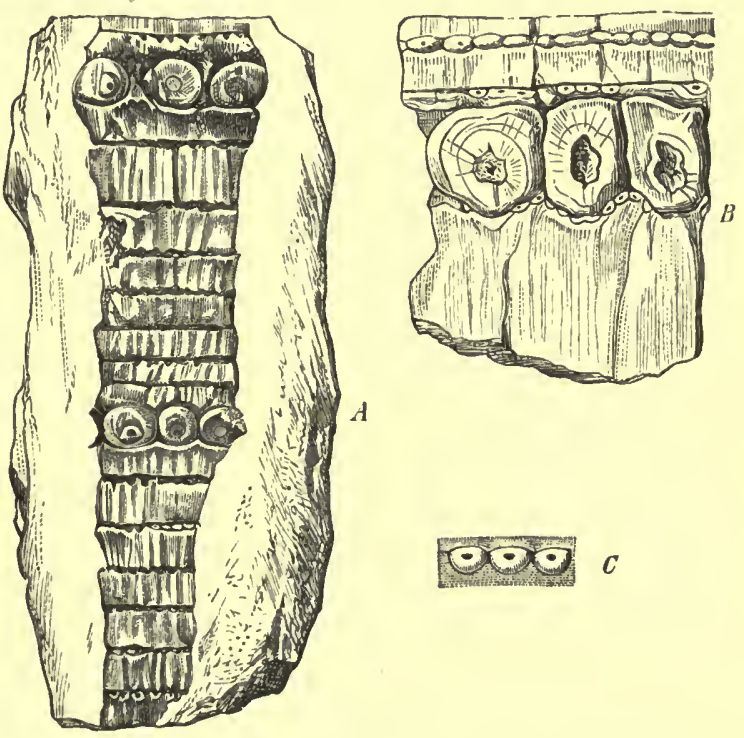

FIG. 42. Surface of stem of Calamitina. $A$ and $B$ with alternating nodes of leaves and branches. $C$ small piece with row of leaf-scars. After Weiss (5). $A$ slightly, $B$ more highly magnified.

state of preservation here described were formerly known by Lindley and Hutton ${ }^{6}$ and others as Cyclocladia; but the name was afterwards applied to quite different objects (Halonia). A well-figured Calamitina of this kind, which was placed with Ulodendron, appears in Steinhauer ${ }^{7}$ under the name of Phytolithus parmatus.

On the other hand there are specimens with perfectly smonth surface, and with the leaves still attached, so that the scars of course are concealed. To these belong the famous Wettin fossils, which have been figured again and again, first by $\mathrm{Germar}^{8}$, then by Schenk $^{9}$, and lastly by Weiss ${ }^{10}$

1 Stur (5), p. I62.

4 von Ettingshausen (5), t. I, f. 4 .

vol. ii, t. I 30 .

f. I and t. 35 , f. I.
2 Weiss (5), t. I6 a, ff. 7,8 , and t. 17, f. I. 5 O. Feistmantel (3), t. I, f. 8.

${ }^{8}$ Germar (1), t. 20, f. I.

Steinhaner (1), t. 6, f. I.

10 Weiss (5), t. I.
3 Weiss (6), t. 17. Lindley and Hutton (1),

? Schenk (2), t. 34 , 
(Fig. 43), and to these must be added the specimen described by Weiss ${ }^{1}$ from Langendreer and perhaps Hippurites longifolia ${ }^{2}$. Nothing can be seen of the nodes; all that appears is a regular transversal row of leaves, which do not touch one another at the base but are separated by tolerably wide gaps, and are very peculiar objects (Fig. $43 \mathrm{~B}$ ). They are composed of an elliptical thickened basal portion, which is traversed by a median furrow and is plainly distinguishable from the long narrowly lanceolate sharply pointed

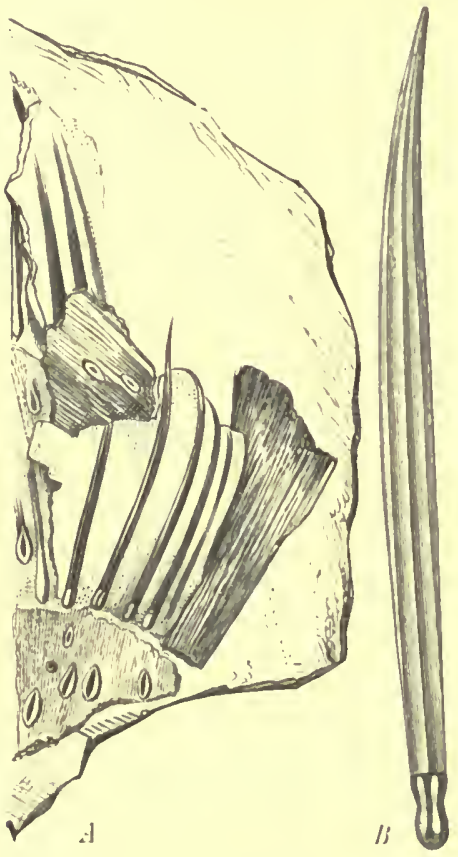

Fici, 43, Leaves of a Calamitina A piece of the smooth surface of the stem with leafwhorls attiched. I' a single leaf showing its peculiarly formed basal portion. After Weiss (5) ; $B$ magnificu.

lamina. The lamina is often torn away and the basal portion alone remains. Leaves which have fallen off entire are according to IVeiss Poacites zeaeformis. I have examined the figure in Schlothcim ${ }^{4}$ and find it comparable rather with the lobes of torn sheaths of Equisctum, but it is in too rough a state to allow of a certain determination.

There are other specimens again besides these, in which we find the leaves attached to the surface of the stem. But the basal portion of the lcaves is of a different form, being shorter and broader, and therefore a less conspicuous object. In these picces the continuous line of scars which is of so common occurrence might remain behind after the fall of the leaves. From the list of figures we may cite those of O. Fcistmantel ${ }^{5}$ and Weiss ${ }^{6}$ (Calamitina varians, var. semicircularis from Bras in Bohemia) and perhaps Hippurites gigantea in Lindley and Hutton ${ }^{7}$ : but it is not quite certain that the latter fossil belongs to the present group, as no branch-node has been preserved. In all these forms the small branchscars, which do not touch one another laterally, are peculiarly formed, being somewhat flattened longitudinally on one side, whence the name of the varicty 'semicircularis.'

Stur ${ }^{8}$ explains the fact, that in Calamitinae it is the surface of the stem which is so frequently observed, by saying that the solid firm outer membrane was set free by maceration, and was then buried by itself. $\mathrm{He}$ states that shreds of the outer membrane belonging to Calamites varians,

1 Weiss (5), t. 17, f. 2.

4 von Schlotheim (1), p. 416, t. 26.

7 Lindley and Hutton (1), vol. ii, t. 114.
2 Lindley and Hutton (1), vol. i, t. 190.

5 O. Feistmantel (3), t. 2, f. 1 .

- Stur (5), p. 162. s Weiss (5). 6 Weiss (5), t. I6, f. 6. 
Stbg, large enough to cover several internodes and sometimes with the leaves still attached, are constantly found at Radnitz along with that species. This explanation, which Weiss ${ }^{1}$ apparently does not accept, since he dismisses it in a few words, seems to me not improbable. The pieces of leafy stem from Wettin are actually shreds of this kind, and answer exactly to Stur's description. This appears from the figures, but I have been able to satisfy myself on the point from the specimens themselves, which were kindly sent to me by von Fritsch. The specimen figured by Weiss ${ }^{2}$ shows the flatly convex outer side, as may be seen from the leaves lying on it and separated from the epidermis by a thin layer of the stone. It is quite irregular in its outline, and nothing can be seen of the cast, of which it must have formed the surface, indeed the gray slaty rock contains a couple of nodular concretions immediately underneath it. Another of the specimens which I received from von Fritsch shows a confused mass of these shreds of leafy outer membrane. The figure in Ettingshausen ${ }^{3}$ may also be compared. The often cited and often figured piece from Wettin ${ }^{4}$ shows partly the epidermis, partly a ribbed impression of the inner surface; Stur explains this by supposing that after the cortical tissue was destroyed by maceration, the mineral matter must have made its way in between the loosened epidermis and the wood, which was still intact. The impression, so far as it shows longitudinal ribs, must therefore answer to the outer surface of the secondary wood, the remainder of it to the inner side of the epidermis; then by uneven fracture partly the one and partly the other side of the cylindrical fracture was disclosed to view. So long as I had only the figures before me, I could not clearly judge of the grounds for this opinion; for the figures are not alike. In Germar ${ }^{5}$ and Schenk ${ }^{6}$ the ribbed portion lies below the epidermal surface, in Weiss' figure above it. I suspect therefore that the two first specimens show one face of the fracture, the third the other face; the contours also are identical in the pieces of the two first authors, in Weiss they are essentially different. I have received Weiss' original specimen from Halle, and have therefore been able to satisfy myself of the correctness of the figure. It is a fragment of a mould, in which the portion of the wood which shows the longitudinal ribbing lies naturally a little above the outer surface, from which it is separated by a thin layer of stone; small remains of the extremely thin rind of coal still cling to its depressions. This last circumstance shows that, as the coal could only be really formed from the wood, the latter lay inside the ribbed surface, and that the ribbing therefore corresponds to the surface of the wood, and not to the medullary tube. And this is exactly the state of things required by Stur's view, which therefore

1 Weiss (5), p. 147 .

4. Weiss (5), t. I, f. 1 .
${ }^{2}$ Weiss (5), t. I, f. 2.

${ }^{5} \operatorname{Germar}(1)$, t. 20, f. I.
3 von Ettingshausen (8), t. 48 , f. 1 . ${ }^{6}$ Schenk (2), t. 35 , f. x. 
in this case also seems to me to be highly probable. When Stur ${ }^{1}$ indeed goes on to say that all the Calamitinae may have been the fertile shoots of other ordinary Calamitae, and supposes the character of this group to have been analogous with that of the homosporous Equisetae, he will find none to share that opinion until he succeeds in producing good and sufficient reasons for it.

The last group is formed of the genus Archaeocalamites, Stur, of which A. radiatus (Bornia radiata, Brongn., Calamites transitionis, Göpp.) is the typical specics. The essential character of the genus, as given by all authors, is the constant non-alternation of the broad flat ribs on the cast, in which also the indentations made by the nodes are often not very pronounced and distinct. The rows of small knobs on the nodal line are seldom plainly seen, and authors differ in opinion respecting their relative position, as has becn already stated. Casts of this kind, usually round but sometimes pressed flat and without any compact rind of coal, are exceedingly plentiful in the Upper Devonian and Carboniferous systems, and are characteristic of them; figures of them will be found in many works, in Schimper ${ }^{2}$ for example and in Stur ${ }^{3}$. They are usually without branches, but, as more recent authors, Stur and Weiss especially, have pointed out, they are occasionally besct with numerous branch-traces, which are found singly or several together on all successive nodes but without giving signs of any regular order. Weiss supposes that the two pieces may have belonged to different parts of the shoot-system; in any case the branched specimens must be very rare, for I have never yet seen one of them.

Our Archaeocalamites occurs in a peculiar state of preservation in the roofing-slates of Moravia. Its remains lie squeezed perfectly fiat between the slates; the organic substance according to Stur ${ }^{4}$ " is replaced only by a very thin, often transparent, brownish membrane, which may have a gold and silver lustre.' Larger stems are very rarely found, and are always in a fragmentary state. But these slates also contain a number of branches which have their appendages attached to them, and show the characters of Archacocalamites in so striking a manner that Ettingshausen ${ }^{5}$ has no doubt that they belong to it. This view has since been confirmed by. Stur's ${ }^{6}$ thorough investigation of these remains, and the two authors also refer Sphenophyllum furcatum ${ }^{7}$ to the same genus. The appendages or leaves, as we prefer to call them with Stur and Ettingshausen, are attached to the nodes in many-membered whorls; they are free and non-coherent down to the base, are narrowly linear, and are branched in a remarkable

\footnotetext{
1 Stur (5), p. 169. ${ }^{2}$ Schimper (1), t. 24 and (4), t. I.

6 von Ettingshausen (7); see also t. 2, f. 3. $\quad$ Stur (6).

3 Stur (5), t. I. Stur (6), p. 6. t. 2 , ff. I, 2 .

7 Geinitz (8), t. I, ff. 10-1 2, and
} 
manner by means of repeated bifurcations. Of this fact there can be no doubt in presence of Stur's ${ }^{1}$ many and excellent figures. The leaves in older whorls stand out at a right angle from the axis; at the upper extremities of the branches, which are preserved in great numbers, they close over one another like leaves in a bud. This says little for the view adopted by Heer ${ }^{2}$, on the strength of some evidently less perfectly preserved specimens, that the organs before us are of the nature of roots. Moreover, Stur ${ }^{3}$ has figured several pieces of stem curved at the base, and bearing on their convex side small tufts of manifest roots, which have small resemblance to the leaves which we have been describing. It is true that we find somewhat different accounts of the foliage of Archaeocalamites in Brongniart ${ }^{4}$ and Schimper ${ }^{5}$. These accounts are based on a famous specimen from the Culm of Burbach near Thann in the Vosges and now in the Museum at Strassburg, which consists of a cast and a piece of the mould which belongs to it. On the surface of the transverse fracture of the piece of stone containing the mould is seen the half of a leaf-whorl projecting at a right angle. This bit of whorl was taken by Brongniart for a close sheath having blunt teeth. But Stur, with whom Schimper in his later publications agrees, has shown that each leaf in the whorl is really free to the base, and that its extremities which are of unequal length

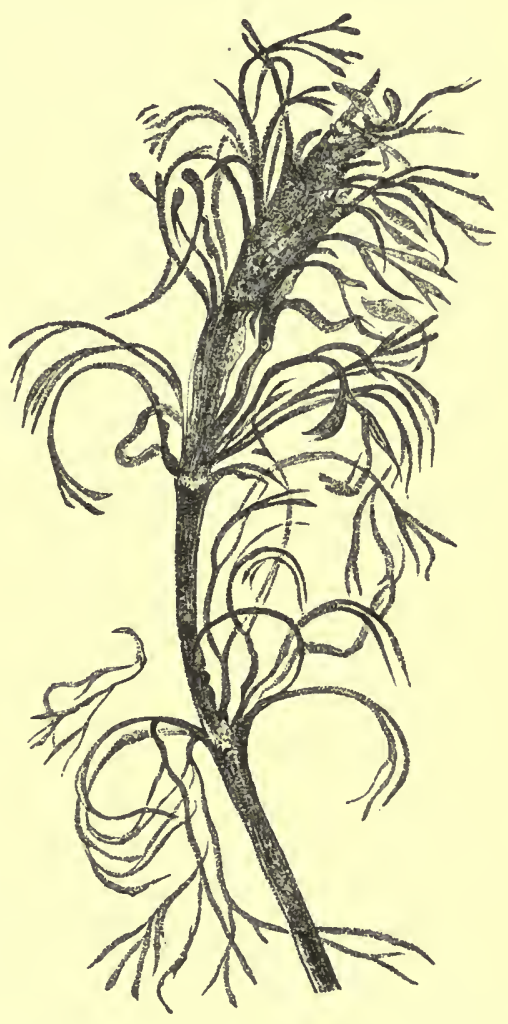

FIG. 44. Vegetative branch of Archaeocalamites radiatus with leaves repeatedly and dichoto.nously branched. After Stur (6).

are not the real apices. He has figured ${ }^{6}$ a similar whorl from the Moravian slates, which is spread out on the surface of the slate, like the specimen from the Vosges, and also shows only the basal portions of the leaves, all the rest having been lost by maceration and rending before the plant was buried. The comparison of these leaves with those of Calamitinae tells us of the great differences which there must have been in the series of Calamariae. Sphenophyllum tenerrimum, Ett., which we

1 Stur (6), t. 2 , f. 8 , and t. 5 , t. I.

2 Heer (5), vol. ii. I, tt. I-7.

${ }^{3}$ Stur (6), t. I.

- Brongniart (1), t. 26, f. I.

5 Schimper (4), t. I, f. C.

${ }^{6}$ Stur (6), t. 2 , f. 7 . 
might also be inclined to place with Archaeocalamites rather than with Sphenophyllum, will be noticed below.

The distribution of Calamitae in the series of deposits is comparatively limited, since they cannot be certainly shown to have existed before the Upper Devonian formation and they disappear again before the Trias. Archaencalamites is the only genus found in the Devonian beds, and in the Culm it is the predominating form. Then its place is taken by Eucalamitac and Stylocalamitae, which are still represented in the Rothliegende by one very abundant form, Calamites gigas. The Calamitinae also are found throughout the true Coal-measures, but do not reach the Rothliegende.

Further, impressions of articulated branches or branch-systems with lcaves in whorls are found distributed throughout the Carboniferous formation in equal abundance with the casts of stones; and these on account of their habit and the striation, like that of Calamitae, which is often to be plainly seen on their older and stronger internodes, it has long been the custom to refer to Calamariae. Though in this case we have no casts, but only impressions on which the substance of the branch is usually prescrved as a rind of coal, we may yet unhesitatingly refer the striation, where it is present, to the ribs of the woody body which have left their impression behind them through the thin rind in the stone. It is in accordance with this, that the terminal ramifications usually show no striae; it may be presumed that no secondary wood was formed in them.

It has been the custom to distinguish these forms into two groups according to the nature of the leaf-whorls, Annulariac found only in the Carboniferous formation, for Dawson's ${ }^{1}$ Devonian forms can scarcely be taken into consideration, and Asterophyllitae which appear to occur in Devonian deposits". In Annularia, Brongn., all the leaves of the whorl cohere at their base into a small patelliform lamina, which like a flat collar surrounds the stem as it passes through its centre. The leaf-teeth are traversed each by a single nerve, and their form varies with the species; in the well-known and abundant Annularia longifolia, which Rothpletz ${ }^{3}$ divides into several species, they are elongate-lanceolate and pointed; in the equally common A. sphenophylloides, Ung., they are much broader, wedge-shaped, and then suddenly contracted, with a blunt rounded extremity. In Asterophyllites, Brongn. (Calamocladus, Schimp.), on the other hand the leaves are quite separated from one another, and they are seldom placed at a right angle to the axis, as in the other genus, but usually incline forwards. They are simple, usually narrow, acicular or linear, of very various but sometimes of considerable length. Good figures 
of different forms of this group are found in Grand' Eury ${ }^{1}$, O. Feistmantel ${ }^{2}$, Schimper ${ }^{3}, Z_{\text {eiller }}{ }^{4}$, Weiss $^{5}$, and Ettingshausen ${ }^{6}$. These Asterophyllitae differ much in the mode and copiousness of their branching and generally in their whole habit. Stur ${ }^{7}$ has recently asserted that some of the forms hitherto unhesitatingly referred to this group had their leaves once dichotomously divided, and he distinguishes them as Volkmannia, Stbg; but this name has in the course of time been applied to so many different things that it would be better to abandon it altogether.

Similar statements are made by Schenk ${ }^{8}$ on the strength of a leafwhorl from St. Ingbert in the collection at Munich. The branches, also with dichotomously divided leaves, which are placed by Grand' Eury ${ }^{9}$ with Arthropitys and are named Bryon, have an entirely different habit and require further study. Stur distinctly claims Volkmannia gracilis ${ }^{10}$ and also Asterophyllites capillaceus ${ }^{11}$ for his genus Volkmannia. Numerous specimens collected by myself from the Skalley mine at Dudweiler near Saarbrücken, which agreed perfectly with the figure of the first of the two species, did not satisfy me as regards this particular character.

We have then gradually become accustomed to look upon Asterophyllitae as branches and branch-systems of Calamitae. Schimper ${ }^{12}$ indeed frankly named the genus Calamocladus. The Annulariae on the contrary have always passed for independent herbaceous water-plants. It would be in vain, however, to seek for distinct proofs of either view in the older literature, if we are not prepared to allow the branch-members of some Asterophyllitae which resemble Calamitae to pass for Calamitae; nor can we derive any help from the anatomy, for no leaf-bearing branch of the group showing structure has yet been found. Grand' Eury ${ }^{13}$ indeed has discovered an indubitable Calamitina with Asterophyllitae attached. Renault ${ }^{14}$, to whom we are indebted for a figure of the piece as it really looks, has therefore transferred the name Asterophyllites to stems of Calamitinae also, and Williamson ${ }^{15}$ does the same. But since this specimen does not justify us in assuming that all Asterophyllitae were borne by Calamitinae, I can only see in this nomenclature a change for the worse. If all stems of Calamitae had the foliage which was described above and which is quite different from that of Asterophyllites, Grand' Eury's observation would prove that there was an interesting heterophylly in the different axes of these plants. Weiss ${ }^{16}$ has shown that Calamitae were not all alike in this respect. He found

1 Grand' Eury (1), t. 32, ff. 2, 3.

2 O. Feistmantel (3), t. 10.

3 Schimper (1), tt. 22, 26.

- Zeiller (3), t. 159. 5 Weiss (1), t. I $2 . \quad{ }^{6}$ von Ettingshausen (3)
${ }^{8}$ Schenk (2), p. 235 ; t. 37, f. $2 . \quad{ }^{2}$ Saporta et Marion.(2), p. $46 . \quad 10$ 5-8, t. I5, f. I. $\quad 11$ Weiss (6), p. 61; t. I1, f. I. ${ }_{12}$ Schimper (1). ${ }^{13}$ Grand' Eury (1), t. 4

Stermberg, (figure diagrammatically represented). $\quad{ }^{14}$ Renault (2), vol. ii, t. 17, f. I. $\quad{ }^{15}$ Williamson (1), v. 10 Weiss (5), p. 99. 
Annulariae, answering nearly to Annularia radiata, Brongn., attached as leafy branches to Calamites ramosus, Artis. He says on this point: 'Calamites, which is particularly easy to recognise in the older portions of its stem by the form of its members, by its ribbing, by the large scars of the main branches, and indeed by its general habit, permits of our bringing a large number of fragments together with certainty under one species. The considerable number of individuals, which have been found recently in the Ruben mine near Neurode in Lower Silesia, almost all in the clay-slate roof of seam No. 7 , and have been most diligently collected, often in great slabs, by Chief-Inspector Völkel, has enabled us to form a more perfect idea of the whole plant in this case than in any other that could be named. The numerous figures which we have given of it rest upon a much larger number of original specimens, so that where there may still be some gaps observable in our figures, we might venture in fact to fill them in, and we believe there can be no longer any doubt as to whether all the single pieces here brought together really belong to one inother.' Hence both Asterophyllitac and Annulariae may belong as leafy branches to Calamitae, though it docs not follow, as Wciss has well shown, that they must in all cascs have belonged to them. It may prove that there were arborescent and herbaccous forms with similar leaves in the group of Calamariac. In any case the classification of Renault ${ }^{1}$, who constitutes two separate families, Asterophylliteae and Annularieae, in his heterosporous Equisetinac, is thus shown to be quite arbitrary.

We have long been acquainted with a large and constantly increasing number of spike-like remains of fructifications with lateral sporangiferous members arranged in whorls. As some of these fructifications have been found connected in a way which admits of no doubt with specimens of Calamariac, we may assume that the rest of them also belong to that group. Heterospory has very recently been ascertaincd in two instances, the macrosporangia occupying the basal, the microsporangia the apical portion of the spike. Williamson ${ }^{2}$ showed this in the case of a spike supposed to belong to Calamostachys Binneyana, and Renault ${ }^{3}$ in that of another which he describes as belonging to Annularia longifolia. Whether this fact is to be assumed as true of all spikes of Calamariae, as is done by Renault, had better be left undecided, and such is Weiss' opinion. The cases of Lycopodium and Selaginella warn us to be cautious in drawing such conclusions.

The spikes, like the other parts of the plants, are presented to us, as might be expected, in different states of preservation. They are either petrified, and then we are able to study the details of their structure; or they appear in impressions, in which case, if the lateral members have been 
brought close to one another, the surface only can be seen, if the arrangement is looser, the organisation also can be examined, but usually much less perfectly than in the petrified specimens. Owing to this difference in the mode of preservation and also to the general similarity of habit, the identification of the several specimens with one another is difficult and uncertain. Premature and misplaced attempts of this kind are among the chief causes of the distracting nomenclature and synonymy, which is nowhere a more serious hindrance to the study of the forms than it is in this case. The old names especially, Volkmannia, Stbg, Bruckmannia, Stbg, have been differently interpreted by almost every later author, and have been connected with various recently discovered types. It will conduce to a better understanding, if with Weiss ${ }^{1}$ we discard them altogether. It is certain that a final system of classification and nomenclature is at once excluded by the fragmentary character of our knowledge of all these remains, and that our only object must be to frame provisional groups, which, corresponding to the state of our knowledge, may afford a general view of the facts as they have been ascertained. Weiss' arrangement secures this advantage in a high degree by refusing to make every difference though not unimportant in itself the occasion of a new name, and by attending only to the ground-plan of the structure; we will follow it therefore in our subsequent remarks.

With the exception of a few remains of abnormal character which will be considered at the end of the chapter, the spikes of Calamariae are all cylindrical in form and more or less thickly covered with leaves, while there is much difference in the relative size of the parts. Wherever it has been possible to examine them, they have been found to be composed of fertile and sterile whorls of leaves which succeed one another in regular alternation. The sterile whorls usually consist of a considerable number of lanceolate sharply-pointed leaves, which are either free or united together by a larger or smaller portion of their bases, the free apices being bent upwards in such a manner as to lie like tiles on the leaf-bases of the whorl next above them of the same description, and to arch over the interposed fertilc leaves, being thus the only ones seen in the surface-view of the whole fructification. The fertile leaves are usually, as in Equisetac, not united together, and are furnished with an umbellately peltate lamina, which bears the sporangia on the under side. According to the relative position of the two whorls to one another Weiss distinguishes the types Calamostachys and Palacostachya, to which latter Huttonia is attached. The entirely provisional names Paracalamostachys and Macrostachya are applied to spikes of imperfectly ascertained structure, in order to connect them with one or the other type, Macrostachya including the forms which in habit resemble forms of Palaeostachya. To 
these must be added Cingularia, Weiss, a fructification of anomalous structure. Stur ${ }^{1}$ considers that he finds his three distinct whorl-traces in regular and characteristic position in each case in the fructification as well as in the stems and branches; but his speculations on this point have been already noticed, and it is unnecessary to go further into them in this place. It is plain that the impressions, the only specimens here in question, are not to be directly compared with the interior casts, on the study of which this author has founded his views.

In Calamostachys, Weiss (Fig. $45 A$ ), the umbellate sporangial leaves are inserted exactly in the middle between every two leaf-whorls; their stalks are at right angles to the axis of the spike, and bear the sporangia at their more or less distinctly expanded and scutiform extremity. Our knowledge of the structure of the fructification in this genus is chiefly derived from a specimen preserved in siderite from Hattingen on the

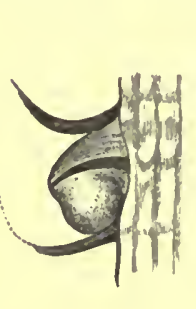

$A$

Fig. 45. Calamostachys, $A$ diagrammatic representation of the structure of the spikes in Calamostachys. $B$ small fragment of the fructification of Calamostachy's (Stachannularia) tuberculata. Between two sterile whorls is a fertile whorl showing the peculiar prickle. like sporangiophore described in the text. A after Weiss (j); $B$ after Weiss (6).

Ruhr, which was first described and figured by Ludwig ${ }^{2}$, then named Volkmannia Ludwigii, Carr. by Carruthers ${ }^{3}$ and Calamostachys typica, Schpr. by Schimper ${ }^{4}$, and has finally been fully elucidated by Weiss ${ }^{5}$ with the addition of fine figures. The specimen contains a number of spikes lying parallel to one another, and may therefore be a fragment of a tuft of fructifications. The leaves in the sterile whorl, about twelve in number, are free almost to the point of attachment, and from their horizontal basal portion the lanceolate upper part curves upwards at a right angle, and exactly covers the curved portion of the leaves of the whorl next above. The whorl of sporangiophores inserted between two leaf-whorls has six members; the members in the successive sporangial whorls are superposed; of the twelve members in the leaf-whorls six appear to alternate, six to be superposed. The substance of the sporangiopliores, especially in the small scutiform expansion, is partly preserved in a few cases only. But the sporangia themselves, which are suspended in fours in a diagonal position from the scutellum of the sporangiophore, are comparatively well preserved. Their wall, which is of one cell-layer only, at least in its present state, is formed of reticulated cells. The doubts expressed by Weiss ${ }^{6}$ respecting the connection between the thickening-ridges and the membrane may have no foundation. The sporangia are filled in uniform manner with the globular

\footnotetext{
'Stur (5). ${ }^{2}$ Ludwig (1).

3 Carruthers (15).

- Schimper (1), vol. i, p. 328.

s Weiss (5), p. 249 ; tt. 18 and 22-24.

6 Weiss (5), p. 253.
} 
spores, which show the triradiate ridge. From their size I should suppose them to be microspores, but this is not certain, for a similar spike, which will be described presently, containing both kinds of spores, shows us that the differences in size need not be very great, and that macrospores also may be formed in large numbers in a sporangium.

We have also learnt something respecting the anatomical structure of the axis ${ }^{1}$. Rind and pith partially preserved are parenchymatous, and are separated from one another by a rather broad closed ring of wood nearly triangular in shape. I was unable to form a clear idea of the character of the imperfectly preserved medullary sheath from the original sections sent me by Weiss for my inspection. A preparation of Williamson ${ }^{2}$ from the nearly allied Calamostachys Binneyana will perhaps supply what is wanting on renewed examination. What there was to be seen was quite in accordance with the structure of Calamitae, but I would rather not at present venture on positive and detailed statements.

A second species, the organisation of which is well known, Calamostachys Binneyana, Schpr., was first figured by Carruthers ${ }^{3}$ as Volkmannia Binneyi, then by Binney ${ }^{4}$ as the fructification of his Calamodendron commune, and lastly and repeatedly by Williamson ${ }^{5}$. It is smaller than the preceding, and while the structure is in essential points the same it is distinguished by the much smaller development of its woody body, and especially by the circumstance that the leaves of the sterile whorls are seen to be united to one another almost as high as the point where they bend over, and therefore form on the tangential section transverse connected laminae ensheathing the sporangiophores, as is represented in Binney ${ }^{6}$. So far all these spikes, which are apparently plentiful in the English calcareous nodules, agree with one another. Nevertheless both to myself and Weiss it appears doubtful whether they really all belong to one another, whether different species of similar habit have not been included under the one name. Williamson ${ }^{7}$, for example, describes a fragment of a spike which has macrosporangia below and microsporangia above. The two are exactly alike and contain numerous spores, which are distinguished merely by a moderate difference in size, the larger having about three times the diameter of the smaller. Now it is very remarkable that Binney, though he figures the radial section of the base of a spike ${ }^{8}$, found no such macrosporangia in it, and it may be suspected that there were none in this particular spike. And on the other hand in the collection of sections in the Botanical Department of the British Museum I have seen similar sections of spikes which appeared to contain only macrospores, and these seemed to show the three

1 Weiss (5), t. 24. 2 Williamson (1), x, t. 16, f. I6. 3 Carruthers (15).

I, tt. 4, 5. $\quad 5$ Williamson (1), v, t. 6; X, t. I5, ff. I3-I ; XI, t. 54, ff. 23-26. I, t. 5 .

7 Williamson (1), xI, t. 54 .

8 Binney (1), I, t. 5, f. 4 .

${ }^{4}$ Binney (1),

${ }^{8}$ Binney (1), 
small undeveloped sister-cells of the tetrad still distinguishable at their apex. Moreover in one of the specimens figured by Williamson ${ }^{1}$ the spores were united in tetrads and still surrounded by the mother-cell, but this might be explained by the young condition of the fructification when it was buried. The vicw lately expressed by Renault on the subject of Calamostachys Binneyana will be noticed presently, when we are considering the species which he has examined.

Weiss ${ }^{2}$ has given the name of Calamostachys superba to a spike known only in longitudinal fracture, which, though not very well preserved, presents essentially the same conditions as the forms already noticed. Whether the leavcs of the sterile whorls, which are marked by the excessive elongation of their apical parts, colhere or not cannot be ascertained, as the specimen shows only the true radial section. It comes from the Augustus mine in the Plauensche Grund near Dresden, and is imbedded in a whitish clay. There is no exact account of the mode of prescrvation. There is another specimen with it in the Museum at Dresden which was found in the same spot, and which Weiss ${ }^{3}$ has named Calamostachys mira. Its radial longitudinal section shows most distinctly the position of the two kinds of whorls and the point of attachment of the sporangia. But it also shows a portion of the surface; we see the free apices of the sterile leaves, which have undoubtedly become united together below into a horizontal lamina after the manner of Calamostachys Binneyana. From the place where the lcaf is bent, and which is not covered by leaves of the whorl next beneath it, a lamelliform emergence hangs down like a curtain, the form and limits of which cannot be determined, but which appears even on the sides of the fracture in the form of a finc line of through section running down in front of the sporangiophores. Weiss says of it ${ }^{4}$, 'bracts . . . with a reflexed appendage protecting the sporangia.' We find something like it also in Huttonia. Weiss also citcs as perhaps analogous with this form a specimen described and figured by Renault $^{5}$ and named Macrostachya infundibuliformis, but which is of so questionable a character that I should not attribute much importance to it.

Mention must also be made here of an object from Autun of which a section was made by Renault $^{6}$, and which was described by him as the fructification of Annularia longifolia. It is evidently a true Calamostachys, though the attachment of the sporangia to the sporangiophore is not clearly shown, and the sterile whorls of entirely free lanccolate leaves, being spread out flat, and even bent a little backwards in the basal portion, do not cover the fertile leaves from the outside. The distinguishing mark in this spike is that its axis, which has a similar structure to that of Equisetum,

1 Williamson (1), x, t. I5, f. $27 . \quad 2$ Weiss (6), t. 4 , f. $2 . \quad{ }^{3}$ Weiss (6), t. 3, f. 1 , and t. 4 , f. I. - Weiss (6), p. 43. ${ }_{5}^{5}$ Renault (2), vol. ii, t. 19, ff. 7, 8. 'Renault (16 and 2), vol, ii, t. 21, f. 2. 
shows a hollow medullary cylinder and a weakly developed ring of primary bundles, in each of which is a lacuna. Renault says distinctly that he has found tracheal elements only in the immediate neighbourhood of the lacuna.

Renault ${ }^{1}$ has also described two other spikes of Calamostachys as Bruckmannia Grand' Euryi and B. Decaisnei. As they were obtained from sections of the siliceous fragments of Grand' Croix, the details only of their structure are known. The structure of their axes agrees perfectly with that of the form already described from Autun. A remarkable feature is the large number of members both in the fertile and in the sterile whorls, eighteen in the fertile whorls in Bruckmannia Grand' Euryi and twelve in B. Decaisnei, while in the sterile whorls there are twice these numbers. With this agreement between the numerical relations and those of Calamostachys Ludwigii, we may assume that there was here the same alternation as in that species. The sporangial leaves have the usual umbrella-like form; they bear four sporangia, as Renault ${ }^{2}$ distinctly states ${ }^{3}$ and as his figure shows, exactly in the position which they have been described as occupying in Calamostachys Ludwigii; the upper surface of the umbrella-roof is strongly developed, and reaches to the leaf-whorl next above it and unites with it. A branch of the foliar bundle, which bifurcates twice, runs to each of the sporangia, which are themselves badly preserved. The spores in Bruckmannia Grand' Euryi lie connected together in fours in their mother-cells, which also unite together in fours ${ }^{4}$. In the sterile whorl the leaves, which cohere below, form the often-mentioned horizontal disk, while their free upper extremities bend sharply over and are directed upwards. There is one circumstance peculiar to these two species and sharply distinguishing them from the typical forms just described, namely, that each sporangiophore is connected by means of a vertical radial plate of tissue with the basal disk of the lcafwhorl next above it, and thus the sporangia, at least those in the upper row, come to lie in radial compartments, which are open below but are covered towards the outside by the extension of the umbrella-roof. In this way I understand, and I believe correctly, Renault's description, in which there is absolutely no room for assuming the presence close.beneath the sterile whorl of a third whorl from which the plates spring, and which Stur ${ }^{5}$ makes the foundation of his interpretation of the structure.

Renault ${ }^{6}$, who formerly ranked all the spikes which we have been describing with his Asterophylliteae and Annularieae, has very recently put forth the view, that a part of them belong as male flowers to Arthropitys, and to Calamodendron as he understands that genus. He expressly mentions Calamostachys Binneyana and C. Grand' Euryi as belonging to this division, and calls their spores directly pollen-grains. He relies in this

\footnotetext{
1 Renault (5), tt. 3, $4 . \quad{ }^{2}$ Renault (5), t. 4, ff. 8, 9. $\quad{ }^{3}$ Renault (5), p. I6. $\quad{ }^{4}$ Renault (5), t. 3 , f. 5. $\quad{ }^{3}$ Stur (5), p. 147 and figures. ${ }^{\circ}$ Renault (17).
} 
matter partly on the structure of the wood in the axis of the spikes, partly on the details observed in the spores, in which he is persuaded that he sees an interior cell-formation resembling that in the pollen-grain of Cordaitac. He appeals also to the combination of the grains into tetrads, comparing them with the tetrads in the pollen of Angiosperms, and lastly to the circumstance that tetrads of perfectly similar character are found in the pollen-chamber of certain Trigonocarpae and of Gnetopsis trigona. $\mathrm{He}$ considers that the leaves of the sterile whorls were coherent in Arthropitys and free in Calamodendron. The following sentence is characteristic ${ }^{1}$ : 'In Calamodendron, Arthropitys, Annularia and some species of Asterophyllites the fructifications are disposed in almost the same manner, that is to say, in the form of spikes composed of sterile and fertile whorls alternately; in most cases it is not possible to determine from the impressions the precise nature of the reproductive bodies belonging to these groups of piants, which are however somewhat remote from one another.' It is not easy to criticise so dogmatic a statement, especially when the grounds for it are all put before us in so brief and prefatory a manner; but I would make the following observation. We have no analogue anywhere of a male flower with alternating fertile and sterile whorls of leaves. That single spore-tetrads are found in the pollen-chamber of wind-fertilised Gymnosperms is not conclusive; every cell which is smaller than the orifice of the micropyle will find its way into it, if it reaches it in its flight. Spores connected together in fours are not known indeed, but are perfectly possible. The interior cell-formation can also prove nothing, if we suppose it to be a rudimentary prothallium, as I do notwithstanding Strasburger's recent arguments; it is peculiar, as we know, to microspores, and the degree of devclopment is of no importance. Lastly, what will Renault do with Williamson's spikes which contain macrospores and microspores? These must necessarily remain with Annulariae in spite of their resemblance to Calamostachys Binneyana. The sole criterion therefore remaining is the secondary wood of the axis of the spikes, and with this we arrive once more at the pctitio principii of Brongniart's school so often mentioned already, which makes the understanding of their writings everywhere so difficult.

Lastly we may unite with Calamostachys Grand' Euryi certain fructifications which Weiss ${ }^{2}$ names C. tuberculata (Fig. $45 \mathrm{~B}$ ), while he makes the genus Stachannularia previously ${ }^{3}$ created for them into a subdivision. Renault and Grand' Eury ${ }^{4}$ especially are inclined to regard the two as directly synonymous, and they may be right, though as the states of preservation are not comparable we cannot at present have positive proof in either direction. Unlike the spikes hitherto described which are all petri-
1 Renault (17).
${ }^{2}$ Weiss (5).
Weiss (6).
${ }^{4}$ Grand' Eury (1), p. 45. 
factions, Calamostachys tuberculata, Weiss, is known only in the form of impressions, which however show the organisation since the sterile whorls are but slightly closed. It is a well-known spike already figured by Sternberg ${ }^{1}$ as Bruckmannia tuberculata, and has been found not unfrequently in the Carboniferous schists of various deposits, at Ilmenau, at Saarbrücken, at Zwickau, and at Schlan in Bohemia. According to Weiss two forms of organisation occur in Calamostachys tuberculata simultaneously on different spikes of the same plant. First there are the ordinary sporangiophores placed in the middle of the member, but each with only two sporangia, one above and the other below. Besides these there are sporangiophores of a different character in the form of stout prickles like those of the rose and bent downwards, which have a single sporangium only in the angle, and are inserted immediately beneath a sterile whorl. This whorl has many members (twenty to thirty according to Weiss), and consists of upward-curved linear leaves. Schenk ${ }^{2}$ has since brought forward some important objections to this account. . He shows that the two types of organisation assumed by Weiss are sometimes found even on the same spike, and he concludes from this that they only represent different modes of preservation of organs originally alike. He says ${ }^{3}$ : 'What I dispute is, that two forms of sporophylls running a different course of development occur normally in the same species, for the history of development in extinct plants is subject to no other laws than those which govern it in living forms.' This, apart from the possibility which exists of a different development of the leaves bearing macrosporangia and microsporangia, is no doubt true. Then to explain the origin of the prickle-like sporangiophores, Schenk supposes that the upper sporangium had its margin forced by the pressure beyond the sporangiophore, and so the two became combined in a common impression. Another similar explanation, which appears to myself and Stur ${ }^{4}$ to be still more satisfactory, and which is quite in keeping with Renault's statements concerning Calamostachys Grand' Euryi, is that the prickle-like sporangiophore is formed of the stalk of the sporophyll and the radial tissue-plate, which connects the latter with the whorl above and which is here torn away to the base. It is true that this mode of explanation presupposes that there were not two or one but four sporangia present as usual, and that only two of these are seen in the impression. The upper one of the two, if still present, must also be flattened together with the vertical wing of the sporangiophore into a homogeneous plate of coal. In this way the structure of Calamostachys tuberculata may be reconciled with that of $\mathrm{C}$. Grand' Euryi. There remains only the peculiarity of the varying length of the internodes, for the whorls of sporophylls are undoubtedly placed far above

1 Sternberg, Graf von (1), Heft I-4, p. 29; t. 2 I, f. 4 .

${ }^{3}$ Schenk (2), p. 232.
${ }^{2}$ Schenk (2), p. 23I, \&c., and t. 36. 
the middle of the interval between two leaf-whorls. Further researches will perhaps succeed in removing these doubts. Nearly allied to Calamostachys tuberculata is C. calathifcra ${ }^{1}$, but in this species only the normal sporophylls with two or four sporangia have at present been observed.

Palacostachya, Weiss, differs from Calamostachys in having the whorls of the sporophylls inserted immediately above the sterile whorls, it may be almost said in the axils of their leaves, so that they project from them at a more or less acute and not at a right angle. Only one form of this type is

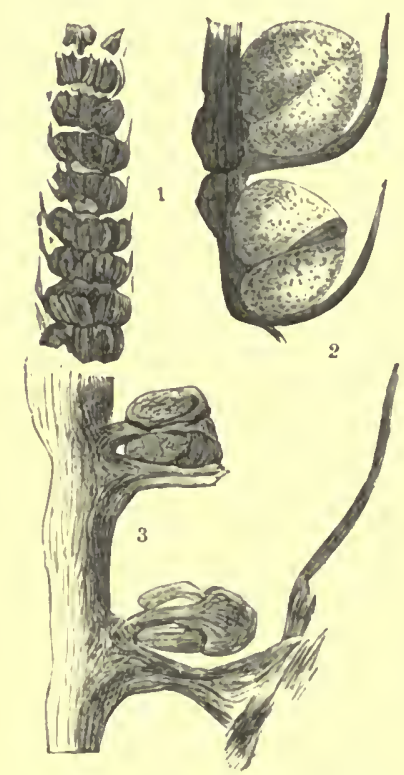

Fic. 46. Palaeostachya. I. Habit of 1 '. elongata from Radnitz in liohemia. 2. Small piece of a similar spike more highly magnified. 3. Picce of the longitudinal section of a spike of 1 '. gracilis, Ren., from Autun. From Zittel's Text-book. known in the petrified state, the rest are all impressions. The silicified specimen in question comes from Autun, and is named by Renault Volkmannia gracilis ${ }^{2}$. He would have done much better if he had given it a new name, considering the difference in age of the beds of Autun and Radnitz, in the latter of which Sternberg's original Volkmannia was found; and also because Sternberg unites branches and cones which it is possible do not belong to one another, while the roughness of his figures precludes the possibility of any certain identification. Renault's ${ }^{3}$ drawings show a hollow axis, and the well-known lacunac answering to the initial bundles reappear in its peripheral tissue.

. The sterile whorls are separated by internodes of some length, and consist of as many as twenty lanceolate free leaves, which are at first straight and spreading, but afterwards bend geniculately upwards, while the clongated apical portions overlap one another like the tiles of a roof. At the bend they show on the dorsal side a round or ridge-like emergence projecting downwards. The sporangiophores are inserted immediately above these sterile whorls and are axillary; their solid stalk expands into a large covering plate, from the inner side of which are suspended four sporangia (Fig. 46, 3).

The most important of the species known to us in good and clear impressions is Palacostachya clongata, Presl ${ }^{4}$, from the coal-producing mountain country of Bohemia (Fig. 46, I and 2). The original specimen in the Museum at Prague shows a much divided branch-system, composed of members with the striation of Calamitae and bearing numcrous elongate-

1 Weiss (6), t. 3, f. I I, and Sterzel (3), t. 28, ff. 2-4.

${ }^{2}$ Sternberg, Graf von (1), Parts 5-8, t. 15, ff. I-3. $\quad{ }_{3}$ Renault (5), t. 2, and (2), vol. ii, tt. 18, I9. 4 Weiss (6), p. 108 ; t. 5. 
cylindrical and somewhat narrow spikes. Another fragment from the Myslowitzer Wald in Upper Silesia referred by Weiss ${ }^{1}$ to this genus is in a lèss perfect state of preservation. The leaf-whorls are formed of many, perhaps twelve, narrow-lanceolate free members which do not touch one another laterally. They seem at the first glance to have obcordate sessile sporangia in their axils; but in many of them may be seen a vertical median strip of tissue running to their apex, which is explained by Weiss to be the sporangiophore and which comes out most plainly in the Myslowitz specimen. If this is the true explanation, as it probably is, then there is in this case no umbrella-like apical expansion. There are some doubts respecting the number of the spores; from the drawings it might be concluded that there were two median spores; but Weiss considers it possible that they were as usual developed in fours.

Of Palaeostachya Schimperiana ${ }^{2}$ we can only conjecture that it belongs to the genus. It is a large long cylindrical spike of considerable thickness and with the habit of the plant usually known in the literature as Macrostachya, Schpr. It appears in Weiss' ${ }^{3}$ earlier publication as Macrostachya Schimperiana. This spike which comes from Saarbrücken and is inclosed in gray argillaceous sandstone is broken through longitudinally, and shows the axis and the sporangiophores in the axils of the leaves in the form of strips of coal, the latter as very fine strokes.

The spikes also which are supposed to belong to the genus Huttonia have only been found up to the prescnt time in the form of impressions. In habit they are extremely like the large impressions of Microstachya, so that it is not easy to distinguish the two without a knowledge of the internal structure. The only species certainly determined as belonging to the genus, Huttonia spicata, a well-known fossil first described by Sternberg ${ }^{4}$, appears unfortunately to be rare, having been found hitherto according to Weiss only in Bohemia and near Eckersdorf in Lower Silesia. Good figures are given in Schenk ${ }^{5}$ and Weiss ${ }^{6}$, the older ones being reproduced in these authors and also in Schimper ${ }^{7}$. I have never myself had opportunity for minute examination of this form, and I therefore keep to Weiss' statements, which however notwithstanding the careful studies on which they are based are still of rather fragmentary character. The sporangiophores for instance are known only from vestiges of remains, which are found on the longitudinal fracture of the spike and which spring from the axils of the leaf-whorls. These whorls are composed of numerous, that is of from sixteen to twenty, free lanceolate members which narrow upwards into subulate extremities, and which from the partial overlapping of

1 Weiss (5), t. 22, f. 15 .

2 Weiss (6), p. $105 ;$ t. 5 , and (5), p. 27 1; t. 21 , f. 8.

(1), p. I22; t. I8. Sternberg, Graf von (2).

(6), t. 13, f. 4 , and t. 14 , and (5), t. 21, f. 9.

${ }^{3}$ Schenk (2), t. 4 I, ff. I, 2.

${ }^{3}$ Weiss

${ }^{6}$ Weiss 7 Schimper (1), t. 17 . 
their margins often appear to unite into a sheath. But close underneath each leaf-whorl is a disk-shaped plate, the margin of which, though very imperfectly preserved, is seen to be divided into obtuse lobes. Whether this object really represents a free sheath, or whether the lobes spring as duplicatures from the dorsal side of the single leaves in a similar manner to that observed in Calamostachys mira or Palaeostachya gracilis, Ren., are points on which Weiss himself does not speak very decidedly. From Schenk's figures cited above, especially from the first of them, we should perhaps incline to the latter supposition.

Besides the remains of fructifications which have been discussed at length in the preceding pages there are still a considerable number of similar objects, which are described in the literature under a great variety of names. So far as their inncr structure is known, they are allied to the types of Calamostachys and Palacostachya. We must not attempt to consider all these remains one by one; we can obtain nothing either from them or from the Macrostachyae or Paracalamostachyae, of which we know the habit only, that can in any way add to our knowledge. Two of them, which were found attachcd to their vegetative parts, will have to be noticed again presently from this point of vicw; here we need not go further into them. One or two remains of impressions of very doubtful character may, however, be mentioned here for completeness sake. These are Volkmannia pseudosessilis ${ }^{1}$ and the analogous form Annularia brevifolia ${ }^{2}$, then Volkmannia effoliata ${ }^{3}$ and lastly Volkmannia Morrisii ${ }^{4}$. A form, which might be suitably named Paracalamostachys has been described by Göppert as Aphyllostachys Iugleriana. It would only be of interest, if, as Göppert supposes, it really came from the Lias. But since it is not ccrtainly known where the specimen, which is in the Museum at Breslau, was found, though it is said to have been picked up near Engern in Hanover, and might very well come from the Coal-measures of Westphalia, as Göppert himself intimates after all, we need not for the present devote any attention to it.

It remains still to notice a few essentially abnormal fructifications, mentioned before as anomalous forms, of which the most important and best-known is Cingularia typica ${ }^{5}$ (Fig. 47). This is a very remarkable fossil, found up to the present time, as far as I know, only at Saarbruicken and St. Ingbert, but not infrequent in those localities and occurring in seams of very different description. The long slender spikes have a thread-like striated axis, with sterile and fertile whorls spread out quite horizontally and closely approximated to one another in pairs. In cach pair of whorls the upper member is sterile, the lower fertile; the

1 Grand' Eury (1), t. 6, f. 3 .

t. 6, f. 2. Hooker (5).

Stur (5), p. 149 (with figure).
2 Schenk (2), p. 233, f. 12. ' Grand' Eury (1), p. 41;

${ }^{3}$ Weiss (6), p. 88 ; tt. 6-8 ; Schimper (1), t. I09, ff. I-4; 
internodes are considerably elongated between the pairs. The leaf-whorl forms a horizontal sheath-plate, which is prolonged outwards into a large number of lanceolate sharply pointed teeth. In contrast to all other known kinds of Calamariae, the fertile whorl does not consist of separate free umbrella-like leaves, but forms a connected circular sheath, independent though inserted on the axis close beneath the sterile whorl, and having its somewhat deeply incised margin composed of wedgeshaped almost truncated lobes. Twelve of these lobes were counted

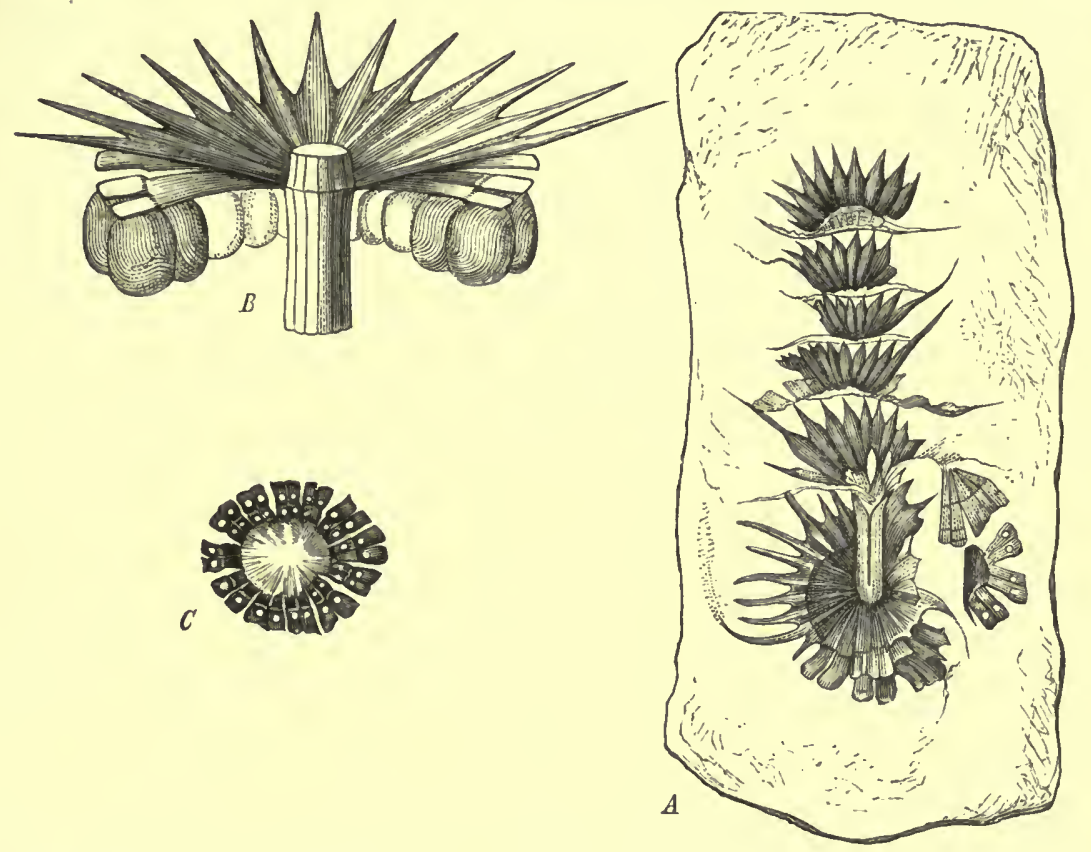

FIg. 47. Cingularia typica, Weiss. $A$ sterile and fertile whorls, the latter in the upper part of the figure in radial fracture. $B$ diagrammatic reconstruction of two whorls. $C$ fertile whorl from the upper side; the clear pits correspond to the spots to which the sporangia were attached beneath. After Weiss (6).

on a perfect whorl figured by Weiss ${ }^{1}$. Stur's reconstruction, in which

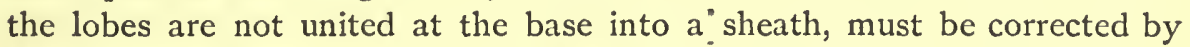
the above description. Each of the lobes is slightly bipartitely marginate along a furrow which follows the median line, and is also divided by a distinct transverse fold into an anterior and a posterior segment. On the under side of each of the somewhat rectangular areolae, formed by the intersection of the median furrow and the transverse fold, is a circular attachmentscar, which when the preservation is good is surrounded, as the sun by its rays, with a delicate radial striation. The sporangia, four in number, were attached to these scars: they were found so connected in a specimen figured by $\mathrm{Weiss}^{2}$, in which they hang vertically downwards from the under side 
of the lobes of the sheath. They are peculiar in form, being a little compressed on one side. They are comparatively very large and are marked with a very fine striation in an oblique direction, which may be distinguished even when they have fallen from the sheath which bore them and lie about beside and between the specimens, as is usually the case. The positions of the entire spikes in the stone are peculiar; they either lie horizontally on the surface of the beds, or, which is the more common case, the slender axis is vertical to the beds, and the separate whorls are spread out flat on their surfaces. This would imply that the whorls were still stiff and rigid when they were buried. Though the spikes usually occur very many together-I found a block of stone on the refuse-heap of the Skalley mine which contained hundreds of them-yet the vegetative organs which bore them are scarcely known; a few specimens only have been found, in which one or two spikes were attached to bits of articulated striated branches resembling those of Calamitae ${ }^{1}$. I did not succeed in finding more of the same kind on the occasion referred to, though I looked for them very carefully. Brongniart's ${ }^{2}$ Equisetum infundibuliforme may also belong to Cingularia. Only the sterile whorls are disclosed by the fracture. I have scen specimens in Goldenberg's collection at Saarbriicken, which were evidently Cingulariae and which answered to Brongniart's figure.

There is another quite peculiar fossil, supposing the reconstruction of it to be correct, which has been described by Williamson ${ }^{3}$, and which was found, unfortunately only in a small fragment, as a petrifaction in a calcarcous nodule from Lancashire. Its hollow axis shows the usual peripheral lacunae which answer to the primary bundles, but here they are curiously approximated to one another in pairs. According to Williamson's account there was only one kind of whorl, in which the leaves were united below into a somewhat concave plate and prolonged above into numerous erect free apices. The sporangiophores are supposed to have been placed on the inner side of the basal plate of the leaf-whorl, and the sporangia to have been attached to them. But the small size and the imperfect state of this fossil give room for many doubts.

The genus Bowmanites, Binney, is also founded on some problematical remains. The type is Bowmanites cambrensis ${ }^{4}$, which was found in some clay iron-stone workings near Hartypool in South Wales, and appears for the most part only in the form of a mould. The chief portions of it are lost; two which were saved are in Binney's collection, which during my many visits to Manchester was always inaccessible. The figures too are partly from sketches by the former owner of the specimen, Mr. Bowman. The compact cylindrical spike surrounded by long erect leaf-tips is attached

1 Weiss (6), t. 7, f. I, and t. 9, f. I. ${ }^{2}$ Brongniart (1), vol. i, t. 12, f. 16.

Williamson (8).

- Binney (1), II, t. 12. 
to the extremity of a branch with striated internodes and somewhat swollen nodes, and showing distinctly the characters of Asterophyllitae. According to the sketch of a longitudinal section by Mr. Bowman reproduced in Binney ${ }^{1}$, the spike would appear to consist entirely of whorls all like one another. In the interval between every two whorls is a row of roundish bodies, which Binney explains as macrospores, but which Weiss ${ }^{2}$ considers to be sporangia. It is in favour of the correctness of the sketch alluded to, that Weiss ${ }^{3}$ figures a fossil of exactly similar structure, Bowmanites germanicus, Weiss, from the Gustav mine near Schwarzwaldau in Lower Silesia. Whether Volkmannia Dawsoni", which will be described presently, belongs, as Weiss thinks, to the group which we are considering, is in my opinion very doubtful. The structure of the axis is not in favour of its belonging to Calamarieac. The same structure might also have been present in well-ascertained Bowmanitae, and remove them from Calamarieae; but only fortunate discoveries can enable us to determine these points.

Lastly, there are a few very imperfectly known fructifications which should be mentioned, and which, though differing to some extent from each other, have been referred by various authors to Archaeocalamites.

There is first of all a series of doubtful impressions known as Pothocites, Paterson from the lowest beds of the Carboniferous formation of Scotland (the Calciferous limestone series), which Kidston ${ }^{5}$ has sought to place with Calamarieae. The older literature of these objects has also been collected by this author. The remains in question are long spikes on the extremities of branches like those of Asterophyllitae, and bearing short leaves. The spikes are divided by constrictions into cylindrical members, and in each constriction is a sterile leaf-whorl composed of short filiform free leaves. The only quite perfect known specimen, Pothocites Grantoni, Paters. ${ }^{6}$ has eight cylindrical members. These members are always much compressed and converted into a tolerably thick compact covering of coal, and appear to consist of numerous small ovoid bodies (sporangia?) arranged in longitudinal and transverse rows. Besides these bodies there are also peculiar star-shaped figures with from four to five rays, also disposed in longitudinal rows and belonging to the surface of the member, so that they are not visible when that is badly preserved; the rays have raised margins ${ }^{7}$. Kidston considers these stars to be sporangia, but I must doubt this, as I have already intimated; but though I have had opportunity of examining several specimens, I am unable to offer any other explanation of them. Again Stur ${ }^{8}$ sees in Asterophyllites spaniophyllus, Feistm., described by O. Feistmante ${ }^{9}$ from the Carboni-

I Binney (1), II, t. I2, f. 3 . - Williamson (9).

ff. $3-5$.

${ }^{8}$ Stur $(6)$.
2 Weiss (5), p. 200.

- Kidston (4), t. 12, f. I3.
3 Weiss (5), p. 201 ; t. 2 I, f. I 2.

${ }^{7}$ Kidston (4), t. 9 , 
ferous limestone of Rothwaltersdorf in Silesia, a branch of Archaeocalamites radiatus bearing terminal fertile spikes, and known by its long dichotomously divided leaves. He gives a new figure ${ }^{1}$ of the impression of the spike, which unfortunately is in a very bad state of preservation. He believes that he recognises in it a spike composed of numerous sporophylls interrupted from time to time by a sterile leaf-whorl. This view is to some extent in accordance with the arrangement of the parts in Pothocites, and it reminds us of the structure of the fructifications, perhaps belonging to Phyllotheca, which was described above on p. 181 . Lastly, Renault ${ }^{2}$ in a preliminary communication has described fructifications, which he says that he has found in a good state of preservation and still attached to their branches. The more detailed account of these objects will perhaps throw more light on them. According to his statements, the 'male fructifications of Bornia' are spikes bearing sporophylls only. These sporophylls, from eight to ten in a whorl, are umbrella-shaped, and as usual bear four sporangia. They come from the anthracite-beds of La Vendée, and, as Renault distinctly says, have been already figured by Grand' Eury ${ }^{3}$. The figure in the text of Grand' Eury's work does not indeed appear to me to answer too well to the description. We are not told whether the spikes which Grand' Eury found attached to his Bryon (see on p. 323 ) are referred, as they might be, to these forms.

It would be very important to know what were the organs of vegetation belonging to each of the fructifications in the rich series which has now been described. On this point unfortunately there are but few quite certain facts to which we can appeal. It has been ascertained in the case of a number of spikes, as appears from the foregoing remarks, that they are attached to leafy branches resembling those of Asterophyllitae, but this leaves us still in ignorance in almost every case of the stems to which the leafy shoots belonged. Conjectures on this subject there are indeed in plenty, based more or less on personal persuasion for which no exact reasons can be given, but such views cannot be discussed here to any profit because of the instability of their foundations. In the following remarks therefore I shall mention only those cases in which spikes of known organisation have been found in direct connection with vegetative parts capable of being determined, for only these can serve as a basis for further research. The first that should be mentioned are Calamostachys tuberculata, Weiss, and C. calathifera, Weiss, both of which were found attached to leafy branches of Annularia longifolia and A. sphenophylloides in impressions near Lugau in Saxony. Sterzel ${ }^{4}$ has illustrated the connection between the two latter forms by means of excellent figures,

\footnotetext{
Stur (6), p. 15, f. 4 .

4 Sterzel (3), t. 28.
}

2 Renanlt (19) and (18).

${ }^{3}$ Grand' Eury (1), p. 54, f. I. 
which are wanting in the case of the others, but we have meanwhile his express testimony ${ }^{1}$. Both leafy branches and fertile spikes were found together attached to rather thick flattened stalks covered with a thin rind of coal, exactly in the manner represented by Weiss ${ }^{2}$. Now Weiss had already compared the piece of stem in his specimen, which has an annular swelling at the upper node, with the doubtful Equisetides lingulatus (see above on p. 178 ); Renault ${ }^{3}$ too, though not as the result of more searching examination, had referred this form to Annularia longifolia, and Schenk ${ }^{4}$ on the strength of the specimen figured had assented though not unreservedly to this view. And now it receives fresh support from Sterzel. Sterzel was not able to distinguish a specimen before him of the remains in question from his Annularia-stalks. He says that there should be eight fertile spikes at the nodes, and their sporophylls should show the customary structure of Calamostachys. Weiss ${ }^{5}$ again has found a quite normal Calamostachys in direct connection with Calamites ramosus and its leaves, that is with Annularia ramosa. Another colossal spike with the habit of Palaeostachya Schimperiana and similar Macrostachyae, which has also been proved to belong to Calamostachys, Calamostachys Solmsi ${ }^{6}$, was found by myself connected with a Calamitina in the Skalley mine at Saarbrücken. The block of stone was of huge size, and contained in its different planes of stratification a large number of spikes a foot long and converging in tufts towards one point. It is true that the connection of the tuft with the impression of Calamitina was not perfect ${ }^{7}$, so that the case cannot be taken as quite certainly established, though personally I am fully convinced that it is to be trusted. Lastly, Palaeostachya arborescens, Weiss, a form so near to $P$. Schimperiana above described that it perhaps coincides with it, has been found in connection with Stylocalamites arborescens, Weiss ${ }^{8}$. To the literature cited by Weiss may be added the figure in Lesquereux ${ }^{9}$, as a fine specimen illustrating the connection in corresponding manner. The specimen is named in the text ${ }^{10}$ Volkmannia crassa, Lesq. It is characteristic of this form that the large cylindrical spikes, which are borne in large numbers on quite short thin branchlets, are every one of them directly attached to the nodes of the stems of Calamitae. There are leaves to be seen in one of Weiss' figures ${ }^{11}$, which may perhaps have belonged to the stem. Such leaves are depicted in Lesquereux also, though they are shorter and apparently still attached.

To the foregoing statement of facts serving as a basis for further conclusions, it will be necessary to add a few words on the points of view

\footnotetext{
1 Sterzel (4), p. 82. 2 Weiss (6), t. 2, f. I.

s Renault (2), vol. ii, p. 127.

Schenk (2), p. 23 i, t. 39 .

5 Weiss $(5)$, p. 184, t. 6.

Weiss (6), t. I8 and (5), p. I77.

7 Weiss (6),

t. I $8, \mathrm{f}$. I.

8 Weiss (5), p. 206; tt. I4, I5, I6.

- Lesquereux (1), vol. iii, t. 90, f. I.

10 Lesquereux (1), vol. iii, p. 7 I9.

11 Weiss (5), t. 6 , f. I.
} 
which may be made use of for or against such a division of Calamariae into Calamitae and Calamodendrae, as is desired by the school of Brongniart. I may say at once that it cannot in fact be strictly proved that all forms of Calamariae belong to one another in the sense of Williamson, Stur and Weiss, but that on the other hand the reasons of the French authors for separating them into two quite different series are in my opinion far from sufficient for that purpose. It will be best therefore, till stronger proofs can be alleged in support of the latter theory, to keep to the more simple view of the English and German authors, treating the whole matter at the same time as an open question.

Of the arguments which must be urged against Brongniart and Renault, there are two of great and special importance. First it must be asked which of the Calamitae are supposed to have borne gymnospermous fructifications, since we find archegoniate fruiting spikes on stems and branches of very various kinds, on Stylocalamitae (Palaeostachya arborescens), on Calamitinae (Calamostachys Solmsi), on Eucalamitae (Calamostachys ramosa) and also on Annulariae (Calamostachys tuberculata and C. calathifera). It is true that Renault has recently endeavoured to meet this difficulty by turning the spikes into male flowers. But this does not seem to me to have been a happy idea; it does not appear why this interpretation should not be extended to all spikes, and thus we should have all the Calamariae united into one group, only under a different set of assumptions and with a different terminology.

On the other side it is to be observed that all known stems of this group were capable of growth in thickness. If there were other Calamitae which had no such power of growth, it must certainly seem very strange that they should never have been found in a state of petrifaction. Grand' Eury himself cannot help expressing his astonishment at this. He says ${ }^{1}$ : 'It is, to say the least, surprising that no one has yet met with a Calamite with the structurc preserved.' The objection, that they may have all perished owing to the more delicate nature of their tissue, cannot be regarded as sufficient, for in that case the young and slender branches of Calamariae could not well have been preserved, whether we suppose them to have belonged to Calamitae or to Calamodendrae. But such branches have been more than once, though not very often, described and figured by Williamson ${ }^{2}$. They show the well-preserved parenchymatous pith, surrounded by a circle of conspicuous primary bundles with large lacunae. It may indeed be replied, that in point of fact remains of stems of Calamitae have been found with the structure of Equisetae and with no secondary growth, and the famous specimens from the Plauensche Grund near 
Dresden, figured and discussed by Petzholdt ${ }^{1}$ and Geinitz ${ }^{2}$, may be cited in proof of this. Petzholdt's Calamitae are imbedded in grayish white Carboniferous sandstone, and show on the transverse section a central space filled with the stone, and surrounded by a rather thick compact envelope of coal. But this layer of coal, itself with a rather irregular outline on the outside and on the inside and with many small projecting teeth, is cut up by a circle of lacunae filled with the stony matter into segments which have the shape of the transverse section of a double T. I have myself seen several sections of the kind in Dresden and Strassburg from Petzholdt himself, and they appear in his tables well-drawn and true to nature. Now he has explained the whole of this structure by the direct unaltered preservation of the original state of the stems, and Schimper ${ }^{3}$ and others have adopted this view. The lacunae therefore in the rind of coal were the vallecular canals, the central space the medullary cavity of the Equisetum-like stem. Still the irregular nature of the layer of coal must cause some hesitation, and its thickncss must seem surprising, if we hold to the view that it was produced from the wall of a herbaceous hollow stem. And in fact Schenk ${ }^{4}$, who has submitted these remains to fresh examination, has succeeded in proving that the mass of coal in it consists entirely of secondary wood, which was torn and broken up only in the process of imbedding; that the lacunac are thus in the middle of the wood and only represent defective places in it, and that they therefore cannot be compared with the vallecular canals. The specimens are in fact remains of Calamodendron or mixed masses of Calamodendron and Psaronius, which are not in question as regards our argument.

The view of Brongniart and his pupils is founded in the main on the petitio principii which will not hear of secondary growth in Archegoniatae. But it appears to me that the facts as observed in Lepidodendron and Sigillaria, and even in the recent Isoëtes, leave so little foundation for this idea, that it can no longer be employed as a main argument. The points brought forward in support of it, where they have not been already disposed of, are of little value. Much importance is attributed for instance to the difference in the thickness of the rind of coal. But thin coverings of coal are formed even when there is only a small amount of secondary growth, and we discover how greatly the amount varied by examining large collections of sections. No one of the many differences which Grand' Eury ascertained in the underground organs of our plants is of such a kind as to imply more than a generic, or shall

\footnotetext{
1 Petzholdt (1).

${ }^{3}$ Geinitz (5).

s Schimper (1), vol. i.

+ Schenk (2),

p. 236.
} 
we say a family difference. All that we learn then in this way is, that in Calamariae we are dealing with a more copiously differentiated series of forms than appears to be the case at first sight. Hence so long as the existence of female flowers or seed of Calamodendrae is not clearly demonstrated, and so long as the difficulties here discussed cannot be quite removed, we shall be obliged to maintain the sceptical position previously described. 


\section{XIV.}

\section{SPHENOPHYLLEAE.}

THE Sphenophyllae are members of one of the most remarkable among the leading genera of the Middle and Upper Coal-measures. They do not pass beyond the Lower Rothliegende, in which they have been found at Autun, and it is doubtful whether the species described from older deposits belong to the group. This is especially the case with Sphenophyllum tenerrimum, Ett. ${ }^{1}$ from the Culm, the beds of Ostrau and Waldenburg, which may even be a Calamites, and be parallel with Archaeocalamites radiatus, and still more with the rather obscure and dubious Devonian remains which Dawson ${ }^{2}$ named Sphenophyllum antiquum.

The genus, owing to its striking appearance, has been repeatedly figured by the old authors; a copious collection of the older literature and of the descriptions of the several species is given by Coemans and Kickx ${ }^{3}$. The slender stems, which in the impressions are simply a thin rind of coal, are articulated, and bear at the nodes leaves in whorls, and branches standing singly and according to the statements of authors in the axils of the leaves. The stems are usually marked by rather strong ridges and furrows, which always run unaltered and uninterrupted over the nodes. Each whorl consists of at least six leaves, often of more, and in that case the number is always a multiple of six, being twelve, eighteen, or even twenty-four. On this point I find that all authors virtually agree. The single sessile leaf broadens and becomes wedge-shaped from a narrow base, and is obtusely rounded at the anterior margin and sometimes toothed (Sphenophyllum Schlotheimii, Brongn., S. emarginatum, Brongn.), or else it is repeatedly and dichotomously divided with more or less deep incisions into broader or narrower points. The lamina of the leaf is traversed by simple unconnected nerves of equal size, which bifurcate once or repeatedly, and are slightly divergent. According to $\mathrm{Schenk}^{4}$ one nerve only enters the base of the leaf. This is certainly true of the form which he has described (Sphenophyllum emarginatum, Brongn., var. truncatum, Schpr), but I should doubt 
its being the same in all species for reasons to be discussed presently. How far the degree of division and incision of the lamina can be employed in determining species requires further consideration, for Coemans and Kickx ${ }^{1}$ state that the stems of several species have deeply incised leaves below, and almost entire leaves above, in the manner of our living Batrachiae. If they mean to infer that Sphenophylleae were aquatic plants, their view is opposed by both Schimper ${ }^{2}$ and Schenk ${ }^{3}$, who appeal to the anatomy of the stem. I prefer not to give a decided opinion on this point for the present. As regards the heterophylly, which Weiss ${ }^{4}$ also regards as an established fact, the only instances of it which I can find are the branched specimens figured in Germar ${ }^{5}$ and Schenk $^{6}$; and in these it is only the main axis which bears incised leaves, those of the lateral branches are alike and have entire margins, so that the comparison with Batrachiae is not exact.

As soon as the wedye-like form of the leaves is disguised by the copious and deep incision of the anterior margin, it necessarily becomes difficult and sometimes quite impossible to distinguish the remains of Sphenophylleae with any certainty from Asterophyllitae and Annulariae. To be convinced of this, we have only to examine the figures of Sphenophyllum angustifolium, Germ. in Schenk ${ }^{7}$. Germar's ${ }^{8}$ figure of the same species is not to be distinguished from an Asterophyllites; it may even be doubted whether it belongs to Sphenophylleac. It is necessary to insist upon this point because of its importance as showing, in opposition to Williamson's results which will be considered further on, that in impressions where the anatomy cannot be examined no certain line of distinction can be drawn between the two genera, if Asterophyllites may be called a genus. We must not lose sight of this in judging of Stur's Asterophyllites mentioned above on p. 314, from which a branch of Sphenophyllum is growing. It is possible that some of the remains which we should now call Asterophyllitae will ultimately prove to be Sphenophyllcae. We have a case already in Sphenophyllum tenerrimum, Ett. which gives room for much doubt. This slender diminutive plant has been figured and described by $\operatorname{Stur}^{9}$ with his usual carc. Its furrowed stems bear whorls of dissimilar once or twice divided leaves, in which the incisions follow the nervation in such a manner, that each point is traversed only by a median nerve. Where the whorls lie spread out in the plane of stratification, the number of leaves has been found to vary; I find the numbers nine, ten, eleven, and twelve given in Stur, which does not quite agree with the regularity observed in genuine Sphenophyllae, though I do not consider the point to be very important. But this specimen might quite as well be comparcd with Archaeocalamites,

${ }^{1}$ Coemans et Kickx (2), p. 139. $\quad{ }^{2}$ Zittel (1), p. 178. 'S Sehenk (2), p. 220. ' Weiss
(1), p. 133 .
${ }^{3}$ Germar (1), t. 6, f. 3 .
S Schenk (2), t. 44, f. 1 .
7 Schenk (2), t. 38 ,
ff. $2,3,5$.
${ }^{8}$ Germar (1), t. 7, f. 8.
- Stur (5), p. 214, t. 7 , 
in which the leaves are of like form, but of somewhat greater length, though we must not omit to say that fructifications occur at the same spot which very probably belong to the stems in question, and which, though imperfectly preserved, yet show some resemblance to those known to have belonged to Sphenophyllum. This is why the plant is considered in this place. If it really belongs to our group, we shall be able to follow the type of Sphenophylleae much farther back than the limits usually assigned to it. An equally strong splitting of the repeatedly forked leaf-blade is figured by Zeiller ${ }^{1}$ in the plant which he has named Sphenophyllum saxifragaefolium.

As abnormal form, whose connection with the group appears not to be entirely free from doubt, may be mentioned first, Sphenophyllum Thonii", hitherto found only in the highest beds of the Carboniferous formation at 11 menau and in France. According to Zeiller ${ }^{3}$ this plant is distinguished essentially from other species of the genus only by the size of its parts, and by the strength and prominence of the nervation of its leaves, in which the anterior margin is slit up into narrow fringe-like teeth. More decided differences appear in the doubtful remains described as Trizygia speciosa ${ }^{4}$, which, as belonging to the Damuda group of the Lower Gondwana system of India, comes from a higher level than that of the Carboniferous formation, perhaps from the Trias. O. Feistmantel ${ }^{5}$ has given a description and figures of this plant, and has also collected the literature. I have seen specimens only in the Botanical Department of the British Museum. The thin filiform stems which are swollen at the nodes bear six-leaved whorls, which appear to be regularly superposed. The roundish wedge-shaped leaves in each node are arranged in three pairs, two of which are exactly opposite to one another, while the third, formed of much shorter members, occupies the interval between them on one side. The arrangement of the leaves is thus unilateral, and there is in all the whorls a broad interval opposite the smaller pair of leaves. Branching has, as far as I know, not yet been observed on the plant. The genus Sphenoglossum found in the blue shales of the apparently Triassic coal-field of Deep River in North Carolina, and described by Enmons ${ }^{6}$, is less known, and as the verticillate broadly wedge-shaped leaves are in fours it can scarcely belong to our group.

Here again it is to Renault ${ }^{7}$ more than to anyone else, and next to him to Williamson ${ }^{8}$, that we owe our knowledge of the inner structure of the Sphenophyllae. This structure has proved to be highly remarkable, and not directly comparable with that of any other plants. A primary

Zeiller (3), t. 16I, ff. 3, 4, 6 .

${ }^{2} \operatorname{Mahr}(1)$, t. 8.

${ }^{3}$ Zeiller (3), p. 34, t. 161, f. 9 .

\& Royle (1), t, 2, ff. I-7.

${ }_{5}^{5}$ Pal. Ind. ser. XII, Pt. II, p. 69, tt. II, 12.

- Emmons (1).

${ }^{7}$ Renault (2), vol. ii, p. 91, and vol. iv, Intror., also (16) and (20).

8 Williamson (1), $\mathrm{v}$ and $\mathrm{Ix}$. 
triarch xylem-strand, the only one which appears at first, is afterwards inclosed by a secondary growth of quite peculiar structure, after the manner observed in growth in thickness in roots. These stems appear, according to Williamson, to be comparatively rare in the calcareous nodules of Lancashire, but they are much more abundant in those of Langendreer, from which I have a considerable number of specimens before me. In Autun also, and especially in the pebbles of Grand' Croix, they have bcen repeatedly found by Renault and Grand' Eury'. The material from Grand' Croix has enabled Renault ${ }^{2}$ to prove that the stalks in question have really belonged to Sphenophyllum. A plane of fracture in a favourable direction showed him an undoubted leaf of that genus, with the characteristic transverse section of the stalk in connection with it. He has repeatedly figured ${ }^{3}$ transverse sections of the stalks, which are surrounded by the leaves still in the original position (Fig. 48,2 ).

If we first cxamine the young stem as yet without growth in thickness, we find it to consist simply of a thick rind inclosing the three-winged bundle. If the transverse section has exactly hit the node, we also get the leaf-tracestrands passing through the rind and running outwards almost at a right angle to the axis. In the leaf-trace may be distinguished an inner bastlayer, which in such young stems is almost always destroyed and replaced by an annular vacant space, and outside the bast Renault ${ }^{4}$ maintains that he has sometimes found the protecting sheath consisting of thick-walled elements closely united laterally with one another. The sheath is surrounded by a thick mantle of primary cortical parenchyma, the hypodermal cells of which are said to be fibre-like. The form of the transverse section of this cortex is peculiar (Fig. 48,2). Generally three-angled approaching to circular in shape, it shows on the outer side at each angle a longitudinal furrow which divides the angle into two ribs lying in pairs side by side. Each pair of ribs lies in front of one of the surfaces of the xylem-strand, the flat sides between the ribs are in front of its angles, and consequently the outer surface does not repeat the form of the central strand. The scction is less frequently simply cylindrical ${ }^{5}$, without any angles and furrows. As the ordinary impressions all belong to the outer surface, we see again how little comparison there can be between any trace-points visible on it and the prominences on the substance which replaces the pith in Calamitae, though such a comparison has been attempted by $\mathrm{Stur}^{6}$. The central xylem-strand consists chiefly of tracheides with bordered pits, which are broadest in the middle and gradually diminish in size towards the angles, and here too are replaced by scalariform vessels. At the extreme edge of 
each wing are two weak initial strands, lying close together and composed of spiral and annular cells with threads that may be unwound, and as there is usually a small gap in the tissue between them, they project into it and form two teeth at the angle of the xylem-strand. The entire xylem-strand is usually uniform, though in the young state its tracheal elements would appear to be accompanied with a parenchyma, which may be supposed to be destroyed at a later period, as the tracheides increase in diameter though

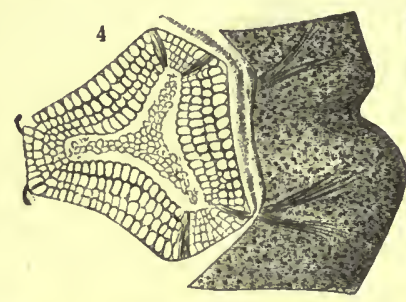

3
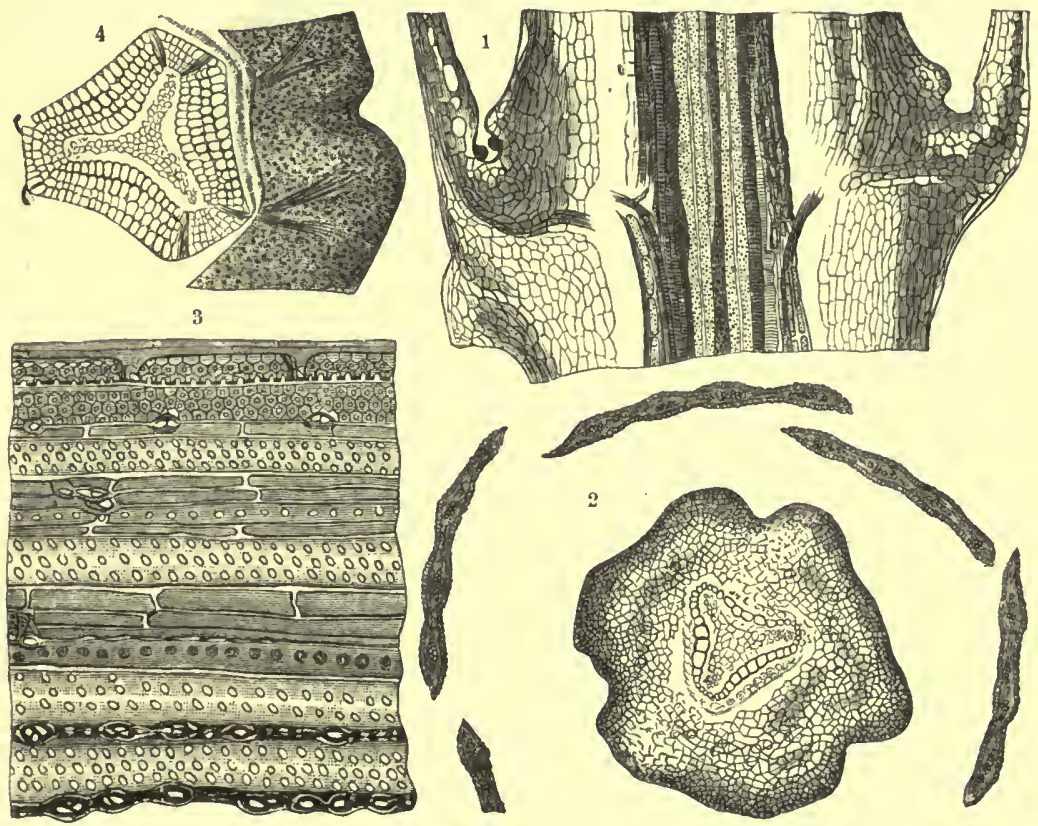

Fig. 48. 1. Longitudinal section of the stem of Sphenophyllum quadrifidum. 2. Transverse section through the same, surrounded by the transverse sections of the leaves, each of which is four-nerved; in the centre the three-winged primary xylem-strand, enclosed in a single layer of secondary wood. 3. Longitudinal section of the stem through the secondary wood, somewhat oblique, so that it is tangential on the lower side and almost radial on the upper. 4. Transverse section of the stem of Sphenophyllum Stephanense, B. Ren., showing the leaf-strands and their attachment to the initial groups of the three-winged woody body ; four layers of secondary wood already formed. From Zittel's text-book.

probably not in number ${ }^{1}$. Renault ${ }^{2}$ has found a macerated silicified stem in which the xylem-strand, by destruction of the more central tissue, is broken up into three curved rows of vessels with their convexity turned towards each other, and with their six free extremities formed of six initial bundles. He supposes therefore that the whole body was originally composed of three separate diarch strands. Van Tieghem ${ }^{3}$ indeed thinks that it was developed from six separate monarch strands united together in pairs, and having their initial bundles on the outer side. Either view is possible

1 Renault (2), vol. iv, Introd. p. 7.

${ }^{2}$ Renault (2), vol. ii, Introd. t. $\Lambda$, f. 2.

3 van

Tieghem (3), p. 173 . 
and plausible; but as there can be no certainty in the matter without a knowledge of the development, we do not gain much by these explanations.

The wood-strand goes through the nodes, as Renault showed, without perceptible change. Here a leaf-trace of a single strand emerges at once and attaches itself to each of the initial bundles. The traces which thus arise in pairs at the corners (Fig. 48,4 ) pass through the rind in a horizontal course and with slight divergence, and usually branch dichotomously while still inside it. If now we may assume that a single bundle enters the leaf in all the forms, as Schenk has shown to be the case in one of them (see above on p. 343), the number of the leaves may be concluded directly from the structure of the transverse section of the node. The node figured by Renault ${ }^{1}$ and given here (Fig. 48,4 ) must thus have borne twelve leaves, those represented by the same author in a previous publication ${ }^{2}$ must have had eighteen. But the difference in their outline shows that these sections belong to different species, in which there might very well be distinctions in this direction, such as are in fact alleged by Grand' Eury ${ }^{3}$. One thing however is by this means absolutely proved, as Renault ${ }^{4}$ has pointed out, namely, that the leaves in consecutive whorls were superposed. And if this can be directly shown in Trizygia speciosa, and its leaves are moreover combined in pairs, it appears to me that we have no slight proof that the plant belongs to the present group. The unequal distribution of the leaves round the periphery of the nodes will be accompanied, as might perhaps be expected, by bilateral symmetry in the structure of the central strand.

Picces of young stems showing only the primary structure are however rare; specimens with sccondary wood more or less developed are much more common. Van Tieghem's ${ }^{5}$ charge against Renault, that he has mistaken the nature of this wood, seems to me, as so put, to be unfounded; Renault has described it correctly, only he has preferred to use a neutral expression which does not prejudge anything, and to call it a 'sheath of punctate tubes.' The woody body in question consists then chicfly of broad tracheal elements, having the form of four-sided prisms with a regularly square transverse section, and with the vertical and radial angles replaced by narrow planes of truncation. On the tangential section therefore they are seen as continuous vessel-like tubes, in the radial direction they have the appearance of being made up of many members set one on another, and looking like the component members of normal vessels (Fig. 48,3). Whether they are really of this kind has not yet been ascertained; there is no appearance of transversal parting walls, but these might have perished by maceration before petrifaction. On the other hand, no pointed extremities pushed in between one another, such as are usual in tracheides, have ever

1 Renault (20), t. 7, f. 3 .

${ }^{2}$ Renault (16), t. 4, ff. 3, 4, and t. I, f. 5 . ${ }^{3}$ Grand' Eury (1), p. 51.

1 Renault (2), vol. iv, Introd. p. 29.

van Tieghem (3), p. I 33 . 
been observed. We can scarcely hope to give a decisive answer in the case of fossil remains to a question which is sometimes so difficult in dealing with living material. These elements are arranged on the transverse section of the stem in regular radial rows, and at the same time in concentric successive layers; they touch one another in the four chief planes which are their lateral boundaries. But the truncation of their angles causes the formation between them of irregularly four-angled spaces, which, as the radial angles suffer a similar truncation, communicate with one another in this direction and form a more or less regularly arranged system. This system is seen, when the preservation is good, to be filled with small-celled parenchyma, the elements of which are radial in radial sections, in others vertical and somewhat elongated ${ }^{1}$. This tissue differs essentially from the medullary rays of other plants in arrangement and distribution, but may be its equivalent as regards function.

The bays in the originally three-winged woody body are soon filled in by a large development of secondary tissue. But this is not brought about in the present case by the introduction of a larger number of tracheides; the concentric layers are always and everywhere maintained with unvarying regularity (Fig. 48, 2, 4). Only the breadth of the elements changes, and is much greater in the portions of the secondary growth in front of the bays than elsewhere. It is peculiar that there is no gradual passage from the one to the other, but that the small-celled portions in front of the angles, which increase in breadth towards the outside and have parabolic inwardly convex bounding lines, are in quite sharp contrast with the others. In this way the primary strand is surrounded by a closed mantle of a secondary formation of tracheides, which proceed from an external cambial zone and pass layer by layer into the permanent state. Specimens are often found, in which one layer only (Fig. 48, 2) or a few are developed ${ }^{2}$, and these are then always equally and fully developed all round. In older stems on the contrary layers are often observed which have not reached their complete development in every part, and here it looks as if this development began in the area of the small-celled corner-portions. The growth in thickness may not last very long. In the transverse sections figured by Renault I find the largest number of concentric layers of wood to be eleven, and he says ${ }^{3}$ that one stem which he has not figured has fifteen. Williamson ${ }^{4}$ indeed has figured a transverse section with a great many more layers, but with Renault I question most decidedly whether this preparation belongs to the group which we are considering. Its secondary wood of scalariform tracheides shows quite normal medullary rays of a single row of cells, such as do not occur in Sphenophyllum. We may

1 Renault (2), vol. iv, Introd. t. c, ff. 3, 4 . ${ }^{3}$ Renault (2), vol. iv, Introd. p. I I.
${ }^{2}$ Renault (20), t. 7, ff. 2, 3, and t. 9, f. 4 . 4 Williamson (1), v, t. 4, f. 2 I. 
therefore consider it to be a transverse section of a root, but to what plant it belongs is quite uncertain. In the nodes the secondary growth is traversed by the leaf-trace-strands, and near each of these is an interspace of tubular form filled with a delicate parenchyma.

In some particularly well-preserved specimens Renault ${ }^{1}$ has observed the bast in the form of a thin-walled crushed tissue surrounding the secondary wood. Single larger lumina in it he considers to be sievetubes. Immediately outside the bast is a layer of tissue, which he ${ }^{2}$ terms a 'suberous layer corresponding to the protecting sheath of the mass of phloem and xylem,' and which he derives from the tangential division of the cells of the protecting sheath. This tissue, with its patelliform or tubular cells in radial rows as given in Renault's figure ${ }^{3}$, looks in fact very like a periderm, and may be a periderm, if Renault's further statements, which I cannot judge of from the material in my possession, are ultimately confirmed. $\mathrm{He}$ says in effect that in the old piece of stem mentioned above with fifteen layers of secondary wood and with the rind removed, there are several of these 'couches subéreuses' present, separated from eacl other by layers of crushed bast ('tissu corné'). This, as he distinctly says ${ }^{4}$, would mean normal formation of bark. The accompanying figurc would ratherlead us to regard these layers of 'tissu corné' to be simply layers of sclerenchyma, such as so often alternate in the phellem with the cork-cells. In that case we must regard the whole not as rhytidom, but as one connected mass of periderm.

The pieces of stem which come under notice are usually short fragments without their leaves, and commonly even without their rind. Renault however has in two cases succeeded in finding specimens which showed the leaves in situ and with their structure preserved. Williamson ${ }^{5}$ also deals with a similar case. Here the stem was imbedded in the stone, and only the longitudinal and the transverse sections could be observed, not the form of the lamina of the leaf. Fig. 48,2 reproduces the drawing in Renault which gives the clearest view of a specimen of the kind. It shows the stem surrounded by six four-nerved leaves. Renault ${ }^{6}$ has also given two transverse sections of another species, his Sphenophyllum Stephanense, taken from a stem at different heights. Only two leaves are distinctly preserved; those in the lower section are three-nerved, in the upper section they are replaced by six small one-nerved transverse sections swollen in the middle, and answering to the three teeth into which each leaf has meanwhile divided. Here too from the position of the leaves there would not have been more than six present. In Williamson's specimen just alluded to the arrangement of the leaves is less clear, because only radial and tangential sections

1 Renault (2), vol. iv, Introd. t. A, f. 3 C. $\quad{ }^{2}$ Renault (2), vol. iv, Introd. p. 4. vol. iv, Introd. t. D, ff. 3, 4 . Renault (2), vol. iv, Introd. p. 13; t. D, f. 4 . (1), v, t. 3 . G Renault (16), t. 4 , ff. 5,6 .

${ }^{3}$ Renault (2), ${ }^{3}$ Williamson 
were observed. The leaf-teeth, several of which are combined together in the lower part of the stem, are enlarged in the middle and one-nerved, and properly comparable with those of Sphenophyllum Stephanense. Williamson, on account of the deep incisions in these leaves which reach nearly to the base, refers his specimen not to Sphenophyllum but to Asterophyllites, and tries to justify this by comparing the facts of the case with the diagnoses of the two genera obtained from impressions. That such a proceeding is inadmissible is evident from our remarks on p. 344 ; the structure of the stem in this specimen is that observed in acknowledged Sphenophyllae and only in them, and is sufficient to prove that it belongs to that group. And if Stur ${ }^{1}$ writes: "As far as we know at present it is the fact, that the Calamariae show as great differences of anatomical structure in the variously leaved branches of the same individual, as we are accustomed to find in living vegetation even in different and very dissimilar families,' it is simply from once more overvaluing the results obtained from impressions. For who will venture to say that the supposed Asterophyllites, from which the branches of Sphenophyllum grew, had not the same structure as Sphenophyllum and was not simply a Sphenophyllum.

Some account is also to be found in Renault ${ }^{2}$ of the structural details of the leaves, but unfortunately he does not say from which of his specimens they are taken. The weak vascular bundles consist only of a few tracheides combined into one strand, and surrounded by delicate bast-elements. Above and between these are hypodermal fibre-strands. Van Tieghem ${ }^{3}$ indeed maintains that the bundles are diploxylous, like those of Cycadeae, but Renault disputes this very decidedly. After seeing the preparations which he was kind enough to demonstrate to me, I must declare myself to be entirely of his opinion. Little is known of the attachment of the lateral branches. No anatomical details are given of the only specimen figured by Renault ${ }^{4}$; it is a suspicious circumstance that there is no node to be seen at the point of departure of the branch, though it may indeed have been rubbed off. Hence the possibility that this fragment may come from a triarch root is not to be ignored. Stur ${ }^{5}$ too has his doubts. The root, the structure of which appears in the transverse section supplied by Renault ${ }^{6}$, has a diarch primary strand in the form of a transversal line and surrounded by secondary wood, which, though perfectly uniform all round, presents in other respects the structure of the stem of Sphenophyllum. Hence we can hardly have any doubt about the true character of this object.

It remains only to examine the fructifications. These appear chiefly in the form of cylindrical spikes with close resemblance in habit to those of Calamariae, and have been repeatedly found as lateral ramifications of leafy

1 Stur (10), p. 328 .

4 Renault (16), t. I, f. 3 .
2 Renault (2), vol. iv, Introd. p. 16, t. B.

3 van Tieghem (3), p. I 73. ${ }^{5}$ Stur (9), p. 16.
${ }^{6}$ Renault (2), vol. iv, t. B, f. 2. 
branchlets undoubtedly belonging to Sphenophyllum, as for instance near Wettin in tolerable abundance. Figures of such objects are to be found in Germar $^{1}$, Geinitz ${ }^{2}$, Schenk ${ }^{3}$, and Schimper ${ }^{4}$, and diagrammatic representations in Grand' Eury ${ }^{5}$. Geinitz and Schimper agree in their accounts of the structure of these spikes, and a careful examination by Schenk ${ }^{6}$ yields the same results. Not having devoted any study to them myself, I will adopt Schenk's description of them in the following remarks. He says that the fructification is composed of moderately crowded uniform sporangiferous whorls. The leaves of the whorls are hollowed out at the base, in some cases forming a spur-like pocket, and then ascend so that their apices reach to the whorl next above, or are imbricated upon it. They resemble the foliage-leaves of the vegetative branches in having the anterior margin divided into several tecth. These fertile leaves are exactly superposed in the consecutive whorls in all Germar's figures. If this is strictly correct, it would agree wcll with the inner organisation of the plant as described to us. On the other hand it would be hard to reconcile or be even irreconcileable with that organisation, if it is really the case, as Schenk thinks, that four leaves were usually united in one whorl. Renault ${ }^{7}$ too protests against this. Schenk states that the specimens hitherto examined were not adapted to settle this point. It may thercfore bc supposed that with better material the number six characteristic of the group will be found also in the fructifications. The sporangia stand singly in the hollow of the base of the leaf, which in Sphenophyllum angustifolium is almost spurred: they are lenticular in shape and sessile, and vary in diameter from one to two and a half millimetres.

Diminutive spikes have been found by Witkowitz with Sphenophyllum tenerrimum in the beds at Ostrau, and as their leaves agree with the leaves of that species in sluape and in their dichotomous branching, they may belong to it. They have been figured and described by Stur ${ }^{8}$. The sporangia lie closely crowded together betwcen the leaf-whorls, filling the space between every two leaves; their insertion has not been exactly ascertained, though Stur inclines to think that they were attached to the axis and not to the base of the leaf.

Hitherto unfortunately no unquestionable inflorescence of Sphenophyllum has been found as a petrifaction. Renault ${ }^{9}$ met with one fragment in the pebbles of Grand' Croix which may possibly belong to the group, but it is involved in too many doubts to be really taken into consideration. The bit of spike, which is only four millimetres in length, shows superposed uniform leaf-whorls and a thin rudimentary central xylem-

\footnotetext{
1 Germar (1), tt. 6, 7. $\quad{ }^{2}$ Geinitz (5), t. 20. 's Schenk (2), t. 38, ff. 1, 2. 4Schimper (1), t. 25. 'Grand' Eury (1), t. 6, ff. 9, I1. 'Schenk (10). 'Renault (20), p. 283 . ${ }^{8}$ Stur (5), p. 222 ; t. 7 , f. 14. (Renault (20), p. 303; t. 9, ff. 9-II.
} 
strand, and has therefore been referred to Sphenophyllum. Bodies like sporangia, but much out of shape, are attached partly in the axils of the leaves, partly to the upper surface of the leaves. Those which originate in the leaves contain granulations of a whitish colour, and it is said that 'these can only be microspores;' in and close to the axillary bodies are one or more larger bodies which are explained to be macrospores, but which seem from the figure to be pluricellular and to have no very pronounced character. Williamson again has described under the name Volkmannia Dawsoni a fossil, known only in one specimen, which from the structure of its axis may perhaps belong to Sphenophyllum, but which, so far as its imperfect preservation enables us to judge, differs essentially in its other details from the recognised structure of that genus. Of the axis only the outer rind and the central bundle-strand are preserved. The latter does in fact appear to consist entirely of tracheal elements, but they are badly preserved. I satisfied myself of this from some preparations kindly lent me by their owner. The transverse section is three-winged, but the wings are shorter and thicker than is usually the case in Sphenophyllae, and have a broader terminal emargination. The sporangiferous leaves are not bent geniculately upwards, and below they are united into a funnel-shaped continuous plate, from the inner surface of which there arise many stalk-like processes. Several leaves are seen together obliquely cut through on the transverse section, owing to the steepness with which the whorl ascends. Then the space between them is filled with numerous sporangia, which are arranged in a single row between the outer, in several rows between the inner leaves; and between and close to the latter there are sections to be seen passing irregularly through the before-mentioned stalks, to which Williamson supposes the sporangia to have been attached. I cannot however find clear proof of this in the preparations. The sporangia contain many rather large globular uniform spores with a reticulately ornamented exosporium, which appears on the section to be covered with small prickles.

Turning for the last time to the question, to which group of recent plants we shall consider Sphenophyllae to be most nearly related, I find it very difficult to give a positive answer. Different authors have attempted various arrangements, which have been discussed at length by Renault ${ }^{1}$. It has gradually become the custom to bring them into the neighbourhood of Lycopodiaceae. Schenk ${ }^{2}$ especially and van Tieghem ${ }^{3}$. have very recently and earnestly supported this view. Stur ${ }^{4}$ and Renault ${ }^{5}$ are the only authors who have not assented to it. The former, relying on his theory of the whorl-traces, would class them with Calamariae; and Renault ${ }^{6}$ unites them with Salviniae, and has defended this arrangement against

1 Renault (20). ${ }^{2}$ Schenk (10), vol. ii.

${ }^{5}$ Renault (2), vol. ii, p. 8r and (20).
3 van Tieghem (3). "Stur (8), (9), and (10).

- Renault (2), vol. ii, p. 8I. 
Schenk particularly and van Tieghem. I can find no grounds for this union with Salvinia, which is opposed to all that we know of the fructifications. The heterospory which is employed to defend it is more than doubtful, and a comparison with the rudimentary central strand of that aquatic plant would be a bold step, even if there was a resemblance between them; but no such resemblance has been disclosed by Janczewski's careful examination of the bundle in Salvinia. On the other hand, as it seems to me, the primary structure precludes all thought of Calamariae and Equisetae. There therefore remains only the series of Lycopodeae, in which we may perhaps find some points of connection. But here too much good-will is needed and various presuppositions. Assuming for instance that the primary central bundle belongs to the concentric type, then it may no doubt be compared with the axile strand of Lycopodiae. But this is as yet only an assumption; the bundle might just as well be a triarch radial strand, and then there would be no resemblance to the structure of the stalk in any living plant. Schenk ${ }^{1}$ endeavours to prove that the verticillate position of the leaves, which does indeed often occur in Lycopodium, is an unimportant difference, but he has overlooked the remarkable superposition of these whorls, which must however be an important element in the question and requires much consideration. To these peculiaritics in Sphenophyllae must be added the structure of the secondary wood, which has no analogue either in living or in any known fossil plants. It is not so much the appearance of this formation, as its absolutely peculiar character, which must make us hesitate, and all the more because, as has been already said, the comparison of the external characters and of the primary structure with those of Lycopodieae rests on very weak foundations. To compare the secondary wood of Sphenophyllum with that of Sigillaria, as van Tieghem proposes, is to my mind simply impossible. It will be best therefore to renounce for the present all forced attempts at classification and to regard the group as sui generis, as standing by itself and independent. I myself incline to the view that it is only from the discovery of fresh specimens further back in the series of deposits that we can hope to find such a place for Sphenophylleae in the system as will be fruitful of further results; but it must be confessed that the prospect of such discoveries is at present unfortunately very small.

'Schenk (10), vol. ii. 

THE CHARACTER OF THE SURFACE IS UNKNOWN.

WE have still to examine a certain number of fossil stems, the position of which is open to question because the character of their surface is quite unknown. All stems of this kind, which could be connected with definite groups of plants, have been discussed in the preceding chapters; here therefore we have to deal only with a few forms, for which no appropriate place could be found before.

The first that may be mentioned is the genus Sigillariopsis, Ren. ${ }^{1}$, which might perhaps have been noticed in the chapter on Sigillariae. Its author has obtained several specimens from the pebbles of Autun. The one which he has figured ${ }^{2}$ consists of a fragment of stem in rather imperfect preservation, which is surrounded by the spirally arranged leaves still in their natural position. The transverse section of the stem, small in diameter and with the rind and pith badly preserved, shows like Sigillaria Menardi a narrow layer of secondary wood with scalariform tracheides on the inside and pitted tracheides on the outside, after the manner of Cycadeae. The longitudinal section ${ }^{3}$ in the same work should also be compared. Inside this ring of wood are numerous primary woodstrands, as in Sigillaria, lying close together, which, as we are expressly told, are in a bad state of preservation, but which have their spiral tracheides outside, as in that genus, and next to these on the inside scalariform and pitted elements. We see that all this agrees perfectly with what is known in the case of Sigillaria Menardi, with the single exception of the pitted tracheides which are not found in that species. The leaves too are similar, narrow-lanceolate or linear, as may be concluded from their rhombic or somewhat irregularly triangular transverse sections; but the rhombic sections show two vascular bundles close to one another, while in the triangular section which is figured there is only a median bundle. Renault considers that the latter is the transverse section of the tip of a leaf, and says ${ }^{4}$ : 'In the broadest part of the leaf are seen two vascular bundles, which are reduced to a single bundle 
towards the point.' Other modes of explanation, for example the supposition of an alternation of leaves, seem to me to be preferable. The transverse section of the trace-bundle, according to the figure and the description , shows a structure essentially similar to that of Cordaites; it is surrounded by a stout parenchymatous sheath, and exhibits the initial group characterised by spiral tracheides between the two wood-strands, the upper one of which forms an irregular group and is surrounded on one side by the lower strand which is in the form of an arch. A hypodermal fibrous layer with blunt projecting ribs is developed beneath the epidermis on both sides of the leaf. I have been obliged to depend entirely on Renault's description for this interesting genus, which I have never examined myself; a fuller account of it from better preserved specimens would be very desirable.

The remains which Renault ${ }^{2}$ has collected together provisionally under the name Poroxylon, and which differ from one another in not unimportant points, are also known to me only from the literature. There is a prospect of a full account of them by Bertrand and Renault, the main results of which have already been published in a short preliminary communication by Bertrand ${ }^{3}$. According to Renault's figures we must here distinguish two separate types, onc of which is represented by Poroxylon Boysseti and P. Edwardsii, the other by P. Duchartrei. While the first two forms, judging by the figure and the description, appear to have much resemblance to Sigillariopsis, and show pith and rind and between them a ring of bundles surrounded by secondary wood, the figure of P. Duchartrei ${ }^{4}$ has a central wood-strand of circular transverse section, in which groups of broad pitted tracheal clements are imbedded in a delicate parenchyma. This central strand is surrounded by a ring of secondary wood divided by very broad medullary rays into a great number of wedges, which in their turn contain narrower rays of parenchyma. The tracheides are pitted. Few scalariform or spiral cells were found on the borders of the central strand. Nothing remains of the rind except a few fragments of secondary bast-wedges answering to the segments of the ring of wood.

It is possible that Bertrand's and Renault's ${ }^{5}$ statements refer only to the type represented by the first-named species. At least I am unable to reconcile the following words with the structure of Poroxylon Duchartrei : 'The centripetal ligneous masses (the primary bundles) do not converge towards the centre of the stem, even in slender stems.' This quite suits the first two species which resemble Sigillariopsis. In these there is a central pith, and in it in P. Edwardsii there are dark points, which Renault takes for gum-passages. Similar passages are found in P. Boysseti in the parenchymatous rind. On the inner border of each segment of the ring of wood

\footnotetext{
${ }^{1}$ Renault (1), t. 13; ff. I-3.

- Renault (1), t. I4, f. 4 .

${ }^{2}$ Renault (1), p. 272, and (2), vol. i, p. I19, t. I6. B Bertrand et Renault (3).

${ }^{3}$ Bertrand (3),
} 
there is a primary bundle with an initial strand towards the outside. The bundle consists of pitted and scalariform tracheides. In the secondary wood there are only pitted tracheides; and these have the bordered pits, which are crowded together as in Araucaroxylon and flattened into a polygonal shape, only on the radial surfaces. The secondary bast-region in Poroxylon Boysseti is homogeneous, in P. Edwardsii ${ }^{1}$ it contains sievetubes with a broad lumen, which are said to resemble those of Encephalartos. Outside it is the thick parenchymatous rind containing a large number of hypodermal fibre-strands with a radially elongated transverse section. Bark is formed according to Bertrand and Renault in Poroxylon Edwardsii; and in this process the first layer of periderm is developed on the inner border of the primary rind. The succeeding layers arise in the bast and cut out flat scales of bark from beneath. The preliminary communication of the two authors already mentioned contains further important anatomicomorphological data, from which I select the following. The phyllotaxy is $\frac{5}{13}$ and the leaf-trace is formed of a single strand. There are lateral buds in the axils of the leaves, but they are not always developed. Unfortunately nothing is said about the leaves themselves. But Renault ${ }^{2}$ has found fragments of leaf-stalks associated with the stems of Poroxylon in the pebbles of Autun, which he inclines to refer to this group on account of their great resemblance to the stems. He says on this point in his Memoir ${ }^{3}$ : "Their structure is so like that of the branches, that there can be no doubt of their connection.' They show first of all on the elliptical transverse section exactly the same short radial hypodermal strengthening ribs mentioned above. In the middle of their stout thick parenchyma, which is marked throughout with isolated dark points, lies a much-expanded vascular bundle which is divided by medullary rays into several segments lying beside one another. The bundle consists of an upper portion of wood, and an under portion of the same to which the bast-layer is attached. The whole gives the impression that secondary growth must have taken place. The upper wood-portion, which in that case would answer to the primary bundle of the stem, is traversed by tracheides without regular arrangement, the scalariform elements being beneath, the pitted above. In the lower portion the pitted tracheides form straight parallel rows, as is usually the case in secondary wood. If all these statements are confirmed, there is not much to be said against placing these two species of Poroxylon with Cycadeae. Still they would differ from our recent forms in the important point, that the trace-bundles maintain the anomalous position of thcir initial strand on the outer side of the bundle even in the stem. 
The next forms to be mentioned are the genera Lyginodendron, Will., and Heterangium, Corda, which seem to stand in a relation to one another similar to that of Poroxylon Boysseti to P. Duchartrei. Lyginodendron Oldhamiamum, Will., a full account of which we owe to Williamson ${ }^{1}$, occurs frequently in the calcareous nodules of the coal-fields of Lancashire and Yorkshire, and also in those of Langendreer and Orlau. A transverse section of a stem in a nodule from the latter locality is figured by Stur ${ }^{2}$. These remains were first discovered by Binney, and were called Dadoxylon Oldhamium. The name Lyginodendron adopted by Williamson was invented by Gourlie, who used it to express the peculiar impressions of rinds with Dictyoxylon-structure mentioned above on pp. 8 and 218 . As the name is no longer necessary for this purpose, Williamson has transferred it to our plant, and not without reason, since some of these impressions do certainly come from it, and it also shows Dictyoxylon-structure in the rind. A full account of the history of this genus will be found in Williamson.

At first sight the transverse section presents essentially the appearance of a stem of Cycadeae. We find a well-developed and rather thick ring of secondary wood divided by many broad medullary rays into numerous plates a few cell-rows in breadth, quite after the manncr of Cycadeae. The elcments of this wood appear to be entirely pitted trachcides. Williamson states that zones have been observed which look like annual rings, but I do not find any in my specimens; they are said to occur particularly on old and very thick specimens, such as the one figured by Williamson ${ }^{3}$. The space inclosed by the ring of wood contains a central mass of parenchyma, which in many cases however is cntirely destroyed, and this is surrounded on all sides by irregularly shaped bundles of varying length and brcadth. These bundlcs immediately adjoin the inner surface of the ring of wood; the elements of smallest transverse section lie on their outer side. The bundles stand in no regular relation to the segments of the ring of wood. They are usually more or less pushed out of their original position, owing to the disappcarance of the central parenchyma and the collapse of the stems; but where these are preserved intact, as in one of Williamson's figures ${ }^{4}$, there the bundles appear less as single separate bundles than as fragments of a ring inclosing the central parenchyma, as in Sigillaria spinulosa (see p. 252-3 and Fig. 49). This would be in favour of the explanation that thcy are axile bundles with a parenchymatous centre, such as we found in Lepidodendrae. Further investigation will be required to determine the truth of the one or the other view.

The rather thick rind separates into three layers. The innermost layer is the bast in the form of wedges, which are the direct continuation of the rays

1 Williamson (1), IV.

2 Stur (2).

s Williamson (1), IV, t. 22, f. 4 .

- Williamson (1), IV, t. 22, f. 2. 
of wood, and like them are separated from one another by broad medullary rays. The middle layer is the parenchymatous inner rind which is seldom preserved ; its closed tissue contains many isolated darker cells. Lastly, the outer rind is always well preserved; it consists of thick-walled elements, and is traversed by hypodermal fibre-plates which appear on the transverse section as crowded radial stripes. The tangential section shows that these plates have a sinuous course, so that they meet in places and coalesce with one another for short distances. In this way fusiform meshes filled with

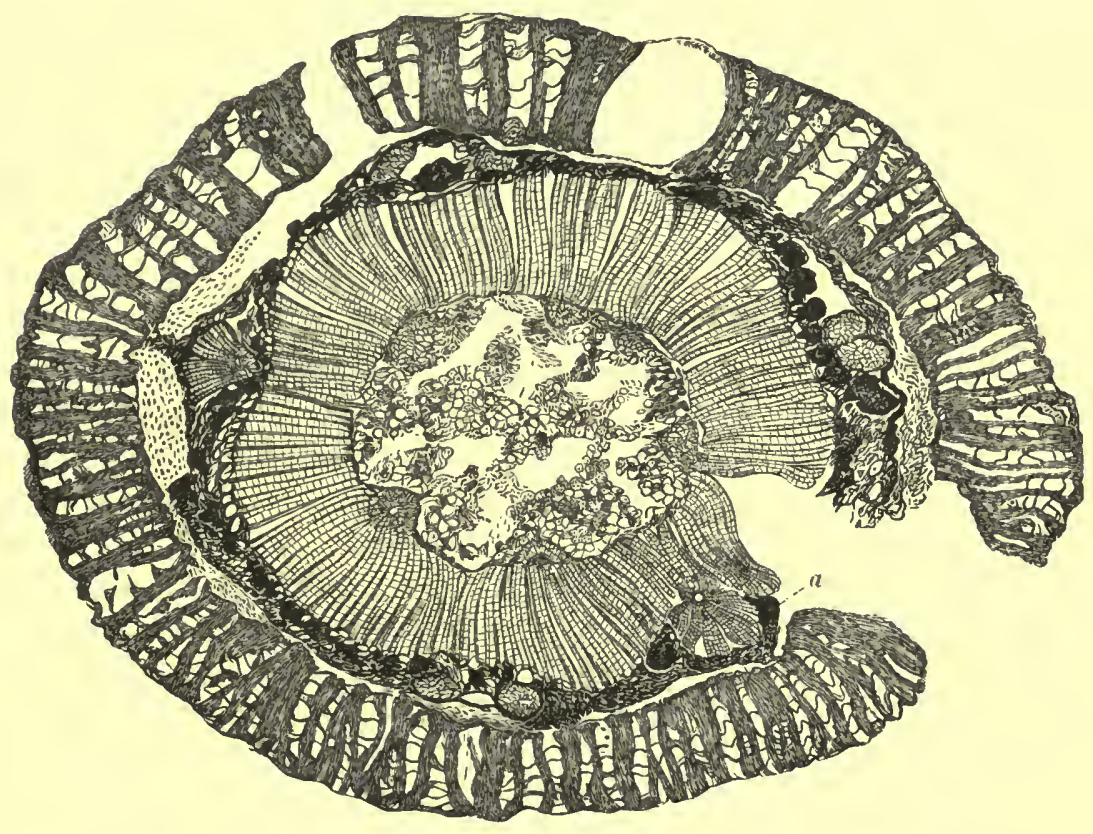

FiG. 49. Lyginodendron Oldhamiamum, Will. Transverse section of the stem according to a preparation from Oldham in my possession; in the centre the parenchyma of the pith partially preserved, and on its outer boundary six irregularly distributed primary bundles with centripetal formation. Next to this on the outside is the ring of wood, which is very like that of Cycadeae. Outside the wood, where the bast-portion has disappeared, are seen in several places the transverse sections of bundles lying side by side in pairs, which probably belong to the emerging leaf-traces. Single similar strands $(a)$ showing growth in thickness perhaps, answer to their lowest portion. Inner and middle rind are destroyed; the outer rind shows Dictyoxylon-structure.

parenchyma are formed between them; we have in a word the well-known Dictyoxylon-structure (Fig. I).

Further investigation is required to make us fully acquainted with the structure of the bundles which pass from this ring of wood to the lateral members. At present there is scarcely anything satisfactory to tell about it. Bundles of different character are met with in the inner rind on every transverse section, but it has not hitherto been possible to determine their course with certainty in the longitudinal direction. These bundles occur in three principal forms. The most frequent are bundles of somewhat irregular roundish-ovate form on the transverse section, which lie side by side in 
pairs and symmetrically with respect to one another; this form is met with in three or four places in every preparation. The distance between. the bundles is of varying breadth; sometimes they are in direct lateral contact with one another (Fig. 49). This depends no doubt on the different heights at which the section has passed through them. It is difficult to determine whether this bundle is concentric or collateral, because the bast-portion has been destroyed; I am also still in doubt respecting the position of the initial strand. It is to be hoped that the fine material which has been recently obtained will soon settle this point. Its tracheal elements are like those of the wood. I am inclined to think that these strands are leaf-traces, though it is strange that they have never been met with in tangential sections in the Dictyoxylon-meshes of the outer rind. Their course must in any case be stecply ascending, since Williamson, on the strength of a longitudinal section which he has figured ${ }^{1}$, declares it to be vertical and parallel to the ring of wood. I cannot however accept the view which he founds on this observation, namely that they are cauline bundles, for reasons which will be mentioned presently. Next we have bundles of occasional but much less frequent occurrence, which are evidently composed of two separate parts. They always stand isolated and unusually close to the outer edge of the wood, where there is always a broad open gap-like primary ray corresponding to them from which they seem to emerge. Each of these bundles consists of an outer normal secondary wood, which has its clements arranged in rows and is usually spread out like a fan, and a primary strand forming its inner boundary and with its tracheides not disposed in any order (Fig. 49a). This strand is exactly like those which bound the pith, and the impression which it gives is as if one of these strands with the piece of secondary wood corresponding to it had come out through the ring of wood. But as traces of a similar secondary growth are found also in the transverse sections of the bundles of the first kind, where they still lie near together, it is natural to regard all these transverse sections not only as collateral, but as actually belonging to one another. If this is the true view, - a point which has yet to be determined,--then the emerging strands, which are simple below and have experienced growth in thickness, would lose this growth further on, and ascending in the rind would ultimately separate into two contiguous branches.

The bundles which have now been described are the only ones which I have myself observed in the material before me. But Williamson ${ }^{2}$ has in some cases met with a third kind, which he takes for the attachment-traces of lateral branches, because he was also able to observe their emergence through the meshes of the Dictyoxylon-rind ${ }^{3}$. Their primary strand

1 Williamson (1), IV, t. 24 , f. II.

2 Williamson (1), IV, t. 22, f. 1 .

3 Williamson (1), IV, t. 25, ff. $14,16$. 
appears to agree perfectly with that of the preceding kind, but it is surrounded by a secondary ring of normal wood divided by medullary rays.

Transverse sections of leaf-stalks are very commonly found in company with the pieces of stem of Lyginodendron, and in such a position that the unbiassed observer would at once think it probable that they belong to the stems. They do in fact show exactly the same habit as the stems, the same sub-epidermal plates of strengthening tissue, and a leaf-trace of two symmetrical elliptical approximated bundles, which resemble minutely the bundles of the first kind described above. Their transverse section is broad, the upper side flat, the lower slightly convex; there are sharply projecting edges on both sides. The resemblance to certain transverse sections of stalks of fern-leaves, for example to one figured by Williamson ${ }^{1}$ and referred to Rhachiopteris aspera, is evident. Moreover, countless fragments of the laminae of this or of a very similar form are always to be found in the immediate neighbourhood of the nodules, and they have on them very commonly small slightly projecting winged ribs, which appear in transverse section as odd, horn-shaped, entirely parenchymatous excrescences. These ribs, strange to say, are found almost invariably in exactly the same form on the leaf-stalks thus associated with Lyginodendron, in which they spring each of them from one of the meshes of parenchyma between the hypodermal Dictyoxylon-plates. Williamson himself inclines to consider that these fernleaves and leaf-stalks belong to the stems of Lyginodendron. He says ${ }^{2}$, 'I have pointed out the existence in the Lancashire nodules of abundance of small stems or petioles, to which I gave the provisional name of Edraxylon. I have since succeeded in connecting these petioles with the leaflets of a Pecopteris. I think it far from impossible that these may prove to belong to Dictyoxylon Oldhamium, but since I have not yet succeeded in correlating them with any certainty, I shall add no more respecting them at present.' Strict proof can only be supplied by sections passing through the point of union of the two.

On the other hand, there is the resemblance to Cycadeae in respect of the structure of the stem, which has been already pointed out. Felix especially has drawn attention to these relations in a preliminary communication ${ }^{3}$. But it is not so much recent Cycadeae which this writer would compare with Lyginodendron, as the partial rings in the pith of Medullosa stellata. Even if the Rhachiopteridae just mentioned really belong to Lyginodendron, this would be no objection to Felix's view, since, as was shown above, there is no essential difference in the lamina of the leaf between Ferns and Cycads; and Osmunda, Myelopteris and Sphenopteris refracta, Göpp. warn us also to be careful in employing the leaf-bundle and its structure as a ground of discrimination. But still there must have been important 
differences in character between the central cylinder inclosed within the ring of wood, and the same cylinder as known in Cycadeae. All these things considered, I abstain from expressing an opinion one way or the other with respect to the affinities of these remains. Renewed investigation will no doubt throw more light upon them. Into speculations respecting certain groups intermediate between Ferns and Cycads which might readily be connected with the present subject, I do not propose to enter here any more than in other places in this work, which would have been suitable for them; the reader will find no difficulty in forming such an idea of them as may be needful from the facts here given, and they will not fit into the frame of such an account of our subject as was intended in the present work.

Corda ${ }^{1}$ has described as Heterangium paradoxum a very imperfect bit of stem from the sphaerosiderites of Radnitz in Bohemia. It is nothing but some shreds of tissue, in which irregular groups of broad and narrow pitted vessels are seen in the middle of a small-celled tissue which has been broken up and disintegrated. Williamson subsequently recognised in these remains some fragments of the central strand of a stem which he had obtained in section from the infra-Carbonifcrous calcarcous nodules of Burntisland, and which he accordingly named Heterangium Grievii ${ }^{2}$. I have received another and similar species through Cash's kindness, which was obtained by Mr. Binns at Halifax from the Lancashire nodules; it will probably be soon and fully described by Williamson. The identification with Corda's specimen may be taken to be perfectly satisfactory; at all events I cannot sympathise with the doubts expressed by Renault ${ }^{3}$, which are founded on too strict an interpretation of Corda's statements.

We shall have an idea of the structure of the stem in Heterangium Grievii, Will., if we imagine the central portion in a stem of Lyginodendron to be occupied by a uniform closed primary vascular bundle, with its tracheal elements in irregular groups and irregularly imbedded in a fundamental parenchymatous tissuc. The surrounding secondary wood is less strongly developed than that of Lyginodendron, but is like it in all other respects. All the tracheal elements have bordered pits. The thick parenchymatous rind is traversed by leaf-traces which are here formed of one strand only; these bundles Williamson in this case accepts as leaf-traces, though they ascend almost as steeply as the analogous bundles in Lyginodendron. The outer hypodermal Dictyoxylon-layer is narrower than in Lyginodendron, but its fibre-plates are more crowded together and of larger size. The inner layer is formed of compact parenchyma, in which transverse lines of darker cells may be seen on the radial section following one another at regular distances.

But the systematic position of Heterangium still remains doubtful, 
even more doubtful than that of Lyginodendron. It cannot well be reckoned with Cycadeae on account of its central primary bundle; and on the other hand, if there were no secondary growth, there would scarcely be any reason for doubting that it is of the nature of Ferns. The large and few leaf-bundles are against its belonging to plants resembling Lycopodiaceae, such as Williamson ${ }^{1}$ has suggested. But the near affinity to Lyginodendron is obvious.

A quite peculiar and still little known genus is Kaloxylon ${ }^{2}$, Will., which was discovered by its author in the Lancashire calcareous nodules, and was subsequently obtained in some specimens from the Burntisland nodules, which are from a much lower part of the series. It consists of axes of very small diameter, and with their centre occupied by a uniform vascular strand. This strand, the only one present in young specimens, slows a somewhat polygonal outline, and is surrounded by a secondary growth formed of wedge-shaped portions not more than six in number, which are traversed by ordinary medullary rays of one row of cells, and are separated from one another by broad gaps or rays. Each gap or ray is wedge-shaped by increase of breadth towards the outside and is filled with parenchyma, and, according to Williamson's ${ }^{3}$ description and figure, answers to a bay in the line of cambium. The rind outside of this cambium-zone is parenchymatous, and according to Felix ${ }^{4}$, who examined sections of Kaloxylon from the Langendreer nodules, is full of lacunae; two layers of somewhat broader fibre-like elongated cells are developed on the extreme outside. As regards the character of the tracheal elements of the wood of Kaloxylon, Williamson says that it belongs to the 'reticulated type.' But this expression is very indefinite, for the English author refers to this type not only true reticulated vessels, but very often also bordered pit-elements, in which owing to imperfect preservation only the outer line of the border of the pit is visible, as for example in Lyginodendron and Heterangium. In a rather oblique transverse section obtained by the author himself I thought I saw scalariform vessels; but the specimen departs a little from the description in other respects, so that I do not quite trust to the determination. Of the affinities of this fossil, which Williamson seeks in Lycopodinae, nothing at all certain can in my opinion be for the present said.

Lastly must be mentioned here certain fossil remains from the Carboniferous formation, which probably represent roots of unascertained genera of Gymnosperms, and which have been described by Williamson ${ }^{5}$ under the name Amyelon radicans. Like many more sections of roots which cannot at present be determined, they occur not unfrequently in the calcareous nodules of Langendreer and England, and often reach a considerable thick-

1 Williamson (1), Iv, p. 405 . vir, t. 6, f. 32 , and t. 7 , f. 34 .
${ }^{2}$ Williamson (1), vII, p. I3; tt. 5-7.

4 Felix (2).
3 Williamson (1), 
ness, due entirely to the compact massive secondary wood. Williamson ${ }^{1}$ has both described and figured them. The copiously branched roots ${ }^{2}$ show in the centrc a triarch primary wood-strand, and next to this and all around it is the secondary wood which is frequently excentric. In older specimens concentric lines like rings of annual growth are plainly to be seen in the secondary wood ${ }^{3}$, and these should be carefully examined, because a true formation of yearly rings has never been observed in any other remains from the Carboniferous formation, and would therefore be particularly interesting. In other respects the wood shows little structural peculiarity. It consists of a uniform mass of pitted tracheal elements, and is traversed by a great many secondary rays, which are formed of a single row of cells, and are often only one cell in depth. Two layers may be distinguished in the thin rind. The inner layer consists of parenchyma with no regular disposition of its cells, but the outer layer shows on the transverse section nothing but short fusiform rows of cells thrust in between one another, each row consisting of a large number of quite flat tabular elements. It is obvious that each of thesc rows represents an original parenchymatous mother-cell, in which a number of tangential divisions were subsequently formed.

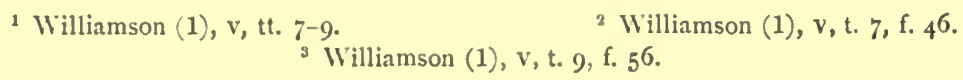




\section{XVI.}

\section{PLANT-REMAINS OF DOUBTFUL AFFINITY, IN WHICH THE CHARACTER OF THE SURFACE ONLY IS KNOWN, WHILE THE STRUCTURE IS UNKNOWN.}

The name Vertebraria, Royle has been given to some obscure fossil remains known at present only from the Damuda beds of India which are probably Triassic, and from the Newcastle beds of New South Wales. I have had the opportunity of seeing many specimens of these remains in the British Museum, and in the collection of Professor Boyd Dawkins at Manchester. The name comes from Royle ${ }^{1}$, who published good figures of his Vertebraria, but unfortunately without description of any kind. Some account of these remains and a full report of the literature will be found in Bunbury ${ }^{2}$ and O. Feistmantel ${ }^{3}$.

The Vertebrariae are cylindrical simple or more or less copiously branched forms with a circular transverse fracture. They fill the thick beds of a brick-red or brownish-gray stone, often crossing the stratification. The circular transverse section is divided by thin bands of coal, which meet in the centre and spread ray-like to the circumference, into a few wedgeshaped masses, which increase in breadth towards the outside, and when regularly disposed might at first sight suggest a comparison with the surface-view of the leaf-whorl of Sphenophyllum. This comparison has in fact been made by $\mathrm{M}^{\text {'Coy }}{ }^{4}$, who finds the chief distinction between Sphenophyllum and Vertebraria in the crowding of the successive whorls, which are so close together as to touch one another. If this were so, we should see the spaces which answer to the surfaces of the leaves covered with a layer of coal, whereas they show in most cases only surfaces of fracture of the stone.

The cylinders are very frequently brought under our observation in radial and tangential longitudinal fractures, and then a strip of coal is seen running down the middle of the cylinder. The radiating bands of coal of the transverse section prove to be so many vertical plates, and appear of

1 Royle (1), t. 2, ff. I-7. Ind. Ser. XII (lower Gondwanas), II, p. 72 ; tt. I 2-I 4 .
${ }^{3}$ O. Feistmantel (1), IIr, p. 84, and Pal. ${ }^{4} \mathrm{M}^{\prime} \operatorname{Coy}(1), \mathrm{p} .1_{4} 6$. 
course on the tangential section as vertical lines. Longitudinal sections of the kind were figured by Royle, and good descriptions of them are given in the Palacontologia Indica ${ }^{1}$. If the radial fracture passes through the intervals between these plates, then there appears on each side of the central strip of coal a series of fractures with rectangular bounding lines passing through the stone; and the transverse dividing planes in these fractures, which do not correspond on the two sides, also seem sometimes to contain traces of coal. More minute examination of the best specimens studied by me would, I believe, bring to light some further remains of structure.

So far as it is possible to judge of the matter from mere outside view, it seems to me that Bunbury, whose opinion is shared by O. Feistmantel, is quite right in supposing that the Vertebrariae were roots or stems with a central solid axis and a less compact cortical cylinder, and that prismatic intercellular spaces in the latter were filled with the substance of the stone, while the diaphragms were preserved in the form of bands of coal. But whether, as Feistmantel assumes, they really belong as roots to Phyllotheca and so to Schizoneura Gondwanensis, with which they are usually associated in the beds, must remain at present undetermined. Specimens of greater thickness are very rare; a figure of such a cylinder is given in O. Feistmantel ${ }^{2}$. The form which Schmalhausen ${ }^{3}$ describes as Vertebraria, from the Lower Oolite of Siberia, can scarcely belong to this group. The figure gives the impression of pinnae of a fern-leaf rolled up after the manner of Scolecopteris, but the description of the remains does not well admit of this interpretation.

The remains named Aethophyllac, of which two species have been found in the quarry in the Buntsandstein at Sulzbad in the Vosges, are as remarkable as they are little understood. No objects certainly belonging to this group have, as far as I know, been found elsewhere. They appear indeed sometimes in lists of Triassic plants from different localities, but in all these cases it is found that the deterninations rest on quite unsatisfactory linear fragments of leaves. The two species, Aethophyllum stipulare, Brongn., and Ae. speciosum, Schpr, the former of which had been previously described by Brongniart ${ }^{4}$ in 1828 , have been carefully examined by Schimper ${ }^{5}$. Aethophyllum speciosum is an acropetally branched stem more than two feet long, bearing linear leaves that lie scattered about on the slab of stone, and having their main axis and lateral branches terminated by long cylindrical spikes which form the fructifications. The spikes appear to be composed of numerous small lanceolate acuminate scales, but these through imperfect preservation are very indistinct. Aethophyllum stipulare

1 Pal. Ind. Ser. XII, II, p. 72.

${ }^{2}$ O. Feistmantel (1), III, t. 6, f. I.

3 Schmalhausen (1), p. 53, t. 7 , ff. $15,16 . \quad$ Brongniart (9), p. 455 ; t. 18, f. I. Schimper (3), p. 37 ; tt. 19,20 , and (1), vol. ii 1, p. 5 I. 
is a similar but smaller stem, and is unbranched in the only known specimen, which is in the Museum at Strassburg. With such imperfect knowledge of these remains, we can hardly expect to succeed in determining their affinities. Schimper wavered originally between Lycopodiaceae and various Monocotyledons. At length he says ${ }^{1}$ : 'We were on the point of declaring in favour of the latter hypothesis (Lycopodiaceae), when minute examination disclosed in the spikes some seeds like small seeds of Coniferae, a discovery scarcely calculated to advance us in our researches.' But he then refers them to Monocotyledons on account of these seeds, about which I have been unable to satisfy myself from the original specimens. I quite agree myself with Schenk's ${ }^{2}$ opinion, that such a classification is altogether in the air, and that it can do no good and may do harm, so long as we have no present proof of the existence of undoubted Monocotyledons or of any Angiosperms in these ancient deposits. It may just be mentioned that another spike-like object, also found in the Buntsandstein of Sulzbad, has been described by Brongniart ${ }^{3}$ as Echinostachys, and figured by Schimper ${ }^{4}$.

How little we know of the real nature of Spirangium ${ }^{5}$ is shown at once by the variety of names which the remains in question have received in the course of time from different authors. The first-known species was described by Brongniart ${ }^{6}$ as Palaeoxyris regularis. It comes from the Buntsandstein of Sulzbad in the Vosges, and has been figured by Schimper and Mougeot ${ }^{7}$. A second species is Palaeoxyris Münsteri, Presl ${ }^{8}$, from the Rhaetic beds of Franconia, which has since been minutely examined by Schenk ${ }^{9}$. Other remains of the same kind are stated by Saporta ${ }^{10}$ to have been found in the Rhaetic beds of Couches near Autun (Spirangium ventricosum ${ }^{11}$ ), and in those of Pålsjö in Schonen by Nathorst ${ }^{12}$. Spirangium Quenstedti, Schpr. (Palaeoxyris ${ }^{13}$ ) comes from the Keuper of Waldhausen near Tübingen. A form which is common in the Wealden formation of Hanover has been described by Ettingshausen ${ }^{14}$ as Palaeobromelia Jugleri, and Schenk ${ }^{15}$ has given fine figures of the same. The genus occurs also in the Carboniferous formation, and has therefore an unusually extended vertical distribution. It is true that the specimens of Palaeoxyris carbonaria from the Upper Carboniferous deposits of Wettin are not above suspicion. These specimens and the remains from the American Coal-measures described by Lesquereux ${ }^{16}$ as Spirangium Prendelii, Lesq. are declared by Schenk ${ }^{17}$ to be

1 Schimper (3), p. $5^{8}$.

2 Zittel (1), p. 358.

$s$ Brongniart (9).

4 Schimper (3), t. 23. 5 Schimper (1), vol. ii I, p. 5 I $5 ;$ t. 80 .

Brongniart (9), p. 456 , t. $20 . \quad{ }^{7}$ Schimper et Mougeot (3), t. 23 , and (1), t. 80, f. I. ${ }^{8}$ Sternberg, Graf von (1), Heft 5-8, t. 59. ${ }^{9}$ Schenk (3), p. I95; t. 45, ff. 7,8 . ${ }_{10}$ Saporta (2), p. $230 . \quad 11$ Schimper (1), t. 8o, f. 4.12 Nathorst (7). ${ }^{13}$ Quenstedt (1), t. 82, f. I. ${ }_{14}$ von Ettingshausen (6). ${ }_{15}^{15}$ Schenk (1), tt. 40, 41. ${ }^{16}$ Stiehler (1) ; Schimper (1), vol. ii I, p. 5 I4 ; Germar (1), t. 33, f. 3 . $\quad{ }^{17}$ Lesquereux (1), p. 5 19; t. 75 . 18 Schenk (3), p. 197; Zittel (1), p. 394. 
absolutely nothing but badly preserved fragments of Lepidodendron. This decision appears to some extent forced and improbable, even in the case of the above remains, but it is shown to be without foundation by the many fine specimens which have been found in the clay-ironstone workings in the Coal-measures of Coalbrookdale (Palaeoxyris helicteroides, Morris). I have seen these remains in a hundred forms in the finest preservation in the British Museum, to which they had been recently removed through the purchase of a large local collection.

These Spirangiae are peculiar fusiform bodies, in which we can distinguish an ovoid enlarged middle portion and two long extremitics which narrow gradually in the form of a cone. They are usually found singly on the planes of stratification; but specimens of Spirangium Jugleri are not uncommon in the Wealden, in which scveral of the fusiform bodies are borne in an umbel on the top of a thin filiform stalk, on which there is no appearance of nodes or appendages of any kind. The surface of the whole body is marked with sharp ribs, usually six in number, which wind spirally round it once or one and a half times, and then straighten themselves out at the conical extremity. In consequence of the strong compression the edges of the two sides are often scen simultaneously, and these cutting one another necessarily produce rhombic areolae. This appearance is particularly striking in the specimen first described by Brongniart, and hence he ${ }^{1}$ took the whole object for a flowering spike and the areolae for imbricated bracts. He compared it with the spikes of the genus Xyris and chose its name accordingly. Ettingshausen perceived Brongniart's error, and supposed that there were six valve-like twisted bract-scales surrounding a central body. But I do not understand from this how he arrived at a comparison with the inflorescences of Aechmea, Pourretia, and Bromelia. By Quenstedt Spirangium is compared with Cycadeae. Schenk ${ }^{2}$ with a greater show of reason suggests for comparison the fructifications of Helicteres with their spirally twisted carpels, but does not express any decided opinion. Schimper also simply places the plant with 'genera incertae sedis.' Nathorst has recently. attempted to work out the comparison with Characeae; he sees in Spirangiae gigantic sporangia of Charae surrounded by spirally twisted envelopetubes. The lateral boundaries of these tubes are supposed to correspond, as in Chara, with the screw-lines. His work is written unfortunately in the Swedish tongue, with which I, like most botanists, am unacquainted, so that I can only refer to reports upon it. Now that I have had the opportunity of examining carefully the numerous specimens of Spirangium Jugleri in the collection at Marburg, and also the large series from the Carboniferous formation in the British Museum, I can only say with Schenk $^{3}$ that Nathorst's view is the most attractive, but that it is impossible to obtain 
the needful proofs in any direction until we can examine specimens in which the structure is preserved.

The Spirangiae do not represent a perfectly isolated type; that there may have been a whole group of similar forms in existence, may be concluded from the recent discovery of the genus Fayolia ${ }^{1}$ by Renault and Zeiller in the coal-mines of Commentry. Figures and a full description of this form may be expected in the great Flora of Commentry, upon which these authors are engaged. The resemblance between Fayolia and Spirangium is obvious, though in the former there are only two much more strongly twisted screw-lines, which appear to answer to the margins of two ribbon-like valves. On each of these is an appendage ('collerette') peculiarly striated and entire or toothed, which is prolonged beneath the beak of the body into a free erect pointed and winged tooth. The plates themselves bear a row of small circular scars, which approach the lower margin and represent the points of attachment of subulate spines which are occasionally preserved.

Some identical remains have been recently and almost simultaneously described by Weiss ${ }^{2}$ and Newberry ${ }^{3}$, which appear to be allied to Fayolia but are unfortunately in a much worse state of preservation. Gyrocalamus palatinus, Weiss, was discovered in the Rothliegende (Lebach beds) near Cusel in the Rhenish Palatinate; Spiraxis major and S. Randallii of Newberry come from the Chemung beds of the Upper Devonian formation, the former having been found in the State of New York, the latter in Pennsylvania. If these forms, as Weiss ${ }^{4}$ assumes without any hesitation, are really to be classed with Fayolia, it would not say much for the relationship of that genus to Characeae; for both Gyrocalamus and Spiraxis, owing to their greater length and more cylindrical form, have much less the appearance of fructifications. The unprejudiced observer would take Weiss' fossil, which is broken off at both ends, simply for a fragment of the cylindrical cast of a stem. The surface unfortunately is very imperfectly preserved, the American specimens showing only the strongly projecting broad obtuse ribs running in very flat spirals; in the German specimen we see that each of the apparently simple ribs consists of two parts, an inferior sharp keel, the proper rib, and a flatly convex strip lying upon it, which belongs to the twisted band and bears a row of indistinct roundish scars exactly at the spot where the scars of the spines appear in the better preserved remains from Commentry.

We may now turn in conclusion to the genus Williamsonia, the last group of fossil remains which we shall have to consider. The species of Williamsonia are very peculiar remains of fructifications, and their precise structure is still very imperfectly known to us. That they are associated

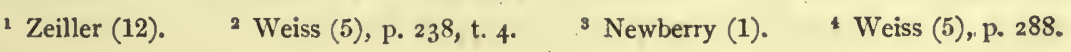


by Williamson ${ }^{1}$ and Carruthers ${ }^{2}$ with leaves and stems of Zamia gigas has been already stated on p. 9I. O. Feistmantel ${ }^{3}$ a mong more recent authors has adhered to this view, while Nathorst ${ }^{4}$ and Saporta and Marion ${ }^{5}$ rightly consider that the grounds on which it rests are insufficient. These remains were first discovered in the Lower Oolites of Whitby. The greater part of the specimens obtained from that locality have found their way along with the Yates collection into the Paris Museum, which may in consequence possess as many of them as all the English collections taken together. Various specimens were next found in the Upper Gondwanas of India and at different levels in them; in the Rajmahal, Cutch, and Jabalpur beds (Jurassic). A full description of these remains will be found in O. Feistmantel. Another species, Williamsonia Forchhammeri, Nath. comes from the Jurassic formation of Bornholm, and other forms have recently been found in France, W. pictaviensis, Sap. et Mar., for example, in the Oxfordian beds in the neighbourhood of Poitiers. According to Saporta and Marion the type goes still further back; these authors state that they have remains of it, at present unpublished, from the infra-Liassic beds of Hettange (Angulatae beds). They also refer to it a fossil, which resembles it but is still doubtful, from the Rhaetic beds of Bayreuth; this form will be found mentioned and figured in $\mathrm{F}$. Braun ${ }^{6}$ under the name of Weltrichia mirabilis, but Schenk ${ }^{7}$, strange to say, has left it unnoticed. The determination has gained probability from the recent discovery of an apparently well-ascertained species, Williamsonia angustifolia ${ }^{8}$ in the Rhactic beds of Hör in Schonen. The best-known species is the large W. gigas, Carr. from Whitby. Specimens in the ordinary state of preservation show a wreath of numcrous broadly lanceolate leaves, lying many deep on one another and curved or connivent into the shape of a bell or dome, and occurring as impressions with a thin rind of coal in the brownish red sandstone of Whitby. The objects found are either moulds of the outer side of the bells, or more commonly the matter which filled the bells in the form of rounded nodules bearing on their surface the impressions of the leaves. In the latter case in the place where the axis must have been and between the leaf-bases there is a hollow space, which under favourable circumstances is prolonged into the interior of the wreath of leaves, and there answers to the space originally occupied by the organs of fructification. A cast has been found in these specimens in a very few instances, corresponding in form to the casts which are artificially obtained. This cast, figured by Williamson ${ }^{9}$ from nature, has the form of a flask with a protuberant body which passes gradually into a narrow neck with

\footnotetext{
i Williamson (10):

2 Carruthers (4).

3 O. Feistmantel (1), II.

4 Nathorst (8).

5 Saporta et Marion (2), p. 234. ' F. Braun (1), t. 2. ${ }^{7}$ Schenk (3).

8 Nathorst (8),

t. 8, f. 8-10. Williamson (10), t. 52, f. 4 and t. 53, ff. 6-8.
} 
an expanded rim. Attached to it is a globular process with its upper extremity somewhat emarginate and even spread out into a small flat surface. This flask-like body is ornamented externally with radiating striae or even with a polygonal mesh-work, which is regarded by authors as the remains of crowded anthers, attached to the extremity of the flaskshaped axis. O. Feistmantel ${ }^{1}$ has figured a doubtful specimen which also perhaps represents the cast of a Williamsonia. The involucre of surrounding leaves is formed according to Saporta of several series, the leaves in which increase successively in length. The stalk, which bears the whole structure and which is covered with lanceolate leaves lying one on another like scales, has been preserved only in a very few cases. The leaves are of a firm and solid character, and have a keel in the middle of the dorsal side; according to Saporta ${ }^{2}$ they show an anastomosing nervation like that of Dicotyledons. I have myself been unable to discover anything of the kind in the specimen in the Paris Museum, in which he observed it, and a French botanist who examined the piece with me for this purpose was not more successful.

In the same beds are found peculiar circular disks with a funnel-shaped depression, and with the margin slit into long lanceolate lobes. According to Williamson ${ }^{3}$ each of these lobes bears not far from its base an ovoid projection formed of two parallel ridges, which Saporta however did not find in the specimens to which he has had access. While Williamson sees in these disks the remains of female flowers (he terms them 'carpellary disks') and in the projections traces of the ovules, Saporta and Marion think that they are only terminal expansions of the above-mentioned flaskshaped axis of the male flowers, and they consider that they have found the two in connection with one another. They say on this point ${ }^{4}$ : "This expansion was the upper termination of the male apparatus and might be compared to the spongy cushion at the top of the spadix of Amorphophallus : one might even be tempted to see in it something analogous to the circle of leaves above the inflorescence in Ananas. The organ in question is certainly the result of a transformation of the upper leaves of the branch which has been changed into a spadix.' It is to be hoped that a publication yet to come from Saporta will contain further and more convincing particulars on this subject.

There are moreover certain other objects which Saporta and Marion have considered to be female fructifications of our plant. For these they refer especially to a specimen found by Nathorst ${ }^{5}$ in Cloughton Bay on the coast of Yorkshire, and named Williamsonia Leckenbyi. Close beside an

O. Feistmantel (1), II, t. 3, f. 3 .

2 Saporta et Marion (2), p. 237.

Williamson (10), t. 52, f. I and t. 53, f. 2 .

- Saporta et Marion (2), p. 240.

Sathorst (8), t. 8, f. 5 .

$\mathrm{B}$ b 2 
involucre, the leaves of which are spread out by pressure into a stellate form, there lies on a surface of gray schist an irregular shred of tissue formed entirely of small cylinders placed palisade-fashion side by side, and showing therefore crowded polygonal facets on its surface. This fragment in their opinion represents a portion of a rolled up spadix beset with peripheral organs. They also figure ${ }^{1}$ a very fine and well-preserved fragment petrified in carbonate of iron and found by Morière in the Oxfordian strata of the Vaches Noires in Normandy, which shows a spadix still in part surrounded by involucral leaves and with its surface actually presenting the same faceted appearance. The facets, which answer to small angularly pyramidal prominences, are arranged with regularity in a circle or rosette around a central deep-lying point. A layer of seeds lying beneath the surface is seen on the longitudinal fracture, and the substance of the spadix underneath the seeds is composed of stout parallel fibres. That this object is a fructification is unquestionable on account of the seeds, and its resemblance to the spadix, described above on p. 95, as belonging to the genus Bennettites, is obvious; its connection with Williamsonia is only concluded from the preserfe of the peripheral lanceolate involucral leaves, but we have scen that these occur in a similar manner in Bennettites. I have no doubt therefore that this specimen belongs to Bennettites, but in saying this I have no intention of prejudging the question of its relation to Williamsonia; for it is still possible that further discoveries may show that the fructifications of Bennettites and Williamsonia both belong to similar stems resembling the stems of Cycadeae, and confirm the opinion of Williamson and Carruthers. But until the truth of these conjectures is ascertained, we must be content to leave the relationship of Williamsonia undetermined. The improbability of F. Braun's and Nathorst's ideas, who would place them, as they would Bennettites, with Balanophorcac or Rafflesiaceae is patent, and needs no prolonged discussion.

1 Saporta et Marion (2), p. 244. 


\section{LIST OF PUBLICATIONS.}

Balfour, J. H. (1) Introduction to the study of Palaeontological Botany. Edinburgh, 1872 .

Benecke, E. W. (1) Ueber die Umgebungen von Esino in der Lombardei. Benecke, Geognostisch-paläontologische Beiträge, Bd. 2, Heft III.

Berendt. (1) Die im Bernstein befindlichen organischen Reste der Vorwelt. Bd. I, Abth. I. Göppert und Berendt, Der Bernstein und die in ihm befindlichen Pflanzenreste der Vorwelt, 1845.

Bergor, H. A. C. (1) Die Versteinerungen der Fịsche und Pflanzen im Sandstein der Coburger Gegend. Coburg, 1829 .

Bergeron, J. (1) Note sur les strobiles du Walchia piniformis. Bulletin de la soc. géologique de France, sér. 3, vol. I2 (1883-1884), p. 533, tt. 27, 28.

Bertrand, C. Eg. (1) Note sur le genre Vesquia, Taxinée fossile du terrain Aachénien de Tournai. Bull. de la soc. bot. de France, vol. 30 (1883), p. 293.

(2) Bertrand et B. Renault. Remarques sur les faisceaux foliaires des Cycadées actuelles et sur la signification morphologique des tissus des faisceaux unipolaires diploxylés. Comptes rendus de l'Acad., 24 Mai, 1886.

(3) Bertrand et B. Renault. Cạactéristique de la tige des Poroxylons (Gymnospermes fossiles de l'époque houillère). Comptes rendus de l'Acad., I7 Mai, I 886.

Beust, F. (1) Untersuchung über fossile Hölzer aus Grönland. Inaug.-Diss. Zürich, 1884 .

Beyschlag, F. (1) Rhacopteris sarana, Beyschlag. Zeitschrift für die gesammten Naturwissenschaften, herausgegeben von dem naturw. Verein für Sachsen und Thüringen in Halle. Folge IV, vol. I (55) (1882), p. 4 II seq.

Binney, E. W. (1) Observations on the structure of fossil plants found in the Carboniferous strata. Palaeontographical Society.

I. Calamites and Calamodendron, 1868.

II. Lepidostrobus and some allied cones, $187 \mathrm{I}$.

III. Lepidodendron, 1872.

IV. Sigillaria and Stigmaria, 1875.

(2) On some fossil plants showing structure from the lower Coal-measures of Lancashire. Quarterly Journal of the Geol. Soc. of London, vol. I 8 (1862), p. 106 seq.

(3) A description of some fossil plants showing structure, found in the lower coal-seams of Lancashire and Yorkshire. Philosophical Transactions, vol. I55 (1865), p. 579 seq.

(4) Some observations on Stigmaria ficoides. Quarterly Journal of the Geological Soc. of London, vol. 15 (1859), p. I7 seq.

(5) E. W. Binney and R. Harkness. An account of the fossil trees found at 
St. Helens. London, Edinburgh and Dublin Philosoph. Mag. and Journ. of Sc., ser. 3, vol. 27 (1845), p. 241 seq.

(6) Description of the Dukinfield Sigillaria. Quarterly Journal of the Geol. Soc. of London, vol. 2 (1846), p. 390 seq.

(7) Remarks on Sigillaria and some spores found imbedded in the inside of its roots. Quarterly Journal of the Geol. Soc. of London, vol. 6 (1850), p. 17.

Bischoff. (1) Lycopodiolithes hexagonus, Bisch. Leonhard's Zeitschrift für Mineralogie, Neue Folge, vol. I (1828), p. 253 seq.

Blanekenhorn, M. (1) Die fossile Flora des Buntsandsteins und des Muschelkalks der Umgegend von Commern. Palaeontographica, vol. 32, Lief. 4 (1886).

Blum, R. (1) Nachträge zu den Pseudomorphosen des Mịneralreiches. 1 (1847), II (1852), III (1863), IV (1879).

Bornemann, J. G. (1) Ueber organische Reste der Lettenkohlengruppe Thüringens. Leipzig, 1856.

Boulay. (1) Le terrain houiller du Nord de la France et ses végétaux fossiles, 1876.

Bowerbank. (1) A history of the fossil fruits and seeds of the London Clay. London, 1840.

Braun, A. (1) Ueber fossile Goniopterisarten. Zeitsclir. der deutsch. geol. Ges., Bd. 4 (1852), p. 545.

(2) Ueber Marsilea Marioni, eine fossile Art aus der Tertiärzeit. Botan. Zeitg., 1872, p. 653.

Braun, Fr. (1) Weltrichia, eine neue Gattung fossiler Rhizantheae. Flora, 1849, p. 705 seq.

Brongniart, A. (1) Histoire des v'égétaux fossiles. Paris, I 828.

(2) 'Végétaux fossiles' in Dictionnaire unizersel d'hist. nat. dirigé par M. Charles d'Orbigny. Paris, vol. 13 (1849), p. 52 seq.

(3) Sur la classification et la distribution des végétaux fossiles en général etc. Mémoires du Muséum d'hist. nat., vol. 8 (1822), p. 203 seq.

(4) Prodrome d'une histoire des végétaux fossiles. Paris, 1828.

(5) Sur les relations du genre Nöggerathia avec les plantes vivantes. Comptes rendus de l'Acad. des Sc. de Paris, vol. 21 (1845), p. I 392 seq.

(6) Recherches sur les graines fossiles silicifiées. Paris, $188 \mathbf{1}$.

(7) Observations sur la structure interieure du Sigillaria elegans comparée à celle des Lépidodendron et des Stigmaria et à celle des végétaux vivants. Archives du Musćum d'hist. nat., z'ol. I (1839), p. 406 seq.

(8) Notice sur un fruit de Lycopodiacées fossiles. Comptes rendus de l'Acad., vol. 67, 17 Aug., 1868.

(9) Essai d'une flore du grc̀s bigarré. Ann. des șc. nat., sér. I, vol. 15 (1828), p. 435 seq.

Bronn. (1) Beiträge zur triasischen Flora und Fauna von Raibl. Leonhard und Bronn, Jahrb. f. Min. etc., 1858, p. 5 I seq.

Brown, Rieh, (1) On a group of erect fossil trees in the Sydney Coalfield of Cape Breton. Quarterly Journal of the Geol. Soc. of Lond., vol. 2 (1846), p. 393 seq.

(2) Description of an upright Lepidodendron with Stigmaria-roots in the roof of the Sidney main coal in the island of Cape Breton. Quarterly Journ. of the Geol. Soc. of Lond., wol. 4 ( 1848 ).

(3) Erect Sigillariae with conical taproots found in the roof of the Sydney main coal in the island of Cape Breton. Quarterly Journ. of the Geol. Soc. of Lond., vol. 5 (1849), p. 354 .

Brown, Rob. (1) Some account of an undescribed fossil fruit (Triplosporites). Transactions of the Linnean Society, vol. 20 (1851), p. 469 seq.

Buckland, W. (1) On the Cycadoideae, a family of fossil plants found in the Oolite quarries of the island of Portland. Transactions of the Geological Society of London, ser. 2, vol. 2.(1829), p. 395 seq. 
(2) Buckland and de la Beche. On the Geology of the neighbourhood of Weymouth and the adjacent parts of the coast of Dorset. Transactions of the Geol. Soc. of Lond., ser. 2, vol. 4 (1835), p. I.

Bunbury. (1) On some fossil plants from the Jurassic strata of the Yorkshire coast. Quarterly Journ. of the Geol. Soc. of Lond., vol. 7 (1851), p. 179 seq.

(2) Notes on a collection of fossil plants from Nágpur, Central India. Quarterly Journ. of the Geol. Soc. of Lond., vol. 17 (I86I), p. 325 seq., tt. 8-I 2.

Carpenter, W. B. (1) Introduction to the study of the Foraminifera. Ray Society. London, 1862.

Carruthers, W. (1) On Gymnospermatous fruits from the secondary rocks of Britain. Seemann's Journ. of Botany, vol. 5 (1867), p. I seq.

(2) On some undescribed Coniferous fruits from the secondary rocks af Britain. Geol. Mag., vol. 6 (1869), p. I seq.

(3) On Beania, new genus of Cycadean fruit from the Yorkshire Oolites. Geol. Mag., vol. 6 (1869), p. 97 seq.

(4) On fossil Cycadean Stems from the secondary rocks of Britain. Transactions of the Linnean Society, vol. 26 (1868), p. $675 \mathrm{seq}$.

(5) On the history, histological structure and affinities of Nematophycus Logani, Carr. (Prototaxites Logani, Dawson) an Alga of devonian age. Monthly Microsc. Journ., vol. 8 (1872), p. 160 seq.

(6) Notes on some fossil plants. Geol. Mag., vol. 9 (1872), p. 49 seq.

(7) On the plant remains from the Brazilian Coal-beds with remarks on the genus Flemingites. Geol. Mag., vol. 6 (I 869), p. 151 seq.

(8) On the structure of a Fern stem from the lower Eocene of Herne Bay. Quarterly Journ. of the Geol. Soc. of Lond., vol. 26 (1870), p. 349 seq.

(9) On some Lycopodiaceous plants from the Old Red Sandstone of the North of Scotland. Seemann's Journ. of Botany, new ser., vol. 2 (1873), p. 321.

(10) Notes on fossil plants from Queensland, Australia. Quarterly Journ. of the Geol. Soc. of Lond., vol. 28 (1872), p. 350 seq.

(11) On the nature of the scars in the stems of Ulodendron, Bothrodendron and Megaphytum, with a synopsis of the species found in Britain. Monthly Microsc. Journ., vol. 3 (1870), p. 144 seq.

(12) On Halonia of Lindley and Hutton, and Cyclocladia of Goldenberg. Geol. Mag., vol. 10 (1873), p. 145 seq.

(13) On the structure of the stems of the arborescent Lycopodiaceae of the Coalmeasures. Monthly Microsc. Journ., vol. 2 (I 869), p. 177 seq., et p. 255 seq., tt. 27, 3 I

(14) On an undescribed cone from the Carboniferous beds of Airdrie,. Lanarkshire. Geol. Mag., vol. 2 (1865), p. 433 seq.

(15) On the structure of the fruit of Calamites. Seemann's Journ. of Botany, vol. 5 (I867), p. 349 seq.

Caruel, T. (1) Observazioni sul genere di Cicadacee fossili Raumeria e descrizione di una specie nova. Bollettịno del Reale Comitato geologico d'Italia, n. 7-8 (1870), p. I 8 I seq.

Castracane degli Antelminelli, F. (1) Die Diatomeen in der Kohlenperiode. Pringsh. Jahrb., vol. 10 (1876), p. I seq.

Clarke, J. M. (1) On Devonian spores. Americ. Journ. of Sc., vol. 29 (1885), p. 284 seq.

Claypole, E. W. (1) On the occurrence of a fossil tree (Glyptodendron) in the Clinton limestane (base of upper Silurian) of Ohio, U.S. Geol. Mag., London, new ser., Decade II, vol. 5 (1878), p. 558 seq.

Coemans, Eug. (1) Description de la Flore fossile du premier étage du terrain crétacé du Haịnaut. Mém. de l'Acad. roy. de la Belgique, vol. 36 (1867).

(2) Coemans, E, et J. J. Kickx. Monographie des Sphenophyllum d'Europe. Bulletin de l'Açad. roy. de Belgique, sér. 2, vol. 18 (I 864 ), p. I34 seq. 
Conwentz. (1) Die fossilen Hölzer von Carlsdorf am Zobten, 1880.

(2) Ueber dic versteinerten Hölzer aus dem Norddeutschen Diluvium. Inaug.-Diss. Breslau, 1876.

Corda, A. J. (1) Beiträge zur Flora der Vorvelt. Prag, 1845.

Cotta, C. B. (1) Die Dendrolithen in Beziehung auf ihren inneren Bau. Dresden, 1832.

Crépin, F. (1) Description de quelques plantes fossiles de l'étage des Psammites du Condroz (Dévonien supérieur). Bulletin de l'Acad. royale Bclg., 2 sér., vol. 38 (1874).

Dana, J. D. (1) United States exploring Expedition under command of Charles Wilkes, U.S. N., Geology, without date.

Daubrée. (1) Minéralisation subic par des débris organiques, végétaux et animaux dans l'ctu thermale de Bourbonne-les-Bains. Comptes rendus de l'Acad. des Sc. de Paris, vol. 81 (1875), p. 1008.

Dawes, J. S. (1) Remarks upon the internal structure of Halonia. Quarterly Journ. of the Geol. Soc. of Lond., vol. 4 (1848), p. 289 seq.

Dawson, J. W. (1) Geological Survey of Canada; Alfred R. Selwyn, F.G.S., Director. -The fossil plants of the devonian and upper silurian formations of Canada. Vol. I (1871), vol. 2 (1882).

(2) Acadian Geology, an account of the geological structure and mineral resources of Nova Scotia, etc., 1855 .

(3) Notes on Prototaxites and Pachytheca discovered by Dr. Hicks in the Denbigshire grits of Corwen. Quarterly Journ. of the Geol. Soc. of Lond., vol. 38 (1882), p. 103.

(4) Notes on new Erian Plants. Quarterly Journ. of the Geol. Soc. of Lond., vol. 37 (1 881), p. 299 seq.

(5) On fossil plants from the devonian rocks of Canada. Quarterly Journ. of the Geol. Soc. of Lond., vol. 15 (1859), p. 477 seq.

(6) On the Flora of the devonian period in North Eastern America. Quarterly Journ. of the Geol. Soc. of Lond., vol. I 8 (1862), p. 296 seq.

(7) Geologicai Survey of Canada; Alfred R. Selwyn, F.G.S., Director-Report on the fossil plants of the lower Carboniferous and Millstone grit formations of Canada. Montreal, 1873.

(8) On the conditions of the deposition of coal, more especially as illustrated by the coal formation of Nova Scotia and New Brunswick. Quarterly Journ, of the Geol. Soc. of Lond., vol. 22 (1 866), p. 95 seq.

(9) On the structure and affinities of Sigillaria, Calamites and Calamodendron. Quarterly Journ. of the Geol. Soc. of Lond., vol. 27 (1871), p. 147 seq.

(11) Further observations on the devonian plants of Maine, Gaspé and New York. Quarterly Journ. of the Geol. Soc. of Lond., vol. I9 (1863), p. 458 seq.

(12) On the lower Coal-measures as developed in British America. Quarterly Journ. of the Geol. Soc. of Lond., vol. 15 (1859), p. 62 seq.

(13) Geological Survey of Canada. Report on the fossil plants of the lower Carboniferous and Millstone grit formations of Canada, 1873 .

(14) Notice of the occurrence of upright Calamites near Pictou, Nova Scotia. Quarterly Journ. of the Geol. Soc. of Lond., vol. 7 (185I), p. 194 seq.

Debey und v. Ettingshausen. (1) Die urweltl. Acrobryen des Kreidegebirgs von Aachen und Maestricht. Denkschr. d. k. k. Acad. d. Wissensch. zu Wicn, vol. 17 (1859), p. 183 seq.

Deecke, W. (1) Ueber einige neue Siphoneen. Neues Jahrb. f. Min., Geol. und Pal. Jahrgang 1883 , Bd. I, p. I seq.

Delesse. (1) Études sur.le métamorphisme. Anṇ. des mines, sér. 5, vol. 12 (1857), pp. 127-708. 
Delgado, J. F. N. (1) Étude sur les Bilobites et autres fossiles des quartzites de la base du système silurique du Portugal. Section des travaux géologiques du Portugal. Lisbonne, I886.

Dyer, W. T. Thiselton. (1) On some coniferous remains from the lithographic stone of Solenhofen. Geol. Mag., vol. 9, No. 5 (May, I872).

Ehrenberg. (1) Ueber das Massenverhältniss der jetzt lebenden Kieselinfusorien und über ein neues Infusorienconglomerat als Polirschiefer von Jastraba in Ungarn. Abh. d. Berliner Akademie, 1836, p. I09 seq.

(2) Ueber noch jetzt zahlreich lebende Thierarten der Kreidebildung und den Organismus der Polythalamien. Abh. der Berliner Akademie, I839, p. 8I seq.

von Eichwald. (1) Lethaea rossica. Stuttgart, I853-1868.

Emmons, Ebenezer. (1) Geological Report of the Midland Counties of North Carolina. New York and Raleigh, 1856.

Essner, B. (1) Ueber den diagnostischen Werth der Anzahl und Höhe der Markstrahlen bei den Coniferen. Abhandlungen der naturforschenden Gesellschaft zu Halle, Bd. I6 (I882).

von Ettingshausen, C. (1) Die Tertiärfloren der Oesterreichischen Monarchie. Abh. der k. k. geol. Reichsanst. zu Wien, Bd. 2 (1855).

(2) Zur Lias- und Oolithflora, Abhandl. der k. k. geol. Reichsanstalt zu Wien, vol. I, Wien, 1852 .

(3) Die Steinkohlenflora von Stradonitz. Abhandl. der k. k. geol. Reichsanstalt zu Wien, vol. I, Abth. 3 (1852).

(4) Die fossile Flora des Tertiärbeckens von Bilin. Denkschr. der k. k. Akademie zu Wien. Math.-natw. Cl., vol. 26 (1867).

(5) Die Steinkohlenflora von Radnitz in Böhmen. Abhandl. der k, k. Reichsanst. zu Wien, vol. 2 (1855).

(6) Ueber Palaeobromelia, ein neues fossiles Pflanzengeschlecht. Abhandl. der k. k. geol. Reichsanstalt zu Wien, vol. I (I 852 ).

(7) Die fossile Flora des mährisch-schlesischen Dachschiefers. Denkschriften der k. k. Akademie zu Wien. Math.-natw. Cl., vol. 25 (1866), p. 77 seq.

(8) Beitrag zur näheren Kenntniss der Calamiten. Sitzungsber. der k. k. Akademie zu Wien. Math.-natw. Cl., vol. 9 (1852), p. 684 seq.

Feistmantel, Karl. (1) Ueber die Nöggerathien und deren Verbreitung in der böhmischen Steinkohlenformation. Sitzungsber. der k. böhm. Ges. d. Wissenschaften in Prag, Jahrgang 1879 , p. 75 seq.

Feistmantel, Ottokar. (1) Palaeontologische Beiträge. Palaeontographica, Supplement 3, Lief. 3, Heft I-4.

1. Ueber die indischen Cycadeengattungen Ptilophyllum und Dictyozamites. Heft I, 1877.

II. Ueber die Gattung Williamsonia in Indien. Heft I, 1877.

III. Paläozoische und mesozoische Flora d. östl. Australiens. Heft 2, 3, 4, I 878-1 879 .

(2) Bemerkungen über die Gattung Nöggerathia, Sternbg., sowie die neuen Gattungen Nöggerathiopsis, Feịstm. und Rhiptozamites, Schmalh.; Sitzungsber, d. k. böhm. Ges. d. Wissenschaften in Prag, Jahrgang I879, p. 444 seq.

(3) Die Versteinerungen der böhmischen Kohlenablagerungen. Palaeontographica, Bd. $23(1875-1876)$.

(4) Ueber Baumfarrenreste der böhmischen Steinkohlen-, Perm- und Kreideformation. Abhandl. der kgl. böhm. Gesellsch. d. Wissenschaften, 6. Folge, Bd. 6 (1873), Prag, 1874.

(5) Das Kohlenkalkvorkommen bei Rothwaltersdorf in der Grafschaft Glatz und dessen organische Einschlüsse. Zeitschr. der deutschen geolog. Gesellschaft, vol. 25 (1878), p. 463 seq. 
Felix, J. (I) Studien über fossile Hölzer. Inaug.-Diss. Leipzig, I882.

(2) Strukturzeigende Pflanzenreste aus der oberen Steinkohlenformation Westphalens. Berichte der Naturf. Gesellschaft zu Leipzig. Jahrg. 1885, p. 7 seq.

Fischer, H. (1) H. Fischer und D. Rüst. Ueber das mikröskopische und optische Verhalten verschiedener Kohlenwasserstoffe, Harze und Kohlen. Groth's Zeitschrift f. Krystallographie, vol. 7 (1882), p. 209 seq.

Fontaine and White. (1) Second geo'ogical survey of Pennsylvania PP. The permian or upper carboniferous Flora of West Virginia and Pennsylvania. Harrisburg, 1880 .

Gardner, J. Starkie. (1) A monograph of the British eocene Flora. Palaeontograph. Soc., vol. 33 (1879), vol. 34 (1880), vol. 36 (1882), vol. 37 (1883), vol. 38 (1884).

Geinitz, H. B. (1) Dyas, I86I.

(2) Nachträge zur Dyas. I. Mitth. aus dem miner. geolog. paläont. Museum in Dresten, Heft 3, Cassel, I880.

(3) Ueber zwei neue dyadische Pflanzen. Jahrb. f. Mineralogie, etc., I863, p. 525.

(4) Geinitz und von Gutbier. Die Versteinerungen des Zechsteingebirges und Rothliegenden oder des permischen Systems in Sachsen, 1848.

(5) Die Versteinerungen der Steinkohlenformation in Sachsen, 1855.

(6) Ueber rhätische Pflanzen - und Thierreste in den argentinischen Provinzen La Rioja, San Juan und Mendoza. Palaeontographica, Supplem. 11I, Lief. 2, Cassel, 1876.

(7) Ueber einige seltene Versteinerungen aus der unteren Dyas und der Steinkohlenformation. Lconhard und Bronn, Neues Jahrbuch für Mineralogie, etc., Jahrgang 1865, p. 385 seq.

(8) Darstellung der Flora des Hainichen-Ebersdorfer und des Flöhaer Kohlenbassins. Preisschrift der Fürstl. Jablonowski'schen Gesellschaft, $V, 1854$.

Germar, E. F. (1) Die Versteinerungen des Steinkohlengebirges von Wettin und Löbejuin im Saalkreis. Halle, 1844-1849.

Gilkinet, A. (1) Sur quelques plantes fossiles de l'étage des Psammites du Condroz. Bulletin de l'Acad. roy. de Belgique, sér. 2, vol. 39 (1875).

Goldenberg, Fr. (1) Flora Saraepontana fossilis. Die Pflanzenversteinerungen des Steinkohlengebirgs von Saarbrücken. Saarbrücken, 1855-1862.

(2) Ueber den Charakter der alten Flora der Steinkohlenformation im allgemeinen und die verwandtschaftliche Beziehung der Gattung Noeggerathia insbesondere. Verhandlungen des naturhistor. Vereins der pr. Rheinlande, vol. 5 (1848), p. 17 seq.

Göppert. (1) Die Gattungen der fossilen Pfanzen, $184 \mathrm{I}$.

(2) Systema Filicum fossilium. N. Acta Leop. Car., vol. 17 Supplem. (1836).

(3) Die fossile Flora der permischen Formation. Palaeontographica, vol, 12, Cassel, 1864-1865.

(4) Monographie der fossilen Coniferen. Natuurk. Verhandelingen van de Hollandsche Maatschappy der Wetensch. te Harlem, 2 Verzam, vol. 6, Leiden, 1850.

(5) De Coniferarum structura anatomica, 1841.

(6) Revision meiner Arbeiten über die Stämme der fossilen Coniferen, insbesondere der Araucariten und über die Descendenzlehre. Botanisches Centralblatt, vol. 5 (1881), p. 378 seq., vol. 6 (1881), p. 27 seq.

(7) Beiträge zur Kenntniss fossiler Cycadeen. N. Jahrb. f. Mineralogie, Geol. u. Pal., 1866.

(8) Ueber die fossilen Cycadeen überhaupt, mit Rücksicht auf die in Schlesien verkommenden Arten. Uebersicht der Arbeiten und Veränderungen der schlesischen Gesellsch. f. vaterländische Cultur, I843. Breslau, 1844, p. II 4 seq.

(9) Ueber die gegenwärtigen Verhältnisse der Paläontologie in Schlesien, sowie über fossile Cycadeen. Denkschr. der schles. Gesellsch. f. vaterländ. Cultur (1853), p. 259 seq. 
(11) Göppert und Stenzel. Die Medulloseae. Eine neue Gruppe der fossilen Cycadeen. Palacontographica, vol. 28 (I88I).

(12) Fossile Flora des Uebergangsgebirges. Nova Acta Leop. Carol., vol. 22, Supplem. Breslau und Bonn, 1852 .

(13) Ueber die Kohlen von Malöwka in Central-Russland, Gouvernement Tula. Sitzungsber. der Münchener Akad. d. Wissensch. Natw.-math. Cl., vol. I (I86I), p. 199 seq.

(14) Abhandlung als Antwort auf die Preisfrage über die Entstehung der Steinkohlen. Natuurk. Verhandl. $v$. de Hollandsche Maatschappy de Wetensch. te Harlem, ser. 2, vol. 4 (I 848 ).

(15) Ueber die Bildung der Versteinerungen. Annalen der Physik und Chemie, Bd. 38 (1836), p. 56 I ; Bd. 42 (1837), p. 595 ; Bd. 54 (1841), p. 570.

(16) Skizzen zur Kenntniss der Urwälder Schlesiens und Böhmens. Nov. Act. Nat. Cur., Bd. 34 (1868).

(17) Ueber den versteinten Wald von Radowenz bei Adersbach in Böhmen und über den Versteinerungsprozess tiberhaupt, Jahrb, d. k. k. geol. Reichsanstalt zu Wien, vol. 8 ( 1857 ), p. 725 seq.

(18) Die tertiäre Flora von Schossnitz in Schlesien. Görlitz, I 855 .

(19) Ueber die fossile Flora der silurischen, der devonischen und unteren Kohlenformation oder des sog. Uebergangsgebirges. Nova Acta Leopoldino-Carolina, Bd. 27 (Jena, 1860), p. 425 seq.

(20) Ueber die Stigmaria ficoides. Zeitschrift der deutschen geolog. Gesellschaft, vol. 3 (1851), p. $278 \mathrm{seq}$.

(21) Göppert und A. Menge. Die Flora des Bernsteins und ihre Beziehungen zur Flora der Tertiärformation und der Gegenwart, vol. I (1883), vol. 2 (bearb. v. Conwentz, 1886).

(22) Ueber Aphyllostachys, eine neue fossile Pfianzengattung aus der Gruppe der Calamarien, sowie über das Verhältniss der fossilen Flora zu Darwin's Transmutationstheorie. Nova Acta Leop. Carol., vol. 32 (1865).

Grand' Eury, Cyrille. (1) Flore Carbonifère du dépt. de la Loire et du centre de la France, 1877.

(2) Mémoire sur la formation de la houille. Annales des mines, sér. 8, t. 2 (1882), p. $99 \mathrm{seq}$. Revision of the above by $G$. de Saporta in Revue des deux mondes, t. 54 (1882), p. 657 seq.

Grey, George. (1) Remarks on some specimens from South Africa. Quarterly Journ of the Geol. Soc. of Lond., vol. 27 (1871), p. 49.

Grisebaoh, A. (1) Ueber die Bildung des Torfs in den Emsmooren aus deren unveränderter Pfanzendecke. Göttingen, I846. (Aus Göttinger Studien, Jahrgang 1845.)

Gümbel, C. W. (1) Die sogenannten Nulliporen, etc. Abh. der Münchener Akad., math.-phys. Cl., Bd. II (I 874).

I. Theil. Die Nulliporen des Pflanzenreichs, Lithothamnium, p. I3.

2. Theil. Die Nulliporen des Thierreichs, Dactyloporideae, p. 23 I.

(2) Beiträge zur Kenntniss der Texturverhältnisse der Mineralkohlen. Sitzber. d. Münch. Akad., math.-phys. Cl., vol. I3 (1883), p. I I I seq.

Hall, J. (1) Natural History of New York, Part VI, Palaeontology, vol. I (I 848), vol. 2 (1851).

(2) Descriptions of the fossil reticulate Sponges constituting the family Dictyospongidae. Thirty-fifth Annual Report of the New York State Museum of Nat. History (I 884), p. 465 seq.

Haughton, s. (1) On Cyclostigma, a new genus of fossil plants from the old red sandstone of Kiltorkan, Co. Kilkenny. Journal of the Royal Dublin Society, vol. 2 (1 859), p. 1 seq. See also Annals and Mag. of Nat. Hist., ser. 3, vol. 5 (1 860), p. 443 seq. 
Hausmann, J. Fr. I. (1) Oryktographie des Harzes, in Holtzmann, Hercynisches Archiv. One volume, Halle, 1805.

(2) Ueber das Vorkommen verschiedener Kieselgebilde in Begleitung des Basaltes. Studien des Göttingischen Vereins bergmännischer Freunde, vol. 7, p. I 39 seq.

Heer, O. (1) Zur Geschichte der Ginkgoartigen Bäume. Bot. Jahrbücher für Systematik, Pflanzengeschichte und Pflanzengeographie, herausgeg. von Engler, vol. I (I 881 ), p. I seq.

(2) Beschreibung der Pflanzen und Insekten in A. Escher von der Linth, Geologische Bemerkungen über das nördliche. Vorarlberg, etc. Neue Denkschriften der allgem. schweizerischen Ges. f. d. ges. Naturw., Bd. I3 (1853), p. 117 seq., t. 6.

(3) Flora fossilis Helvetiae, 1876-77.

(4) Ueber das geologische Alter der Coniferen. Botan. Centralblatt, Bd. 9 (1882), p. 237 seq.

(5) Flora fossilis arctica, vol. 1-7 (1868-1883).

(7) Beiträge zur Kreideflora. I. Fl. v. Moletein in Mähren. Neue Denkschr. d. allgem. schweiz. Ges. f. d. ges. Naturw., Bd. 23 (1869), n. 2.

(8) Zur Gieschichte der Ginkgoartigen Bäume in Engler's Botanischen Jahrbüchern, Bd. I (I 881 ), p. I seq.

(9) The lignites and clays of Bovey Tracey, Devorishire. Philosophical Transactions, vol. 152 (1862), pt. 2.

(10) Dic Urwelt der Schweiz. Zürich, 1865.

(11) Flora tertiaria Helvetiae. Winterthur, $1855-1856$.

(12) Miocäne baltische Flora. Beiträge zur Naturkunde Preussens, herausgegeben v. d. k. physikalisch-ökonomischen Gesellschaft zu Königsberg, vol. 2 (1869).

(13) Ueber permische Pflanzen von Fünfkirchen in Ungarn. Mittheilungen aus dem Jahrbuch der k. ungarischen geol. Anstalt, vol. 5 (1878), p. I seq.

(14) Contributions à la flore fossile du Portugal. Zürich, 1881 .

(15) Beiträge zur Kreideflora. II. Zur Kreideflora von Quedlinburg. Neue Denkschriften d. allgem. schweizer. Gesellsch. f. d. ges. Naturw., Bd. 24 (Zürich, 1871), n. 2.

(16) Les charbons feuilletés de Dürnten et d'Utznach. Discours de M. le Professeur O. Hecr, traduit par M. Charles-Th. Gaudin. Archives des sciences de la Bibliothèque universelle de Genc̀ve, vol. 2 (1858), p. 305 seq.

Heyer, F. (1) Beiträge zur Kenntniss der Farne des Carbon und des Rothlicgenden im Saar-Rhcingebiet. Botanisches Centralblatt, Bd. 19 (1884), p. 248 seq.

Hick, Th. and Cash, Wm. (1) Contributions to the fossil Flora of Halifax, pt. IV. Proceedings of the Yorkshire Geological and Polytechnic Society, New ser., vol. 8 (1883), p. 85 seq.

(2) Myriophylloides Williamsoni, Hick and Cash. Proceedings of the Yorkshire Geological and Polytechnic Society, vol. 7 (188I), part IV, p. 400 seq.

Hicks, H. (1) On the discovery of some remains of plants at the base of the Denbigshire grits near Corwen, North Wales. Quarterly Journ. of the Geol. Soc. of Lond., vol. 37 (1881), p. 482, t. 25.

(2) Additional notes on the land plants from the Pen $y$ Glog slate-quarry near Corwen, North Wales. Quarterly Journ. of the Geol. Soc. of Lond., vol. 38 (1882), p. 97 seq.

Hirschwald. (1) Ueber Umwandlung von verstürzter Holzzimmerung in Braunkohle im alten Mann der Grube Dorothea bei Clausthal. Zeitschr. d. deutschen geol. Ges., Bd. 25 (1873), p. 364.

Hooker, J. D. (1) J. D. Hooker and E. W. Binney. On the structure of certain limestone nodules enclosed in seams of bituminous Coal, with a description of some Trigonocarpons contained in them. Philosophical Transactions, vol. I45 (1855), p. 149 seq. 
(2) On the sphaeroidal bodies resembling seeds from the Ludlow bonebed. Quarterly Journ. of the Geol. Soc. of Lond., vol. 9 (1853), p. 12.

(3) Remarks on the structure and affinities of some Lepidostrobi. Memoirs of the Geological Survey of Great Britain, vol. 2 (I 848 ), pt. II, p. 440 seq.

(4) On some peculiarities in the structure of Stigmaria. Memoirs of the Geological Survey of Great Britain, vol. 2 (I 848), pt. II, p. 43 I seq.

(5) On a new species of Volkmannia. Quarterly Journ. of the Geol. Soc. of Lond., vol. Io (1854), p. 199 seq.

Kidston, R. (1) On the fructification of Zeilleria delicatula, Sternbg, with remarks on Urnatopteris tenella, Brongn. and Hymenophyllites quadridactylites, Gutb. Quarterly Journ. of the Geol. Soc. of Lond., vol. 40 (1884), p. 590 seq., t. 25.

(2) On the relationship of Ulodendron to Lepidodendron, Bothrodendron, Sigillaria and Rhytidodendron. Annals and Magazine of Natural History, ser. 5, vol. I6 (1885), p. 123 seq.

(3) On a new species of Psilotites from the Lanarkshire Coalfield. Annals and Magazine of Natural History, ser. 5, vol. 17 (1886), p. 494 seq.

(4) On the affinities of the genus Pothocites, Paterson; with the description of a specimen from Glencartholm, Eskdale. Annals and Magazine of Natural History, ser. 5, vol. 11 (1883), p. 297 seq.

(5) On a new species of Lycopodites, Gold. from the calciferous Sandstone series of Scotland. Annals and Magazine of Natural History, ser. 5, vol. I4 (I884), p. II I seq.

Kleeberg, A. (1) Die Markstrahlen der Coniferen. Botan. Zeitung (1885), p. 673 seq.

Knop. (1) Beiträge zur Kenntniss der Steinkohlenfornation in dem Rothliegenden im Erzgebirge. N. Jahrb. f. Min. v. Leonhard u. Bronn (1 859), pp. 532-60I, 671-720.

Kraus, G. (1) Mikroskopische Untersuchungen über den Bau lebender und vorweltlicher Nadelhölzer. Wïrzburger Naturwissenschaftl. Zeitschrift, vol. 5 (1 864), p. I 44 seq.

(2) Einige Bemerkungen iüber die verkieselten Stänme des fränkischen Keupers und zur Kenntniss der Araucarien des Rothliegenden und der Steinkohlenformation. Wïrzburger Naturw. Zeitschr., vol. 6 (1866), p. 64 seq.

(3) Beiträge zur Kenntniss fossiler Hölzer. Abhandlungen der Naturforschenden Gesellschaft zu Halle, Bd. I6 (1882).

Kuntze, O. (1) Ueber Geysirs und nebenanstehende verkieselte Bäume. Das Ausland, 1880.

de Lapparent, $\mathbf{A}$. (1) Traité de géologie, $2^{\mathrm{me}}$ édition (1885).

Leckenby, J. (1) On the sandstones and shales of the oolites of Scarborough, with descriptions of some new species of fossil plants. Quarterly Journ. of the Geol. Soc. of Lond., vol. 20 (1864), p. 74 seq.

Lesquereux, Leo. (1) Description of the Coal Flora of the carboniferous formation in Pennsylvania and throughout the United States. Second Geological Survey of Pennsylvania, Report of Progress P. Harrisburg, vols. I and 2 (1880), vol. 5 (1884).

(2) On a branch of Cordaites bearing fruit. Proceedings of the American Philosoph. Soc., vol. 18 (1879).

(3) Geological Survey of Illinois.

Vol. 2. Palaeontology. New York, 1866.

Vol. 4. Geology, Palaeont. New York, 1870.

(4) David Dale Owen's Second Report of a Geological Reconnaissance of the middle and southern Counties of Arkansas. Philadelphia, 1860.

(5) Land plants recently discovered in the silurian rocks of the United States. Proceedings of the American Phil. Soc., vol. 17 (1877).

Lindley, J. and Hutton. (1) The fossil Flora of Great Britain, vol. I (1831-32), vol. 2 (1833-35), vol. 3 (1837). 
Link. (1) Ueber den Ursprung der Steinkohlen und Braunkohlen nach mikroskopischen Untersuchungen. Abhandl. d. Berliner Akad., 1838, p. 33.

Ludwig, R. (1) Calamitenfrüchte aus dem Spatheisenstein bei Hattingen an der Ruhr. Palaeontographica, vol. Io (1861), p. II seq.

(2) Fossile Pflanzen aus dem tertiären Spatheisenstein von Montabaur. Palaeontographica, vol. 8 (1859-61), p. 160 seq.

(3) Zur Paläontologie des Urals. Palaeontographica, vol. 10 (1861), p. 17 seq.

Lyell, Ch. (1) Second visit to the United States of North America, sec. ed., vol. 2 (1850).

(2) Travels in North America, vol. I (1845).

M'Coy, F. (1) On the fossil Botany and Zoology of the rocks associated with the coal of Australia. Annals and Magazine of Nat. Hist., vol. 20 (London, 1847), p. 145 seq.

Mahr. (1) Ueber Sphenophyllum Thonii, eine neue Art aus dem Steinkohlengebirge von llmenau. Zeitschrift d. deutschen geolog. Gesellschaft, vol. 20 (1868), p. 433.

Marion, A. F. F. (1) Sur les caractères d'une Conifère tertiaire voisine des Dammarées (Doliostrobus Sternbergii). Comptes rendus de l'Acad. de Paris, vol. 99 (1884), p. 821 .

(2) Description des plantes fossiles des calcaires marneux de Ronzon (Haute Loire). Annales des Sc. Nat., sér. 5, vol. 14 Bot. (1872), p. 326 seq.

Mettenius, G. (1) Filices horti Lipsiensis, 1856.

Michelin. (1) Iconographie zoophytologique, 1840-1847.

Mietzsch. (1) Geologie der Kohlenlager, 1875.

Muck, F. (1) Grundzüge und Ziele der Steinkohlenchemie, I88I.

Munier-Chalmas. (1) Observations sur les Algues calcaires appartenant au groupe des Siphonés verticilleses (Dasycladies Harv.) et confondues avec les Foraminiferes. Comptes rendus hebd. des séances de l'Acad. des Sc., vol. 85 (1877), pp. 814-817. Uehersetzung in bot. Ztg., 1879, p. 165.

(2) Observations sur les Algues ćalcaires confondues avec les Foraminifères et appartenant au groupe des Siphonées dichotomes. Bull. de la Soc. Géol. de France, 3 sér. vol. 7 , p. 661 .

Nathorst, A. G. (1) Om spir af nigra evertebrerade djur m. m. och deras palaeontologiska betydelse. Kongl. Svenska Akademiens Handlingar, vol. 18, n. 7 (1881).

(2) Bidrag til Sveriges fossil Flora. Kongl. Svenska Vetenskaps-Akad. Handlingar, vol. 14, n. $3(1876)$.

(3) Bidrag til Sieriges fossil Flora. II. Floran vid Höganäs och Helsingborg. Kongl. Svenska Akademiens Handlingar, vol. 16, n. 7 (1878).

(4) Om Floran i Skånes kolförande Bildningar. (1) Floran vid Bjuf. Sveriges Geologiska Undersökning Stockholm, 1878 und 1879.

(5) Några anmärkningar om Williamsonia, Carr. Öfversigt af Kongl. VetenskapsAkad. Förhandlingar, 1880, n. 9, p. 33 seq.

(6) Beiträge zur fossilen Flora Schwedens. Stuttgart, 1878. German edition of No. 2 with various alterations; table IV contains the supposed fruits of Sagenopteris, which are wanting in the Swedish original.

(7) Om Spirangium och dess Förekomst i Skånes kolförande Bildningar. Öfvers. af Kongl. Vet.-Akademiens Förhandlingar, 1879.-Sveriges Geologiska Undersökning Afhandlingar, ser. C, n. 36, 1879. A notice of it appeared in the Botanisches Centralblatt, vol. I (1880), p. 293.

(8) Några anmärkningar om Williamsonia, Carr. Öfversicht af Kongl. VetenskapsAkademiens Förhandlingar, 1880, n. 9. 
Naumann, C. F. (1) Ueber den Quincunx als Gesetz der Blattstellung bei Sigillaria und Lepidodendron. Neues Jahrbuch f. Min. Geogn. Geol. u. Petrefactenkunde von Leonhard und Bronn. Jahrgang I842, p. 410 seq.

Newberry, J. S. (1) Descriptions of some peculiar screwlike fossils from the Chemung rocks. Annals of the New York Academy of Sciences, late Lyceum of Natural History, vol. 3 (1885), p. 217.

\section{Palaeontologia indica.}

Series II. Fossil Flora of the Gondwana system.

Vol. I. Pt. I. Rajmahal series in the Rajmahal hills, by T. Oldham and Morris (1863). Calcutta, 1880.

Pt. II. Jurassic Rajmahal Fl. in the Rajmahal hills, by Ottok. Feistmantel (I877).

Pt. III. Liassic Fl. of the Rajmahal group from Golapilli near Ellore, South Godavary, by O. Feistmantel (1877).

Pt. IV. Upper Gondwana flora of the outliers of the Madras coast, by O. Feistmantel (I879).

Vol. 2. Pt. I. Jurassic flora of Kach, by O. Feistmantel (1876).

Pt. 1I. Flora of the Jabalpur Group in the S. Narbada region, by O. Feistmantel (1877).

Series XII. Fossil Flora of the Lower Gondwanas.

I. Flora of the Talchir Kaharbari beds, by O. Feistmantel. Calcutta, 1879.

II. Flora of the Damuda and Panchet Divisions, by O. Feistmantel. Calcutta, I880-8I.

Petzholdt, A. (1) Ueber Calamiten und Steinkohlenbildung, I84I.

Prisl, C. B. (1) Tentamen Pteridographiae. Prag, I836.

Quenstedt. (1) Handbuch der Petrefactenkunde, 2. Auflage (I867).

Reinsch, P. F. (1) Neue Untersuchungen über die Mikrostruktur der Steinkohle etc., I88I.

Renault, Bernard. (1) Structure comparée de quelques tiges de la Flore carbonifère. Nouv. Arch. du Muséum, sér. 2, vol. 2 (1879), p. 21 3 seq.

(2) Cours de Botanique fossile, Anné I (1881), II (1882), III (1883), IV (1885).

(3) Renault et C. Eg. Bertrand. Grilletia Sphaerospermii, Chytridiacée fossile du terrain houiller supérieur. Comptes rendus de l'Acad. de Paris, 1885 (I 8 Mai).

(4) Recherches sur les végétaux silicifiés d'Autun et de St. Étienne; Étude du genre Botryopteris. Ann. des sc. nat., Bot., sér. 6, vol. I (1875), p. 220 seq., tt. 10, I1.

(5) Recherches sur la fructincation de quelques végétaux provenant des gisements silicifiés d’Autun et de St. Étienne. Ann. des. sc. nat., Bot., sér. 6, vol. 3 (1876), p. 5 seq., tt. $\mathrm{I}-4$.

(6) Recherches sur les végétaux silicifiés d'Autun. II. Étude du genre Myelopteris. Mém. présentés par div. savants à l'Académie de Paris, vol. 22 (1875), n. 10.

(7) Étude de quelques végétaux silicifiés des environs d'Autun. Ann. des sc. natur., sér. 5, vol. 12 (I 869), p. I6I seq. tt. $3^{-1} 4$.

(8) Renault et Grand'Fury. Recherches sur les végétaux silicifies a' Autun. I. Étude du Sigillaria spinulosa. Mém. prés. par div. savants à t'Académie de Paris, vol. 22 (1875), n. 9.

(9) Sur les fructifications des Sigillaires. Comptes rendus des séances de l'Acad. d. sc., 7 Déc., 1885.

(10) Étude sur les Stigmaria, rhizomes et racines de Sigillaires. Annales des sciences géologiques, vol. 12 (1881), p. I seq.

(11) Renault et Zeiller. Sur quelques Cycadées houillères. Comptes rendus de l'Acad. de Paris, 8 Févr., 1886. 
(12) Renault et Zeiller. Sur un nouveau genre de fossiles végétaux. Comptes rendus de l'Acad. des sciences, 2 Juin, 1884.

(13) Recherches sur les végétaux fossiles du genre Astromyelon. Annales des sciences géologiques, vol. 17 (1885).

(14) Nouvelles recherches sur le genre Astromyelon. Mémoires de la soc. des sciences natur. de Saône et Loire, 1885.

(15) Recherches sur quelques Calamodendrées et sur leurs affinités probables. Comptes rendus de l'Acad. des sc. de Paris, vol. 83 (1876), p. 574.

(16) Recherches sur Corganisation des Sphenophyllum et des Annularia. Ann. des sciences nutt., sér. 5, vol. I 8 (1873), p. 5 seq.

(17) Sur les fructifications des Calamodendrons. Comptes rendus de l'Acad. de Paris, vol. I02, I 5 Mars, I 886.

(18) Sur les fructifications mâles des Arthropitus et des Bornia. Comptes rendus de l'Acad. des sc., vol. I02, 15 Juin, 1886.

(19) Sur le genre Bornia, F. Röm. Comptes rendus de l'Acad. des sc., vol. 102, 7 Juin, 1886.

(20) Nouvelles recherches sur la structure des Sphenophyllurn et sur leurs affinités botaniques. Annales des sciences naturelles, sér. 6, vol. 4 (1877), p. 277 seq.

(21) Renault et Zeiller. Sur des Mousses de l'époque houillère. Comptes rendus de l'Acad. des sc. de Paris, vol. 100 (2 Mars, 1885), p. 660.

Reuss, A. E. (1) Die Versteinerungen der böhmischen Kreideformation, 1845-1848.

Richter, R. (1) Der Kulm in Thüringen. Zeitschrift d. deutsch. geol. Gesellschaft, Bd. 16 (1864), p. 155 seq.

von Roehl. (1) Fossile Flora der Steinkohlenformation Westphalens, einschliesslich Piesberg bei Osnabrück. Palaeontographica, vol. I 8 (1868-1869), p. I seq.

Römer, A. (1) Beiträge zur geologischen Kenntniss des nordwestlichen Harzgebirges.

1. Abth. Palaeontographica, III (1854), p. I seq.

2. " " $"$ III (1854), p. 69 seq.

3. " $, \quad, \quad$ V $(1855-1858)$, p. I seq.

4. " $" \quad " \quad$ IX $(1862-1864)$, p. I seq.

5. " " " XIII (1866), p. 201 seq.

Römer, Ferd. (1) Lethaea geognostica, vol. I (I880).

Rothpletz, A. Die Flora und Fauna der Kulmformation bei Hainichen in Sachsen. Botanisches Centralblatt, I 880, vol. I, Gratisbeilage III.

Royle, J. F. (1) Illustrations of the botany and other branches of the natural history of the Himalayan mountains and of the flora of Cashmere, 1839.

Salter, J. W. On some remains of terrestrial plants in the o!d red sandstone of Caithness. Quarterly Journ. of the Geol. Soc. of Lond., vol. 14 (1858), p. 72 seq.

Sandberger, F. (1) Die Flora der oberen Steinkohlenformation im badischen Schwarzwald. Verhandl. d. naturwissensch. Vereins in Karlsruhe, Heft I (1864), p. 30 seq.

de Saporta, G. (1) À propos des Algues fossiles, 1882.

(2) Sap. et Marion. Évolution du règne végétal; Phanérogames, vol. I. Bibliothique scientifique internationale publ. s. l. dir. de M. Ém. Alglave, vol. 52 (1885).

(3) Sap. et Marion. Évolution du règne végétal; Cryptogames. Bibliothèque scientifique internationale publ. s. l. dir. de M. Em. Alglave, vol. 39 (1881).

(4) de Baporta. Paléontologie française, sér. 2, végétaux. Plantes jurassiques.

Vol. I. Algues Equisetacées, Characées, Fougères, 1873.

Vol. 2. Cycadées, 1875.

Vol. 3. Conifères ou Aciculariees, 1884.

(5) Études sur la végétation du sud-est de la France. Part. I, nn. 3, 4. Ann. des sc. nat., sér. 4, vol. I7 (1862), p. I91 seq.

(6) Études sur la vég. cu sud-est de la France. Part. I, nn. 5, 6. Ann. des sc. nat., sér. 4, vol. 19 (1863). 
(7) Études sur la végétation du sud-est de la France. Part Il, n. 1. Ann. des sc. nat., sér. 5, vol. iii. (1865).

(8) Études sur la végétation du sud-est de la France. Part II, n. 2. Ann. des sc. nat., sér. 5 , vol. iv. (1865).

(9) Prodrome d'une flore fossile des travertins anciens de Sézanne. Mémoires de la Société Géol. de France, sér. 2, vol. 8 (1865-1868).

(10) Le monde des plantes avant l'apparition de l'homme, 1879.

(11) Observations sur la nature des végétaux réunis dans le groupe des Nöggerathia. Comptes rendus de l'Acad. des sc., vol. 86 (1878), 25 Mars, 1 and 8 Avril.

(12) Les Organismes problématiques des anciennes mers. Paris, 1884.

(13) Nouveaux documents relatifs à des fossiles végétaux et à des traces d'invertébrés associés dans les anciens terrains. Bull. de la Soc. Bot. de France, sér. 3, vol. 14 (I 886), p. 407 seq.

Schenk, A. (1) Beiträge zur Flora der Vorwelt, IV. Die Flora der nordwestdeutschen Wealdenformation. Palaeontographica, vol. I9 (1874), p. $203 \mathrm{seq}$.

(2) Richthofen, China. Bd. 4. Pflanzliche Versteinerungen v. A. Schenk. Berl., 1883.

(3) Die fossile Flora der Grenzschichten des Keupers und Lias Frankens, I 868.

(4) Beiträge zur Flora der Vorwelt, III. Die fossilen Pflanzen der Wernsdorfer Schichten in den Nordkarpathen. Palacontographica, vol. 19 (1871), p. I seq.

(5) Ueber die Pfianzenreste des Muschelkalkes von Recoaro, in E. W. Benecke, Geo. gnostisch-paläontologische Beiträge. Bd. 2; Heft I (1868), p. 71 seq.

(6) Ueber einige in der Braunkohle Sachsens vorkommende Pflanzenreste. Botan. Zeitung, 1869, p. 375.

(7) Ueber die Flora der schwarzen Schiefer von Raibl. Würzburger naturwiss. Zeitschrift, vol. 6 (1866-1867), p. Io seq.

(8) Ueber die Gattungen Elatides, Heer, Palissya, Endl., Strobilites, Schpr. Englers bot. Jahrbücher f. Systematik, Pflanzengeschichte und Pflanzengeographie, vol. 5 (1884), p. 341 .

(9) Ueber Medullosa elegans. Englers bot. Jahrbiicher f. Systematik, Pflanzengeschichte und Pflanzengeographie, vol. 3 (1882), p. 156 seq.

(10) Ueber die Fruchtstände fossiler Equisetineen. Botan. Zeitung, Bd. 34 (1876), I. Annularia, p. 529 seq., II. Sphenophyllum, p. 625 seq.

(11) Die während der Reise des Grafen Bela Széchenyi in China gesammèlten fossilen Pflanzen. Palaeontographica, vol. 31 (1884).

Schimper, W. Ph. (1) Paléontologie végétale, vol. I (1869). vol. $2(1870-1872)$. vol. 3 (1874).

(2) Handbuch der Paläontologie, see Zittel.

(3) Sohimper et Mougeot. (I) Monographie des plantes fossiles du grès bigarré de la chaine des Vosges, Leipzig, I844.

(4) Les végétaux fossiles du terrain de transition des Vosges. (Terrain de Transition des Vosges par J. Köchlin-Schlumberger et W. Ph. Schimper.) Strassburg, 1862.

von Schlotheim, E. (1) Die Petrefactenkunde auf ihrem jetzigen Standpunkte, 1820Nachträge, Abth. I u. II, I 822-1823.

Schlüter, A. (1) Coelotrochium Decheni, eine Foraminifere aus dem Mitteldevon. Zeitschr. d. deutsch. geol. Ges., Bd. 31 (1879), p. 668.

Schmalhausen, J. (1) Beiträge zur Juraflora Russlands. Mém. de l'Acad. imp. des sc. de St. Pétersbourg, sér. 7, vol. 27, n. 4 (1879).

(2) Die Pflanzenreste der Steinkohlenformation am östlichen Abhange des Uralgebirges. Mém. de l'Acad. imp. des sciences de St. Pétersbourg, sér 7, vol. 31, n. 13 (1883).

(3) Die Pflanzenreste aus der Ursastufe im Flussgeschiebe des Ogur in Ostsibirien. Mélanges physiques et chimiques tirées du Bull. de l'Acad. imp. des sciences de St. Pétersbourg, vol. 9 (1876), p. 625 seq. 
Schmid, E. E. und Schleiden. (1) Die geognostischen Verhältnisse des Saalthals bei Jena, 1846 .

Schmitz, Fr. (1) Fruchtrest aus der Steinkohlenformation. Sitzungsbericht der niederrhein. Gesellschaft für Natur- und Heilkunde zu Bonn, 14 Juli, 1879.

Schultze, F. Ueber das Vorkommen wohlerhaltener Cellulose in Braunkohle und Steinkohle. Monatsber. der Berliner Akad., Jahrg. 21 (1855), p. 676 seq.

Schweinfurth, G. (1) Zur Beleuchtung der Frage über den versteinerten Wald. Zeitschrift der deutschen geol. Gesellschaft, vol. 34 (1882), p. 139 seq.

Sendtner, O. (1) Die Vegetationsverhältnisse Südbayerns, 1854.

Senft, F. (1) Die Humus-, Marsch-, Torf- und Limonitbildungen, 1862.

Graf zu Solms, H. (1) Dic Coniferenformen des deutschen Kupferschiefers und Zechsteins. Paläontologische Abhandlungen von Dames und Kayser, vol. 2, Heft 2, Berlin, I 884 .

Stefani. (1) Vorläufige Mittheilung über die rhätisclıen Fossilien der apuanischen Alpen (Bactryllium). Verhandl. d. k. k. geol. Reichsanstalt zu Wien (1882), p. 96 seq.

Steinhauer, H. (1) On fossil reliquia of unknown vegetables in the coal strata. Transactions of the American Philosophical Socicty held at Philadelphia, vol. I, new ser. (1818), p. $265 \mathrm{seq}$. (The portion on Stigmaria was reprinted in Lindley und Hutton, fossil Flora, vol. 1, 3i-36.)

Steinmann, G. (1) Zur Kenntniss fossiler Kalkalgen (Siphoneen). Neues Jahrbuch f. Mineralogie, Geologie und Paläontologie, 13d. 2 (1880), p. I 30 seq.

(2) Referat über Munier Chalmas 2. Neues Jahrb. f. Minera'ogie, Geognosie und l'aläontologie (1882), p. 321 .

Stenzel, C. G. (1) Ueber die Staarsteine. Nova Acta Lcop. Carol., vol. 24 (1854), p. 823 seq.

(2) Ueber Farnwurzeln aus dem Rothliegenden. Nova Acta Leop. Carol., vol. 26, P. I (1857), p. 221 sec.

(3) Rhizodendron Oppo'iense, Göpp. Ergänzungsheft zum 63. Jahresbericht der schlesischen Gesellschaft für vaterländische Kultur. Breslau, I886.

Graf von Sternberg, Caspar. (1) Versuch einer geognostisch botanischen Darstellung der Flora der Vorwelt. Leipzig, 1821-1838.

(2) Beschreibung der Huttonia spicata, einer neuen fossilen Pflanze. Verhandlungen der Gesellschaft des vaterländischen Museums in Böhmen. Jahrgang 1837. Beilage C zur Rede des Präsidenten in der Versammlung vom 5. April, 1837, t. I.

Sterzel, J. T. (1) Ueber Scolecopteris clegans Zenk. und andere fossile Reste aus dem Hornstein von Altendorf bei Chemnitz. Zeitschr. der deutschen geologischen Gesellschaft, vol. 32 (1880), p. I seq.

(2) Die fossilen Pflanzen des Rothliegenden von Chemnitz. Fünfter Bericht der Naturf. Gesellschaft zu Chemnitz (1875), p. 151.

(3) Ueber die Fruchtähren von Annularia sphenophylloides Zenker etc. Zeitschr. der deutschen geologischen Gesellschaft, vol. 34 (I882), p. 685.

(4) Paläontologischer Charakter der oberen Steinkohlenformation und des Rothliegenden im erzgebirgischen Becken. Siebenter Bericht der Naturf. Gesellschaft zu Chemnitz (1881).

Stiehler. (1) Brief an Herrn von Carnall. Zeitschr. der deutschen geologischen Gesellschaft, vol. 2 (1850), p. 181 .

Stokes, Ch. (1) Notice respecting a piece of recent wood partly petrified by carbonate of lime with some remarks on fossil woods. Transactions of the Geol. Soc. of Lond., scr. 2, vol. 5, London, 1840.

Strasburger, Eduard. (1) Ueber Scolecopteris elegans, Zenk. Jenaer Zeitschrift f. Naturw., vol. 8 (1874), p. 88 seq. 
Stur, D. (1) Beiträge zur Kenntniss der geologischen Verhältnisse von Raibl und Kaltwasser. Jahrb. d. k. k. geol. Reichsanstalt zu Wien, Bd. 18 (I868).

(2) Ueber die in Flötzen reiner Steinkohle enthaltenen Steinrundmassen und Torfsphärosiderite. Jahrb. der k. k. geol. Reichsanstalt zu Wien, vol. 35 (I885), p. 6I 3 seq.

(3) Die Carbonflora der Schatzlarer Schichten. I. Farne. Abh. d. k. k. geol. Reichsanstalt zu Wien, Bd. I I, Abth. I (1885).

(4) Zur Morphologie und Systematik der Culm-und Carbonfame. Sitzber. d. k. k. Akad. d. Wissensch. zu Wien, Bd. 88 (1883), 12. Juli.

(5) Die Culmflora der Ostrauer und Waldenburger Schichten. Abh. d. k. k. geol. Reichsanstalt zu Wien, vol. 8, Heft II (1877).

(6) Die Culmflora des mährisch-schlesischen Dachschiefers. Abh. d. k. k. geol. Reichsanstalt zu Wien, vol. 8, Heft I (1877).

(7) Die obertriadische Flora der Lunzer Schichten und des bituminösen Schiefers von Raibl. Sitzber. d. k. Akad. d. Wissensch. zu Wien, I 885, I. Märzheft.

(8) Zur Morphologie der Calamarien. Sitzber. d. k. Akad. d. Wissensch. zu Wien, Math.-naturw. Classe, Bd. 83, Abth. I (188I), Heft V, p. 409 seq.

(9) Ist das Sphenophyllum in der That eine Lycopodiacee? Jahrb. d. k. k. geol. Reichsanstalt zu Wien, Bd. 27 (1877), p. 7 seq.

(10) Sphenophyllum als Ast auf einem Asterophylliten. Verhandl. d. k. k. geol. Reichsanstalt zu Wien, Jahrgang 1878 , p. 327 seq.

Temme. (1) Der am Piesberg gefundene und aufgestellte Wurzelstock einer Sigillaria. Sechster Jahresbericht des naturwissenschaftl. Vereins zu Osnabrück (1885), p. 266, c. tab.

Thompson, D'Arcy W. (1) Notes on Ulodendron and Halonia. Transact. of the Edinburgh Geological Society, vol. 3, pt. 3 (1880), p. 34 I seq.

van Tieghem, Ph. (1) Sur le ferment butyrique (Bacillus Amylobacter) à l'époque de la houille. Comptes rendus hebd. de l'Acad. de Paris, vol. 89 (I879), p. I 102 seq.

(2) Traité de Botanique, I 884.

(3) Sur quelques points de l'anatomie des Cryptogames vasculaires. Bull. de la Soc. Bot. de France, vol. 30 (1883), p. 169 séq.

Unger, F. (1) Chloris protogaea, I847.

(2) Beitrag zur näheren Kenntniss des Leithakalkes. Denkschriften der k. k. Akad. d. Wissensch. zu Wien, Bd. I4 (1858).

(3) Die fossile Flora von Kumi auf der Insel Euboea. Denkschriften der k. k. Akad. d. Wissensch. zu Wien. Math.-natw. Cl., Bd. 27 (1867), p. 27 seq.

(4) Iconographia plantarum fossilium. Denkschriften der k. k. Akad. d. Wissensch. zu Wien, vol. 4 (1852), p. 73 seq.

(5) F. Unger und R. Richter. Beitrag zur Paläontologie des Thüringer Waldes. Denkschriften der Wiener Akademie. Mathem.-naturw. Classe, vol. II (I856).

(6) Versuch einer Geschichte der Pflanzenwelt (1852).

(7) Der versteinerte Wald bei Cairo. Sitzber. der mathem.-naturw. Classe der Wiener Akad., vol. 35 (1 858), p. 209 seq.

(8) Ein fossiles Farnkraut aus der Ordnung der Osmundaceen nebst vergleichenden Skizzen über den Bau des Farnstammes. Denkschriften der k. k. Akad. der Wissensch. zu Wien. Mathem.-naturw. Classe, vol. 6 (1854), p. 137 seq.

(9) Ueber die Struktur der Calamiten und ihre Rangordnung in Gewächsreich. Flora, Jahrgang $23, \mathrm{Bd} .2$ (1 840 ), p. 654 seq. Unger's drawings were published for the first time in Petzholdt's Calamiten und Steinkohlenbildung, tt. 7, 8; some of the figures were reproduced by Göppert in his Permische Flora.

(10) Anthracitlager in Kärnthen. Sitzber. der k. k. Akad. d. Wissensch. zu Wien. Mathem.-naturw. Classe, vol. 6o, Abth. I (187o), p. 777 seq.

$$
\text { C C } 2
$$


Vanuxem, Lardner. (1) Natural History of New York, Geology, Part III (I 842).

Vater, H. (1) Fossile Hölzer der Phosphoritlager Braunschweigs. Zeitschrift der deutschen geol. Gesellsch., vol. 36 (1884), p. 783 seq.

Velenovsky. (1) Die Gymnospermen der böhmischen Krcideformation, 1885.

Visiani, R. de. Piante fossili della Dalmazia.

Volkmann, G. A. (1) Silesia subterranea, 1720.

Walch, J. E. J. (1) Die Naturgeschichte der Versteinerungen zur Erläuterung der Knorrischen Sammlung von Merkwürdigkeiten der Natur., vol. I, Nürnberg, 1773.

Weiss, Ch. E. (1) Fossile Flora der jüngsten Steinkohlenformation und des Rothliegenden im Saar-Rheingebiet. Bonn, 1869.

(2) Einige Carbonate aus der Steinkohlenformation. Jahrb. d. k. preuss. geol. Landes • anstalt, 1884, p. 113 seq.

(3) Zur Flora der ältesten Schichten des Harzes. Jahrb. d. k. preuss. geol. Landesanstalt, I 884 . Berlin, I885.

(4) Ueber Lomatophloios macrolepidotus, Goldenb., Zeitschrift der deutschen geol. Gesellsch., Bd. 33 (188I), p. 354. See also Botan. Centralblatt, vol. 8 (1881), p. 157.

(5) Bciträge zur fossilen Flora III. Steinkohlen-Calanarien II. Abhandl. zur geologischen Specialkarte von Proussen und den Thïringischen Staaten, vol. 5, Heft 2, p. 87 seq. Berlin, 1884 .

(6) Beiträge zur fossilen Flora I. Steinkohlen-Calamarien mit besonderer Berïcksichtigung ihrer Fructificationen. Abhandl. zur geol. Specialkarte von Preussen, vol. 2, Heft I (1876).

(7) Vorläufige Mittheilungen über Fructificationen der fossilen Calamarien. Zeitschrift der deutschen geol. Gesellsch. zu Berlin, vol. 25 (1873), p. 256 seq.

(8) Sphenophyllum, Asterophyllites, Calamites. Neues Jahrbuch für Min., Geol. u. Paläont., Jahrgang 1879 , p. 260 seq.

(9) Ueber eine Buntsandsteinsigillaria und deren nächste Verwandte. Jahrbuch der kgl. preuss. geolog. Landesanstalt für I 885 (I 886 ), p. 356.

Williamson, W. C. (1) On the organisation of the fossil plants of the coal-measures.

Pt. I. Calamites. Philos. Transact., $187 \mathrm{I}$, p. 477 scq.

1\%. 11. Lycopodiaceae, Lepidodendreae and Sigillarieae. Philos. Transact., 1872, p. $197 \mathrm{seq}$.

P\%. III. Lycopodiaceae, continued. Philos. Transact., 1872, p. 283 seq.

Pt. IV. Dictyoxylon, Lyginodendron, Hcterangium. Philos. Transact., I873, p. $377 \mathrm{seq}$.

1'.V. Asterophyllites. Philos. Transact., I874, p. 41 seq.

I't. VI. Ferns. Philos. Transact., 1874, p. $675 \mathrm{seq}$.

I't. VII. Myelopteris, Psaronius, Kaloxylon. Philos. Transact., I876, p. I seq.

Pt. VIII. Ferns, Gymnospermous Stems and Seeds. Philos. Transact., 1877, p. $213 \mathrm{seq}$.

Pt. IX. Philos. Transact., 1878, p. $319 \mathrm{seq}$.

Pt. .X. Philos. Transact., 1880, p. 493 seq.

Pt. XI. Philos. Transact., I $88 \mathrm{I}$, p. 283 seq.

Pt. XII. Philos. Transact., I 883, p. 459 seq.

(2) On some undescribed tracks of invertebrate animals from the Yoredale rocks and on some inorganic phenomena produced on tidal shores simulating plant remains. Memoirs of the Literary and Philosophical Society of Manchester, ser. 3, vol. 10 (1885), p. 19 seq.

(3) Contributions towards the history of Zamia gigas, Lindl. et Hutt. Transact. of the Linnean Society, vol. 26 (1868), p. $663 \mathrm{seq}$.

(4) On the structure and affinities of the plants hitherto known as Sternbergiae. Memoirs of the Literary and Philosophical Society of Manchester, ser. 2, vol. 9 (185I), p. 340. 
(5) Williamson, W. C. et M. Hartog. Les Sigillaires et les Lépidodendrées. Ann. des sc. nat., sér. 6, vol. xiii. (1882), p. 339 seq.

(6) A monograph on the morphology and histology of Stigmaria ficoides. Palaeontographical Society, 1887.

(7) On the structure of the woody zone of an undescribed form of Calamite. Memoirs of the Literary and Philosophical Society of Manchester, ser. 3, vol. 4 (1869), p. 155 seq.

(8) On a new form of Calamitean strobilus from the Lancashire Coal-measures. Memoirs of the Literary and Philosophical Society of Manchester, ser. 3, vol. 4 (I 870 ), p. 248 seq.

(9) On the organisation of Volkmannia Dawsoni. Memoirs of the Literary and Philosophical Society of Manchester, ser. 3, vol. 5 (1871), p. 27 seq.

(10) Contributions towards the history of Zamia gigas, Ldl. et Hutt. Transactions of the Linnean Society, vol. 26 (I868), p. 663 seq.

Witham of Lartington, W. (1) The internal structure of fossil vegetables found in the carboniferous and oolitic deposits of Great Britain, Edinburgh, I 833.

Wright, Berlin H. (1) Notes on the Geology of Yates County, New York. Thirtyfifth Annual Report on the New York State Museum of Nat. Hist. (1884), p. 195 seq.

Wünsch, E. A. (1) Carboniferous fossil trees imbedded in Trappean ash in the isle of Arran. Seemann's Journ. of Botany, vol. 5 (1867), p. 305.

Zeiller, R. (1) Sur des traces d'Insectes simulant des empreintes végétales. Bulletin de la Soc. Géol. de France, sér. 3, vol. 12, p. 676.

(2) Observations sur quelques cuticules fossiles. Ann. des sc. nat. (Bot.), sér. 6, vol. xiii. (I 882), p. 21 3 seq.

(3) Végétaux fossiles du terrain houiller de la France. Extrait du tome IV de l'explication de la carte géologique de la France, i 880.

(4) Note sur quelques plantes fossiles du terrain permien de la Corrèze. Builetin de la Soc. Géol. de France, sér. 3, vol. 8 (i $879-80$ ), p. 196 seq.

(5) Note sur le genre Mariopteris. Bulletin de la Soc. Géol. de France, sér. 7, vol. 3 (I 879), p. 92.

(6) Sur quelques genres de Fougères fossiles nouvellement créés. Ann. des sc. nat., sér. 6, vol. xvii. (1884).

(7) Fructifications de Fougères houillères. Ann. des sc. nat., sér. 6, vol. xvi. (1883).

(8) Sur les affinités du genre Laccopteris. Bulletin de la Soc. Bot. de France, vol. 32 (1885), p. 22 seq.

(9) Note sur quelques troncs de Fougères fossiles. Bulletin de la Soc. Géol. de France, sér. 3, vol. 3 (1874-1875), 1875.

(10) Note sur quelques troncs de Fougères fossiles. Bulletin de la Soc. Géol. de France, sér. 3, vol. 3 (1875), p. 574 seq.

(11) Observations sur les genres Ulodendron et Bothrodendron. Bulletin de la Soc. Géol. de France, sér. 3, vol. 14 (1885), p. I68 seq.

(12) Cônes de fructification des Sigillaires. Ann. des sc. nat., sér. 6, vol. xix. (1884), p. $256 \mathrm{seq}$.

(13) Note sur la Flore du Bassin houiller de Tête (Région du Zambèse). Annales des Mines, sér. 8, vol. 4 (1883), p. 594.

de Zigno, A. (1) Flora fossilis formationis oolithicae. Padova, 1873-1885.

Zittel, K. A. (1) Handbuch der Paläontologie, Bd. II, Lieferung I (1879) und II (1880), bearbeitet von W. Ph. Schimper. Lieferung III (1884) und IV (1885), bearbeitet von $A$. Schenk. 



\section{N D E X.}

A.

Abies Pindrow, 83 .

- Webbiana, 83 .

Abietineae, 54, 67, 68, 70, 81,91 .

Abietites Crameri, Heer, 56, 57.

- Linkii, Dk. 12, 56.

Acetabularia, 43.

Acetabularieae, 42, 43 .

Acicularia, d'Archiac, 42.

Acrostichum, 146.

Aechmea, 368.

Aetheotesta, Brongn. I19, 120.

Aethophyllae, 366.

Aethophyllum speciosum, Schpr, 366.

- stipulare, Brongn. 366.

Albertia, Schpr, 54, 75 .

Alectoruridae, 51 .

Alectorurus, $5 \mathrm{I}$.

Alethopteris, 135, 146, 157 , 162,163 .

- aquilina, 16r.

- australis, Morris, 154 .

Algae, 84 .

Alsophilina Kaunitziana, Dorm. 166.

Amorphophallus, 371 .

Amphitetras, 35 .

Amyelon radicans, Will. 363 .

Amygdaleae, 25.

Anabathra pulcherrima, With. 222, 224.

Anachoropteris, Cda, 159, 160.

Ananas, 371.

Anaxetım, 138 .

Ancistrophyllum, 284.

- stigmariaeforme, 202.

Andriania, F. Braun, 154.

Androstachys, Grand' Eury, 150.

Androstrobus Balduini, Sap. 90.

- borealis, Nath. 9I.
Androstrobus Guerangeri, Brongn. 90.

- sibiricus, Heer, 90.

Angiopterideae of Stur, 143 148.

Angiopteridium, Schpr, I 49.

Angiopteris, I45, I 49, I63.

Angiosperms, I, 15, 43, 97, $304,367$.

Animals, tracks of, $47 \mathrm{sq}$.

Annularia, 31 4, 322-324,330, 340,344 .

- brevifolia, 334 .

- longifolia, 322, 324, 328, 338.

- radiata, Brongn. 324.

- sphenophylloides, Ung. 322,338 .

Annularieae, 324, 329.

Anomorhoea, Eichw. I66.

Antholithus anomalus, Carr. I 22.

- Lindleyi, Carr. 122.

Aphlebia tenuiloba, Sternb. 134.

Aphlebiae, 124, 133 sq., 152.

Aphlebiocarpeae of Stur, I 43 , I 52.

Aphlebiocarpus Schützei, Stur, I 52.

Aphyllostachys Jugleriana, Göpp. 334.

Aporoxylon primigenium, Ung. 84 .

Araucaria, 57, 68, 81, 92, 204.

- Bidwillii, 57.

- Brodiaei, Carr. 57.

- excelsa, 68.

- microphylla, Sap. 57.

- Moreauana, 57.

- Philippsi, Carr. 57.

- sphaerocarpa, Carr. 57.

Araucarieae, 56, 67, 71 .

Araucarites, 12, 77, 81.

- cutchensis, O. Feistm. 57.

- macropterus, O. Feistm. 57.

- spiciformis, Germ. I 50.
Araucaroxylon, 81-84, 100, 104, 109, I10, 171, 357 .

- medullosum, Kr. 109.

Archaeocalamites, Stur, 3 I 3 , 320-322, 337, 344 .

- radiatus, 300, 309, 313, $315,320,338,343$.

Archegoniatae, I 16, 223, 231, 259, 262, 34I.

Arctopodium, 188.

- insigne, 188.

- radiatum, I 88 .

Aroideae, 280.

Arthrophyceae, 50.

Arthrophycus Harlani, Hall, 49.

Arthropitys, 8I, 297, 300, $302,307,323,329$.

- bistriata, Göpp. 298, 30 I, 302.

- lineata, Ren. 30r.

- medullata, Ren. 301.

Arthrostigma, Daws. 293.

Arthrotaxis, 58, 72, 78 .

Arthrotaxites, 6I, 74.

- lycopodioides, Ung. 72.

Artisiae, 6, 109, 110, 200, $211,212,255$.

Aspidiaria, Presl, 198, 201.

Asplenium, 157.

- spectabile, Heer, 157.

- whitbyense, Heer, 157.

Asterocarpus Meriani, Heer, 144.

-Sternbergii, Göpp. 144.

Asterochlaena, Cda, I73, 188.

- Cottai, Cda, r 73.

Asterophylliteae, 324, 329.

Asterophyllites, 314, 322, $324,330,338,344,35 \mathrm{I}$.

Asterophyllites, Ren. 316.

- capillaceus, Weiss, 323 .

- spaniophyllus, O.F eistm. 337.

Asteropteris, Daws. 188.

- noveboracensis, Daws. 173. 
Asterotheca, Presl, 144.

Asterotheceae of Stur, 143.

Astromyelon, Will. 297, 301, $305,307$.

- augustodunense, Ren. 306,307 .

- dadoxylinum, Ren. 306, 307.

- nodosum, Ren. 306.

Aulacomnion, 15.

Aviculopecten, 31.

Azolla, 182, 183, 185 .

\section{3.}

Bacillariae, 35 .

Bacillus Amylobacter, van Tiegh. 35 .

Bacteria, 34.

Bactryllium, 36 . Schmidii, Heer, 36 .

Baiera, 62 sq., 88 .

- Czekanowskiana, Heer, 64.

- digitata, Heer, 64. longifolia, Heer, 63,65 .

- münsteriana, Heer, 64 .

- paucipartita, Nath. 64 .

- pluripartita, Schpr, 63.

- virginica, Font. et White, 64.

Balanophoreae, 98, 130, 372.

Basidiomycetes, 34 .

Bathypteris, Eichw. 166.

Batrachiae, 344 .

Beania, Carr. 90.

- gracilis, Carr. 90.

Belemnopteris, O. Feistm. 138.

Bennettiteae, 98.

Bennettites, Carr. 91, 92, 94 sq., 119, 372.

- Gibsonianus, Carr. 94,96.

- maximus, Carr. 98.

-- Peachianus, Carr. 98.

- portlandicus, Carr. 99.

- Saxbyanus, 92, 93, 98.

liergeria, 199 sq., 205, 200, $213,220,247$.

- angulata, Stbg, 199.

Berwynia Carruthersii, Hicks, 192.

Betula nana, 16.

Bilobites, Dekay, 50.

Biota borealis, Heer, 60.

Bolbopodium, Sap. 92.

Bornetella, Mun. Chalm. $4 \mathrm{I}$.

Bornia, 338.

- enosti, Ren. 301.

- radiata, Brongn. 320.

- radiata, 300 .

Bothrodendron, Ldl. et Hutt. 202, 209, $210,246$.
Bothrodendron punctatum, Grand' Eury, 9, 209.

Botrychium, 151, 152, 223.

Botryopterideae, 147,150 sq.

Botryopteris, Ren. 150, 173.

Bowenia, I62.

Bowmanites, Binn. 336, 337 .

- cambrensis, Binn. 336.

- germanicus, IVeiss, 337.

Brachyphyllum, Brongn. 54, $57,72,78$.

- Jauberti, Sap. 79.

- insigne, Heer, 79.

- mamillare, Brongn. 79.

- Moreauanum, Sap. 79.

- münsteri, Schenk, 69.

- Nepos, Sap. 79.

Briardina, Mun. Chalm. 42.

Bromelia, 368 .

Bruckmannia, Stbg, 325.

- Decaisnei, Ren. 329.

- Grand' Eury, Ren. 329.

- tuberculata, Stbg, 33I.

Bryon,Grand'Eury, 323, 338.

Bryozoa, 45.

Bucklandia, Brongn. 92.

Bucklandia, Carr. 93.

Biittneriaceae, 6 .

Byrrhus, 52.

Bythotrephis, 48 , 50.

\section{C.}

Cacalia, 280 .

Cacteae, 258.

Caenopteris, 135, 150.

Calamariae, 26, 175,189 , $35 \mathrm{I}-353$.

Calamarieae, 294 sq.

Calamitae, 296, 305, 307 sq., 320,322 sq., 327, 339, $340,346$.

Calamitea bistriata, Cotta, 298.

- striata, Cotta, 298.

Calamiteae, 296.

Calamites, 4, 5, 12, 160, 177 , 294 sq., 305 .

- approximatiformis, Stur, 314.

- approximatus, Brongn. $303,316$.

- arborescens, Stbg, 316.

- arenaceus, 177, 294.

- cannaeformis, Schloth. 308.

- cistiformis, Stur, 314.

- Cistii, Brongn. 308.

- cruciatus, Stbg, 308, 316.

- gigas, 322.

- Mougeotii, 294.

- multiramis, Weiss, 308, $315,316$.

- ostraviensis, Stur, 309,3 I4.
Calamites ramifer, Stur, 308 , 314.

- ramosus, Artis, 308, 316, $324,339$.

- Suckowii, Brongn. 308, 316.

- transitionis, Göpp. 320.

- varians, Stbg, 316, 318.

- Volkmanni, Ett. 122.

Calamitina varians,var.semicircularis, Weiss, 318.

Calamitinae, 312, 315-318, $320-322,339,340$.

Calamocladus, Schpr, 322, 323.

Calamodendreae, 296, 298, 307.

Calamodendron, 23, 299, $307,308,316,329,340$, 342.

- commune, Binn. 327 .

- striatum, Göpp. 298.

Calamophyllites, Grand' Eury, 316.

Calamopteris, Ung. 160.

Calamostachys, 178, 326, 328-330.

- Binneyana, Schpr, 324, $327,329$.

- calathifera, Weiss, 332, 338,340 .

- Grand' Euryi, 329, 331.

- Ludwigii, 329.

- Mira, Weiss, 328, 334.

- ramosa, Weiss, 340 .

- Solmsi, Weiss, 339, 340.

- superba, Weiss, 328.

- tuberculata, Weiss, 326, $330,331,338,340$.

- typica, Schpr, 326.

Calamosyrinx, Ung. 160.

- devonica, Ung. 160.

Calathiops, Göpp. 123, 130.

Callitris, 60, 111 .

- curta, Stkic. Gardn. 60.

- Ettingshauseni, Gardn. 60.

Calymmatotheca, Zeill. 149.

Calymmatotheca, Stur, 154, 155.

- Stangeri, Stur, 155.

Camptophyllum, Nath. 79.

Camptopteris, Presl, 138.

Cancellatae, 245, 251.

Cancellophycus, $5 \mathbf{I}$.

Cannophylliteae, 126.

Cannophyllites, Brongn. 123 , 136.

- Virleti, Brongn. 126.

Cardiocarpeae, 127.

Cardiocarpon, Will. 120.

Cardiocarpus, Brongn. 104, 119. 
Cardiocarpus augustodunensis, Brongn. 118.

- orbicularis, Brongn. 127.

- sclerotesta, Brongn. 118 , 119.

Cardiopteris Köchlini, Schpr, 137.

Carpoliths, 76, 117, 89, 296.

Caulerpiteae, 49.

Caulerpites, 46, 48, 77 .

Caulopteris, Cda, 166.

Caulopteris, Ldl et Hutt. 165.

- Cottacana, Ren. 167.

- Giffordi, Lesq. 169.

- gracilis, Ldl. et Hutt. 274.

Cedroxylon, Kraus, 81-83.

Cembra, 55, 56 .

Cephalotaxites insignis, Heer, 61.

Cephalotaxus, 61, 62 .

Ceratostrobus echinatus, Vel. 59.

- sequoiaephyllus, Vel. 59.

Ceratozamia, 88, I 19.

Chamaecyparis sphaeroidea, 18.

Chara, $37,368$.

- Bleicheri, 36 .

- hispida, 37 .

- Jaccardi, 36.

Characeae, $36,368,369$.

Cheilanthes, 89, 157.

Cheirolepis, Schpr, 69.

- Escheri, Heer, 69.

Chelepteris, Cda, 166.

Chirotherium-slabs, 46.

Chlorosporeae, 36.

Chondriteae, 50.

Chondrites, 48.

Chordophyceae, 50.

Chorionopteris gleichenioides, Cda, 156.

Cingularia, Weiss, I 78, 326 .

- typica, Weiss, 334, 335.

Cladophlebis, 157 .

Cladoxylon, Ung. 173.

- dubium, Ung. 188.

- mirabile, Ung. I 88.

Clathraria, Mant. 92, 244246, 251, 26I.

- Lyellii, Schenk, 93.

Clathropodium, Sap. 92, 94.

- foratum, Sap. 95.

- sarlatense, Sap. 92.

- Trigeri, Sap. 92, 93.

Clathropteris, Brongn. 138, I 54 .

Clepsydropsis, Ung. 160.

Codonospermum, Brongn. 120.

Coelotrochium Decheni, Schlüt. 43 .
Colpoxylon Aeduense, Ren. 103.

Conchophyllum Richthofeni, Schenk, 62.

Conchyophycus Marcignyanus, Sap. 47.

Condylites squamatus, Dyer, 74.

Coniferae, 8, 12, 24, 25, 33, 46, 53 sq., 104, 111,117 , $140,141,152,192,200$, 298, 367 .

Coniopteris, Brongn. 157.

Conostoma, Will. 120.

Convallarites, 179.

Corallineae, 45 .

Corallorhiza, 292.

Cordaianthus Grand' Euryi, Ren. $114,115$.

- Lacattii, Ren. I 15.

- Penjoni, Ren. 112.

- Saportanus, Ren. II2, I13.

- subglomeratus, Ren. 112, II 3 .

-Williamsoni, Ren. II4, I 5 .

- Zeilleri, Ren. I14, II 5.

Cordaiteae, 75, 80, 84, 104 sq., 126, 127, 158, 200, $249,255,257,260$.

Cordaites, 2, 6, 12, 21, 23, 93, 104, 105, 108, 109, $110,330,356$.

- alloidius, Grand' Eury, 108.

- angulosostriatus, Grand' Eury, 106, 107.

- crassus, Ren. 107.

- duplicinervis, Grand' Eury, 106.

- microstachys,Weiss, 108.

- principalis, Gein. I05.

- Robbii, Daws. I 10.

- tenuistriatus, Ren. I07.

Corophium longicorne, 48.

Coscinodiscus, 35 .

Cosmarium, 184 .

Crossochorda, 49, 50.

Crossotheca Crépini, Zeill. 155 .

Crustaceae, 178.

Cruziana, d'Orb. 50.

Cryptomeria, 59, 72 .

- Sternbergii, Gardn. 59.

Ctenophorae, 50.

Culmites, 6r.

Cunninghamia, 57.

Cupressineae, 53,60 sq., 69 , $70,72,79,81$.

Cupressinites curtus, Bow. 60.

Cupressinoxylon, $8 \mathbf{I}$.
Cupressinoxylon Protolarix, Göpp. 83.

Cupressoxylon, 81-83.

Cutleria, 47.

Cyathea Brunonis, Wall. 155.

Cyatheaceae, 133, 154-156, 168.

Cyathocarpus eucarpus, Weiss, 144.

Cycadeae, 53, 57, 85 sq., ı o6, $111,117,118,125,126$, $134,139-141,152,161-$ $163,2 \mathrm{II}, 224,225,25 \mathrm{I}$, 256, 257, 262, 28I, 355, $363,368,372$.

Cycadeospermum hettangense, Sap. 87.

Cycadeostrobus, 92.

- Brunonis, Carr. 92.

Cycadeoxylon Fremyi, Ren. 100.

Cycadites Escheri, Heer, 92.

- involutus, Stbg, 26.

Cycadoidea, Buckl. 99.

- megalophylla, Buckl. 99.

- microphylla, Buckl. 99.

Cycadopteris, Zigno, 87, 141 .

- Bauniana, Zigno, 141.

Cycadospadix Hennoquei, Schpr, 86.

- Moreauana, Sap. 86.

Cycas, 86, 90, 92, 100, 102, 235.

- Blandfordianus, Oldh. 86.

- constrictus, O. F eistm. 86 .

- Dicksoni, Heer, 86.

- Lorteti, Sap. 86.

- pectinatus, Berger, 86.

- Rajmahalensis, Oldh. 86.

- rectangularis, Braun, 86.

- revoluta, 86.

- Römeri, Schenk, 86.

- Steenstruppii, Heer, 86.

- taxodinus, 86.

- zamioides, Leck. 86.

Cyclocladia, Gold. $213,214$.

Cyclocladia, Ldl. et Hutt. 317.

Cyclocrinus, 43.

Cyclopitys Heerii, Schmalh. 57.

Cyclopteris, 62, 124, 136, $137,140,141,182$.

- digitata, 62, 64 .

- dilatata, Ldl. et Hutt. 125.

- obliqua, Brongn. 125.

- rarinervia, Göpp. 125.

- reniformis, Brongn. 125.

- trichomanoides, Brongn. 134.

Cyclostigma, 293.

- australe, O. Feistm. 293. 
Cyclostigma hercynicum, Weiss, 293.

- kiltorkense, Haught. 293.

Cylindropodium, Sap. 93, 94.

- liasinuin, Sap. 93.

Cymopolia, 37-40.

Cyparissidiun, Heer, 71.

- minimum, Vel. 71.

- pulchellum, Vel. 7 I.

- septentrionale, Nath. 71.

Cyperaceae, 15 .

Cyrtophlebium, 137 .

Cystoseirites, 47.

Czekanowskia, Hecr,65, 193.

D.

Dacrydium, 63.

Uactylopora, 37 .

- cribrosa, M. Chalm. 41.

- Eruca, Carp. 39.

Dactyloporidae, 43 .

Dactylotheca, 148.

Dadoxylon, 81 .

- Hallii, Daws. 83 .

- Newberryi, Daws. 83.

- Oldhamium, Binney, 358.

- ouangondianum, Daws. $83,110$.

Dammara, 54, 57, 75, 81 .

- albens, Presl, 57.

- borcalis, Heer, 57 .

- macrosperma, Heer, 57.

Dammarites albens, Presl, 93.

- crassipes, Göpp. 93.

Danaca, 149.

Danaeaccac, I 49.

Danaceae of Stur, 143.

Danaeites, Göpp. 149.

- Hecri, Zigno, 149.

- saraepontanus, Stur, 149.

Danaeopsis marantacea, Heer, 136, 149.

Dasycladeae, 37 .

Decaisnella, M. Chalm. 39.

Dechenia, Göpp. 203.

- euphorbioides, Göpp. 203.

- Römeriana, Göpp. 203.

Delesseritae, 48.

Desmidieae, I 83 .

Desmopteris, Stur, 147.

Diacalpe, B1. 155.

Diatomaceae, 35,36 .

Dicalamophyllum altendorfense, Sterz. 79.

Dichoneuron Hookeri, Sap. 139, 141.

Dichopteris, Zigno, Eo.

Dicksonia, 157.

- Buvignieri, Ren. 166, 167 .
Dicksonia Saportana, Heer, 157.

Dicotyledons, 280, 281, $37 \mathrm{I}$.

Dicranophyllum, Grand' Eury, 66, 67.

Dictyolithes Beckii, Hall, 48.

Dictyophyllum, Ldl. et Hutt. $138,154$.

- rugosum, Ldl.et Hutt. 138.

1)ictyophyteae, 50.

Dictyophyton, 50.

Dictyoptcris, Gutb. 1 38, 139.

Dictyothalamus, Göpp. 122.

- Schrollianus, Göpp. 130.

Dictyoxylon, 8, 21 7, 2 1 8, 247, $252,254,255,283,358$, 359-363.

- Oldhamium, Will. 361.

Dictyozamites, Oldh. 139.

Didymochlaena, 131 .

Didymophyllum Schottini, Göpp. 202, 284.

Dioon, 90.

Diplazites, Göpp. 137.

Diplopora, 42.

- annulata, Gümb. 4I.

Diplotesta, Brongn. I1 9.

Diplotmema, Stur, $133,156$.

- geniculatum, Stur, 156.

- zwickauiense, Gutb. 156.

Diploxylon, Cda, 224, 225, 254.

- cycadoideum, Cda, 222.

Discomycetes, 34 .

Discophorites, 49 .

Discopteris, Stur, 146.

Diselma Archeri, Hook. 53.

Dolerophylleae, 125,1 26, 1 37 .

Dolerophyllum, Sap. 123, 1 24, 125, 126.

- Cöpperti, Sap. 141.

Doleropteris pseudopeltata, Grand' Eury, 124.

Doliostrobus Sternbergii, Marion, 59.

Dorycordaites, 105.

Drepanophycus spiniformis, Göpp. 192.

Drynaria, 138.

- appendiculata, 138 .

E.

Echinostachys, Brongn. 367.

Echinostrobus, 79.

- princeps, 6 I.

- Sternbergii, Schpr, 72.

Edraxylon, Will. 361 .

Eleoxylon, Brongn. 82.

Eleutherophyllum, Stur, 178.

Encephalartos, 102.

- gorceixianus, Sap. 85 .
Encrinite, 189.

Endogenites, Spreng. 159.

- echinatus, Brongn. 92.

Entomolepis cynarocephala, Sap. 74.

Eolirion primigenium, Schenk, 66.

Eophyton, Torell, 46, 48, 50, 190.

Eopteris Morierii, Sap. I31.

Ephedra, 65, 116, 127, 129.

Ephedrites, 123, 127.

- antiquus, Heer, 127.

Epipogium, 292.

Equisetaceae, 175 sq., 311.

Equisetides, Schpr, 178.

- brevidens, Schpr, 178.

- lingulatus,Germ. 178,339.

- Wrightiana, Daws. 178.

Equisetinae, 296, 324.

Equisetites, 175, 177, 179, I 80, 294, 295, 308.

- arenaceus, Bronn, 176178.

- Burchardti, Dunk. 177, 178.

- columnaris, Brongn. 178 .

- münstcri, Stbg, 178.

Equisetum, 176, 181, 294$296,303,307,310,313$, 3 I $4,318,320,341,354$.

- infundibuliforme, Brongn. 336.

- laterale, Phill. 180.

- mirabile, Stbg, 178, 189.

Erica, 16.

- mediterranea, 27.

Eriotesta, Brongn. 120.

Espera, Decaisne, 43.

Eucalamites, Weiss, 316,322, 340.

Eunotia, 35.

Euphorbiae, 258.

Eupteris, 135.

Euryphyllum, O. F eistm. 88.

F.

Favularia, 242, 243, 245, 250.

Fayolia, Ren. et Zeill. 369.

Feildenia, 62, 66.

Fenela, 61.

Fenelopsis

Schenk, 6r.

Ferns, 6, 12, 20, 26, 87, 89, $131 \mathrm{sq}$.

Ficoideae, 280.

Filices, 131 sq.

Fittonia, Carr. 93.

Flabellaria borassifolia, Stbg, 108.

- chamaeropifolia, Göpp. 93. 
Flabel'aria, principalis, Goniolina 43.

Germ. Io8.

Flemingites, Carr. 237.

Florideae, $44,48$.

Foraminiferae, 37,40 .

Fragilaria, 35 .

- rhabdosoma, 35 .

- striolata, 35 .

Friçia, Vel. 90.

Fucaceae, 84 .

Fucoides, 77.

- Zonarites, Brongn. 64 .

Fungi, 34 .

$$
\text { G. }
$$

Gallionella, 35 .

- aurichalca, 35 .

- distans, 35 .

Gangamopteris, O. Feistm. 138.

Gasteromyces farinosus, Ludw. 34 .

Geinitzia, 72.

- cretacea, 72 .

- formosa, 72.

- hyperborea, 72.

Ginkgo, 62 sq., 8I, 88, II I, I 8 , I I9, I 8 I.

- adiantoides, Heer, 63 .

- biloba, 62 .

- digitata, Heer, 62, 63, 64 .

- Huttoni, Heer, 62, 64.

- sibirica, Heer, 64.

Ginkgophyllum, Sap. 66.

- flabellatum, Sap. 66.

- Grasseti, Sap. 66.

- Kamenskianum, Sap. 66.

Gleichenia, I 33 .

Gleicheniaceae, I46, I 53, I $54,156$.

Glossophycus, 5 I.

Glossopteris, O. Feistm. 138.

Glossozamites, Schpr, 88.

- Zittelii, Schpr, 88.

Glyptodendron eatonense, Claypole, 194.

Glyptolepis Keuperiana, Schpr, 68.

Glyptostrobus, 59.

- chinensis, 53.

- europaeus, Heer, 59.

- Ungeri, Heer, 59.

Gnetaceae, 116，117，126, $127,129,296$.

Gnetopsis, Ren. I21, 129.

-- elliptica, 127, I28, 307.

- hexagona, Ren. I27.

- trigona, Ren. 127, 330.

Gnetum, I16, I19, I27, 129.

- Thoa, 127.

- urens, 127.

Goniatites, 31 .
Goniophlebium, I 37.

Goniopteris, 137 .

- arguta, Göpp. 137.

- emarginata, Göpp. I 37.

Grand' Eurya, Stur, 148.

Grand' Eurya, Zeill. I 47, I 50.

- autunensis, Stur, I48.

- Renaulti, Stur, I 48.

Granularia, 50.

Graptolite, 187 .

Grasses, 15.

Grilletia Sphaerospermii, Ren. et Bertr. 34 .

Gymnosperms, 2, 23, 26, 28, $53,97,104$, I I 3 , I I 7, I 26, I 29, I 4 I, 223, 240, 257, $260,296,330,363$.

Gymnostomum ferrugineum, Ludw. $5 \mathrm{I}$.

Gyrocalamus palatinus, Weiss, 369.

Gyrochorda, 48, 50.

Gyrolithae, 49.

Gyrophyllites, 49.

Gyroporella vesiculifera, Gümb. 42.

Gyropteris, Cda, I 59.

\section{H.}

Halimeda, 84 .

Haliserites Deckenianus, Göpp. 192.

Halonia, Ldl. et Hutt. $213^{-}$ 2I 5,230 sq., 317.

Halymenitae, 48 .

Halymenites Arnaudi, Sap. 48.

Hapalopteris, Stur, I 48.

Haplocalameae of Ung. 160.

Haploporella, Gümb. 39 .

Hawlea, Cda, 145, I46.

Hawleeae, Stur, I 43, I 45.

Helicteres, 368.

Helminthostachys, I 52.

Hemitelia capensis, R. Br. 133.

Heterangium, Cda, 283, 358, 362,363 .

- Grievii, Will. 362.

- paradoxum, Cda, 362 .

Hexapterospermum, Brongn. IIg.

Hippurites gigantea, Ldl. et Hutt. 318.

- longifolia, Ldl. et Hutt. 318.

Holothuriae, 50.

Huttonia, Stbg, 325, 333.

- spicata, Stbg, 333 .

Hydroid polypes, I89.
Hydropteridae, 182.

Hymenophylleae, 153.

Hymenophyllites, I 35, 153.

- delicatulus, Stbg, 153.

- Humboldti, Göpp. I 53 .

Hymenophyllum, Weissii, Schpr, 153.

Hypneae, I 5, 52, I 86.

\section{I.}

Inolepis, 54, 70.

Isoëteae, I 92.

Isoëtes, 65, 106, I97, 219, $223,225,257,259,262$, 280, 34I.

- lacustris, 192.

Isoëtites, I 86.

Itieria, Sap. 75.

\section{J.}

Jungermannieae, 52 .

Juniperus virginiana, 53.

K.

Kalopteris, Cda, 159.

Kaloxylon, Will. 363 .

Kalymma, Ung. I60.

Kaulfussia, 144.

Kaulfussieae of Stur, I 43.

Keckiae, 49.

Knorria, Stbg, 200-205, 207, $210,213,284$.

- imbricata, Stbg, 200.

- longifolia, 284 .

- princeps, Göpp. 20 I.

- Richteri, Gein. 203.

- Sellonii, Stbg, 202.

Krannera, Vel. 57.

- mirabilis, Vel. 93.

\section{L.}

Labiatae, 300.

Laccopteris, Presl, I 54.

Lageniopteris, Ren. I 58.

- obtusiloba, Ren. 158.

Lagenostoma, Will. I 20.

Laminaritae, 48.

Leiodermaria, 242-246, 251 , 252, $26 \mathrm{I}$.

Leiodermarieae, 225, 262.

Lenzites, 34 .

Lepacyclotes, Emmons, I 76.

Lepidodendreae, 9, 21, 110 , 183, I 84, I 94 sq., 241 , 242 , $252,255,263,286,288$.

Lepidodendron, $7,12,26$, $34,108,186,194$ sq. 24 I$245,246-248,254,258-$ 
260, 265, 283, 296, 34I, 358,368 .

Lepidodendron, aculeatum, 190, 201.

- australe, $\mathrm{M}^{\mathrm{c}} \mathrm{Coy}, 200$.

- brevifolium, Ett. $2 \mathrm{O}_{4}$.

- costatum, Lesq. 242.

- diplotegioides, Lesq. 199.

- elegans, Brongn. 203.

- Göppertianum, 197.

- gracile, Brongn. 203.

- Haidingeri, Eit. 195, 204.

- Harcourtii, With. 225 sq., 23I, 232, 237-239, 253, $254,257,259$.

- Jutieri, Ren. 2 I 8, 253, 259.

- longifolium, Brongn. 204.

- nothum, Ung. 199, 200, 227.

- obovatum, O. Feistm.199.

-rhodumnense, Ren. 216 , 217.

Richteri, Ung. 227.

- rimosum, Gein. 284.

- selaginoides, Stbg, 204, $216,218,221$.

- squamosum, Göpp. 227.

- Sternbergii, Brongn. 195, 203, 204.

- tenerrimum, Eichw. 9.

- tetragonum, Gein. 199.

- vasculare, Binney, 2 I6, 218,222 sq., 228, 238.

-Veltheimianum, 195, 201, 206, 207, 209.

- IVilliamsoni, 226-228.

Lepidophloios, 199, 208, 209, 210 sq.,224, 228, 232, 235 , $236,245$.

- brevifolius, WVill. 228, 239.

- laricinus, 214.

- obcordatus, Lesq. 213.

Lepidophyllum, 204,235,236.

Lepidostrobus, 184, 225, 232 sq.

- Brownii, Schpr, 233, 238.

- Iabadianus, Schpr, 237, 238.

- Goldenbergii, Schpr, 234.

- levidensis, Binn. 237.

- nacrocystis, Lesq. 234.

-- ornatus, Hook. 233.

- princeps, Lesq. 235.

- Rouvillei, 238.

- variabilis, O. Feistm. 235.

- Wïnschianus, Binn. 237.

Leptocaryon, Brongn. 119.

leptophloeum, Daws. 209.

- rhombicum, Daws. 200.

Leptostrobus, Heer, 69.

Leptoxylon geminum, Cda, 225.
Lesleya grandis, Lesq. 134 .

Libocedrus, $60,6 \mathrm{I}$.

Lichens, 34 .

Lithothamnion, 45.

- ramosissimum, Ung. 45.

Lomaria, 87.

Lomatophloios, 110, 200, $210,211,212$.

- crassicaulis, Cda, IIo, 219 note, 228.

- macrolepidotus, Weiss, 235.

Lomatopteris, Schpr, 141.

Lonchopteris, Brongn. 138.

Lophophytum, 98.

Lycopodeae, 354.

Lycopodiaceae, 173, I 88, 190, 192, 195, 208, 296, 353,367 .

Lycopodinae, $280,363$.

Lycopodites, 186 sq.

- denticulatus, Goldenb. I 86.

- elongatus, Goldenb. 186.

- falcatus, Ldl. et Hutt. 187.

- Gutbicri, Göpp. 187.

- Maakii, Lesq. I 86.

- macrophyllus, Goldenb. 187.

- Matthewi, Daws. 187.

- Milleri, Salter, 192.

- pinnaeformis, Göpp. I 89.

- Plumula, Daws. I 89.

- primaevus, Goldenb. 187.

- Richardsoni, Daws. 187.

- Stichlerianus, Göpp. 186.

- Stockii, Kidst. 187.

- uncinatus, Lesq. I 86.

- Vanuxemi, Daws. 189.

Lycopodium, 171, 186, 197, I $98,203,236,258,281$, 324,354 .

- annotinum, 208.

- laterale, 208.

-- lucidulum, 208.

- pachystachyum, I 88.

- Phlegmnaria, 186, 187.

- punctatum, 187,188 .

- Renaultii, Ren. 187, I88.

- Selago, 208, 235.

Lyginodendron, Will. I4I, $217,283,358,361-363$.

- Landsburghii, 218.

- Oldhamianum, Will. 358 , 359.

Lygodium, 157.

M.

Macropterygium, Schpr, 88. - Bronnii, Schpr, 111, 14 I.
Macrostachya, Schpr, 333, 334,339 .

Macrostachya, Weiss, 325.

- infundibuliformis, Ren. 328.

- Schimperiana, Weiss, 333.

Macrotaeniopteris, Feistm. 136.

Macrozania, 163.

Malacotesta, 120.

Mantellia, Brongn. 92, 93.

Mantellia, Carr. 99.

- inclusa, Carr. 99.

- nidiformis, Carr. 99.

Marattia, 131, 136, 149.

- sect. Eupodium, 144.

Marattiaceae, 133, 143 sq., 163,168 .

Marattieae of Stur, 143.

Marchantia, 52.

Mariopteris, Zcill. 133.

Marsilea, 306.

- Marioni, A. Br. 181.

Marsileaceae, 138, I81.

Marsilidium speciosum, Schenk, 182.

Marsilioideae, 175 .

Matonia, 154.

Medullosa, 92, 98, 100.

- elegans, Cotta, 160.

- Leuckarti, Göpp. et Stenz. 103, 16I note.

- Ludwigii, Göpp. et Stenz. 102.

- stellata, Cotta, 101, 102, $36 \mathrm{I}$.

- var. interrupta, IOI.

- - major, IOI.

Medullosae, Ioo.

Medulloseae, 85 .

Meesia, 15.

Megalopteris, Daws. 126, I 36.

- Dawsoni, Hartt. 126.

Megaphytum, Artis, 167, $169,207,242$.

Membranipora, 48.

Microcachrys tetragona, Hook. 53.

Microzamia gibba, Cda, 90.

Monocotyledons, 104, 160, $281,367$.

Moriconia Cyclotoxon, Deb. et Ett. 6I.

Mosses, $15,52$.

Munieria, 42 .

Musaceae, 123.

Muscites polytrichaceus, Ren. et Zeill. 52.

Myelopitys medullosa, Cda, 103. 
Myelopteris, Ren. 161, 255, 259, 361.

Myeloxylon, Brongn. 160164.

Myriophylloides Williamsonis, Hick et Cash, 305.

Myriotheca, 146.

$$
\text { N. }
$$

Navicula, 35 .

Nematophycus, 45.

- Hicksii, Ett. 84.

- Logani, Daws. 120.

Nematoxylon

crassum, Daws. 84.

Neomeris, Harv. 37, 39, 41 .

Nephrolepis, I3I.

Nephropteris, Brongn. 124.

Neuropteris, 136 .

- Loshii, Brongn. 134, 136.

- rarinervis, Bunb. I34.

Nicolia aegyptiaca, 30 .

Nilssonia, Brongn. 87, 139, I 4 O.

- polymorpha, Schenk, I 39.

- serotina, Heer, 86.

Nöggerathia, Stbg, 66, 87, 104, 105, I39, 141, 142, I5O, 151 .

- cyclopteroides,

Göpp. I 24, 125 .

- flabellata, 141 .

- foliosa, 141 .

- Göpperti, Eichw. 123.

- Hislopi, 110.

- obovata, I Io.

- palmaeformis, Göpp. 108.

- prisca, Dana, I 10.

- vogesiaca, Bronn, 88, I4I.

Nöggerathiopsis, O. Feistm. 88, IIO.

Nyctyomyces, 34 .

\section{O.}

Odontopteris, 137.

- obtusiloba, Naum. 136.

- Reichiana, Gutb. I34.

Oidospora, 184.

Oldhamia, 50.

Oleandra, 136.

Oleandridium, 136 .

Oligocarpia, Göpp. 145, 146.

- Brongniartii, Stur, 146.

- Gutbieri, Göpp. 145.

- lindsaeoides, 145.

- quercifolia, Göpp. 134.

Oncopteris Dorm. 166.
Onychium, I 57.

Ophioglossaceae, I 51 .

Ophioglossum, 106, 138, 163,171 .

Opuntiae, 280.

Ormoxylon erianum, $G$. et S. N. 83.

Osmunda, I 50, 173.

Osmundaceae, 148, I 54, I63, 173.

Osmundites, I72, 173.

- Dowkeri, Carr. 172.

- schemnicensis, Ung. 172.

Otopteris, Ldl. et Hutt. 87.

Otopteris, Schenk, 139.

Otozamites, F. Br. 87, 89, I 39.

- brevifolius, F. Br. 89.

- Bunburyanus, Zigno, 89.

- marginatus, Sap. 89.

Ovulites, Lam. 44.

\section{P.}

Pachyphyllum, Sap. 77.

- cirinicum, Sap. 77.

- rigidum, Sap. 77.

Pachypteris, Zigno, 87.

Pachytesta, Brongn. II 8 , I 19.

Pachytheca, Hook. I20.

Pagiophyllum, Heer, 77-79.

Palacobromelia Jugleri, Ett. 367.

Palaeocyparis, Sap. 61, 75.

Palaeopteris, Schpr, 153.

- hibernica, Forbes, 137.

Palaeostachya, Weiss, 325, 332,334 .

- arborescens, Weiss, 339, 340.

- elongata, Presl, 332.

- gracilis, Ren. 334.

- Schimperiana, Weiss, $333,339$.

Palacovittaria, O. Feistm. I38.

Palaeoxylon, Brongn. 81.

Palaeoxyris carbonaria, Stiehl. 367.

- helicterioides, Morris, 368.

- münsteri, Presl, 367.

- regularis, Brongn. 367.

Palissya, 55, 73, 74 .

- aptera, Schenk, 73, 74 .

- Braunii, Schenk, 73.

Palmacites carbonigerus, Cda, 160.

- leptoxylon, Cda, 160.

Palmae, 24, 104, 280.

Paracalamostachys, Weiss, 325,334 .
Pecopteris, 135, 136, I43, 145-149, 157, 1 59, 361.

- arborescens, Schl. 143.

- aspera, Brongn. I47.

- Bucklandi, Ldl. et Hutt. I 45.

- Cottai, Cda, 167.

- crenata, Stby, 145.

- Cyathea, Brongn. 143.

- densifolia, Ren. 158.

- dentata, Gein. I34.

- exigua, Ren. I48, 158.

- exilis, Phil. 148.

- Geriensis, I 57.

- intermedia, Ren. I44.

- Meriani, Brongn. I44.

- Miltoni, Germ. 145.

- Murrayana, I 57.

- plumosa, Art. 147.

- polymorpha, Brongn. I 43.

- Radnicensis, Stbg, 134 .

- truncata, Germ. I44.

- Williamsonis, Brongn. I 54.

Penicillus, Lam. 43 sq.

Peronosporites antiquarius, Worth. Sm. 34 .

Peuce Withami, Ldl. et Hutt. 83.

Philonotis, 15.

Phlebopteris, I 37.

Phoenicopsis, 62, 65, 88, 93, 192.

Phragmites vulgaris, 15 .

Phyllochorda, 50.

Phyllocladus, 61, I34, I 40.

- rotundifolius, Heer, 62.

Phyllostrobus Lorteti, Sap. 60.

Phyllotheca, Brongn. 179, I $80,338,366$.

- australis, Brongn. 179.

- Brongniartiana, Zigno, 179.

- deliquescens, Schmalh. 180,181 .

- equisetiformis, Zigno, 179.

- indica, 180.

- sibirica, Heer, I8I.

Phymatoderma, 48, 49 .

Physematopitys, Göpp. 8I.

Phytolithus

parmatus, Steinh. 317.

Picea, 55 .

Pilularia, I81.

Pinites, 55, 81.

- Andraei, Coem. 55.

- Briarti, Coem. 55.

- Conwentzianus, 83.
Göpp. 
Pinites Corneti, Coem. 55 .

- depressa, Coem. 55.

- Dunkeri, Carr. 55.

- gypsaceus, Göpp. 4.

- Heeri, Coem. 55.

- latiporosus, Cram. 82.

- Leckenbyi, Carr. 55.

- longissima, Vel. 55.

- Lundgreni, Nath. 55.

- Mantellii, Car. 55.

- Omalii, Coem. 55.

- patens, Carr. 55.

- Protopicea, Vel. 55.

- Quenstedti, Heer, 55.

- Reussii, Cda, 55.

- sussexiensis, Carr. 55.

- Toillezi, Coem. 55.

Pinus, 56.

- sect. Pinea, 55.

- canariensis, 56.

- Coemansi, Sap. 55.

- deflcxa, Sap. 56.

- divaricata, Sap. 56.

- echinostrobus, Sap. 56.

- fallax, Sap. 56.

- longifolia, Roxb. 83 .

- Nordenskiöldi, Heer, 57.

- Palacostrobus, Ett. 56.

- Pseudotaeda, Sap. 56.

- resurgens, Sap. 56.

- Saturni, Ung. 56.

- trichophylla, Sap. 56.

Pissadendron, $8 \mathrm{I}, 83$.

Pitus, With. 8I.

- primaeva, With. 109.

Pityoxylon, Kraus, 81-83.

Platylepis, Sap. 93.

Pleocnemiae, 137 .

Plumalina, 189 .

'oacitcs zeacformis,Schloth. 318.

I'oacordaites, 105, 108.

- lincaris, Grand' Eury, 108, 122.

Podocarpeae, 81 .

Podocarpus, 3, 56, 6I.

- sect. Nageia, 66.

Podosphenia nana, 35 .

Podozamites, 88, 91, 93, III.

- distans, Presl, 88.

Polleriana, 244.

Polylophospermum, Brongn. I 19, 307 .

Polyphysa, 43 .

Polypodiaceae, 168.

Polypodium, 146.

Polyporus, 34 .

Polypterospermum, Brongn. I19.

Polythalamiae, 35 .

Polytrichum, 52.
Polytrypa, 37-39.

Poroxylon, 356.

- Boysseti, Ren. 356-358.

- Duchartrei, Ren. 356, 358.

- Edwardsii, Ren. 356, 357.

Pothocites, Paters. 337.

- grantoni, Paters. 337.

Pourretia, 368.

Proangiosperms, 43, 1 1 1 , 139.

Progymnosperms, 126.

Protopitys, Göpp. 81 .

- Buchiana, Göpp. 298.

Protopteris, Cda, 166, 172.

- fibrosil, Stengel, 167.

- microrhiza, Cda, 172.

- Witteana, Schenk, 166.

Protosalvinia bilobata, Daws. 121.

Protostigma sigillarioides, Lesq. 194.

Prototaxitcs, Daws. 84.

- Logani, 84.

Psaronius, 12, 23, 168 sq., 341.

- arenaccus, Cda, 169.

- bibractensis, Ken. 169.

- carbonifer, Cda, 169, 172.

- Freislebeni, Cda, 169.

- Gutbieri, Cda, 170.

- infarctus, Ung. 169.

- musaeformis, Cda, 169.

Pseudowalchia frondosa, Ren. 77.

Psilophyton, Crép. 135, 186, I $89 \mathrm{sq}$.

- cornutum, Lesq. 192.

- Dechenianum, Carr. 192.

- elegans, Daws. 192.

- glabruin, Daws. 191.

- gracillimum, Lesq. 192.

- princeps, Daws. 190, 191, 192.

- robustius, Daws. 190, 191.

Psilotaceae, 189.

Psilotites, 186.

- lithanthracis, Gold. 189.

- unilateralis, Kidst. 189 .

Psilotum, 204, 288, 292.

Psygmophyllum, Schpr, 66.

Pteris aurita, 138 .

Pterophyllum, Brongn. 88, $139,140$.

- blechnoides, Sandb. 85.

- comptum, Ldl. et Hutt. 139.

- Cottaeanum, Gein. 85.

- giganteum, Schenk, 88.

- Grand' Euryanum, Sap. et Mar. 85 .

- Jägeri, Br. 88.
Pterophyllum inflexum, Eichw. 85.

- Schaumburgense, Dk. 88.

Ptilophyllun, Morr. 89.

Ptilophyton, Daws. 186, 189.

- lineare, Lesq. 189.

- Vanuxemi, Daws. 189.

Ptychocarpus hexastichus, Weiss, 144.

Ptychotesta, Brongn. 119.

Purpura lapillus, 48.

Pyrenomycetes, 34 .

R.

Radiolariae, 183, 184.

Rafflesiaceae, 372 .

Raumeria, Göpp. 99.

- Cocchiana, Caruel, 100.

- Reichenbachiana, Göpp. 100.

- Schulziana, Göpp. 99.

Receptaculites, 43 .

Renaultia, Stur, 144, 148.

Retinospora, 53.

Rhabdocarpus, 104, $118,119$.

Rhachiopteridae, 132,157 sq., 361 .

Rhachiopteris, Will. 159.

- aspera, Will. 158, 361.

- duplex, Will. 160.

Rhacophyllum adnascens, Ldl. et Hutt. 133.

- filiciforme, Gutb. 134.

- laciniatum, Font. et White, 134 .

Rhacopteris, Schpr, 142, 151.

- paniculifera, 151 .

- sarana, Beyschl. 142.

Rhipidopsis, Schmalh. 64 .

Rhipidopteris, 156.

Rhiptozamites, Schmalh. 88, 111 .

- Göpperti, Schmalh. 93.

Rhizocedroxylon , Hohenneggeri, Felix, 82 note.

Rhizogonium, 52.

Rhizomopteris, Schpr, 166.

Rhizopterodendron oppoliense, Göpp. 167, 172.

Rhodea, 135.

- patentissima, Ett. 135 .

Rhynchogonium, Heer, 120.

Rhytidodendron minutifolium, Boulay, 210.

Rhytidolepis, 242-247, 250, 25 I, 262. 
S.

Saccoloma, 168.

Saccopteris, Stur, 146, 147.

Sagenaria fusiformis, Cda, 218.

Sagenopteris, Presl, 138, I 82.

- rhoifolia, Presl, 138.

Salisburia primigenia, Sap. 64.

Salisburieae, 2, 62, 64, I37.

Salvinia, I82, 353, 354 .

Salviniaceae, I82 sq.

Samaropsis, 127.

Sapindaceae, IO2.

Saportaea salisburioides, Font. et White, 64 .

Sarcopteris Bertrandi, Ren. $148,158$.

Sarcotaxus, Brongn. II9.

Scaphidopteris Gilliotti, Ren. I 58.

Schidolepium, Heer, 69.

Schizaeaceae, 148.

Schizodendron, Eichw. 166.

Schizolepidium, 69.

Schizolepis, F. Br. 69 sq.

- Braunii, Schenk, 70.

- Follini, Nath. 70.

- permensis, Heer, 70.

Schizoneura, Schpr, I79, 180.

- gondwanensis, O. Feistm. I 79, 366.

- Heerensis, Schpr, 179.

- Meriani, Schpr, I79.

Schizopteris pinnata, Grand' Eury, I 50.

Schützia, Göpp. 123.

- anomala, Gein. 130.

Sciadopitys, 56, 57 .

Scirpus caespitosus, 16.

Scleropteris, Sap. 157.

Scolecopteris, Zenk. 143, I $44,366$.

- Cyathea, 144.

- elegans, Zenk. 143.

Scolithus, Haldem. 50.

Scolopendrium, 136 .

Scrophulariaceae, 300 .

Selaginella, 186, 187, 197, 236, 240, 286, 288, 324 .

- Martensii, 288.

- spinulosa, 236.

Selaginites, 186.

- cavifolius, Lesq. 186.

- Erdmanni, Germ. 186.

Selenocarpus, Schenk, 154.

Selenochlaena, Cda, 159.

Selenopteris, Cda, I 59.
Semapteris carinthiaca, Ung. 246.

- tessellata, Ung. 246.

Senftenbergia, Cda, I47, 148,155 .

- elegans, 147.

Senftenbergieae of Stur, $143,147$.

Sequoia, 58, 59, 68, 71 .

- Couttsiae, Heer, 58, 83 .

- crispa, Vel. 58.

- fastigiata, Stbg, 58.

- gigantea, 58, 59 .

- Langsdorffii, Brongn. 58, 59.

- Reichenbachii, Heer, 58.

- sempervirens, 58 .

- Smithiana, Heer, 58.

- Sternbergii, Heer, 59.

Sequoieae, 56, 58.

Sigillaria, 6-9, 12, 23, 196, 223-225, 242 sq., 26o, $270,281-283,285,34 \mathrm{I}$, 354,355 .

- aequabilis, Gold. 247.

- alveolaris, Gold. 251.

- Brardi1, 243, 245, 247, $250,25 \mathrm{I}, 26 \mathrm{I}$.

- cactiformis, Gold. 248.

- contracta, Brongn. 243.

- Cortei, 247.

- Defrancei, Brongn. 245.

- Deutschiana, Brongn. 244.

- discophora, Koen. 209.

- Dournaisii, Brongn. 245.

- elegans, Brongn. 243, $245,247,248,25$ I.

-- Eugenii, Stur, 248.

- Hausmanniana, Göpp. $24 \mathrm{I}$.

- hexagona, Brongn. 243, 248.

- Knorrii, Brongn. 245, 249, 25 I.

- laevigata, 247.

- Lalayana, Schpr, 249, 250.

- leioderma, Brongn. 245.

- lepidodendrifolia, Brongn. 245, 247.

- Lorwayana, Daws. 250.

- mamillaris, $25 \mathrm{I}$.

- Menardi, 209, 245, 251$255,259,355$.

- microstigma, Brongn. 247.

- obliqua, Brongn. 245.

- oculata, Gein. 25 I.

- oculina, Blanck. 242.

- Polleriana, Brongn. 244.

- polyploca, Boulay, 26I.
Sigillaria reniformis, Brongn. $246,248$.

- rhomboidea, 247 .

- rimosa, Gold. 247.

- Saulii, Brongn. 243, 254.

- scutellata, Brongn. 25I, $26 \mathrm{I}$.

- spinulosa, 243, 246, 249, $25 \mathrm{I}-256,259,358$.

- Taylori, Carr. 209.

- tessellata, 245, 247, 250.

- Vanuxemii, Göpp. 24I.

- vascularis, Binn. 224, 225.

- venosa, Brongn. 245.

- Voltzii, Brongn. 242.

Sigillariae, 196, 218, 223$225,257-263,284$.

Sigillarieae, 106, 218, 223, 23I, 241 sq., 286.

Sigillariopsis, Ren. 355, 356.

- Decaisnei, Ren. 278.

Sigillariostrobus, Gold. 260, $26 \mathrm{I}$.

- nobilis, Zeill. 26I.

- Tieghemi, Zeill. 26 I.

Siphoneae, 50, 5 I.

Solenites, 192.

- furcatus, Ldl. et Hutt. I 93.

- Murrayana, Ldl. et Hutt. 192.

Sorotheca, Stur, 155.

Sphaereda paradoxa, Ldl. et Hutt. 90.

Sphaeropteris, Wall. I 55.

- barbata, Wall. I 55 .

Sphagnum, I 5, 16.

- Ludwigii, Schpr, 5 I.

Sphallopteris, Schpr, I 66.

Sphenoglossum, Emmons, 345.

- quadrifolium, Emmons, I 82.

Sphenolepidium, 54, 7 I, 72.

- Kurrianum, Heer, 7 I.

- Sternbergianum, Heer, $7 \mathrm{I}$.

- Terquemi, Sap. 71.

Sphenolepis, Schenk, 7 I, 73.

Sphenophyllum, 26,31 4, 322, 343 sq., 365 .

- angustifolium, 344, 352.

- antiquum, Daws. 343.

-- emarginatum, Brongn. 343.

- - var.truncatum, Brongn. 343.

- furcatum, Gein. 320.

- quadrifidum, 347.

- saxifragaefolium, 345 . 
Sphenoplyyllum Schlotheimii, Brongn. 343.

- Stephanense, Ken. 347, 350.

- tenerrimum, Ett. 314, $32 \mathrm{I}, 343,344,352$.

- Thonii, Mahr, 345 .

Sphenopteris, I35, I 36, I43, $146,147,164$.

- acutiloba, Stbg, I34.

- Coemansi, Andr. 146.

- Condrusorum, Gilk. 135, 192.

- coralloides, Gutb. et Gein. 134, 147.

- crenata, Ldl. et Hutt. 133, 147.

- erosa, Gutb. et Gein. 147.

- Essinghii, Andr. 147.

- formosa, Gutb. 134.

- Goldenbergii, Andr. I 46.

-- Hoeninghausii, Brongn. 135.

- refracta, Göpp. 160, 164, I 88,361 .

Sphenozamites, I4r.

- Rochei, Ren. 85.

Spliyropterideae of Stur, 143.

Sphyropteris, Stur, 148.

Spirangium, Schpr, 367, 369.

- Jugleri, 368.

- Prendelii, Lesq. 367.

- Quenstedti, Schpr, 367.

- ventricosum, Sap. 367.

Spiraxis major, Newberry, 369.

- Randallii, Newberry, 369.

Spirophyton cauda galli, 51 .

Spiropitys, Göpp. 81.

Spiropteris, I3I.

Sponges, 50.

Sporangites Huronensis, Clarke, I 21.

Sporocarpon, W'ill. 175, 182, 184.

- asterioides, Will. 183.

- compactum, Will. I83.

- elegans, Will. 183.

- ornatum, Will. 183 .

- pachyderma, Will. I83.

- tubulatum, Will. 183.

Stachannularia, Weiss, 330.

- tuberculata, Weiss, 326.

Stachyopitys Preslii,Schenk, 66.

Stachypteris, Pomel, I 57.

Stangeria, 87, 94, 126.

Stapeliae, 280.

Staphylopteris, Lesq. 155. - asteroides, Lesq. 155.
Staphylopteris sagittatus, Lesq. 155.

- stellata, Lesq. 155.

- Wortheni, Lesq. 155.

Stemmatopteris, Cda, 166.

Stenzelia, Göpp. 160.

Stephanospermum, Brongn. I1 $9,127,307$.

- akenioides, Brongn. I18, I I 9 .

Stereocalameae of Ung. 160.

Stigmarhizes, Ren. 290, 292.

Stigmarhizomes, Ren. 289, 290.

Stigmaria, 4, 8, 12, 22, 31, $214,231,255,259,263$ sq.

- abbreviata, 269.

- Anabathra, 268.

- augustodunensis, 283.

- conferta, 269.

- ficoides, 263 sq.

- var. sigillarioides, Göpp. 270.

- var. undulata, Göpp. 270.

- perlata, Daws. 263.

- rimosa, Gold. 268, 269.

-- stellata, Eichw. 269.

Stigmariopsis, Grand' Eury, 291.

Strobilites Bronnii, Göpp. 78 .

Strobus, 55.

Stylocalamites, Weiss, 316, 322,340 .

- arborescens, Weiss, 339.

Stylonurus, 178 .

Swedenborgia, Nath. 72 .

Sycidium, Sandb. 43.

Synedra capitata, 35 .

Syringodendron, Stbg, 247, 282,29 I.

\section{1.}

Taeda, 55.

Taenidiae, Heer, 50.

Taeniopteris, 135, 136.

- marantacea, Presl, 136, 149.

- Münsteri, 136, 149.

- Smithsii, Lesq. 136.

Taonurus, 5 I.

Taxineae, 6I sq., 8I, I05, 110.

Taxites, $8 \mathrm{r}$.

Taxodieae, 54, 56 .

Taxodium, 59 .

- distichum, 18.

- miocaenum, 59.

Taxospermum, Brongn. 119.
Taxospermum Gruneri, I 8.

Taxoxylon, 82, 83 .

Taxus, 61, 62, 116, 129.

Tecoma radicans, 230.

Tempskja, Cda, I59, I60, 174.

- pulchra, Cda, 160.

Terquemella, M. Chalm. 4I.

Thallophytes, 34 sq.

Thamnopteris Schlechtendalii, Eichw. 66.

Thaumatopteris, Göpp. 138 , I 54 .

- Münsteri, Göpp. 138.

Thinnfeldia, 6I, 87, I 34, 140.

- crassinervis, Gein. 140.

Thuiopsis, 60.

Thyrsoporella, 37 .

- cribrosa, Gümb. $4 \mathrm{I}$.

Thyrsopteris, Kze, 156, 157.

- gracilis, Heer, 156.

- Maakiana, Heer, 156.

- Murrayana, Heer, 156.

- schistorum, Stur, I 57.

Todea, 135, 150 .

- Lipoldi, Stur, 135.

- Williamsonis, Schenk, 154 .

Torreya, 61, 62.

Tracks of animals, 48, 49.

Traquairia, Carr. 175, 182, 183.

Triceratium, 35 .

Trichomanites Göpp. 153.

Beinerti,

Trichopitys, Sap. 66.

- heteromorpha, Sap. 66.

Trigonocarpon, Will. 120.

- olivaeforme, Will. 120.

Trigonocarpus, Brongn. $119,330$.

Triletac, 237.

Triphyllopteris Collombi, Schpr, 137, 15 I.

Triploporella Fraasii, Steinm. 42.

Triplosporites, R. Br. 238.

Tripterospermum, Brongn. 120.

Trizygia speciosa, Royle, 345,348 .

Trochophyllum, Lesq. 189.

Tsuga, 55 .

Tubicaulis dubius, Cotta, 159.

- primarius, Cotta, 159, 174 .

- solenites, Cotta, 159.

Tylodendron speciosum, Weiss, 8o, 84 .

Tymphanophora, Ldl. et Hutt. 157. 
U.

Ullmannia, Göpp. 26, 54, 77, 78.

- Bronnii, 78.

- frumentaria, 78 .

- lycopodioides, 78 .

- orobiformis, 78 .

- selaginoides, 78 .

Ulodendron, Stbg, 206 sq., $213,232$.

- commutatum, Schpr, I 95, 206, 207.

- Lindleyanum, Stbg, 209.

- majus, Ldl. et Hutt. 209.

- minus, Ldl. et Hutt. 209.

Uphantaenia, 50 .

Uteria Encrinella, Mich. 40.

$$
\text { v. }
$$

Vascular Cryptogams, 53.

Vertebraria, Royle, 365, 366.

Vesquia Tournaisii, Bertr. 62.

Vexillum, Rouault, 50.

Volkmannia, Stbg, 325.

- Binneyi, Carr. 327.

- crassa, Lesq. 339.

- Dawsoni, Will. 337, 353.

- effoliata, Grand' Eury, 334.

- gracilis, Stbg, 323, 332.

- Ludwigii, Carr. 326.

- Morrisii, Hook. 334.

- pseudosessilis, Grand' Eury, 334.
Voltzia, Schpr, 67, 76 .

- coburgensis, Schatur. 6870.

- heterophylla, Brongn. 53 , 68.

- hexagona, Bisch. 68, 69.

- hungarica, Heer, 68.

- Liebeana, Gein. 68.

- raiblensis, Stur, 69.

- recubariensis, 68.

W.

Walchia, Stbg, 54, 75 sq.' I 86, 204.

- filiciformis, Stbg, 76 .

- piniformis, Stbg, 76 .

Weltrichia mirabilis, F. Br. 370.

Whittleseya, Lesq. 66.

Widdringtonia, 60, 71 .

- antiqua, Sap. 60.

- brachyphylla, Sap. 60.

- helvetica, Heer, 60.

- microcarpa, Sap. 60.

Williamsonia, 43, 91, 94, 369 sq.

- angustifolia, Nath. 370 .

- Forchammeri, Nath. 370.

- gigas, Carr. 370.

- Leckenbyi, Nath. 372.

- Morierei, Sap. et Mar. 98.

- pictaviensis, Sap. et Mar. 370.

Worms, tubes of, 48, 50 .
Wormskioldia sanguinea, 48.

$\mathrm{X}$.

Xyris, 368.

Y.

Yatesia, Carr. 93.

Yuccites, Schpr et Moug. III.

\section{Z.}

Zamia gigas, 370 .

Zamiostrobus orientalis, Heer, 91.

- Ponceleti, Sap. 90.

- Saportanus, Schpr, 86, 91.

- stenorrhachis, Nath. 9I.

Zamitae, 88 sq.

Zamites carbonarius, Ren. et Zeill. 85 .

- epibius, Sap. 85.

- Feneonis, Br. 88.

- gigas, 91, 94 .

Zeilleria, Kidst. I 54 .

Zippea, Cda, 167, 169.

- disticha, Cda, I68.

Zittelina, M. Chalm. 4I.

Zonaria, 47.

Zonarites digitatus, Brongn. 46.

Zygopteris, Cda, I 50, I 59, I60, 173.

Zygosporites, Will. I82, I84. 


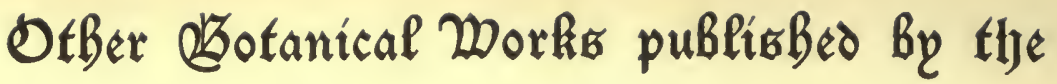 Elarendon (presr.}

History of Botany (I530-1860). By Julius vọN SACHS. Authorised Translation, by H. E. F. Garnsey, M.A. Revised by Isaac Bayley Balfour, M.A., M.D., F.R.S. Crown 8vo, Ios.

Comparative Anatomy of the Vegetative Organs of the Phanerogams and Ferns. By Dr. A. DE BARY. Translated and Annotated by F. O. Bower, M.A., F.L.S., and D. H. ScotT, M.A., Ph.D., F.L.S. Royal 8vo, half morocco, £I $2 s .6 d$.

Outlines of Classification and Special Morphology of Plants.

A new Edition of SACHS' Text-Book of Botany, Book II. By Dr. K. Goebel. Translated by H. E. F. GARnsev, M.A., and Revised by ISAAC BAYLEY [BAI.Four, M.A., M.D., F.R.S. Royal 8vo, half morocco, I I $_{\text {is. }}$

Lectures on the Physiology of Plants. My Julius von SaCis.

Translated by H. Marshali. Ward, M.A., F.L.S. Royal 8vo, half morocco. £i 11 s. $6 d$.

Comparative Morphology and Biology of Fungi, Mycetozoa and Bacteria. By Dr. A. De BARY. Translated by H. E. F. GARnSEy, M.A., and Revised by IsaAC Bayley Balfour, M.A., M.D., F.R.S, Royal Svo, half morocco, \&.1 $2 s .6 \%$.

Lectures on Bacteria. By Dr. A. DE BARY. Sccond Improved Edition. Translated by H. E. F. Garnsey, M.A., and Revised by IsAac BAyley BALFOUR, M.A., M.D., F.R.S. Crown 8vo. $6 s$,

Annals of Botany. Edited by ISAAC BAyLey BALFour, M.A., M.D., F.R.S., SYDney H. Vines, D.Sc., F.R.S., and W. G. FARLOW, M.D.

Vol. I. Parts I-IV. Royal 8vo, half morocco, gilt top, £I I6s.

Vol. II. Parts V-VIII. £2 $2 s$.

Vol. III. Parts IX-XII. £2 I2s. $6 \%$.

Vol. IV. Parts XIII. I2s. 6d. ; XIV. I3s. 6d.; XV. 10s. 6d.; XVI. in the press.

Vol. V. Part XVII. Ios. $6 \%$.

\section{Oxford}

AT THE CLARENDON PRESS

LONDON : HENRY FROWDE

CXFORD UNIVERSITY PRESS WAREHOUSE, AMEN CORNER, E.C. 






\section{UNIVERSITY OF TORONTO} LIBRARY

$$
\begin{gathered}
0 \\
0 \\
0
\end{gathered}
$$

Do not

remove

the card

from this

Pocket. 
